UNIVERSIDADE DE SÃO PAULO

FACULDADE DE ARQUITETURA E URBANISMO

\title{
A OBRA DE RINO LEVI E A TRAJETÓRIA DA ARQUITETURA MODERNA NO BRASIL
}

TESE DE DOUTORAMENTO

Maria Beatriz de Camargo Aranha

ORIENTADOR:

Prof. Dr. Lucio Gomes Machado

São Paulo, 2008 
Aos meus pais, Mariozito e Maria Ignês, meus orientadores na vida, sempre. 


\section{AGRADECIMENTOS}

À minha irmã Maria Cecília pela compreensão e apoio em todos os sentidos que a palavra abarca e a minha sobrinha Marina, por organizar o meu "mar de papéis".

Ao meu orientador, Prof. Dr. Lúcio Gomes Machado, pela dedicação e firmeza com que acompanhou minha pesquisa.

Aos membros da banca do exame de qualificação, Prof. Dra. Fernanda Fernandes da Silva e Prof. Dr. Paulo Yassuhide Fujioka pela argüição atenta e pelas sugestões importantes para os eventuais acertos desta tese.

Aos meus colegas da FAU PUC-Campinas, em especial Abílio Guerra, Luis Espallargas Gimenez, Luis Fernando Campanella Rocha, Mirtes Maria e Vera Santana Luz pela amizade generosa e debate instigante nestes vinte anos de convivência.

Aos arquitetos do Escritório Rino Levi Arquitetos Associados pela acolhida, em particular Antonio Carlos San'Anna Jr. e Luiz Roberto Carvalho Franco (in memoriam) pelo acesso aos arquivos e acervos assim como pelos relatos de convivência e participação no escritório.

A Iara Maier e Luiz Nogueira pela editoração e captação de imagens. 


\section{RESUMO}

O objetivo desta tese é a inclusão da obra de Rino Levi na história da Arquitetura Moderna no Brasil. Esta inclusão pressupõe a história como um processo de mudança sem atenção concentrada em periodizações, marcos arquitetônicos ou arquitetos inaugurais.

Esta análise, devido ao seu caráter - inserção de uma produção em um processo só pode ser construída enquanto narrada.

E a narrativa tem início no papel ocupado por Rino Levi na historiografia, que se revelou caracterizada pela dualidade arquitetura de gênio x arquitetura de ofício, esta última perfeitamente caracterizada por um arquiteto como Rino Levi.

Uma das características da arquitetura de ofício é a de trabalhar com referências e esta foi a instância adotada para a análise realizada no segundo momento desta tese.

Devido à abrangência da obra do arquiteto - em tempo e número de projetos foram feitos dois recortes. O primeiro percorreu o período de formação e os primeiros projetos de Rino Levi, enquanto o segundo examinou uma seleção de projetos da década de 50, que oferece oportunidade privilegiada para o entendimento de como as referências operam na obra de um arquiteto de ofício.

\section{ABSTRACT}

The purpose of this thesis is the inclusion of Rino Levi's work in the history of Modern Architecture in Brazil. This inclusion assumes the history as a change process without any attention focused on periods, architectonic landmarks or inaugural architects.

This analysis, due to its feature - insertion of a production in a process - can only be made while it is narrated.

And the narrative starts in the role performed by Rino Levi in the historiography that was revealed characterized by dual genius architecture $\mathrm{x}$ office architecture, the last one perfectly characterized by an architect like Rino Levi.

One of the features of office architecture is to work with references and this was the instance adopted for the analysis made at the second moment of this thesis.

Due to the scope of the architect's work - in time and number of projects - two cutouts were made. The first went through the formation periods and the first Rino Levi's projects while the second examined a project selection of the 50 s that offers a privileged opportunity to understand how references act in the work of an office architect. 


\section{SUMÁRIO}

AGRADECIMENTOS

RESUMO / ABSTRACT

4

INTRODUÇÃO

ARQUITETURA MODERNA NO BRASIL X ARQUITETURA MODERNA BRASILEIRA

ARQUITETURA DE GÊNIO X ARQUITETURA DE OFÍCIO 12

CAPÍTULO 1 - RINO LEVI NA HISTORIOGRAFIA

1.1 - RINO LEVI NOS MANUAIS

1.2 - RINO LEVI NAS TESES

1.2.1 - A Tese de Lúcio Gomes Machado

1.2.2 - A Tese de Renato Anelli

71

1.2.3 - Rino Levi nas monografias . 82

1.3 - SÍNTESE 103

104

CAPÍTULO 2 - RINO LEVI NA HISTÓRIA

107

2.1 - QUESTÕES DE FORMAÇÃO

109

2.1.1 - Contexto Italiano

109

2.1.2 - Contexto Carioca

2.2 - OS PRIMEIROS PROJETOS

131

2.2.1 - As primeiras residências e habitações coletivas

2.2.2 - O contexto Internacional 155

2.2.3 - O Contexto Nacional . 192

2.3 - OS PROJETOS DA DÉCADA DE 1950

2.3.1 - O Concurso para o Plano Piloto de Brasília

2.3.2 - As residências unifamiliares

2.4 - SÍNTESE 
FONTE DAS IMAGENS

ANEXOS

293

Anexo o1: Listagem dos Projetos do Escritório Rino Levi

294

Anexo 02: A obra do escritório Rino Levi nos periódicos

305

Anexo 03: Memorial do Plano Piloto de Brasília do Escritório

335

Rino Levi 


\section{INTRODUÇÃO}

Como está explicitada já no título da tese, nossa intenção será inserir a obra de Rino Levi em um processo: o da Arquitetura Moderna no Brasil. A primeira questão que se coloca está na própria formulação do problema e diz respeito ao papel ocupado pelo arquiteto na historiografia sobre o período. Hoje, começo do século XXI, persistem nessa historiografia inúmeras lacunas. Na tentativa de entender esses vazios é preciso lembrar que na FAU-USP dos anos 70 essa área praticamente inexistia no currículo. Os alunos discutiam, calorosamente, nos corredores, no bar, no GFAU, nas reuniões com os professores, nos grupos de estudo, a qualquer hora e lugar, menos nas salas de aula. Mais de trinta anos depois se pode levantar a hipótese de que os professores eram os personagens ativos desta história e discuti-la significava colocar-se em discussão.

De qualquer maneira, boa parte dessa história ainda está para ser escrita. A natureza e a utilidade do trabalho do arquiteto, a possibilidade da arquitetura desempenhar sua função social e as instâncias que possibilitam a sua produção, as diferentes atitudes de projeto e os desdobramentos dessas questões marcaram profundamente todas as polêmicas das últimas décadas do século passado. São ainda elas que norteiam este trabalho.

\section{ARQUITETURA MODERNA NO BRASIL X ARQUITETURA MODERNA BRASILEIRA ${ }^{1}$}

A historiografia sobre a Arquitetura Moderna no Brasil é escassa e, na

\footnotetext{
${ }^{1}$ As hipóteses que apresentamos a seguir foram por nós levantadas no artigo Rino Levi: arquitetura como ofício. Óculum, Campinas, Faculdade de Arquitetura e Urbanismo da PUC-Campinas, no 3, mar. 1993, p. 46-53. Foram trabalhadas, também, na nossa dissertação de mestrado Rino Levi: arquitetura como ofício. FAU-USP, 2003
} 
maioria das vezes, pontual. Embora não explicitamente, indica, quase sempre, duas leituras que se diferenciam desde a sua formulação: uma trabalha com a noção de arquitetura moderna no Brasil, outra com a noção de arquitetura moderna brasileira. A diferença é muito mais profunda que mera questão semântica. Entre no Brasil e brasileira se divide praticamente toda a historiografia e a crítica da década de 20 até hoje (nada mais contemporâneo no Brasil do que o falso debate arquitetura nacional $x$ arquitetura internacional).

A discussão sobre a produção historiográfica (não só a arquitetônica) e sobre diferentes conceitos de história, ocupa grande espaço hoje em dia em diferentes áreas do conhecimento. Se na maioria delas podemos falar em resistência ao conceito de história linear, factual, periodizada, na arquitetura moderna no Brasil mesmo onde parece haver divergência, o conceito de história é o mesmo. Tomemos como exemplo o confronto entre Lúcio Costa ${ }^{2}$ e Geraldo Ferraz ${ }^{3}$. Em 1948, em dois artigos de jornal ${ }^{4}$, a polêmica nacional $x$ internacional se explicita: Geraldo Ferraz contesta a qualificação de "pioneiro da arquitetura moderna brasileira” dada a Lúcio Costa: Ferraz reivindica para os arquitetos Gregori Warchavchik ${ }^{5}$ e Flávio de Carvalho ${ }^{6}$, a

${ }^{2}$ Lúcio Costa (1902-19980) nasceu em Toulon, França. Filho de um engenheiro naval a serviço do governo brasileiro, foi educado na Inglaterra e na Suíça. Radicou-se definitivamente no Brasil em 1916, quando a família retornou ao Rio de Janeiro. Formou-se arquiteto pela Escola Nacional de Belas Artes em 1924 à qual retornou como diretor em 1930, promovendo uma frustrada reforma do ensino. Convocado pelo ministro Gustavo Capanema a projetar a sede do Ministério de Educação e Saúde, dos ex-alunos: Affonso Eduardo Reidy, Jorge Moreira, Carlos Leão, Ernani Vasconcelos e Oscar Niemeyer. Trouxe Le Corbusier ao Brasil como consultor. Foi vencedor, em 1957, do concurso para o Plano Piloto da Nova Capital no Brasil, formando com Oscar Niemeyer, autor dos principais edifícios, a dupla responsável pelas características formais de Brasília. Faleceu em sua casa no Rio de Janeiro em 13 de junho de 1998.

3 Benedito Geraldo Ferraz Gonçalves (1905-1979) nasceu em Campos Novos, SP. Dedicou-se ao jornalismo, à crítica de arte e à literatura. Em 1933, fundou e dirigiu o semanário Homem Livre, em São Paulo, e posteriormente, com Mário Pedrosa, o jornal Vanguarda Socialista, no Rio de Janeiro.Em parceria com a esposa Patrícia Galvão (Pagú) publicou em 1935 o romance Famosa Revista. Sua mais famosa ficção, Doramundo, é de 1956. Como crítico de arte, foi um dos organizadores do Salão de Maio, em 1937, e publicou obra sobre Lívio Abramo e vários ensaios sobre a arte moderna brasileira.

${ }^{4}$ O artigo de Geraldo Ferraz chama-se "Falta o Depoimento de Lúcio Costa”, publicado no jornal Diário de São Paulo, em 01/01/1948. O de Lúcio Costa é “Carta Depoimento”, publicado n’ O Jornal, em 14/03/1948, em resposta ao artigo de Ferraz. Ambos foram republicados na coletânea do CADERNO 3, publicado pelo CAD (Centro de Apoio Didático), FAU-PUCCAMP, maio de 1991.

${ }^{5}$ Gregori Warchavchik (1896-1976) nasceu em Odessa, Rússia. Iniciou seus estudos de arquitetura nessa cidade, interrompendo-os em 1918, quando emigrou para a Itália; concluiu-os em 1920, no Instituto Superior de Belas Artes de Roma, tendo trabalhado nos dois anos seguintes como assistente de Marcello Piacentini. Emigrou para o Brasil em 1923, contratado pela maior empresa construtora do país, a 
introdução, já na década de 20, em São Paulo, da "corrente de arquitetura mais avançada do mundo". Costa rebate a argumentação de Ferraz, apontando para a "feição tão peculiar e tão desusado e desconcertante vigor" da arquitetura moderna brasileira e para o "advento do arquiteto Oscar de Almeida Soares"7 como seu responsável.

As duas posições, obviamente, são diferentes. Mas a divergência se restringe à eleição de diferentes fatos históricos: a concepção de história é semelhante. Ambos trabalham com a noção de periodização, de marcos arquitetônicos, de arquitetos inaugurais. Para Ferraz, o arquiteto precursor é Warchavchik e o marco é a casa da Rua Santa Cruz[o1], de 1927, em São Paulo. Lúcio Costa elege Niemeyer e o projeto do MES[o2], de 1936, no Rio de Janeiro. Nem a Costa, nem a Ferraz, ocorre considerar a história como processo, onde marcos e autores teriam papel secundário.

Companhia Construtora de Santos. Na década de 20, constrói uma série de casas modernistas em São Paulo. Na década de 30, foi sócio de Lúcio de Costa, fazendo a primeira casa modernista do Rio de Janeiro, a da Rua Toneleiros, de 1931, sendo também professor da Escola Nacional de Belas Artes.

${ }^{6}$ Flávio de Carvalho (1899-1973) nasceu em Barra Mansa, RJ. Estudou em famosos internatos franceses e ingleses. Formou-se em engenharia e artes plásticas na Inglaterra , retornando ao Brasil em 1922, dedicando-se às mais variadas atividades, incluindo a arquitetura, a pintura, a gravura e a escultura. Ainda na década de 20, participa de diversos concursos de arquitetura, com projetos-manifestos revelando uma leitura muito particular do modernismo europeu.

${ }^{7}$ Essa é a maneira "genuinamente nacional" pela qual Costa se refere a Oscar Niemeyer;

Oscar Niemeyer (1907-) nasceu no Rio de Janeiro e formou-se arquiteto na Escola Nacional de Belas Artes em 1934. Na condição de mais jovem arquiteto, participou da equipe responsável pelo MES. Seus projetos na Pampulha, na década de 40, lhe rendem fama internacional, alimentada pelos públicos para Brasília. Tem a maior obra já construída por um arquiteto, com projetos significativos nas principais cidades do país e no exterior. 


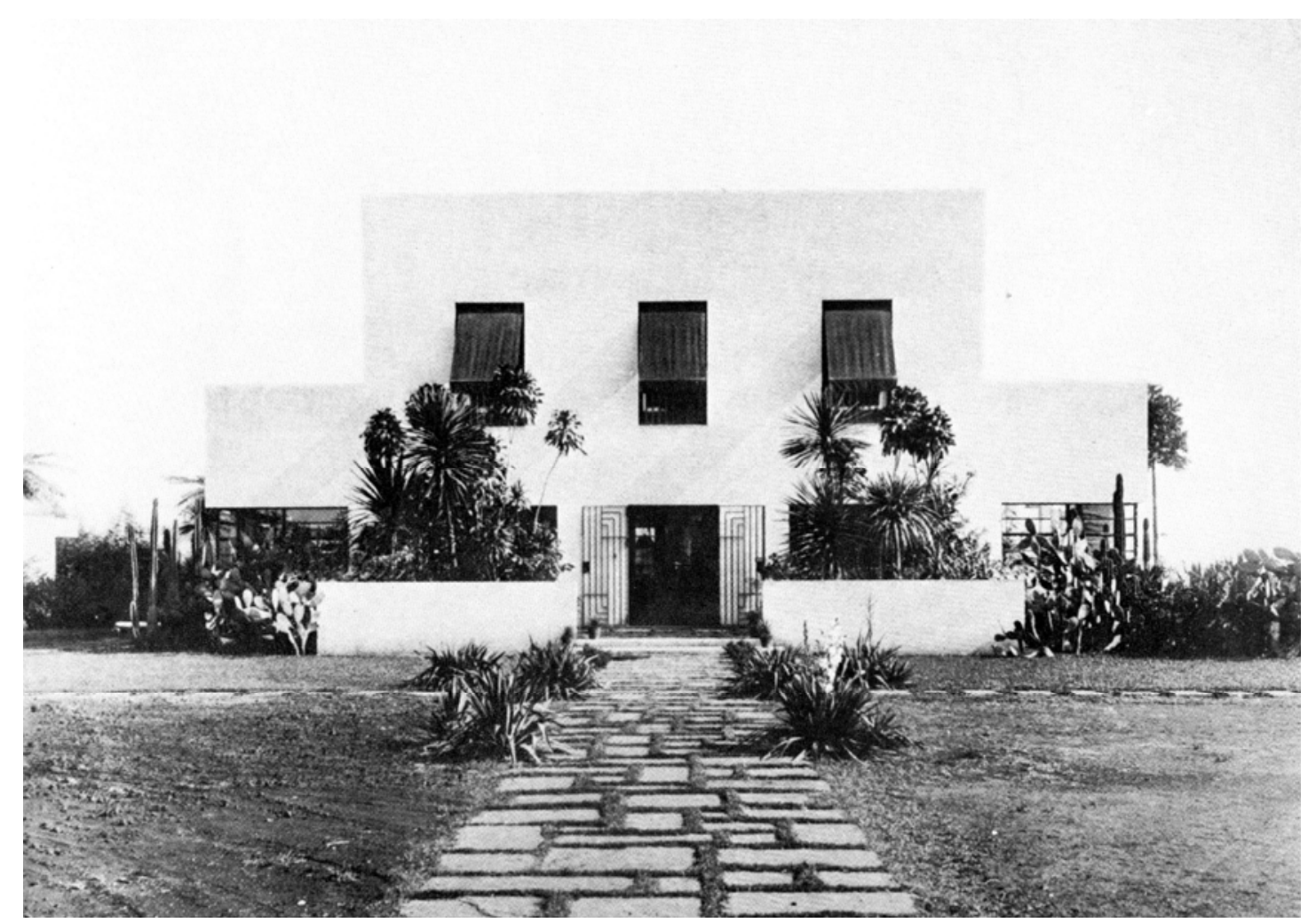

[01] Casa da Rua Santa Cruz, São Paulo, SP. Arquiteto Gregori Warchavchik, 1927. 


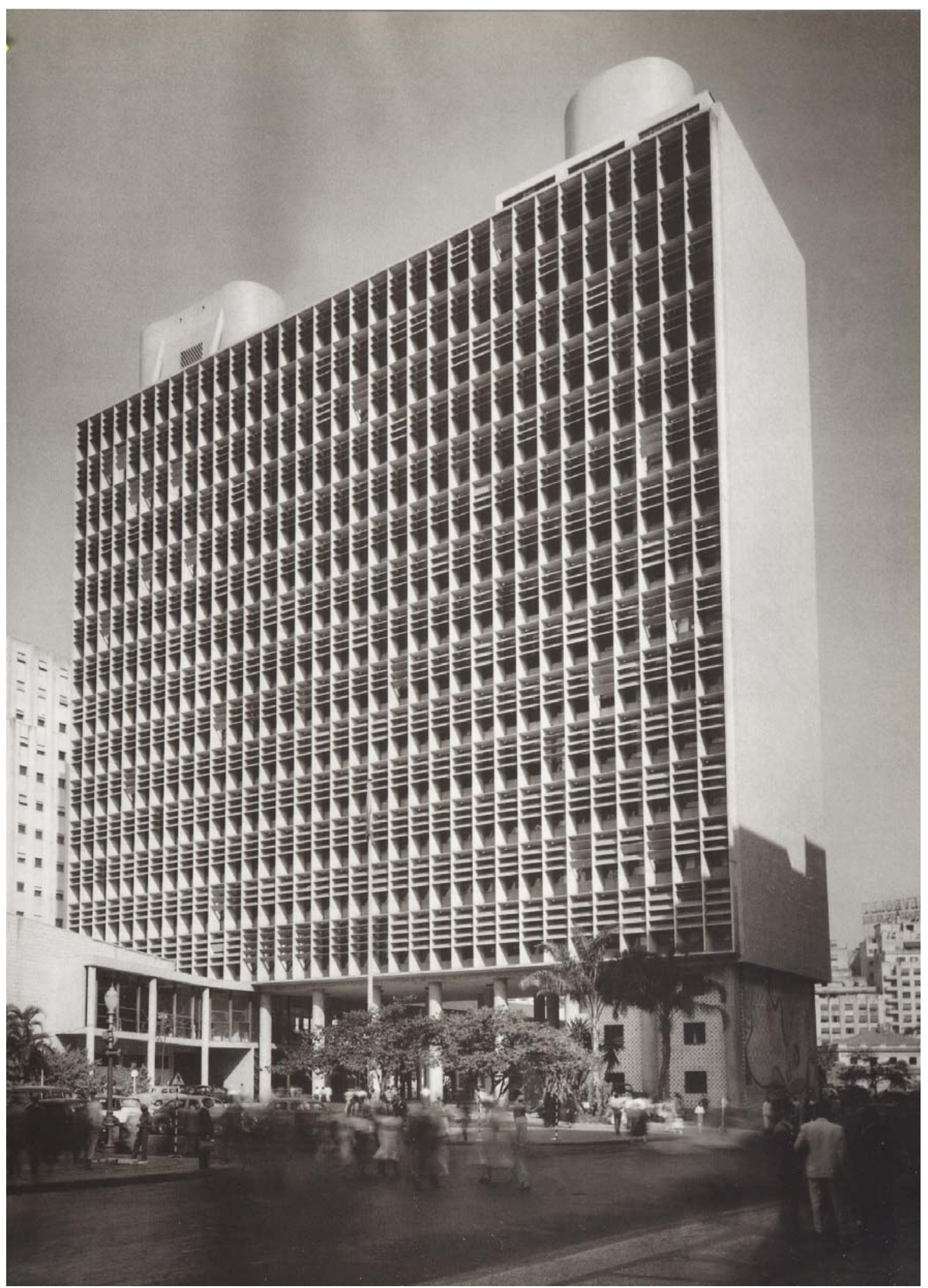

[02] Edifício-sede do MES-Ministério da Educação e Saude (depois MEC, hoje Palácio Gustavo Capanema), Rio de Janeiro, RJ. Arquitetos Lúcio Costa, Jorge Machado Moreira, Ernani Vasconcelos, Affonso Eduardo Reidy, Carlos Leão e Oscar Niemeyer, consultoria de Le Corbusier, 1936. 


\section{ARQUITETURA DE GÊNIO X ARQUITETURA DE OFÍCIO}

O exemplo do embate entre Lúcio Costa e Geraldo Ferraz, além de marcar $\mathrm{o}$ conflito arquitetura moderna brasileira $\mathrm{x}$ arquitetura moderna no Brasil, aponta outra circunstância importante da nossa historiografia: a extrema valorização das individualidades. Não há o menor constrangimento em trabalhar com a noção de gênio para qualificar arquitetos Delineia-se aqui uma das questões que serão examinadas: a dualidade arquitetura de gênio $x$ arquitetura de ofício.

No artigo já citado, Lúcio Costa, referindo-se a Oscar Niemeyer, diz que "foi nosso gênio nacional que se expressou através da personalidade eleita desse artista”. Essa análise de Costa não é gratuita, ao contrário, é respaldada pela própria postura de Niemeyer perante a produção da arquitetura: os grandes gestos, o projeto definitivo nos croquis iniciais, a inspiração. O oposto da noção de arquitetura como ofício: trabalho interdisciplinar, o projeto definitivo como resultado de um processo, o conhecimento. Postura perfeitamente caracterizada por um arquiteto como Rino Levi ${ }^{8}$.

Há aqui o risco de incorrer na mesma questão que foi apontada para a dualidade nacional $\mathrm{x}$ internacional: a opção por um dos termos da equação que pressupõe a exclusão do outro. O que interessa, no entanto, não é contrapor a postura de Rino Levi à postura de Oscar Niemeyer, valorando-as no sentido de eleger uma delas. Ao contrário, a proposta é perceber como de posturas diferentes perante a produção de arquitetura resultam ideários e realizações também diferentes.

\footnotetext{
${ }^{8}$ Rino Levi (1901-1965) nasceu em São Paulo, SP. Filho de pais italianos, estudou na Escola Alemã e no Instituto Médio Dante Alighieri, ambos em São Paulo, onde recebeu as bases de uma formação européia que seria completada na Itália, para onde viaja em 1921, ingressando na Escola Preparatória e de Aplicação para os Arquitetos Civis de Milão.Em 1924, transfere-se para a Escola Superior de Arquitetura de Roma. Estagia por pouco tempo no escritório de Piacentini, num período em que o arquiteto gozava do prestígio de ser o condutor do processo de modernização da arquitetura na Itália. Forma-se em 1926, retornando ao Brasil, onde trabalha pouco mais de um ano na Companhia Construtora de Santos, no lugar de Warchavchik, de quem foi amigo.
} 
A partir do colocado acima, a tese foi dividida em dois blocos, organizados segundo as questões levantadas. O primeiro trabalha com a produção historiográfica e o papel que nela é dado a Rino Levi ou, ainda, ao Escritório Rino Levi Arquitetos Associados ${ }^{9}$. Do balanço já feito, parece-nos importante marcar algumas questões. A primeira é a noção de escola presente na historiografia da arquitetura. Poucas vezes explicitada, mas, quase sempre implícita, entende-se por escola o conjunto de procedimentos e ideário comum a um grupo de arquitetos. A historiografia da arquitetura moderna no Brasil já consolidou duas delas: a carioca e a paulista. que serão detalhadas no decorrer deste estudo. O escritório Rino Levi não está diretamente ligado a nenhuma das duas escolas e isso se explicará exatamente pela sua diferente atitude perante a produção da arquitetura. De todas essas leituras, constata-se que a arquitetura de ofício está longe de ocupar o espaço dedicado na historiografia à arquitetura de gênio.

O segundo bloco, através da análise de projetos, lança uma hipótese que justifica o espaço ocupado pela arquitetura de ofício na historiografia. A questão central para a presente hipótese é que a partir da análise dos projetos pode-se caracterizar a postura do arquiteto perante a sua produção, e é dela que resultam ideários e realizações. A partir daí é que mostraremos como se materializou a arquitetura de ofício, como o programa e o detalhe é que qualificam o seu desenvolvimento, como procedimentos generalizados jamais vão se sobrepor às necessidades particulares e como se opera com referências.

Isso não significa partir de uma classificação prévia dos projetos e

\footnotetext{
${ }^{9}$ O escritório foi fundado em1927, quando o arquiteto Rino Levi iniciou suas atividades profissionais. Em 1941, o arquiteto Roberto Cerqueira Cesar associa-se ao escritório. Em 1951, junta-se a eles o arquiteto Luis Roberto Carvalho Franco. O fundador faleceu em 1965. O escritório continuou suas atividades sob a denominação de Rino Levi Arquitetos Associados S.C. Ltda. Em 1972 é o arquiteto Paulo J. V. Bruna quem se associa e em 1986 é o arquiteto Antonio Carlos Sant'Anna, que começara a trabalhar no escritório como estagiário em 1974, que se tornou sócio.
} 
fazer com que a produção de Levi caiba na leitura: seria inverter o processo de análise. A idéia é que há uma profunda diferença entre a noção de influência e a noção de referência. Por influência, entende-se uma subjetiva presença de um ideário ou de repertório alheio, sem nenhum controle do autor. Ao contrário, por referência entende-se uma escolha objetiva, consciente, por um ideário ou repertório que o autor conhece profundamente, domina e elege.

Entendendo que a arquitetura de ofício se define a partir de instâncias de grande abrangência, foi necessário eleger uma delas e optou-se pelo trabalho com referências. Depois de definida a instância de análise, se mostrou necessário o recorte de um período. A abrangência da produção de Rino Levi e seu escritório - tanto em tempo quanto em quantidade - mostrou-se incompatível com a natureza deste trabalho. Mesmo se nos restringíssemos ao período em que o titular estava vivo, ainda estaríamos falando de quatro décadas.

Nesse contexto optou-se por dois recortes. O primeiro percorreu o período de formação de Levi na Itália, o cotejamento com a formação de européias, que ele acompanhava e que lhe serviram de referência. Outra vez, o paralelo com a experiência dos arquitetos brasileiros foi estabelecido.seus colegas italianos e um paralelo com a formação dos arquitetos da futura escola carioca. Trabalhou-se ainda com o início de sua produção no Brasil, a análise das primeiras obras e o cotejamento com as experiências

No segundo recorte a intenção foi manter a instância de análise e trabalhar um novo período. Isso significa dizer que foi mantida a preocupação com as referências de projeto mas, agora, em obras da década de 50. A escolha temporal não foi aleatória. Considerou-se que - embora o uso de referências seja uma constante - nesta década um grupo particular de projetos oferece oportunidade privilegiada para o exame de como elas operam. No período referido, o escritório terá a 
possibilidade de se envolver em situações que vão desde o concurso para o Plano Piloto de Brasília até uma série de residências unifamiliares. A idéia é que programas muito diferenciados, obedecendo à hipótese levantada, serão resolvidos com partidos muito diversos. 


\section{CAPÍTULO 1 - RINO LEVI NA HISTORIOGRAFIA}

Insistimos no fato de que a historiografia sobre arquitetura brasileira é extremamente escassa. Sobre o período que se convencionou chamar de moderno, a historiografia é mínima, o que é um tanto paradoxal, afinal a produção arquitetônica da época é vastíssima, sua repercussão é enorme, podendo-se até falar em um quase consenso entre críticos e historiadores internacionais sobre sua qualidade. No entanto, contamos com apenas dois livros, publicados no período, que se propõem ao levantamento sistemático da produção nacional: Brazil Builds, de Philip Goodwin' (1943), e Modern Architecture in Brazil, de Henrique Mindlin (1956) ${ }^{2}$. Significativamente, os dois volumes trazem Brasil com "z". São, no mínimo, intrigantes, as circunstâncias que levaram um historiador americano, Goodwin, a escrever a primeira obra sobre o tema; ou as razões que levaram o arquiteto brasileiro Henrique Mindlin a escrever em inglês o segundo levantamento de arquitetura moderna no Brasil, editado também em francês e alemão. A tradução para o português só iria acontecer 43 anos depois, em 1999. Apenas na década de 80 é publicado um outro levantamento dessa produção: Arquitetura Contemporânea no Brasil ${ }^{3}$, do arquivista paleógrafo, ex-aluno da Escola de Chartes, Yves Bruand. Na verdade, embora apareça em 1981, o livro é a tradução da tese de doutoramento que o francês Bruand apresentou no final da década de 60.

Nos levantamentos acima mencionados, o papel atribuído a Rino Levi é secundário em Bruand e mínimo em Goodwin e Mindlin. Esse

\footnotetext{
${ }^{1}$ GOODWIN, Philip L.. Brazil Builds: Architecture New and Old, 1652-1942. Fotografias de O. E. Kidder Smith, New York, The Museum of Modern Art, 1943.

2 MINDLIN, Henrique E.. Modern Architecture in Brazil. Prefácio de S. Gideon. Rio de Janeiro, Colibris Ltda., 1956, $1^{\text {a }}$ edição.

${ }^{3}$ BRUAND, Yves. Arquitetura Contemporânea no Brasil. Trad. Ana Maria Goldberg. São Paulo,Perspectiva, $1^{a}$ ed., 1981. Tradução de L'architecture contemporaine au Brésil.
} 
contexto torna mais importante o livro Rino Levi ${ }^{4}$, publicado em Milão, 1974, pela Edizioni di Comunità. Essas avaliações serão analisadas adiante.

Na década de 90 os primeiros balanços dessa produção foram feitos ${ }^{5}$, embora importantes, tiveram uma circulação restrita aos meios acadêmicos, onde surgiram como dissertações ou teses de programas de pós-graduação, particularmente da USP, UNICAMP e da EESCUSP. Também nesses programas, novos estudos surgiram, alguns trabalhando especificamente com a obra de um arquiteto, outros com a documentação da arquitetura moderna em uma cidade ou região. É nesse contexto que aparecem os primeiros trabalhos de fôlego sobre Rino Levi. O inaugural é Rino Levi e a renovação da Arquitetura Brasileira de Lúcio Gomes Machado ${ }^{6}$, seguido por Arquitetura e Cidade na Obra de Rino Levi de Renato Anelli ${ }^{7}$. Uma edição ampliada do segundo foi publicada em $2001^{8}$ e as três produções serão analisados adiante.

Em que pese a importância das monografias ou dos recortes geográficos, parte substancial da historiografia da arquitetura moderna brasileira ainda está por ser escrita. Devido a essa lacuna bibliográfica, torna-se evidente a importância que os periódicos de arquitetura adquirem como registro dessa produção. Paradoxalmente, se os títulos são poucos, as revistas nacionais especializadas em

\footnotetext{
${ }^{4}$ Rino Levi, Milano, Edizioni di Comunità, 1974. Introdução de RobertoBurle-Marx e Nestor Goulart Reis Filho.

${ }^{5}$ Dois exemplos desses exames historiográficos me parecem particularmente interessantes: o de Carlos Alberto F. Martins na sua dissertação de mestrado Arquitetura e Estado no Brasil: elementos para uma investigação sobre a constituição do discurso moderno no Brasil; a obra de Lúcio Costa (1924-1952), FFLCH-USP,1988; e o de Agnaldo Aricê Caldas Farias na sua dissertação de mestrado Arquitetura Eclipsada: notas sobre história e arquitetura a propósito da obra de Gregori Warchavchik, introdutor da arquitetura moderna no Brasil, IFCH-UNICAMP,1990. Também é significativo o texto de Glória Maria Bayeux, O Debate da Arquitetura Moderna Brasileira nos anos 50. São Paulo, dissertação de mestrado, FAU-USP, 1991.

${ }^{6}$ MACHADO, Lúcio Gomes. Rino Levi e a Renovação da Arquitetura Brasileira. São Paulo, tese de doutorado, FAU-USP, 1992.

${ }^{7}$ ANELLI, Renato Luiz Sobral. Arquitetura e cidade na obra de Rino Levi. São Paulo, tese de doutorado, FAU-USP, 1995.

${ }^{8}$ ANELLI, Renato; GUERRA, Abílio; KON, Nelson. Rino Levi - arquitetura e cidade. São Paulo, Romano Guerra Editora, 2001.
} 
arquitetura e urbanismo são numerosas e de alta qualidade, particularmente nas décadas de 40 a $60^{9}$. Também é expressivo o espaço que a produção brasileira ocupa nas revistas internacionais.

No caso de Rino Levi, a presença nos periódicos é desproporcional à presença nos livros. Nestes, a participação é modesta, enquanto a obra do escritório foi publicada regularmente nas mais importantes revistas especializadas do mundo e, constantemente, em todas as nacionais. A questão também será analisada posteriormente.

Assim, o papel do escritório Rino Levi na historiografia vai ser analisado nas seguintes instâncias: nos manuais, nas teses, nas monografias e nos periódicos.

\section{1 - RINO LEVI NOS MANUAIS}

A designação manuais, no presente trabalho, se refere aos títulos que realizam um levantamento panorâmico da arquitetura brasileira. $\mathrm{O}$ primeiro deles, como já apontei, é o famoso Brazil Builds, livro organizado pelo Museu de Arte Moderna de Nova York em 1943 e responsável pelo primeiro grande impacto de divulgação internacional da arquitetura brasileira. Seu autor, o arquiteto Phillip L. Goodwin é, na época, presidente da Comissão de Arquitetura do Museu e da Comissão de Relações Exteriores do Instituto Norte Americano de Arquitetos. O livro é, na verdade, o catálogo de uma grande exposição de mesmo nome, organizada pelo MOMA. Goodwin, na apresentação, comenta que:

"O Museu e o Instituto, achavam-se ambos na primavera de 1942, ansiosos por tratar relações com

\footnotetext{
${ }^{9}$ Um levantamento importante é feito por Clara Luiza Miranda em A crítica nas revistas de arquitetura nos anos 50 : a expressão plástica e a síntese das artes. São Carlos, dissertação de mestrado, EESC-USP, 1998.
} 
o Brasil, país que ia ser nosso futuro aliado. Por esse motivo e pelo desejo agudo de conhecer melhor a arquitetura brasileira..."

Dessa maneira, o autor não deixa de esclarecer, logo de início, as razões que o levaram a compilar e sistematizar a nossa arquitetura. Segundo suas próprias palavras, tão ou mais importante do que conhecer melhor a nossa produção, o livro é um instrumento de organização para uma política de boa vizinhança com o país que, em pleno Estado Novo, parece se afastar do Eixo em direção aos Aliados. Assim, em que pese a qualidade de exemplos já reconhecidos como o Pavilhão Brasileiro de Nova York ${ }^{11}[\mathbf{o 3}]$ ou o Edifício do Ministério da Educação e Saúde Pública - $M E S^{12}[\mathbf{o 4}]$, parecia prudente enfatizar o caráter de modernização do país e a constituição de uma identidade nacional tão caros ao período Vargas.

\footnotetext{
${ }^{10}$ GOODWIN, Phillip L., op. cit., p. 7

${ }^{11}$ Pavilhão do Brasil na Exposição Internacional de Nova Iorque, Nova Iorque, EUA. Arquitetos Lúcio Costa e Oscar Niemeyer, 1939.

12 Edifício-sede do MÊS-Ministério da Educação e Saúde (depois MEC, hoje Palácio Gustavo Capanema), Rio de Janeiro, RJ. Arquitetos Lúcio Costa, Jorge Machado Moreira, Ernani Vasconcelos, Affonso Eduardo Reidy, Carlos Leão e Oscar Niemeyer, consultoria de Le Corbusier, 1936.
} 


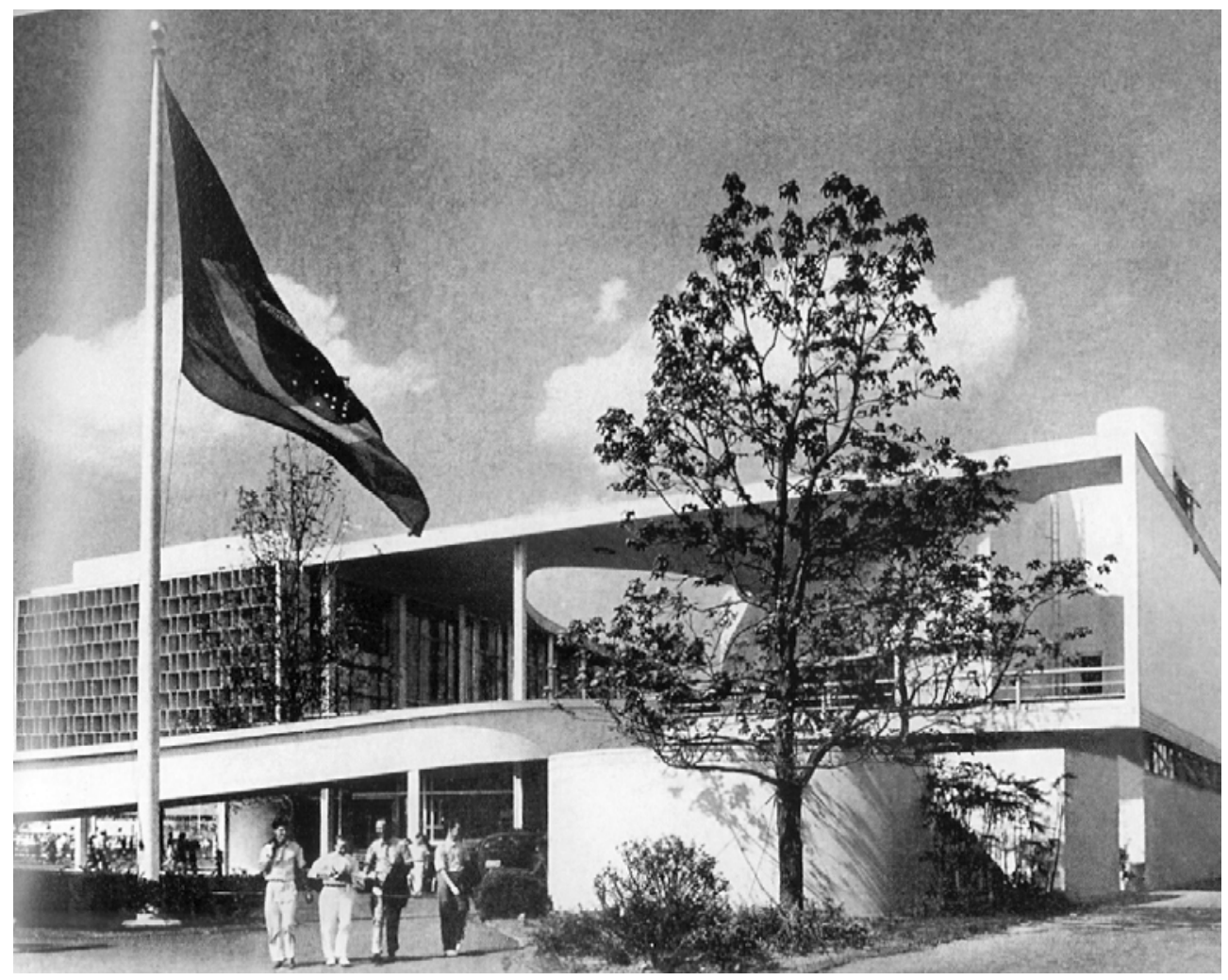

[03] Pavilhão do Brasil na Exposição Internacional de Nova Iorque, Nova Iorque, EUA. Arquitetos Lúcio Costa, Oscar Niemeyer e Paul Lester Wiener, 1939. 


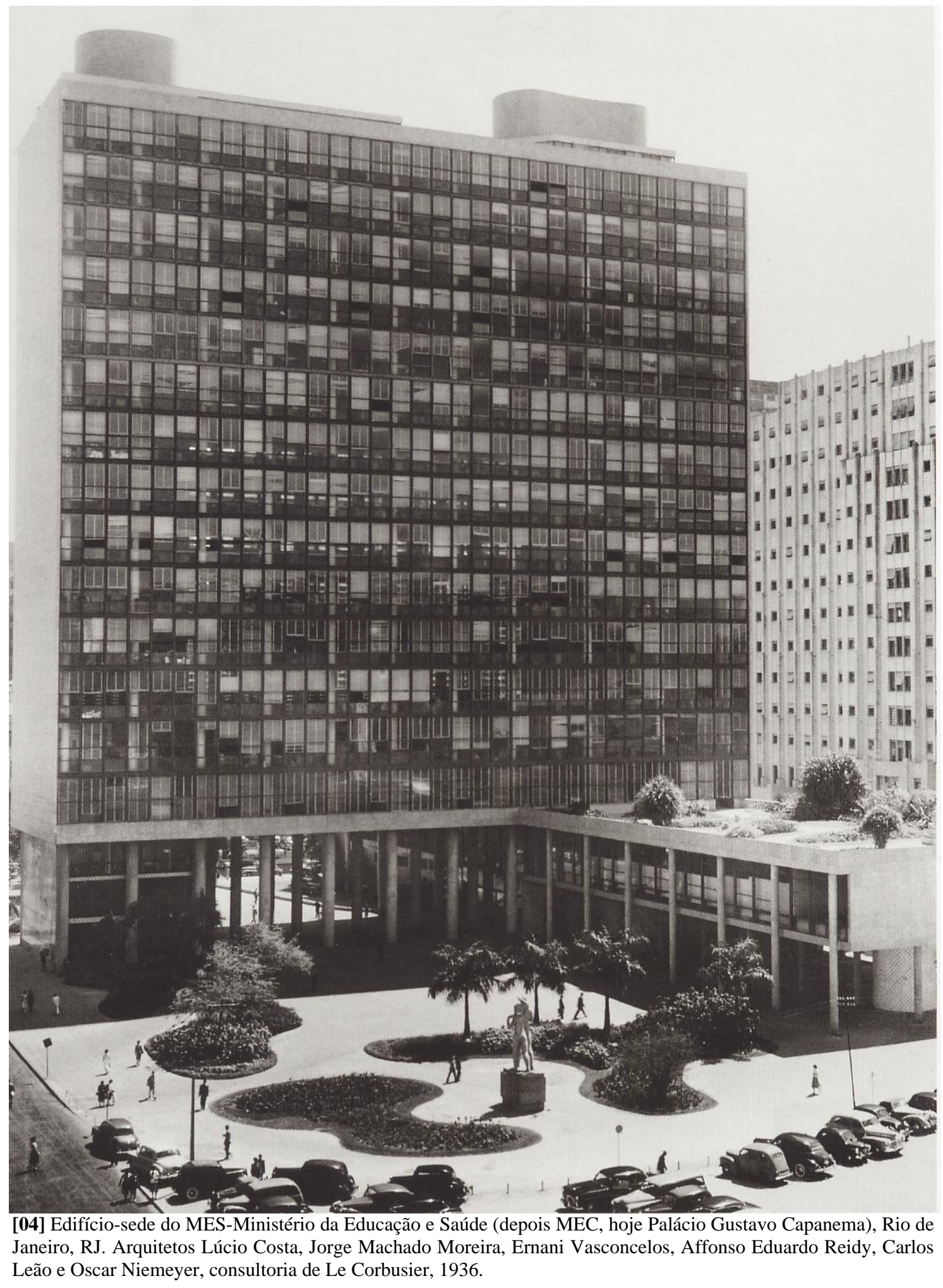

A sistematização operada pelo livro, destaca dois momentos importantes para a nossa arquitetura: o período colonial e o moderno. Ficam de fora as últimas décadas do século XIX e as primeiras do 
século XX e, com elas, nossas experiências com o neo-clássico, o ecletismo, o art nouveau e o neo-colonial. Acentua-se também, a naturalidade da passagem da arquitetura tradicional para a moderna. A seleção de projetos e obras apresentados no livro dá ênfase a originalidade das soluções coloniais e como ela se reproduz nos nossos grandes edifícios públicos da época. Tal originalidade é o grande foco dessa seleção, além do destaque para o edifício do MES que marca a referência que a obra de Le Corbusier será para a nossa arquitetura moderna ${ }^{13}$. Observamos, dessa forma, como vai se constituindo uma leitura de grande permanência na nossa historiografia.

\footnotetext{
${ }^{13}$ Charles-Édouard Jeanneret (1887-1965), vulgo Le Corbusier, nasceu na cidade suíça de La Chaux-deFonds. Sem cursar formalmente uma escola de arquitetura, seu desprendimento e interesse acabaram por lhe proporcionar o mais intenso aprendizado, tendo contato direto com as mais variadas fontes da nova arquitetura que nascia no início do século XX - esteve com Josef Hoffmann em Viena (1907), com Tony Garnier em Lyon (1908), com Auguste Perret em Paris (vários meses em 1910) e com Peter Behrens em Berlim (1911/12). Desde o início de suas considerações sobre a nova arquitetura - que se expressavam através de projetos não construídos e de textos -, Corbusier defendia uma articulação de escalas que envolvia a cidade, o edifício e o objeto utilitário, englobando-os em um mesmo raciocínio que derivava diretamente da nova sociedade industrial que se instaurava no mundo ocidental, reordenando as relações humanas. Ao buscar uma arquitetura e um urbanismo que fossem consonantes com a nova sociedade industrial acabou dando um novo significado e um novo sentido para a disciplina. $\mathrm{O}$ uso intensivo do concreto armado e a apropriação do conceito fabril de standard, levaram-no, ainda na década de 10, a formular a estrutura Domino - arranjo de pilares, vigas, lajes e escadas que permitiria a construção de qualquer programa arquitetônico. Em 1922 propôs a Cidade Contemporânea para 3 milhões de habitantes, emblema até hoje da cidade funcional pois já setorizava a cidade segundo as atividades humanas e alavancava o automóvel ao posto de principal veículo de transporte. Foi um dos mais entusiastas fundadores dos CIAM - Congressos Internacionais de Arquitetura Moderna - e o principal redator da Carta de Atenas, de 1945. Seus diversos livros - Por uma arquitetura, 1925, Os três estabelecimentos humanos, 1945, e dezenas de artigos sobre arquitetura e urbanismo - são republicados até hoje em todo o mundo. Sua obra construída é pequena proporcionalmente ao total de obras concebidas, mas numericamente expressiva e exuberante. A Ville Savoye, de 1929, a Unidade de Habitação em Marselha, 1947, a capela de Notre Dame du Haut em Ronchamp, 1950, a cidade de Chandigarh na Índia, 1951, o Convento de La Tourette, 1957 e diversas outras, são obras que exemplificam o que há de melhor na produção do século passado.Le Corbusier manteve estreito contato com o Brasil mas, devido aos acasos da historia, não teve a oportunidade de ver uma obra sua construída no país. Por sua obra, militância e principalmente - difusão de idéias no seio das diversas sociedades, seguramente Le Corbusier pode ser considerado o principal arquiteto do século XX e um dos mais importantes intelectuais do período.
} 
A seleção de Goodwin termina com a apresentação do Conjunto da Pampulha ${ }^{14}\left[\mathbf{0}_{5}\right]$, na época ainda em construção, mas já apontado como caminho e suporte das particularidades da nossa arquitetura, condições que lhe garantiriam espaço no contexto internacional. São Paulo é lembrado quase que exclusivamente pelas suas experiências urbanísticas. Dessa maneira, arquitetos como Gregori Warchavchik e Flávio de Carvalho são considerados irrelevantes, assim como Rino Levi, que é brevemente citado no texto pelo seu Projeto Escolar para São Paulo ${ }^{15}$. Assim Goodwin se refere ao Instituto Superior de Filosofia, Ciências e Letras Sedes Sapientiae[o6] de 1942, o único projeto de Levi documentado no livro ${ }^{16}$. Esse espaço restrito destinado à produção da arquitetura de São Paulo da década de 20 é outra leitura de grande permanência.

\footnotetext{
${ }^{14}$ O. NIEMEYER. Conjunto da Pampulha. 1942-1943. Juscelino Kubitschek, então prefeito de Belo Horizonte, incumbe Niemeyer de projetar um conjunto de edifícios em torno do lago artificial da Pampulha, um novo loteamento, na época, a alguns quilômetros da capital mineira. O programa, destinado a configurar o centro de uma futura área de lazer, previa cinco edifícios: um cassino, um clube elegante, um salão de danças popular, uma igreja e um hotel de férias que não chegou a ser construído. Juscelino acrescentou uma casa de fim de semana de uso particular, em um gesto didático e exemplar à sociedade de Belo Horizonte, de cujo apoio dependia o sucesso do loteamento.

${ }^{15}$ GOODWIN, Phillip L., op. cit. , p. 87 e p. 92.

${ }^{16}$ GOODWIN, Phillip L., op. cit., pp. 146/147.
} 
[05]

Marquise da Casa

de Baile do

Conjunto da

Pampulha, Belo

Horizonte, MG.

Arquiteto Oscar

Niemeyer,

1942/43.
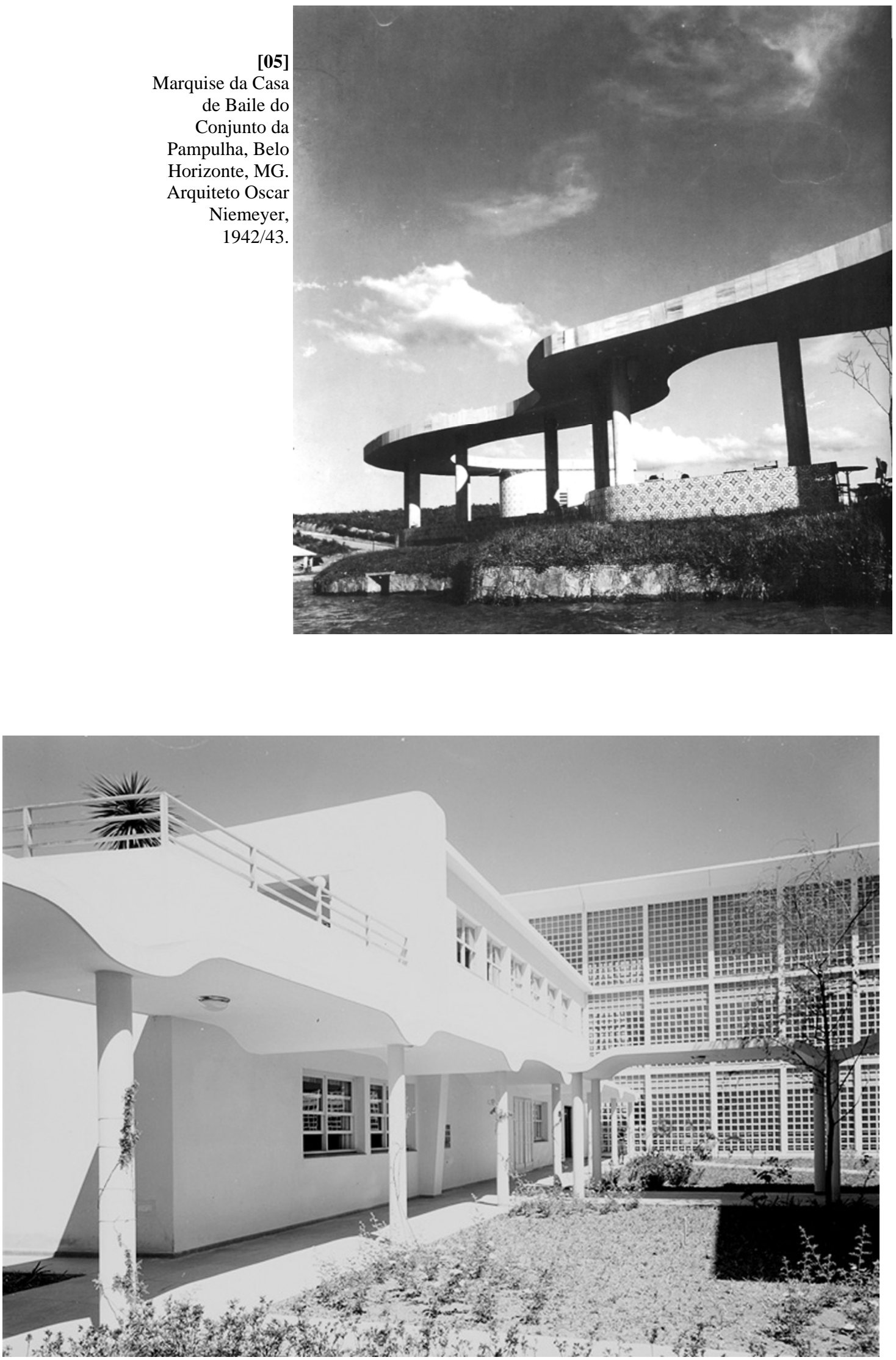

[06] Instituto Superior Sedes Sapientiae, São Paulo, SP. Arquiteto Rino Levi, 1941/42. 
O segundo manual de leitura panorâmica só vai ser lançado em 1956, ou seja, uma década e meia mais tarde: Modern Architecture in Brazil, do arquiteto Henrique Mindlin ${ }^{17}$. Como já foi dito, o livro foi escrito em inglês e editado também em francês e alemão, ficando clara a sua função de divulgar a arquitetura brasileira no exterior. $O$ próprio autor abre o trabalho comentando:

"Este trabalho foi concebido inicialmente como um suplemento ao livro Brazil Builds, de Philip E. Goodwin, uma magnífica apresentação da antiga e nova arquitetura no Brasil, publicada pelo Museu de Arte Moderna de Nova York, e ilustrado com esplêndidas fotografias de G. E. Kidder Smith. No entanto, como Brazil Buidls está esgotado há vários anos, decidiu-se mais tarde incluir aqui alguns dos exemplos mais importantes ali mostrados anteriormente. Assim será possível dar uma imagem mais completa do desenvolvimento da arquitetura moderna no Brasil, dos seus primórdios no final dos anos 20 até os dias de hoje."

Na verdade, muito mais que mera atualização do livro de Goodwin, Mindlin representa uma mudança nos critérios de seleção e uma abrangência muito maior no levantamento de obras que cobre, já, a produção de mais de 120 arquitetos. O critério usado para a organização das mais de duzentas e cinquenta páginas de documentação desses projetos é funcional. Assim, o primeiro bloco se dedica a "Casas, Edifícios Residenciais, Hotéis e Conjuntos

\footnotetext{
${ }^{17}$ Henrique Ephim Mindlin (1911-1971) nasceu em São Paulo e formou-se engenheiro-arquiteto na Universidade Mackenzie em 1931. Foi um dos mais importantes divulgadores da arquitetura moderna brasileira no exterior e, além do livro Arquitetura Moderna no Brasil, teve participação destacada no citado Brazil Builds. Foi professor, pesquisador, e inaugurou no Rio de Janeiro, onde se radicou na década de 50, o primeiro escritório de arquitetura em moldes profissionais. Em 1957, com Giancarlo Palanti, foi o quinto colocado no concurso para o Plano Piloto de Brasília. Morreu aos 60 anos, em 1971, mas ainda hoje o escritório Mindlin e Arquitetos Associados funciona sob a direção da antiga equipe de sócios e colaboradores.

${ }^{18}$ MINDLIN, Henrique, op. cit., p. 21.
} 
Habitacionais", seguido de "Escolas, Hospitais, Igrejas, Prédios Esportivos e de Recreação, Museus e Pavilhões de Exposições", "Administração, Comércio e Indústria", fechando com o bloco "Transporte, Urbanismo e Paisagismo". Observa-se uma grande diferença em relação ao critério que privilegia os grandes edifícios públicos.

Como também já foi citado, só em 1999 o livro será traduzido e editado em português ${ }^{19}$. Mantendo o prefácio de S. Gideon e praticamente o seu formato original, a edição ganha uma apresentação de Lauro Cavalcanti e um bloco de "Projetos Complementares 1956 - 1960", onde é incluída uma seleção de projetos de Henrique Mindlin realizados após a primeira edição. É exatamente Cavalcanti quem comenta que

"Uma das grandes virtudes do livro de Henrique
Mindlin é o igual tratamento e importância dados a
prédios já consagrados e àqueles que, por sua
menor escala ou por ter um autor menos
proeminente, poderiam, apesar de suas grandes
qualidades, permanecer desconhecidos"

Nesse processo de ampliação do acervo da boa arquitetura moderna no Brasil, Mindlin inclui Rino Levi. Assim, são apresentados os projetos Cinema Art Palácio (na verdade, o cinema mostrado é o Ufa Palace) [o7], São Paulo-1936, Cinema Ipiranga e Hotel Excelsior[o8], São Paulo, 1941, Depósito e Fábrica da Companhia Café Jardim[o9], São Paulo, 1942, Casa de Rino Levi[1o], São Paulo, 1944, Maternidade da Universidade de São Paulo[11], com F. A. Pestalozzi e Roberto Cerqueira Cesar, São Paulo, 1944, Sede do Instituto de Arquitetos do Brasil Departamento de São Paulo[12], com outros, São Paulo, 1942,

\footnotetext{
${ }^{19}$ MINDLIN, Henrique. Arquitetura Moderna no Brasil. Trad. Paulo Pedreira; prefácio de S. Gideon; apresentação de Lauro Cavalcanti. Rio de Janeiro, Aeroplano Editora, 1999.

${ }^{20}$ CAVALCANTI, Lauro. MINDLIN, Henrique E., Arquitetura Moderna no Brasil, p.12.
} 
Teatro da Sociedade de Cultura Artística[13], com Roberto de Cerqueira Cesar, São Paulo, 1951, Edifício do Banco Paulista de Comércio[14], com Roberto de Cerqueira Cesar, São Paulo, 1947, Edifício Residencial Prudência[15], com Roberto de Cerqueira Cesar, São Paulo, 1944, Projeto do Edifício da Companhia Nacional de Seguros de Vida de São Paulo[16], com Roberto de Cerqueira Cesar, São Paulo, 1952, Residências dos Estudantes da Universidade de São Paulo[17], com Roberto de Cerqueira Cesar, São Paulo, 1953, Casa de Milton Guper[18], com Roberto de Cerqueira Cesar, São Paulo, 1951, Casa de Olivo Gomes[19], com Roberto Cerqueira Cesar, São José dos Campos, 1953. Conjunto Habitacional para operários da Tecelagem Parahyba S.A[20], com Roberto Cerqueira Cesar, São José dos Campos, $1954 \mathrm{e}$ Instituto Central do Câncer (Hospital Antônio Candido de Camargo)[21], com Roberto Cerqueira Cesar, São Paulo, 1954.

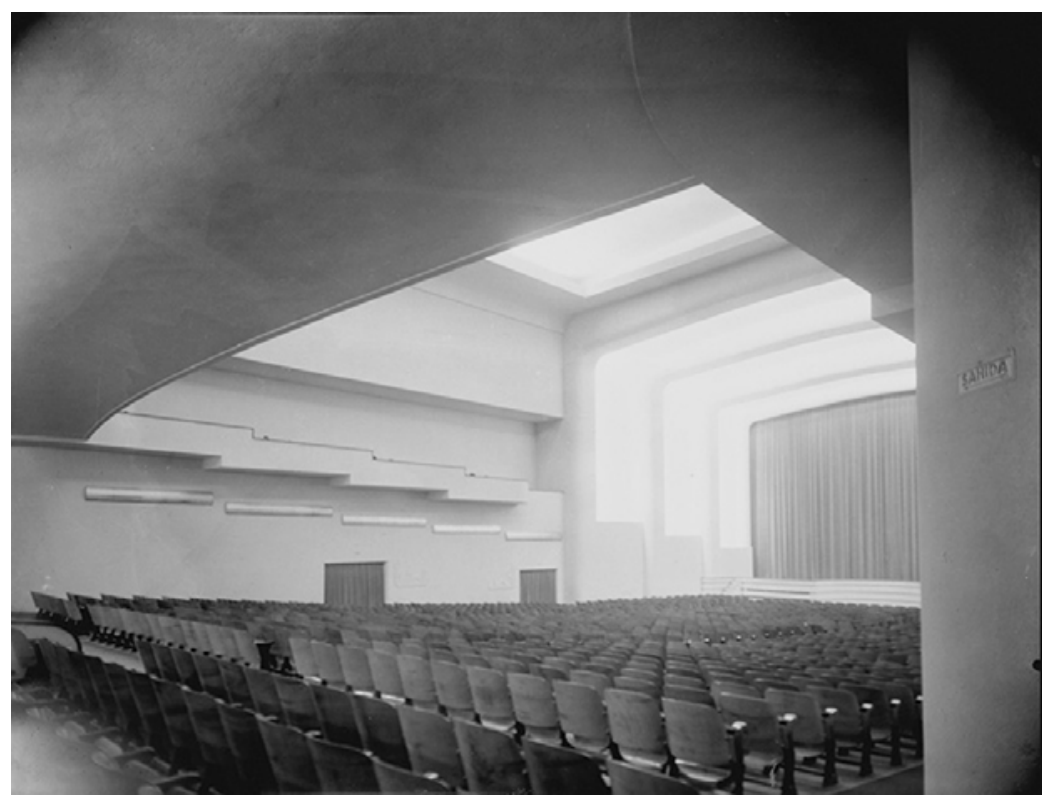




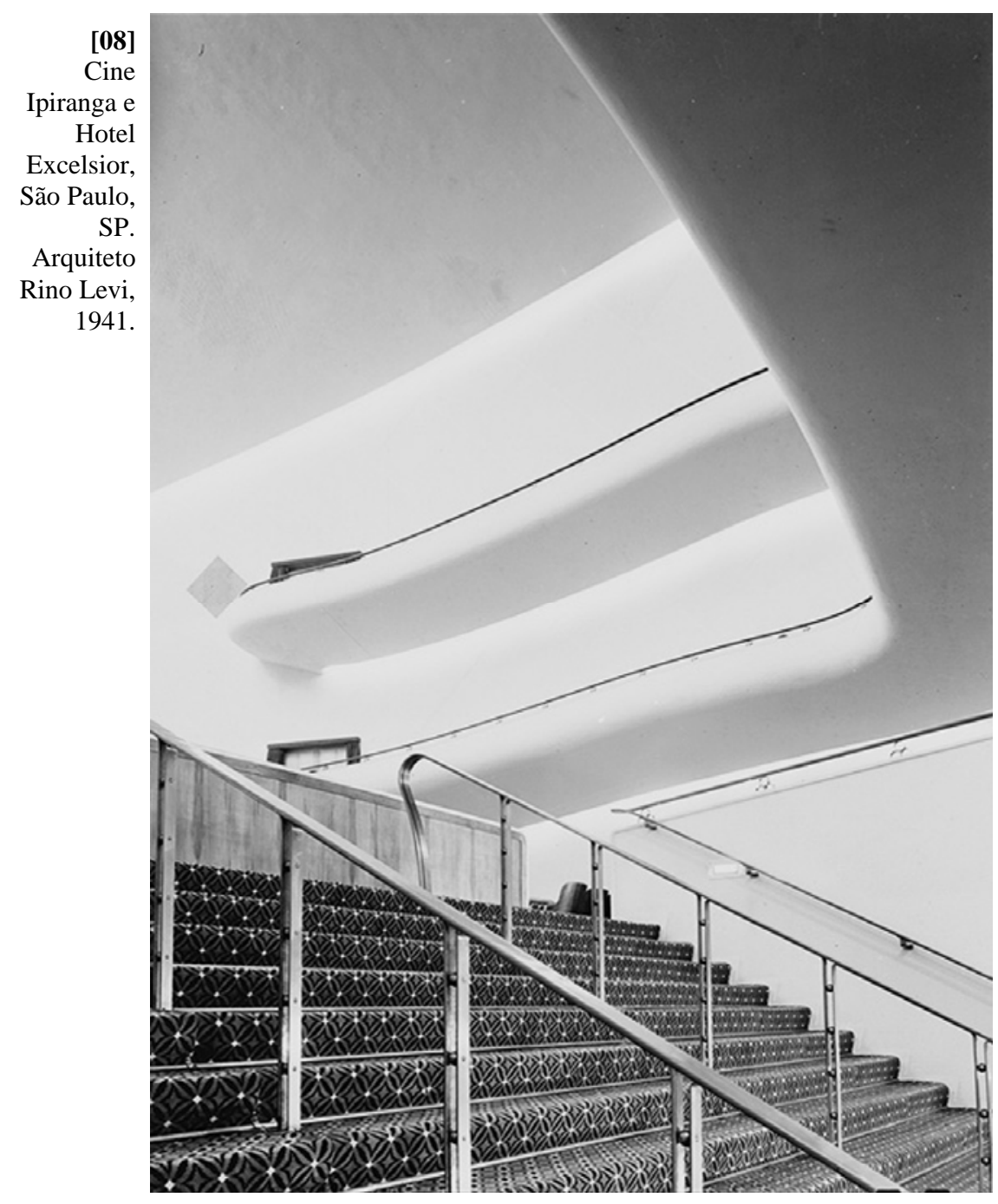




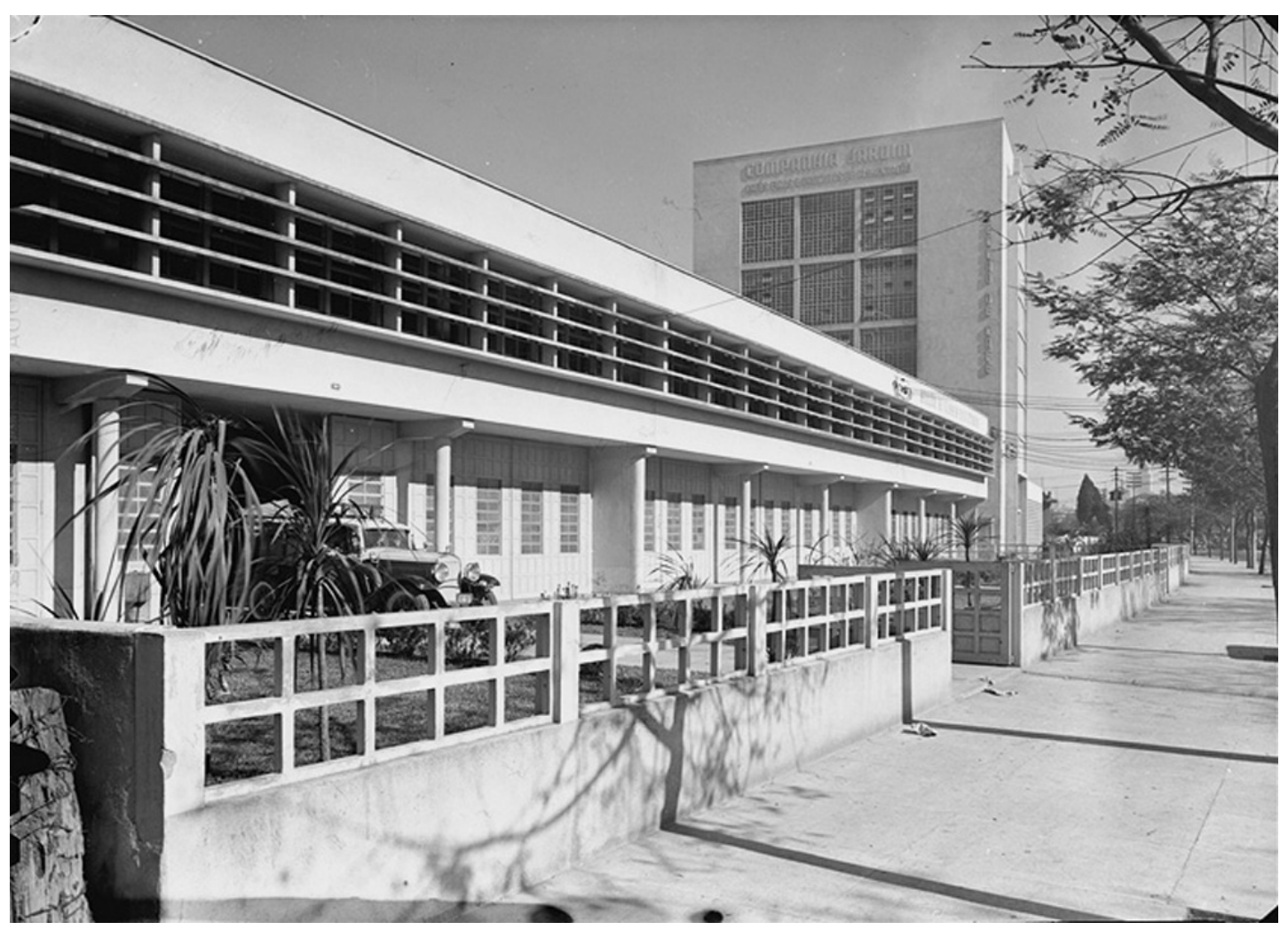

[09] Cia. Jardim de Cafés Finos, São Paulo, SP. Arquiteto Rino Levi, 1942.

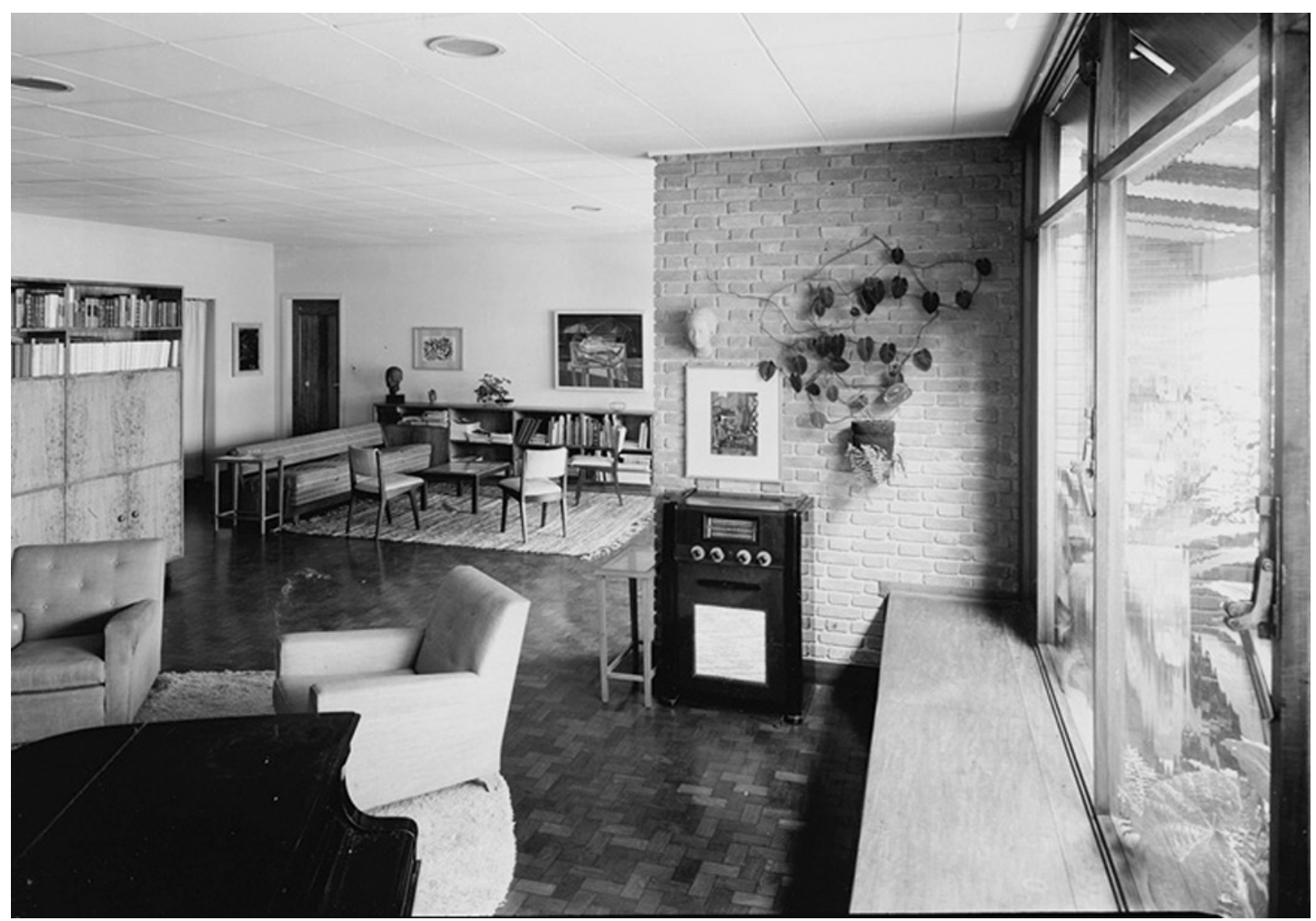

[10] Residência Rino Levi, São Paulo, SP. Arquiteto Rino Levi, 1944. 

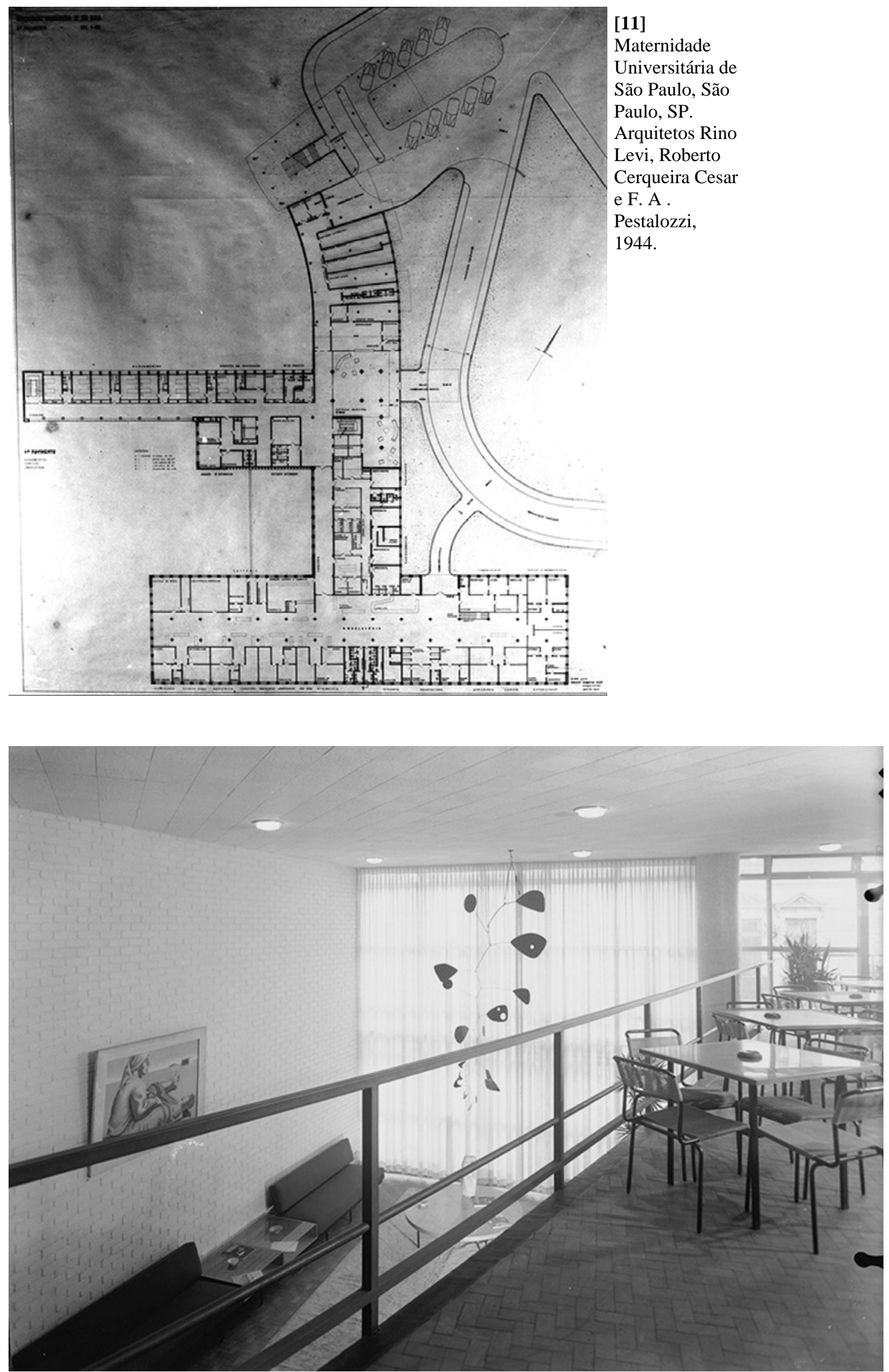

[12] Edifício Sede do Instituto dos Arquitetos do Brasil ( $1^{\circ}$ classificado ex aequo), São Paulo, SP. Arquitetos Rino Levi, Abelardo de Souza, Galiano Ciampaglia, Hélio Duarte, Jacob Ruchti, Miguel Forte e Zenon Lotufo, 1947. 

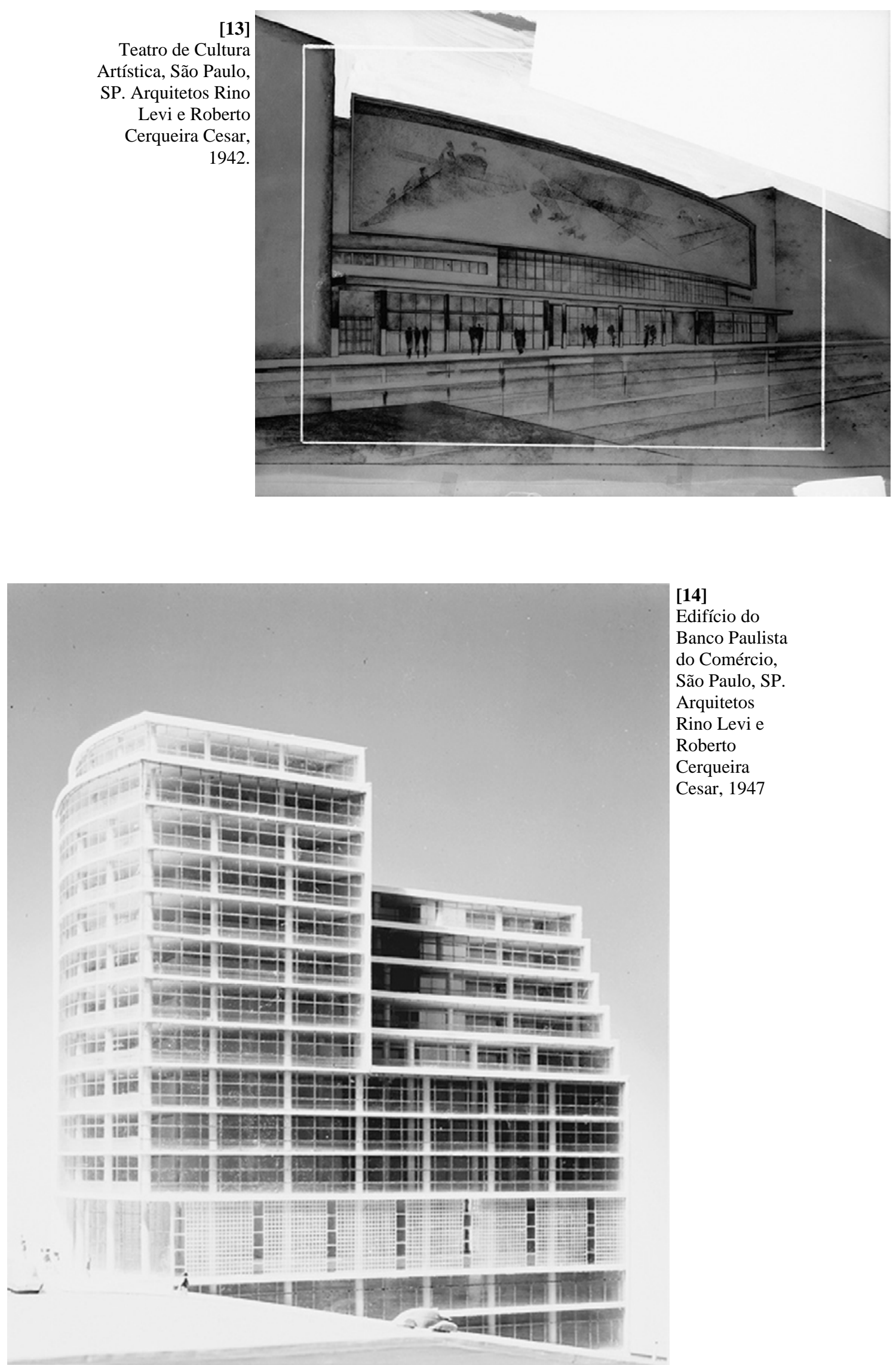

[14]

Edifício do

Banco Paulista

do Comércio,

São Paulo, SP.

Arquitetos

Rino Levi e

Roberto

Cerqueira

Cesar, 1947 


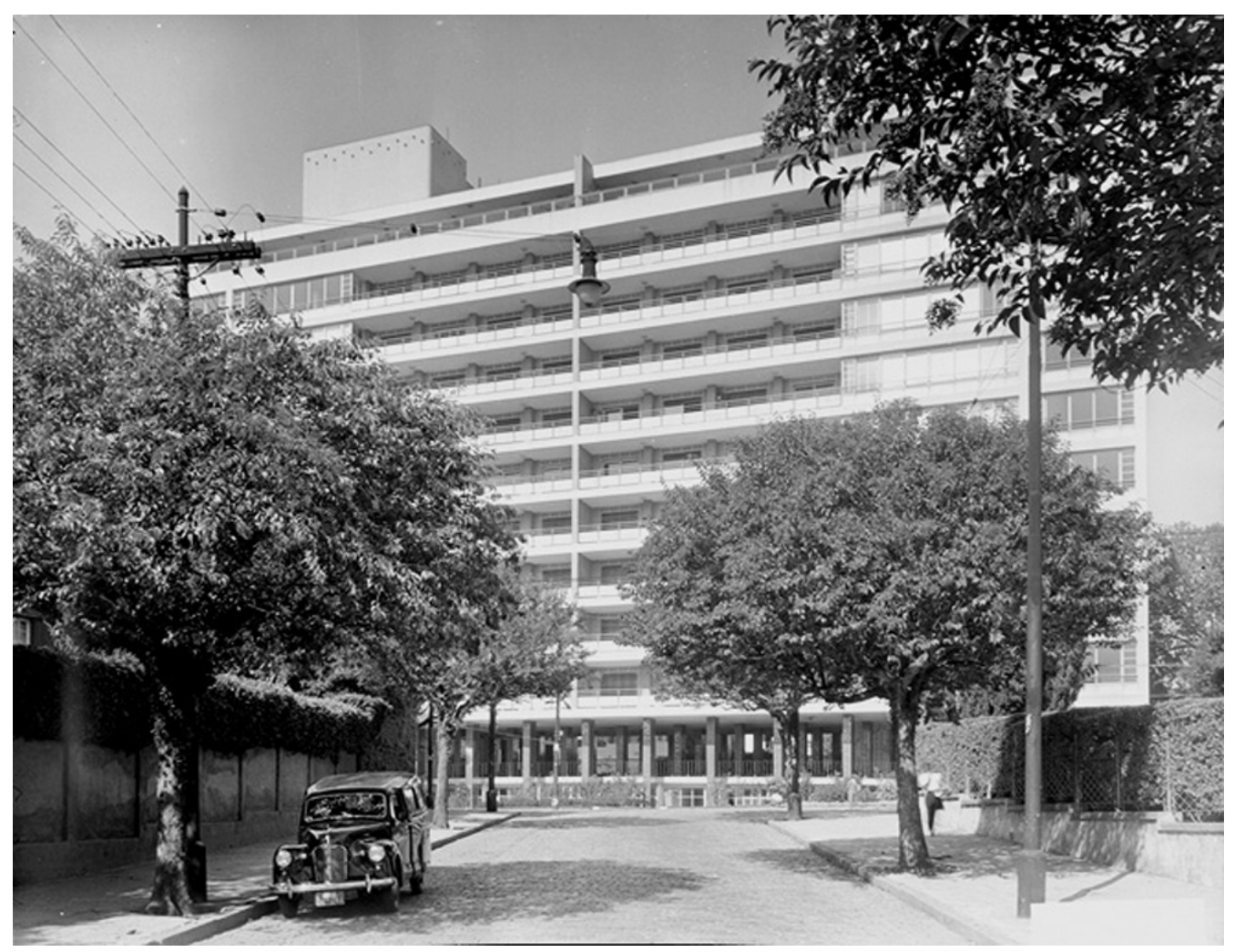

[15] Edifício de Apartamentos Prudência, São Paulo, SP. Arquitetos Rino Levi e Roberto Cerqueira Cesar, 1944.

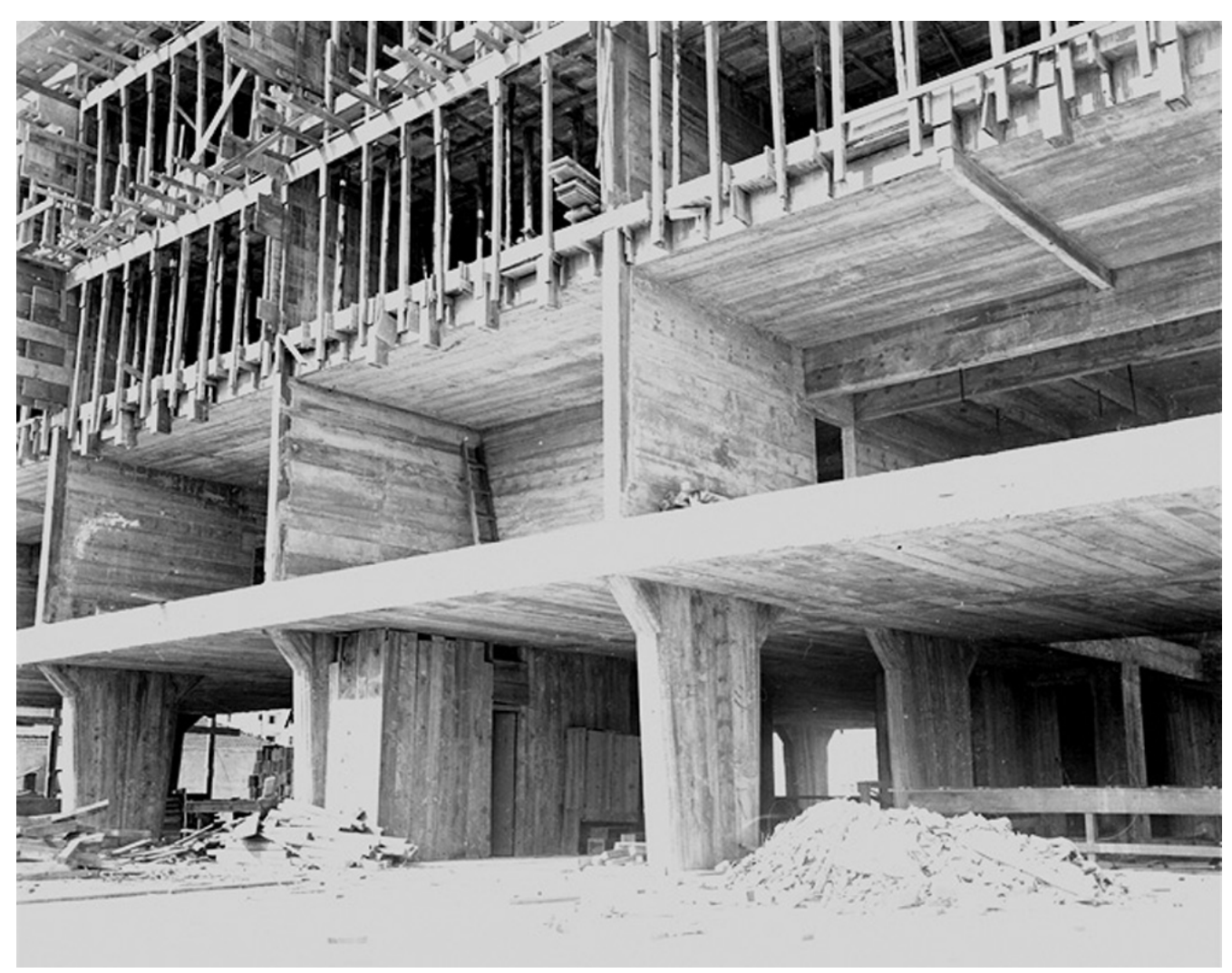

[16] Edifício de Escritórios da Cia. Nacional de Seguros de Vida de São Paulo, São Paulo, SP. Arquitetos Rino Levi e Roberto Cerqueira Cesar, 1952. 


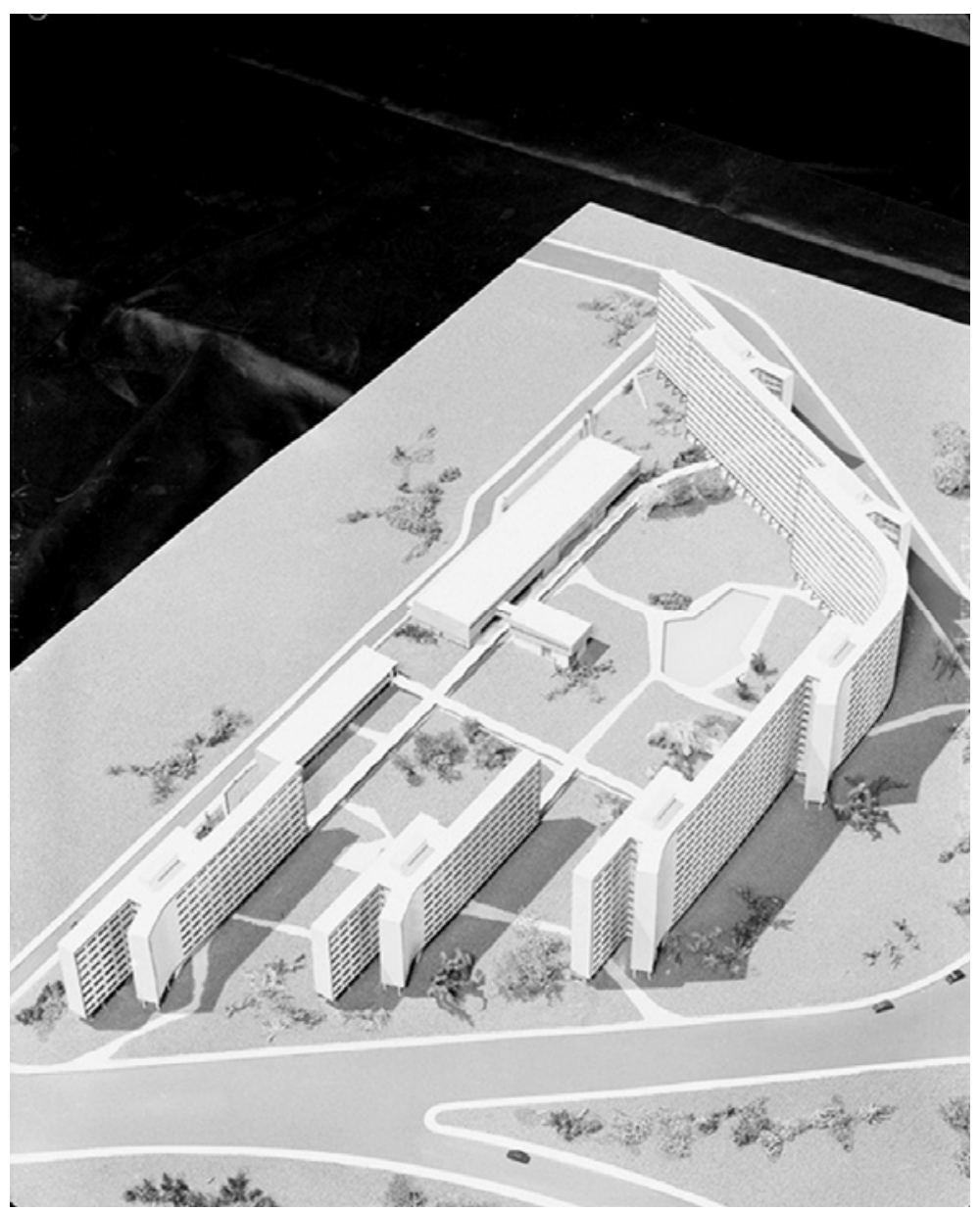

[17]

Conjunto

Residencial

Estudantil da

Universidade

de São Paulo,

São Paulo, SP.

Arquitetos Rino

Levi e Roberto

de Cerqueira

Cesar, 1953.

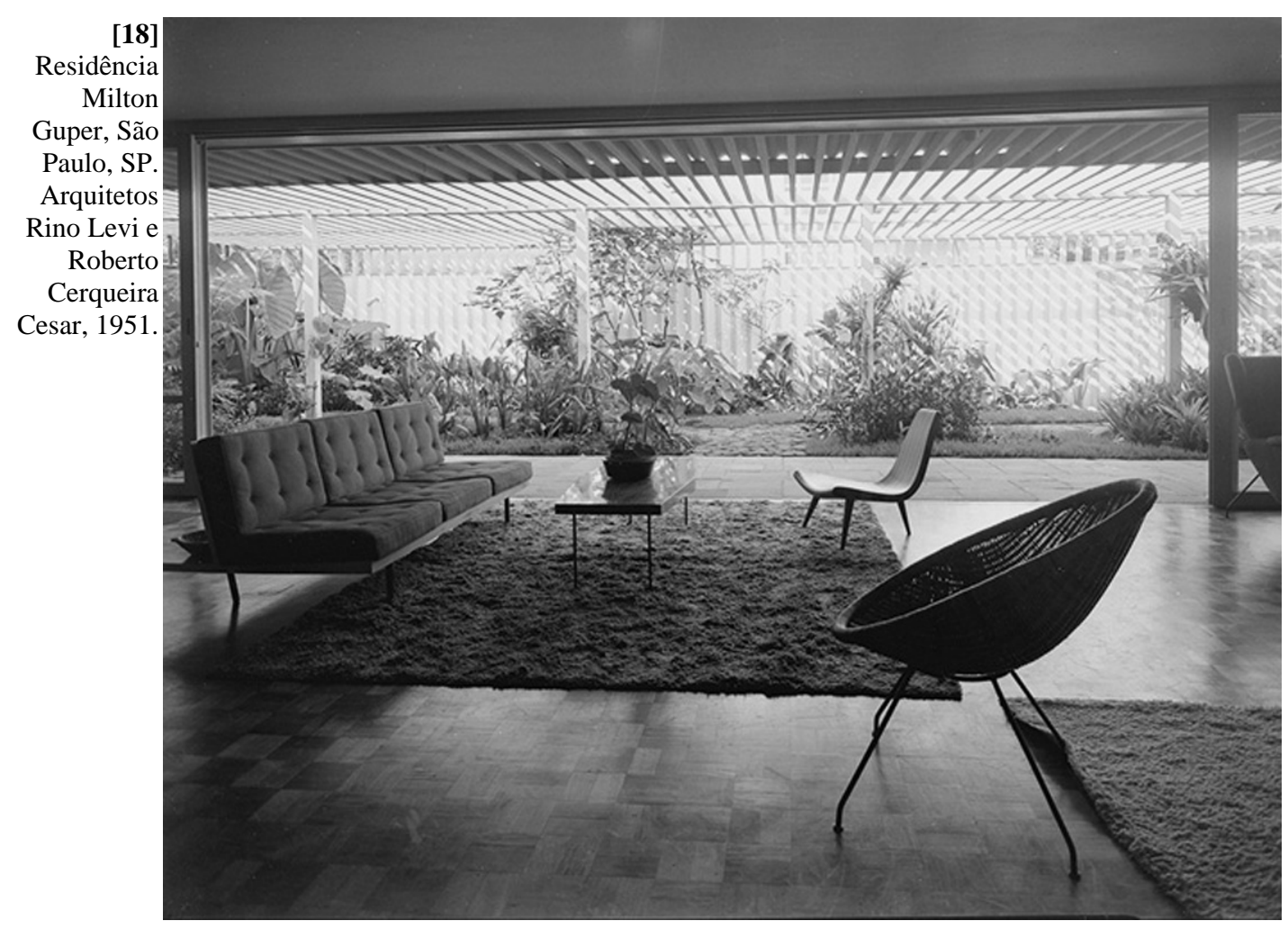




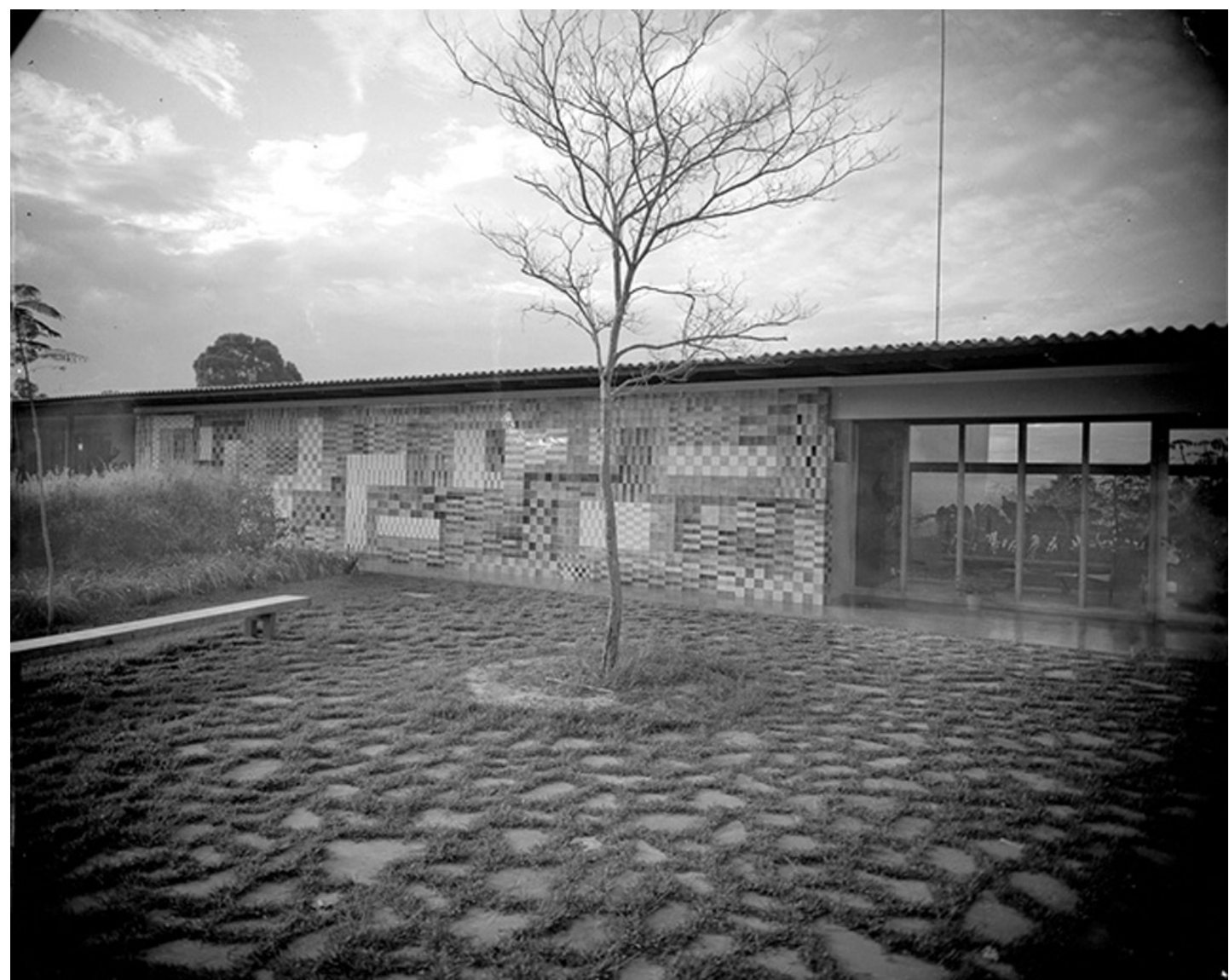

[19] Residência Olivo Gomes, São José dos Campos, SP. Arquitetos Rino Levi e Roberto Cerqueira Cesar, 1953.
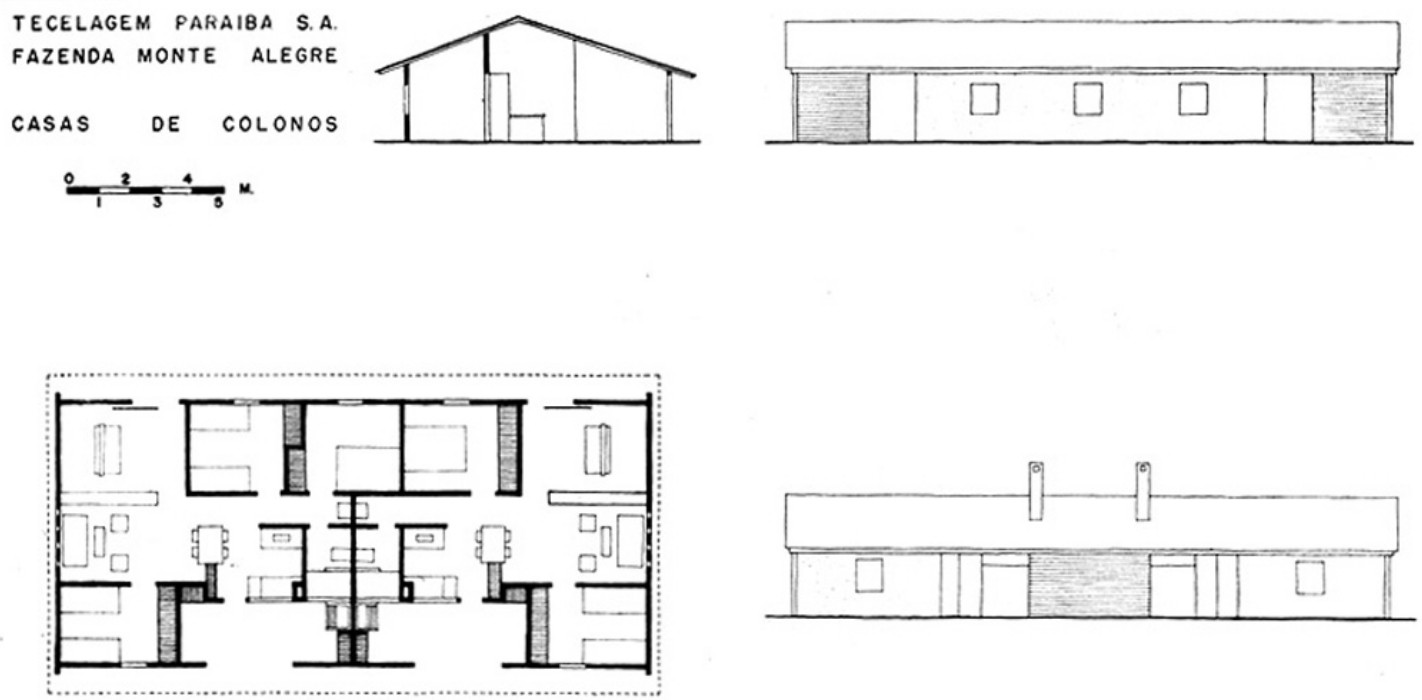

[20] Conjunto Residencial Tecelagem Parahyba S/A, São José dos Campos, SP. Arquitetos Rino Levi e Roberto Cerqueira Cesar, 1954. 


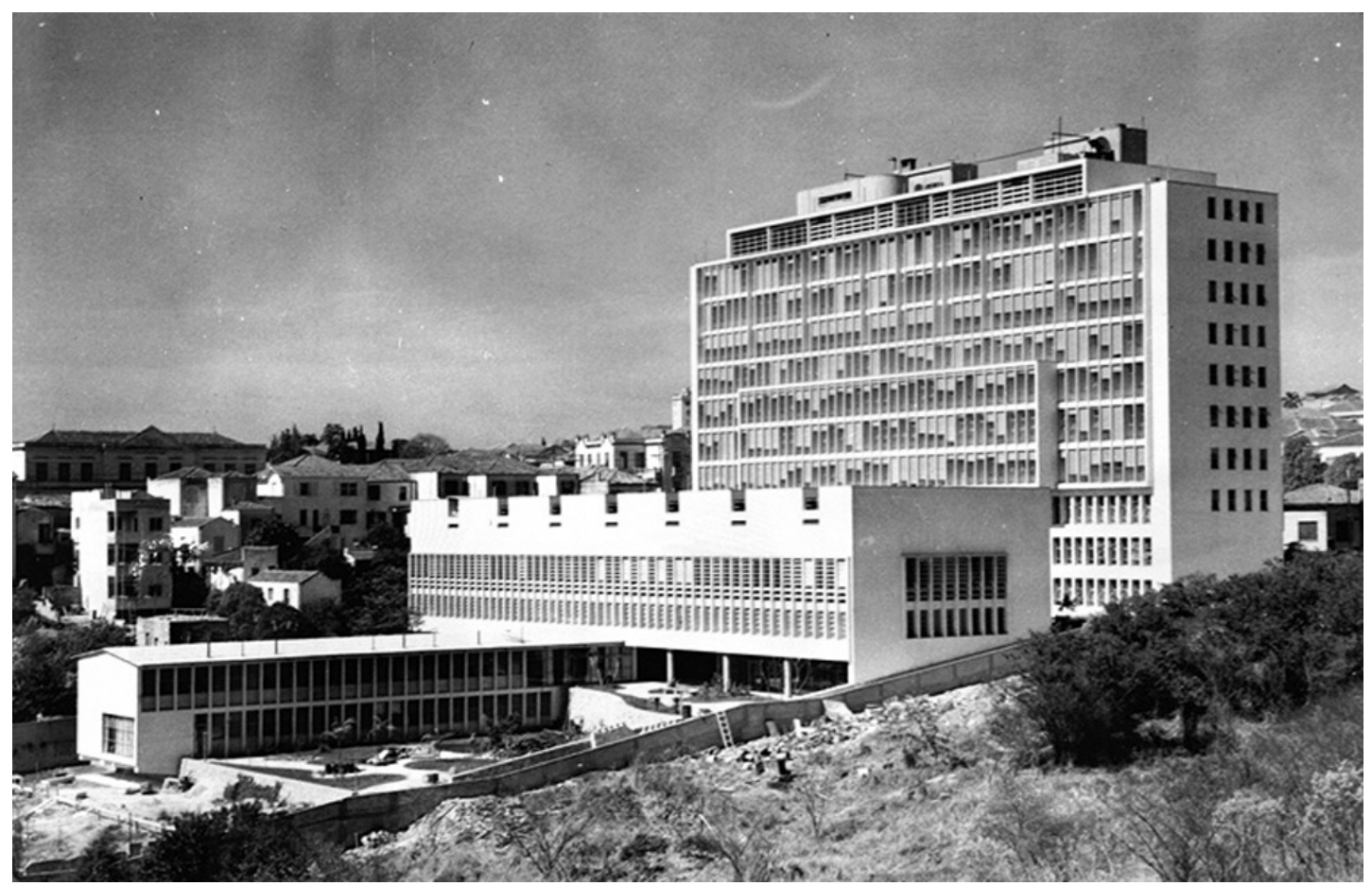

[21] Hospital Antônio Cândido de Camargo, do Instituto Central do Câncer, São Paulo, SP. Arquitetos Rino I.evi e Roherto Cernueira C.esar. 1947/54

A relação acima demonstra como, inequivocamente, há agora um espaço para a documentação das obras de Rino Levi, nesse período já trabalhando regularmente com Roberto Cerqueira Cesar. Apesar disso, no texto que apresenta a Arquitetura Moderna no Brasil, onde Mindlin retoma as principais diretrizes definidas por Goodwin, ele ainda está ausente. Aparece apenas na nova apresentação, onde Lauro Cavalcanti - na listagem dos arquitetos que o Brasil produziu - cita que "Rino Levi explorou, com maestria, o espaço arquitetural a serviço do conforto do usuário" ${ }^{21}$. Teria, no entanto, que esperar mais duas décadas e meia para, com o livro de Bruand, passar a fazer parte da história.

Carlos Martins observa que:

"Assim como o texto de Goodwin, o trabalho de Mindlin não deixa de constituir um marco referencial na historiografia da arquitetura

\footnotetext{
${ }^{21}$ MINDLIN, Henrique, op. cit., p.12.
} 
brasileira. De um lado pela amplitude e rigor do levantamento da produção arquitetural que realiza, de outro por que vai, no seu texto, ainda que curto, constituindo um esquema explicativo, cuja sobrevivência teremos a oportunidade de verificar e, afinal, porque a própria característica de "cadastramento" de projetos vai acabar por definir um estilo historiográfico na arquitetura brasileira. A rigor é comum na bibliografia de arquitetura a edição de levantamentos documentais precedidos por um breve texto de apresentação. No Brasil, entretanto, eles constituem o grosso da produção $e$ recebem o status de historiografia." 22

A situação se modifica com o texto de Yves Bruand, que reconhece, logo no prefácio, que sua escolha do tema:

“(...) surgiu da constatação de que a arquitetura brasileira só conhecera dois grandes períodos de atividade criadora: o da arte luso-brasileira dos séculos XVII e XVIII, estudado por Germain Bazin numa tese recente, e o período atual, abordado apenas superficialmente em publicações de caráter documental. (...) Aqui não será abordado o problema da documentação, que é tratado como apêndice na parte dedicada às fontes e a bibliografia. (...) Esperamos, contudo, que, apesar de suas falhas e do risco de ver suas conclusões novamente questionadas em prazo talvez bastante curto, este trabalho permaneça útil, não só pela documentação reunida, bem como por sua tentativa

${ }^{22}$ MARTINS, Carlos Alberto F. , op. cit., p. 29. 
de síntese, mesmo que possa esta parecer ligeiramente prematura. ${ }^{23}$

Dessa maneira, se por um lado Bruand perpetua a leitura dos dois momentos importantes para a nossa arquitetura, por outro desloca o foco da nossa incipiente historiografia, avaliando como superficial o nosso estilo constituído por pequeno esquema explicativo seguido de cadastramento de projetos. Propõe, até por força de sua formação, uma análise crítica dessa produção, comparando fontes e cotejandoas com diferentes versões e, pela primeira vez, construindo uma interpretação "não apenas da evolução interna da série arquitetônica, mas das suas relações com a situação cultural, técnica e política em que se desenvolve." ${ }^{24}$ Neste contexto, finalmente, Rino Levi, ou melhor, o Escritório Rino Levi Arquitetos Associados, passa a fazer parte da história.

A primeira questão interessante na síntese de Bruand está ligada a sua tentativa de apresentação do Brasil aos europeus ${ }^{25}$. Assim, dedica o seu primeiro capítulo ao Meio Brasileiro e sua influência sobre a Arquitetura $^{26}$, onde trabalha com o Meio Geográfico, As Condições Econômicas e As Condições Históricas. Com essa perspectiva, observa, por exemplo, características "desconhecidas dos arquitetos europeus, como cortes frequentes no fornecimento de água, o que obriga a prever em todo edifício um reservatório, cuja capacidade varia em função do consumo, mas deve, em qualquer hipótese, assegurar autonomia por

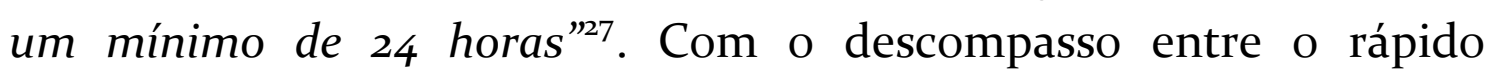
crescimento das cidades e o oferecimento pelo Estado de água encanada, surge a caixa d'água que impõe uma nova utilidade para os

\footnotetext{
${ }^{23}$ BRUAND, Yves, op. cit., p.7/ 8.

${ }^{24}$ MARTINS, Carlos Alberto F., op. cit., p. 44.

${ }^{25}$ Bruand, pesquisador da École de Chartres, foi professor do Departamento de História da Faculdade de Filosofia, Letras e Ciências Humanas da Universidade de São Paulo, período em que desenvolveu sua tese de doutoramento, apresentada na França, que deu origem ao livro comentado.

${ }^{26}$ BRUAND, Yves, op. cit., pp. 11-29.

${ }^{27}$ BRUAND, Yves, op. cit., p. 13.
} 
telhados, ou - no caso da adoção das lajes planas - um novo elemento de projeto

Ainda preocupado com o clima, nota que os sistemas de aquecimento interno são praticamente inexistentes, "ponto que merece ser ressaltado, pois é um aspecto fundamental em outros países, e implica uma série de limitações. Já o arquiteto brasileiro, não tendo que se preocupar com a instalação de uma complicada rede de encanamentos, tem muito mais liberdade na elaboração do projeto, podendo frequentemente propor soluções mais independentes" ${ }^{28}$.

Trabalhando as nossas condições econômicas e sociais, Bruand observa que o Brasil viu-se numa situação social intermediária, entre a civilização industrial de tipo europeu ou norte-americano e o antigo regime, cujas consequências podem ser sentidas ainda hoje. Sob esse aspecto, "as leis municipais, denominadas Códigos de Obras, não raro conservam os vestígios de um passado relativamente recente; exemplo característico é a possibilidade legal, em São Paulo, de colocar no fundo do terreno, em construção separada, as dependências de empregada: trata-se evidentemente de um resquício da senzala"29.

Quando comenta as nossas Condições Econômicas, trata dos Recursos Naturais e Materiais Tradicionais, dos Materiais Artificiais e Contexto Industrial, observando "que o êxito do concreto armado no Brasil não pode ser explicado unicamente por razões econômicas, mas não há dúvidas de que estas tiveram um papel decisivo, pois seus componentes básicos, areia e cascalho, eram encontrados em qualquer lugar, a preços muito baixos. Além disso, a preparação do concreto no próprio canteiro de obras não exigia operários qualificados, fato importante num país onde eles são escassos, mas que, em compensação, conta com uma abundante mão-de-obra não qualificada. ...O concreto armado era o único material moderno que se prestava ao

\footnotetext{
${ }^{28}$ BRUAND, Yves, op. cit. , p. 13.

${ }^{29}$ BRUAND, Yves, op. cit., p. 20.
} 
trabalho artesanal e, por conseguinte, o mais bem adaptado às necessidades de um país subdesenvolvido. (...) Portanto, independentemente de suas qualidades técnicas e plásticas, o concreto armado apresentava a vantagem de ser, de longe, o material mais barato para toda estrutura de maior porte" ${ }^{\circ}$.

A primeira referência feita a Rino Levi se dá quando Bruand analisa a presença dos produtos metalúrgicos na arquitetura brasileira. Apesar da matéria-prima abundante, eles dependiam da existência de uma poderosa indústria e, os esforços para sua implementação remontam à época do império. Mesmo assim, "o primeiro edifício com estrutura de aço construído no Brasil (1954), foi projetado por Rino Levi e equipe; trata-se da Garagem América[22], na Rua Riachuelo em São Paulo. (...) o aço não era uma solução econômica, que pudesse concorrer com o concreto armado, o que acontece ainda hoje, ao menos em relação aos grandes edifícios, apesar das importantes usinas siderúrgicas brasileiras criadas no após-guerra" ${ }^{\prime 1}$. Embora aponte o pioneirismo do escritório, Bruand o trata, literalmente, como nota de rodapé. A questão parece de grande relevância e voltará a ser abordada .

\footnotetext{
${ }^{30}$ BRUAND, Yves, op. cit., p. 16.

${ }^{31}$ BRUAND, Yves, op. cit., p. 17.
} 


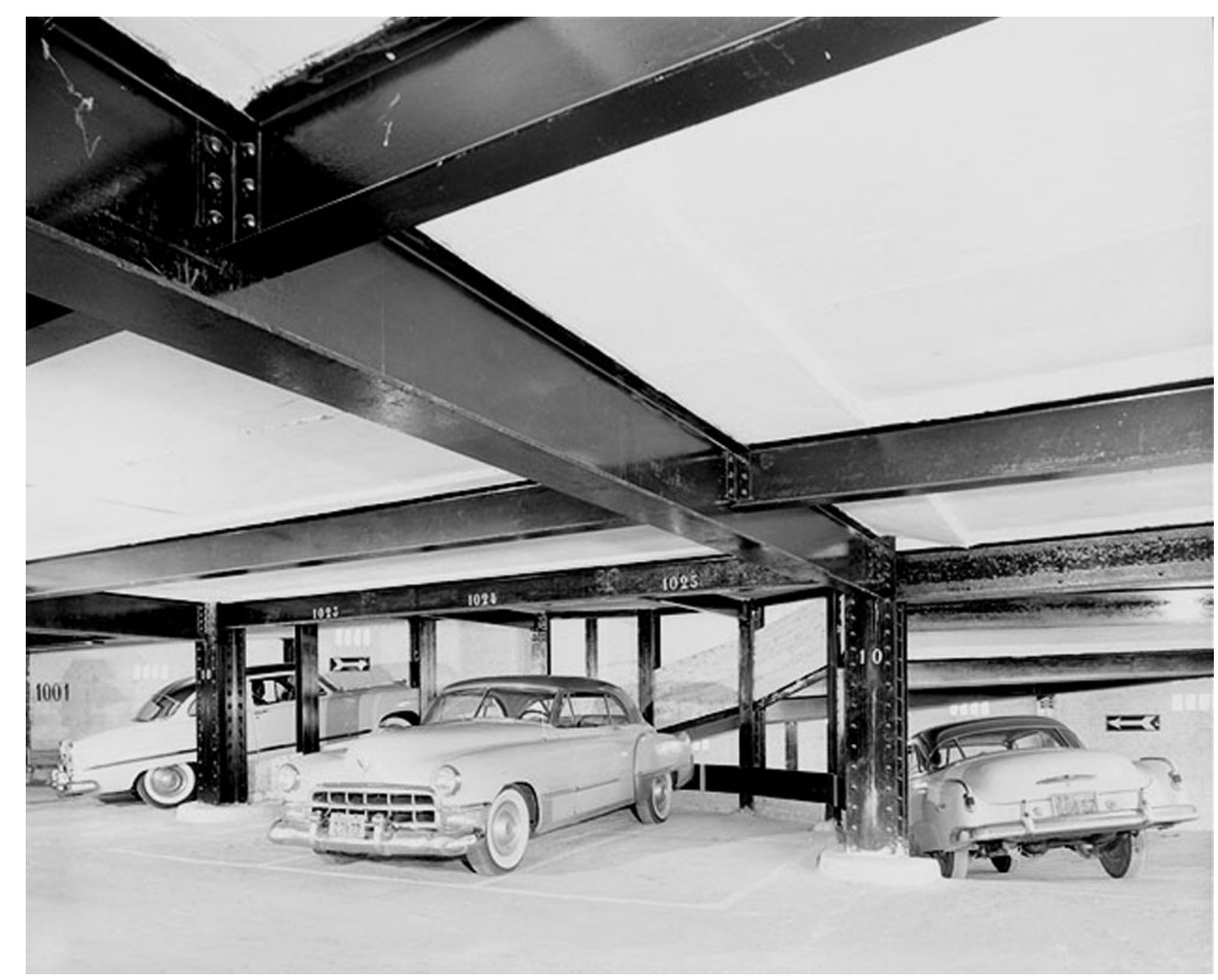

[22] Garagem América, São Paulo, SP. Arquiteto Rino Levi, 1952/54.

Apresentado o Brasil, o próximo passo é a apresentação da sua arquitetura. A periodização começa com o capítulo De um Ecletismo sem Originalidade à Afirmação Internacional da Nova Arquitetura Brasileira (1900-1945). Nos manuais anteriores, a produção entre os dois momentos considerados de excelência na arquitetura brasileira nem aparecia. Agora, mesmo que considerados sem originalidade, são introduzidos os estilos classicizantes, os medievais e pitorescos, o artnouveau e o neocolonial, todos classificados como "Estilos Históricos"32.

Segundo Bruand, "assim como evidentemente os estilos históricos não desapareceram de um momento para outro, o movimento moderno não surgiu repentinamente. Por mais que assim possa parecer, ele é no

\footnotetext{
${ }^{32}$ BRUAND, Yves, op. cit., pp. 33-59.
} 
entanto resultado da evolução do pensamento de alguns grupos intelectuais brasileiros, especialmente paulistas, evolução essa que criou um mínimo de condições favoráveis, sem as quais as primeiras realizações do gênero não teriam frutificado"33. Essa evolução é tratada sob o nome de As Premissas da Renovação (1922-1935), onde são abordadas a vanguarda paulista e a Semana de Arte Moderna, o papel e a obra de Gregori Warchavchik e os manifestos de 1925. Encontramos aqui a segunda referência a Rino Levi, outra vez como nota de rodapé, quando da sua carta enviada ao jornal $O$ Estado de São Paulo e publicada em 15 de outubro de 1925, sob o título $A$ Arquitectura e a Esthética das Cidades. Nessa época, Rino também é estudante de arquitetura em Roma, primeira de uma série de semelhanças ao percurso de seu colega mais velho ${ }^{34}$.

O terceiro personagem dessas premissas de renovação, citado por Bruand, é Flávio de Rezende Carvalho, “que tendo já em 1927 proposto um projeto moderno para a fachada do Palácio do Governo do Estado de São Paulo35[23], jamais soube esse arquiteto se impor; seu diletantismo e a falta de receptividade que suas idéias encontraram junto à opinião pública explicam a total ausência de repercussão obtida por uma obra, cujo autor parecia, à primeira vista, estar mais fadado ao sucesso do que um imigrante recém-chegado. (...) enquanto Warchavchik se preocupava, acima de tudo, com a viabilidade de construir aquilo que projetava, Flávio de Carvalho acumulava projetos não edificados e contentava-se com dissertações teóricas em congressos de arquitetura. Sua influência foi tão insignificante que a opinião pública atribuía suas raras realizações a Warchavchik, como o

\footnotetext{
${ }^{33}$ BRUAND, Yves, op. cit., p. 61.

34 A carta de Levi é publicada quinze dias antes do artigo de Warchavchik, Acerca da Arquitetura Moderna, sair em um dos grandes jornais do Rio de Janeiro, o Correio da Manhã, em $1^{\circ}$ de novembro de 1925. O artigo é conhecido como o $1^{\circ}$ manifesto de arquitetura moderna no Brasil.

${ }^{35}$ Primeiro projeto de arquitetura de Flávio de Carvalho, realizado em concurso público para o Palácio do Governo de São Paulo, em 1927, intitulado pelo próprio autor como Eficácia.
} 
conjunto de casas do bairro do Jardim América em São Paulo ${ }^{36 " 37}$ [24]. Dessa maneira, se Bruand inscreve Flávio no processo de renovação, o faz de forma quase desrespeitosa.

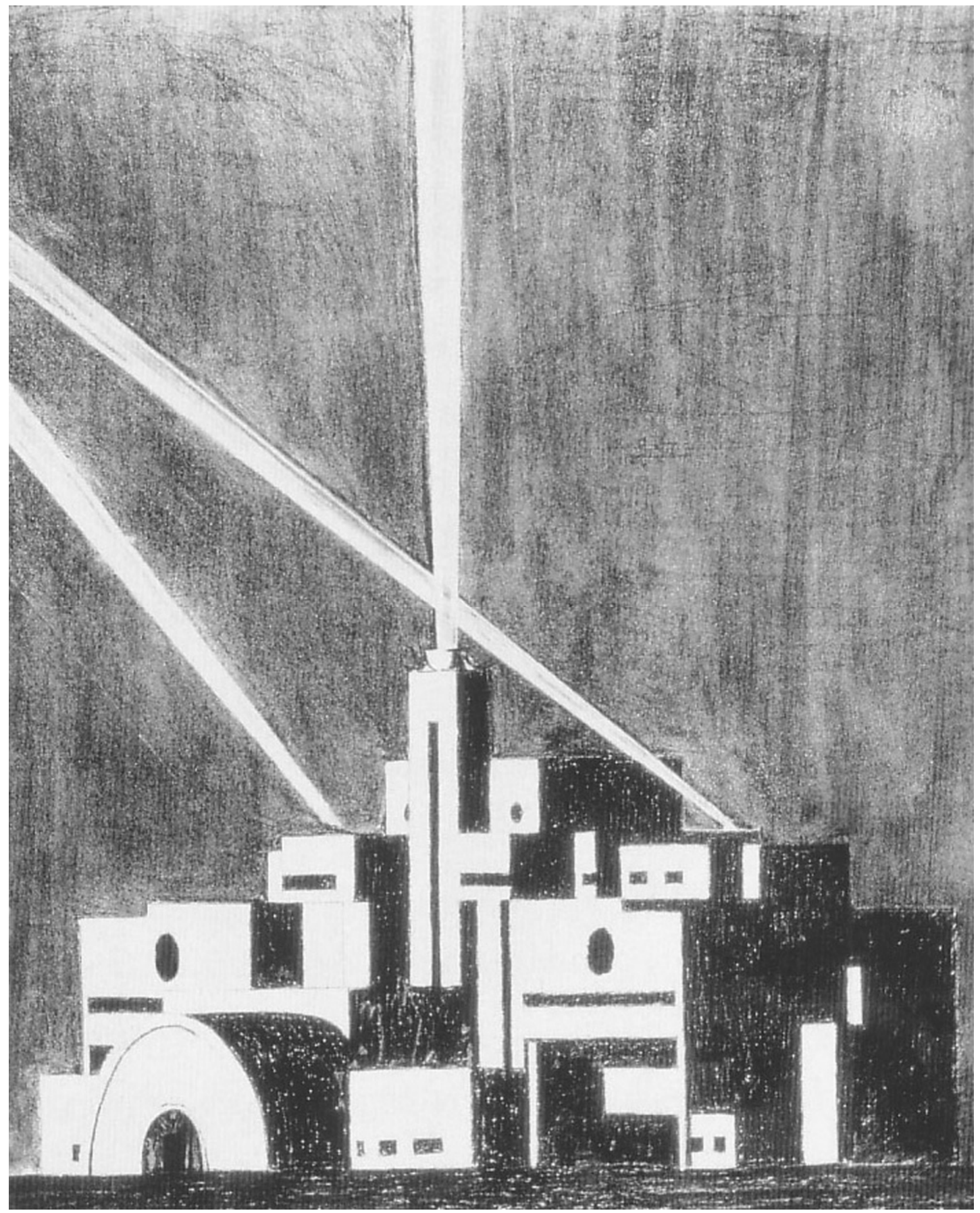

「23l Palácio do Governo - concurso búblico. São Paulo. SP. Arauiteto Flávio de Carvalho.1927.

\footnotetext{
${ }^{36}$ Vila das Alamedas Lorena e Ministro Rocha Azevedo, São Paulo, SP, projeto de 1936, inaugurada em 1938. Em forma de L, são ao todo dezessete casas: dez de frente para as alamedas, e sete internas, dando para uma praçinha.

${ }^{37}$ BRUAND, Yves, op. cit., p. 64.
} 


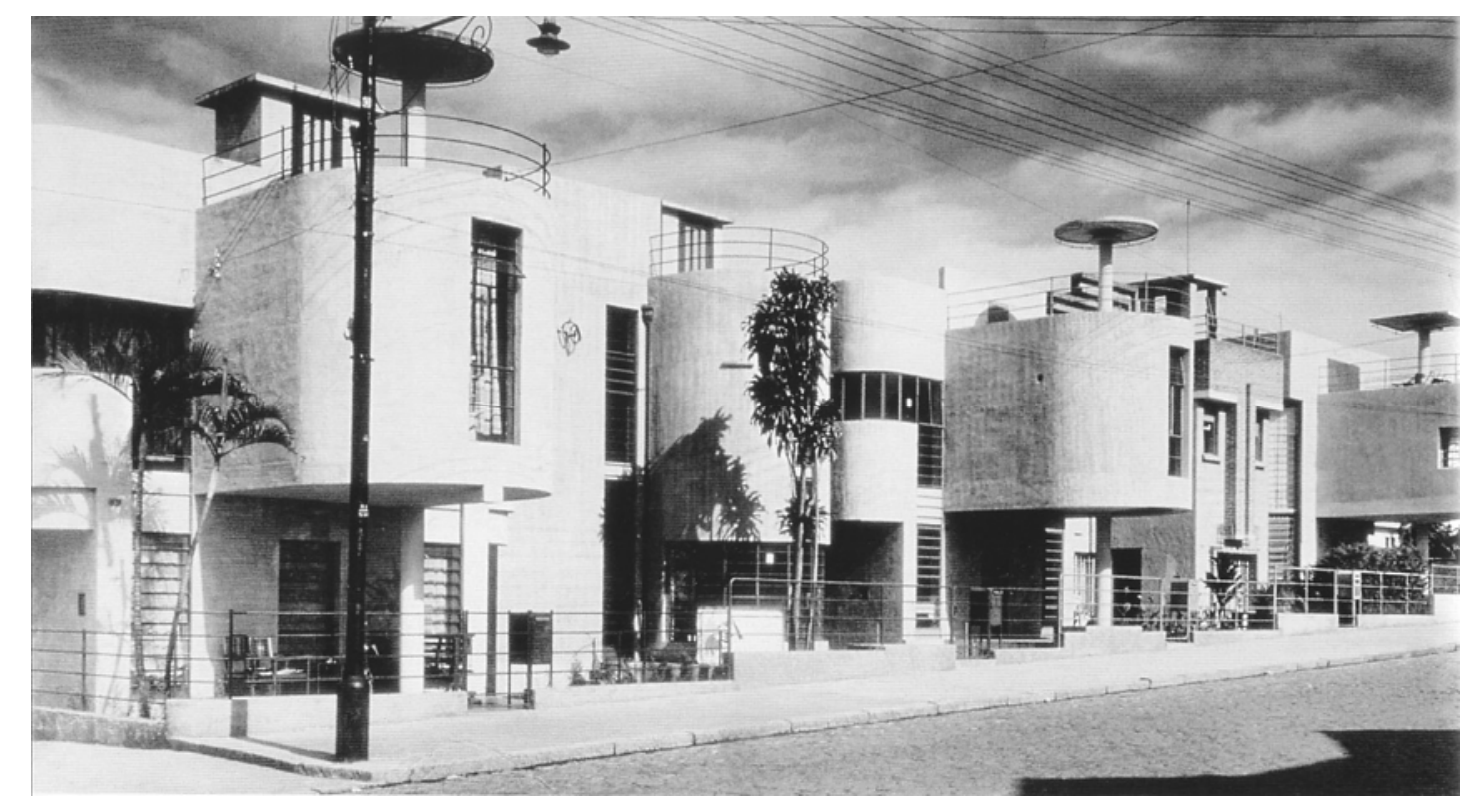

[24] Vila das Alamedas Lorena e Ministro Rocha Azevedo, São Paulo, SP. Arquiteto Flávio de Carvalho, 1936/38.

Ficam restritas a Warchavchik e a Levi as manifestações teóricas que tiveram importância nas décadas de vinte e trinta em São Paulo, mas, para Bruand, o papel do primeiro é mais relevante. São dele as únicas obras analisadas do período: a casa do próprio arquiteto, à Rua Santa Cruz, 1927/28, considerada a primeira casa moderna em São Paulo e o grupo de projetos propiciado pelo sucesso desta.

De qualquer maneira, outra vez estava reservado ao Rio de Janeiro o papel mais importante. Bruand descreve o começo da arquitetura moderna no Rio de Janeiro, destaca a tentativa de Reforma da Escola de Belas-Artes e abre um rápido parênteses para Luís Nunes e o Movimento do Recife, quase ensaios para a Transformação Decisiva (1936-1944), capítulo que começa consagrando, outra vez, o Ministério da Educação e Saúde. O concurso, os diversos projetos, a elaboração do projeto definitivo pela equipe brasileira, tudo é analisado em detalhe. A ênfase fica por conta da contribuição de Le Corbusier e a profunda influência de sua estadia em 1936, a valorização dos elementos locais e sua consequente originalidade. 
Esse caráter peculiar é ainda a categoria de análise mais significativa em toda a segunda parte do livro: A Maturidade da Nova Arquitetura Brasileira: Unidade e Diversidade. Nela, o primeiro capítulo é dedicado à Arquitetura Nova e Tradição Local, onde o destaque fica com Lúcio Costa, embora seja apontada sua influência nas pesquisas paralelas dos outros arquitetos brasileiros. No segundo capítulo, O Triunfo da Plástica, esse papel cabe a Oscar Niemeyer. A Continuidade Racionalista marca o momento maduro da arquitetura brasileira. Neste terceiro capítulo - depois de destacar o papel de Affonso Reidy $^{38}$ - Bruand analisa as grandes construções de Rino Levi: prédios, hospitais, fábricas, etc..

Constatando que até aquele momento pouco tinha falado da nova arquitetura feita em São Paulo, Bruand aponta "dois motivos principais: de um lado, a menor vivacidade dos talentos paulistas e o atraso maior com que se impuseram, e, de outro, o fato de as criações mais originais não se encaixarem na linha propriamente racionalista, embora derivem dela indiscutivelmente" 39 . Dessa maneira, aceita e reitera com naturalidade o fato de a historiografia omitir os arquitetos que não se encaixam no racionalismo, neste caso sinônimo do raciocínio corbusiano. Conclui que Rino Levi "permaneceu fiel, mais que Warchavchik, à marca recebida durante a estadia na Itália (o que pode ser facilmente explicado por suas origens) e revelou ser menos sensível à influência de Le Corbusier do que a maioria de seus colegas

\footnotetext{
38 Affonso Eduardo Reidy (1909-1964), cidadão brasileiro, nasceu acidentalmente em Paris. Seu pai, engenheiro de nacionalidade britânica, fixou residência no Rio de Janeiro, após casar-se com brasileira , filha de um arquiteto italiano. Estudou no Curso de Arquitetura da Escola Nacional de Belas Artes (19261930), participando como estagiário, ainda na condição de estudante, do Plano de Remodelação, Extensão e Embelezamento da Cidade do Rio de Janeiro, projeto do urbanista francês Alfred Agache, Em 1931 foi assistente de Gregori Warchavchik, participando da fracassada renovação do ensino na escola levada a frente por Lúcio Costa, nomeado diretor pelo presidente Getúlio Vargas. Concursado em 1932, tornou-se funcionário da Prefeitura do Distrito Federal, onde pôde realizar suas mais importantes obras - os conjuntos habitacionais de Pedregulho (1948) e da Gávea (1952), o Museu de Arte Moderna do Rio de Janeiro -MAM-RJ (1952). Em 1936 foi um dos membros da lendária equipe de arquitetos que projetou o MÊS. Foi responsável, entre outras obras urbanas, pelo Plano de Urbanização da Esplanada do Castelo, em 1938. Sua experiência como urbanista, a maior dentre os arquitetos modernos brasileiros, torna muito estranha e polêmica sua ausência do concurso para o Plano Piloto de Brasília.

${ }^{39}$ BRUAND, Yves, op. cit., p. 249.
} 
brasileiros, devido a sua profunda vinculação a um país europeu de alta tradição cultural" ${ }^{40}$..

Para Bruand, essa referência é lida como um erro presente nos dois primeiros projetos analisados. Na Faculdade de Filosofia, Ciências e Letras "Sedes Sapientiae" da Pontifícia Universidade Católica de São Paulo[25] (1941/42), ao lado do elogio à concepção moderna tanto na técnica quanto na estética, lamenta o emprego sistemático de uma tonalidade ocre para os revestimentos, pois essa cor neutra, lembrança da Cidade Eterna transposta para os trópicos, não convinha a uma arquitetura austera que não era animada por diferenças marcantes de relevo. O prédio de apartamentos Prudência ${ }^{41}$ [26] padece do mesmo defeito, pois "foi considerada como um modelo pela flexibilidade obtida na disposição interna dos cômodos, mas o abuso de cores escuras, emprestadas da gama dos marrons, não contribui para valorizar a obra no plano plástico" ${ }^{42}$

\footnotetext{
${ }^{40}$ BRUAND, Yves, op. cit., p.249.

${ }^{41}$ Edifício Prudência, São Paulo, SP, 1944, com Roberto Cerqueira Cesar.

${ }^{42}$ BRUAND, Yves. Op. cit., p.250.
} 


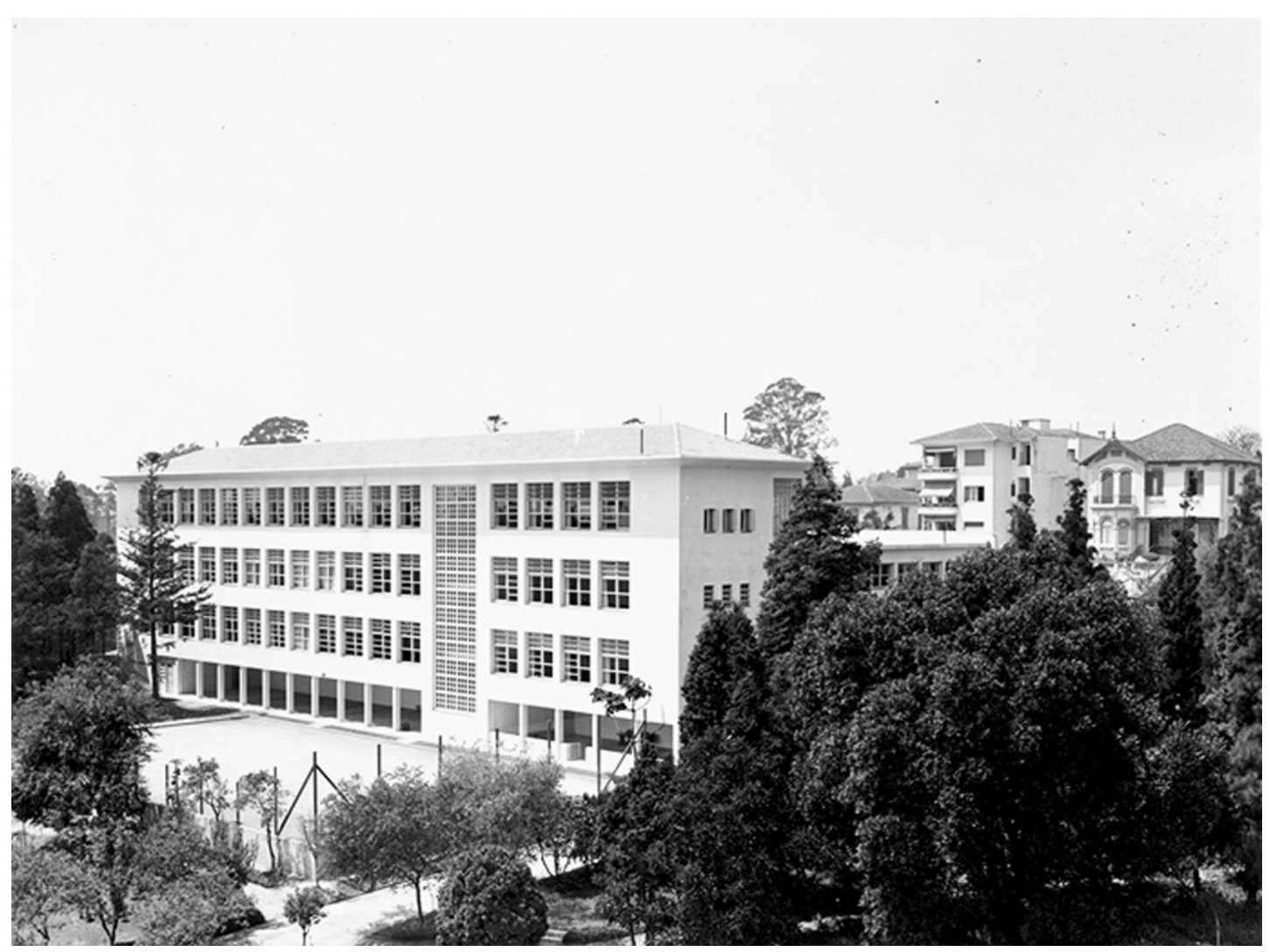

[25] Instituto Superior Sedes Sapientiae, São Paulo, SP. Arquiteto Rino Levi, 1941/42. 


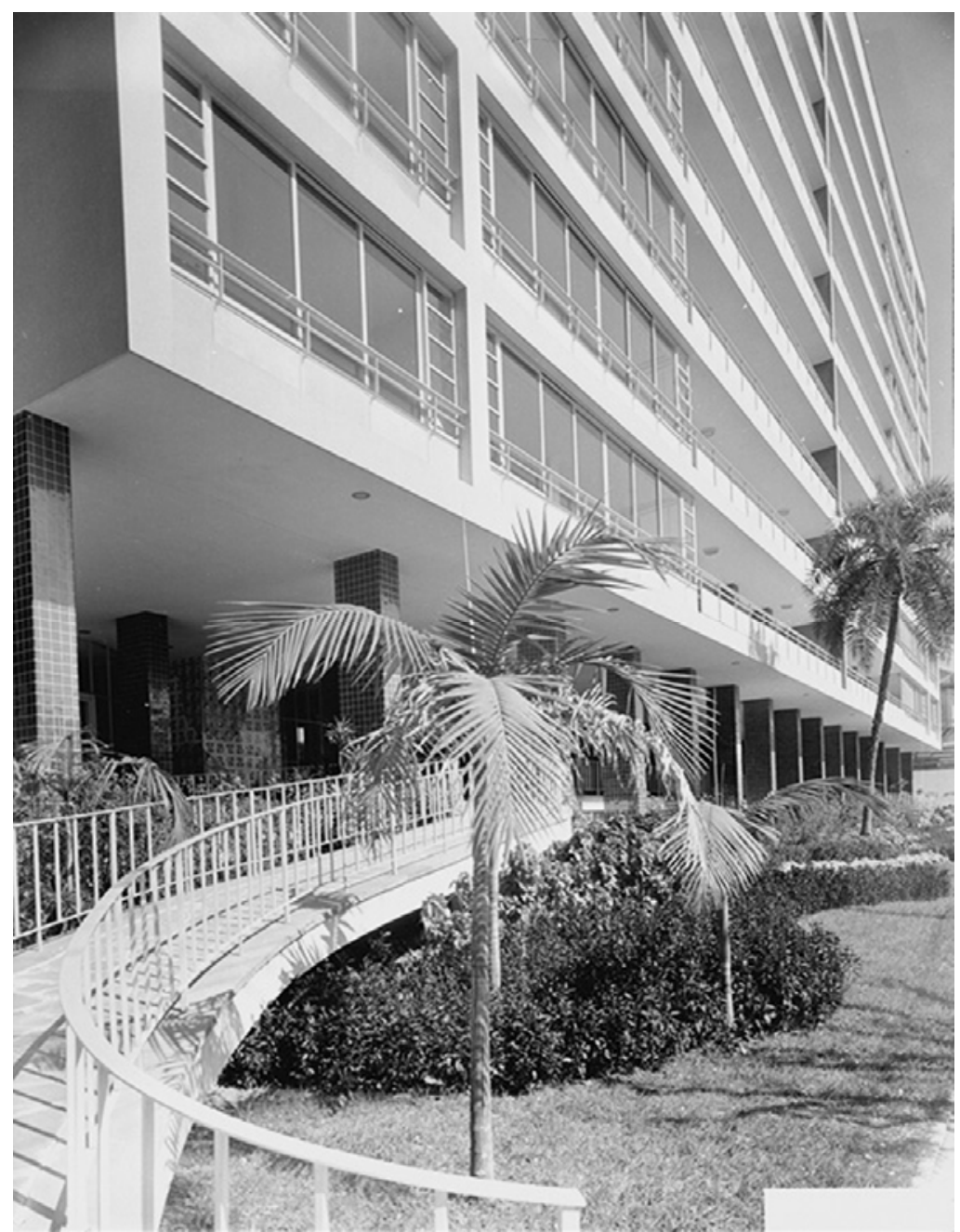

[26] Edifício de Apartamentos Prudência, São Paulo, SP. Arquitetos Rino Levi e Roberto Cerqueira Cesar, 1944.

Os projetos mais bem sucedidos nesse tipo de programa são, segundo Bruand, o Edifício Seguradora Brasileira ${ }^{43}[27$ e o Banco SulAmericano $^{44}[\mathbf{2 8}]$. Destaca, também, a sólida reputação internacional alcançada pelo escritório, graças a seus projetos de hospitais extremamente bem estudados no plano funcional. O mais importante deles seria o Instituto Central do Câncer ${ }^{45}$ [29], "onde as soluções achadas para resolver racionalmente os problemas de circulação interna, levando em conta a forte inclinação do terreno e as exigências do programa, foram notáveis, bem como a segurança da orientação e a

\footnotetext{
43 Edifício Companhia Seguradora Brasileira, São Paulo, SP, 1948/56. O prédio tem 18 pavimentos: garagem em sub-solo, lojas ao nível da rua, sobrelojas, terraços jardim com playground e 14 andares com apartamentos.

${ }^{44}$ Banco Sul-Americano do Brasil S/A, São Paulo, SP, 1960/63, atual Banco Itaú, Av. Paulista, 1948.

${ }^{45}$ Hospital Antônio Cândido de Camargo, do Instituto Central de Câncer, São Paulo, SP, !947/54.
} 
ligação dos três blocos, que se harmonizam num todo equilibrado apesar da diferença de tamanho" ${ }^{46}$. Lembra ainda o Hospital Albert Einstein $^{47}[30]$, elogiando o projeto original que previa uma planta em " $T$ ", com um bloco vertical para a hospitalização, destacando-se da horizontalidade da ala de serviços. Na intersecção do " $T$ " foi criada uma única prumada de circulação vertical. Conseguiu-se, assim, nítida separação de funções sem prejuízo das contiguidades necessárias.

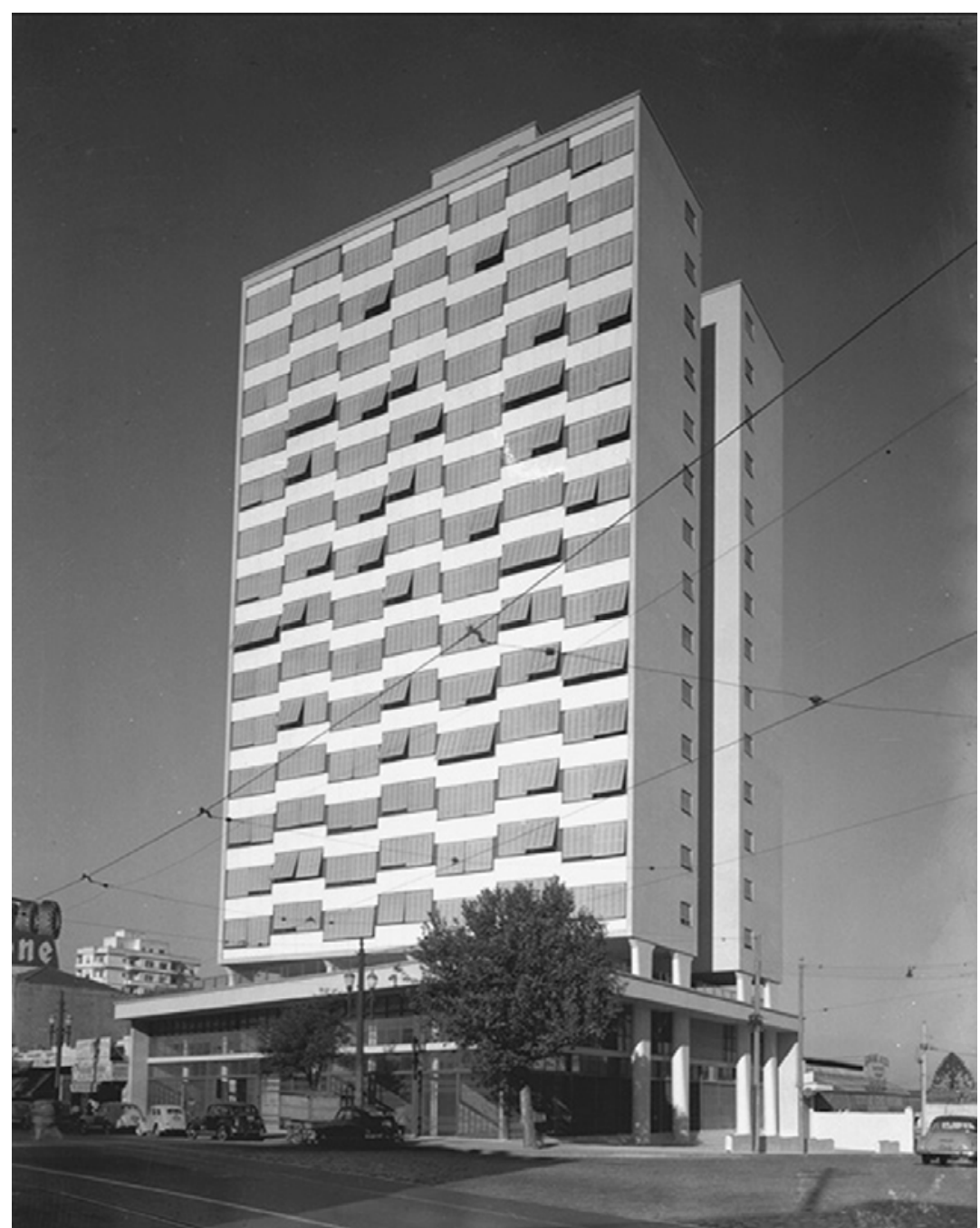

[27] Edifício de Escritórios da Cia. Nacional de Seguros de Vida de São Paulo, São Paulo, SP. Arquitetos Rino Levi e Roberto Cerqueira Cesar, 1952.

\footnotetext{
${ }^{46}$ Bruand, Yves, op. cit., p. 251.

${ }^{47}$ Hospital Geral Albert Einstein, São Paulo, SP, 1958. O ante-projeto foi o vencedor de um concurso para o qual foram convidados alguns dos mais importantes escritórios brasileiros. Este foi completamente modificado pela empresa de construção e a sociedade comanditária, sem a aprovação dos arquitetos, que ao final foram chamados para "salvar" o projeto modificado.
} 
[28]

Banco Sul-Americano S/A Av. Paulista 1948, São Paulo, SP. Arquitetos Rino Levi, Roberto Cerqueira Cesar e Luís Roberto Carvalho Franco, 1960/65.
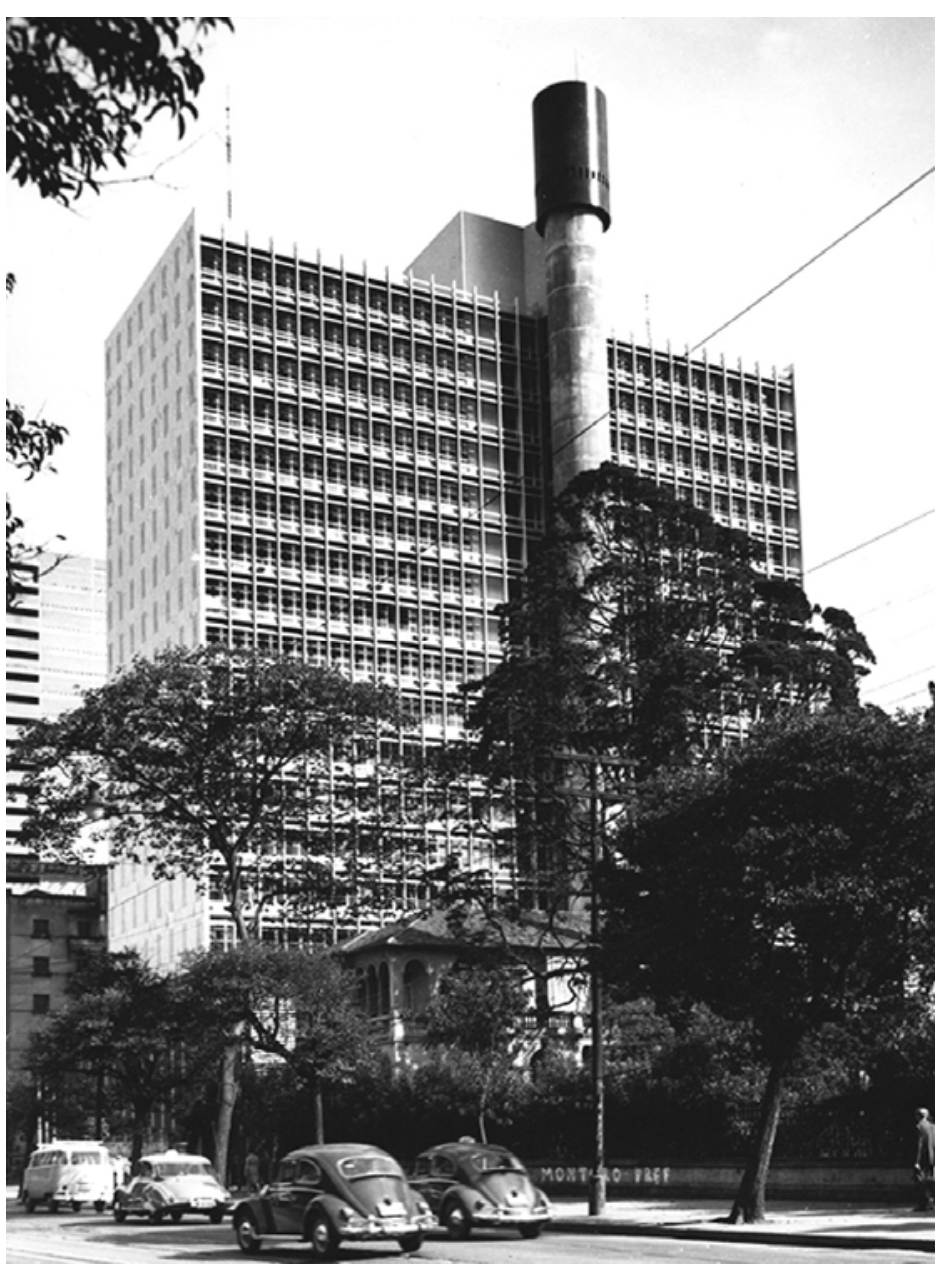


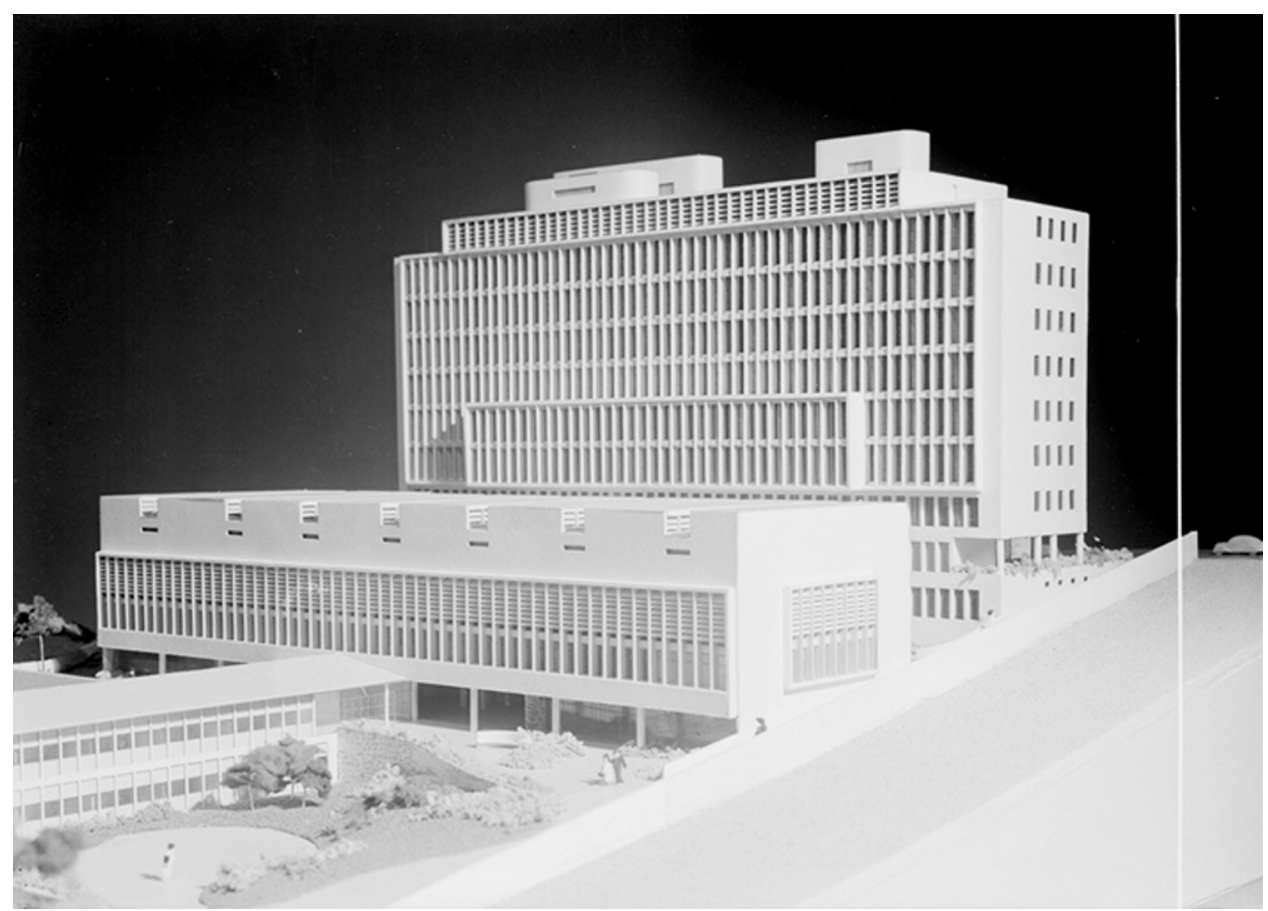

[29] Hospital Antônio Cândido de Camargo, do Instituto Central do Câncer, São Paulo, SP. Arquitetos Rino Levi e Roberto Cerqueira Cesar, 1947/54.

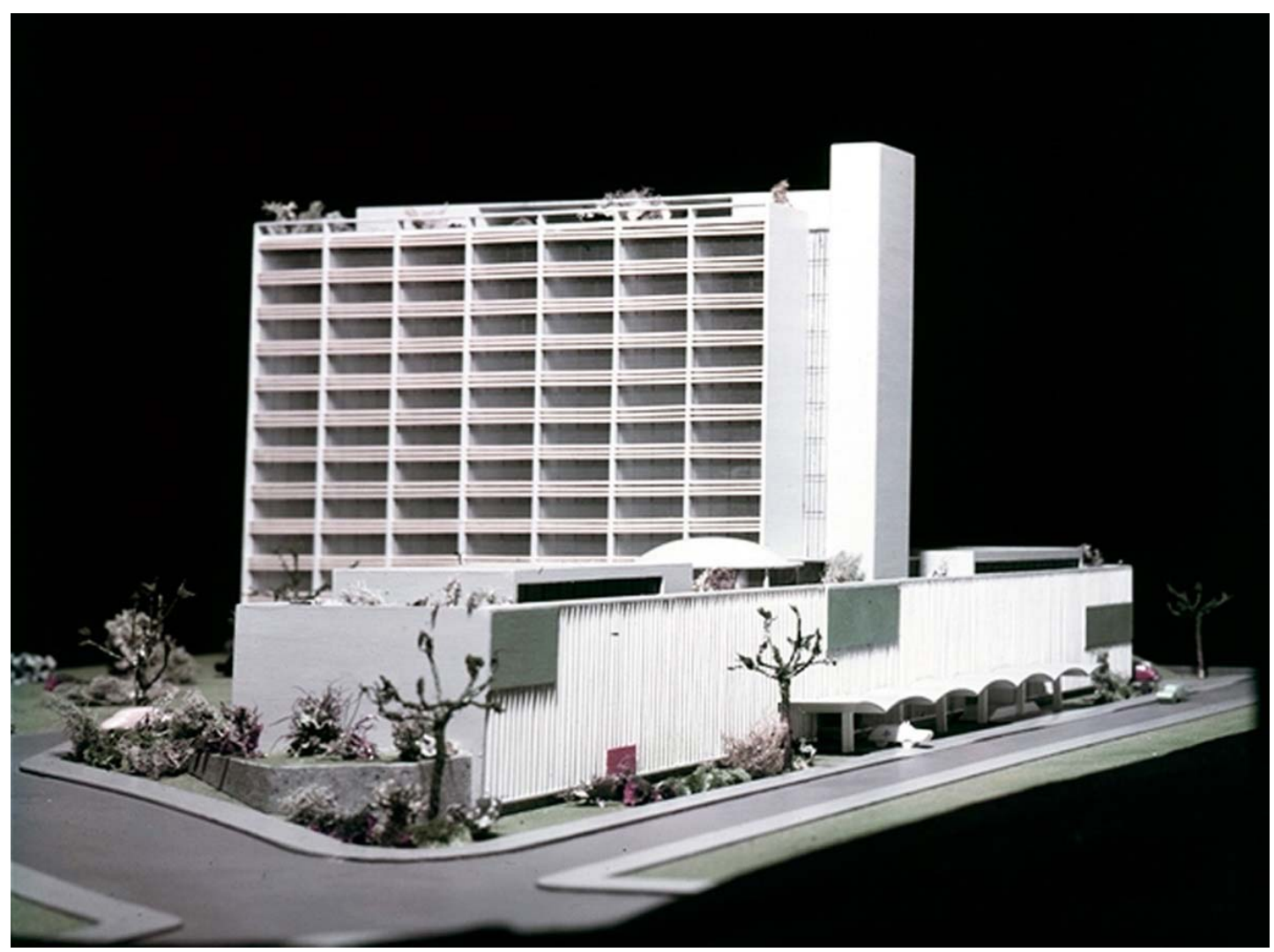

[30] Hospital Geral Albert Einstein, São Paulo, SP. Arquitetos Rino Levi, Roberto Cerqueira Cesar e Luís Roberto Carvalho Franco, 1958. 
Para Bruand, "não é de espantar que a arquitetura industrial apareça como um setor onde eles se impuseram de modo mais brilhante" ${ }^{48}$. Isso devido à qualidade plástica resultar da simples exploração racional dos materiais, escolhidos e utilizados na melhor adaptação possível a cada programa tratado. No caso, as estruturas metálicas eram convenientes para esse gênero, especificamente utilitário, que frequentemente exigia grandes espaços livres e uma cobertura leve. Assim, "os vigamentos da fábrica Arno ${ }^{49}$ foram concebidos a partir das varas de aço comum, empregadas nas estruturas de concreto armado: constituem um modelo do gênero, com sua rede aérea de verdadeiras vigas de treliça que se cruzam audaciosamente no espaço. O mesmo se pode dizer dos hangares situados ao lado de uma plantação ${ }^{50}$ [31], onde as duas abóbodas paralelas são formadas por uma série de ferros perfilados, completados por suportes longitudinais do mesmo tipo" ${ }^{11}$.

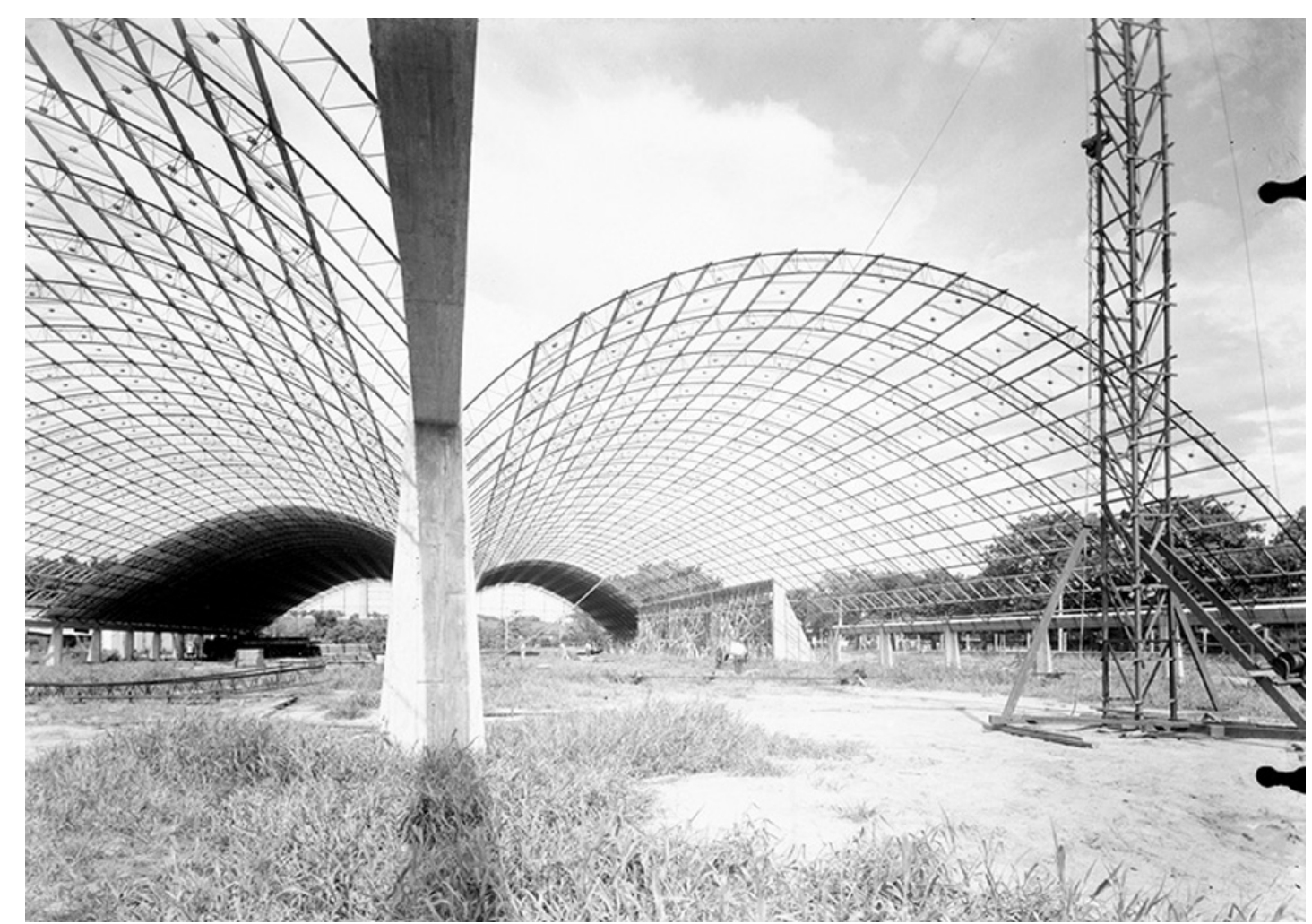

[31] Galpão e posto de gasolina da Tecelagem Parahyba, São José dos Campos, SP. Arquitetos Rino Levi, Roberto Cerqueira Cesar e Luís Roberto de Carvalho Franco, 1953.

\footnotetext{
${ }^{48}$ BRUAND, Yves, op. cit., p. 252.

${ }^{49}$ Indústria Arno S/A, Ind. e Com., São Paulo, SP, 1950.

${ }^{50}$ Galpão e Posto de Gasolina da Tecelagem Parahyba, São José dos Campos, SP, 1953.

${ }^{51}$ BRUAND, Yves, op. cit., p. 252.
} 
Os dois projetos analisados que encerram esse segmento são a Leiteria Parahyba ${ }^{52}$ [32] e o Paço Municipal de Santo André53[33], as últimas realizações do escritório com o titular ainda vivo. Do primeiro é elogiada a estrutura: base de finos pilares e uma cobertura em cimento armado. A flexibilidade é total: os espaços livres alternam com as partes semi-fechadas ou inteiramente fechadas, de acordo com as necessidades práticas, mas, "isso não prejudica a pureza geométrica e a unidade da arquitetura que se insere habilmente na paisagem, sem procurar apagar-se perante ela. A ausência de revestimentos confere a essa fábrica rural a austeridade que convém a um edifício industrial, sem fazer com que perca sua leveza tipicamente brasileira" ${ }^{54}$. Destaca ainda, como seu elemento essencial, o esbelto véu de concreto engrossado no prumo dos suportes por nervuras que não são visíveis e conservam um aspecto perfeitamente liso para a face inferior da laje: na verdade, Bruand descreve o raciocínio da laje nervurada com viga invertida, que será recorrente na arquitetura paulista.

\footnotetext{
${ }^{52}$ Usina de Leite Parahyba, São José dos Campos, SP, 1963/65.

${ }^{53}$ Centro Cívico de Santo André - $1^{\circ}$ lugar em concurso, Santo André, SP, 1965/69.

${ }^{54}$ BRUAND, Yves, p. cit., p. 253.
} 


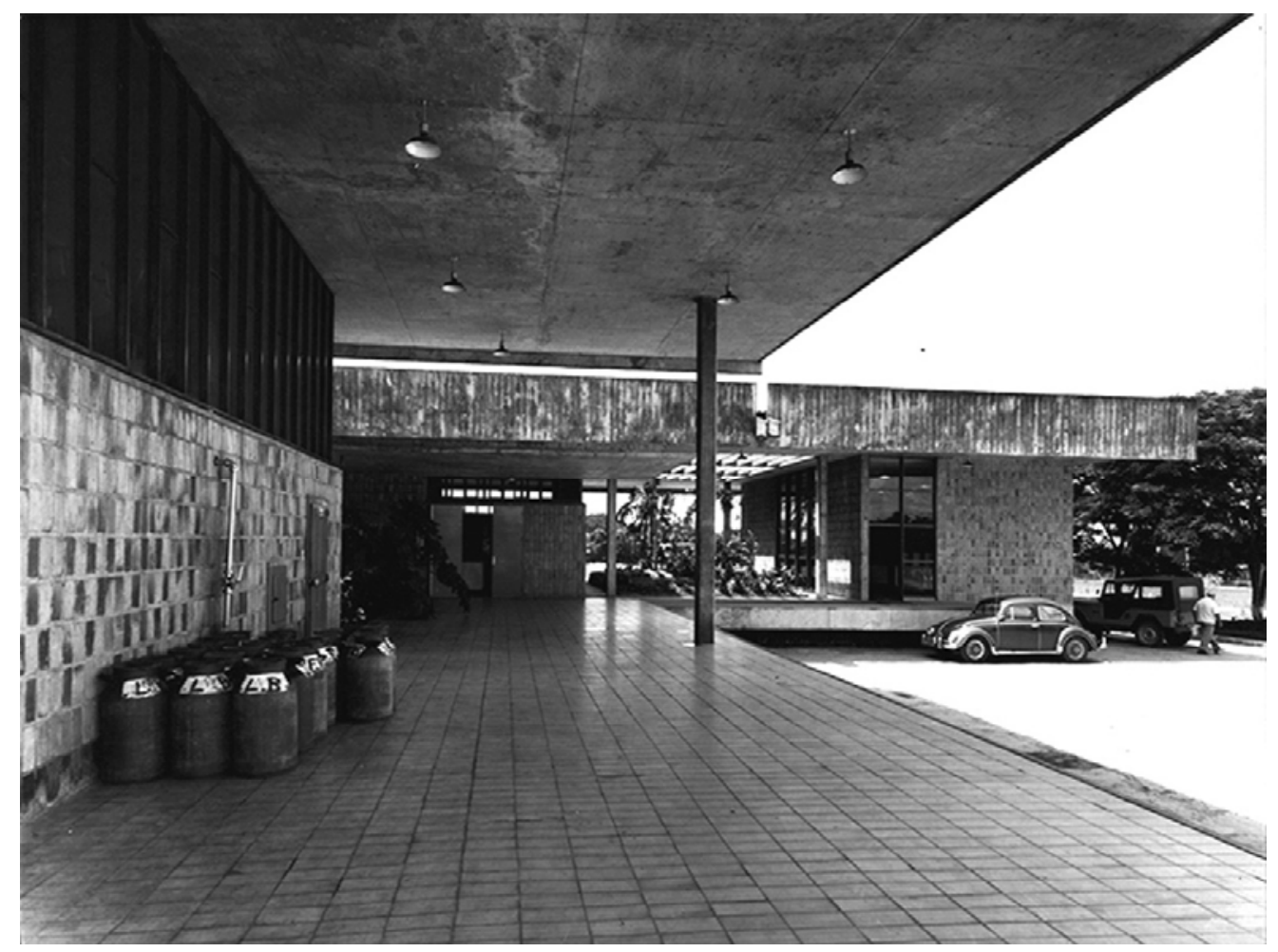

[32] Usina de Leite Parahyba, São José dos Campos, SP. Arquitetos Rino Levi, Roberto Cerqueira Cesar e Luís Roberto de Carvalho Franco, 1963/65.

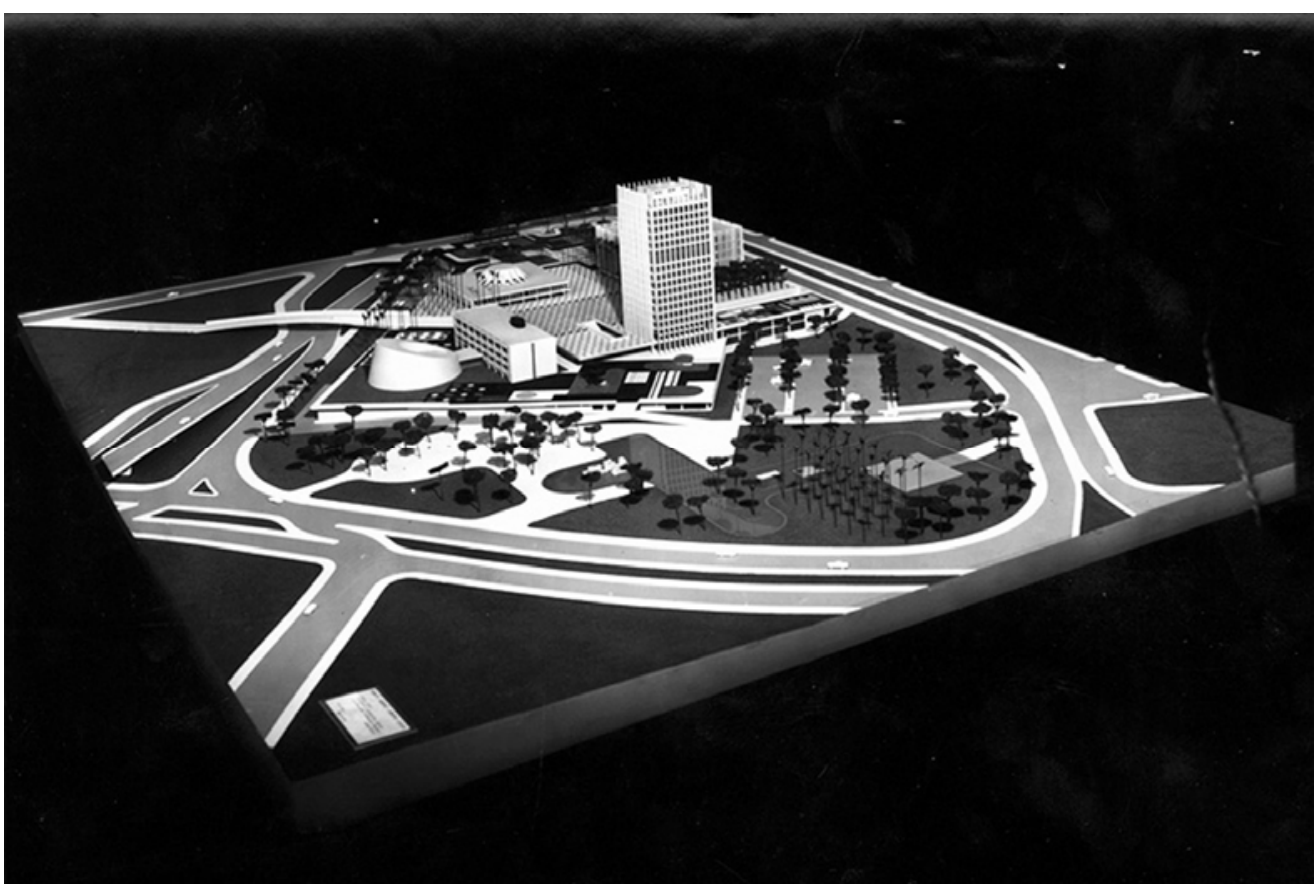

[33] Centro Cívico de Santo André (concurso - $1^{\circ}$ lugar), Santo André, SP. Arquitetos Rino Levi, Roberto Cerqueira Cesar e Luís Roberto de Carvalho Franco, 1965.

Do Paço Municipal é destacada a tendência para pesquisas plásticas mais extensas, atribuída à influência exercida pelo prestígio reforçado 
de Lúcio Costa e Niemeyer, depois do triunfo alcançado em Brasília. Esse seria responsável, também, pela evidente retomada do princípio da Praça dos Três Poderes[34]: “é claro que a arquitetura não é tipicamente formal como a de Brasília; os edifícios de volumes prismáticos puros, de fachadas sem relevo com estrutura externa exposta, conservam o racionalismo apreciado pelos autores do projeto. (...) essas variações sobre temas já tratados estão longe de ser isentas de interesse; elas mostram os desenvolvimentos que arquitetos sérios podem extrair de invenções de colegas que tenham dotes criativos mais agudos, sem cair na cópia e, principalmente, sem perder a personalidade própria" 55 .

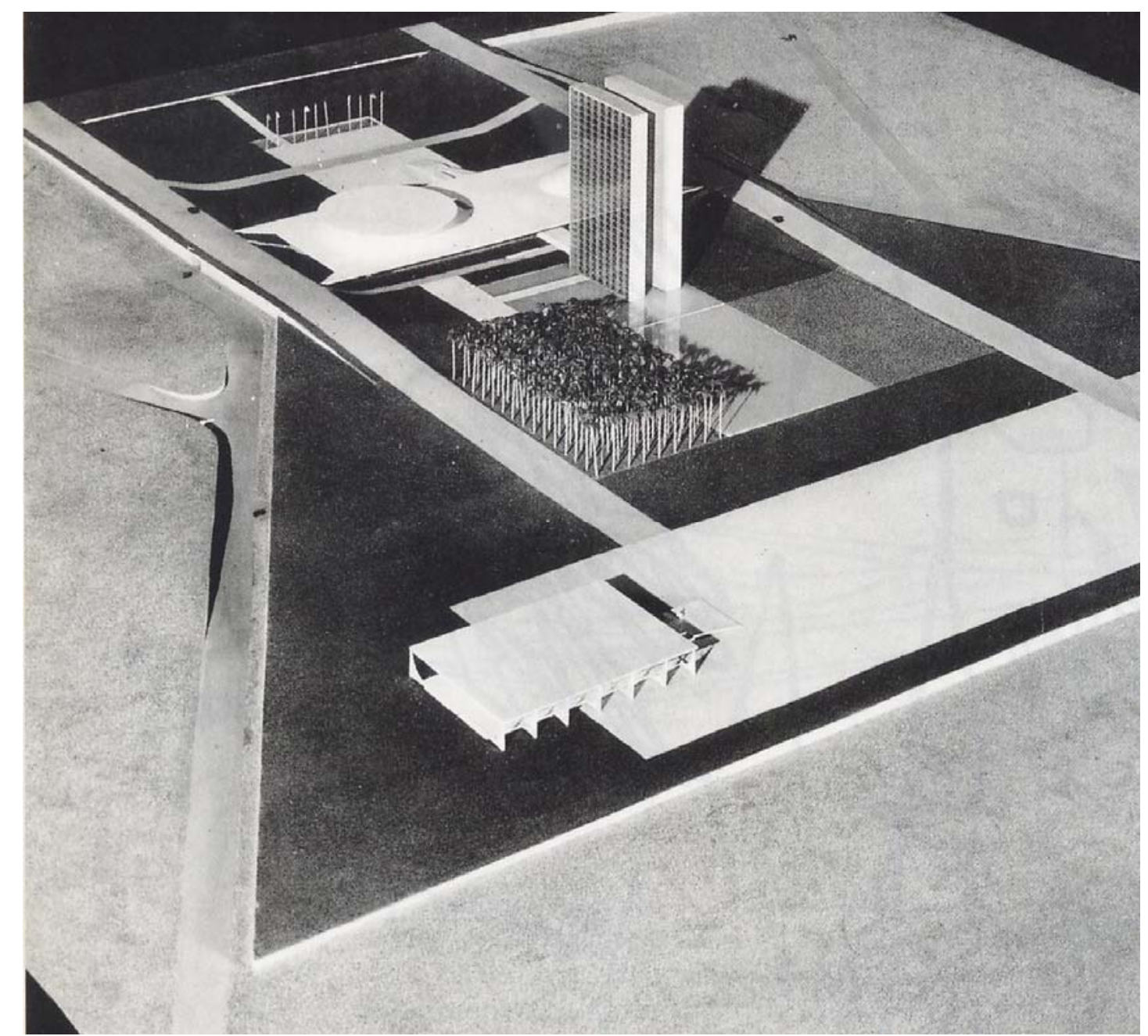

[34] Praça dos Três Poderes, Brasília, DF. Arquitetos Lúcio Costa (Plano Piloto) e Oscar Niemeyer (projetos de arquitetura), 1957.

\footnotetext{
${ }^{55}$ BRUAND, Yves, op. cit., p. 255.
} 
Dessa maneira, Bruand faz um elogio um tanto dúbio: se por um lado encontra interesse na personalidade própria do escritório, por outro valoriza as invenções dos arquitetos com criatividade mais aguçada. $\mathrm{O}$ comentário não deixa de ser surpreendente, uma vez que o próprio Bruand reconhece que as preocupações propriamente formais jamais exerceram, na obra de Rino Levi e seus associados, um papel independente das considerações de ordem funcional. Isso equivaleria a admitir que as necessidades do programa nunca seriam sacrificadas pelo partido, o que indica uma atitude de projeto, uma decisão e, nesse sentido, não uma questão de maior ou menor criatividade.

\section{Ainda no segmento sobre a Maturidade da Nova Arquitetura} Brasileira, encontramos As casas de Rino Levi: relações naturezaarquitetura e introspecção ${ }^{56}$. Bruand inicia declarando que "embora a obra de Vilanova Artigas ${ }^{57}$ esteja longe de ser homogênea e se divida claramente em vários períodos cronológicos de inspirações diversas, a de Rino Levi - ao contrário - é um modelo de continuidade, conforme foi ressaltado quando foram estudados seus grandes edifícios inteiramente orientados pelos princípios racionalistas. Assim poderia

\footnotetext{
${ }^{56}$ BRUAND, Yves, op. cit. , pp. 273-281.

57 João Batista Vilanova Artigas (1915-1985) nasceu em Curitiba. Estudou engenharia e arquitetura em São Paulo, onde se formou na Escola Politécnica da USP em 1915. Como estudante, trabalhou no escritório de Oswaldo Bratke em 1936/37, onde, entre outras atividades rotineiras de iniciantes, detalhava esquadrias, o que se mostrou posteriormente fundamental na sua obra de arquiteto. Em 1939 fez trabalhos junto com Warchavchik, obtendo o segundo lugar no concurso para o Paço Municipal de São Paulo. Em 1940 começa a lecionar no curso de Arquitetura da Escola Politécnica a cadeira de "Estética, Composição e Urbanismo”. Em 1947 ganhou bolsa de estudos nos Estados Unidos, sob o amparo da Fundação Guggenhein, quando examina com atenção a obra de F. L. Wrigth. Em 1948 já tem cadeira própria na recém fundada Faculdade de Arquitetura e Urbanismo da Universidade de São Paulo. Sua carreira docente intensa e engajada culmina na construção da FAU-USP em 1961. Como arquiteto, após uma primeira fase com forte influência do organicismo wrightiano, torna-se o principal ideólogo do chamado "brutalismo paulista”, defesa radical das construções em concreto armado aparente, com estruturas arrojadas e grandes vãos, onde a grande integração com o território ao nível do solo e as transformações internas das plantas e programas eram defendidas como alavancas da transformação social em prol de uma sociedade mais democrática. Além do mencionado edifício da FAU-USP, quase sempre com seu sócio Carlos Cascaldi, projetou significativos edifícios com os mais variados programas: o Estádio do Morumbi, o edifício residencial Louveira, a Garagem de barcos Santa Paula Iate Clube, dezenas de casas unifamiliares, os Ginásios Estaduais de Guarulhos e Itanhaém, o conjunto habitacional Zezinho Magalhães em Guarulhos e as Estações rodoviárias de Londrina e Jaú. Participou ativamente da vida institucional - com Eduardo Kneese de Mello e Rino Levi, foi um dos mais ativos criadores do IABSP - e política - desde o segundo pós-guerra era filiado ao Partido Comunista Brasileiro - do país. Em 1969 foi cassado pelo regime militar, sendo aposentado compulsoriamente do cargo na universidade. Retornou após a anistia, um pouco antes de sua morte.
} 
espantar um pouco que seu nome apareça neste capítulo se ele não se tivesse tornado célebre por um certo número de residências elegantes, das quais muitas revistas especializadas sublinharam o caráter introvertido, bem como a íntima integração natureza-arquitetura que nelas era feita" ${ }^{8}$. Ao contrário de Bruand, o que pode causar estranhamento não é imaginar uma referência orgânica nas casas, mas sim um modelo de continuidade na obra de Levi.

O estudo dos grandes edifícios a que Bruand se refere é exemplo da diversidade das referências do escritório, que variam não só no decorrer do tempo, mas também, para diferentes programas no mesmo período. Artigas, ao contrário, apó

s um breve período de referência wrightiana, e um corbusiano via arquitetos cariocas, constituiu um repertório próprio que Bruand vai tratar como brutalismo paulista e que "o tornou um verdadeiro chef de file, pois não é exagero falar de uma escola paulista de ambições vigorosas, decidida a suplantar, no futuro, sua rival carioca no panorama brasileiro" ${ }^{59}$. Essa é outra questão que parece relevante e que voltará a ser discutida neste trabalho.

Quanto à questão das casas, a primeira que Bruand estuda é a residência do arquiteto $^{60}$, onde observa que o partido é de um edifício térreo, fechado sobre si mesmo, onde a vida familiar deveria desenrolar-se sem possibilidade de interferências externas. Todos os usos são organizados a partir de três pátios internos e "não se pode pensar numa concepção mais intimista, mas é evidente que se trata de uma nova versão do pátio mediterrâneo, o que é facilmente explicado pelas origens e pela formação italiana de Rino Levi, mais do que por uma inspiração da corrente orgânica. Outra prova disso é a disposição das galerias abertas, protegidas apenas por um brise-soleil de cimento, nos dois lados da casa ladeados pelo jardim principal: corredor ao

\footnotetext{
${ }^{58}$ BRUAND, Yves, op. cit., p. 273.

${ }^{59}$ BRUAND, Yves, op. cit., p. 305.

${ }^{60}$ Residência Rino Levi, São Paulo, SP, 1944.
} 
mesmo tempo arejado e abrigado ou elemento de transição entre o ambiente reservado interno e a orgia de luz e verde para a qual abre esse ambiente, o papel e o modo de emprego são os da tradição romana, sempre viva, adaptada a um contexto moderno e tropical" ${ }^{\prime 1}$.

O mesmo raciocínio é aplicado nas casas Milton Guper $^{62}$, Paulo Hess ${ }^{63}$ e Castor Delgado Perez ${ }^{64}$. Na primeira, "o grande êxito é a criação original de uma continuidade interior-exterior tão completa que leva a fundir o lado de dentro e o de fora em proveito exclusivo daquele; de fato, o salão e a sala de jantar formam um só corpo com o jardim, graças às grandes portas de correr de vidro, que se apagam quase totalmente e constituem o único obstáculo material; a intimidade, porém, é preservada pelo fechamento rigoroso desse prolongamento externo por meio de um jogo de paredes e grades associados a uma pérgula de cimento armado"65. Já na casa de Delgado Perez, a mudança está quanto ao aspecto externo. Sua fachada abriga, como sempre, garagem e dependências de serviço, mas, "a aparência neutra usual nos projetos anteriores cedeu lugar a oposições vivas de volumes $e$ cores, mais próximas de uma estética racionalista um pouco agressiva do que da maneira discreta anterior" ${ }^{\prime 66}$.

Não se pode, no entanto, deduzir que os arquitetos abandonaram o estudo das condições particulares de cada caso: "a melhor prova de que nenhum princípio imutável entrava nesse gênero de programa é fornecida pela composição totalmente diferente da casa de Olivo Gomes $^{67}$. Desta vez, tratava-se de uma residência rica, isolada em pleno campo, consequentemente não submetida às limitações de toda ordem das obras urbanas; a liberdade de expressão dos autores do projeto era completa. Ora, bem longe de pensar numa criação

\footnotetext{
${ }^{61}$ BRUAND, Yves, op. cit., p. 274.

62 Residência Milton Guper, São Paulo, SP, 1951/53.

63 Residência Paulo Hess, São Paulo, SP, 1952/55.

${ }^{64}$ Residência Castor Delgado Perez, São Paulo, SP, 1958/59.

${ }^{65}$ BRUAND, Yves, op. cit., p.277.

${ }^{66}$ BRUAND, Yves, op. cit., p.280.

${ }^{67}$ Residência Olivo Gomes, São José dos Campos, SP, 1953.
} 
intimista, voltada para dentro, imaginaram uma obra amplamente aberta para a paisagem, onde ressurge todo o vocabulário apreciado pelo movimento brasileiro: blocos puros de contornos retilíneos, pilotis, paredes de vidro protegidas por grandes telhados salientes, terraço em balanço, escada em caracol e degraus suspensos, cerâmicas murais e jardim artificial de Burle Marx exercendo um papel de transição com o contexto natural, mas marcando bem a recusa de submeter-se cegamente a ele." 68

A última citação de Rino Levi se dá na terceira parte do livro Arquitetura e Urbanismo. Nela, após estudar O Arranjo das Cidades Antigas e A Criação das Cidades Novas, no segmento Brasília, apoteose do urbanismo brasileiro, Bruand fala dos projetos não aceitos no concurso para o plano piloto. Comenta que todos os projetos divulgados pelas revistas especializadas tinham um ponto em comum: sua inspiração racionalista. "Neles encontra-se sistematicamente a divisão entre as quatro funções principais enunciadas pela Carta de Atenas de 1933 (habitar, trabalhar, cultivar o corpo e o espírito, circular), a atribuição de setores bem definidos a cada uma delas, a preocupação de substituir a antiga rua por uma nova concepção que desse prioridade aos espaços livres e aos blocos isolados pontuando com sua massa ordenada as vastas superfícies não construídas, a definição de um tipo de célula de base cuja multiplicação constituiria um dos elementos fundamentais do plano de conjunto, enfim a regularidade e a geometria estrita tanto do conjunto quanto das partes que o formam."69

As diferenças, notáveis, entre os projetos também são examinadas. No caso do projeto do escritório Rino Levi ${ }^{70}$, a ênfase é dada a proposital falta de valorização dos edifícios administrativos, "pois o efeito plástico da composição iria provir dos prédios de apartamentos de

\footnotetext{
${ }^{68}$ BRUAND,Yves, o p. cit., p. 281.

${ }^{69}$ BRUAND, Yves, op. cit., p. 356.

${ }^{70}$ Plano Piloto de Brasília, concurso - $3^{\circ}$ lugar, Brasília, DF, 1957.
} 
trezentos metros de altura perto dos quais as outras construções teriam parecido subalternas. Não há dúvida de que a experiência era vigorosamente original e revolucionária na maneira de colocar os problemas. Nesse sentido, ela era uma aposta, como a própria Brasília, mas pode-se perguntar se seus autores concorreram realmente com a idéia de ganhar, dando provas de muita ingenuidade, ou se se entregaram a um brilhante exercício de estilo e a uma demonstração teórica das possibilidades oferecidas por uma cidade vertical ideal. (...) enfim, não era lógico fazer com que a aglomeração crescesse em altura e levasse a uma forte concentração relativa quando o que menos faltava era justamente espaço". ${ }^{11}$

$\mathrm{Na}$ verdade, o próprio memorial do anteprojeto e as posições defendidas pelo escritório na polêmica instalada após o concurso, mostram que eles concorreram para ganhar: cada superbloco é um conjunto de 32 edifícios de 20 andares cada um, imaginando-se que os projetos de cada edifício poderiam eventualmente serem entregues a arquitetos diferentes. Todo esse conjunto é sustentado por uma grande estrutura de aço em cujo cálculo foram adotados apenas perfis fabricados no Brasil. Quanto a questão do espaço de sobra, o argumento para a verticalização e a alta densidade estava na inexistência de infra-estrutura de sobra. O plano piloto seria implantado em pleno planalto central, deserto, e qualquer solução horizontal implicaria em custos elevados nos sistemas viários, hidráulicos e elétricos, o que se mostrou verdadeiro. $\mathrm{O}$ anteprojeto, diferentemente do vencedor Lúcio Costa, previa a possibilidade de crescimento com o acréscimo de novos conjuntos, o que justificaria o investimento.

Pelo exposto, fica clara a afirmação de que, com Bruand, o escritório Rino Levi e associados passa a fazer parte da história da arquitetura moderna no Brasil. Se, por um lado, não é personagem de destaque

\footnotetext{
${ }^{71}$ BRUAND, Yves, op. cit., p. 357.
} 
nos momentos decisivos, categoria presente ainda mais uma vez, por outro, já deixou de ser figurante sem importância.

Também pode ser inscrito como manual o livro de Carlos Lemos ${ }^{72}$ Arquitetura Brasileira ${ }^{73}$, que como o próprio nome indica, é um panorama de 500 anos da nossa arquitetura. As questões modernas são tratadas no capítulo Os tempos Recentes, que engloba as transformações das seis décadas iniciais do século XX. Das duas primeiras, descreve as experiências com o ecletismo, o neocolonial, o art nouveau e o art deco, que considera de longa permanência, como veremos.

Se a década de 20 terminou "já tendo havido alguns fatos que viriam a influir na formação dos primeiros e raros adeptos da arquitetura moderna então praticada na Europa, mas, verdadeiramente sem terem tido repercussão popular" arquitetura art deco, que chegou a ter certa popularidade e, devido a compreensíveis confusões dentro do povo mal informado, era, na maioria das vezes, chamada de futurista, apelido que já haviam dado à casa modernista de Warchavchik". ${ }^{75}$ [35]

\footnotetext{
72 Carlos A C. Lemos, nascido em 1925, é paulista e formou-se em arquitetura pela Universidade Mackenzie. Durante os anos 50 participou da equipe de projeto do Parque Ibirapuera, chefiada por Oscar Niemeyer, tendo dirigido, mais tarde, o escritório desse arquiteto carioca em São Paulo. Como professor do Departamento de História da Arquitetura e Estética do Projeto da FAUUSP, dedicou-se a estudar a arquitetura brasileira e a questão do patrimônio cultural. Publicou inúmeros livros, entre eles Cozinhas, etc., Arquitetura Brasileira, Escultura Colonial Brasileira e História da Casa Brasileira.

${ }^{73}$ LEMOS, Carlos - Arquitetura Brasileira, São Paulo, Melhoramentos, EDUSP, 1979.

${ }^{74}$ LEMOS, Carlos, op. cit., p.134.

${ }^{75}$ LEMOS, Carlos, op. cit., p. 136.
} 


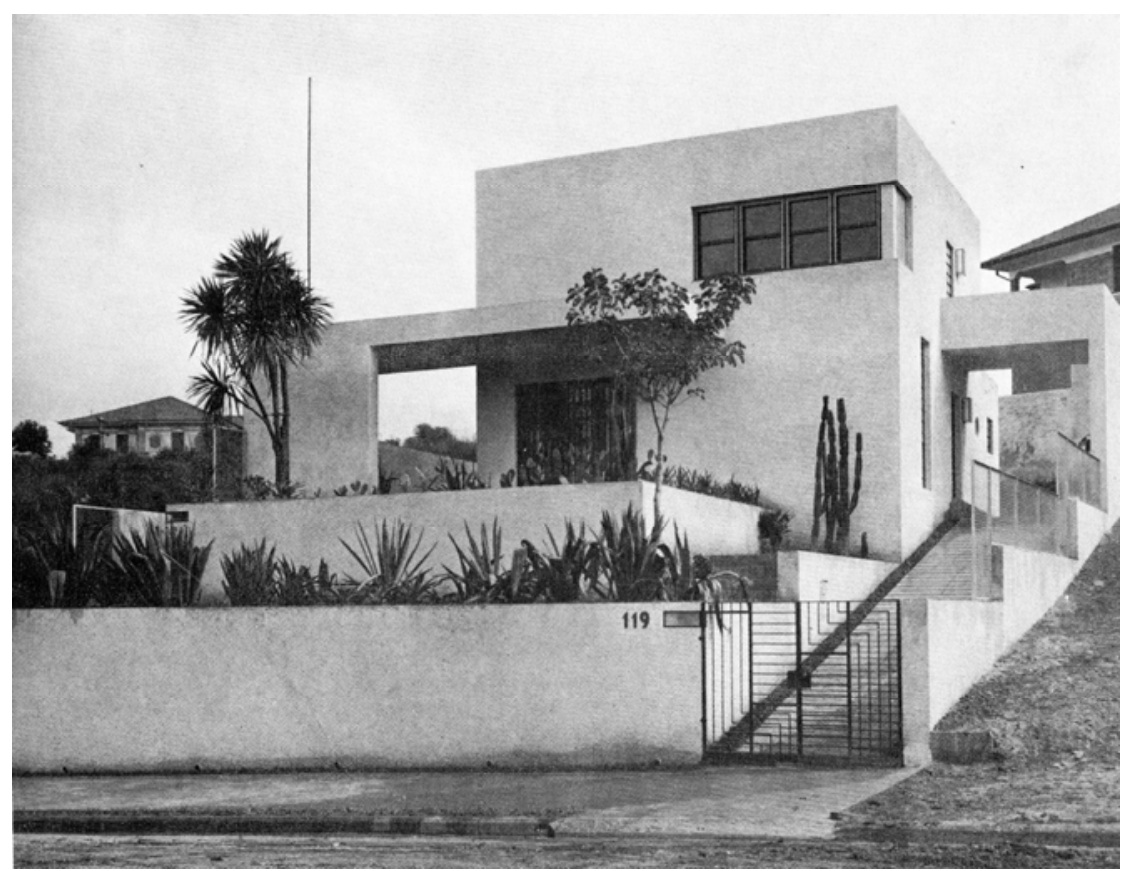

[35] Casa Modernista, São Paulo, SP. Arquiteto Gregori Warchavchik, 1927.

Rino Levi aparece como um dos fatos da década de 20: sua Carta de 1925 junta-se ao artigo Acerca da Arquitetura Moderna de Warchavchik e a visita e palestras proferidas por Le Corbusier ${ }^{76}$. Lemos alinhava alguns outros fatos paulistas, da década de 30, como Flávio de Carvalho, Álvaro Vital Brasil ${ }^{77}$ e Júlio de Abreu Júnior ${ }^{78}$. No entanto, "Flávio só escandalizou e sua obra não foi olhada com seriedade.. (. .) Vital Brasil foi o arquiteto de uma obra só: ninguém deu

\footnotetext{
${ }^{76}$ Le Corbusier , que retornava de Buenos Aires e Montevidéu, é recebido no Rio de Janeiro e em São Paulo, em 1929, com muitas honras, inclusive pelos políticos, que talvez não conhecessem seus escritos, mas que sabiam-no importante como teórico de planejamento.

77 Álvaro Vital Brasil (1909-1997) nasceu em São Paulo, filho Vital Brasil Mineiro da Campanha, médico, sanitarista, cientista e professor, então diretor do Instituto Butantã, e de Maria da Conceição Philipina de Magalhães Brazil. Em 1919, muda-se com a família para Niterói, onde seu pai funda o Instituto Vital Brazil. Conclui o curso secundário no Colégio Rezende, no Rio de Janeiro. Entre 1929 e 1933, cursa Arquitetura na Escola Nacional de Belas Artes e Engenharia Civil na Escola Politécnica, no Rio de Janeiro. Enquanto estudante, trabalha como desenhista na firma Dolabela Portela e Cia. Ltda., onde mantém contato com o engenheiro Emílio Baumgart. Em 1936, vence o concurso para o Edifício Esther, junto a Adhemar Marinho, seu sócio desde 1934. Com dezenas de projetos nas seis décadas seguintes, publicados nos mais importantes livros e periódicos nacionais e internacionais, é homenageado postumamente pelo IAB-RJ em 1997 e pelo DOCOMOMO - International Working Party for Documentation and Conservation of Buildings em 1999.

${ }^{78}$ Júlio de Abreu Júnior (1895-?) nasceu em São Paulo. Formou-se na Escola de Belas Artes de Paris em 1918. De volta a sua cidade natal, trabalha principalmente na década de vinte, dedicando-se mais a construções industriais. Segundo o próprio Carlos Lemos em Arquitetura Moderna Paulistana, ao contrário do que normalmente se afirma, a atribuição da primeira construção moderna na cidade de São Paulo deve ser dada ao excelente e pioneiríssimo prédio de apartamentos que o arquiteto constrói em 1927.
} 
maior atenção ao Edifício Esther ${ }^{79}[36]$, primeiro prédio realmente moderno de São Paulo, até hoje admirado pelas suas inúmeras qualidades e idéias avançadíssimas para a época. (...) Júlio fez interessante edifício de apartamentos ${ }^{80}$ na Avenida Angélica,[37] e nada mais". Conclui que "assim, na capital paulista por muito tempo isso se daria - só vozes isoladas e intermitentes"

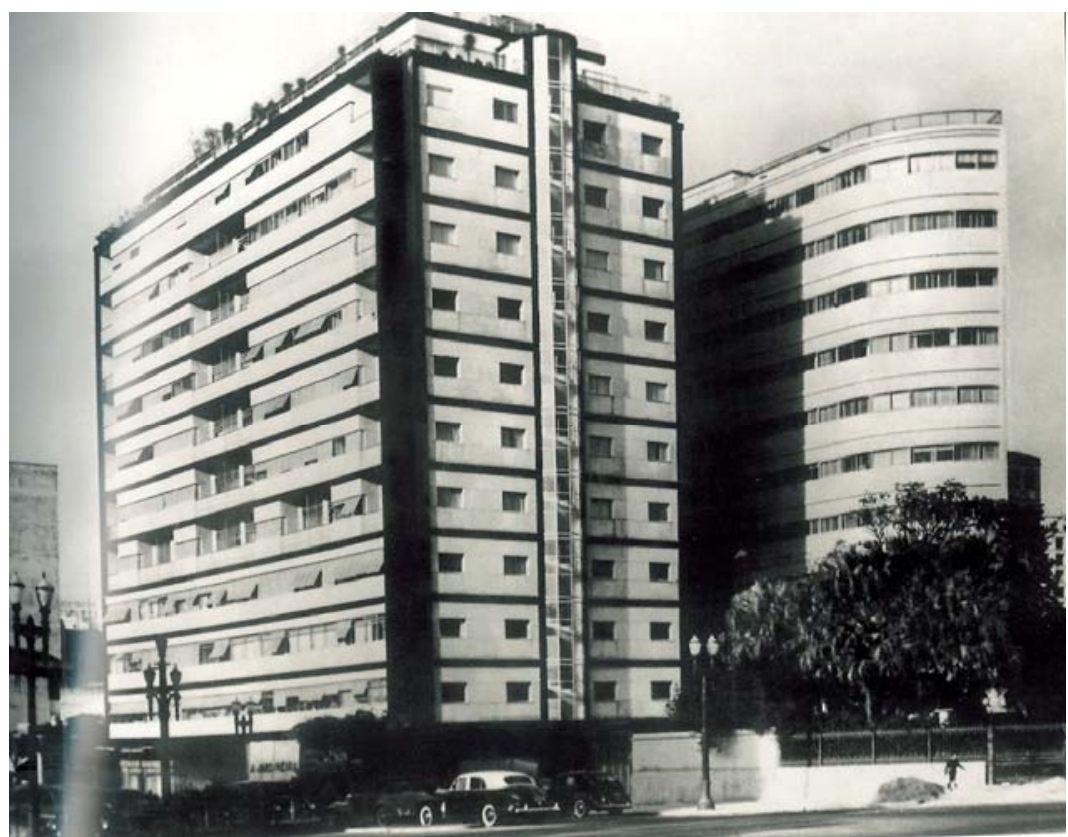

[36] Edifício

Esther, São

Paulo, SP.

Arquiteto

Álvaro Vital

Brasil, 1936.
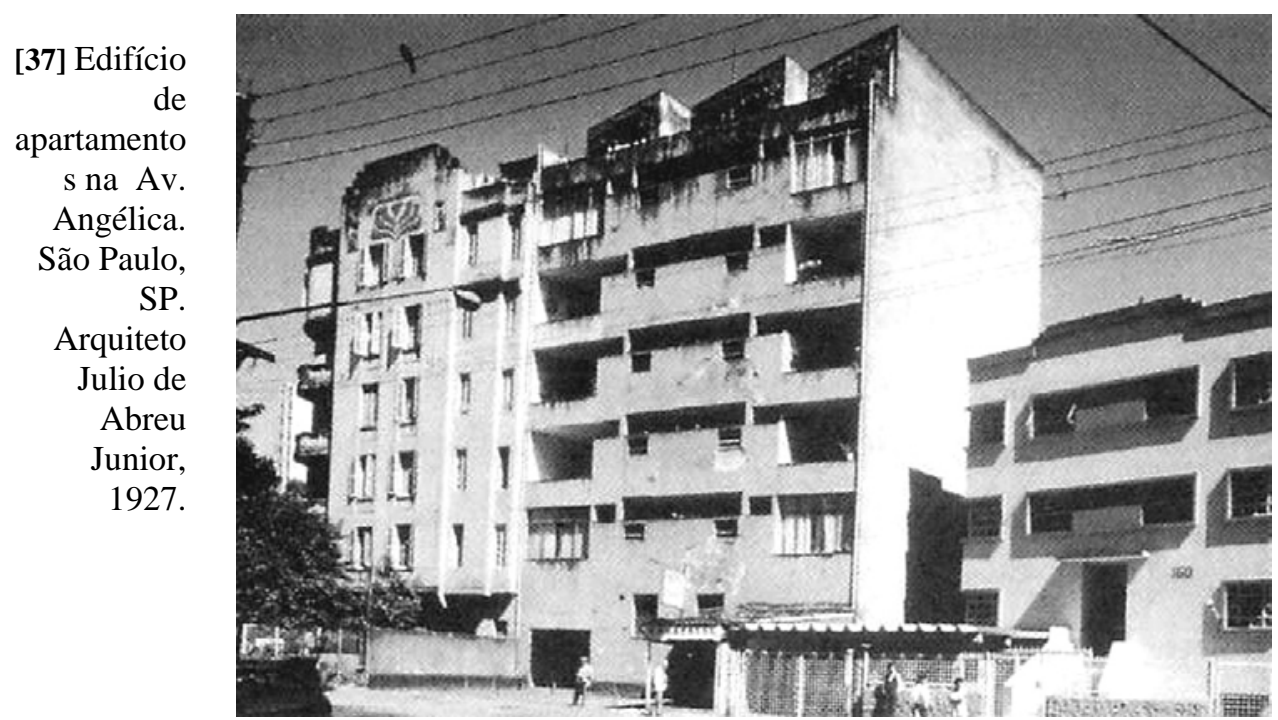

\footnotetext{
${ }^{79}$ Edifício Esther, São Paulo, SP, 1936.

${ }^{80}$ Edifício de Apartamentos, Av. Angélica 172, São Paulo, SP, 1927.

${ }^{81}$ LEMOS, Carlos, op. cit., p.139.
} 
Para Lemos, seria Le Corbusier quem - com as palestras de 1929 "realmente abriu os olhos de alguns jovens arquitetos e deu impulso a outros já conhecedores de sua obra, como Lúcio Costa que, logo depois, foi nomeado diretor da Escola Nacional de Belas Artes, onde, em brevíssima gestão, introduziu reformas de base e, com seu poder carismático, influenciou os alunos para sempre”. ${ }^{82}$ E, mais ainda, "nossa arquitetura muito deve ao fato de, em 1935, estarem à frente do Ministério da Educação e Saúde homens esclarecidos e abertos às novas correntes, como Gustavo Capanema e Rodrigo Melo Franco de Andrade". ${ }^{83}$ Vemos retomada a tese da transformação decisiva no Rio de Janeiro da década de 30 e do marco inaugural no edifício do Ministério[38]: "sua construção demorou alguns anos e, depois de pronto veio o edifício a constituir o grande marco da arquitetura moderna brasileira, o divisor de águas, que separa e propicia o renome internacional de nossos profissionais do Rio de Janeiro." ${ }^{84}$

\footnotetext{
${ }^{82}$ LEMOS, Carlos, op. cit., p. 134.

${ }^{83}$ LEMOS, Carlos, op. cit., p.140.

${ }^{84}$ LEMOS, Carlos, op. cit., p. 141.
} 


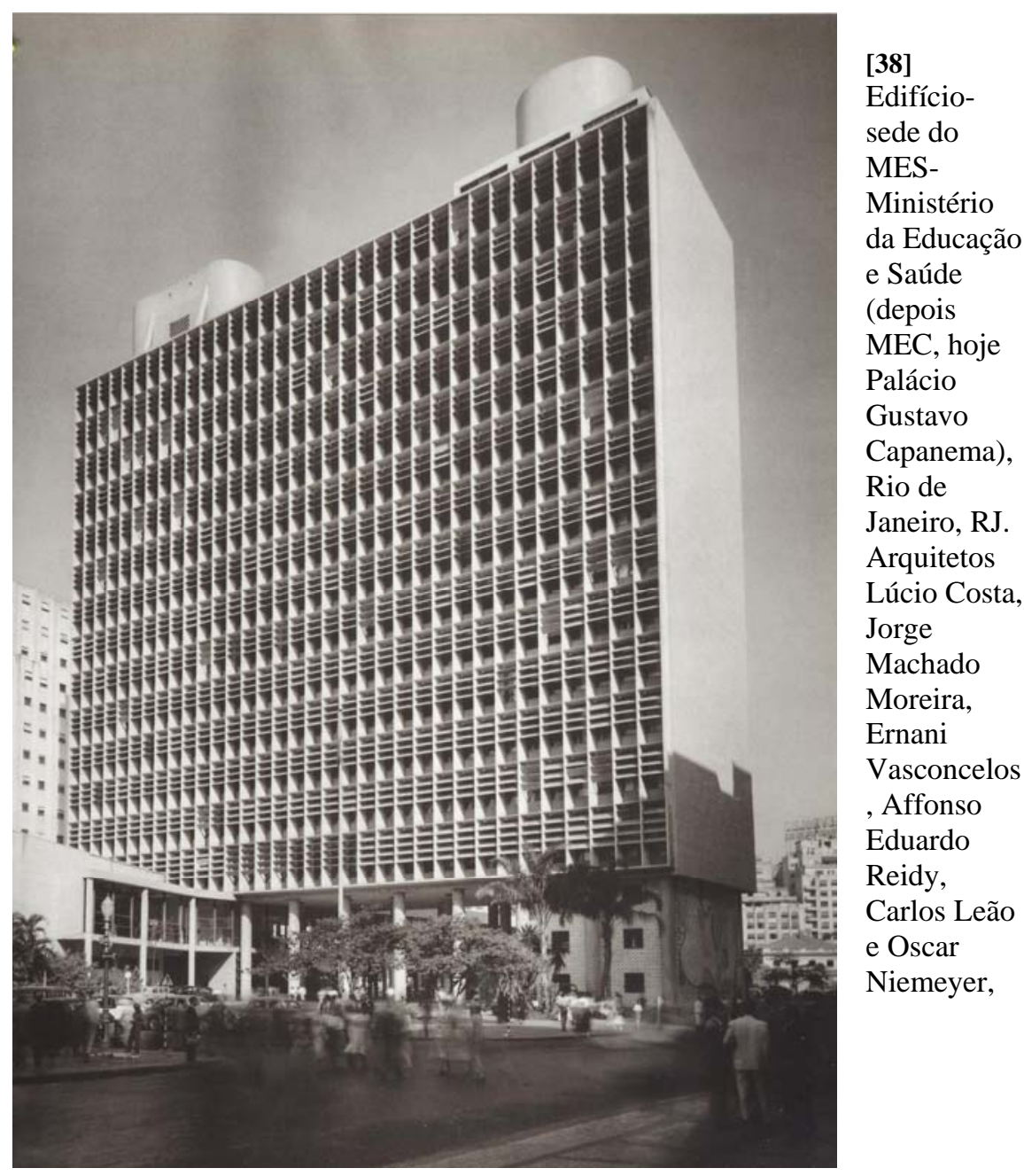

Os dez anos seguintes veriam a consagração dessa expressão cultural nacional, caracterizada por recriações e invenções locais. Para Lemos, "todos juntos, com o mesmo propósito de renovação modernista, procuravam em seus projetos uma linguagem brasileira para os postulados funcionalistas - chegaram até a ressuscitar as velhas treliças, antigos combongós e os tradicionais azulejos de revestimentos de fachadas e tudo mais que pudesse servir de ponte entre o passado autêntico e o presente já valorizado pelo concreto armado, com seus pilotis, terraços, jardins e quebra-sois, os célebres brises do novo jargão profissional." ${ }^{85}$

\footnotetext{
${ }^{85}$ LEMOS, Carlos, op. cit., p. 142.
} 
Lúcio é o mensageiro do passado autêntico e Oscar Niemeyer o responsável pela valorização do concreto armado, "mostrando a sua grande capacidade criadora que sempre vai exigindo, essa é a palavra exata, do concreto armado comportamentos e situações insuspeitadas numa permanente busca de soluções que, em verdade, não demonstram insatisfação com achados anteriores mas indicam o contínuo desejo de explorar ao máximo as possibilidades plásticas do material, cuja racionalidade de emprego e uso evidentemente não está contida em meia dúzia de fórmulas e tanto quanto de normas técnicas." ${ }^{86}$ Os dois seriam responsáveis por uma escola carioca, caracterizando a capital do país como pólo irradiador, mais uma vez, não só de um estilo ou corrente, mas de toda uma tecnologia e de novo modo brasileiro de encarar a arquitetura moderna.

Segundo Lemos, a arquitetura paulista só vai se alterar na década de 40, quando da chegada de significativo número de arquitetos estrangeiros e da instalação das Faculdades de Arquitetura da Universidade Mackenzie e da Universidade de São Paulo. Nesse momento Lemos volta a falar de Rino Levi que, junto a Oswaldo Bratke $^{87}$, são os raros arquitetos com escritórios próprios e projetando para clientela particular, independentemente dos construtores. Destaca o quanto os edifícios de Rino vão ser marcantes na paisagem da cidade que experimentava o avassalador movimento de sua reconstrução, conhecendo "os sacrifícios de um processo de metropolização sem peias, sem leis e sem imaginação, além da proverbial pobreza de verbas da Prefeitura e da indiferença do Estado, responsável pela grande parte dos serviços da infra-estrutura." 88

\footnotetext{
${ }^{86}$ LEMOS,Carlos, op. cit. , p. 152.

${ }^{87}$ Oswaldo Arthur Bratke nasceu em Botucatu, SP, em 1907. Em 1926 ingressa no curso de Engenharia da Escola de Engenharia Mackenzie, onde se forma em 1931. Em 1930 ganha o concurso para o viaduto Boa Vista, inaugurado em 1932. Em 1933 associa-se a Carlos Botti, formando escritório que só se desfaz com a morte do sócio em 1942. Em 1948 visita a costa oeste dos Estados Unidos, conhecendo as obras de Richard Neutra e Frank Lloyd Wrigh, referência para uma série de residências célebres na década de 50, além de vários edifícios. Nas décadas de 60, 70 e 80 dá uma série de consultorias em planejamento urbano. Morre em 1997.

${ }^{88}$ LEMOS,Carlos, op. cit., p.153
} 
A notoriedade de seus edifícios foi acompanhada pelo reconhecimento de sua seriedade profissional de homem minucioso, que ia às últimas indagações em seus desenhos de pormenorização de detalhes construtivos, em seus esquemas funcionais, em seus gráficos de circulação. Por conta dessas características, Lemos vai fazer uma surpreendente análise:

"Rino foi o anti-Oscar por excelência; em vez de se livrar dos condicionantes do partido, procurava-os para tentar vencê-los. Disso, decorreu uma arquitetura sobriamente bem composta, com cada coisa no seu lugar, justificando toda uma teoria muito bem estudada, como no caso de seus hospitais, assunto de constantes palestras, conferências e escritos. Não podemos dizer que tenha sido um artista livre, onde a liberdade aliada à imaginação levassem-no a soluções personalistas por excelência. Não. Rino Levi foi o fiel servidor das regras e seu mérito está em tê-las servido com bom gosto." ${ }^{99}$

Explicita-se, mais uma vez, a contraposição arquitetura de gênio $\mathrm{x}$ arquitetura de ofício. Lemos, como já dissemos, dirigiu o escritório paulista de Niemeyer e abertamente valoriza a genialidade e a pesquisa plástica sobre as outras instâncias da criação arquitetônica. Assim, justifica-se que, segundo ele, caiba a João Batista Vilanova Artigas a definição da arquitetura paulista. Como professor da recém fundada FAUUSP, "inicia seu grande movimento de renovação do ensino da arquitetura, dando, antes de tudo, aos jovens arquitetos um novo enfoque da realidade em que viviam, de modo que pudessem abordar os problemas de trabalho com uma nova visão crítica. Sua obra arquitetônica é vasta e em permanente evolução, também baseada na plasticidade do concreto armado. (...) Na sua arquitetura tudo está à vista, o seu concreto aparente, sem os subterfúgios dos revestimentos, dos disfarces, dos enriquecimentos decorativos, está sempre a definir

${ }^{89}$ LEMOS, Carlos, op. cit., p. 154. 
espaços inesperados e muito claros na intenção, que sempre atende ao programa com o máximo de pertinência." ${ }^{\circ}$

Desta maneira, Lemos alinha-se a leitura de valorização de uma arquitetura moderna peculiarmente brasileira e, dentro dela dois momentos em especial: uma escola carioca, com Lúcio Costa e Oscar Niemeyer como protagonistas e, uma escola paulista em torno da figura de Vilanova Artigas. Assim, como observa Lúcio Gomes Machado em obra que será comentada a seguir, nivela-se em posição inferior "um grande número de obras e arquitetos com propostas discordantes do partido predominante. No entanto, ao realçar, como demérito, a atenção aos detalhes e o fato de ser servidor de regras, tocou nos pontos em que, verdadeiramente, a arquitetura de Rino Levi se sobressai, não pelo bom gosto, mas pelo domínio da profissão." ${ }^{11}$

Esse domínio da profissão é demonstrado pelo próprio Lemos quando, trabalhando com a questão do clima e a arquitetura brasileira, comenta que os locais quentes e úmidos provocaram providências tendentes a evitar o sol direto nas paredes externas das residências, como $\mathrm{o}$ uso do alpendre. Acompanhando $\mathrm{o}$ desenvolvimento dessas proteções, apresenta alpendres de residências rurais do Ceará e de Minas[39]. Nos locais quentes, há necessidade de se obter franca renovação de ar dos interiores, providenciando-se aberturas opostas que propiciam correntes de ventilação. Exemplifica com moradia popular contemporânea em Marabá, na bacia amazônica. A seguir, comenta as varandas protegidas por treliças e venezianas, e os pátios guarnecidos por venezianas corridas. Exemplifica com um antigo sobrado de São Luís do Maranhão, cujos fundos são francamente ventilados, e com duas residências em Alcântara, também no Maranhão. Termina o comentário "com um exemplo de arquitetura moderna empregando um

\footnotetext{
${ }^{90}$ LEMOS, Carlos, op. cit., p. 158.

${ }^{91}$ MACHADO, Lúcio Gomes. Rino Levi e a Renovação da Arquitetura Brasileira. São Paulo, tese de doutorado, FAU-USP, 1992.
} 
grande pergolado em pátio interno de residência paulista projetado por Rino Levi." ${ }^{22}$ [40]

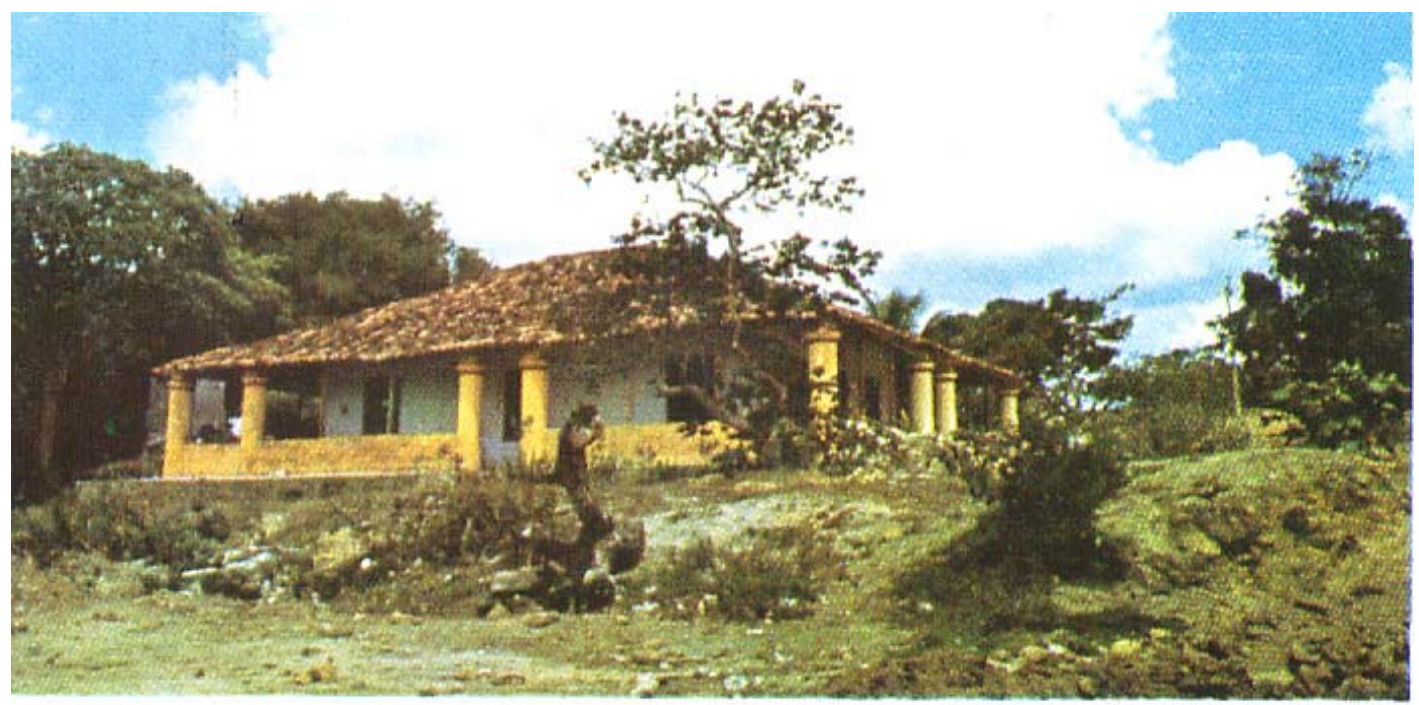
zoto 3

Foto 4

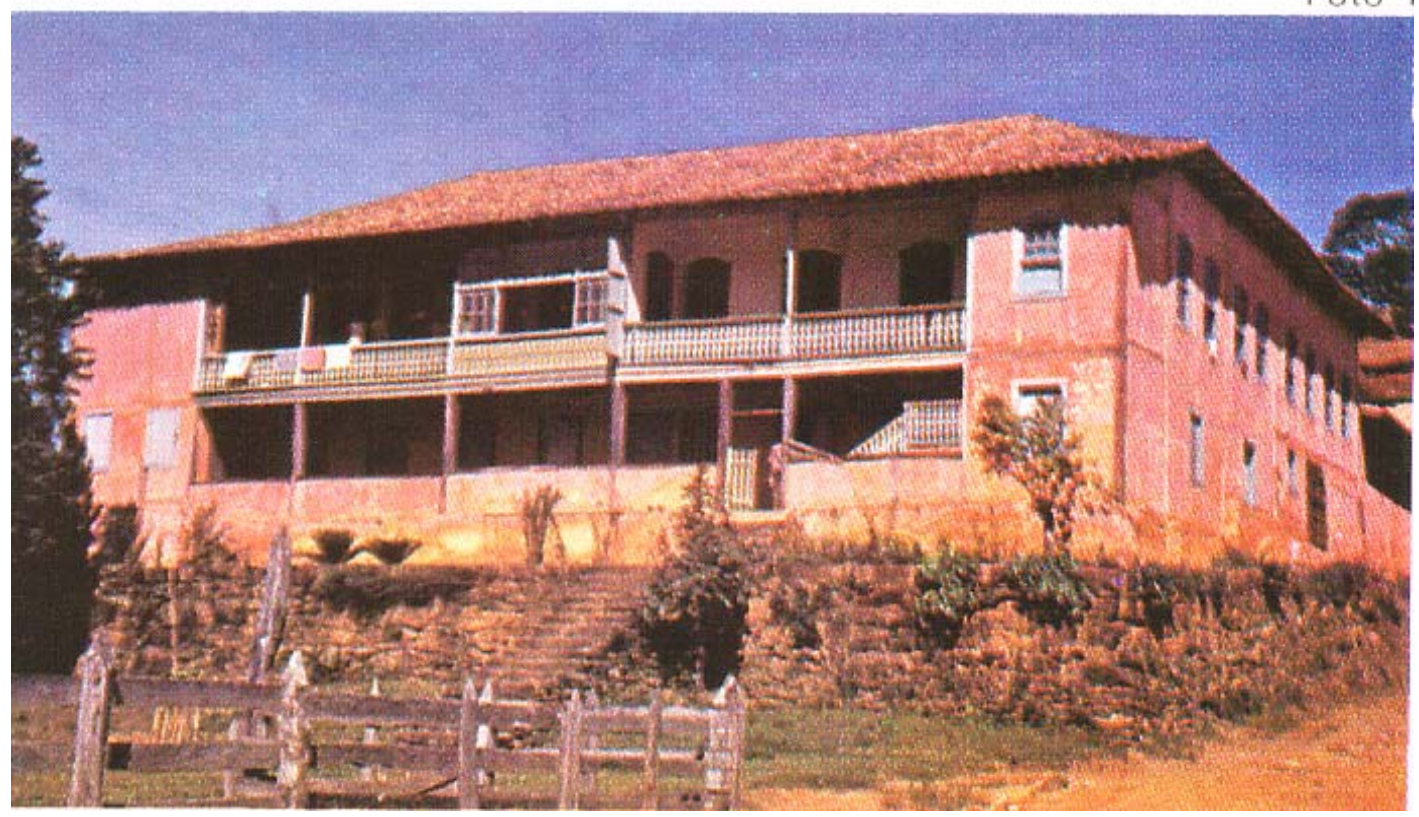

[39] ] Residências rurais do Ceará e de Minas

${ }^{92}$ LEMOS, Carlos, op. cit., p.122. 


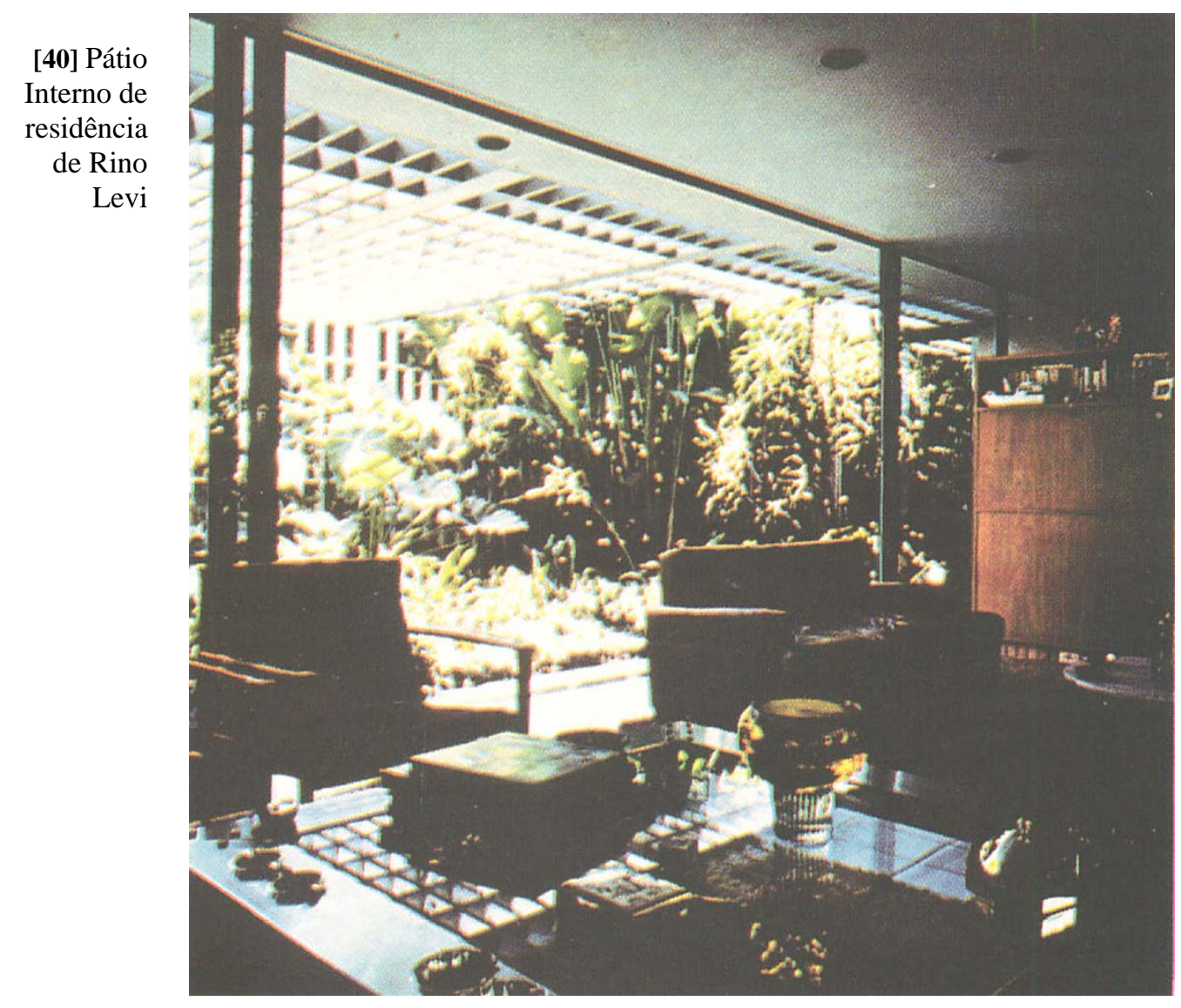

\section{2 - RINO LEVI NAS TESES}

Na década de 90 - conforme já descrita - é intensa, nos meios acadêmicos, a produção de teses que se voltam para o período moderno da nossa arquitetura. É o momento em que os primeiros balanços dessa historiografia são feitos, onde se explicita a construção de tramas, leituras e discursos que a constituem. Como consequência dessas revelações, novos levantamentos panorâmicos ou pontuais são feitos, algumas vezes, mantendo o estilo esquema 
explicativo/cadastramento: com a proposta de introduzir uma nova leitura, limitam-se a outra seleção.

No entanto, surgem também novas análises críticas, reavaliando o processo da arquitetura moderna em uma cidade ou região, ou ainda, especificamente o papel de um arquiteto e sua obra. Muitas delas, talvez a maioria, vai se dedicar justamente a produção com propostas discordantes do partido predominante na historiografia já analisada. Assim, são alçados a protagonistas do processo moderno da arquitetura no Brasil, arquitetos relegados a segundo plano por estarem à margem das escolas brasileiras. Rino Levi é um deles. Como também já foi dito, dois trabalhos de fôlego são apresentados sobre ele no programa de pós-graduação da FAUUSP: a tese de Lúcio Gomes Machado e a de Renato Anelli. São elas que analisaremos a seguir.

\subsection{1. - A TESE DE LÚCIO GOMES MACHADO ${ }^{93}$}

A hipótese já está explicitada no título da tese: Rino Levi e a Renovação da Arquitetura Brasileira. O ponto de partida de Lúcio Gomes é que, na medida em que os historiadores da arquitetura moderna têm mantido durante décadas a obra dos arquitetos que colaboraram com o projeto do MES como seu ponto de referência central, ficam relegados para segundo plano ou ignorados "conjuntos de realizações e obras de arquitetos que, trabalhando em outros contextos, contribuíram decisivamente para a conformação do panorama atual de nossa arquitetura. (...) Neste contexto, a obra de Rino Levi adquire especial importância, em razão da qualidade e do volume de sua obra, mas também em razão da influência que teve sobre o desenvolvimento da arquitetura em nosso meio." 94

\footnotetext{
93 MACHADO, Lúcio Gomes. Rino Levi e a Renovação da Arquitetura Brasileira. São Paulo, tese de doutorado, FAU-USP, 1992.

${ }^{94}$ MACHADO, Lúcio Gomes, op. cit.
} 
No sentido de construir essa nova inserção do trabalho de Rino Levi, Lúcio começa reconstituindo o surgimento do Movimento Moderno nos Estados Unidos e Europa, indicando teorias e obras que configuraram o quadro da arquitetura onde ele se formou. $O$ ambiente da cidade de São Paulo quando da sua volta e as iniciativas de renovação da arquitetura são o próximo objeto de investigação. Os textos de Rino Levi, os textos críticos sobre ele e o quadro teórico que baliza suas atividades vêm a seguir. Esse processo culmina com a análise do desenvolvimento e das características de sua obra.

O capítulo A Crítica da Obra de Rino Levi analisa, em ordem cronológica, os autores que, com importância diferenciada, inserem a obra de Rino Levi no contexto de um quadro mais abrangente da História da Arquitetura Brasileira.

O percurso seguido por Lúcio foi o que orientou esta leitura historiográfica e o papel do escritório Rino Levi. O entendimento de que toda história é construção - , argumentada sim, mas, construção justifica este novo estudo, pois hipóteses diferentes resultam diferentes leituras.

Em que pese a pertinência e a qualidade do percurso seguido por Lúcio, mais importante para o presente trabalho é o capítulo $A$ Arquitetura de Rino Levi. Nele uma periodização é proposta para a trajetória de Rino Levi, resultado do cotejamento das obras, dos textos do arquiteto e do panorama da arquitetura brasileira e internacional. A partir desse cotejamento cinco períodos são definidos:

1 - Projetos cuja expressão baseia-se na justaposição de volumes, normalmente geometrizados. Ex.:Edifício Columbus, 1932,São Paulo[41] Primeiramente prismáticos, a eles são anexados volumes gerados por curvas. 


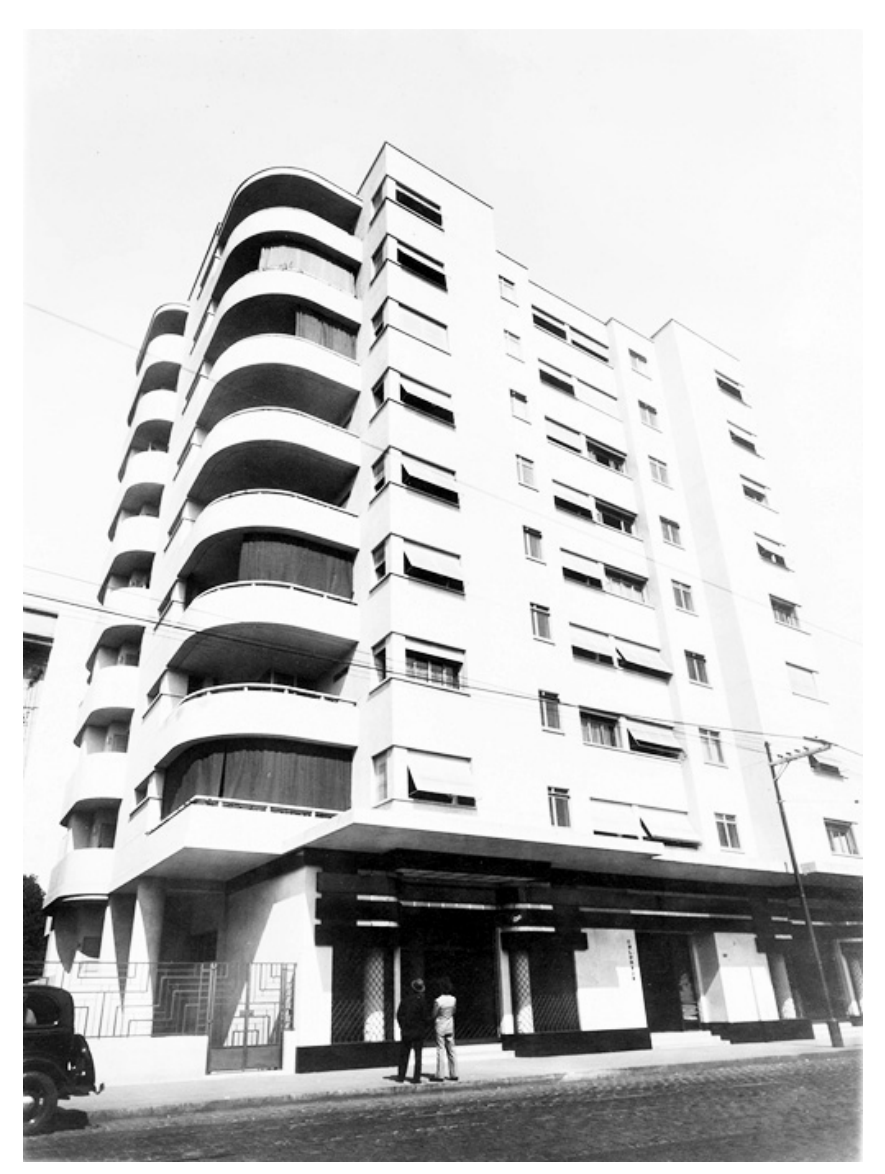

[41] Edifício Columbus, São Paulo, SP. Arquiteto Rino Levi, 1932.

2 - Projetos nos quais as superfícies de elementos vazados ou grelhas destinadas à proteção contra a insolação têm preponderância na configuração geral dos volumes.Ex. Instituto Superior Sedes Sapientiae,1940, São Paulo.[42] 


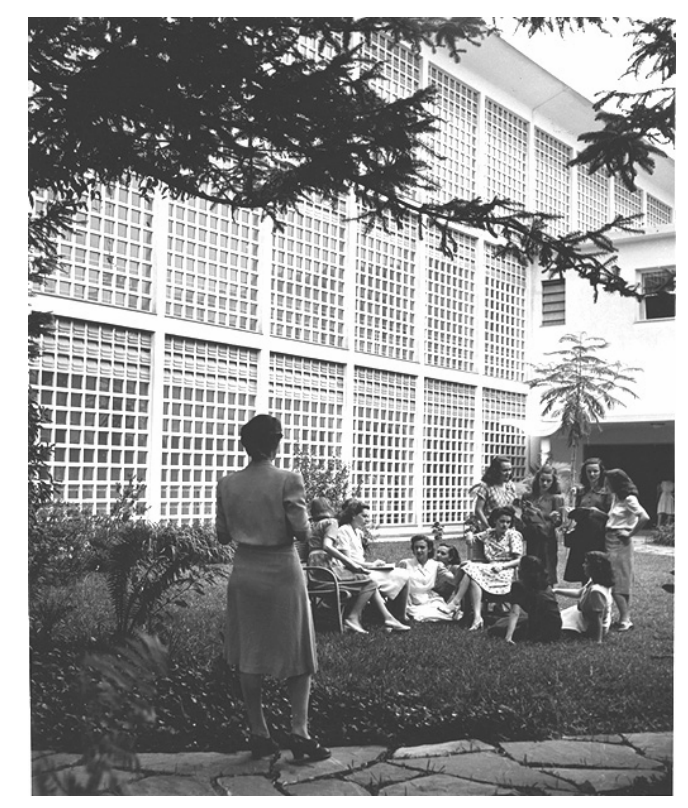

[42 Instituto

Superior

Sedes

Sapientiae,

São Paulo,

SP. Arquiteto

Rino Levi,

1940.

3 - Projetos em que a expressão fundamenta-se na reunião de funções em blocos prismáticos isolados, normalmente em altura.

4 - Projetos em que são buscadas formas de continuidade do espaço, especialmente entre o espaço interno e o externo.

5 - Projetos nos quais a proteção contra a insolação excessiva é controlada por meio de disposição de brise-soleil, assumindo este elemento papel preponderante na composição do volume.Ex. Edifício Concórdia, 1955,São Paulo [43]. 


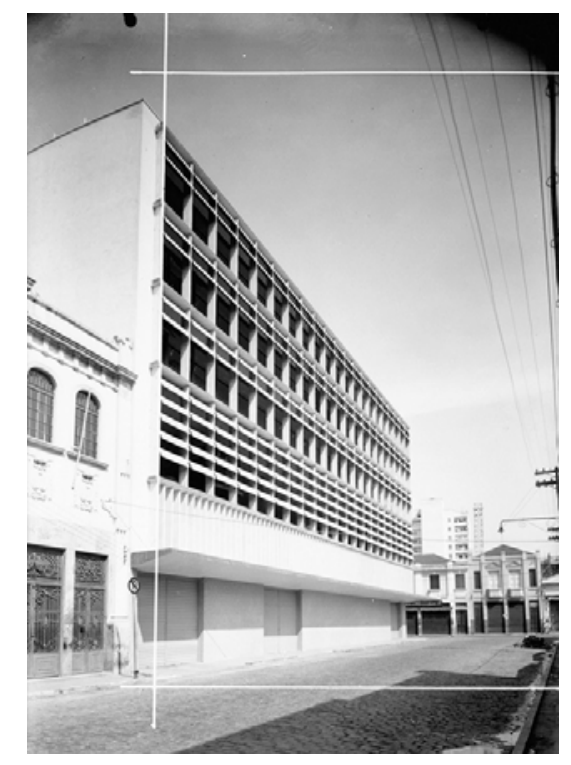

[43] Edifício

Concórdia,

São Paulo,

SP.

Arquitetos

Rino Levi,

Roberto

Cerqueira

César e Luis

Roberto

Carvalho

Continuando seu raciocínio, Lúcio propõe outra forma de agrupamento, a partir da função ou programa para as quais foram projetadas. Estabelecido esse critério, são definidas as Características da Obra de Rino Levi, a partir das origens do vocabulário formal de que lança mão o arquiteto. Assim, são definidos treze grupos:

1 - Volumes que tem como origem o que é usualmente denominado de arquitetura expressionista, isto é, aquela em que se recorre a superfícies convexas e côncavas executadas em concreto, explorando o potencial desta técnica, a elaboração de detalhes e a introdução de superfícies de vidro.

2 - Volumes cuja origem seria encontrada nas primeiras experiências da arquitetura racionalista européia, ainda muito calcada numa tentativa quase didática de transposição das experiências cubistas para a arquitetura.

3 - Evolução desta última, passam os volumes, tomados em escala maior, a representar funções distintas, deixando de ser um exercício meramente formal: a volumetria resulta da correta conexão dos diversos grupos de funções a serem abrigadas.Ex. Hotel Excelsior, 1941, São Paulo [44]. 


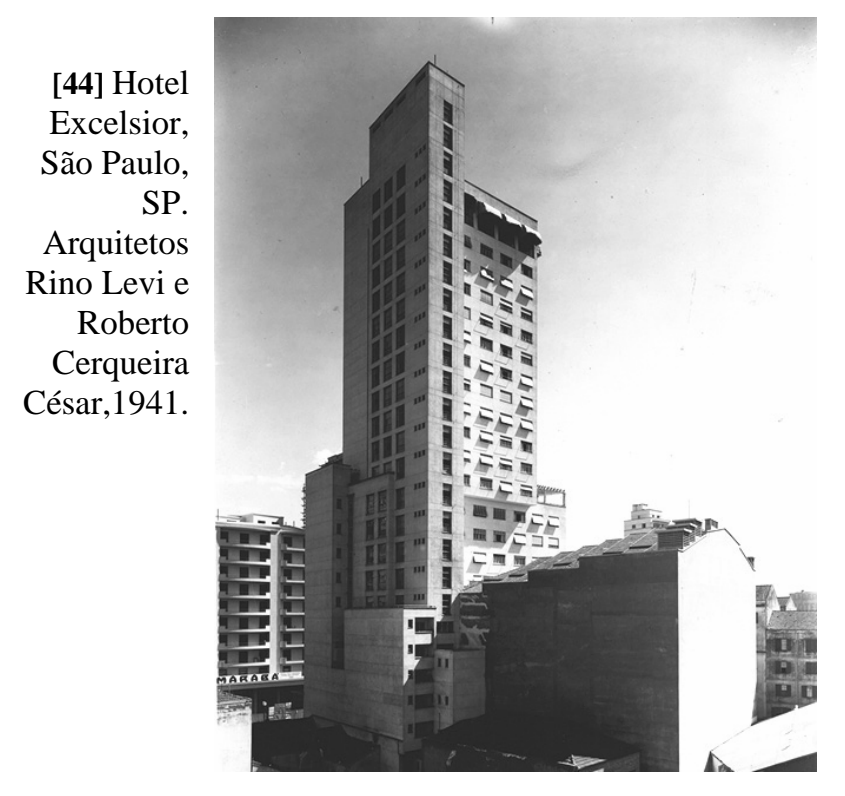

4-Grandes edifícios residenciais resolvidos com a adoção de blocos prismáticos, cuja origem podemos localizar na escola de Chicago, e seu posterior desenvolvimento a partir das soluções para a habitação coletiva realizadas no contexto do racionalismo europeu, nos projetos de Le Corbusier, Mies e Gropius. Partido posteriormente estendido a projetos de uso administrativo.

5 - Projetos cuja forma está diretamente ligada à solução técnica de programas específicos.

6 - Projetos cujo partido tem sua expressão arquitetônica vinculada ao tratamento que é dado à proteção contra insolação excessiva, tais como: brise soleil, grelhas de elemento vazado, superfícies vazadas (ex.: Edifício Concórdia, 1955, São Paulo) [45], pérgulas e persianas de enrolar. 


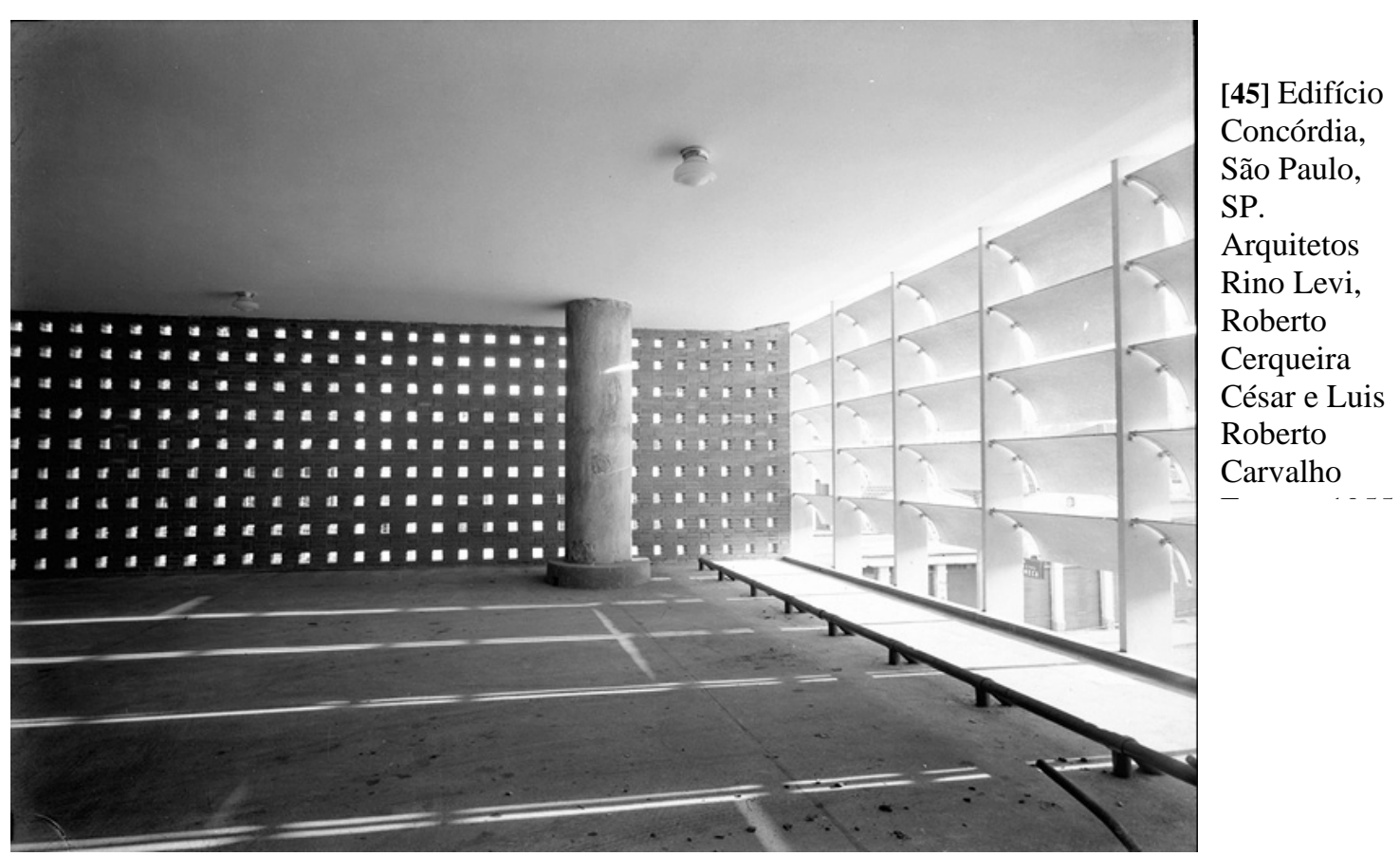

7 - Projetos cujo partido é definido pelo desenho das superfícies das fachadas, tais como: repetição de módulos, repetição de volumes ou saliências e a incorporação de superfícies em balanço.

8 - Projetos que adotam formas de tratamento de superfícies e emprego de materiais próximos à arquitetura que Banham denominou de Brutalismo. ${ }^{95}$ Ex.: Usina de Leite Parayhba, 1964, São José dos Campos [46].

${ }^{95}$ BANHAM, Reyner, The New Brutalism, New York, 1966. 


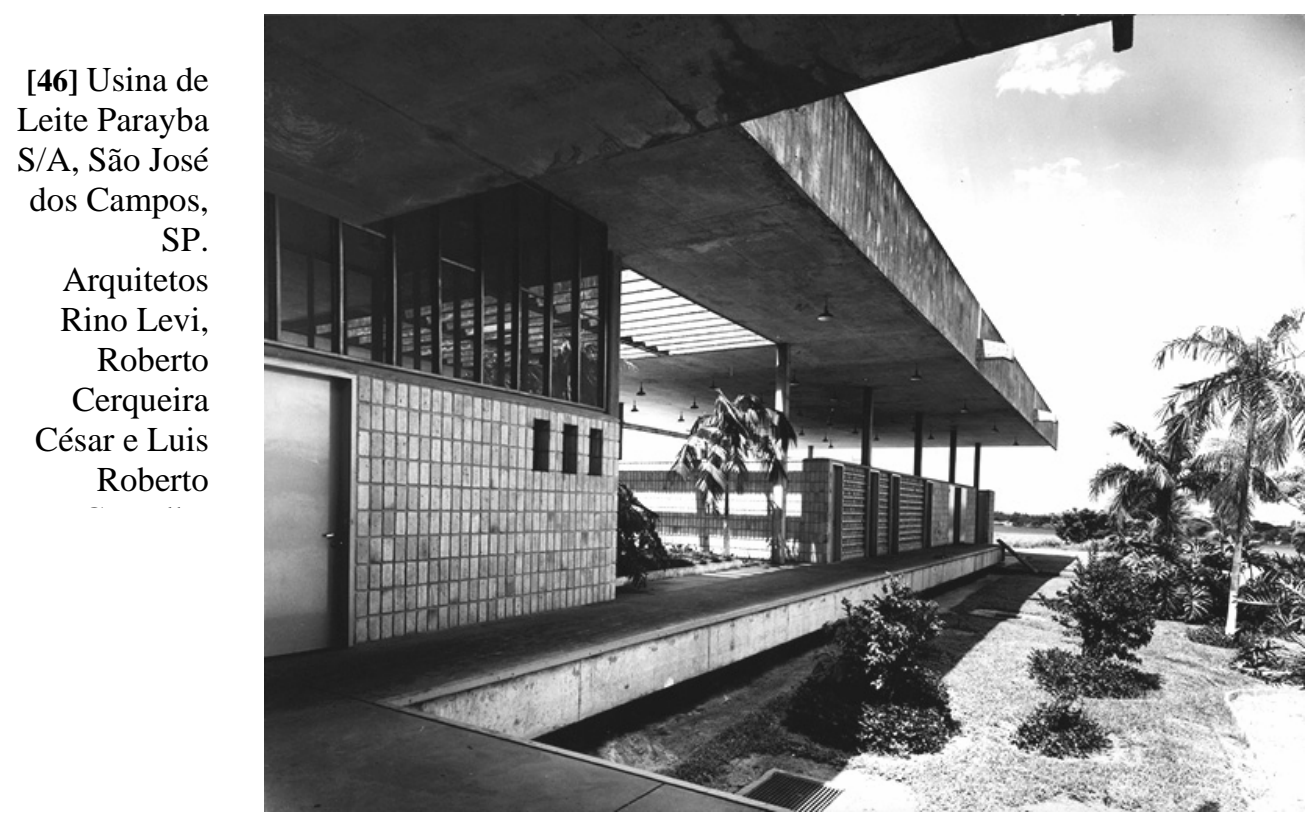

9 - Projetos que adotam o raciocínio da planta livre, entendida como a disposição da estrutura de forma independente das vedações.

10 - Projetos onde a finalidade utilitária imediata requer uma solução estrutural original.

11 -Projetos de residências onde é marcante a importância dada à comunicação entre os espaços internos e externos, dada por meio da continuidade das superfícies horizontais, através de pérgulas seguindo os forros ou ambientes voltados para pátios internos.

12 - Integração de obras de arte à arquitetura, acompanhando a corrente racionalista de origem francesa.Ex.: Edifício Prudência,1944, São Paulo [47] 


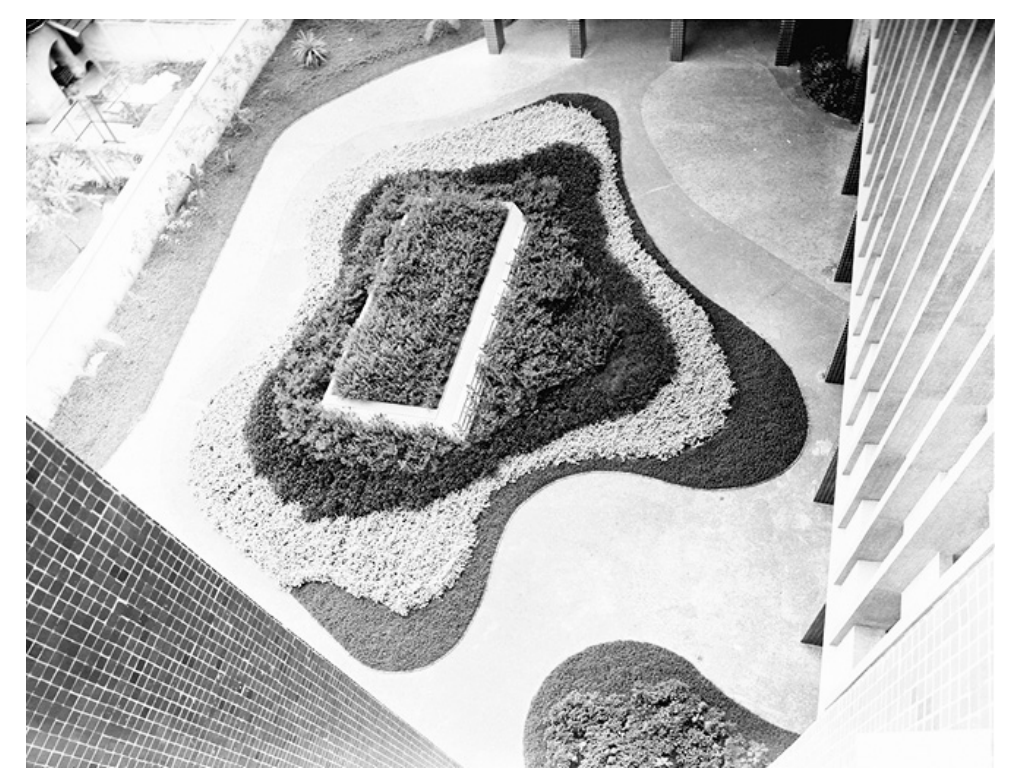

[47] Edifício

Prudência,

São Paulo,

SP.

Arquitetos

Rino Levi e

Roberto

Cerqueira

César, 1944.

13- Projetos concebidos como montagem de componentes industrializados, inserindo a arquitetura no âmbito das demais atividades industriais, em especial as do ramo metalúrgico-mecânico.Ex.:Edifício Sarti,1935, São Paulo [48].

[48 Edifício

Sarti, São

Paulo, SP.

Arquiteto

Rino

Levi,1935.

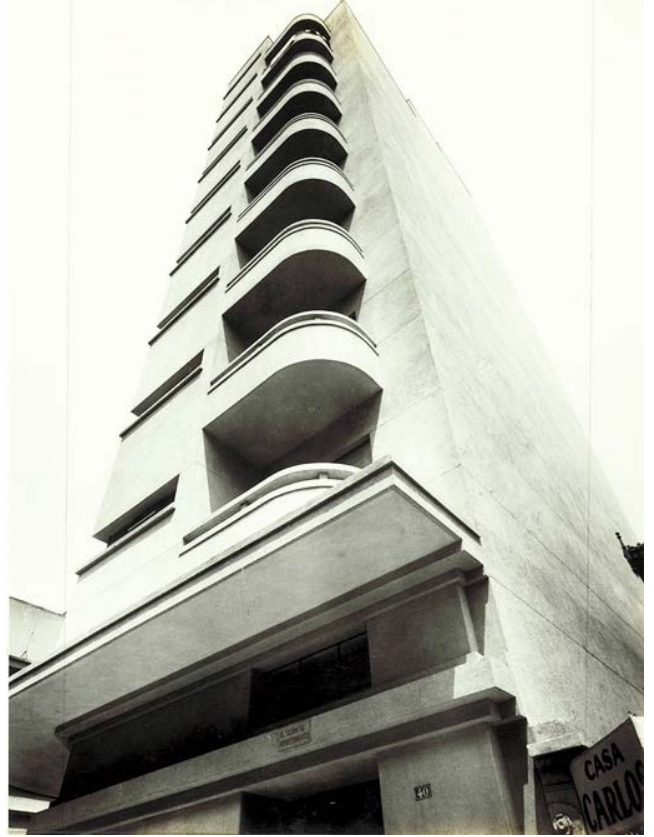


A partir desse exame, Lúcio conclui que houve "uma progressiva incorporação de novas formas de projetar ou de novos dispositivos construtivos para solucionar os programas. Por outro lado, não se pode inferir relação entre os programas e as características permanentes na obra." ${ }^{96}$

O capítulo é encerrado com Uma Seleção das Obras de Rino Levi, onde o critério usado é o significado "para o entendimento de suas propostas, privilegiando as construídas e as que por seu partido ou peculiaridades construtivas adquiriram especial interesse." 97

Finalizando todo o processo exposto, Lúcio Gomes alinha dez Conclusões:

1 - A História da Arquitetura, em particular a transição da arquitetura acadêmica para o Movimento Moderno, deve ser retomada com o objetivo de tornar mais claros os pontos de contato entre essas duas concepções do espaço construído.

2 - A corrente principal da História da Arquitetura não incorpora a arquitetura brasileira, com raras exceções para o grupo do Rio de Janeiro, mesmo assim, de forma marginal.

3-A arquitetura moderna brasileira deve ser estudada em seu contexto específico e seu estudo também deve ser reconsiderado, de forma a recompor sua trajetória, incorporando contribuições da mais alta importância que tem sido desconsideradas pela crítica, como a obra de Rino Levi. Sua importância prende-se à profundidade e abrangência de suas propostas, ao volume de projetos e à diversidade de problemas enfrentados.

4 -As influências citadas parecem se refletir sobretudo nos aspectos formais. As adaptações necessárias, no entanto, 
respeitam a concepção da arquitetura como um fenômeno da sociedade industrial, da qual partem solicitações novas, e que proporcionam meios até então inéditos para o seu enfrentamento.

5 - Sua formação, embora marcante, não impediu que, ao enfrentar os novos programas, projetasse uma obra de grande mérito e originalidade, possibilitando uma contribuição individual no decorrer de sua carreira.

6 -Suas primeiras obras são mais do que sobrepor à cidade caipira uma imitação diluída de cidade européia. No decorrer de sua carreira, o acompanhamento de tendências da arquitetura européia não é feita de forma mimética, mas buscando a sua adequação às condições locais em termos de programas, clima, meio cultural e natural

7 -Diferentemente da corrente predominante da arquitetura moderna brasileira, que enfatizava a originalidade formal, conseguiu impor-se à cidade provinciana por meio de especial atenção aos aspectos relacionados com a técnica construtiva e com a solução de programas complexos, para o que lançava mão de equipes multidisciplinares.

8 -Sua obra, desenvolvida em grande parte na cidade de São Paulo, é uma das balizas do que aqui é reconhecido como arquitetura moderna: tanto cronologicamente como na sua implantação, acompanha a reconstrução e a expansão da cidade.

9 -Desenvolveu detalhes construtivos que inovaram as técnicas usuais em nosso meio, constituindo processos de representação gráfica que foram incorporados às práticas padrão adotadas no Brasil. 
10 - Incorporando a produção industrial e voltando-se para ela, sua obra é, no Brasil, uma continuidade das propostas que emanaram da Bauhaus.

Dessa maneira, essa nova leitura da produção do escritório Rino Levi recoloca o seu papel no movimento moderno brasileiro, ao mesmo tempo em que explicita como ela foi responsável por novos paradigmas para a atuação profissional dos arquitetos. Dela surgiram várias referências que alimentam as hipóteses levantadas neste trabalho.

\subsection{2 - A TESE DE RENATO ANELLI ${ }^{98}$}

A tese de Anelli Arquitetura e cidade na obra de Rino Levi também explicita sua hipótese já no título: vai ser importante a análise da sua obra através das concepções urbanísticas implícitas nos projetos, onde o arquiteto procura ultrapassar os limites das intervenções pontuais. A segunda instância importante desta nova leitura é uma outra explicação para o papel secundário ocupado por Levi na linha preponderante da historiografia brasileira de arquitetura. A primeira diferença apontada por Anelli é que Levi teria uma grande quantidade de conceitos coincidentes com aqueles identificáveis nas obras de Oscar Niemeyer e Lúcio Costa. Pela sua leitura "a procura de uma identidade brasileira na relação com a natureza e a admiração por Le Corbusier foram os dois principais temas em comum." 99

Anelli lembra a posição de Lemos, já analisada aqui, de que a obra de Levi seria menor por estar muito contida dentro de regras, ao contrário da imaginação livre de Niemeyer. Pergunta, então "se esse

\footnotetext{
98 ANELLI, Renato Luiz Sobral. Arquitetura e cidade na obra de Rino Levi. São Paulo, tese de doutorado, FAU-USP, 1995.

99 ANELLI, Renato, op. cit., p.X.
} 
atributo (a imaginação livre) fosse objeto de uma ferrenha oposição, daquele e de vários outros arquitetos, ainda seria válida a sua utilização como parâmetro para o julgamento de seu valor?"100 Ao primeiro impulso de responder negativamente, considera que "o desenvolvimento da pesquisa revelou as proximidades de Levi com muitos dos dilemas enfrentados por Costa, resultando entretanto em propostas bastante diferenciadas, mas nunca num internacionalismo alheio aos temas básicos da brasilidade. É possível a identificação de um diálogo entre os partidos dos dois arquitetos. Hoje podemos afirmar que Levi representa uma outra brasilidade possível, sem vinculações políticas com o Estado desenvolvimentista, mais aberta ao diálogo internacional e à condição urbana contemporânea." ${ }^{101}$ Dessa maneira, não contesta a brasilidade como instância de julgamento, ao contrário, advoga para Rino Levi esse atributo.

Com relação ao segundo tema, a relação com Le Corbusier, Anelli faz uma leitura semelhante. Reconhecendo a formação conservadora que Levi teve na Itália, aponta que está "dentro de um ensino que começava a emancipar-se da academia, era tensionada pela avalanche de novas propostas, oriundas da Europa transalpina, as quais eram avidamente assimiladas pela sua jovem geração." ${ }^{102}$ Uma dessas novas propostas era o ideário corbusiano, que pôde ser lido em profundidade. Segundo Anelli, "nesse quadro, Levi deve ao ensino italiano uma leitura própria da obra de Le Corbusier, que se difere tanto da interpretação realizada por Lúcio Costa, a ponto de chegar a ser identificado como não-corbusiano." ${ }^{103}$ Novamente, o problema não estaria na pertinência do que é valor, mas em equívoco de julgamento. Assim, é correto ter na referência corbusiana uma instância de avaliação, mas errado julgar que Rino Levi não a tenha.

\footnotetext{
${ }^{100}$ ANELLI, Renato, op. cit., p.IX.

${ }^{101}$ ANELLI, Renato, op. cit., p. XII.

${ }^{102}$ ANELLI, Renato, op. cit., p.XIII.

${ }^{103}$ ANELLI, Renato, p. cit., p. XIII.
} 
Podemos concluir que, segundo Anelli, a injustiça apontada no papel secundário ocupado por Rino Levi na historiografia, é menos responsabilidade das categorias nela usadas, e mais em falha na interpretação das reais motivações do arquiteto. Propondo essa reinterpretação, sua tese está dividida em três capítulos. No primeiro, trata o período de formação italiana, o paralelo com seus colegas, os seus trabalhos de escola e seus primeiros projetos no Brasil. No segundo, trata do seu conceito da arquitetura como uma das artes, situando-o entre seus contemporâneos brasileiros e identificando seus principais procedimentos projetuais. No terceiro, analisa sua obra através das concepções urbanísticas implícitas nas relações interior/exterior.

O primeiro capítulo retoma os dois manifestos de 1925, de Warchavchik e de Levi, já mencionados. Anelli aponta que o primeiro reproduzia diretamente as propostas corbusianas, enquanto $\mathbf{o}$ segundo revelava-se mais influenciado pelas especificidades do debate italiano. O ensino de urbanismo, como veremos, foi uma das principais inovações introduzidas pela escola unificada de Roma e daí resultaria a principal diferença entre eles (Levi priorizava em sua carta-manifesto a estética das cidades), que pode ser explicada pelos distintos momentos em que ambos passaram pela formação romana (Warchavchik se forma um ano antes da unificação da escola).

As especificidades do debate italiano vão ser exaustivamente trabalhadas, e Anelli analisa a divisão do ensino de arquitetura entre as academias e os politécnicos, ou seja o Instituto de Belas-Artes de Roma, a Academia de Brera e o Politécnico de Milão. Foi com estes últimos que ocorreu a primeira tentativa institucional de integração do ensino artístico e técnico-científico para a formação do arquiteto, ainda em 1865, com a criação da Escola de Aplicação para os Arquitetos Civis. A proposta baseava-se numa concepção de arquitetura estruturada em duas partes, o organismo e o simbolismo. 
Tudo que concernia à funcionalidade e construtibilidade do edifício, dependente de uma lógica mais racional que artística, é o organismo. A beleza e todos os aspectos relativos à cultura e à expressão artística comporiam o seu caráter simbólico. A união entre as duas partes constituiria os estilos. Anelli ressalta como "frente à recémconquistada unidade nacional italiana, carecia-se de um estilo novo que simbolizasse a nação. $O$ ensino teria assim dupla função, estudar o orgânico e os estilos históricos, conhecimento estabilizado da arquitetura, enquanto se pesquisava o desenvolvimento do novo estilo italiano" 104

A escola decorrente dessa proposta teve pouco sucesso em decorrência das dificuldades - na Itália daqueles anos - em se estabelecer os limites entre as atribuições do arquiteto e as do engenheiro civil. $\mathrm{O}$ baixo índice de inscrições atesta o insucesso: no período entre 1867 e 1915 formaram-se apenas 99 arquitetos civis. Em 1903, uma reforma destinada a corrigir os problemas do projeto original, configura uma nova estrutura que permaneceria inalterada até a criação da Faculdade de Arquitetura de Milão em 1933. Dividiram-se as escolas preparatórias (os dois primeiros anos) em unidades especiais para engenheiros civis e arquitetos. Foram reduzidas as disciplinas técnico-científicas, aumentadas as artísticoarquitetônicas, além de acrescidas algumas disciplinas de cultura geral.

“A concepção do biênio preparatório reforçava a divisão do ensino da arquitetura não apenas entre arte e técnica, mas entre um primeiro momento destinado exclusivamente ao conhecimento analítico dos estilos e um segundo, onde se pretendia o aprendizado de composição."105 Limitado aos três últimos anos, o ensino de composição mantinha a estrutura acadêmica baseada na prática de atelier, onde o discípulo era dirigido pelo mestre arquiteto. "Ainda

\footnotetext{
${ }^{104}$ ANELLI, Renato, op. cit., p. 14.

105 ANELLI, Renato, op. cit., p. 15.
} 
que tenha sido a primeira experiência de ensino integrado, a escola criada pelo Politécnico não conseguiu tornar-se referência nem para o ensino, nem para a prática da arquitetura, o que não impediu que nela se formassem alguns dos mais importantes arquitetos italianos, inclusive alguns dos que viriam a promover o movimento racionalista." ${ }^{106}$

É curioso que o ambiente arquitetônico romano, mais atrasado culturalmente, tenha produzido uma proposta destinada a ter maior sucesso. Acompanhando a sua formulação, Anelli recua ao sec. XIX, e relata a intensa disputa entre diversos profissionais com formação diferente, mas com atribuições semelhantes. Nela se confrontavam o arquiteto civil formado pelos cursos de arquitetura das escolas politécnicas, os professores de desenho arquitetônico formados pelas academias de belas-artes e ainda os engenheiros civis.

Mudança efetiva nesse quadro só vai surgir com um novo campo, provocado pelo intenso crescimento das cidades italianas. "Os diferentes tipos de arquitetos eram pouco adequados para atender a demanda urgente por um controle das modernizações das cidades, fosse seguindo critérios artísticos, fosse de acordo com métodos científicos." ${ }^{107}$ Um novo agrupamento, contrapondo-se aos higienistas e sanitaristas, se organiza: as associações de cultores da arquitetura. "Essas reuniões de artistas, professores de desenho arquitetônico, nobres e literatos batalhavam pela defesa dos valores ambientais e artísticos das cidades italianas." ${ }^{108}$

As associações tinham forte caráter romântico e preservacionista, como a de Veneza, que conseguiu barrar todas as propostas de modernização urbana. Criou-se uma tendência nacional que pretendia a conservação integral do ambiente das cidades, entendido

\footnotetext{
106 ANELLI, Renato, op. cit., p. 16.

${ }^{107}$ ANELLI, Renato, op. cit., p. 22.

${ }^{108}$ ANELLI, Renato, op. cit., p. 23.
} 
como lugar de manifestação da cultura italiana. Entretanto, o desenvolvimento se acelerava, tornando-se impossível o simples desconhecimento das necessidades advindas do crescimento urbano. Um outro posicionamento, pretendendo o controle artístico das transformações e não a sua simples recusa, se afirma. "Faltava, aos membros das associações, a competência para elaborar propostas alternativas, que também atendessem as modernas demandas por higiene, por condições mais ágeis de circulação da produção, ou ainda por complexos tipos funcionais necessários à vida do sec. XX."109

Visando garantir a eficiência das intervenções na cidade, a criação da Escola Superior de Arquitetura de Roma tem a sua base na proposta do arquiteto integral. Unindo o saber técnico-científico e o conhecimento artístico, esse novo arquiteto deveria atuar com competência na defesa dos valores artísticos das cidades italianas. Apesar da fundamentação urbanística do architetto integrale, estava ausente da proposta original para a nova escola qualquer disciplina de projeto urbanístico: bastava o usual treinamento compositivo para que o arquiteto pudesse intervir com pertinência na cidade. Os problemas seriam os mesmos que os enfrentados no projeto de um edifício, mudando apenas a escala da intervenção. "Foi Marcello Piacentini quem desenvolveu uma teoria e uma disciplina, Edilizia Cittadina, com o objetivo de estudar as especificidades do projeto urbanístico." da cidade, ficou excluído de Edilizia todo tipo de conhecimento oriundo dos sanitaristas e higienistas, assim como o das ciências sociais.

Anelli lembra que o momento no qual surgiu o architetto integrale não estava muito distante das pesquisas realizadas na Alemanha pela Werkbund. "Apesar de serem duas propostas de interação entre arte e técnica, tratava-se de situações inteiramente distintas, pois estava ausente das associações artísticas italianas o relacionamento com um

\footnotetext{
109 ANELLI, Renato, op. cit., p. 23.

${ }^{110}$ ANELLI, Renato, op. cit., p. 25.
} 
intenso processo de industrialização." baseada no desenvolvimento da tradição histórica italiana, fonte das maiores glórias nacionais, tornava-se consenso entre toda o produção arquitetônica italiana entre-guerras. Modernização sem ruptura, característica que a distinguiu no campo internacional de sua época. Para realizar tal objetivo se concentraram num primeiro momento os esforços da nova Scuola Superiore di Architettura di Roma com os da revista Archittetura ed Arti Decorative, que se tornou em 1927 órgão oficial de divulgação do Sindicato Nacional de Arquitetos. Apenas no final dos anos 20 surgiriam novos agrupamentos, revistas e escolas, que constituíram um ambiente bastante complexo. Diversificava-se o entendimento de como poderia se dar a transformação da história em valor vivo e contemporâneo."112

A descrição de todo esse processo é acompanhada pela influência exercida na formação de Rino Levi, que, como já vimos, permaneceu na Itália de 1921 a 1926. Em Milão permaneceu de 1921 a 1923, na Escola Preparatória e de Aplicação para os Arquitetos Civis, e apesar do ensino de arquitetura não acompanhar, a cidade foi - ao lado de Turim - o centro onde se manifestaram propostas arquitetônicas inovadoras, com grande efervescência cultural nos anos 20.

Anelli comenta que Levi convive com os colegas num ambiente culturalmente estimulante, estudando junto aos principais futuros protagonistas do movimento racionalista italiano, inclusive Giuseppe Terragni. Porém, "nos anos em que isso acontece, o grupo ainda estava começando a se constituir, sem ter nenhuma clareza de quais eram as posições das vanguardas modernas existentes em outros países. Havia alguma simpatia dos estudantes pelas inovações da arquitetura moderna, mas isso ainda não resultava na ação vanguardista que eles assumiriam alguns anos depois da passagem de Levi pela escola."13

\footnotetext{
${ }^{111}$ ANELLI, Renato, op. cit., p. 25.

${ }^{112}$ ANELLI, Renato, op. cit., p. 26.

113 ANELLI, Renato, op. cit., p. 87.
} 
Portanto, qualquer semelhança entre sua arquitetura e a de seus colegas milaneses deve ser atribuída a outras causas que não à sua permanência na escola de Milão.

A transferência de Rino Levi para a Escola de Roma se dá em fevereiro de 1924. Como já vimos, o período em que permaneceu na cidade foi marcado pela gestação de novas posições. Ao contrário do acontecido em Milão, os seus colegas de turma tornaram-se arquitetos inexpressivos, sobre os quais existem poucas referências. No entanto, conviveu com colegas mais novos como Adalberto Libera, Mario Ridolfi e Luiggi Vietti, o que atesta o seu contato com as primeiras inquietações daqueles que assumiriam um importante papel de vanguarda na arquitetura italiana.

Assim, durante o período cursado por Levi as elaborações racionalistas ainda não haviam produzidos os primeiros frutos, nem em Roma, nem em Milão. Pelo contrário, "a produção de Piccinato, saudado como arquiteto modelo formado pela escola romana, indica um caminho incerto. Os trabalhos do aluno Rino Levi denotam algumas características mais constantes desse ambiente. O gosto neoclássico mediado por uma influência vienense ou germânica, a preocupação construtiva embasando a pesquisa artística, os desenhos vistosos demonstrando a origem na Accademia di San Luca, a composição arquitetônica como variação sobre temas tipológicos, são algumas constantes que revelam o matiz romano desses exercícios." 114 Esses trabalhos serão analisados adiante.

Segundo Anelli, "a produção escolar de Rino Levi representa um momento de inflexão. Não apresenta nem a plena adequação com a produção dos professores, nem uma pesquisa inovadora. Contido dentro dos limites então sugeridos pelos professores, Levi incorpora as metodologias e conhecimentos fornecidos pela escola, deixando o início

${ }^{114}$ ANELLI, Renato, op. cit., p. 90. 
de uma investigação formal inovadora para o seu retorno a São Paulo. Frente às especificidades do seu país, suas explorações formais poderiam ter maior concretude."115

O primeiro capítulo é encerrado exatamente com a análise dessas primeiras obras no Brasil e os primeiros projetos modernos de Rino Levi. Anelli classifica como claramente marcados pela sua formação italiana os projetos de 1927 ao início de 1929. Assim são incluídos, de 1927, a residência Godofredo Silva Telles, a residência H. Telles Ribeiro, a fábrica Pianos Brasil, o concurso do Automóvel Clube de São Paulo e o concurso para um monumento no Lago de Santo Amaro. De 1928 são lembrados os conjuntos de casas geminadas, um para Melhen Zacarias e outro para Luiz Manfro. Em 1929 Levi realiza mais dois projetos, o edifício Gazeau e a residência Vicente Giaccaglini, não construída.

O segundo grupo, marca o momento em que Rino Levi passou a desenvolver seus primeiros projetos com formas modernas, afastando-se dos resquícios estilísticos ainda presentes nos anteriores. Segundo Anelli, "esses primeiros projetos que pretendiam ser modernos, apresentavam linhas e volumetrias simples, e um despojamento na composição das suas massas e aberturas. As proposições de Le Corbusier, Walter Gropius e demais arquitetos modernos que Levi conhecera durante o período da sua formação na Itália sofriam agora uma adaptação às condições paulistas." ${ }^{16}$ Nele estão incluídos os estudos para o Edifício Columbus (o primeiro projeto é de 1930 e conhece mais quatro versões até a definitiva de 1933), o conjunto de casas econômicas para Regina Previdelli (1930), residência Delfina Ferrabino (1931), residência Luiz Manfro (1931), Pavilhão Elequeiroz (1931), dois conjuntos de casas econômicas para Dante Ramenzoni (1931/32) e residência Francisco Gomes (1932).

\footnotetext{
${ }^{115}$ ANELLI, Renato, op. cit., p. 104.

116 ANELLI, Renato, op. cit., p. 112.
} 
Este conjunto de projetos marca o início das obras modernas de Rino Levi. Segundo Anelli "suas características ainda estão fortemente ligadas ao período de sua formação na Itália, mas já se referem não mais às obras de seus professores e sim às de seus colegas. Nesses anos temos suas primeiras aquisições de livros italianos que divulgam as obras inauguradoras do movimento racionalista. (...) Entretanto, a produção de Levi nestes anos foi marcada por uma grande diversidade de referências, revelando mais um momento de procura do que de afirmação propositiva. O acompanhamento dos trabalhos italianos constituía um importante parâmetro para suas explorações formais." ${ }^{117}$

Um segundo parâmetro é apontado como importante para a compreensão do período: o relacionamento de Levi com Warchavchik. Segundo Anelli "a semelhança de alguns dos primeiros projetos de casas de Levi com os de Warchavchik revela que este servia de referência local para a sua desejada evolução em direção aos procedimentos modernos. A mesma origem de formação resultava numa metodologia projetual semelhante, e Warchavchik estava alguns anos mais adiantado na sua aproximação com a arquitetura moderna. Entretanto, Levi apresentaria uma evolução que rapidamente o diferenciaria do modernismo de Warchavchik. Em primeiro lugar por uma maior atenção à funcionalidade e aos conhecimentos científicos necessários para atender aos novos programas de uso; em segundo, por uma ênfase no caráter urbanístico da arquitetura." ${ }^{118}$ As questões da funcionalidade e conhecimentos científicos serão o objeto do segundo capítulo, A arquitetura como uma das artes, e a ênfase no caráter urbanístico o objeto do terceiro, Por uma estética da cidade com alma brasileira.

Anelli começa o segundo capítulo investigando o que seria para Levi o caráter clássico da arquitetura moderna. Alinhavando as várias referências feitas a ele ao longo dos seus textos, conclui que o objetivo

${ }^{118}$ ANELLI, Renato, op. cit., p. 127. 
seria alcançar a forma harmônica, superando todos os ecletismos e historicismos, descartados como cópias superficiais das obras do passado. Dessa maneira, inclui Levi no grupo de arquitetos modernos que operam dentro dos domínios de uma conceituação clássica, no qual estaria inscrito, também, Le Corbusier. Recorre a Panofsky ${ }^{119}$ "por considerarmos que sua leitura do pensamento classicista pode nos ajudar a identificar a origem de algumas interpretações modernas contrastantes entre si." 120

Várias são as oportunidades nas quais Levi se refere ao trabalho do artista-arquiteto como uma expressão do seu espírito interior, próximo, portanto, do conceito clássico da idéia artística. Segundo essa concepção, a beleza só é atingida quando o artista consegue imprimir na matéria a imagem de tal Idéia. Panofsky mostrou como o desenvolvimento histórico desse conceito produziu diversas formulações, interessando aqui "as diferenças entre uma concepção que defende o caráter metafísico da origem da Idéia, e uma concepção onde ela deriva do conhecimento da natureza pelo artista." ${ }^{\prime 21}$ Pelas posições expressas, Levi se filia a segunda interpretação.

Panofsky opõe a origem da Idéia na contemplação do sensível (presente no classicismo do sec. XVII) à origem metafísica da Idéia como dádiva divina, conferida ao gênio, independentemente do seu conhecimento da natureza (presente no maneirismo). Dessa forma, o classicismo desenvolve a concepção Renascentista, segundo a qual a Idéia deriva do conhecimento das leis universais que regem a natureza. O espírito renascentista possuía uma Idéia, ou melhor, uma síntese correspondente ao conhecimento de sua época. O espírito moderno deveria realizar a mesma operação.

119 PANOFSKY, Erwin. Idea - Contribuición a la história de la teoria del arte. Madrid, Ediciones Cátedra, 1989.

${ }^{120}$ ANELLI, Renato, op. cit., p. 133.

${ }^{121}$ ANELLI, Renato, op. cit., p. 132. 
Uma das várias versões dessa operação é realizada por Le Corbusier. Citando Carlos Martins ${ }^{122}$, Anelli indica como o purismo apresentado no livro Aprés Le Cubisme aproxima esta concepção ao mundo moderno das novas técnicas industriais: "Aquilo que é o mais característico de nossa época, já o dissemos, é o espírito industrial, mecânico, científico. A solidariedade da arte com esse espírito não deve conduzir a uma arte feita pela máquina, nem a figurações de máquinas. A dedução é diferente: o estado de espírito que vem do conhecimento da máquina oferece visões profundas sobre a matéria e, em consequência, sobre a natureza." ${ }^{123}$

Assim, a produção industrial não se contrapõe ao novo espírito artístico, pois ambos são, a seu modo, frutos da ciência moderna. Ao aprimorar o conhecimento sobre a natureza, a ciência aproxima o espírito das leis que a regem, entre as quais as da proporção, fundamento da beleza. O novo espírito do artista formado em contato com as ciências e técnicas modernas é capaz de construir uma idéia artística onde arte e técnica possam se fundir, numa síntese sem contradições.

Anelli ressalta a sintonia de Rino Levi com o pensamento corbusiano. Cita o texto escrito para a revista do III Salão de Maio, onde ele afirma:

"As leis da arte, que estão num plano diferente do da técnica, obedecem a fatores imutáveis da alma humana, ao passo que a forma técnica, após a sua evolução, se extingue. Os ensinamentos que nos pode dar a tradição adaptam-se aos progressos técnicos e a evolução social, esses ensinamentos são as que residem no espírito." ${ }^{124}$ Anelli chama a atenção para o fato de que a separação entre dois planos, um material , onde se localiza a técnica, mutável historicamente e outro espiritual,

\footnotetext{
${ }^{122}$ MARTINS, Carlos. Razão e Natureza em Le Corbusier. Madri, Tese de Doutorado, Escola Politécnica de Madrid, 1992.

${ }^{123}$ Ozenfant e Jeanneret - Aprés le cubisme, p. 33, apud MARTINS, op. cit.

${ }^{124}$ Rino Levi, “O que há na arquitetura”, Revista do Salão de Maio, 1939, apud ANELLI, op. cit.
} 
imutável, onde estão as leis da arte, é um ponto de contato entre a estruturação italiana do orgânico e simbólico, com as novas formulações puristas.

Em outro trecho do mesmo texto Levi reforça esse contato:

"O estudo da função e das qualidades da obra arquitetônica é tão intimamente ligado à técnica quanto às leis da proporção. Para se chegar a fins estéticos concretos, em harmonia com a função dos vários elementos constituintes da obra, necessário se torna conter e selecionar a fantasia de certos valores orgânicos. Esse processo é evidentemente um limite à livre expansão artística, limite esse que constitui fator inerente à atividade do arquiteto.(...)A finalidade da arquitetura não é o cálculo, apesar desta não poder prescindir do mesmo, mas sim e exclusivamente a forma. Enquanto esta é resultado de uma vontade criadora tendendo a tornar-se um símbolo, aquele nasce de um processo mecânico ao qual não interessa a plástica em si. ${ }^{125}$

Assim, a funcionalidade técnica e as leis de proporção não são contraditórias, estando todas coordenadas harmonicamente na construção de uma unidade orgânica, raciocínio coincidente com o pensamento clássico. Por outro lado, Levi deixa explícita sua oposição à plena liberdade artística, pois a harmonia exige contenção.

Também Lúcio Costa estrutura sua concepção de arquitetura em uma parte funcional e outra plástica, identificando-as respectivamente com os estilos gótico e clássico:

"Abrangendo a arquitetura duas ordens distintas de problemas, problemas de natureza ORGÂNICA e FUNCIONAL e problemas de

${ }^{125}$ LEVI, Rino, op. cit. 
natureza PLÁSTICA e IDEAL - pode-se encarar a composição arquitetônica de duas maneiras fundamentalmente distintas: a primeira consiste em partir da ordem funcional e desenvolver o tema plástico em consequência dela, como por exemplo, na arquitetura chamada gótica; a segunda, em partir de uma concepção plástica ideal e de subordinar a ela as necessidades de natureza orgânica e funcional, - como na arquitetura dita clássica, por exemplo. No primeiro caso a expressão plástica DESABROCHA (como nas plantas); no segundo caso, ela se DOMINA E CONTÉM (como nos sólidos geométricos)." ${ }^{126}$

Anelli lembra que "Costa reserva aos gênios a síntese desses pólos opostos, enquanto aos outros resta seguir o seu direcionamento, trabalhar resolvendo os problemas técnico-funcionais e esperando que a expressão plástica desabroche"127: Segundo Costa, "se, em determinadas épocas, certos arquitetos de gênio revelam-se aos contemporâneos desconcertantemente originais (Brunellesco no começo do século XV, atualmente, Le Corbusier), isto apenas significa que neles se concentram em um dado instante preciso (...) as possibilidades até então sem rumo de uma nova arquitetura." 128

Como já observado, Lúcio Costa vai mais longe e elege também o nosso gênio nacional: Oscar Niemeyer. Lembra Anelli que "é Costa quem abre espaço conceitual para que Niemeyer surja como o realizador das possibilidades até então sem rumo de uma nova arquitetura." ${ }^{129}$ Lembrando-nos das afirmações de Levi no texto do III Salão de Maio, já analisado, fica claro que no seu ideário não existe espaço para nenhum gênio. As diferenças estariam entre as características do procedimento realizado por Niemeyer e os princípios defendidos por Levi.

\footnotetext{
${ }^{126}$ COSTA, Lúcio, “Considerações sobre ensino da arquitetura”, revista Espaço, nº 3.

${ }^{127}$ ANELLI, Renato, op. cit., p. 139.

${ }^{128}$ COSTA, Lúcio, "Razões da nova arquitetura", Revista da Diretoria de Engenharia da PDF, Rio de Janeiro, jan. 1936.

${ }^{129}$ ANELLI, Renato, op. cit., p. 141.
} 
Segundo Anelli, Levi mantém - até em suas últimas obras - uma noção da arquitetura como composição de elementos:

"O problema estético, porém não muda. Mudam os elementos de composição, mas não se alteram as leis e princípios que governam a plástica. Os problemas da disposição ordenada, da harmonia de ritmos, dos acordes, das proporções, e da integração de todos esses fatores numa unidade, são sempre os mesmos. A estética baseia-se no ser humano, que em sua essência não varia."130

Anelli comenta que o desdobramento dessa diferença para o plano ideológico seria inevitável. Com a crescente hegemonia da corrente representada por Costa e Niemeyer sobre a arquitetura moderna brasileira, a figura de Levi torna-se menor para a historiografia. $\mathrm{O}$ papel reservado a Rino Levi se torna o de pioneiro nos anos 20, ao lado de Warchavchik, enquanto lhe é conferida uma posição secundária para o período após os anos 40.

Outra questão importante levantada por Anelli está no item Os segredos do métier. ${ }^{131}$ Nele, é lembrada a conclusão de Levi de que "na base dos critérios expostos, existe hoje uma noção mais clara da verdadeira função do arquiteto. Este deixa de ser eco de conceitos extravagantes e atrasados, baseados numa noção errônea de tradição e se torna o estudioso de todos os segredos do métier. É ele um artesão, sempre em luta com problemas inéditos." ${ }^{32}$

A comparação com o ofício do artesão induz a alguns desdobramentos. Para o arts and crafts o artesão une cultura popular e conhecimento da ação sobre a matéria. Aparentemente Levi se abre para esta concepção, aproximação que seria reforçada pelas referências à obra de Walter Gropius, e ao arquiteto como

\footnotetext{
${ }^{130}$ LEVI, Rino, "Evolução da arquitetura”, Aula inaugural da Faculdade de Arquitetura da Universidade do Rio Grande do Sul, 1958.

${ }^{131}$ ANELLI, Renato op. cit., p.147.

${ }^{132}$ LEVI, Rino, “ Técnica hospitalar e arquitetura”, palestra proferida no Museu de Arte de São Paulo, 1948.
} 
coordenador de equipe. "Porém Levi não perde a noção do artista clássico-renascentista, que se expressa inspiradamente. Levi parece caminhar no limite entre as duas concepções."

Segundo Anelli, "no Brasil, foi a geração de Rino Levi, a mesma da Warchavchik e Costa, que estruturou a profissão do arquiteto, malgrado todos os contratempos gerados pelo provincianismo local. A rigor, não se pode dizer que Levi estivesse dentro de uma tradição do ofício do arquiteto no Brasil, pois este, antes da sua geração, era limitado, arraigadamente acadêmico e arredio às inovações técnicas. Mais correto seria afirmarmos que Levi está entre os que fundam as bases contemporâneas da profissão, ou seja, desenvolvem um conjunto de procedimentos que estruturam e regulamentam a prática arquitetônica. A generalização desses procedimentos pode ser entendida como a constituição de uma nova tradição do ofício, na qual, obviamente, ele se enquadra perfeitamente, pois foi um dos seus criadores." ${ }^{34}$

Outra concepção que aproxima Levi de Gropius é a de arquiteto coordenador. Em 1956, discutindo a natureza do trabalho do arquiteto, Levi diz que "o arquiteto não é um especialista. Tanto se estende, porém o seu campo de ação, que ele não pode dispensar, no desenvolvimento do seu trabalho, da colaboração de inúmeros especialistas. Na expressão de Gropius, o arquiteto é um coordenador, cuja missão é unificar os inúmeros problemas sociais, técnicos, econômicos e plásticos inerentes à construção. “135

Essa aproximação com Gropius parece significar a expressão de uma diferença com os rumos da arquitetura moderna brasileira. Anelli lembra que também na Itália, ainda antes da guerra, a oposição entre

\footnotetext{
${ }^{133}$ ANELLI, Renato, op. cit., p. 148.

${ }^{134}$ ANELLI, Renato, op. cit., p.150.

${ }^{135}$ LEVI, Rino, “O ensino da arquitetura”, conferência realizada na Universidade Mackenzie, a convite do Grêmio da Faculdade de Arquitetura, São Paulo, 16/10/1956.
} 
Gropius e Corbusier estava sendo instrumentalizada. "A citação de Gropius pode ser vista dentro deste quadro, como uma operação de demarcação de especificidades em meio a uma arquitetura que se pretendia cada vez mais unitária. Não parece ser por acaso que a primeira citação mais explícita seja uma definição do que é o arquiteto, que aponta para a sua própria dissolução numa equipe."136

Antes de passar à analise mais propriamente de projeto, Anelli faz um último cotejamento entre Levi e outro colega: estuda as diferenças em relação a Vilanova Artigas. A instância para a comparação vai ser o papel destinado à arte, inclusive à arquitetura, na sociedade. Para Levi, arquitetura é arte, o que não significa qualquer afastamento da realidade concreta da sociedade:

"Contudo, o fato da arquitetura se ocupar de tais problemas essenciais à vida do homem não lhe tira o caráter de verdadeira arte, a qual, em qualquer de suas manifestações, é obra de criação do espírito e portanto de personalidade do artista, embora este, consciente ou inconscientemente, exprima os anseios e as aspirações da sociedade."137

Anelli observa que "para conferir à idéia artística tal capacidade de mediação entre o indivíduo e a coletividade, Levi evita qualquer concepção da sociedade como portadora de contradições internas. Para ele existe um processo evolutivo da sociedade em direção a uma condição harmônica. O modelo da harmonia seria a própria natureza, regida por suas leis imutáveis, sendo a arte a sua intérprete. O convívio do homem com a arte e com a natureza permitiria o incremento desse processo evolutivo. Alguns estariam mais adiantados e outros mais atrasados, sendo dever dos primeiros educar os segundos. Temos aqui uma concepção orgânica da sociedade e do papel do intelectual." ${ }^{138} \mathrm{Um}$

${ }^{136}$ ANELLI, Renato, p. cit., p.154.

${ }^{137}$ LEVI, Rino, “Técnica hospitalar e arquitetura”, op. cit..

138 ANELLI, Renato, op. cit., p.156. 
dos principais desdobramentos dessa concepção é a sua reação à incompreensão geral da opinião pública frente à arte moderna.

Levi aponta a ambigüidade do papel do arquiteto nesse processo, onde "o grande público é incapaz de se adaptar ao espírito inovador, peculiar à arte, pelo qual sente viva repulsa. Aceita passivamente a rotina, sem admitir qualquer possibilidade de contestação, pois ela representa para ele, um refúgio cômodo e seguro. (...) O arquiteto, cuja atividade depende de terceiros, mais do que qualquer outro artista, é vítima dessa situação, com a qual está perfeitamente habituado. Não é raro que, mesmo antes de receber as informações básicas sobre o tema, lhe sejam feitas imposições de ordem plástica. Resulta daí uma situação ambígua, da qual só poderá sair dignamente desde que saiba vencer tais imposições." 39

Na opinião de Levi, os arquitetos brasileiros não estão tendo muito sucesso nessa luta, segundo o teor de carta para Adalberto Libera, que estava na Itália, onde diz que "vejo com tristeza como, depois de tantos anos de luta e esforços para dar à arquitetura uma orientação sana, o campo esteja ainda agora dominado por Piacentini. Aqui a coisa está exatamente no mesmo ponto, não obstante as impressões que se possa ter das publicações sobre a arquitetura no Brasil. O que se fez de bom constitui uma exceção. Em comparação com aquilo que se faz de péssimo é praticamente zero. O mais importante é que os problemas que dizem respeito aos interesses coletivos não existem. Salvo alguns poucos arquitetos favorecidos pelo governo, durante um certo período no qual tivemos um ministro simpatizante da arquitetura moderna, todos os outros continuam a ter problemas mal colocados, com caráter prevalentemente especulativos e para terrenos impróprios. Assim perdemos todas as nossas energias e os anos vão passando sem qualquer esperança."

\footnotetext{
${ }^{139}$ LEVI, Rino, “Técnica hospitalar e arquitetura”, op. cit..

${ }^{140}$ LEVI, Rino, carta enviada em resposta a carta de Adalberto Libera de 30/12/1946, da Itália, Arquivo Rino Levi, apud ANELLI, p. cit..
} 
Anelli comenta como "Levi considera que as exemplares ações do grupo de arquitetos favorecidos pelo governo não constituem uma grande conquista. Acusa os limites dessas ações frente ao intenso processo de crescimento das cidades brasileiras, em especial São Paulo, após a Segunda Guerra Mundial. Reclama que a maioria dos arquitetos seja mantida afastada dos projetos de maior interesse para a sociedade. Dessa maneira não poderiam cumprir os principais objetivos para os quais foram formados." ${ }^{141}$

Nesse contexto, Levi faz uma defesa enfática da liberdade artística, que foi, por vezes, confundida com a defesa da arquitetura como uma arte pura, ocasionando o divórcio entre o criador e a multidão. Lúcio Gomes Machado sugere que os motivos dessas declarações de Levi, contra qualquer interferência na criação artística, têm um sentido político, em razão das disputas internas da arquitetura moderna brasileira. Seriam, sim, uma "não aceitação de censura ou de direção do processo de criação, aspectos então intensamente discutidos em razão da intensificação da Guerra Fria." ${ }^{142}$

Anelli considera que "os manifestos de Vilanova Artigas já no início dos anos 50 atestam a virulência com a qual o debate arquitetônico foi envolvido pela polarização entre URSS e EUA."143

"Pretendendo diminuir as contradições da burguesia caduca, desmascaram-se muitos líderes do movimento modernista - cada qual por sua vez. Aparecem claramente agora, o que sempre foram: ideólogos da classe dominante, defensores impertérritos da ordem burguesa, da alardeada civilização ocidental. Para os arquitetos progressistas do Brasil, neste livro (Le Modulor) é a linguagem do pior

\footnotetext{
${ }^{141}$ ANELLI, Renato, op. cit., p. 158.

${ }^{142}$ MACHADO, Lúcio Gomes, op. cit., p. 106.

${ }^{143}$ ANELLI, op. cit., p.159.
} 
dos inimigos do nosso povo, o imperialismo americano. Cumpre-nos repudiá-lo." 144

Anelli observa que Artigas inverte os termos da costumeira acusação feita pelos conservadores, onde a arquitetura moderna era obra dos bolchevistas. Mantendo a vinculação direta entre arquitetura e política, Artigas acusa a arquitetura moderna de imperialista.

O desdobramento deste raciocínio de Artigas para o campo cultural resultou numa nova divisão, agora não apenas entre modernos e acadêmicos, mas entre comunistas e imperialistas. $\mathrm{O}$ interlocutor de Levi, quando este defende a liberdade absoluta da arte, é certamente Artigas, não se tratando de um manifesto pela arte pura separada da sociedade.

Anelli retoma, então, a análise de projetos que já iniciara com as primeiras obras, agora tendo como critério "A construção da forma". ${ }^{145}$ Levi desenvolve seus primeiros projetos com a elaboração de um volume único que abriga todos os ambientes exigidos pelo programa. São assim as primeiras casas, os primeiros prédios de apartamento e os cinemas. Os primeiros conjuntos de casas desdobraram esse procedimento com a repetição em série de uma unidade modular.

Os projetos dos cinemas acarretaram a necessidade de combinação de duas atividades que exigiam volumetrias diferenciadas, optando Levi pela sobreposição destes volumes. No projeto do UFA-Palace ${ }^{146}$ em 1936, o arquiteto opera a sua primeira incorporação do conhecimento científico na arquitetura, com rigorosos estudos de acústica, cujo principal resultado formal são as paredes seguindo uma curvatura parabolóide para melhor difusão sonora.

\footnotetext{
${ }^{144}$ ARTIGAS, Vilanova, “Le Corbusier e o imperialismo”, Fundamentos, maio de 1951.

145 ANELLI, Renato, op. cit., p.163.

${ }^{146}$ Cine UFA-Palace, São Paulo, SP, 1936.
} 
Para ilustrar a riqueza de possibilidades da colaboração cência/arquitetura, Levi lembra que ela abrange também a colaboração dos artistas: "superfícies convexas para fins acústicos são obtidas por meio de relevos nas paredes e no forro." 47 Todas essas questões seriam aperfeiçoadas nos projetos seguintes de mesmo programa: o Cine Universo ${ }^{148}$, Ipiranga ${ }^{149}$ e o Teatro Cultura Artística $^{150}$. No caso de polifuncionais, como cinema/hotel, Levi projetava dois volumes monofuncionais, sobrepondo-os.

Dois projetos de 1937 indicam uma outra linha de experimentação na formalização do conjunto, com a disposição de diversos ambientes funcionais dentro dos limites de um único volume. São eles o UFAPalace de Recife ${ }^{151}$ e o projeto para o concurso do Aeroporto Santos Dumont $^{152}$. No caso do aeroporto, um volume em paralelepípedo que culmina nas duas extremidades com dois semi-cilindros. A forma em semi-cilindro já havia sido usada na casa Pedro Porta ${ }^{153}$ e no Edifício Guarani $^{154}$. Anelli aponta as referências explícitas do aeroporto a dois projetos italianos da época: a Estação de Florença (1932/35), de Gionanni Michelucci, e o Edifício dos Correios de Roma (1933/35) de Mario Ridolfi e Marcello Fagiolo.

No caso do projeto de Recife o volume único era obtido pela disposição diagonal do cinema com o prédio comercial. Segundo Anelli "a interpenetração de elementos das quatro faces do volume indica uma intenção de unificação formal entre duas formas advindas de usos distintos, respondendo a situações urbanas diferenciadas, pois dois lados margeavam uma praça." 155

\footnotetext{
${ }^{147}$ LEVI, Rino, “Síntese das artes plásticas” , Revista Acrópole, set. 1954, pp. 567/568.

${ }^{148}$ Cine Universo, São Paulo, SP, 1936.

${ }^{149}$ Cine Ipiranga e Hotel Excelsior, São Paulo, SP, 1941.

150 Teatro Cultura Artística, São Paulo, SP, 1942.

${ }^{151}$ Cine UFA-Palace (ou Art Palácio) e edifício de escritório, Recife, PE, 1937.

152 Aeroporto Santos Dumont (concurso), Pç. Santos Dumont, Rio de Janeiro, RJ, 1937.

${ }^{153}$ Residência Pedro Porta, São Paulo, SP, 1936.

${ }^{154}$ Edifício Guarany, São Paulo, SP, 1936.

155 ANELLI, Renato, op. cit., p. 179.
} 


\subsection{3 - RINO LEVI NAS MONOGRAFIAS}

Duas monografias foram publicadas sobre Rino Levi com quase trinta anos entre elas. A primeira é Rino Levi, publicada em Milão, 1974, pela Edizioni di Comunitá ${ }^{156}$. O livro traz um texto de Roberto Burle Max "Depoimento sobre Rino Levi" e outro de Nestor Goulart Reis Filho "A arquitetura de Rino Levi”. Os dois introduzem uma seleção de 47 projetos do Escritório Rino Levi Arquitetos Associados, que até a publicação de Rino Levi: Arquitetura e Cidade ${ }^{157}$, constituíram a mais ampla cobertura das 4 décadas de produção.

Com essa nova monografia de Renato Anelli, a publicação da obra de Rino Levi ganha uma nova dimensão. Com edição de Abílio Guerra, o livro apresenta fichas de 58 projetos, sempre com texto descritivo, documentação gráfica e fotográfica. Seis projetos ganham um ensaio fotográfico de Nelson Kon: o Edifício Guarani, o Edifício Sedes Sapientiae, a Residência Olivo Gomes, o Banco Sul Americano do Brasil S.A., o Centro Cívico de Santo André e o Edifício Sede da FIESP/SESP/SESI.

O texto de Renato Anelli resume e reorganiza as hipóteses levantadas na sua tese, já analisadas. O livro conta, ainda, com apresentações dos sócios do escritório: Roberto Cerqueira César, Luis Roberto Carvalho Franco, Paulo Bruna e Antonio Carlos Sant'nna Junior. Os textos se completam com prefácio de Lucio Gomes Machado, que também apresenta as hipóteses da sua tese, também já analisada.

No seu prefácio, Gomes Machado destaca como a publicação "representa um marco na produção bibliográfica brasileira ao aliar ao

\footnotetext{
${ }^{156}$ Rino Levi, Edizioni de Comunita, Milão, 1974.Introdução de Roberto Burle Max e Nestor Reis Filho.

${ }^{157} 166$ ANELLI, Renato; Guerra, Abílio; Kon, Nelson. Rino Levi: Arquitetura e Cidade. São Paulo, Romano Guerra Editora, 2001.
} 
relevante texto projeto gráfico de alta qualidade, a reprodução de parte do acervo iconográfico do Escritório Rino Levi - em grande parte inédito em livros - além de ensaios fotográficos e originais de Nelson Kon. ${ }^{158}$

\section{3- SÍNTESE}

Neste capítulo fizemos um balanço da produção historiográfica sobre a Arquitetura Moderna no Brasil. Na verdade apresentamos mais um balanço, pois, como já foi dito, nos últimos anos alguns deles têm sido feitos. E nenhum deles, assim como este, é neutro: são sempre seletivos. Se parece pertinente este outro balanço é porque aqui o foco é outro: reavaliar o papel dado à produção de Rino Levi. Temos consciência de que esta preocupação é absolutamente datada. É comum dar-se ao termo datado um caráter pejorativo, opondo-o às questões fundamentais, atemporais, universais, globalizantes. A noção aqui usada é de preocupação datada no sentido de estar em fase com as discussões, questões e problemas contemporâneos à ela, que é exatamente o que lhe confere interesse.

Vivemos um momento particularmente rico em trabalhos específicos sobre a produção de um arquiteto. No caso de Rino Levi, vimos como dois desses trabalhos - o de Lúcio Gomes Machado e o de Renato Anelli - são análises extensas e intensas sobre o conjunto de sua obra. Outra vez, se nos detemos sobre esse conjunto é porque neste trabalho as hipóteses são outras, como veremos no próximo capítulo.

Desde já, é importante salientar algumas delas:

\footnotetext{
${ }^{158}$ MACHADO, Lucio Gomes, "Prefacio in. ANELLI, Renato.Rino Levi: Arquitetura e Cidade, op.cit. p.23
} 
A primeira é a noção de escola presente na historiografia da arquitetura. Poucas vezes explicitada, mas, quase sempre implícita, entende-se por escola o conjunto de procedimentos e ideário comum a um grupo de arquitetos. A historiografia da arquitetura moderna no Brasil já consolidou duas delas: a carioca e a paulista. Consequência imediata dessa consolidação é que a grande maioria dos arquitetos acaba sendo considerada fora, à margem, antes ou depois das ditas escolas.

Por escola carioca entende-se o grupo de arquitetos que a partir da década de 30, no Rio de Janeiro, vai desenvolver uma atitude de projeto comum. Nas questões teóricas, a figura mais importante será Lúcio Costa, papel que caberá a Oscar Niemeyer nos procedimentos diretamente ligados ao projeto.

Por escola paulista entende-se o grupo que se forma a partir da década de 5o, em São Paulo, em torno da figura de Vilanova Artigas, central tanto nas questões teóricas quanto nas de projeto.

O escritório Rino Levi Arquitetos Associados não está diretamente ligado a nenhuma das duas escolas. Isso se explica exatamente pela sua diferente atitude perante a produção da arquitetura.

A segunda é como fica explicitada a contraposição arquitetura de gênio $X$ arquitetura de ofício. Referindo-se a Levi, Carlos Lemos vai fazer uma surpreendente análise: "Rino foi o anti-Oscar por excelência; em vez de livrar-se dos condicionantes do partido, procurava-os para tentar vencê-los. Disso decorreu uma arquitetura sobriamente bem composta, com cada coisa no seu lugar, justificando toda uma teoria bem estudada, como no caso de seus hospitais, assunto de constantes palestras, conferências e escritos. Não podemos dizer que tenha sido um artista livre, onde a liberdade aliada à imaginação levasse-o a soluções personalistas por excelência. Não. 
Rino Levi foi o fiel servidor das regras e seu mérito está em tê-las servido com bom gosto" ${ }^{159}$.

Lemos dirigiu o escritório paulista de Niemeyer e abertamente valorizou a genialidade e a pesquisa plástica sobre as outras instâncias da criação arquitetônica. Como observa Lúcio Gomes Machado, nivela-se em posição inferior "um grande número de obras e arquitetos com propostas discordantes do partido predominante. No entanto, ao realçar, como demérito, a atenção aos detalhes e o fato de ser servidor de regras, tocou nos pontos em que, verdadeiramente, a arquitetura de Rino Levi se sobressai, não pelo bom gosto, mas pelo domínio da profissão"16o.

A terceira diz respeito aos trabalhos que se concentram na análise de um dado arquiteto, onde paralelamente a uma quase denúncia da visão hegemônica da historiografia que excluiria o seu objeto, acabam por redimi-lo numa operação de inclusão que usa, muitas vezes, os mesmos critérios e instâncias de análise antes criticadas. Assim, acabam definindo as características do arquiteto pelas suas peculiaridades e singularidades, ao mesmo tempo em que, paradoxalmente, tentam inscrevê-lo nas escolas.

A hipótese desta pesquisa, ao contrário, não é nem de redenção do escritório Rino Levi e, menos ainda, de ressaltar a sua singularidade. A proposta é de inclusão do escritório na história, ou seja, em um processo de mudança sem a atenção concentrada em periodizações, marcos arquitetônicos ou arquitetos inaugurais.

\footnotetext{
${ }^{159}$ LEMOS, Carlos, op. cit. P. 158

${ }^{160}$ MACHADO, Lúcio Gomes, op. cit.,
} 


\section{CAPÍTULO 2 - RINO LEVI NA HISTÓRIA}

Neste capítulo serão tratadas as questões centrais que embasam a hipótese principal: é da análise dos projetos que se pode caracterizar a postura do arquiteto perante a produção da arquitetura e é dela que resultam ideários e realizações. Será a partir dessa análise que será mostrado como se materializou a "arquitetura de ofício", como se desenvolve o projeto pela equipe interdisciplinar, como o programa e o detalhe é que qualificam o seu desenvolvimento, como procedimentos generalizados jamais vão se sobrepor às necessidades particulares.

Não se está partindo de uma classificação prévia dos projetos, tentando fazer com que a produção do escritório caiba na presente leitura. Isso seria inverter o processo de análise. Parte-se da idéia de que há uma profunda diferença entre a noção de influência e a noção de referência. Por influência, entende-se uma subjetiva presença de um ideário ou de repertório alheio, sem nenhum controle do autor. Ao contrário, por referência entende-se uma escolha objetiva, consciente, por um ideário ou repertório que o autor conhece profundamente, domina e elege.

Os arquitetos brasileiros, de uma maneira geral, são completamente avessos a declarar que tem referências em outras produções: parecem condenados a reinventar a roda a cada novo projeto. Por outro lado, é quase comum recebermos arquitetos estrangeiros que declaram, sem nenhum constrangimento, que a arquitetura moderna no Brasil foi uma importante referência na sua produção.

Neste trabalho parte-se da hipótese de que o escritório de Rino Levi teve inúmeras referências. Levi conhecia profundamente a história da 
arquitetura e a arquitetura contemporânea a ele. Seu escritório sempre esteve na vanguarda em termos de pesquisas em préfabricação, uso de estruturas e materiais novos e racionalização de processos construtivos. Essas características permitiram que, como já comentado, Bruno Zevi se referisse à arquitetura de Rino Levi como um discurso sobre o discurso de Mendelsohn, Gropius e Le Corbusier. A produção do escritório abarcou muitos outros discursos e constituiu, ele próprio, referência para a produção da arquitetura moderna brasileira. Isso é o que se procurará demonstrar.

Quando falamos em análise de projeto é quase imediata a expectativa de uma avaliação, um julgamento. Quando se faz uma avaliação sobre uma obra, estamos de fato na instância do julgamento. Mas, só podemos "julgar" uma obra em particular, na medida em que se está no âmbito de problemas específicos. A obra será avaliada quanto à pertinência de suas soluções técnicas, o custo, decisões quanto ao programa, etc. Neste caso, está-se no campo interno da competência profissional - campo dos "saberes acumulados" - que só advém pela prática profissional. Outra coisa muito diferente é considerarmos que, embora uma obra particular possa sofrer um julgamento pontual, o conjunto de trabalhos do arquiteto pode ser objeto de uma reflexão mais ampla.

Talvez uma das grandes dificuldades em arquitetura seja um contato com a produção que não se transforme em julgamento, a possibilidade do diálogo de uma produção com outra produção. É o que este estudo se propõe a fazer. Para isso, serão utilizadas as análises de obras específicas já estudadas. Muitas delas já fazem essa "conversa" e, nesses casos, ela será retomada. 


\section{1 - QUESTÕES DE FORMAÇÃO}

\subsection{1 - CONTEXTO ITALIANO}

O primeiro cotejamento proposto é entre os trabalhos do período escolar de Rino Levi e de outros arquitetos em formação no mesmo período. Como já vimos, Anelli faz uma extensa análise dos exercícios de Levi em Milão (anos letivos de 1921/22 e 1922/23) e Roma (anos letivos de 1923/24, 1924/25 e 1925/26) e os relaciona com os currículos das escolas e dos seus colegas italianos. É interessante retomá-los e colocá-los em relação à formação dos seus colegas brasileiros. As fontes de Anelli são duas: o histórico escolar de Levi nos arquivos da Faculdade de Arquitetura da Università degli Studi di Roma, que ele mesmo pesquisou, e uma seleção de trabalhos feita pelo próprio Levi, documentada em álbuns do seu arquivo particular.

De Milão, Levi só elege um exercício: Rilievo della Facciata del Pallazzo Barromeo[o1], 1923, identificado por Anelli, para a disciplina Architettura II, do professor Giuseppe Fei, com o seguinte programa: "Relevo do verdadeiro: completo, do todo e dos particulares; exercícios informadores dos próprios estudos e suas aplicações resumidas".

\footnotetext{
${ }^{1}$ ANELLI, Renato, op.cit.,p.91
} 


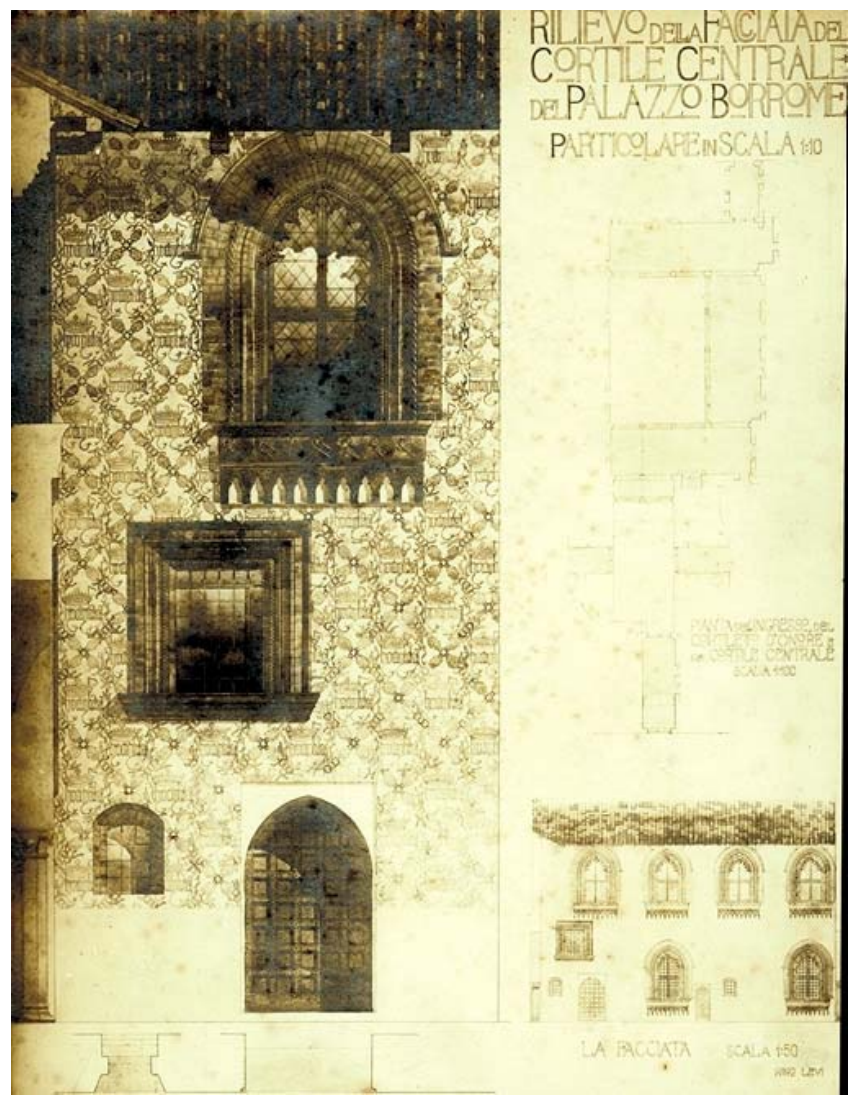

[01] Rilievo della Facciata del Pallazo Barromeo, trabalho do aluno Rino Levi na Scuola Preparatoria e di Applicazione per gli Architetti Civili, Milão, 1923

O primeiro dos seis exercícios selecionados de Roma é "Hotel ou sede para o Touring Club Italiano"[02], 1923/24, para a disciplina Composizione architettonica, dos professores Manfredo Manfredi e Arnaldo Foschini. "Projeto neoclássico, mas com características compositivas que o aproximam a algumas obras de J. Hoffman. Acompanha, portanto, a tendência expressa por Piacentini, de uma aproximação com a produção vienense."

${ }^{2}$ ANELLI, Renato, op.cit.p.92 


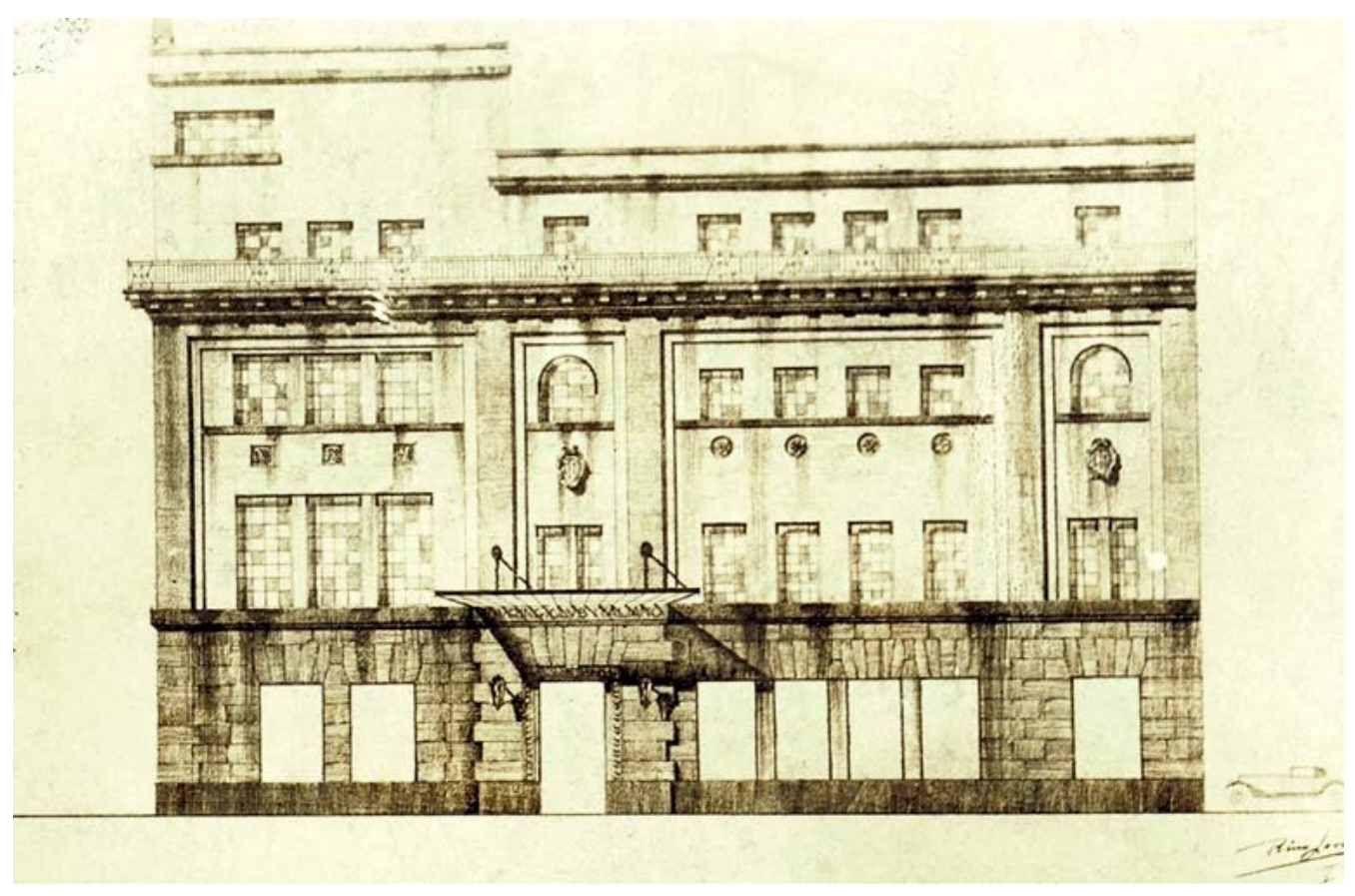

[02] Hotel ou sede do Touring Club Italiano, trabalho do aluno Rino Levi na Scuola Superiore di Architettura, Roma, 1923/24.

O segundo é Palazzo per esposizione d'armi[o3], 1924/25, para a disciplina Composizione architettonica, do professor Manfredo Manfredi. "Projeto com planta circular e possivelmente radial, dominado ao centro por um volume cilíndrico coberto por uma cúpula, com amplas aberturas envidraçadas. Ao redor do centro apresentam-se grandes massas opacas, que se abrem radialmente para o acesso principal, num átrio também envidraçado. Os jardins acompanham a forma circular do edifício, criando um fechamento de média altura. A preponderância, nos volumes centrais, das aberturas envidraçadas em relação às paredes, reduzidas à estrutura, é compensada pela opacidade dos volumes circundantes. A forma da planta se assemelha a um projeto de teatro feito por Piccinato em 1926 e antecipa o projeto de uma igreja, com planta octogonal, apresentado por este na "Primeira exposição de arquitetura racional" em 1928, ou ainda o projeto de P. Aschieri para a Casa dos Cegos de Guerra, de 1930. Tais semelhanças revelam que este tema geométrico - variações sobre uma planta central - estava presente na escola de Roma."3

\footnotetext{
${ }^{3}$ ANELLI, Renato, op.cit.,p.93
} 


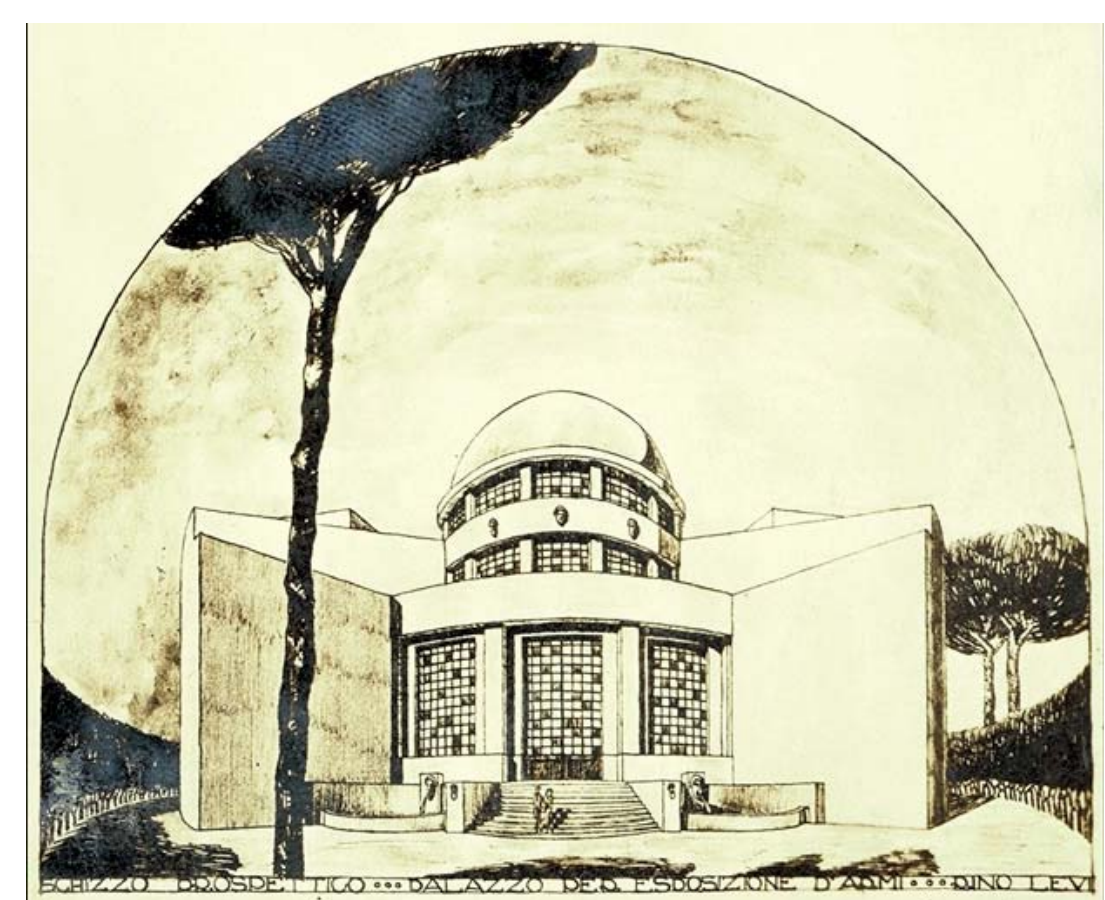

[03] Palazzo per esposizione d'armi, trabalho do aluno Rino Levi na Scuola Superiore di Architettura, Roma, 1924/25.

O terceiro é Progetto di uma Banca[04] e [05], 1925/26, para a disciplina Composizione architettonica, do professor Manfredo Manfredi. "O projeto apresenta forte semelhança com o Tribunal de Justiça de Messina projetado por Piacentini em 1923 e concluído em 1928. Observe-se a coincidência entre este exercício e o estágio realizado por Levi, durante o último ano da escola, no escritório de Piacentini. A fachada com ordem colossal apresenta a mesma proporção e ritmo do projeto piacentiano. O aluno Rino Levi desenvolve para todas as quatro fachadas o tema das colunas destacadas da parede, que Piacentini havia reservado apenas para a entrada monumental. Levi resolve o edifício com uma planta em grelha cartesiana, com a divisão dos ambientes seguindo rigidamente a sua modulação. Pequenos deslocamentos de algumas paredes em relação aos eixos da malha adequam a ordem ideal às necessidades funcionais específicas de determinados ambientes. $O$ conjunto central se eleva em relação à cota dominante do edifício, criando uma volumetria cúbica destacada das ordens das 4 fachadas. Atenção para a solução das quinas, onde a coluna se repete nas duas projeções, separando os 
planos das fachadas e denotando o conhecimento de um dos procedimentos renascentistas relativo à composição do volume tão apreciado pelos neoclássicos." 4

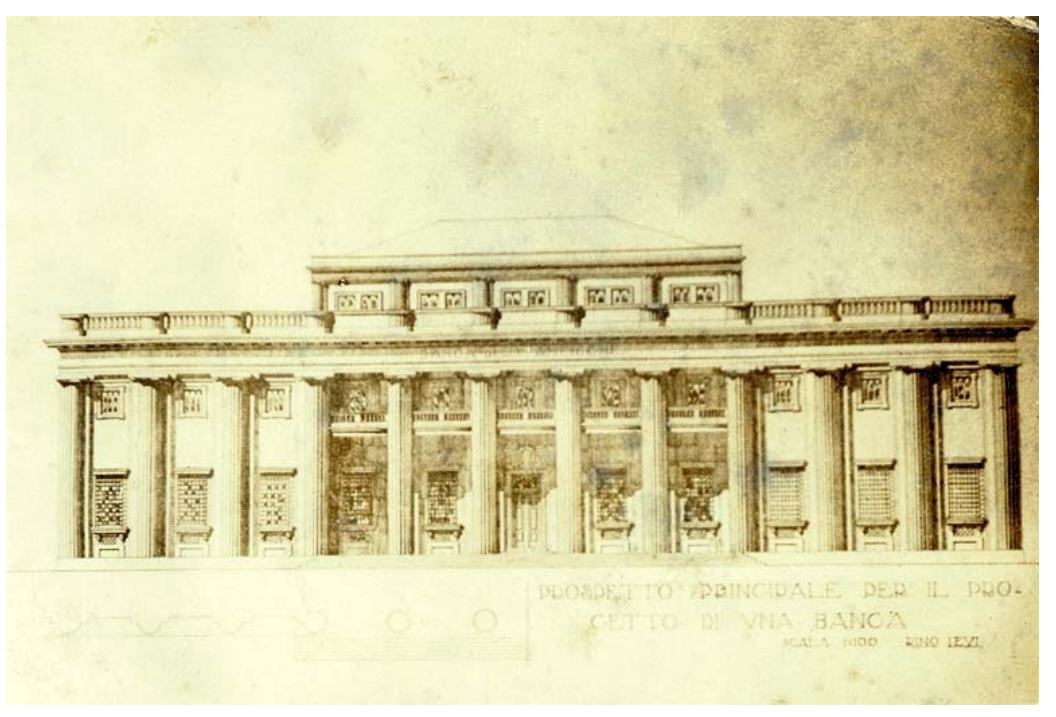

[04] Progetto di uma Banca - elevação, trabalho do aluno Rino Levi na Scuola Superiore di Architettura, Roma, 1925/26.

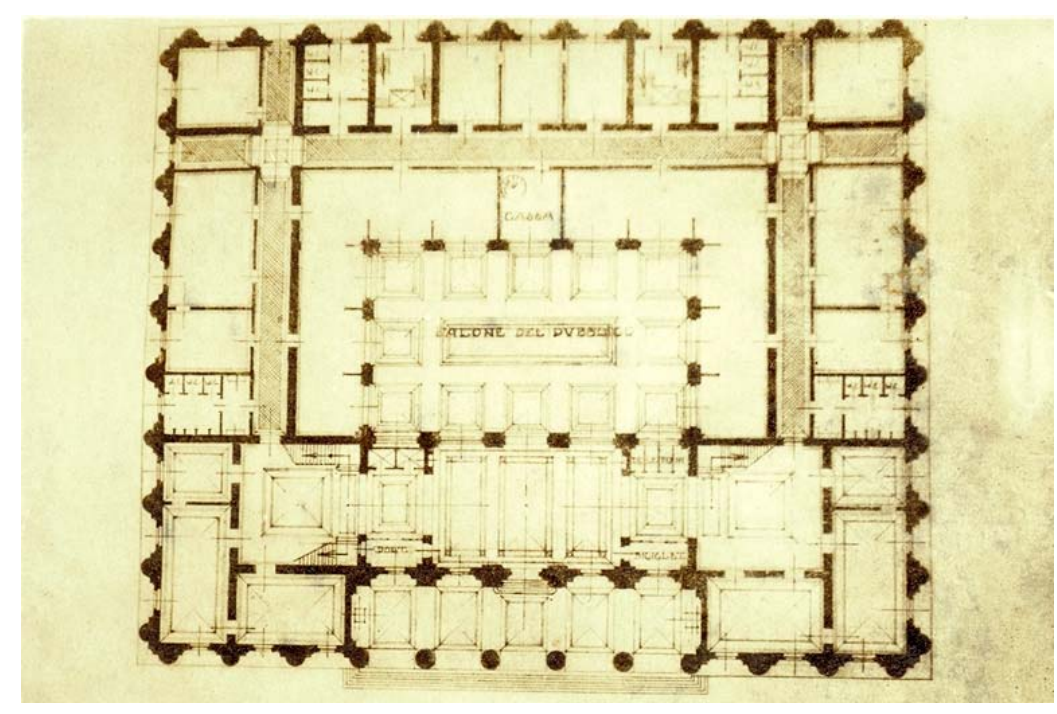

[05] Progetto di uma Banca - planta, trabalho do aluno Rino Levi na Scuola Superiore di Architettura, Roma, 1925/26.

O quarto é "Projeto de um interior - decoração"[o6], 1924/25 para a disciplina Arredamento e decorazione interna, do professor Vittorio Grassi. "Este exercício de decoração de uma sala é realizado sob influência das obras de Gio Ponti, então amplamente divulgadas pelas

\footnotetext{
${ }^{4}$ ANELLI, Renato, op.cit.,p.95
} 
revistas Architettura e Arti Decorative e Domus, representando o que havia de mais moderno em Milão. A repetição de temas geométricos no vigamento do forro e em painéis nas paredes cria texturas vibrantes que requalificam o sóbrio ambiente de proporções e aberturas neoclássicas. É atingido assim o objetivo da disciplina, que pretendia "exercícios de decoração e de mobiliário prevalentemente de caráter moderno, em relação com o estudo da composição arquitetônica". O caráter dominante do ambiente criado revela influências do movimento secessionista vienense, bastante apreciado pelos artistas italianos, mantendo-se, porém, distante dos excessos ornamentais que se manifestariam na exposição de Paris de 1925."

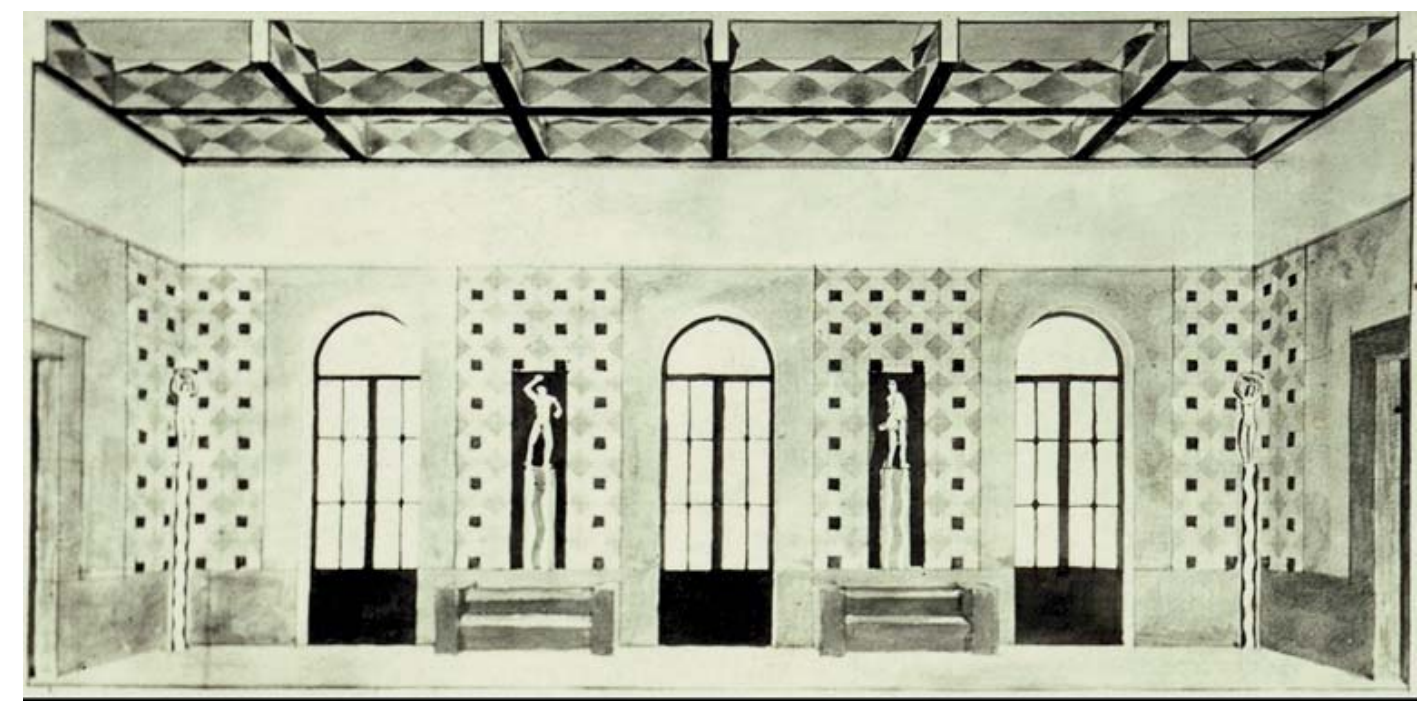

[06] Projeto de um interior - decoração, trabalho do aluno Rino Levi na Scuola Superiore di Architettura, Roma, 1924/25.

O quinto é Porto fluviale[o7], 1925/26, para a disciplina Scenografia do professor Quirino Angeletti. "O painel apresenta três planos de profundidades distintas e dispostos em perspectiva oblíqua: o primeiro com a água do rio e as construções na margem; o segundo com dois monumentos verticais e no terceiro, um fundo com uma acrópole e uma paisagem de montanhas. O conjunto rio/margem, do primeiro plano, é dominado por dois ancoradouros e uma larga escada, a qual conduz ao segundo plano, onde se encontram os dois curiosos monumentos. Trata-

\footnotetext{
${ }^{5}$ ANELLI, Renato, op.cit.,p.97
} 
se de dois arcos dispostos perpendicularmente à margem, sem nenhum desenho ornamental nas suas superfícies, mas coroadas nas quatro extremidades por elementos verticais que sugerem uma vegetação esculpida. O terceiro plano apresenta um conjunto de montanhas e acrópole, e acompanha o sentido oblíquo da perspectiva. O restante do painel, cerca de dois terços, é reservado ao céu, com nuvens esfumaçadas que dominam a composição". ${ }^{6}$

"A disciplina de Angeletti foi um ponto de contato com as pesquisas de vanguarda do teatro italiano. A temática presente na sua disciplina de cenografia não se restringe a intervenções no interior do palco. Sugere projetos cenográficos a céu aberto e cinematográficos, como forma de superação dos limites dos teatros existentes. Ao não se conter ao estudo da decoração de cena, engloba os princípios do espetáculo, discutindo as diversas possibilidades da sua concepção espacial. Seria na disciplina de Angeletti que Levi incorporaria alguns dos princípios básicos do espetáculo que estariam presentes nos seus projetos de cinemas, auditórios e teatros. " 7

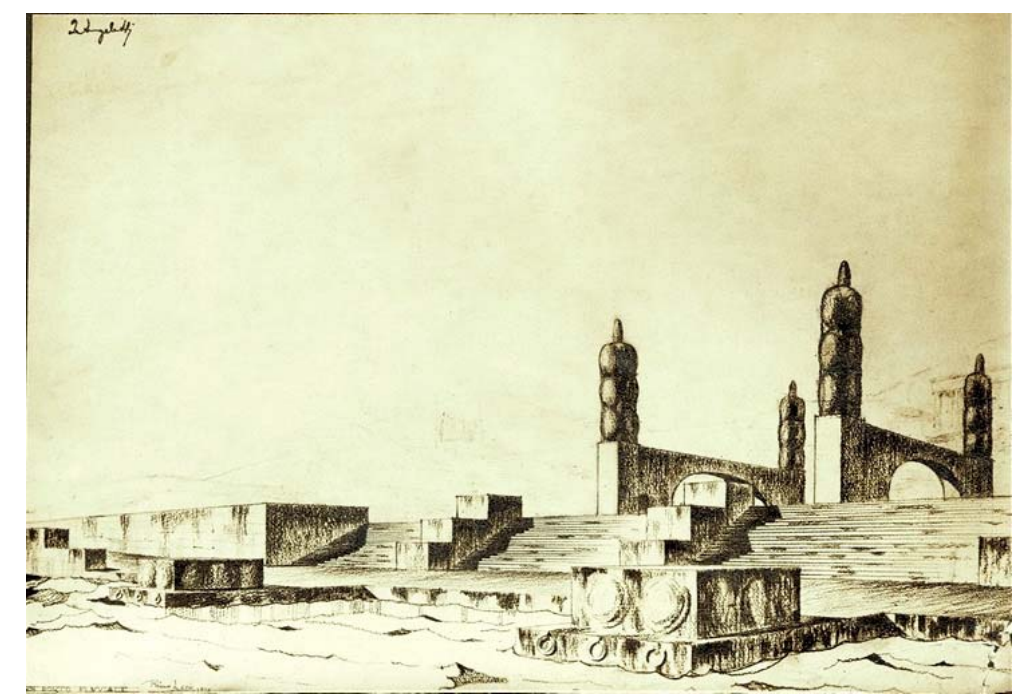

[07] Porto fluviale - Scenografia, trabalho do aluno Rino Levi na Scuola Superiore di Architettura, Roma, 1925/26.

${ }^{6}$ ANELLI, Renato, op.cit.,p.97

${ }^{7}$ ANELLI, Renato, op.cit. 
O sexto, e último, é Veduta prospettica di uno dei due cortili simmetrici - Palazzo dello Sport[o8], 1925/26, trabalho de graduação. "O projeto apresenta um pátio clássico, com suas arcadas e ao centro uma fonte decorada com estátua feminina. O desenho, à maneira usual das academias italianas, revela uma atenção com as mais sutis nuances de luz e sombra, demonstrando ser esse o tema predominante no ambiente. A atenção ao desenho das pedras que constituem o piso e os arcos dá continuidade à pesquisa do primeiro trabalho, o relevo do Palazzo Barromeo, uma busca pela materialidade das formas."

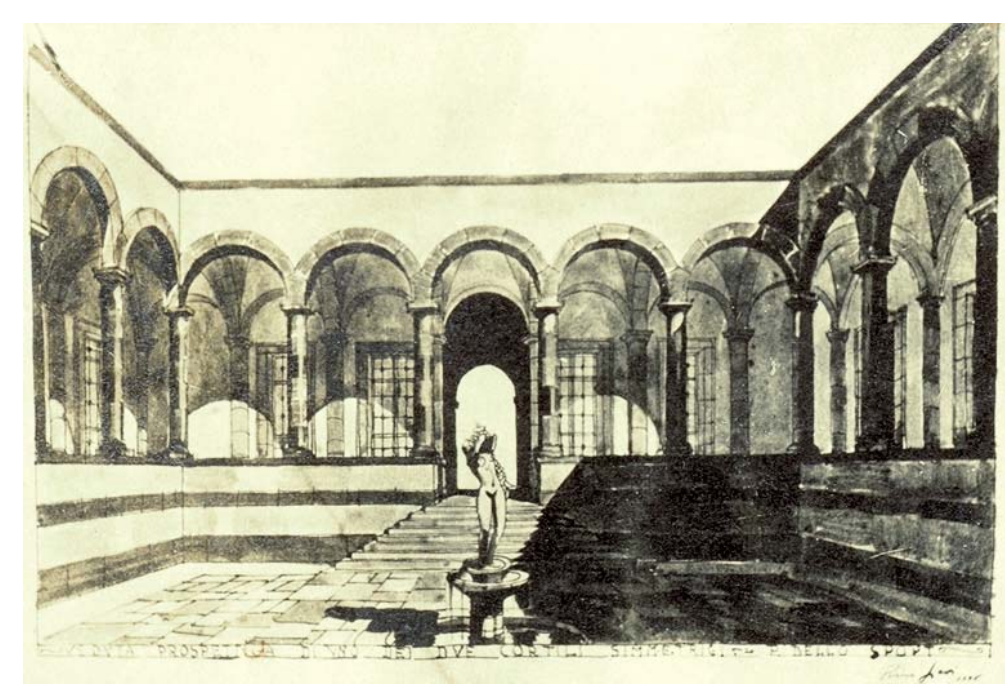

[08] Veduta prospettica di uno dei due cortili simmetrici - Palazzo dello Sport, , trabalho do aluno Rino Levi na Scuola Superiore di Architettura, Roma, 1925/26.

Os motivos que levaram o arquiteto Rino Levi a apresentar essa seleção de trabalhos no seu álbum devem também merecer atenção. Parece querer demonstrar duas características: o ponto de partida para o seu longo percurso - até a definição por uma produção baseada nas vanguardas modernas - e a existência de alguns pontos de intersecção entre esses dois momentos.

Se os trabalhos examinados tratam da formação de Levi e de seus colegas italianos, é também interessante o contato com a formação que tiveram os seus futuros colegas brasileiros. Sem pretender um

\footnotetext{
${ }^{8}$ ANELLI, Renato, op.cit.,p.98
} 
estudo rigoroso, mas antes, partindo de relatos pontuais, podemos ter uma aproximação do contexto brasileiro daquele momento.

\subsection{2 - CONTEXTO CARIOCA:}

O primeiro relato é o de Abelardo de Souza, que na introdução à série de dados e depoimentos que reúne sobre os arquitetos "precursores $e$ primeiros criadores da Arquitetura Moderna Brasileira" ${ }^{\text {, dá um }}$ testemunho pessoal da sua passagem pela ENBA - Escola Nacional de Belas Artes do Rio de Janeiro. Nascido em 1908, ingressou na escola em 1928. Em linguagem bem humorada, muitas vezes irônica, traça um quadro da vida acadêmica daquele tempo. "Antes dos anos trinta, era uma constante cópia dos vários estilos que imperavam na época, vindos todos de outras terras. Para a arquitetura residencial, que era o que mais se fazia, copiava-se o "espanhol"; com seus avarandados em arcos, suas janelas protegidas por grades de ferro retorcido formando desenhos os mais variados, seus pátios internos pavimentados com lages de pedra e um poço no meio, geralmente sem água." 10

Com certeza, Abelardo carrega na tinta com o intuito de valorizar o que chama de "a outra revolução de 1930: Lúcio Costa". "Mas, antes dela, outro estilo muito em voga naquela época era o inglês ou Tudor que, apesar de suas diferenças, eram confundidos quando copiados, porque seus criadores empregavam os mesmos elementos: pórticos de pedra, vãos guarnecidos com vigas de madeira (geralmente alvenaria pintada imitando madeira); fachadas com estrutura de madeira aparente como se estivesse suportando a cobertura (simples tábuas

\footnotetext{
${ }^{9}$ SOUZA, Abelardo. Arquitetura no Brasil: depoimentos. São Paulo, Diadorim, Ed. Da Universidade de São Paulo, 1978.

${ }^{10}$ SOUZA, Abelardo, op. cit., p.15.

${ }^{11}$ SOUZA, Abelardo, op. cit., p.26.
} 
pregadas na alvenaria); telhados com várias águas; pesada porta de madeira dando acesso ao hall sempre pavimentado com lages de pedra e paredes revestidas com lambris de madeira. "O living-room (é preciso lembrar que o estilo é inglês) sempre tinha uma grande lareira, simplesmente decorativa, pois com o clima tropical do Rio, não poderia ter outra função."

Com a clara intenção de valorização do MES, define que "para os prédios públicos, como o edifício da Câmara dos Deputados, a Câmara dos Vereadores, chamada Gaiola de Ouro pelo seu custo de construção, a sede do Jóquei Clube hoje demolido, o próprio Jóquei Clube da Gávea, assim como para os palacetes, residências dos snobs ou novos ricos, o estilo era o clássico. Os Luizes variavam do XIV ao XVI segundo a inspiração do arquiteto. $O$ nosso colonial tão puro e tão autêntico, quando construído ou projetado de forma a levar em conta suas origens, acabou tão deturpado que quando entrava na dança, o melhor que acontecia eram prédios como o da Escola Normal do Rio de Janeiro[og] ou o da Faculdade de Direito de São Paulo." ${ }^{3}$

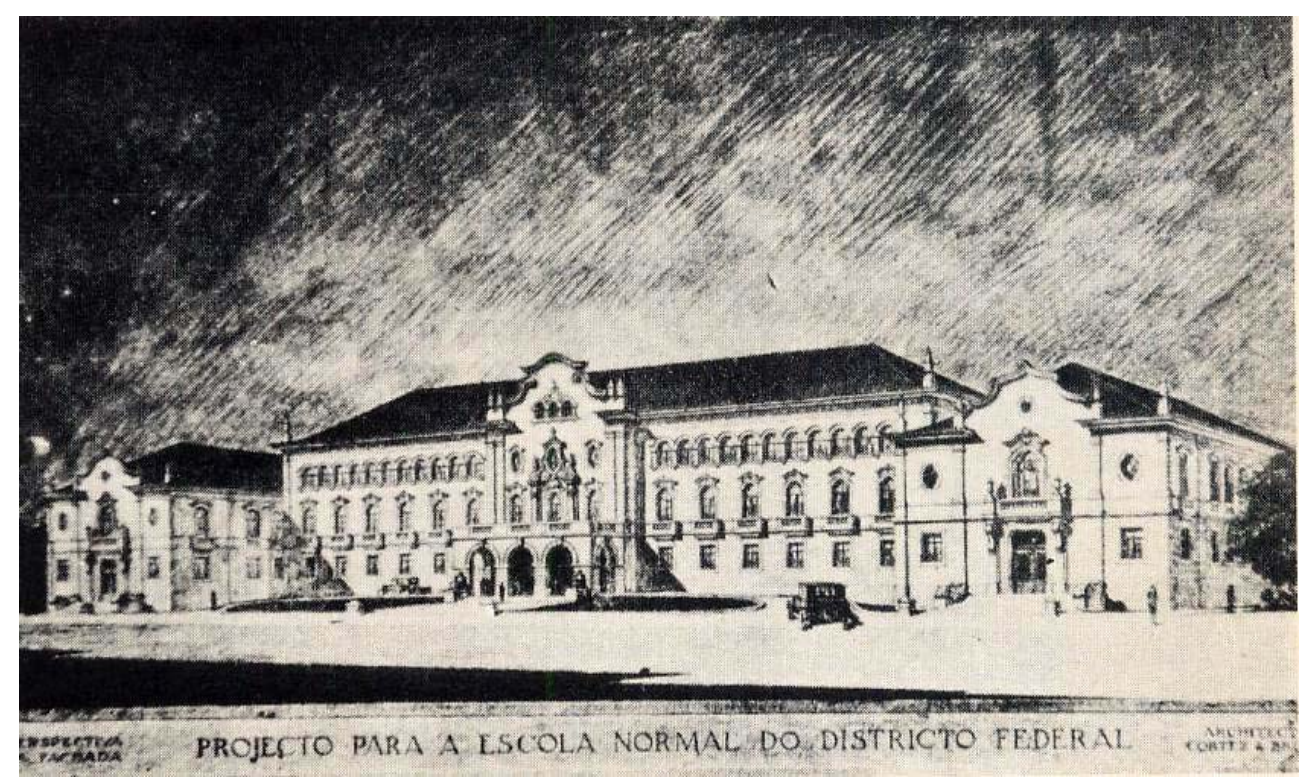

[09] Escola Normal do Rio de Janeiro, RJ, década de 20 - “falso estilo colonial” segundo Abelardo de Souza.

\footnotetext{
${ }^{12}$ SOUZA, Abelardo, op. cit., p.16.

${ }^{13}$ SOUZA, Abelardo, op. cit., p.18.
} 
Sobre a origem dos estilos, comenta que "duas revistas que eram, na época, muito difundidas entre os estudantes, eram a Mi Casita que se não nos enganamos, era de origem argentina e uma outra, bem brasileira feita por um aluno da ENBA, seu proprietário, seu editor, seu redator, autor da maioria dos projetos apresentados e, também, seu distribuidor. Alguns de seus projetos eram antológicos: as fachadas das casas eram a reprodução das iniciais dos nomes de seus proprietários[1o]; A para o seu Antonio, B para o seu Benedito e assim por diante. Afora essa cartilha arquitetônica, como se fora uma precursora do Mobral, nada se criava naquela época. Ou melhor, quando começaram a aparecer no Rio os primeiros arranha-céus, aí então os nossos arquitetos deram largas às suas imaginações: resolviam a planta e a fachada como se fosse uma residência e empilhavam-na até a altura desejada. Estava pronto o arranha-céu. Qual patisseurs, com coluninhas, balaústres, gregas e frontões, faziam verdadeiros bolos de noiva. Um exemplo desse conjunto de monstrinhos é a Cinelândia no Rio[11]"14

\footnotetext{
${ }^{14}$ SOUZA, Abelardo, op. cit., p.22.
} 


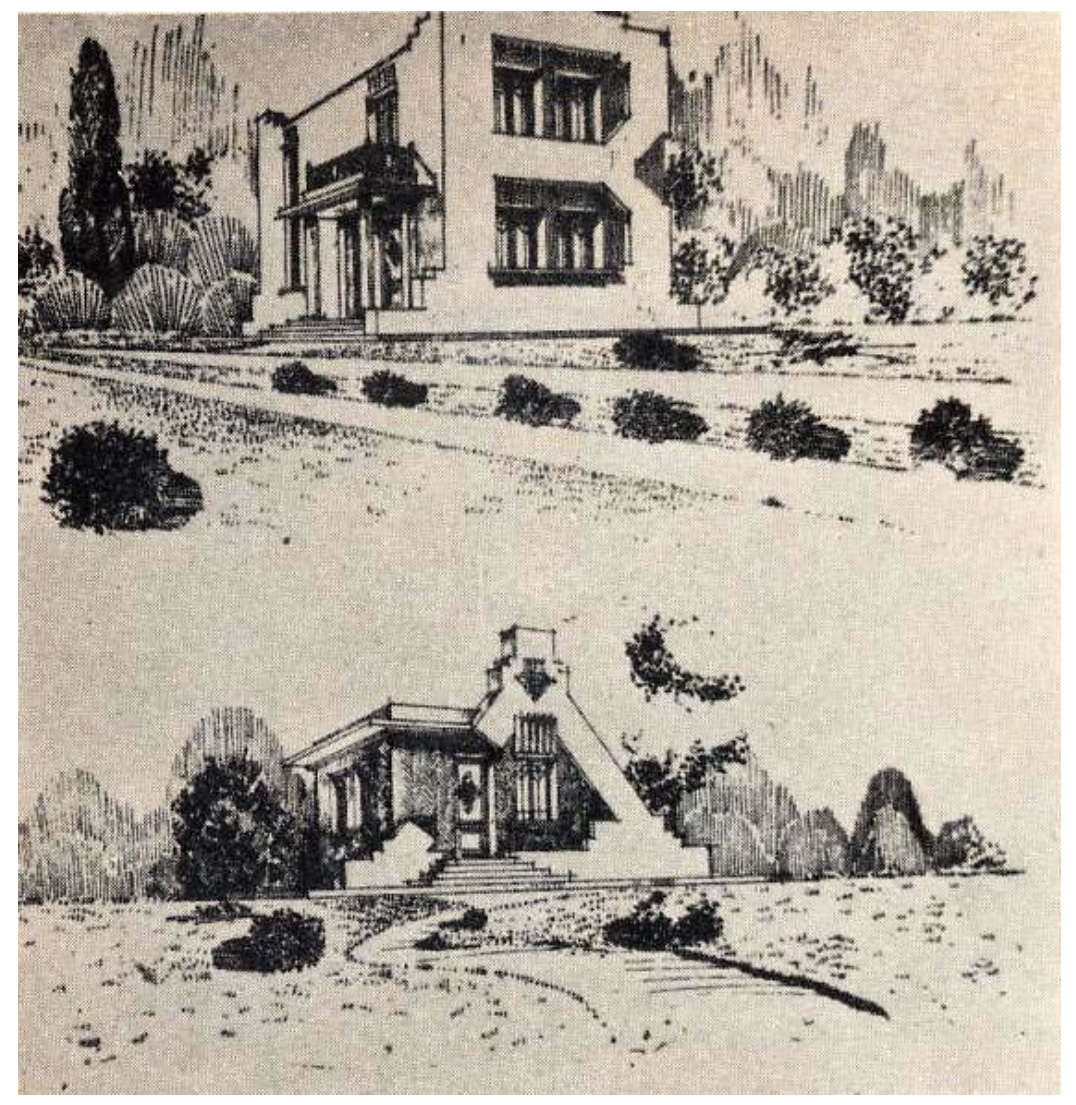

[10] Casas com fachadas reproduzindo as iniciais do proprietário, aluno da Escola Nacional de Belas Artes do Rio de Janeiro, RJ, década de 20 - "Cartilha Arquitetônica”, segundo Abelardo de Souza.

Sobre as disciplinas descreve que "durante os três primeiros anos, tínhamos aulas em comum com os alunos de pintura, escultura e gravura. Era o Curso Geral, como era chamado. Tínhamos aulas de Desenho Figurado, Escultura de Ornatos, Descritiva, Perspectiva, História das Artes e Física e Química Aplicada às Artes. Na cadeira de Desenho Figurado, dada por um velho artista espanhol, Modesto Broccos, grande desenhista, copiávamos exaustivamente modelos de florões, capitéis, bustos, sem direito a qualquer criação ou interpretação. Papel canson no cavalete, fusain (carvão) e miolo de pão como borracha. Foi uma boa experiência, pois quase todos os exalunos, hoje formando a velha guarda da arquitetura, desenham bem. 


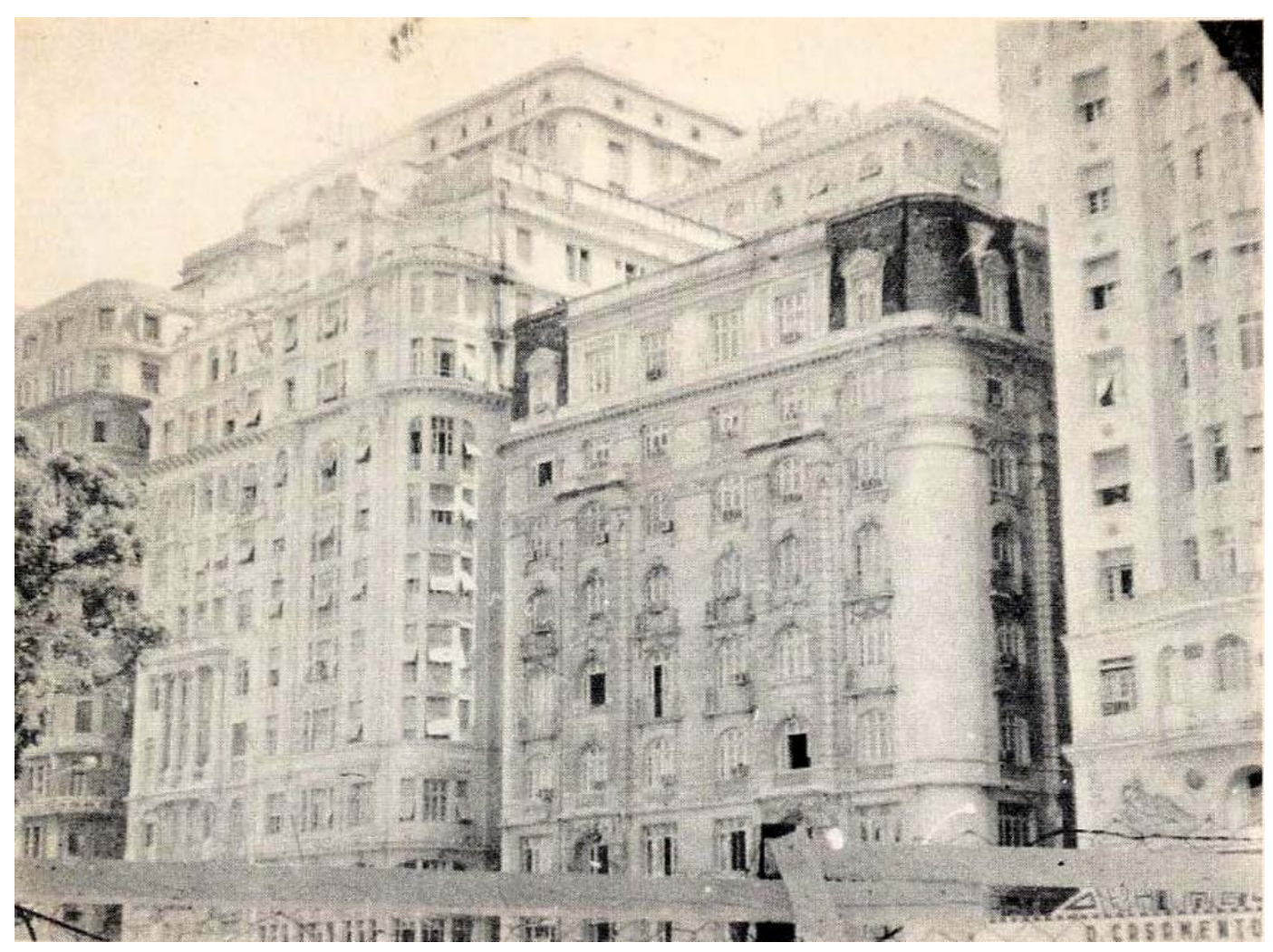

[11] Foto panorâmica “Cinelândia”, Rio de Janeiro, RJ - “falso estilo clássico” segundo Abelardo de Souza.

Na cadeira de Escultura de Ornatos, copiávamos novamente, só que em barro, os mesmos capitéis, os mesmos florões, vasos e bustos. (...) Nos três primeiros anos tínhamos uma cadeira que, para nós era a principal: composição de arquitetura. Fazíamos em plantas, cortes e fachadas, projetos de pórticos, pavilhões de caça, fontes, tudo dentro da mais completa inutilidade. A nossa opção era escolher o estilo; ou o colonial, ou o espanhol, ou o inglês, tudo "inspirado" nas revistas[12]; caso optássemos pelo clássico, era o Vignola que nos guiava. Continuávamos a não criar nada, uma vez que tudo já estava criado. Copiávamos. " 15

\footnotetext{
${ }^{15}$ SOUZA, Abelardo, op. cit., p.22.
} 


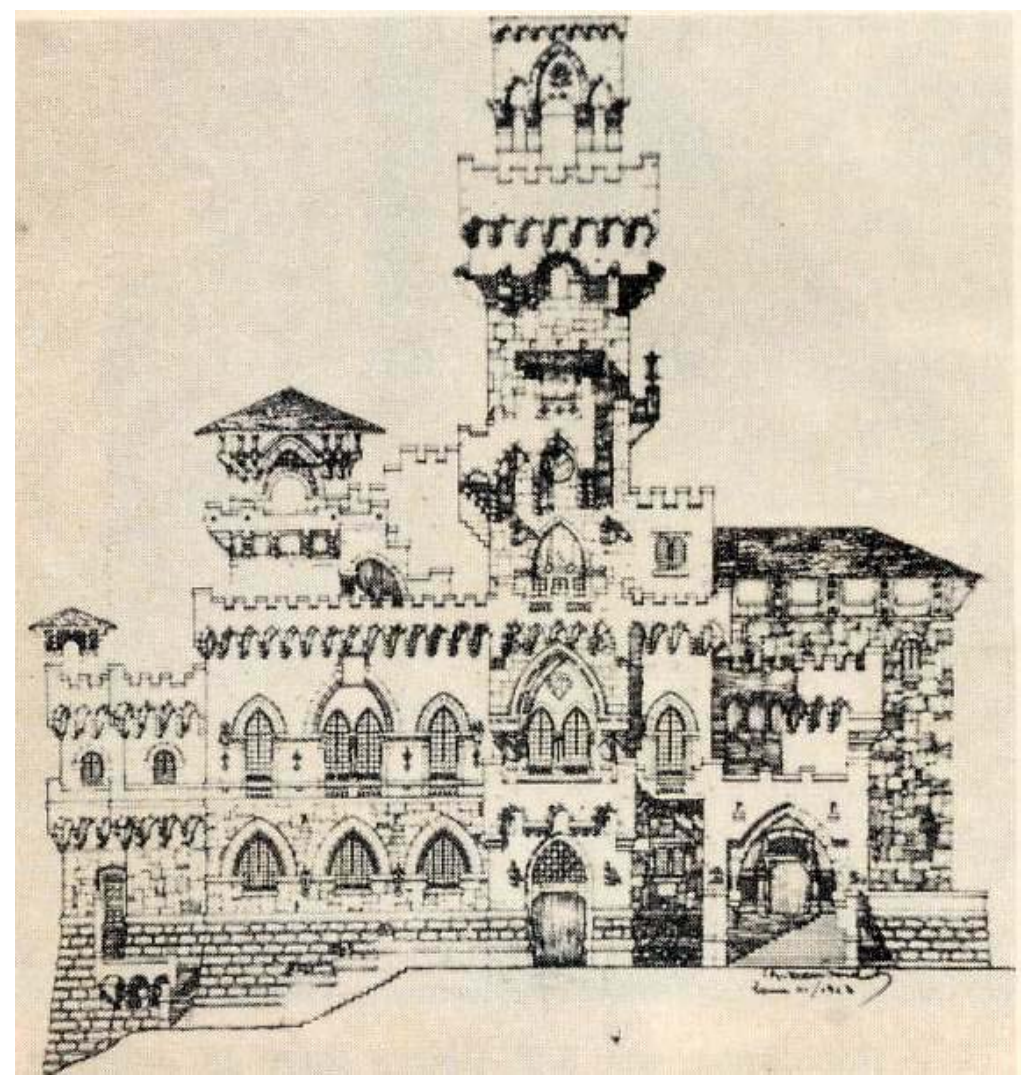

[12] Projeto de residência, aluno da Escola Nacional de Belas Artes do Rio de Janeiro, RJ, década de 20 - "alta confusão arquitetônica” segundo Abelardo de Souza.

Outra vez, em que pese a ironia do relato de Abelardo, podemos supor que ele seja representativo do juízo que sua geração - a chamada escola carioca - fazia a respeito da outra escola, a ENBA carioca. Diz ele que "do quarto até o sexto ano, a Cadeira de Composição de Arquitetura, vista hoje e mesmo para nós, alunos daquela época, era dada de uma maneira verdadeiramente lamentável, para não dizer ridícula. Os temas dados, como se fossem uma herança vinculada, que passava de ano para ano, de turma para turma, se repetiam de uma maneira impressionante. Nos primeiros anos eram aqueles pórticos, aquelas fontes, aqueles pavilhões de caça já descritos. Nos últimos anos, os temas dados eram, então, fora de qualquer realidade, já naquela época. Coisas como: uma residência para uma família distinta. Ou então: uma sala de passos perdidos, nome dado às antecâmaras dos gabinetes presidenciais. Ou ainda: projetar uma torre 
para residência de um filósofo numa ilha deserta. Esse tema foi dado para a turma formada em 1929, turma de Affonso Eduardo Reidy." 16

Temos registros da passagem de outros arquitetos da época pela ENBA. O percurso de Jorge Machado Moreira ${ }^{17}$ é exemplar. Aluno da escola de 1927 a 1932, os seus projetos de estudante são testemunho do processo descrito por Abelardo de Souza, e, mais ainda, da reforma promovida por Lúcio Costa. No catálogo organizado por Jorge Czajkowski $^{18}$, vemos documentados exercícios das duas épocas. Czajkowski comenta que seguindo a doutrina historicista do curso de arquitetura da Escola Nacional de Belas Artes na época, Jorge Machado Moreira faz uso de estilos diversos com vistas à correta caracterização dos temas propostos. Para além da habilidade no manejo das diferentes linguagens, é evidente o cuidado com a solução funcional e o domínio da composição plástica.

Do período anterior a reforma de 1930, vemos dois exercícios: "uma Entrada para uma quinta presidencial"[13], e uma “Torre elevatória d'água"[14]. Sobre eles, Czajkowski comenta que "a entrada da quinta presidencial configura adequadamente um edifício representativo do poder público tanto pela escolha da gramática do classicismo, quanto pela imponência da volumetria. O uso do estilo românico no elevatório d'água, justificado pelo precedente das torres medievais, possibilita ao

\footnotetext{
${ }^{16}$ SOUZA, Abelardo, op. cit., p.23.

17 Jorge Machado Moreira (1904-1992) nasceu em Paris, França. Passou a infância e a adolescência no Rio Grande do Sul e iniciou curso universitário na Escola de Arquitetura de Montevidéu. Mudou-se para o Rio de Janeiro em 1927, onde cursou a Escola Nacional de Belas Artes, formando-se em 1932. Participante da equipe de jovens arquitetos responsáveis pelo Ministério da Educação e Saúde, foi o principal coordenador do projeto e construção da Cidade Universitária do Rio de Janeiro de 1936 a 1962. Foi atuante membro do Instituto de Arquitetos do Brasil, ocupando diversos cargos ao longo das décadas. Com atividade acadêmica esporádica, dedicou-se a projetos em seu escritório, com dezenas de residências e edifícios para uso diversos. Seu projeto para a Faculdade de Medicina do Rio Grande do Sul foi premiado no Congresso Pan-americano de Lima, em 1947. Foi responsável pelos principais projetos da cidade universitária, dentre eles o Instituto de Puericultura e Pediatria, o Hospital das Clínicas e a Faculdade Nacional de Arquitetura.

${ }^{18}$ CZAJKOWSKI, Jorge/organizador. Jorge Machado Moreira. Rio de Janeiro, Centro de Arquitetura e Urbanismo do Rio de Janeiro, 1999. Catálogo da exposição Jorge Machado Moreira, março a maio de 1999.
} 
estudante um exercício pitoresco no arranjo com os volumes correspondentes a espaços internos específicos." 19

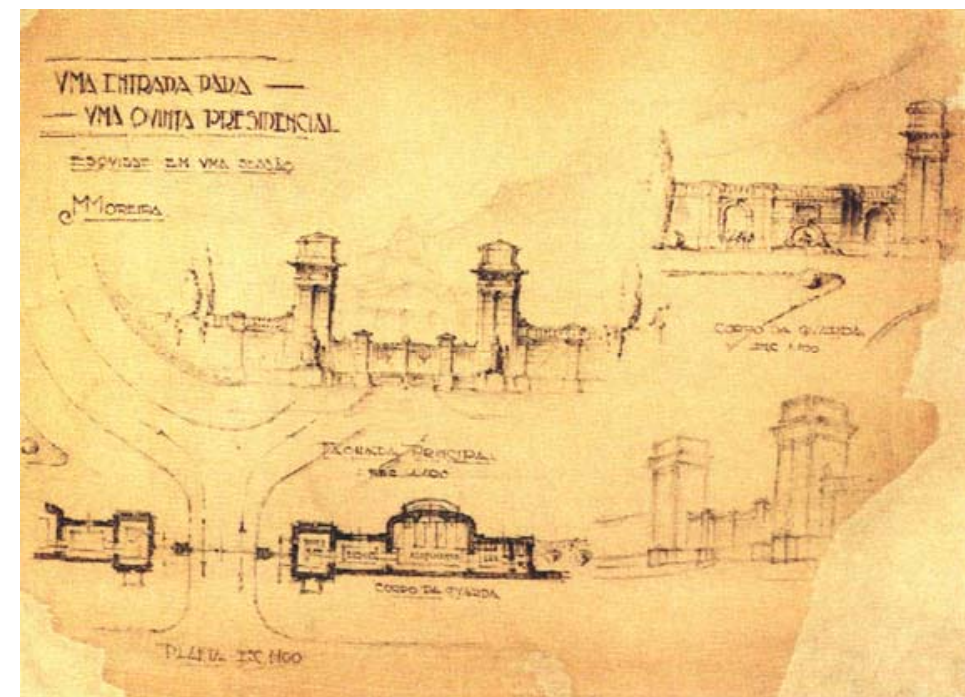

[13] "Uma entrada para uma quinta presidencial", trabalho do aluno Jorge Machado Moreira no Curso de Arquitetura da Escola Nacional de Belas Artes do Rio de Janeiro, RJ, 1927/28.

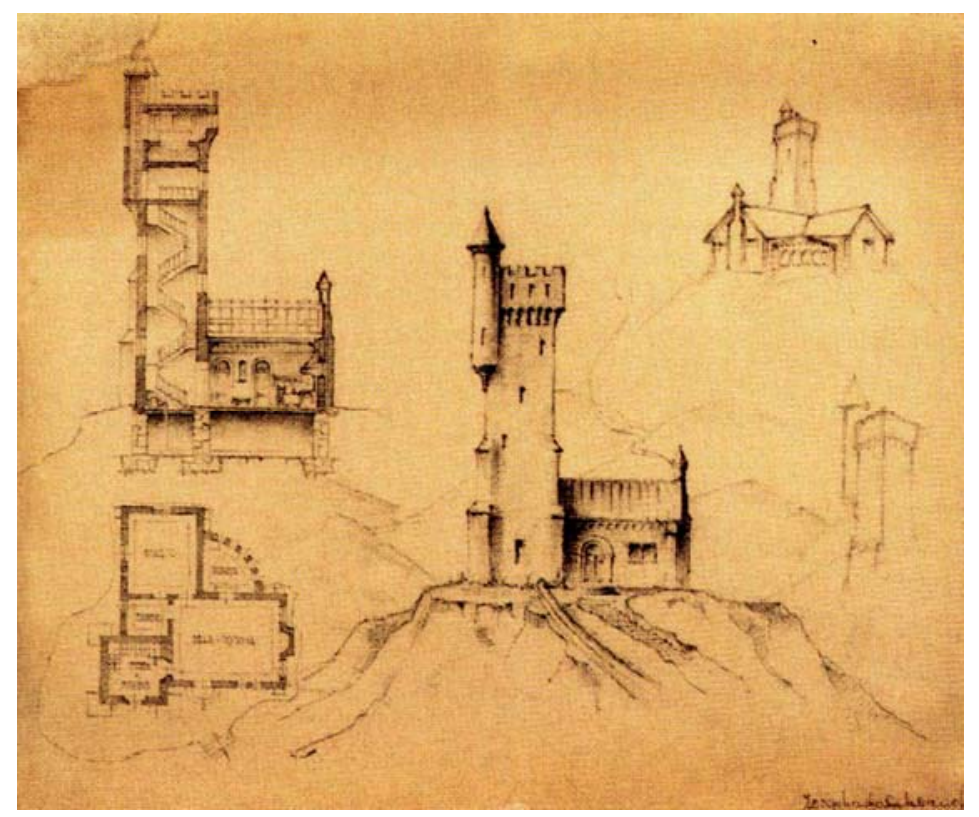

[14] “Torre elevatória de d'água”, trabalho do aluno Jorge Moreira Machado no Curso de Arquitetura da Escola Nacional de Belas Artes do Rio de Janeiro, RJ, 1928/29.

Do período posterior à reforma de 1930 vemos, também, dois exercícios: A Moda - confecções, sedas e novidades[15], e um Edifício

${ }^{19}$ CZAJKOWSKI, Jorge, op. cit., p. 36 
para renda[16]. Sobre eles, Czajkowski comenta que "no ateliê de modas, o sentido contemporâneo advém da composição dinâmica da esquina com a tipografia art déco e as superfícies planas e curvas, opacas e transparentes, como também da preocupação em marcar a estrutura e desenhar elementos arquitetônicos passíveis de serem produzidos em série. O sentido econômico do edifício para renda perpassa o projeto por inteiro: a modulação rigorosa da estrutura, a composição espacial rígida e a diagramação ascética das fachadas com a linguagem modernista." ${ }^{20}$

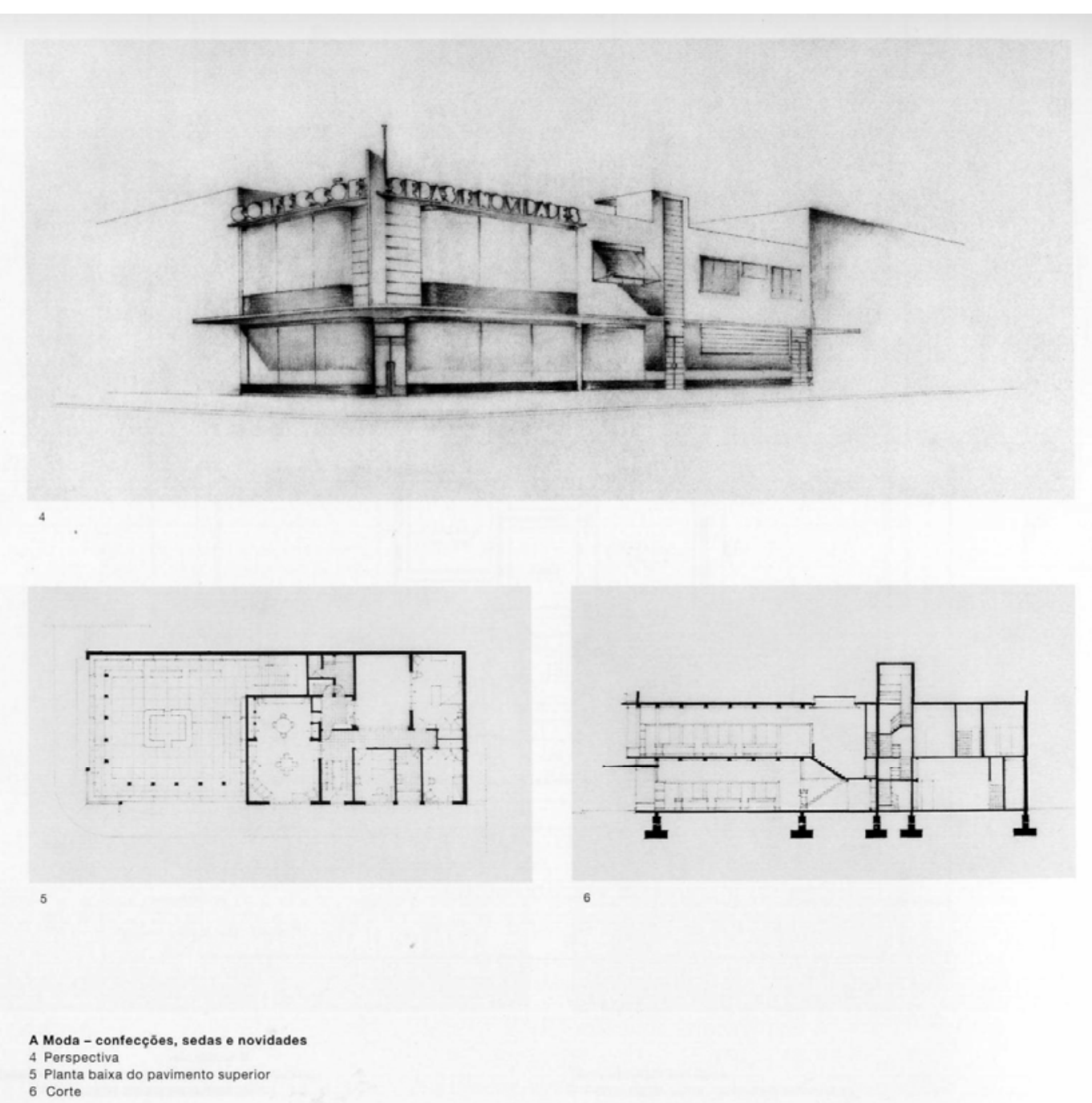

[15] “A Moda - confecções, sedas e novidades”, trabalho do aluno Jorge Moreira Machado no Curso de Arquitetura da Escola Nacional de Belas Artes do Rio de Janeiro, RJ, 1930/31.

${ }^{20}$ CZAJKOWSKI, Jorge, op. cit., p.36. 
Um percurso imprescindível é o do próprio Lúcio Costa. No seu "Lúcio Costa: Registro de uma vivência" comenta que "meu pai - que estranhamente sempre desejou ter um filho" artista “- matriculou-me na Escola Nacional de Belas Artes, onde afinal me formaria arquiteto. Ainda vestido de menino inglês e muito mais moço que os outros, sempre fui respeitado porque desenhava melhor que eles." ${ }^{22}$ Estamos em 1917 e Costa permanece como aluno até 1924. Empregado como desenhista na firma Rebecchi "com Evaristo Juliano de Sá, fiscalizei a construção do meu primeiro projeto, Casa em estilo inglês para Rodolfo Chambelland[17] e [18], na Avenida Paulo de Frontin. Sempre que, no viaduto, passava por lá, via a ponta da sua empena aflorando da copa das árvores, - até que um dia sumiu." ${ }^{23}$

${ }^{21}$ COSTA, Lúcio. Lúcio Costa: registro de uma vivência. São Paulo, Empresa das Artes, 1995.

${ }^{22}$ COSTA, Lúcio, op. cit., p. 12.

${ }^{23}$ COSTA, Lúcio, op. cit., p.15. 


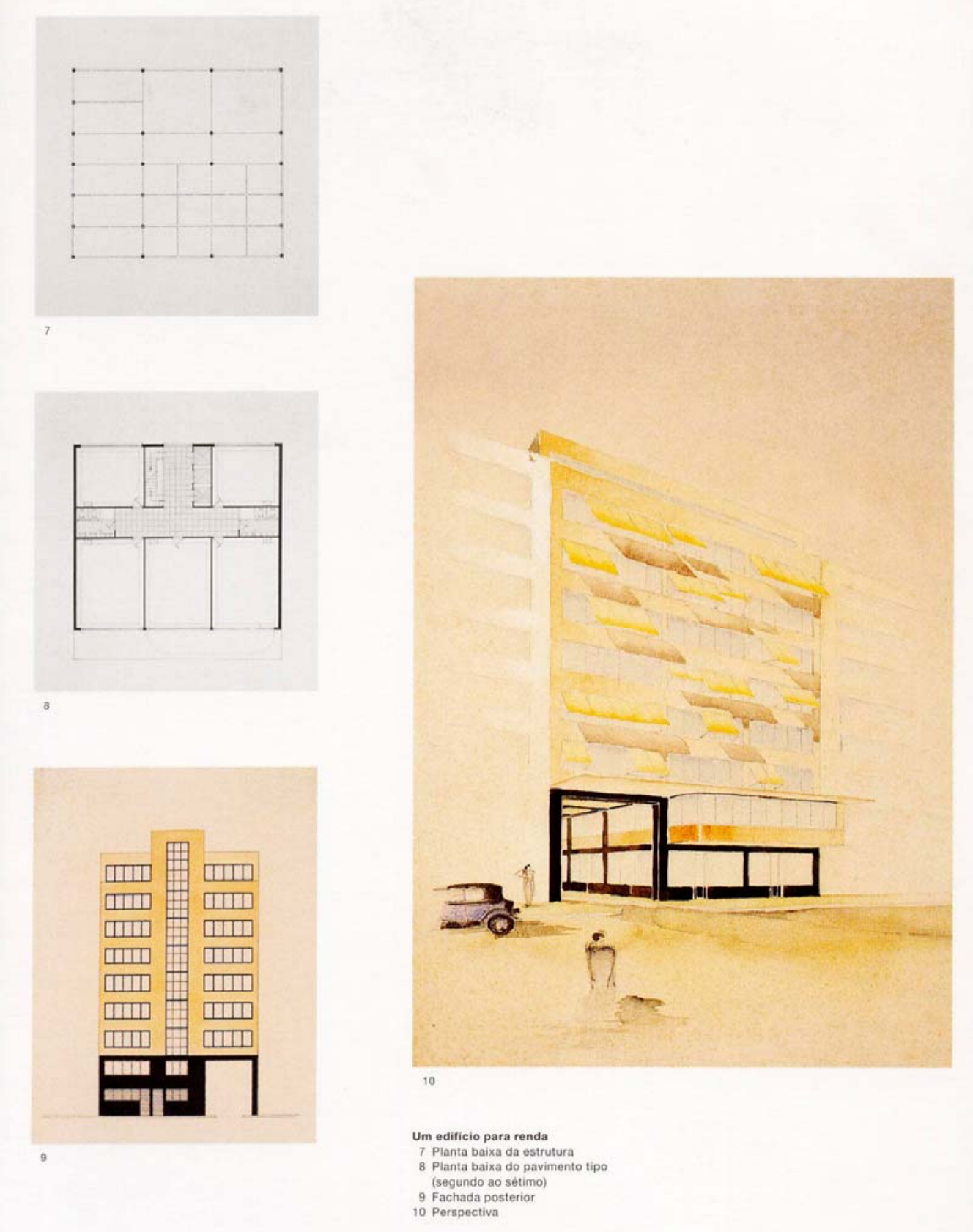

[16] “Um edifício para renda”, trabalho do aluno Jorge Moreira Machado no Curso de Arquitetura da Escola Nacional de Belas Artes do Rio de Janeiro, RJ, 1930/31.

Muito mais sóbrio que Abelardo de Souza, faz um comentário não tão diferente dos dele, quando diz que "era a época do chamado ecletismo arquitetônico. Os estilos históricos eram aplicados sans façon de acordo com a natureza do programa em causa. Tratando-se de igreja, recorria-se ao receituário românico, gótico ou barroco; se de edifício 
público ou palacete, ao Luiz XV ou XVI; se de banco, ao Renascimento italiano; se de casa, a gama variava do normando ao basco, do missões ao colonial." ${ }^{24}$

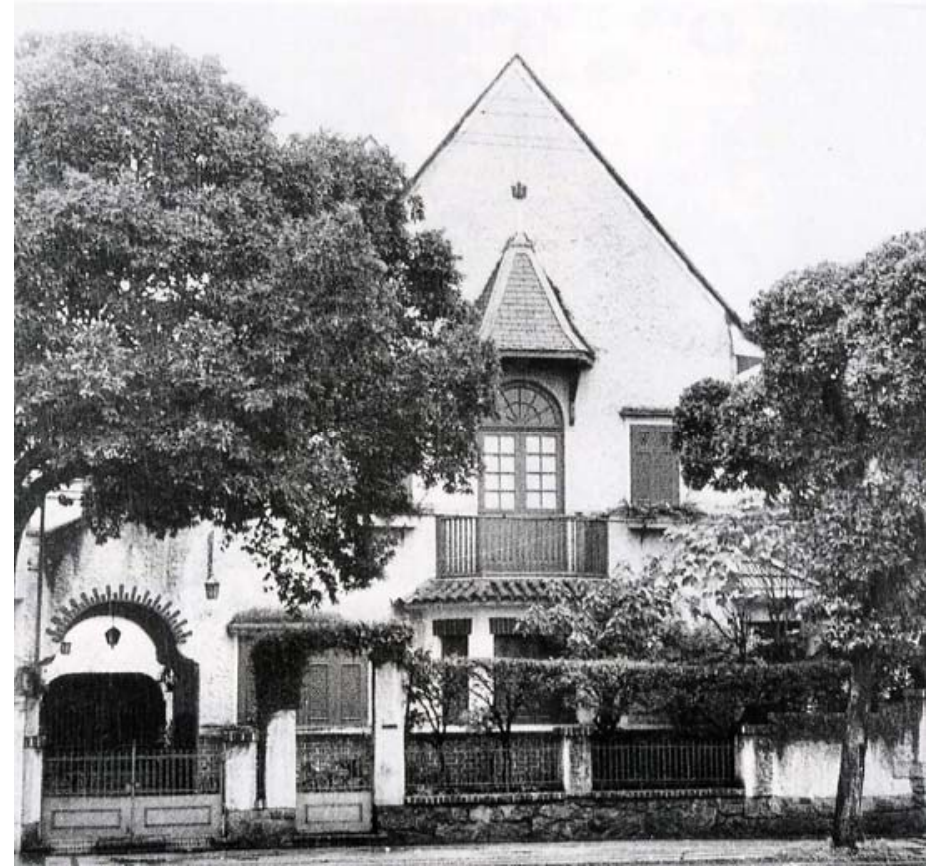

[17] Residência Rodolfo Chambelland, Rio de Janeiro, RJ, 1921/22. Arquiteto Lúcio Costa. Foto da fachada.

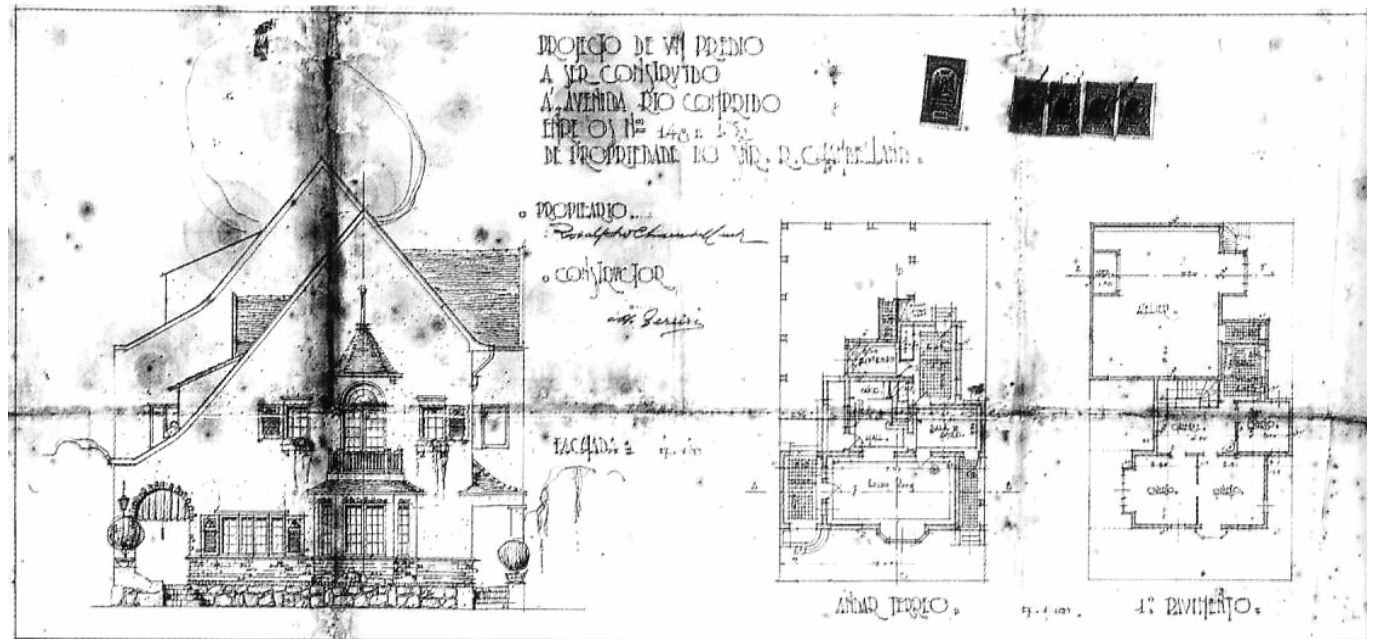

[18] Residência Rodolfo Chambelland, Rio de Janeiro, RJ, 1921/22. Arquiteto Lúcio Costa. Projeto; fachada, plantas andar térreo, $1^{\circ}$ andar.

Desse período do ecletismo acadêmico Costa seleciona e documenta nos seus Registros mais três projetos: Casa Arnaldo Guinle[19],

${ }^{24}$ COSTA, Lúcio, op. cit., p.15 
Teresópolis, com a legenda estilo inglês, Embaixada do Peru[2o], 1927/28, com legenda Equívoco neocolonial e Embaixada da Argentina[21], 1927/28, com legenda Ilusão florentina. Deste último, objeto de concurso público, conhecemos também a participação de Flávio de Carvalho, que comentaremos adiante.

Assim, se na década de trinta Costa tem papel de destaque nas grandes mudanças sofridas pela arquitetura brasileira, na de 20 está inserido no ecletismo reinante.

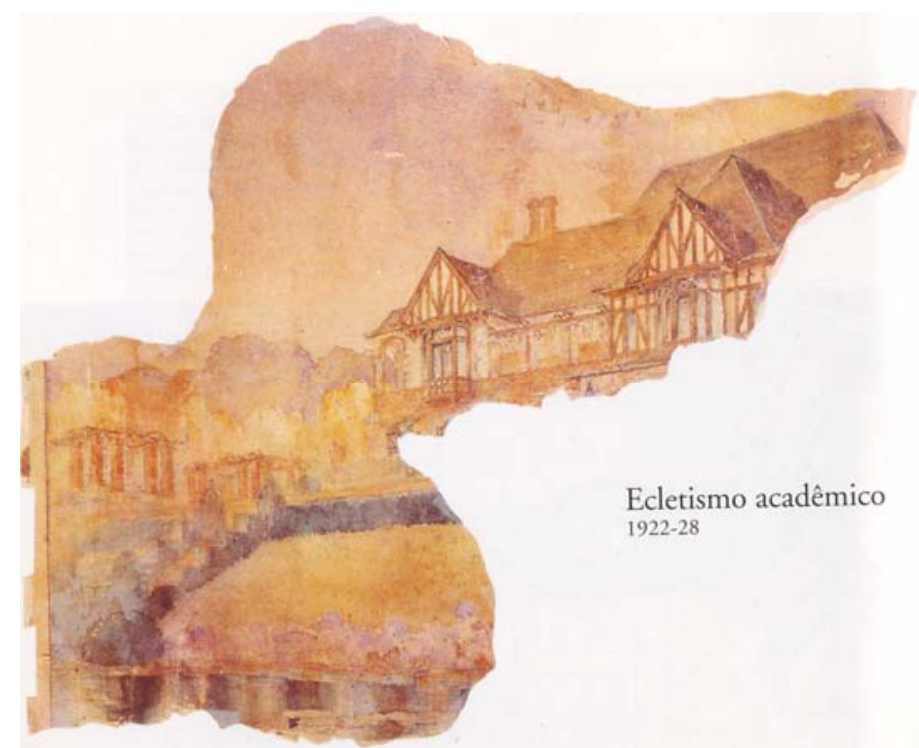

[19] Casa Arnaldo Guinle, Teresópolis, RJ, década de 20. Arquiteto Lúco Costa. Legenda do arquiteto: "Estilo inglês"

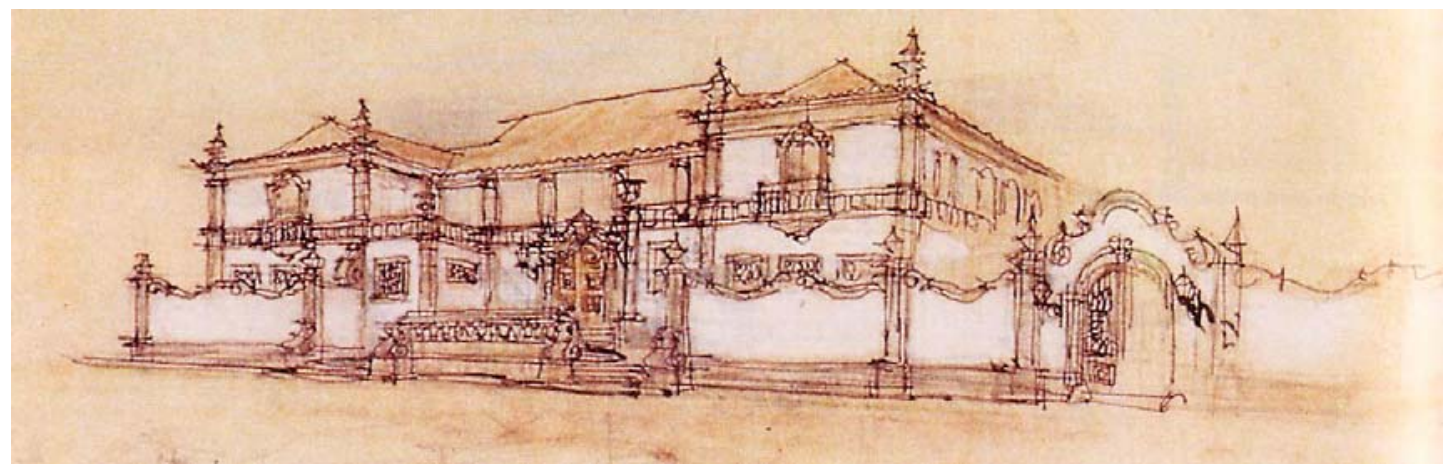

20] Embaixada do Perú, concurso público, Rio de Janeiro, RJ, 1927/28. Arquiteto Lúcio Costa. Legenda do arquiteto: Equívoco "neo-colonial”. 


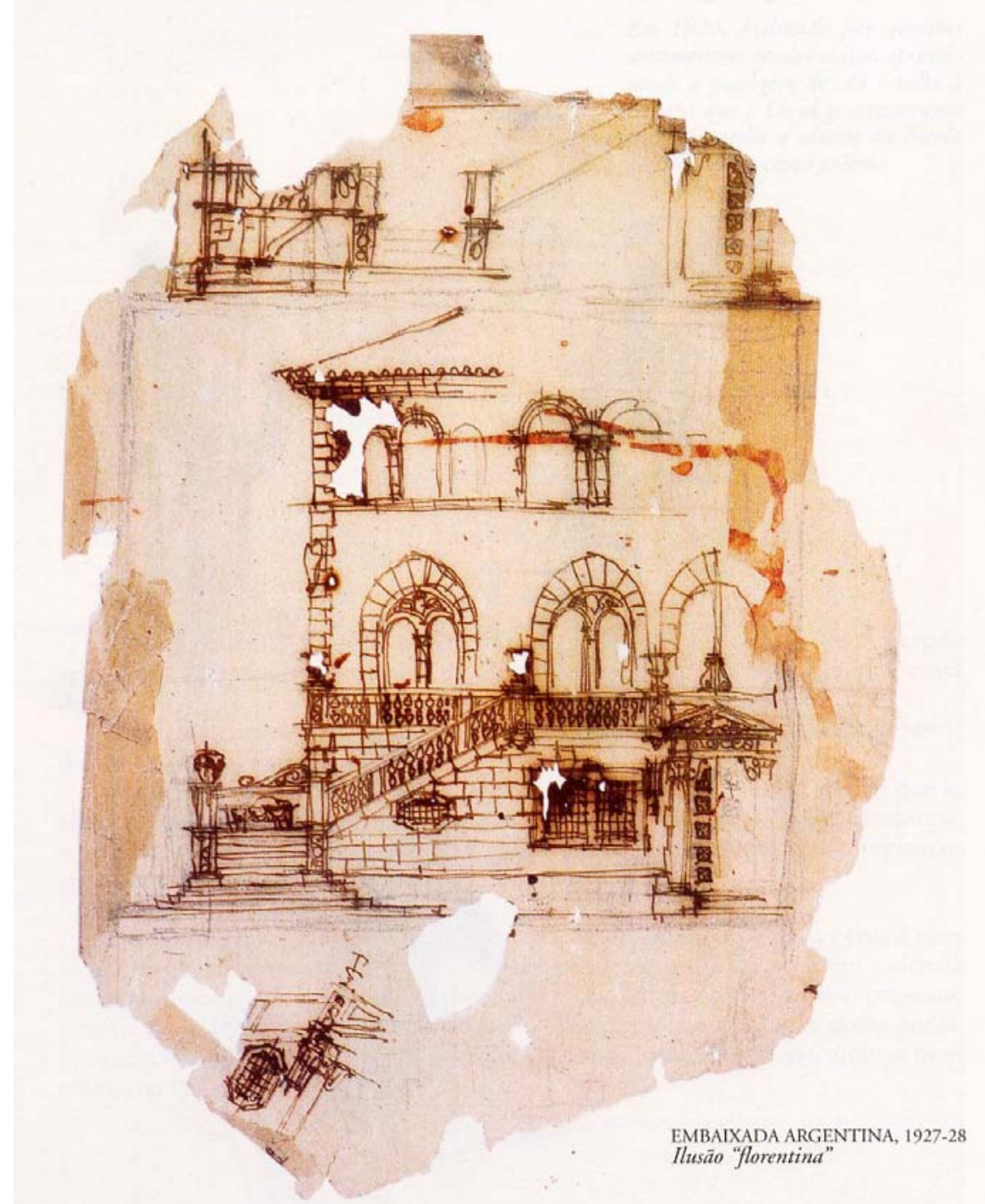

[21] Embaixada da Argentina, concurso público, Rio de Janeiro, RJ, 1927/28. Arquiteto Lúcio Costa. Legenda do arquiteto: Ilusão "florentina”

Pelo visto, o ambiente da arquitetura carioca em geral - e o ensino da ENBA em particular - é, nesse período, muito pouco clássico e bastante eclético. Muito diferente do ambiente italiano da formação de Rino Levi. Esse contraste talvez explique o ritmo e o caráter desigual observado no processo de mudança de Levi e de seus colegas brasileiros. Para os arquitetos brasileiros, a tradição mais frouxa permitiu um ritmo mais veloz, mas um caráter mais superficial. Para Levi, a tradição mais rigorosa obrigou um ritmo mais lento, mas um caráter mais profundo. 


\section{2 - OS PRIMEIROS PROJETOS}

\subsection{1 - AS PRIMEIRAS RESIDÊNCIAS E HABITAÇÕES COLETIVAS}

Da produção inicial de Rino Levi, o primeiro projeto mais conhecido é a Residência Ferrabino ${ }^{25}$. Dela conhecemos duas versões: a primeira, que indica como proprietário Alberto Ferrabino[22], é formada por um prisma retangular para o corpo principal e um outro menor, no fundo do lote, para a edícula.

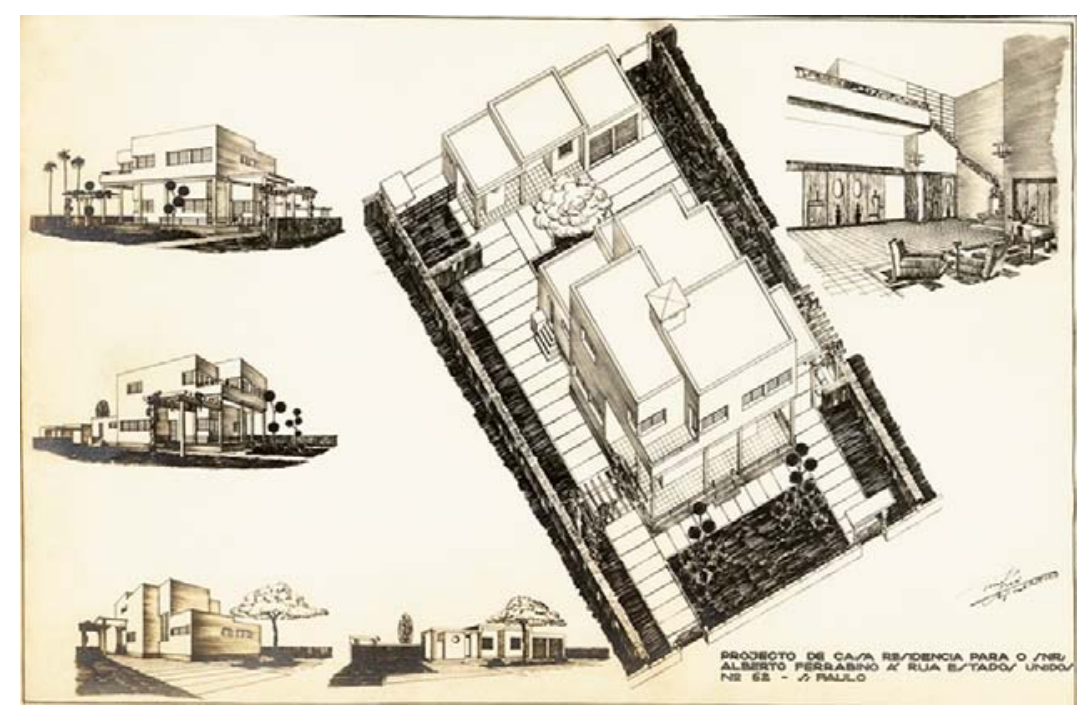

[22] Residência Ferrabino, São Paulo, SP, 1931. Arquiteto Rino Levi. Projeto completo, $1^{\mathrm{a}}$ versão para o Sr. Alberto Ferrabino.

Descrita assim, a residência parece não apresentar muita diferença em relação ao sobrado convencional do período que, como já mencionamos, mantém resquícios da implantação casa-grande, terreiro e senzala. No entanto, mesmo mantendo a exigência dos proprietários da dependência de empregados, Levi consegue ocupar o lote de uma maneira muito mais dinâmica. Os dois prismas são tratados da mesma maneira[23] [24], com o mesmo cuidado, e o

\footnotetext{
${ }^{25}$ Residência Ferrabino, São Paulo, SP, 1931. Arquiteto Rino Levi.
} 
convencional quintal do fundo é transformado em jardim de uso da família[25].

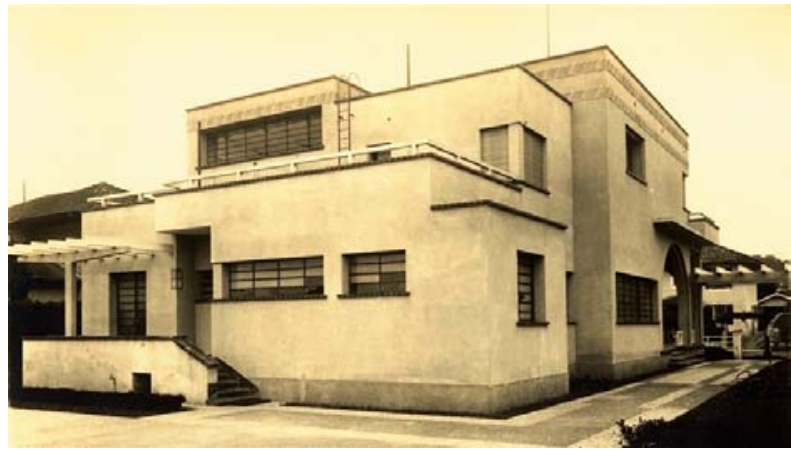

[23] Residência Ferrabino, São Paulo, SP, 1931. Arquiteto Rino Levi. Fachada posterior do bloco principal.

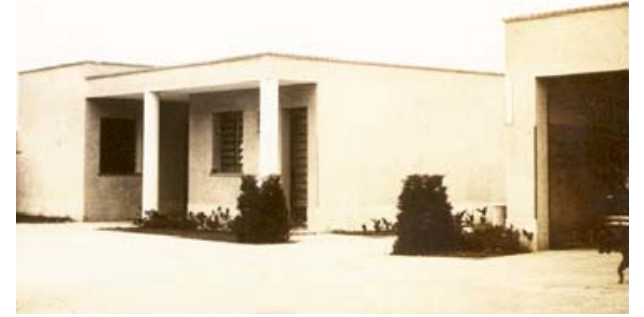

[24] Residência Ferrabino, São Paulo, SP, 1931. Arquiteto Rino Levi. Fachada bloco posterior.

Os prismas são movimentados por volumes de altura e profundidade variadas, por pérgulas e por aberturas e marquises, num raciocínio próximo das vanguardas modernas européias, como analisaremos adiante.

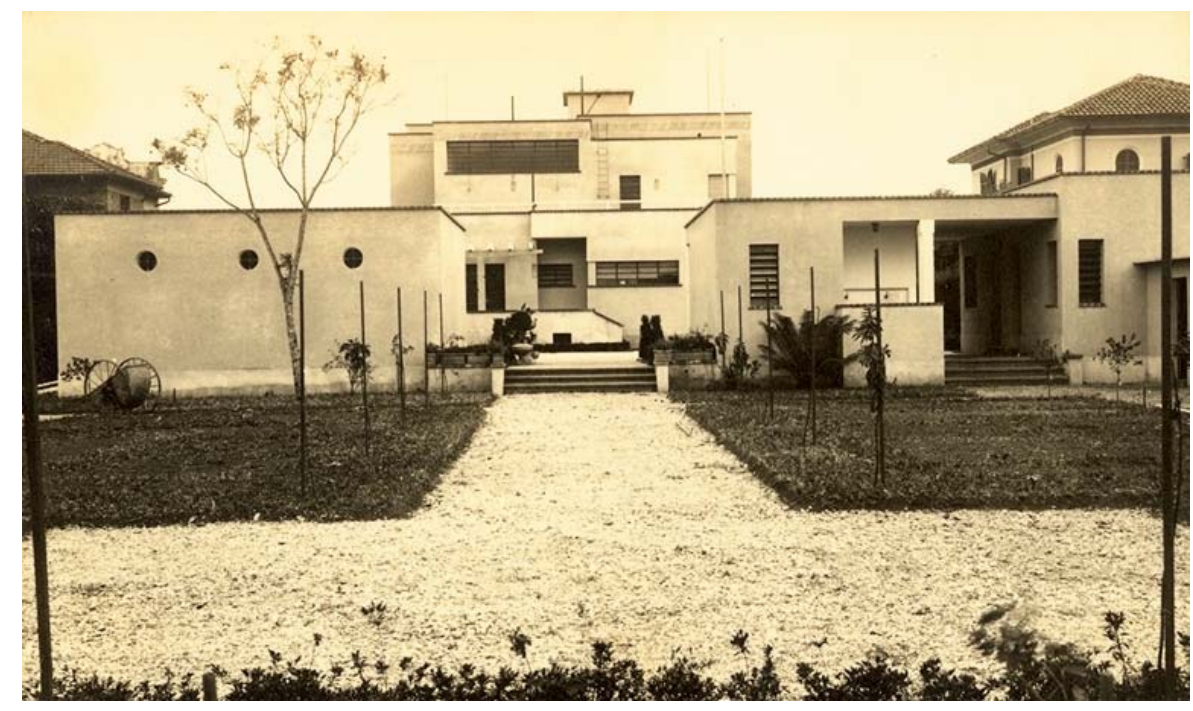

[25] Residência Ferrabino, São Paulo, SP, 1931. Arquiteto Rino Levi. Vista desde o fundo do lote.

A segunda versão, construída, indica como proprietária Delfina Ferrabino[26], mantém em larga medida as características apresentadas, mas introduz elementos decorativos na volumetria originalmente limpa. Esses acréscimos se concentram na fachada para a rua[27], como rusticagem na platibanda, arcos e balaústres na 
varanda[28]. Warchavchik já tinha sofrido esse mesmo tipo de intromissão na sua casa da Rua Santa Cruz, neste caso por parte da prefeitura. Para Levi, como as exigências eram da proprietária, não coube a estratégia da falta de dinheiro para terminar o projeto, como fez seu colega brasileiro ou seu colega italiano Giuseppe Terragni no Novocomum.

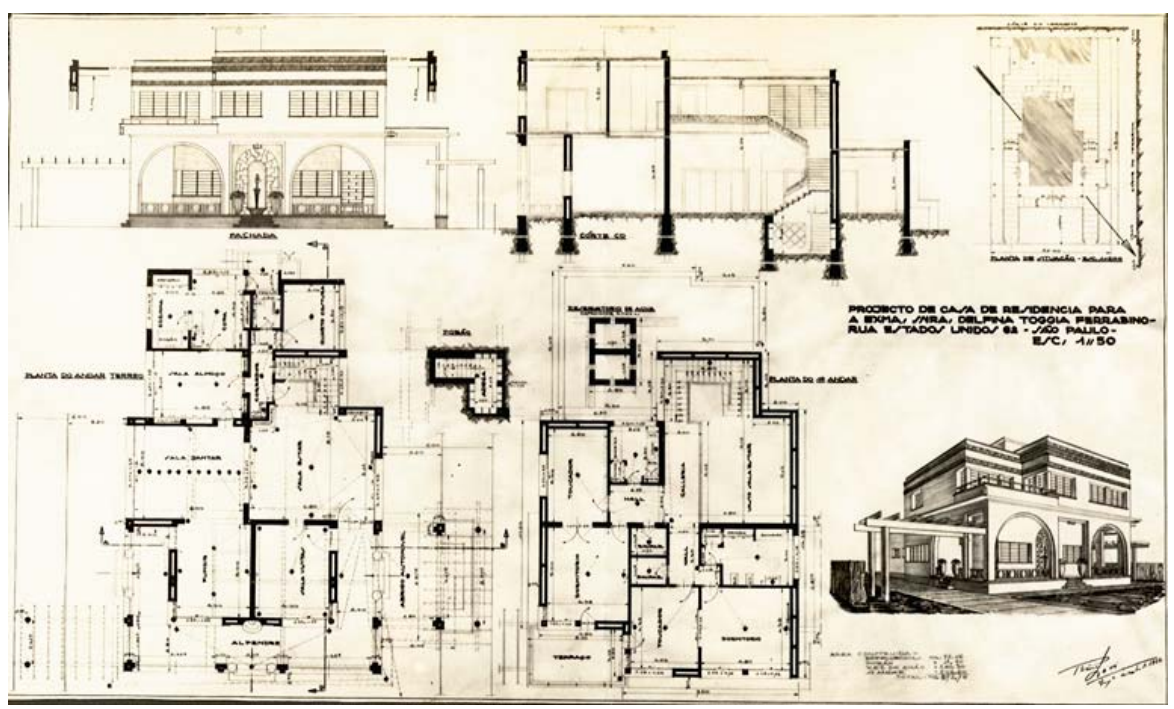

26] Residência Ferrabino, São Paulo, SP, 1931. Arquiteto Rino Levi. Projeto completo, $2^{\mathrm{a}}$ versão para a Sra. Delfina Ferrabino.

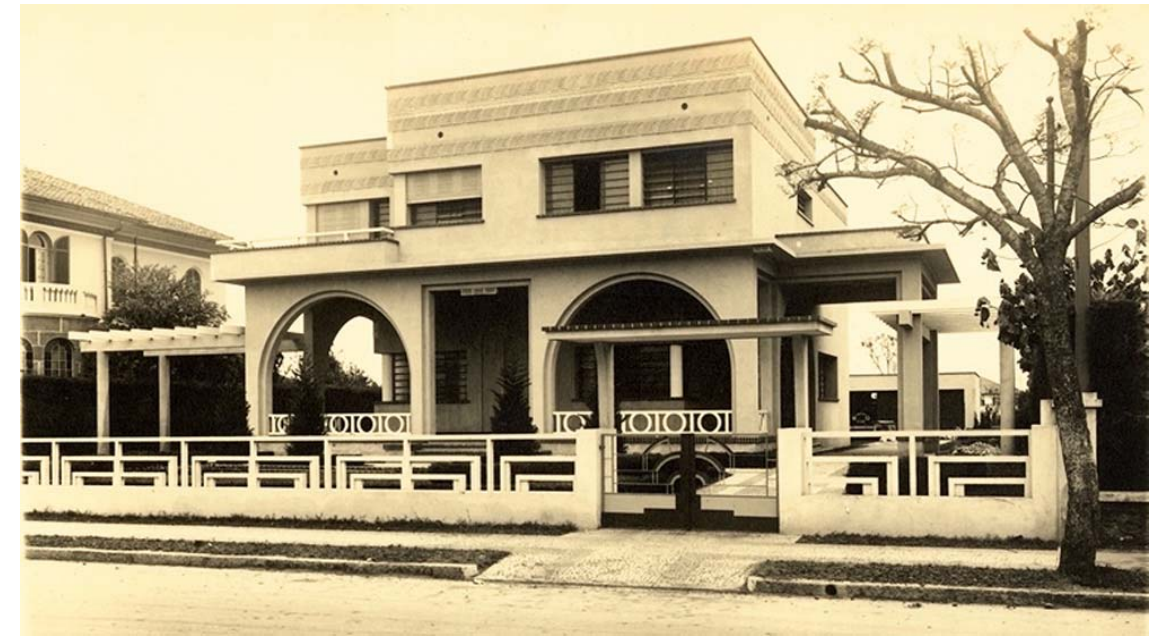

[27] Residência Ferrabino, São Paulo, SP, 1931. Arquiteto Rino Levi. Fachada para a rua. 


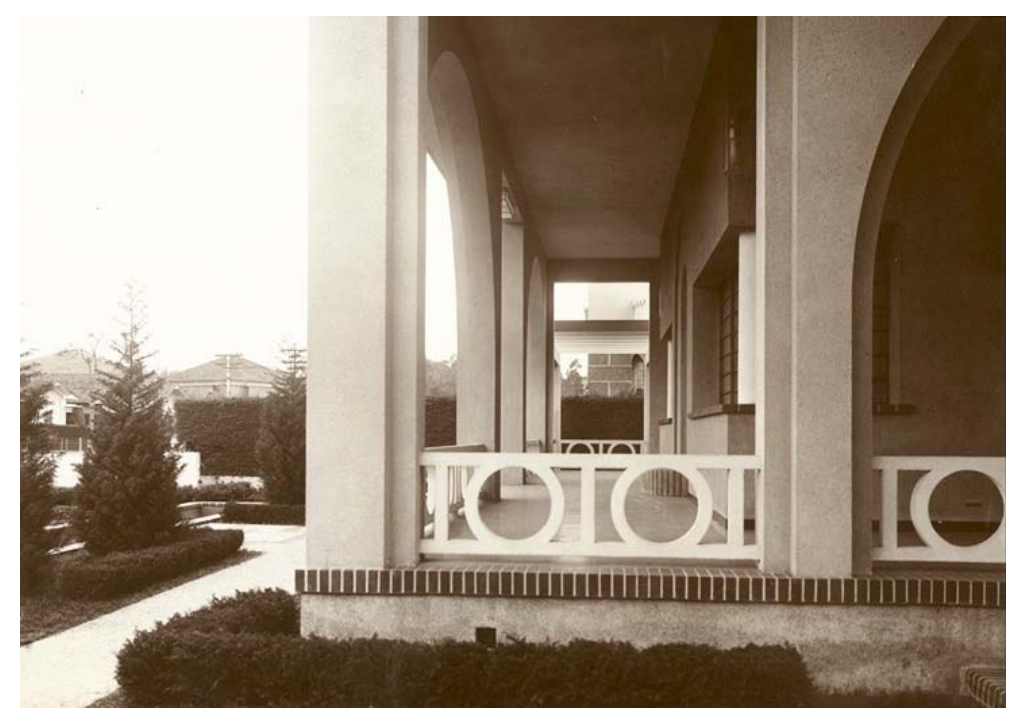

[28] Residência Ferrabino, São Paulo, SP, 1931. Arquiteto Rino Levi. Detalhe dos arcos e balaustres incorborados na segunda versão do proieto.

No interior da residência, onde móveis e decoração tiveram a contribuição do artista plástico John Graz, observamos detalhes que serão retomados em projetos posteriores. O elegante corrimão da escada será usado no projeto para o concurso do Viaduto do Chá[29]. Uma modernidade sóbria estará presente na iluminação natural[30], no desenho dos pisos[31], nos detalhes de marcenaria[32], nos móveis, tapetes e luminárias[33].

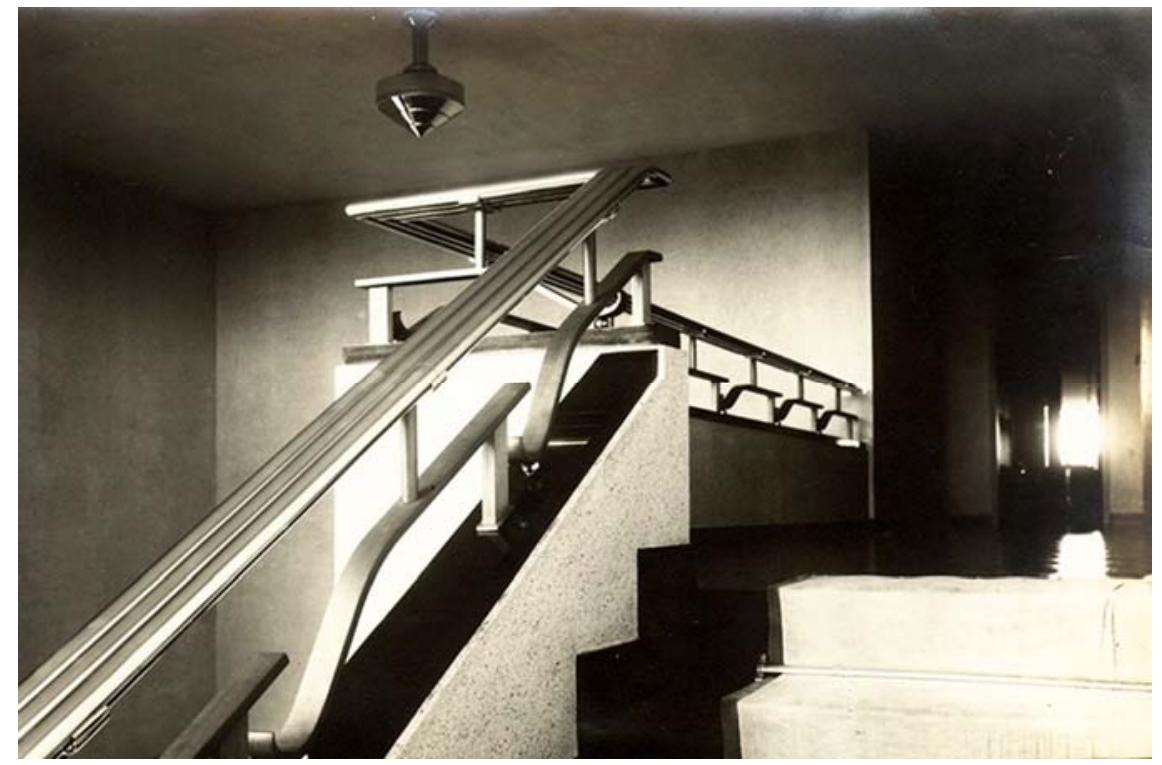

[29] Residência Ferrabino, São Paulo, SP, 1931. Arquiteto Rino Levi. O detalhe do corrimão retornará no projeto para o concurso do Viaduto do Chá. 


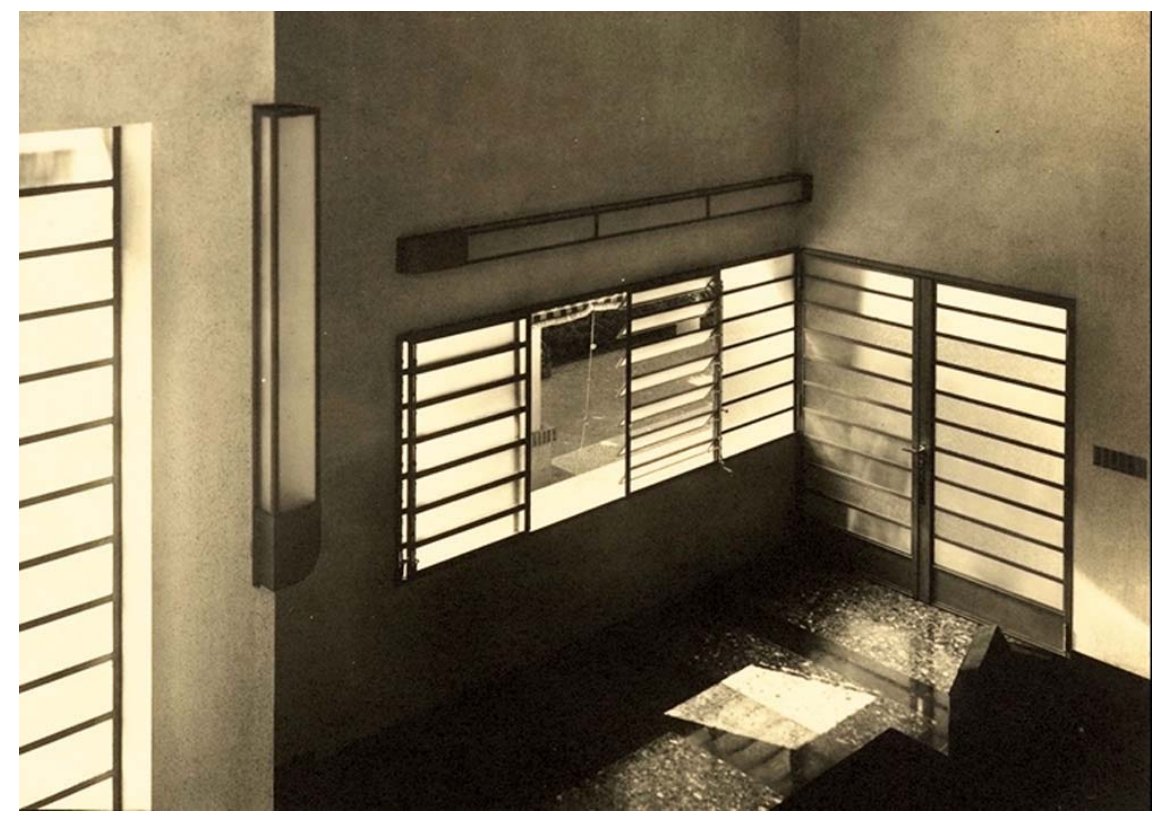

[30] Residência Ferrabino, São Paulo, SP, 1931. Arquiteto Rino Levi. Detalhe iluminação natural.

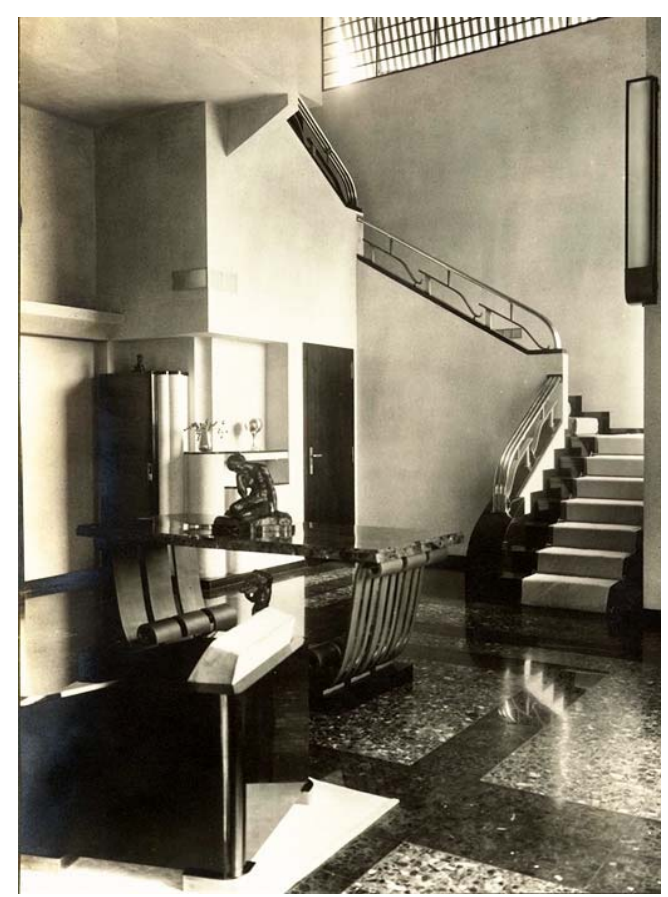

[31] Residência Ferrabino, São Paulo, SP, 1931 Arquiteto Rino Levi. Hall da escada.

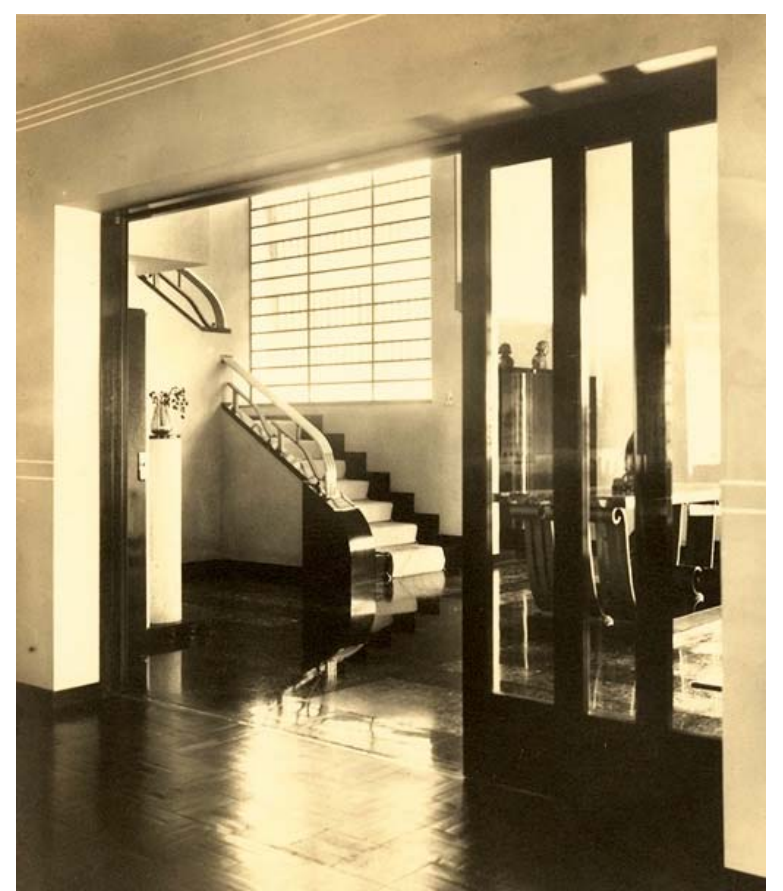

[32] Residência Ferrabino, São Paulo, SP, 1931. Arquiteto Rino Levi. Detalhe portas de correr. 


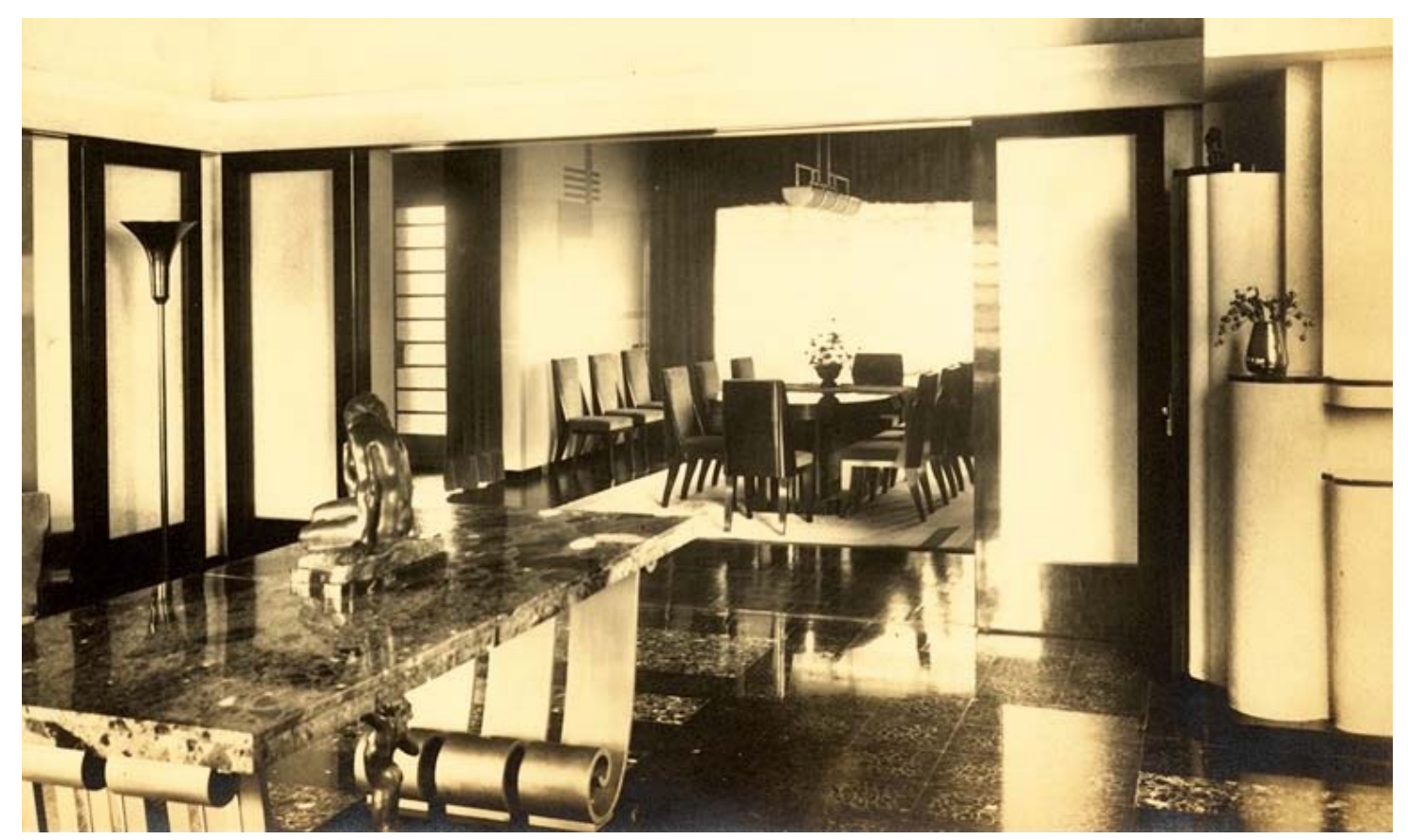

[33] Residência Ferrabino, São Paulo, SP, 1931. Arquiteto Rino Levi. Vista da sala de jantar.

Embora algumas vezes a residência Ferrabino apareça como o primeiro projeto de Rino Levi, antes dela o arquiteto já tem uma produção. Além do trabalho junto a Cia. Construtora de Santos, segundo a listagem feita pelo escritório já em 1927 participa de três concursos públicos, faz dois projetos de residências e uma fábrica de pianos. Deles conhecemos dois concursos, o do Automóvel Clube de São Paulo, e o Progetto per um monumento a De Penedo sulle rive del Lago di Santo Amaro ${ }^{26}$ [34], ambos com escassa documentação. Quanto aos projetos temos uma foto da Fábrica de Pianos Brasil ${ }^{27}$ [35], algumas da reforma da casa de Godofredo Silva Telles e o projeto para H. Telles Ribeiro.

\footnotetext{
${ }^{26}$ Monumento a "De Penedo" (concurso), São Paulo, SP, 1927. Arquiteto Rino Levi.

${ }^{27}$ Fábrica de Pianos Brasil, São Paulo, SP, 1927. Arquiteto Rino Levi.
} 


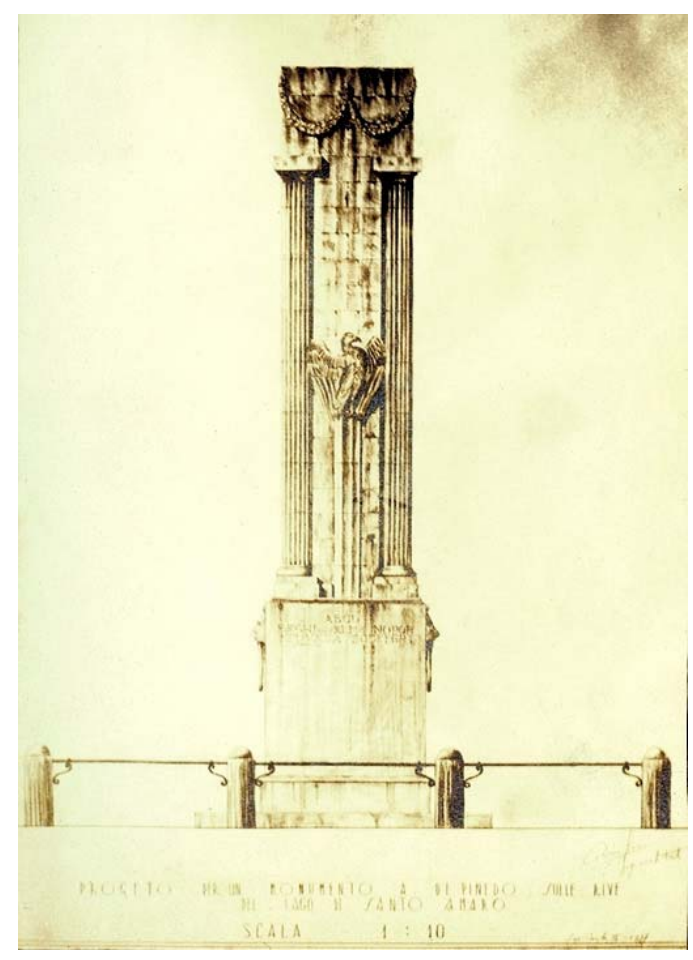

[34] Progetto per um monumento a De Penedo sulle rive del Lago di Santo Amaro, concurso, Saõ Paulo, SP, 1927. Arquiteto Rino Levi.

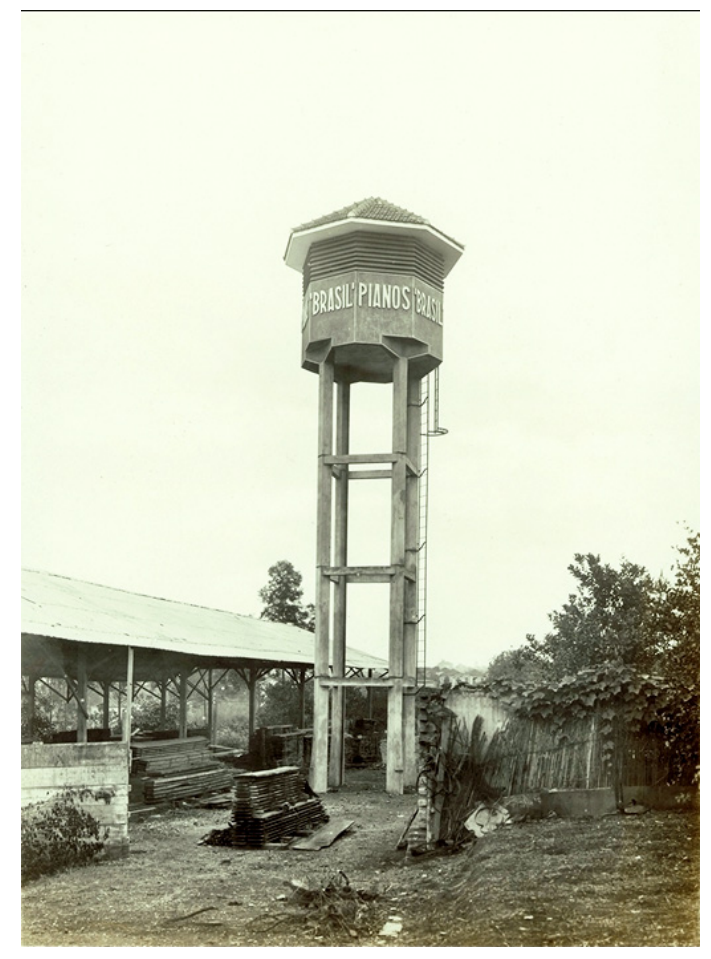

35] Fábrica de Pianos Brasil, São Paulo, SP, 1927. Arquiteto Rino Levi.

O concurso para o Automóvel Clube de São Paulo ${ }^{28}$ era destinado para um lote de forma triangular no Largo do Ouvidor, no centro de São Paulo, com vistas para o Vale do Anhangabaú. O partido adotado por Levi é um monumental edifício em altura[36] que explora as possibilidades geométricas do lote[37] [38]. A fachada para o Largo do Ouvidor é rigorosamente simétrica, enquanto a do Anhangabaú é escalonada culminando em torres octogonais, cobertas com tijolos cerâmicos[39]. Anelli comenta sobre o projeto "que é grande a semelhança com o Palazzo Körner, projetado em Milão em 1923" ${ }^{29}$.

\footnotetext{
${ }^{28}$ Anteprojeto do Edifício para Sede Social do Automóvel Clube de São Paulo, concurso, São Paulo, SP, 1927.

${ }^{29}$ ANELLI, Renato, op. cit., p. 105.
} 


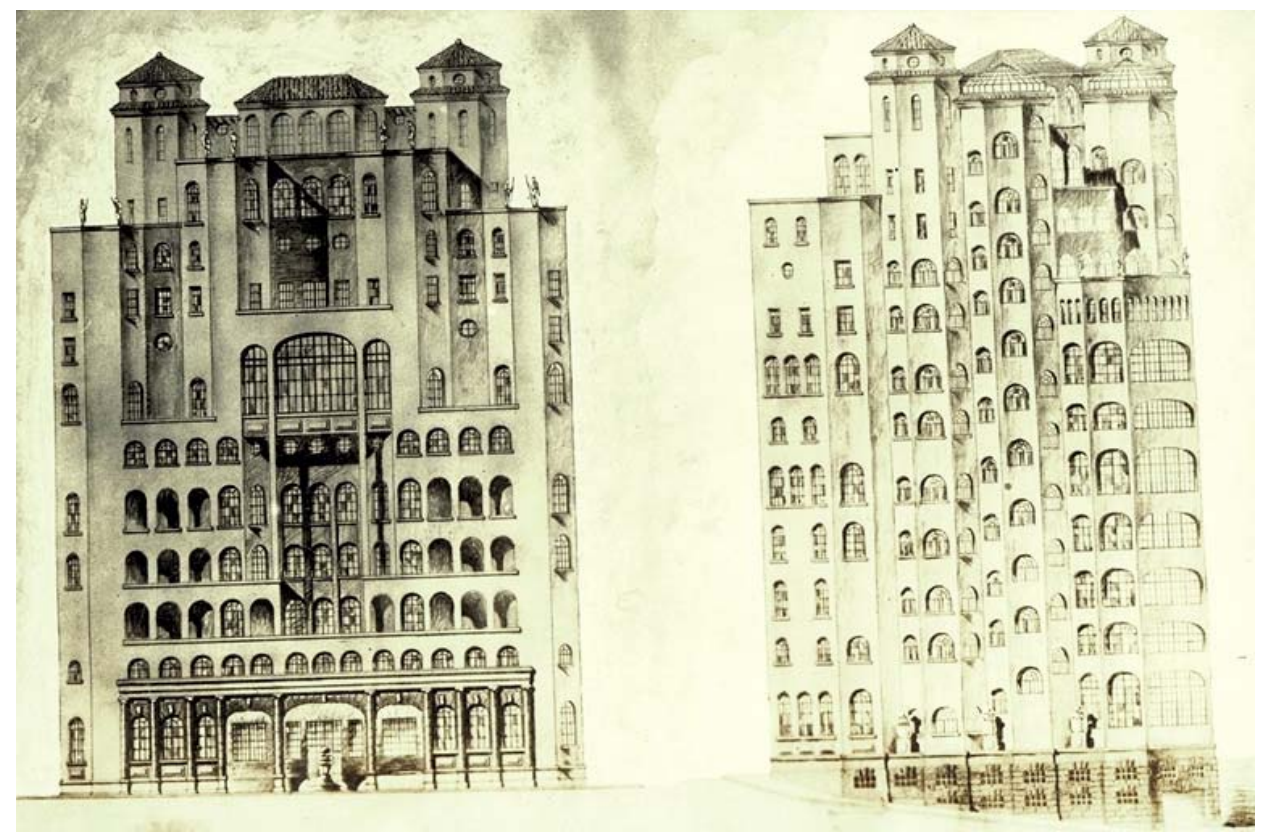

Ante-projeto para a Sede Social do Automóvel Clube de São Paulo, concurso, São Paulo, SP, 1927. Arquiteto Rino Levi. Elevações: para o Largo do Ouvidor e lateral.

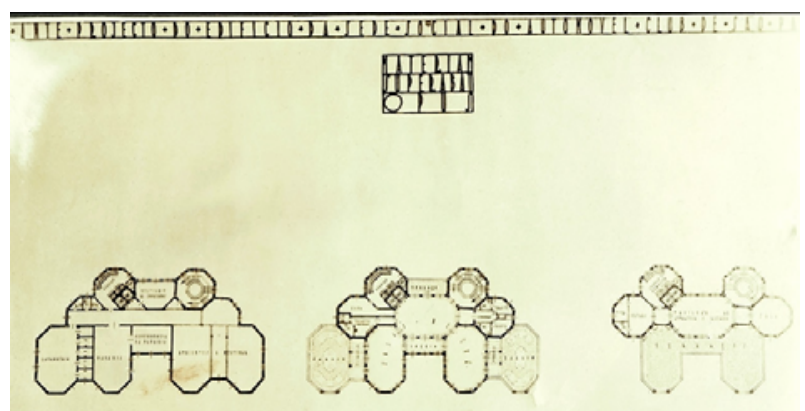

[37] Ante-projeto para a Sede Social do Automóvel Clube de São Paulo, concurso, São Paulo, SP, 1927. Arquiteto Rino Levi. Plantas.

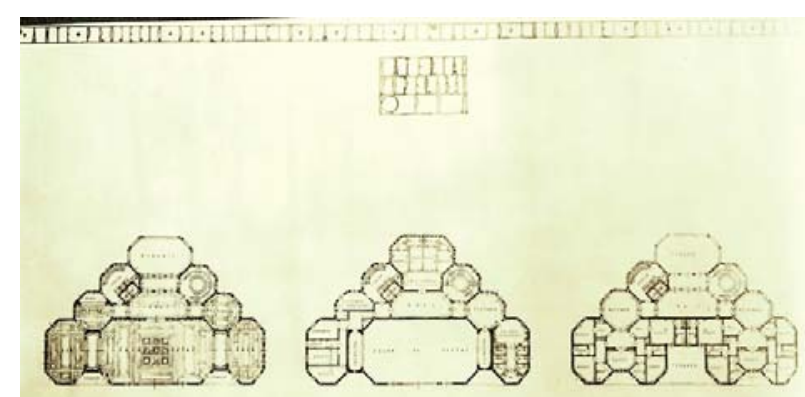

[38] Ante-projeto para a Sede Social do Automóvel Clube de São Paulo, concurso, São Paulo, SP, 1927. Arquiteto Rino Levi. Plantas.

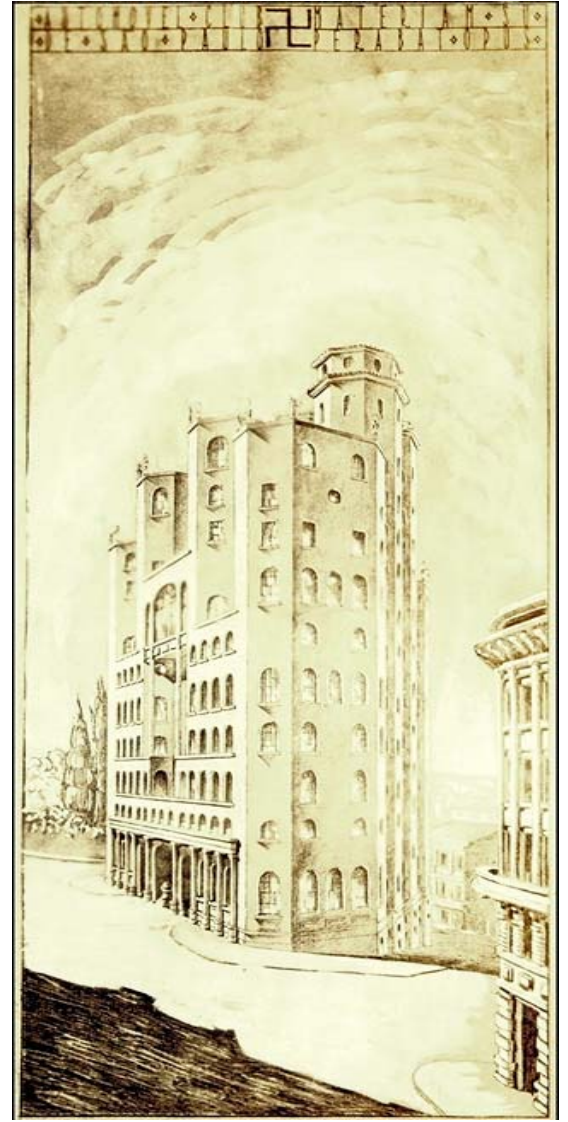

[39] Ante-projeto para a Sede Social do Automóvel Clube de São Paulo, concurso, São Paulo, SP, 1927. Arquiteto Rino Levi. Perspectiva para o Vale do Anhangabaú. 
Sobre o Projeto para Godofredo Silva Telles ${ }^{30}$, é o próprio Rino Levi quem diz que "como não podia deixar de ser, sofri a influência da arquitetura italiana, sobretudo a de Roma. Voltando ao Brasil, em 1926, fiz um grande esforço para me libertar dessa influência. Assim, é possível que a reforma da Casa Silva Telles estivesse ainda presa ao formalismo acadêmico." ${ }^{11}$ Dessa maneira, a composição da fachada demonstra ainda essa filiação, embora aqui reduzida só ao ritmo das aberturas e espaços cheios, sem ornamentação[40]. O mesmo comentário se presta aos sóbrios espaços internos[41] [42].
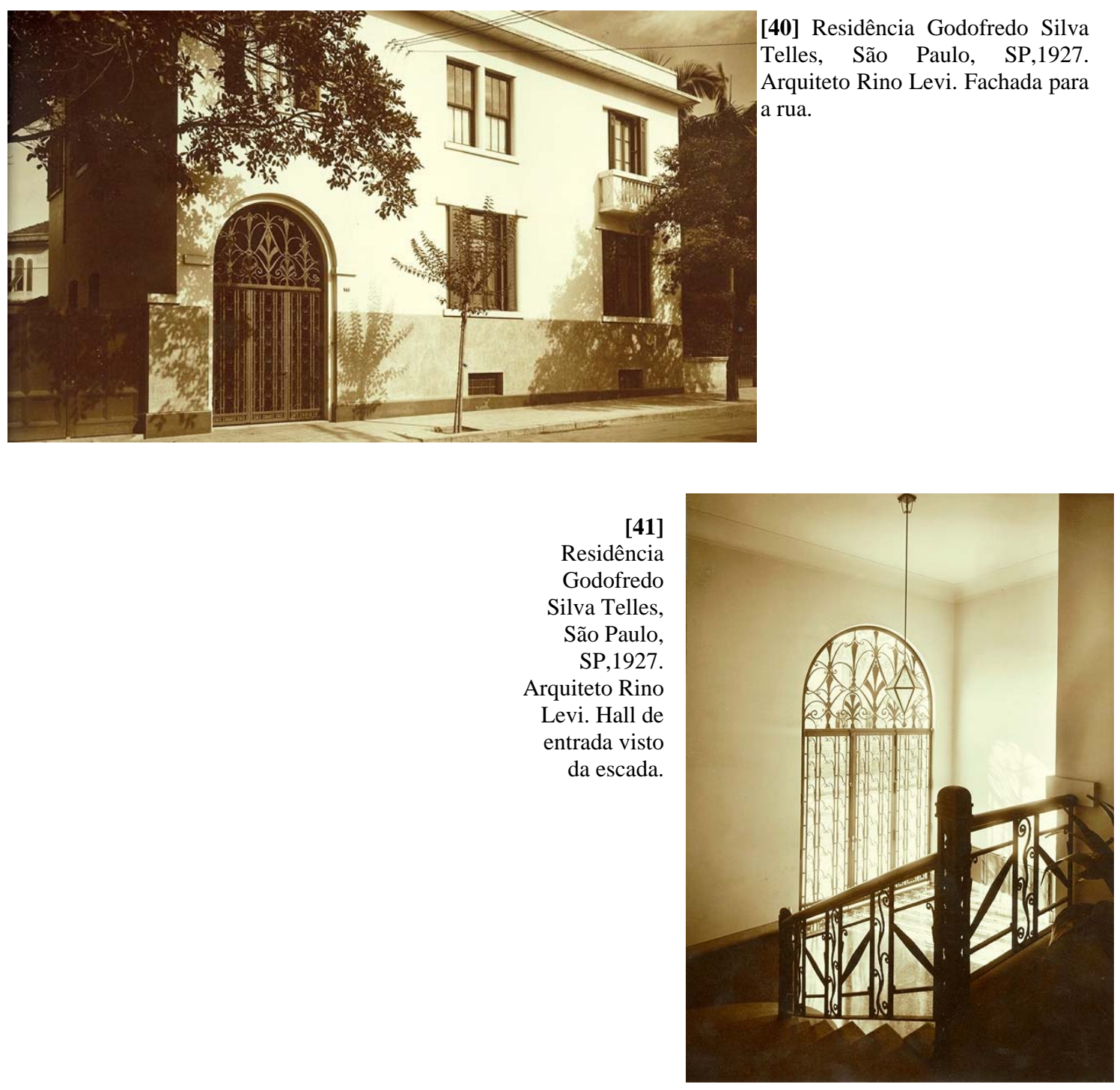

\footnotetext{
${ }^{30}$ Residência Godofredo Silva Telles, São Paulo, SP. Arquiteto Rino Levi.

${ }^{31}$ Resposta de Rino Levi à carta do Prof. Paulo F. dos Santos de 24/07/1964. Arquivo Rino Levi, Pasta 69. Apud ANELLI, op. cit.
} 


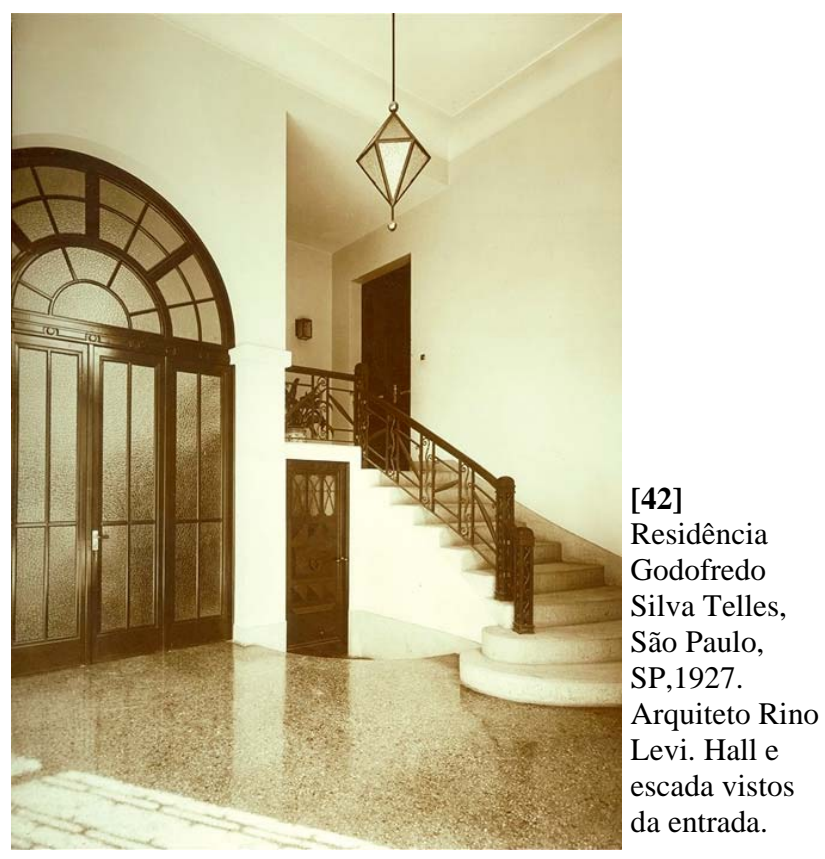

Ainda mais acadêmico que o anterior é o projeto não construído da Casa de campo para $H$. Telles Ribeiro. ${ }^{32}$ A casa mostra semelhanças com as vilas italianas, na sua composição simétrica, nas suas aberturas porticadas em duas fachadas e no arranjo dos seus jardins[43]. Internamente, a casa mantém o eixo central, onde ficam as salas de jantar e de estar, articulando duas alas separadas, uma com os dormitórios, outra com serviços e garagem. Uma novidade na implantação é a parte posterior do lote, ocupada com horta e pomar[44].

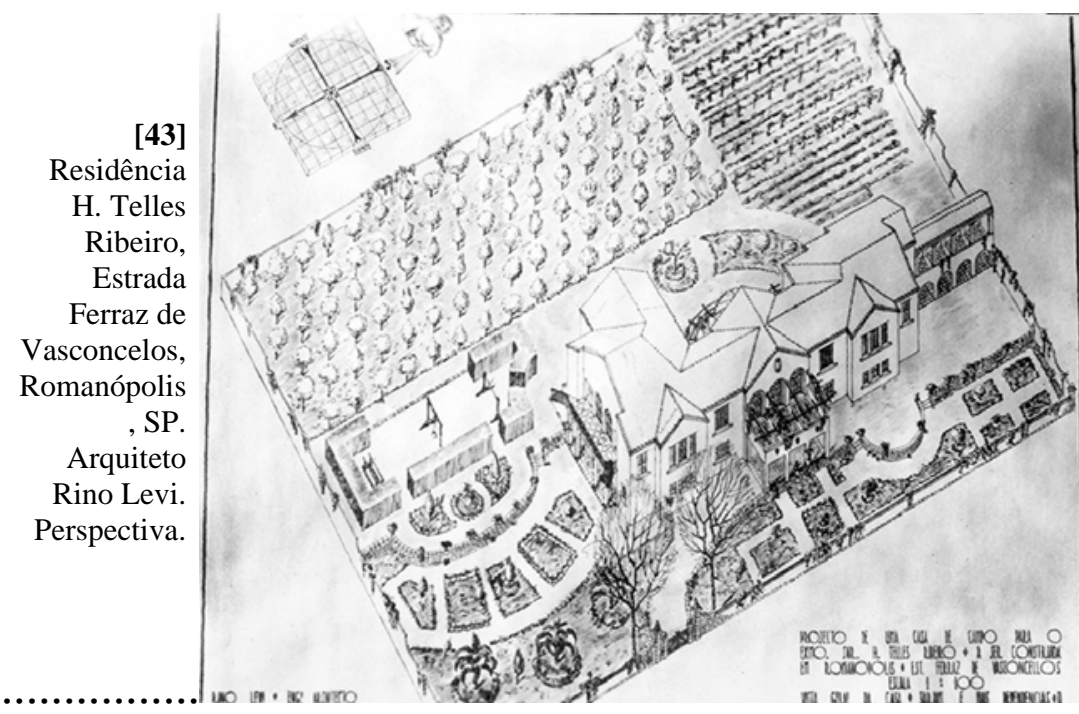

\footnotetext{
${ }^{32}$ Residência H. Telles Ribeiro, Estrada Ferraz de Vasconcelos. Romanópolis, SP, 1927. Arquiteto Rino Levi.
} 


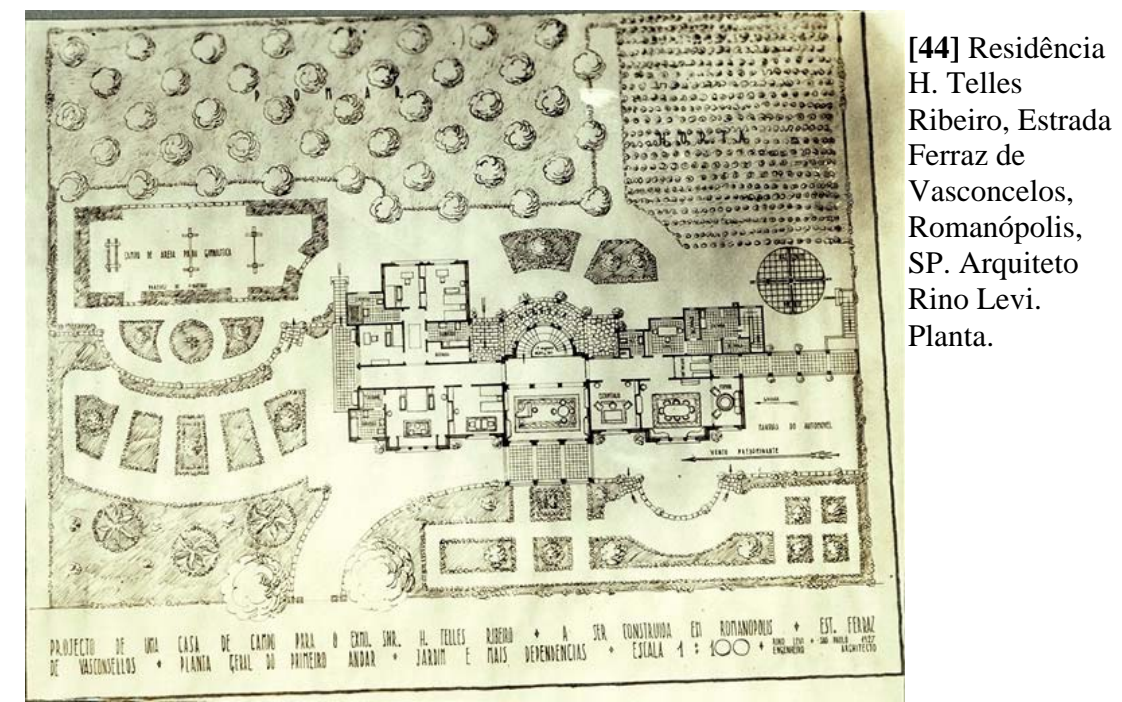

Na mesma década de 20 e começo da década de 30, Rino Levi tem uma série de projetos, alguns construídos, aonde o afastamento desse formalismo acadêmico vai se consolidando. O começo está em duas séries de Casas Geminadas para Melhen Zacarias ${ }^{33}$ e Luis Manfro ${ }^{34}$, em 1928. Nas duas estão presentes, em primeiro lugar, a idéia de série, de módulo que se repete. Nas duas a solução adotada foi de um longo prisma retangular coberto por um telhado de quatro águas. No projeto Zacarias, há uma movimentação dada pela repetição irregular das casas[45], enquanto no projeto Manfro, o movimento se dá pela irregularidade das aberturas dos módulos que são rebatidos dois a dois[46]. O grande declive do terreno a partir da rua no conjunto Zacarias é vencido com grandes pilares[47], solução que se repetirá em muitos outros projetos.

\footnotetext{
${ }^{34}$ Série de casas para Luiz Manfro, Saõ Paulo, SP, 1928. Arquiteto Rino Levi.
} 


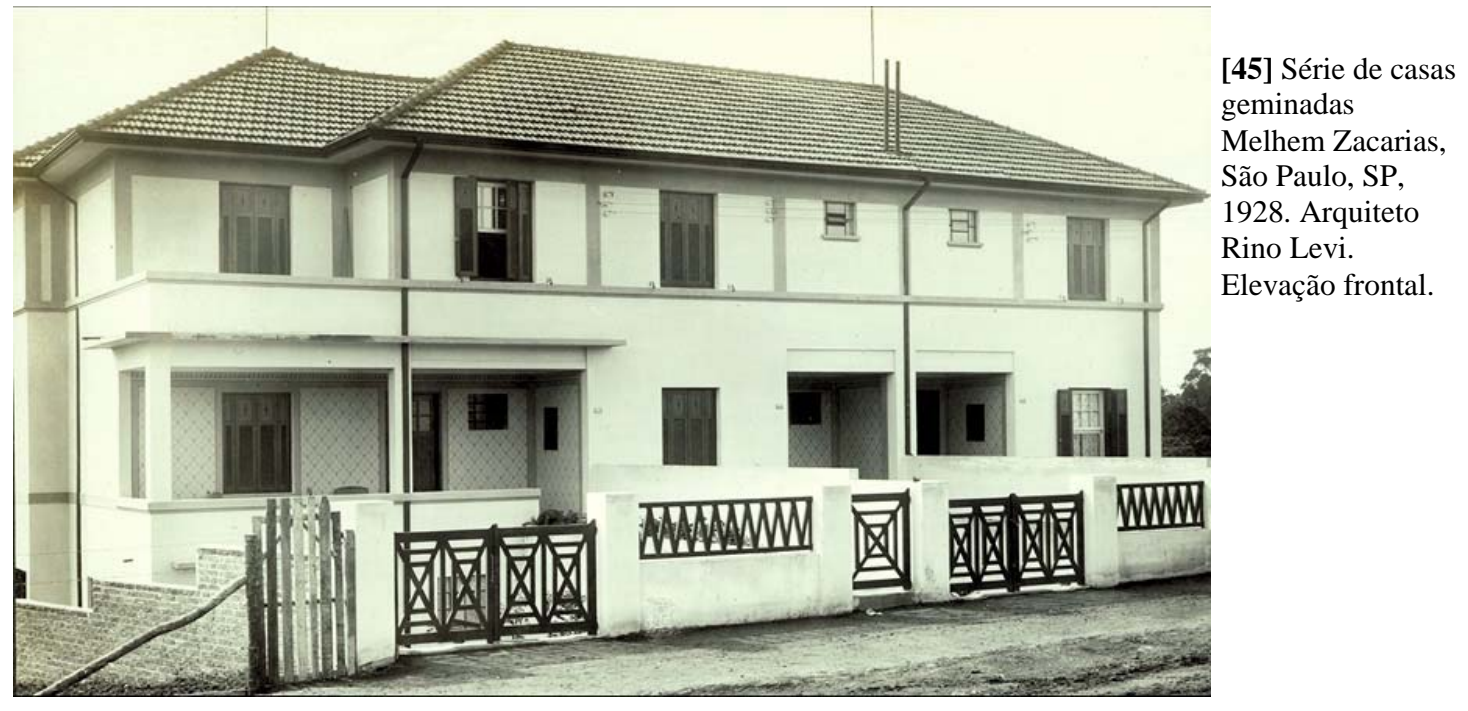

[46]

Série de casas geminadas Luiz

Manfro, São

Paulo, SP.

Arquiteto Rino

Levi. Elevação

frontal.
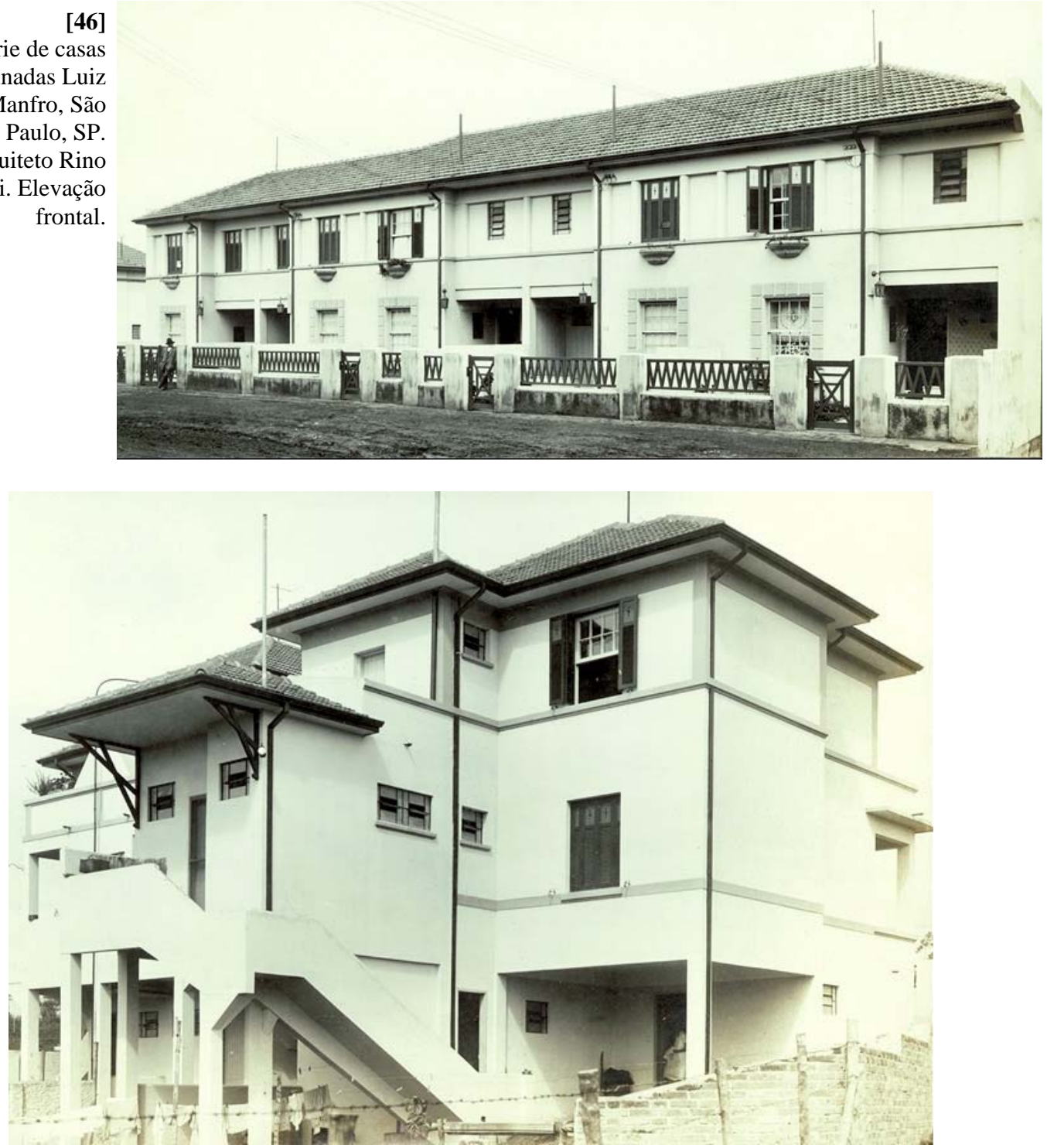

47] Série de casas geminadas Melhem Zacarias, São Paulo, SP. Arquiteto Rino Levi.

Elevação posterior. 
Dois projetos, ainda anteriores a Residência Ferrabino, consolidam a adesão às vanguardas modernas. O projeto de Casas Econômicas em série para Regina Previdelli ${ }^{35}$ e o projeto para a Residência Paulo Lajolo no Rio de Janeiro. ${ }^{36}$ Nas casas em série é clara a opção pelos princípios modernos corbusianos: módulos de volumes cúbicos, suspensos por pilotis, estruturados por uma grelha que atesta o conhecimento da estrutura dominó de Le Corbusier[48]. A justaposição deslocada dos módulos cria prismas retangulares movimentados. Esse movimento é reforçado, ainda, pelas aberturas: uma quadrada e central para cada módulo e outras circulares nas extremidades dos prismas.

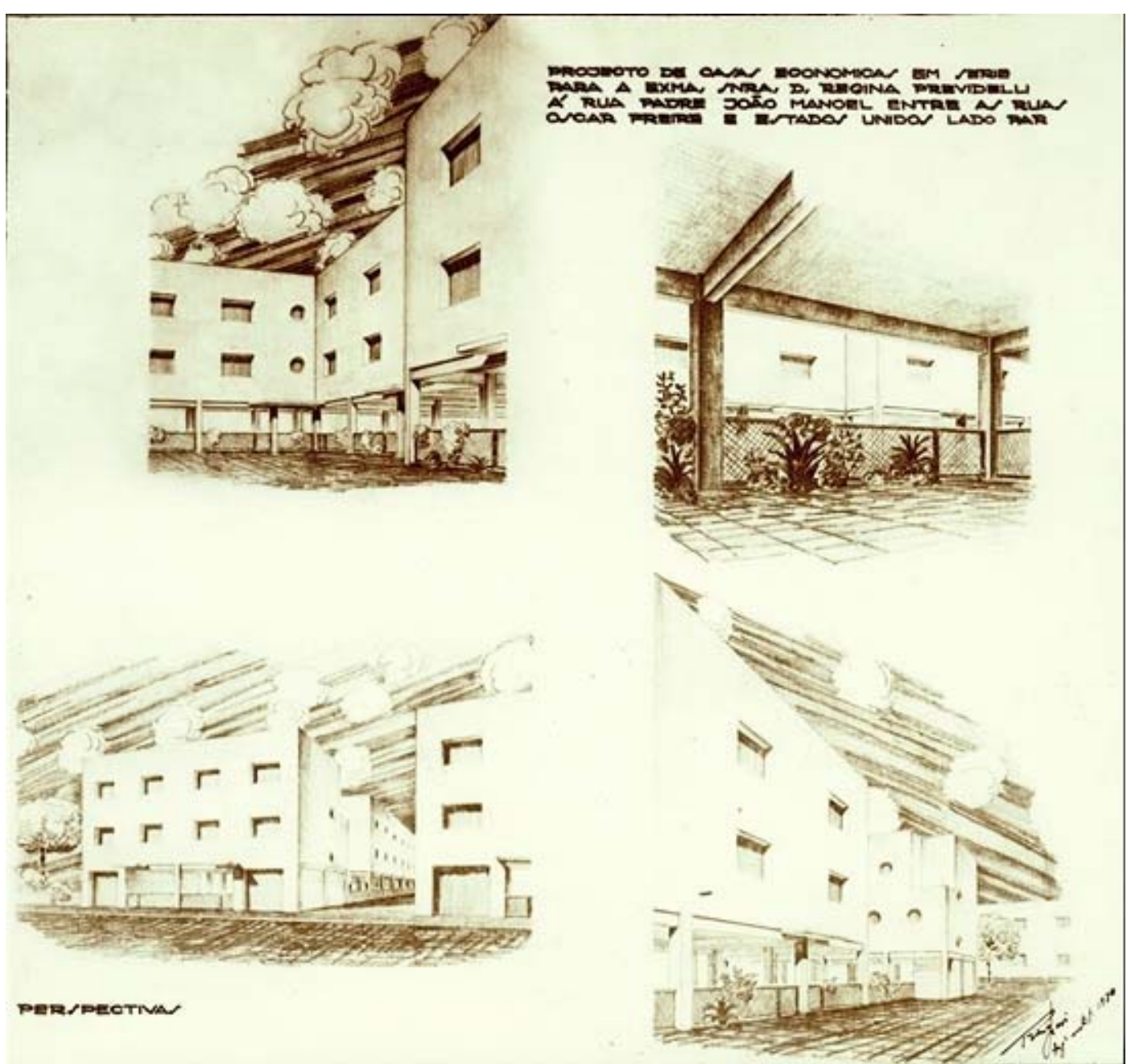

48] Casas econômicas em série para Regina Previdelli, São Paulo, SP, 1930. Arquiteto Rino Levi. Projeto 35 Casas econômicas em série para Regina Previdelli, R.Padre João Manuel, São Paulo, SP, 1930. Arquiteto Rino Levi.

${ }^{36}$ Residência Paulo Lajolo, Rio de Janeiro, RJ, 1931. Arquiteto Rino Levi. 
Na Residência Lajolo a referência está mais nas vanguardas alemãs e holandesas, como veremos. O prisma retangular é agora composto por um único volume solidamente apoiado no chão, movimentado por saliências e marquises[49]. As aberturas percorrem as elevações sem pilares nas arestas, ou com pilares recuados, demonstrando as possibilidades estruturais dos novos materiais, recurso já utilizado por Warchavchik. O prisma é arrematado por marquise curva que lhe confere maior dinamismo.

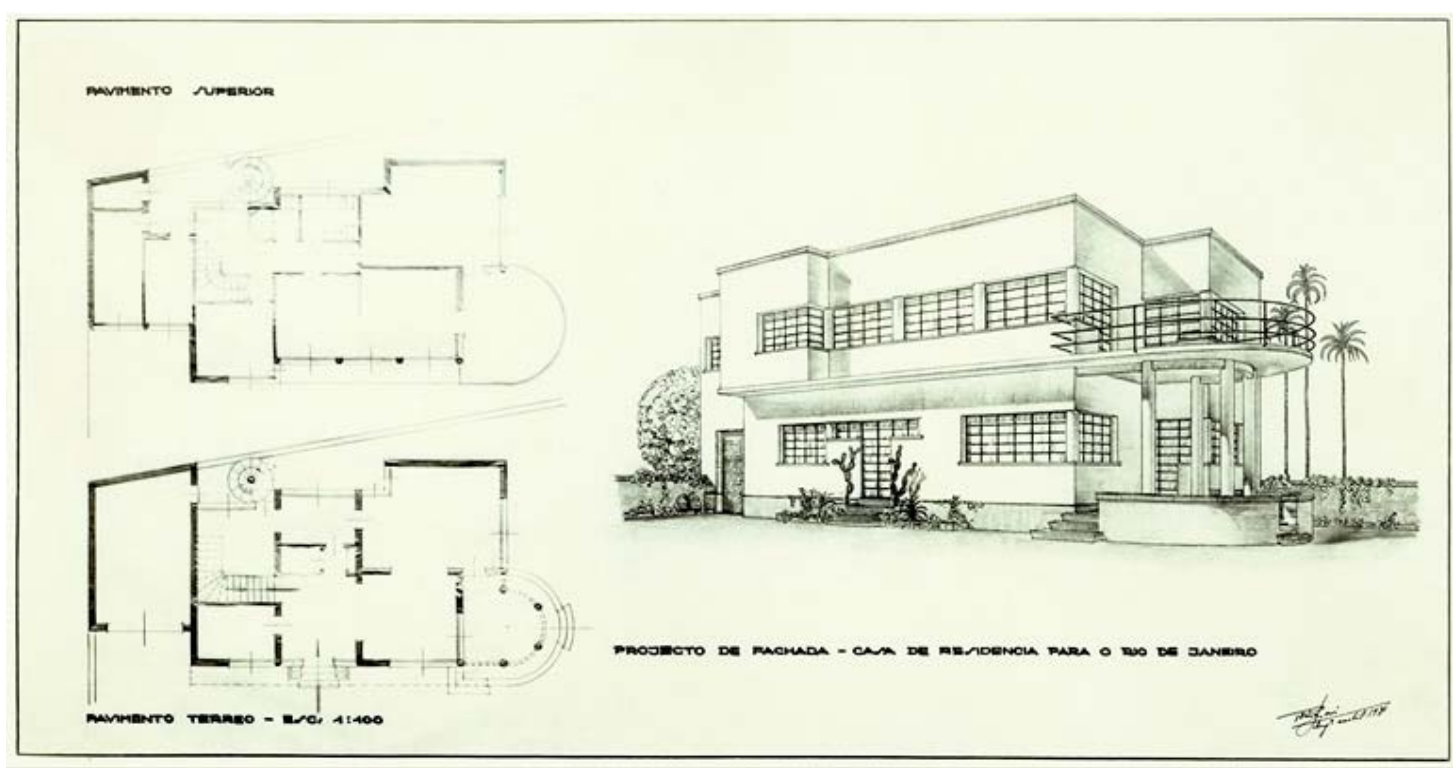

[49] Residência Paulo Lajolo, Rio de Janeiro, RJ, 1931. Arquiteto Rino Levi. Projeto completo.

Um pouco posteriores, mas dentro deste raciocínio, estão também as residências não construídas para o Comendador Andrea Matarazzo ${ }^{37}$, para Luiz Manfro ${ }^{38}$ e para Cesar Trípoli ${ }^{39}$. A residência Matarazzo[5o] apresenta solução muito próxima à da residência Ferrabino, já examinada[51]. Com a mesma movimentação dos volumes e as mesmas aberturas, o prisma é agora mais retangular, caráter reforçado pelo prolongamento da marquise deixado em balanço. Esta cresce também perpendicularmente ao bloco e se apóia em pilar linear. Os dois raciocínios são utilizados por Warchavchik. A edícula -

\footnotetext{
${ }^{37}$ Residência Comendador Andrea Matarazzo, R. São Carlos do Pinhal, São Paulo, SP, 1932. Arquiteto Rino Levi

${ }^{38}$ Residência Luiz Manfro, R. dos Apeninos, São Paulo, SP, 1932. Arquiteto Rino Levi.

${ }^{39}$ Residência Cesar Trípoli, Av. Brasil, São Paulo, SP, 1933. Arquiteto Rino Levi.
} 
agora implantada lateralmente ao bloco principal - também acentua o sentido longitudinal.

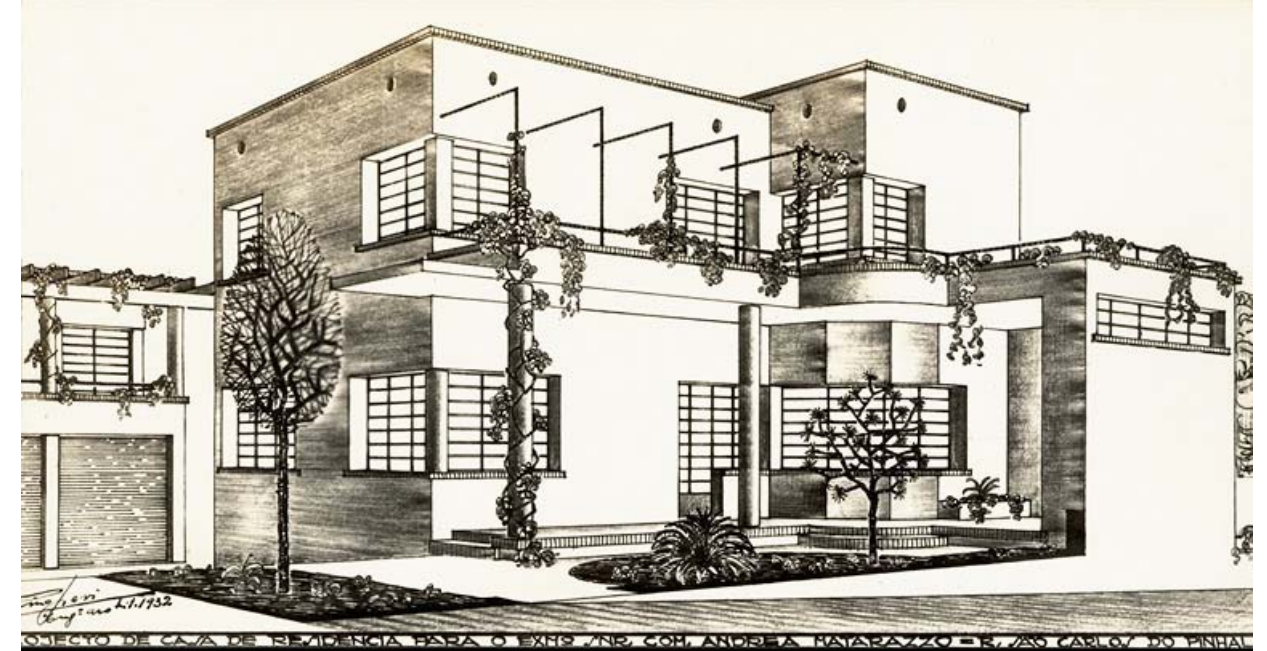

[50] Residência Comendador Andrea Matarazzo, São Paulo, SP, 1932. Arquiteto Rino Levi. Perspectiva.

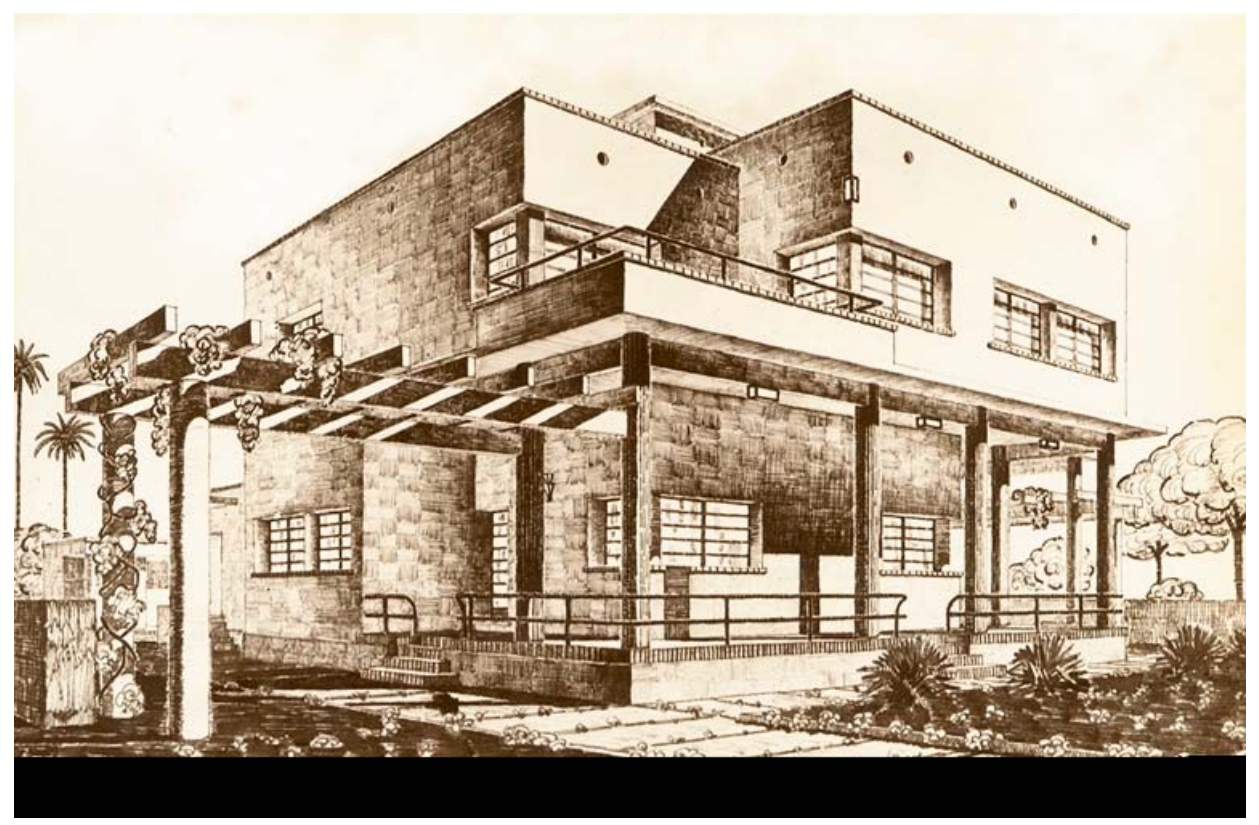

[51] Residência Ferrabino, São Paulo, SP, 1931. Arquiteto Rino Levi. Perspectiva.

A residência Luiz Manfro apresenta o mesmo partido implantado em pequeno lote[52]. A marquise, neste caso, é prolongada até o limite do lote criando um terraço-jardim no andar superior. O pequeno espaço da varanda sobre ela é "ampliado" com o chanframento da aresta do escritório e com o arredondamento da laje por onde se dá o acesso do automóvel à garagem na edícula. Esses procedimentos se 
repetem na residência César Trípoli[53], onde o pequeno desnível do terreno em direção à rua permite que o arredondamento seja no nível do piso.

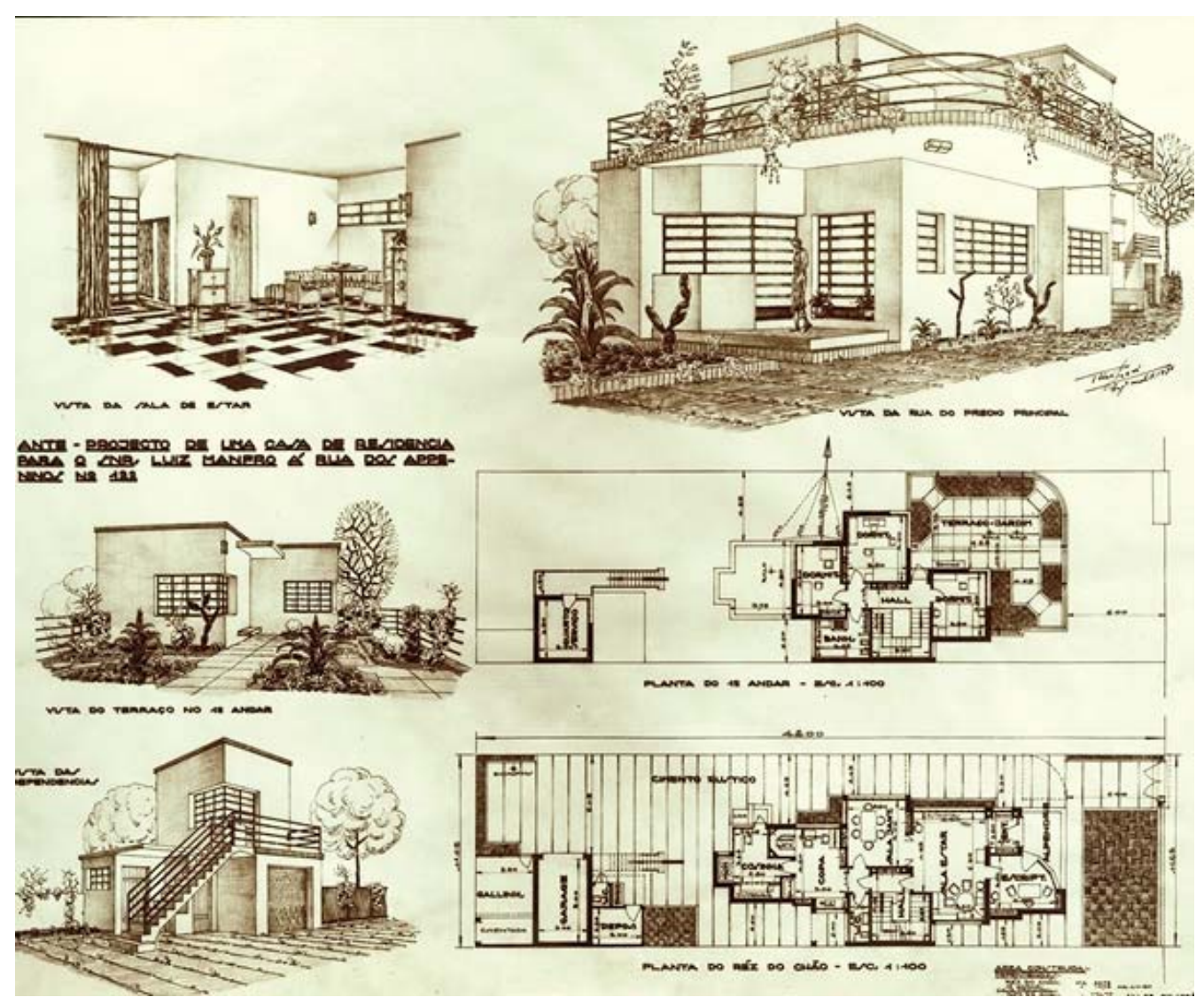

[52] Residência Luiz Manfro, São Paulo, SP, 1932. Arquiteto Rino Levi. Projeto completo. 


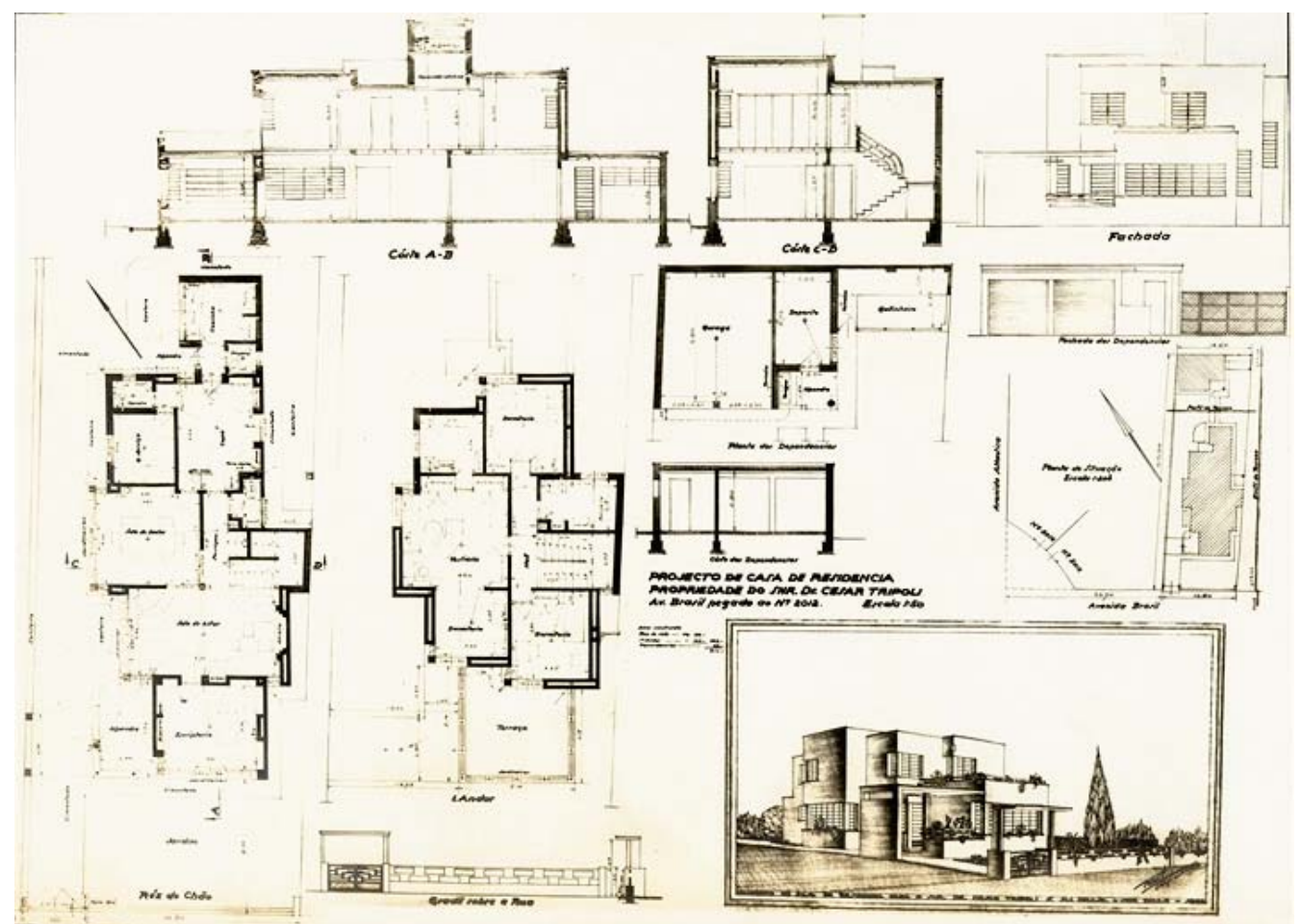

[53] Residência Cesar Trípoli, Saõ Paulo, SP, 1933. Arquiteto Rino Levi. Projeto completo.

Do mesmo período e dentro do mesmo contexto, temos como projetos executados as duas séries de Casas Econômicas para Dante Ramenzoni ${ }^{40}$, a residência Francisco Gomes (Vila Júlia) ${ }^{41}$ e a residência Jeanne Maronat ${ }^{42}$. As duas séries Ramenzoni retomam alguns procedimentos das séries Zacarias e Manfro, mas com diferenças fundamentais. Na primeira série Ramenzoni[54] são justapostas quatro unidades porém, ao invés do telhado de quatro águas, o prisma retangular é coberto com laje plana. Esta é escalonada, seguindo a declividade do terreno, recurso usado também nos acessos e nos jardins frontais, organizados em patamares. A unidade da série é mantida por pergolados nas fachadas, que unem os volumes aos pares.

\footnotetext{
${ }^{40}$ Casas econômicas em série para Dante Ramenzoni, R. Vitor Emanuel esq. R. Mazzini, São Paulo, SP, 1931, $1^{\circ}$ conjunto. Arquiteto Rino Levi.

${ }^{41}$ Residência Francisco Gomes (Vila Júlia), Al. Franca, São Paulo, SP, 1932. Arquiteto Rino Levi.

42 Residência Jeanne Maronat, R. Loefgren, São Paulo, SP, 1932. Arquiteto Rino Levi.
} 


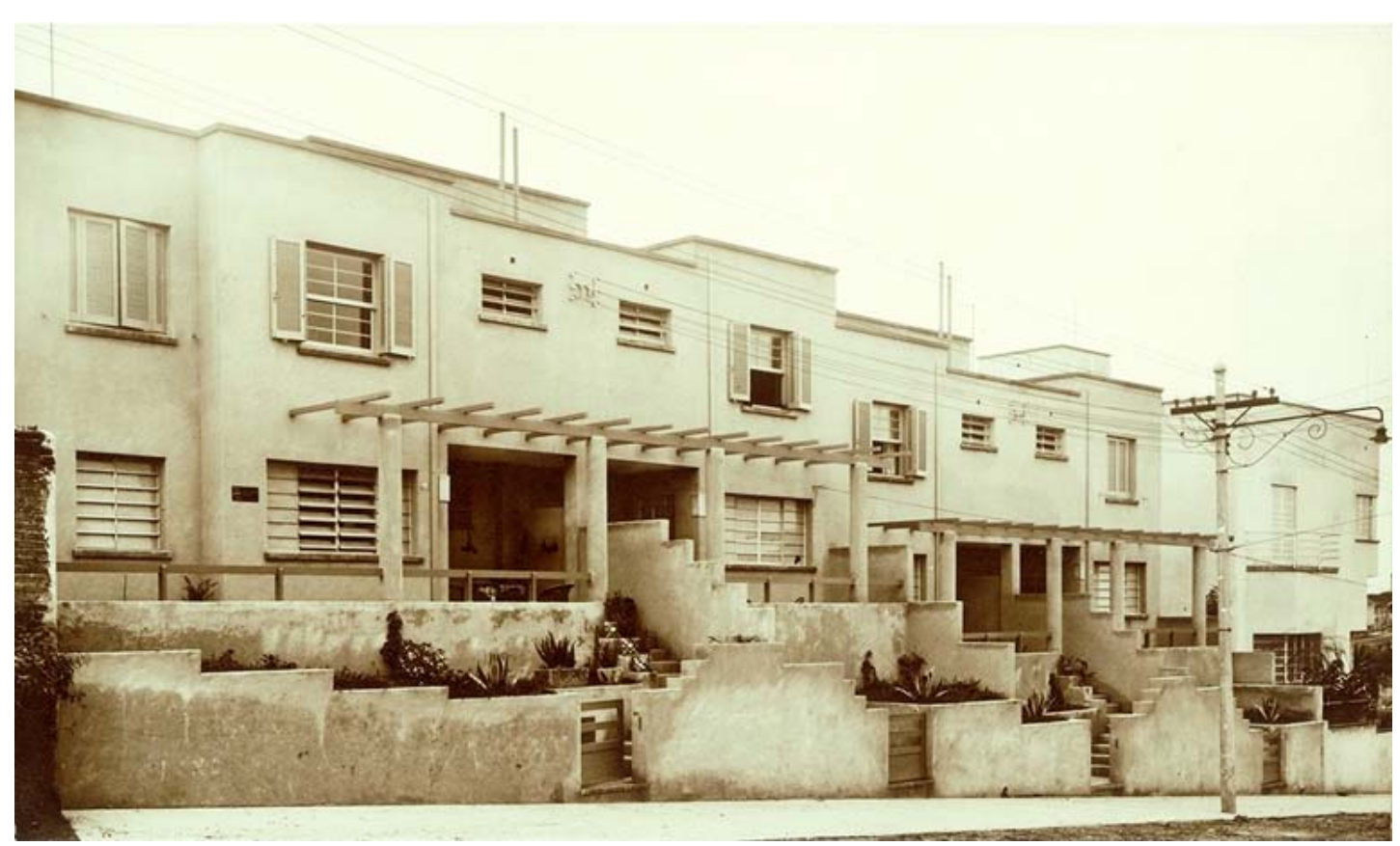

[54] Casas econômicas em série para Dante Ramenzoni, $1^{\circ}$ conjunto, São Paulo, SP, 1931. Arquiteto Rino Levi. Foto panorâmica elevação R. Vitor Emanuel.

O conjunto é completado pela residência do proprietário, implantada no lote de esquina[55], situação que determina suas características. A aresta do prisma cúbico é quebrada no térreo por um chanfro no volume e na janela que percorre as duas fachadas sem pilar. Esse é reposto no primeiro andar com a aresta recomposta em balanço, o que, como diz Anelli, "revela que esse elemento tinha sentido mais estético que técnico, não se constituindo como um limite de capacidade tecnológica dos seus propositores, como muitas vezes foi sugerido". ${ }^{43}$ As janelas venezianas de duas folhas das residências econômicas são substituídas aqui por venezianas de rolo e que abrem perpendicularmente à fachada, o que reforça as aberturas no volume. As garagens são trazidas para o limite frontal do lote e sua cobertura utilizada como terraço-jardim[56].

${ }^{43}$ ANELLI, Renato, op. cit., p. 122. 


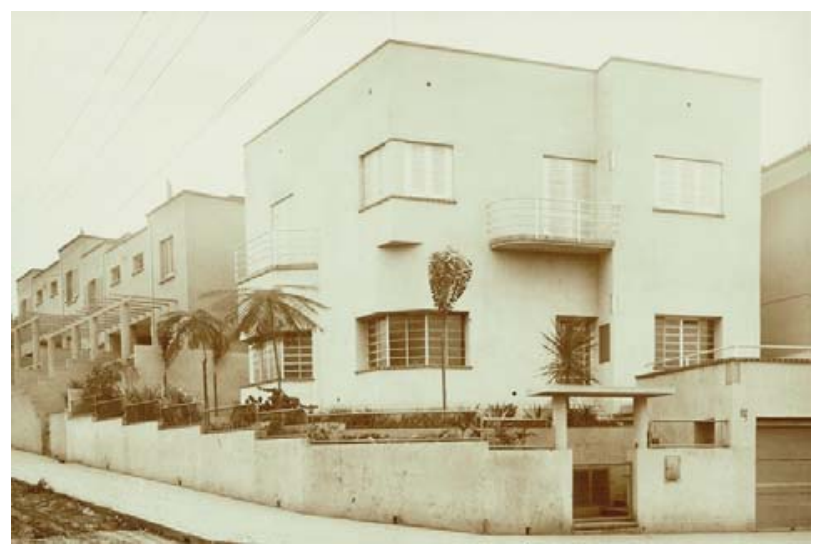

[55] Residência Dante Ramenzoni, São Paulo, SP, 1931. Arquiteto Rino Levi. Foto esquina R. Vitor Emanuel com R. Mazzini.

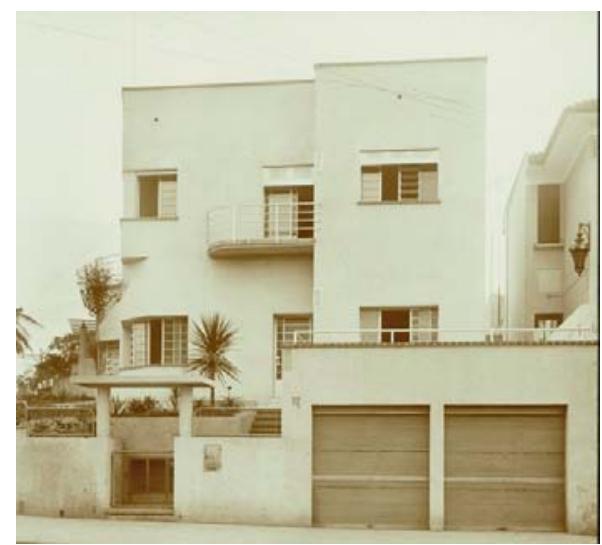

[56] Residência Dante Ramenzoni, São Paulo, SP, 1931. Arquiteto Rino Levi. Foto elevação R. Mazzini.

A segunda série Ramenzoni tem programa e situação urbana semelhante à primeira, mas a densidade pretendida era maior. A implantação e o partido foram mantidos: residência unifamiliar no lote da esquina e unidades em série no lote retangular ao longo da rua[57]. Mas a maior densidade, doze unidades, faz com que sejam agrupadas em dois edifícios de seis unidades cada um, escalonados para acompanhar a declividade do terreno. Dessa maneira, metade delas são voltadas para a rua[58] e a outra metade para o interior do lote[59]. Todas possuem balcão em balanço, o que reforça o movimento do conjunto. 


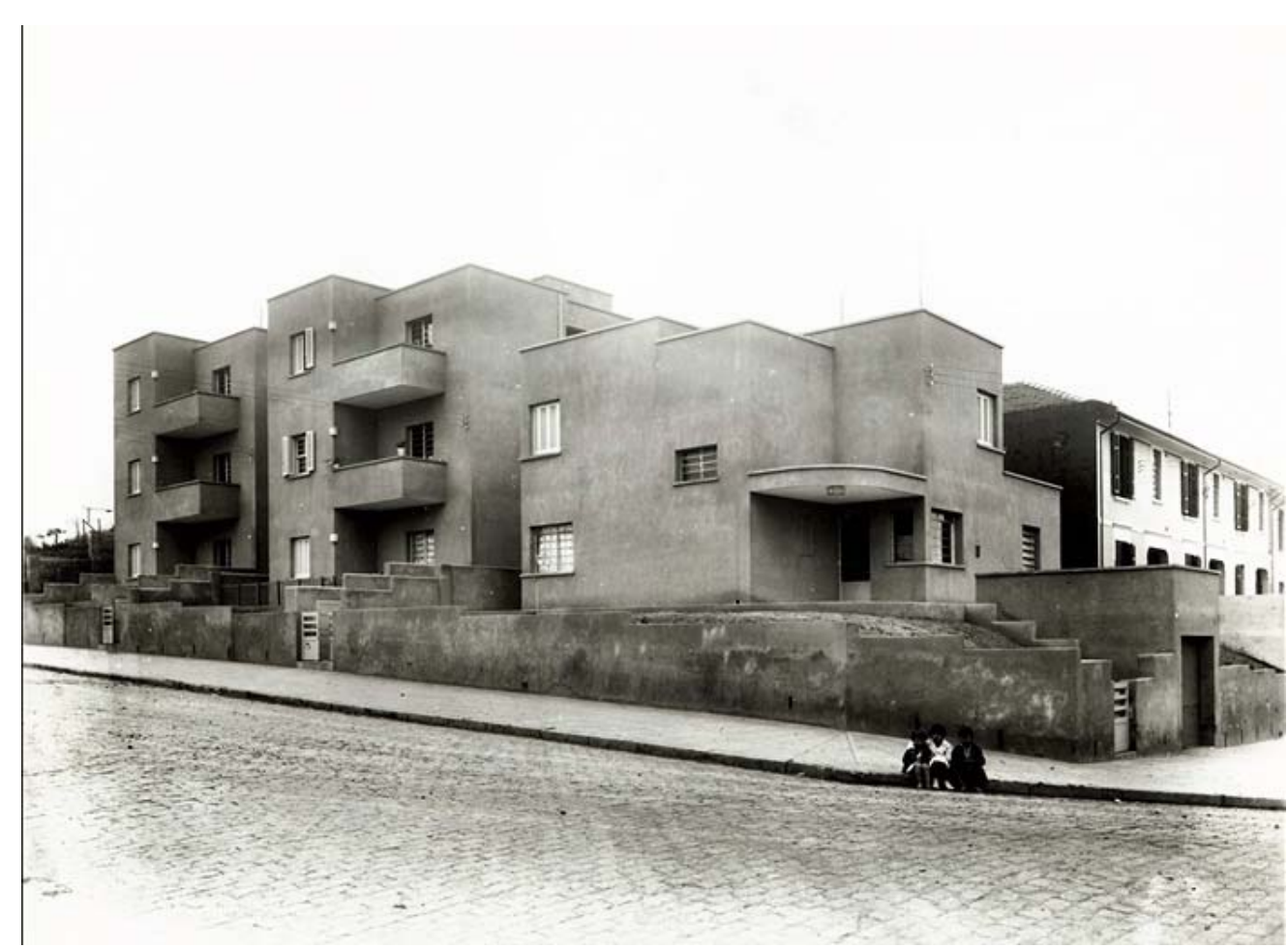

[57] Casas econômicas em série para Dante Ramenzoni, $2^{\circ}$ conjunto, São Paulo, SP, 1932. Arquiteto Rino Levi. Panorâmica.

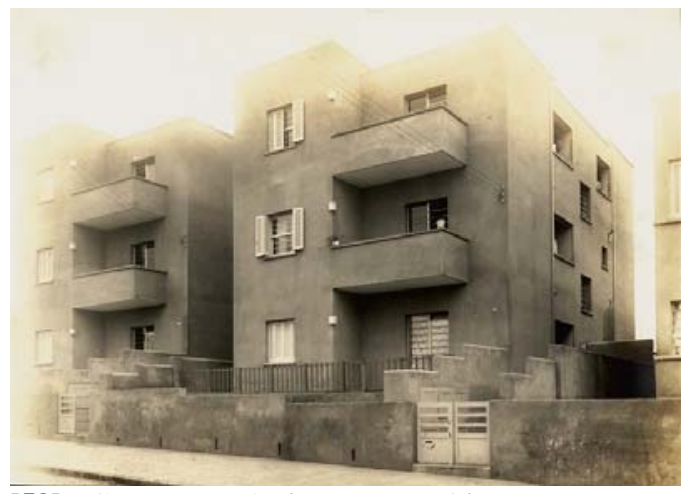

[58] Casas econômicas em série para Dante Ramenzoni, $2^{\circ}$ conjunto, São Paulo, SP, 1932. Arquiteto Rino Levi. Elevação para a rua.

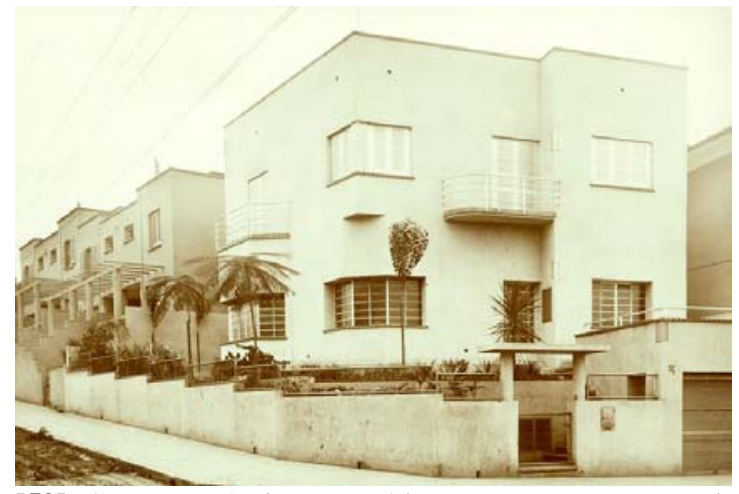

[59] Casas econômicas em série para Dante Ramenzoni, $2^{\circ}$ conjunto, São Paulo, SP, 1932. Arquiteto Rino Levi. Elevação para o fundo do lote.

A residência unifamiliar, mais modesta do que a da série anterior, mantém o procedimento de quebrar a aresta da esquina com um chanfro. Neste caso, o chanfro percorre todo o volume que é - em parte - recomposto com uma marquise arredondada[6o]. Na fachada para a outra rua novamente o volume é recortado criando um terraço$\operatorname{jardim}[\mathbf{6 1}]$. 


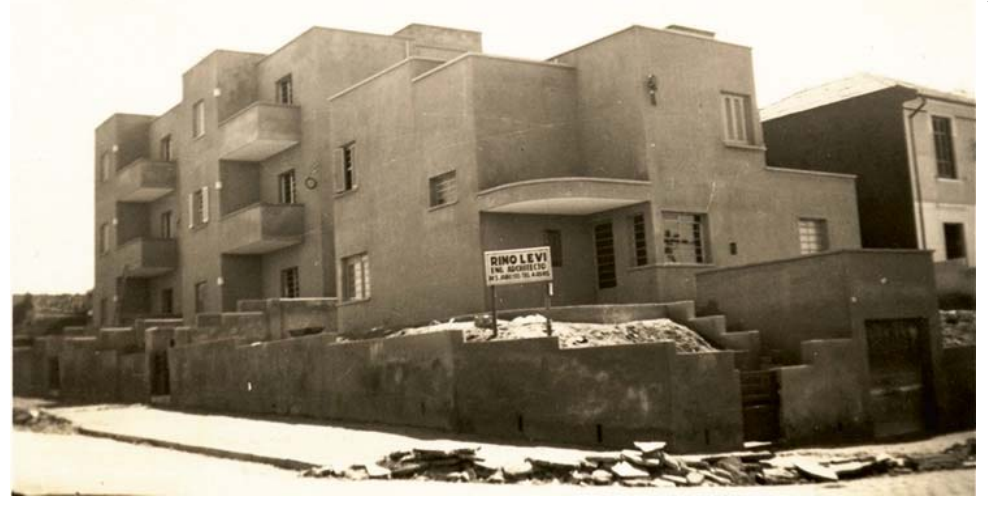

[61] III -1934

Casas econômicas em série para Dante Ramenzoni, $2^{\circ}$ conjunto, São Paulo, SP, 1932. Arquiteto Rino Levi. Elevação esquina.

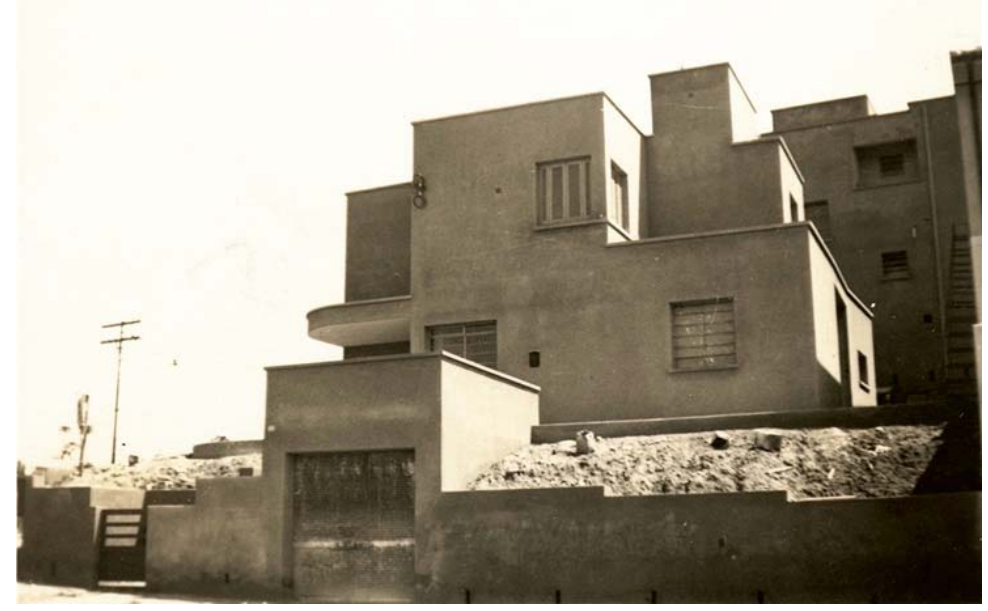

Na residência Francisco Gomes (Vila Júlia) observarmos a materialização de procedimentos presentes desde a residência Lajolo. $\mathrm{O}$ volume único, neste caso quase cúbico, é novamente movimentado por saliências, reentrâncias, marquises e pergolados[62]. O acentuado declive do terreno possibilita a singular solução de manter o prisma cúbico afastado, tanto da calçada quanto do solo[63]. O acesso é resolvido por passarela coberta por pergolado que liga a calçada à varanda de entrada[64]. Longos pilares assentam o volume ao solo[65], como já observado no conjunto Zacarias. No interior, observamos a generosidade da iluminação natural, a modernidade das luminárias e das tapeçarias, nem sempre acompanhada pelo mobiliário[66]. O mesmo se pode dizer do detalhamento do corrimão 


\section{da escada, neste caso, acoplado a estantes[67].}

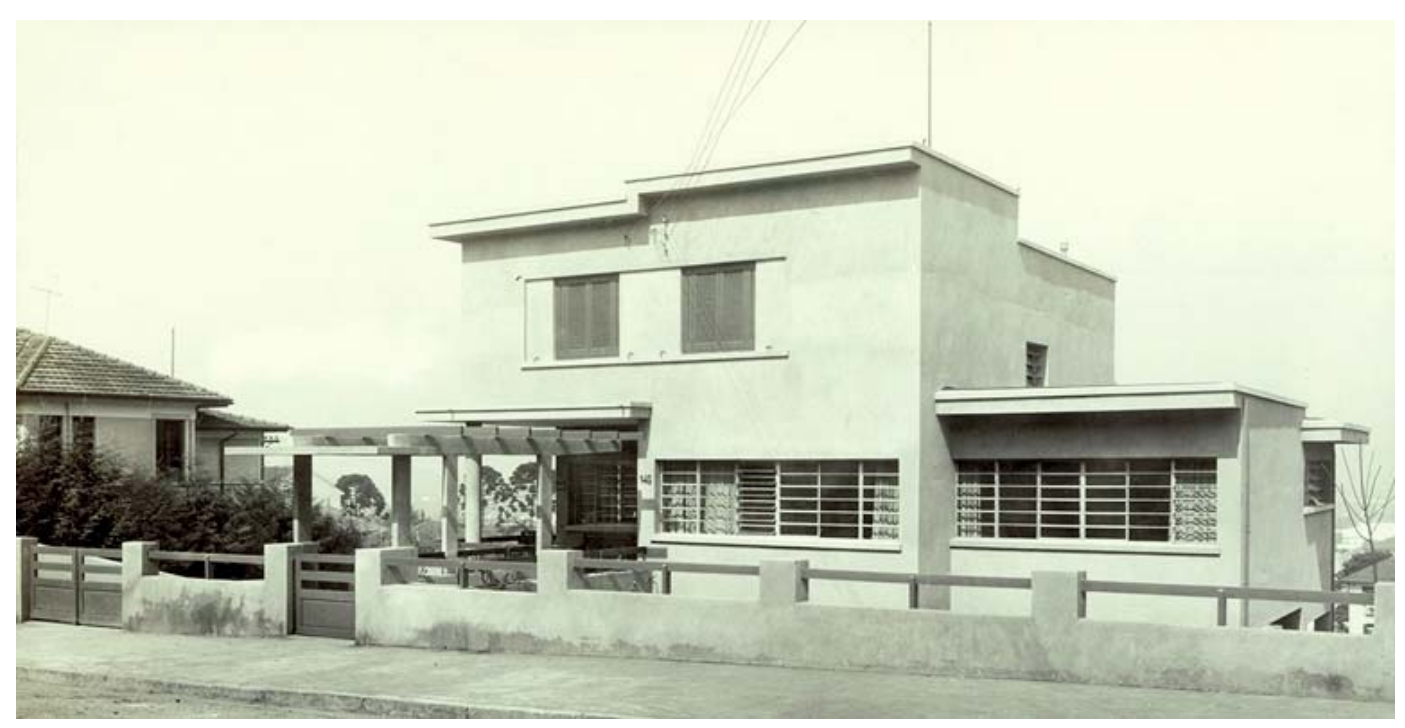

[62] Residência Francisco Gomes (Vila Júlia), São Paulo, SP, 1932. Arquiteto Rino Levi. Panorâmica..

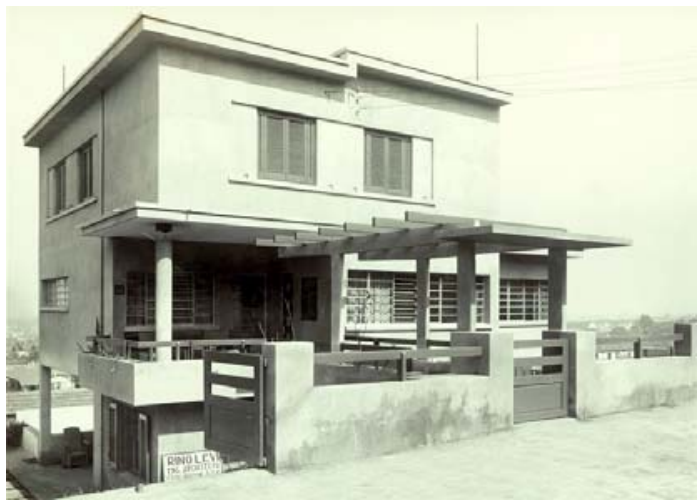

[63] Residência Francisco Gomes (Vila Júlia), São Paulo, SP, 1932. Arquiteto Rino Levi. Detalhe declive do terreno.

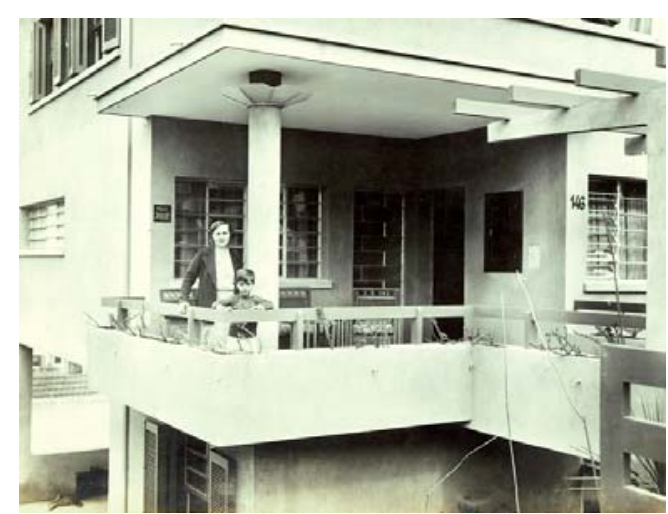

[64] Residência Francisco Gomes (Vila Júlia), São Paulo, SP, 1932. Arquiteto Rino Levi. Detalhe acesso.

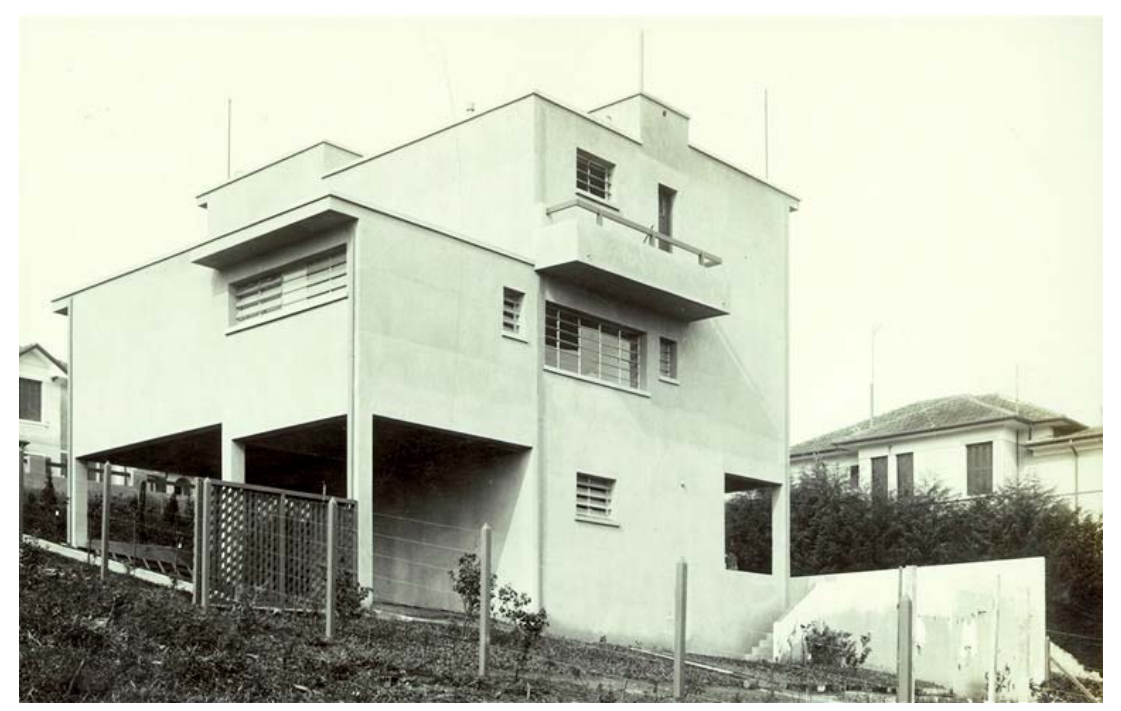

[65] Residência Francisco Gomes (Vila Júlia), São Paulo, SP, 1932. Arquiteto Rino Levi. Fachada posterior. 


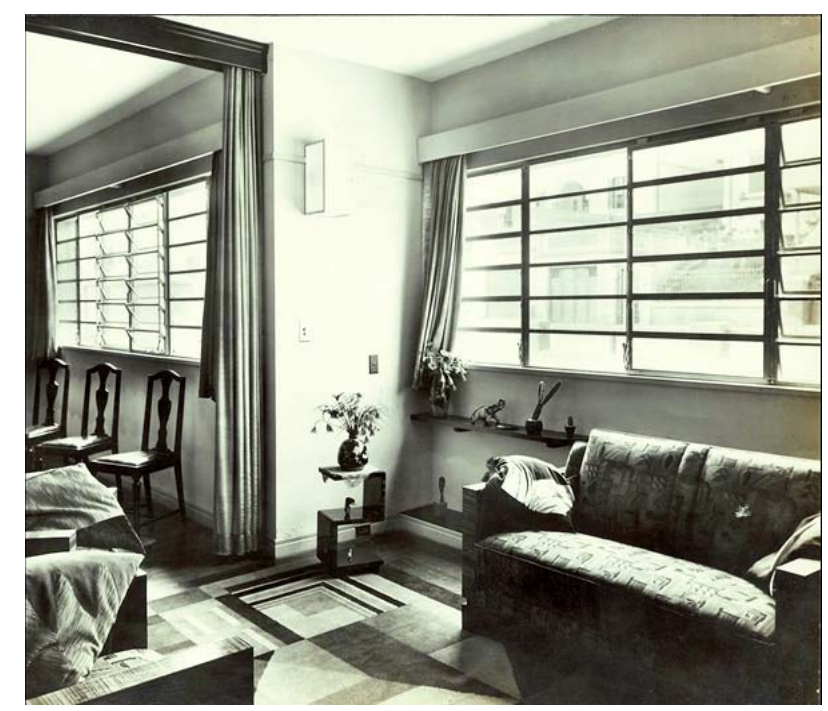

[66] Residência Francisco Gomes (Vila Júlia), São Paulo, SP, 1932. Arquiteto Rino Levi. Interior.

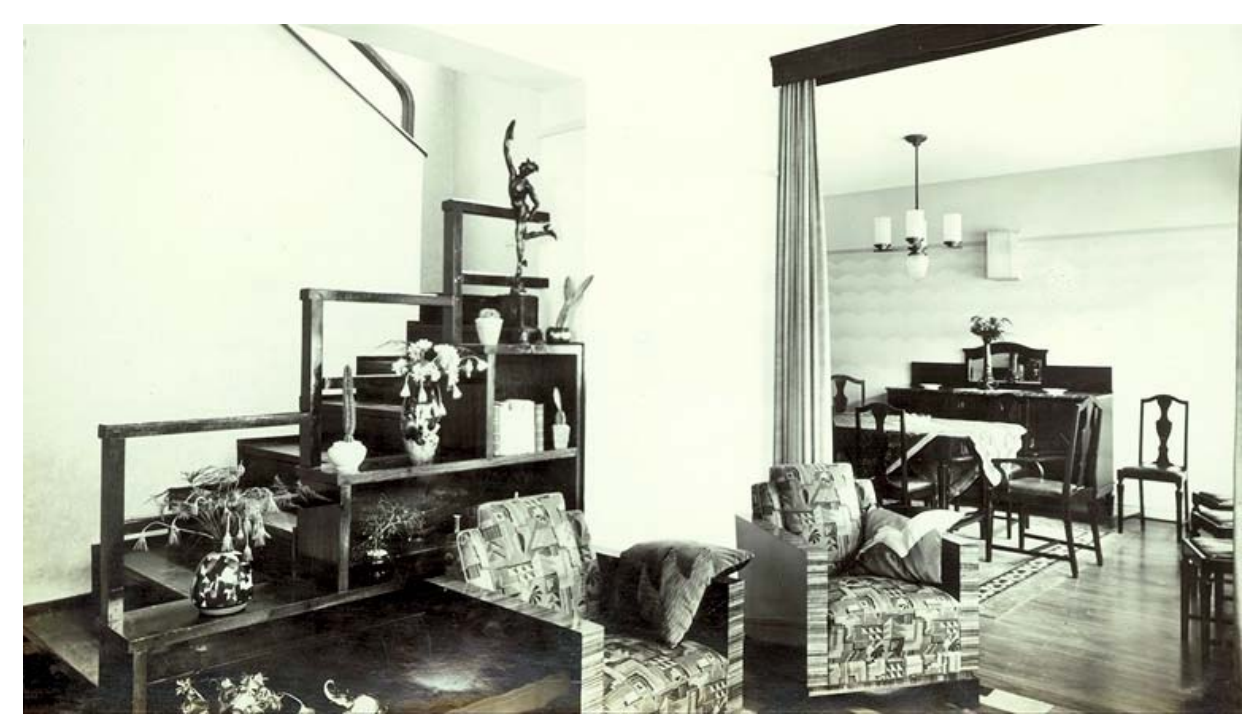

[67] Residência Francisco Gomes (Vila Júlia), São Paulo, SP, 1932. Arquiteto Rino Levi. Interior.

Na residência Jeanne Maronat, mais uma vez constatamos o prisma cúbico movimentado[68]. Às aberturas percorrendo duas fachadas, já conhecidas, são acrescidas pequenas marquises. No pequeno lote $o$ pergolado sobe ao terraço-jardim e o fundo do lote, tradicional quintal, é elevado a um segundo jardim. Para isso a fachada posterior é tratada com o mesmo cuidado que a frontal[69]. 


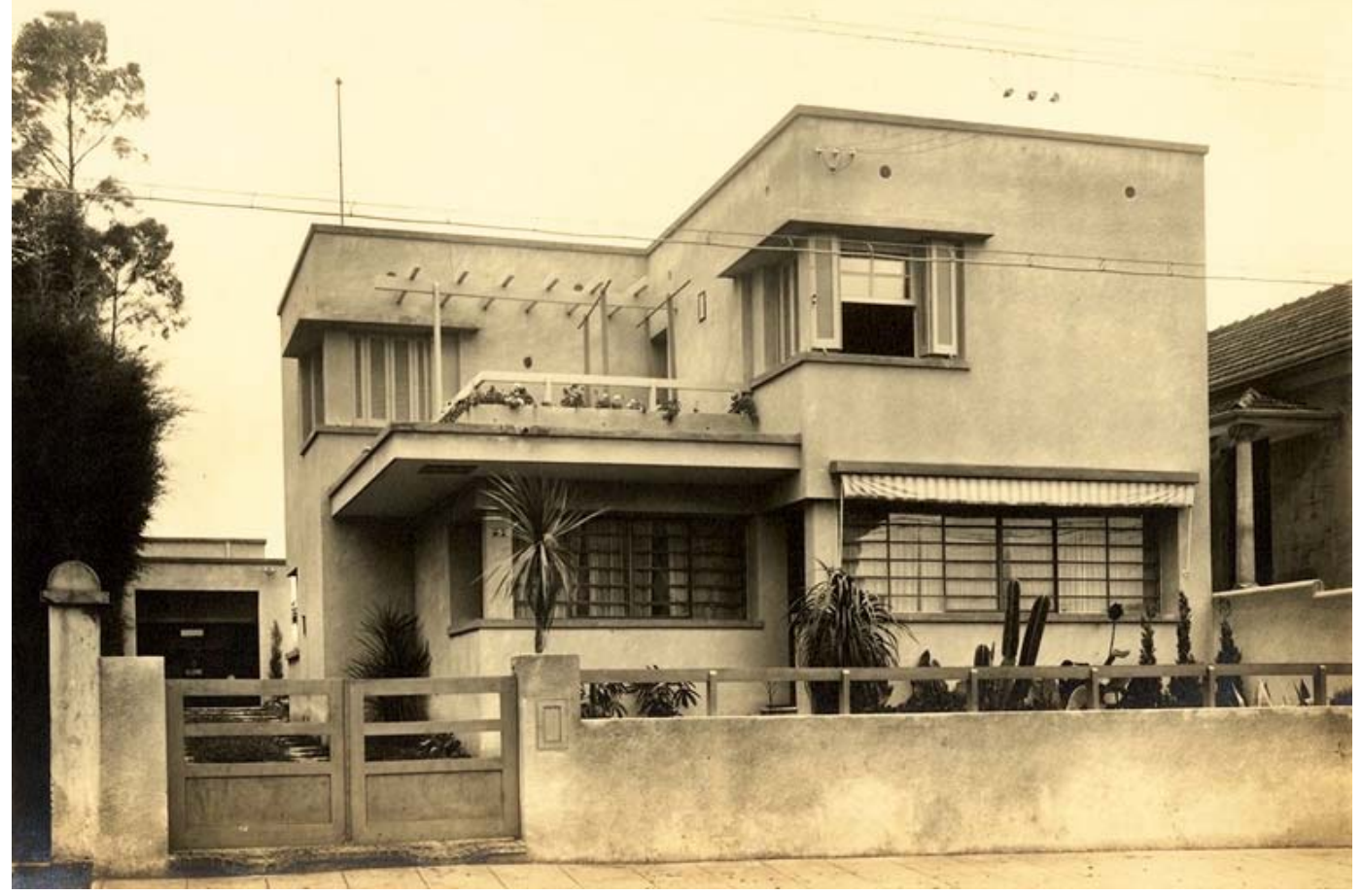

[68] Residência Jeanne Maronat, São Paulo, SP, 1932. Arquiteto Rino Levi. Fachada frontal.

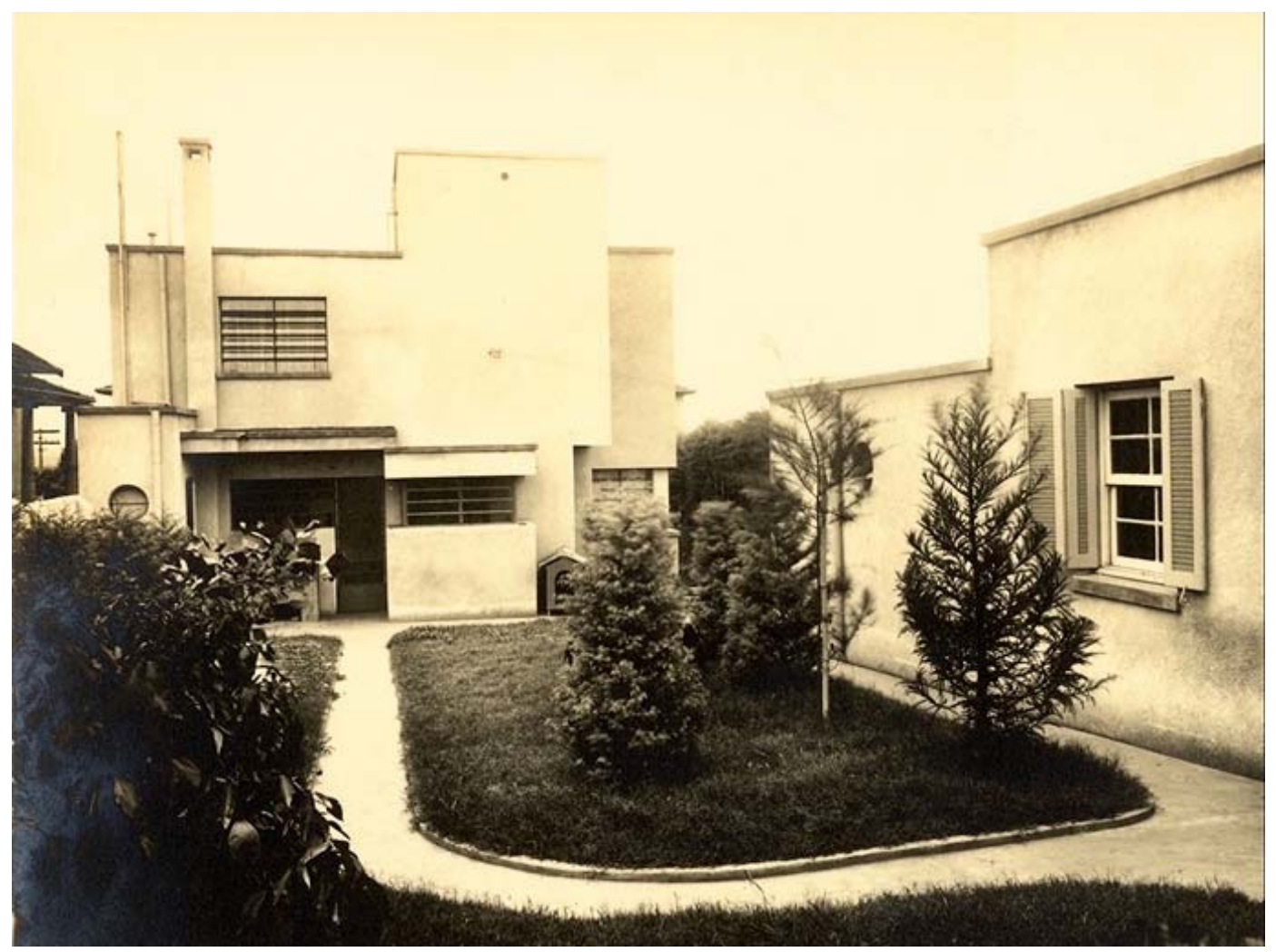

[69] Residência Jeanne Maronat, São Paulo, SP, 1932. Arquiteto Rino Levi. Fachada posterior. 
Uma primeira síntese pode ser feita desses primeiros anos da produção de Rino Levi. O ano de 1927 é marcado por projetos ainda fortemente ligados à formação acadêmica italiana, praticamente a sua única referência. A partir de 1928, uma série de projetos, construídos ou não, vai marcando o seu afastamento da academia e a incorporação das referências das diversas vanguardas modernas européias. Desses, o único onde a referência é exclusivamente corbusiana é o projeto de casas econômicas em série para Regina Previdelli. Em todos os outros, existe clara referência às vanguardas austríacas, alemãs, holandesas e, obviamente, italianas.

\subsection{2 - O CONTEXTO INTERNACIONAL}

O próprio testemunho de Rino Levi confirma essa leitura: "Foi Piacentini que me fez conhecer o primeiro livro de Le Corbusier, Vers une Architecture, que comprei logo em seguida. (...) Pessoalmente, creio que fui influenciado por Le Corbusier. Li todos os seus livros, logo após publicados, e acompanhei a sua obra. Mas, por ocasião do projeto da casa Ferrabino, meu interesse era, igualmente, por todos os demais movimentos que reagiam contra o ecletismo e que lutavam por uma renovação da arte." 44 Seu contato com esses movimentos começa ainda na Itália através da leitura de periódicos como Archirettura ed Arti decorative, que já no seu primeiro número de maio/junho de 1921, trazia artigos sobre a nova arquitetura alemã.

Pela biblioteca de Rino Levi, sabemos que ele acompanhou - mesmo depois de vir para o Brasil - não só a seqüência do periódico citado, como também Domus e La Casa Bella, que aparecem em 1928. Na sua biblioteca encontramos também exemplares dos principais livros da época, grande parte na primeira edição em francês.

\footnotetext{
${ }^{44}$ Resposta de Rino Levi à carta do Prof. Paulo F. Santos de 24/07/1964. Arquivo Rino Levi, Pasta 69. Apud ANELLI, op. cit.
} 
Sabemos, portanto, que Levi conhecia os projetos de Adolf $\operatorname{Loos}^{45}$, como a Vila Steiner ${ }^{46}$, com sua invulgar fachada frontal composta de uma cobertura arqueada de metal[7o], que se converte em laje plana, possibilitando que a fachada posterior tivesse três pisos[71], absolutamente isentos de ornamentos, movimentados pelas aberturas e avanço do volume nas extremidades. Ainda a movimentação de volumes é raciocínio dominante na Vila Moller $^{47}$ de 1927. Neste caso, do prisma retangular avança um volume cúbico, mantendo rigorosa simetria na fachada[72]. A principal preocupação de Loos residia não nos princípios abstratos, formais - é sabido que ele rejeitava as experiências feitas na prancheta - mas sim nas proporções e requisitos humanos em torno dos quais procurava criar o espaço. Achava que a convenção rígida de pisos regulares era uma camisa-deforça demasiada apertada: variar os pés-direitos dos pisos foi um dos resultados mais significativos das suas idéias no Raumplan (plano

\footnotetext{
${ }^{45}$ Adolf Loos (1870-1933) frequentou a Staatsgewerbeschule, em Reichenberg, antes de fazer os seus estudos na Tehnische Hochschule, em Dresda, em 1890, tendo a seguir passado três anos nos Estados Unidos, onde foi à Feira Mundial de Chicago e trabalhou durante a sua estada como construtor e desenhista. Em 1896 voltou à Europa e instalou-se em Viena, onde exerceu a sua influência primeiramente através do que escrevia. De 1897 em diante publicou artigos, principalmente na Neue Freie Presse, de Viena. Esses artigos foram mais tarde coligidos e impressos como Ins Leere Gesprochen (1921) e Trotdzem (1931). Loos atacava sem descanso o ornamento superficial, decorativo, que achava supérfluo e já nem moderno, sequer. A sua defesa radical dessas opiniões e o polêmico artigo "Die Protemkinsche Stadt" (A cidade Potemkine) acabou, finalmente, numa ruptura entre si e os arquitetos importantes da Secessão de Viena, Hoffmann e Olbrich. Os primeiros louvores a Loos resultaram da sua reconstrução do Museu do Café, em Viena - que devido ao seu interior austero e sem decoração, passou a ser conhecido por Café Nihilismus - e pelo interior disciplinado, mas, elegante do Knize Atelier. Em 1907, encomendaram-lhe o Kärntner Bar (Bar da Caríntia), um bar minúsculo onde a habilidosa utilização de espelhos criava a ilusão de espaço: a fachada espetacular ostentava a tabuleta American Bar, e quatro pilastras de mármore aguentavam uma cobertura oblíqua com bandeira das Stars and Strips feita em vidro colorido. Em 1908, Loos publicou o famoso Ornamento e Delito, um apelo à forma bela e com um objetivo. Com a casa na Michaelerplatz (1909/11), Loos demonstrou o que queria dizer com aquilo: a parte comercial, no térreo, era revestida de mármore verde de Cipollino, enquanto a fachada da zona de apartamentos, na parte superior do edifício, era simplesmente caiada. As janelas não possuíam caixilho algum, como se tivessem sido estampadas na empena. $\mathrm{O}$ projeto foi recebido com grande hostilidade e as autoridades citadinas não paravam de pedir que se detivesse a obra. Ao mesmo tempo, Loos trabalhava em Viena, na Vila Steiner, onde o tamanho do prédio era obscurecido, na parte da frente, por uma cobertura abobadada que se estendia para baixo, até ao nível da cobertura do térreo. Em 1912 fundou uma Escola de Arquitetura, sem autorização oficial, e ensinou alguns alunos, sem pagamento, entre eles Neutra e Schindler. Em 1920, Loos tornou-se arquiteto-chefe da Siedlungsamt de Viena, mas, abandonou o cargo dois anos depois e mudou-se para Paris. Deu aulas na Sorbonne e construiu a residência e atelier do dadaísta Tzara (1925/26). Em 1928 projetou uma casa para Josephine Baker, com um revestimento de mármore preto e branco, mas que nunca foi construída. Alguns dos edifícios mais importantes do seu último período de trabalho incluem a Vila Moller, em Viena (1927/28) e a Vila Müller, em Praga (1930), onde mais uma vez Loos consegue os seus efeitos criando uma tensão entre o material dispendioso e a forma rigorosa.

${ }^{46}$ Vila para Lilly e Hugo Steiner, Viena, Áustria, 1910. Arquiteto Adolf Loos.

${ }^{47}$ Vila para Hans e Anny Moller, Viena, Áustria, 1927/28. Arquiteto Adolf Loos.
} 
volumétrico). Resolvia a planta no espaço, como ele mesmo explicou. É o que podemos ver no interior da Vila Moller[73].

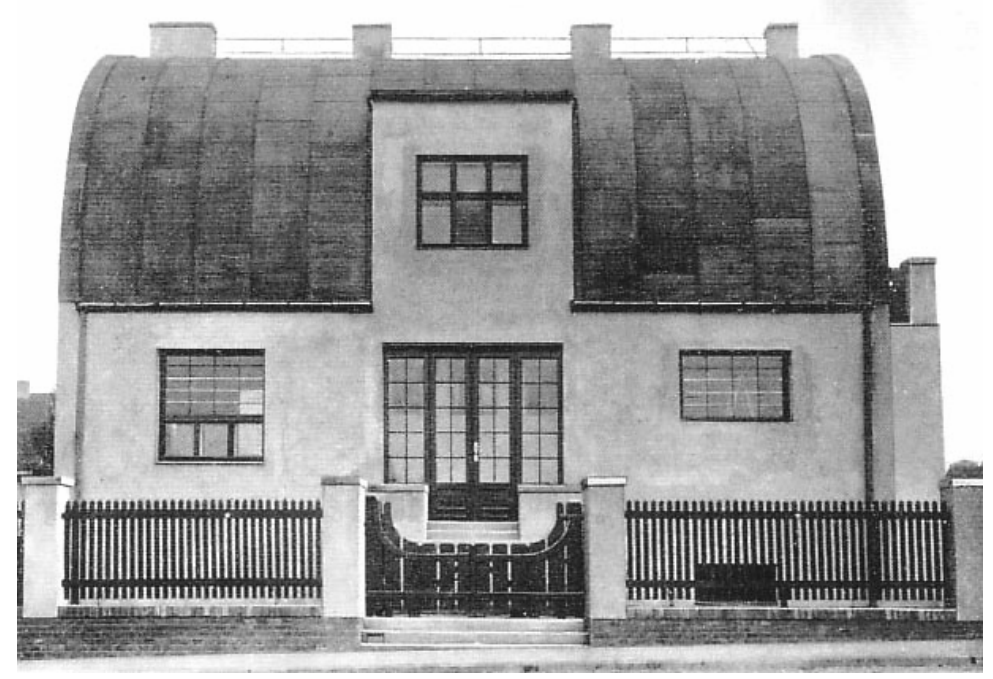

[[70] Vila para Lilly e Hugo Steiner, Viena, Áustria, 1910. Arquiteto Adolf Loos. Fachada frontal.

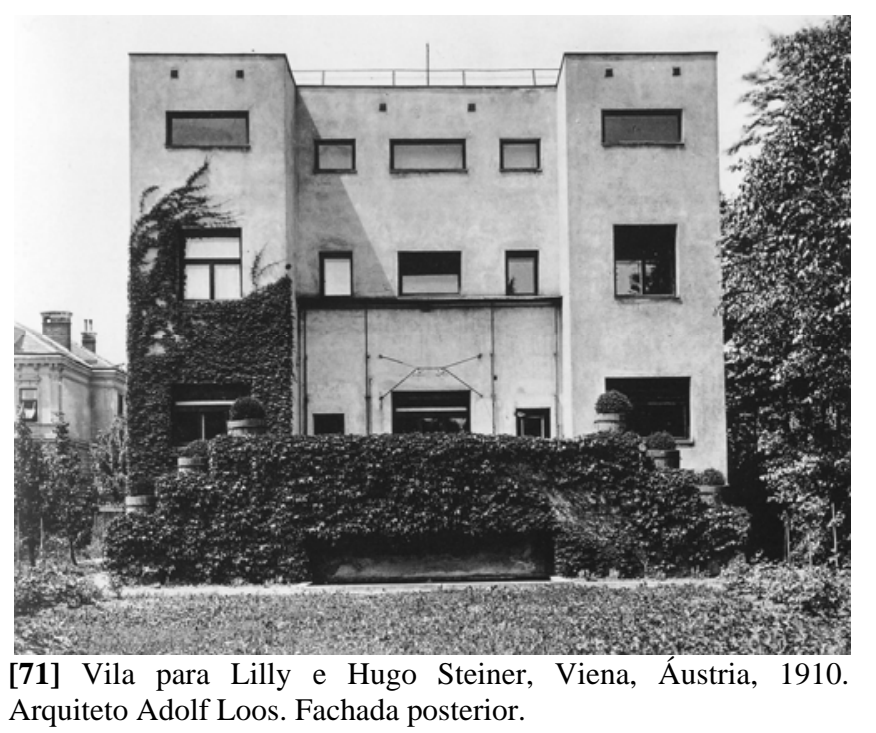

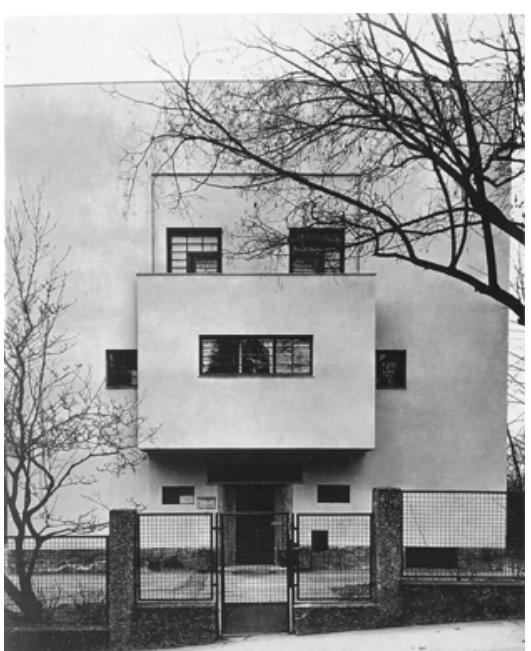

[72] Vila para Hans e Anny Moller, Viena, Áustria, 1927/28. Arquiteto Adolf Loos. Fachada principal. 


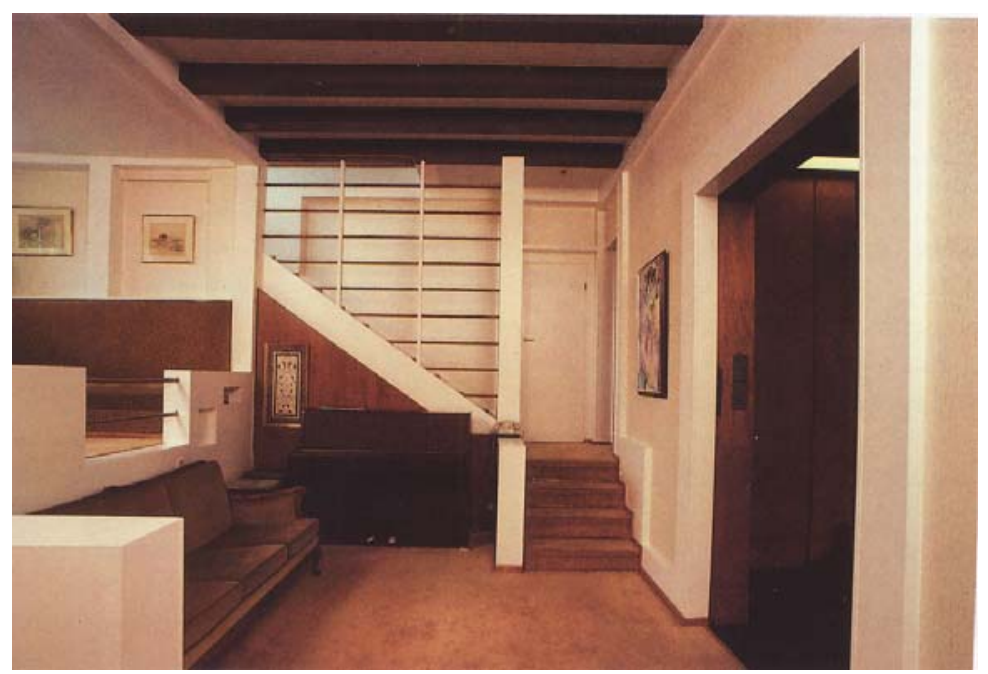

[73] Vila para Hans e Anny Moller, Viena, Áustria, 1927/28. Arquiteto Adolf Loos. Área de convívio elevada na janela da sacada que dá para a rua.

\section{Pela biblioteca de Rino Levi sabemos, também, que ele acompanhou o início das vanguardas alemãs, entre elas a Bauhaus. Criada em 1919, na cidade de Weimar, por Walter Gropius ${ }^{48}$, surgiu da fusão da Escola}

\footnotetext{
${ }^{48}$ Walter Gropius (1883-1969) estudou arquitetura de 1903 a 1907 na Technische Hochschule de Berlim e Munique. Depois de obter o diploma fez as habituais viagens ao estrangeuro, visitanto vários países europeurs. A sua experiência prática foi adquirida no estúdio de Peter Behrens e, em 1910, abriu um atelier com Adolf Meyer. Os dois colaboraram num projeto para a fábrica de sapatos Fagus, em Alfed an der Leine (1910/14). O edifício consiste numa estrutura retangular de suporte, com pilares nos cantos, e uma fachada em grelha, feita com placas de vidro em caixilhos de metal, um dos primeiros exemplos de fachada cortina. Em 1914, construíram uma fábrica modelo para a Exposição da Werkbund, em Colônia. Depois da guerra, por recomendação de Henry van de Velde, Gropius foi nomeado diretor da Grossherzogliche Kunstgewebeschule de Weimar (Escola Grã-Ducal de Artes Aplicadas de Weimar) e da Grossherzogliche Hochschule für bildende Kunst (Academia Grã-Ducal de Artes). Em 1919, Gropius fundiu as duas escolas numa só - a Bauhaus Estatal. Quando esta foi forçada a se mudar, Gropius planejou um novo complexo para a escola em Dessau (1925/26). A idéia básica era que as diferentes formas das unidades do edifício, correspondentes às funções principais da escola, deviam se interligar. O complexo abrangia casas para os mestres-artesãos e para o diretor. (1925/26). De 1926 a 1928, Gropius executou o seu projeto maior, o complexo Törten, perto de Dessau, onde usou, parcialmente, elementos pré-fabricados de concreto armado. Também em Dessau, constrói a Konsumverein (Sociedade Cooperativa), em 1927, e o Departamento de Emprego da Cidade (1927/29). Seguiram-se mais edifícios para a Urbanização Residencial de Dammerstock, em Carlsrue (1928/29), um projeto coordenado por Gropius. Ao mesmo tempo, enquanto trabalhava para Erwin Piscator, aperfeiçoou o seu conceito de "teatro total", com o palco giratório que podia ser transformado num proscénio ou em palco com várias profundidades (1927). Em 1928, o arquiteto deixou a diretoria da Bauhaus, em favor de Hannes Meyer, e mudou-se para Berlim, onde se tornou arquiteto supervisor do bairro Siemensstadt (1929/30), ficando ele próprio encarregado de dois blocos - casas altas e esguias com pérgulas. Depois de os nazistas terem tomado o poder, Gropius emigrou para a Inglaterra, em 1934, e, até 1937, trabalhou com o arquiteto Maxwell Fry em projetos como a Casa Bem Levy, em Londres (1935), e o Colégio da Aldeia de Impington, em Cambrudgeshire (1936/40). Quando the ofereceram o posto de professor de arquitetura em Harvard, foi para os EUA. Aí colaborou estreitamente com Marcel Breuer em esquemas como habitações para trabalhadores, em New Kensington (1941), e, mais tarde, trabalhou com Konrad Wachsmann na produção em massa de casas (1943/45). Em 1946, Gropius fundou o grupo TAC, The Architects Collaborative, com artistas jovens. Um efeito notável desse esforço coletivo foi o Centro para Licenciados e o Dormitório na Universidade de Harvard, com sete blocos residenciais e um centro comunitário (1949/50). As obras mais importantes do fim da sua carreira incluem o Edifício da PANAN, com 59 andares, prismático, em Nova Iorque (1958/63), concebido em colaboração com o TAC, Pietro Belluschi e Emery Roth and Sons, a Fábrica de Porcelanas Rosenthal, em Selb (1965/67), e a Fábrica de Vidros Thomas, em Amberg (1967/69). Gropius expôs as suas teorias arquitetônicas em numerosas publicações como Intertionale Architektur (1925), Bauhausbauten Dessau (1930) e The New Architecture and The Bauhaus (1935).
} 
de Artes e Ofícios do grão-ducado da Saxônia, fundada por Henry Van de Velde, em 1906, com a Academia de Belas Artes, também do grãoducado. Os seus primeiros anos ainda foram nitidamente influenciados pela introspecção emotiva do Expressionismo do pósguerra, como se pode ler no seu primeiro manifesto de 1919: "Deixemnos criar, pois, um novo grêmio de artesãos, sem as divisões de classe que erguem uma barreira arrogante entre artesão e artista! Deixem-nos desejar, conceber e construir o novo edifício do futuro, que reunirá tudo numa forma única: arquitetura, escultura e pintura... um símbolo cristalino de uma fé nova e vindoura." 49

Em 1925, os princípios geradores da Bauhaus não revelavam mais nenhum vestígio expressionista. Em compensação, Gropius falava de ofícios futuros, determinados igualmente pela tecnologia e pela forma, atuando "como um meio de trabalho experimental para a produção industrial (...) A Bauhaus deseja contribuir para o desenvolvimento da habitação - apropriada para a época -, desde a mais simples aparelhagem até a casa acabada. Convencida de que a casa e mobiliário devem estar relacionadas entre si racionalmente, a Bauhaus procura que a forma de um objeto derive das suas funções reais e limitações naturais - através de uma pesquisa sistemática teórica e prática nos campos formal, técnico e econômico. A natureza de um objeto é determinada pela sua serventia. Antes de uma vasilha, uma cadeira ou uma casa poder funcionar bem, deve estudar-se a sua natureza... Essa pesquisa da natureza dos objetos faz com que as formas surjam de uma determinada avaliação de todos os métodos modernos de produção e construção, bem como dos materiais modernos, formas essas que divergem dos modelos que existem e muitas vezes parecem estranhos e surpreendentes." ${ }^{\circ}$

Esse padrão analítico de Gropius é materializado quando a Bauhaus muda para Dessau. No projeto para a nova sede do instituto, todo o

\footnotetext{
${ }^{49}$ GROPIUS, Walter, 1919

${ }^{50}$ GROPIUS, Walter, 1925
} 
complexo foi engendrado de acordo com a função. Além do novo edifício da Bauhaus, Gropius construiu uma casa para o diretor[74] e [75] e três séries de casas para os professores[76], concebidas como modelos para uma nova maneira de viver em fase com a era da máquina. Baseavam-se no sistema de módulos de "um conjunto de blocos de edifícios em grande escala: casas que são compostas de peças pré-fabricadas, variáveis, funcionais." ${ }^{11}$ Embora os objetivos da estandardização da construção não tivessem sido atingidos em Dessau - as casas eram feitas, de fato, de uma maneira convencional[77] - a manipulação formal dos volumes demonstrou de maneira convincente a presença estética que se pode obter quando tudo é reduzido a meia dúzia de formas cúbicas. Uma produção em maior escala e mais industrializada será conseguida nas experiências com as Siedlungs (bairro habitacional), que serão analisadas adiante.

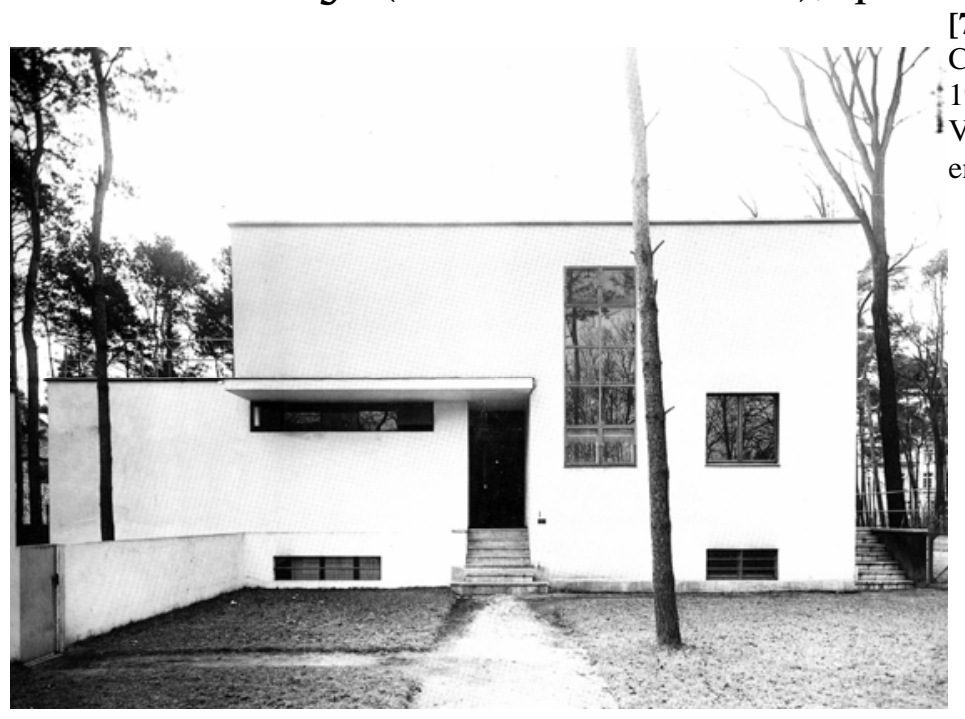

[74]

Casa do diretor na Bauhaus em Dessau,

1925/26. Arquiteto Walter Gropius.

Vista do norte a partir da rua e a entrada principal.

${ }^{51}$ GROPIUS. Walter, 1926 
[75]

Casa do diretor na Bauhaus em Dessau, 1925/26. Arquiteto Walter Gropius. Vista do lado sudoeste com a entrada lateral e as varandas de cima e de baixo.
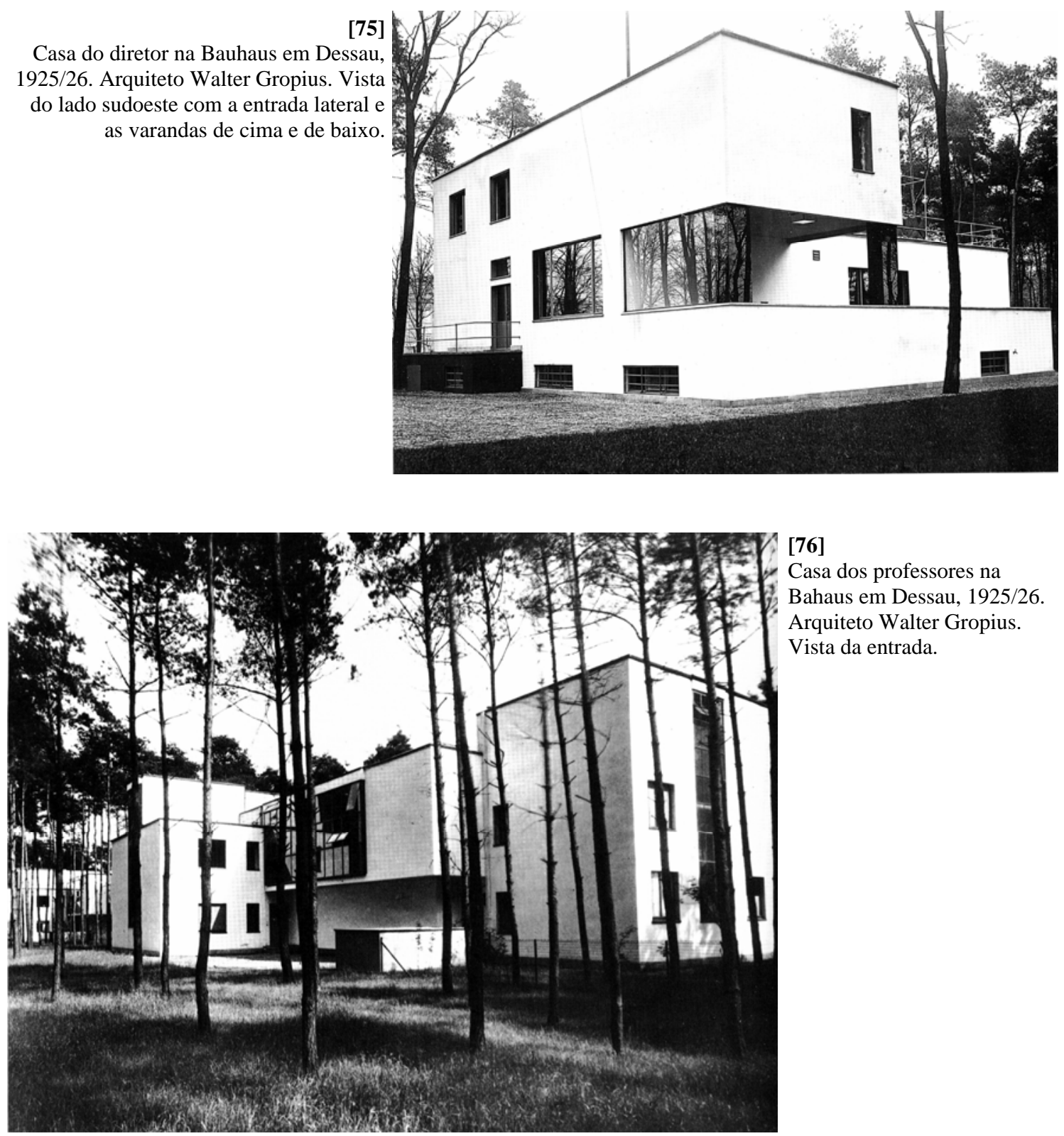

[76]

Casa dos professores na

Bahaus em Dessau, 1925/26.

Arquiteto Walter Gropius.

Vista da entrada. 


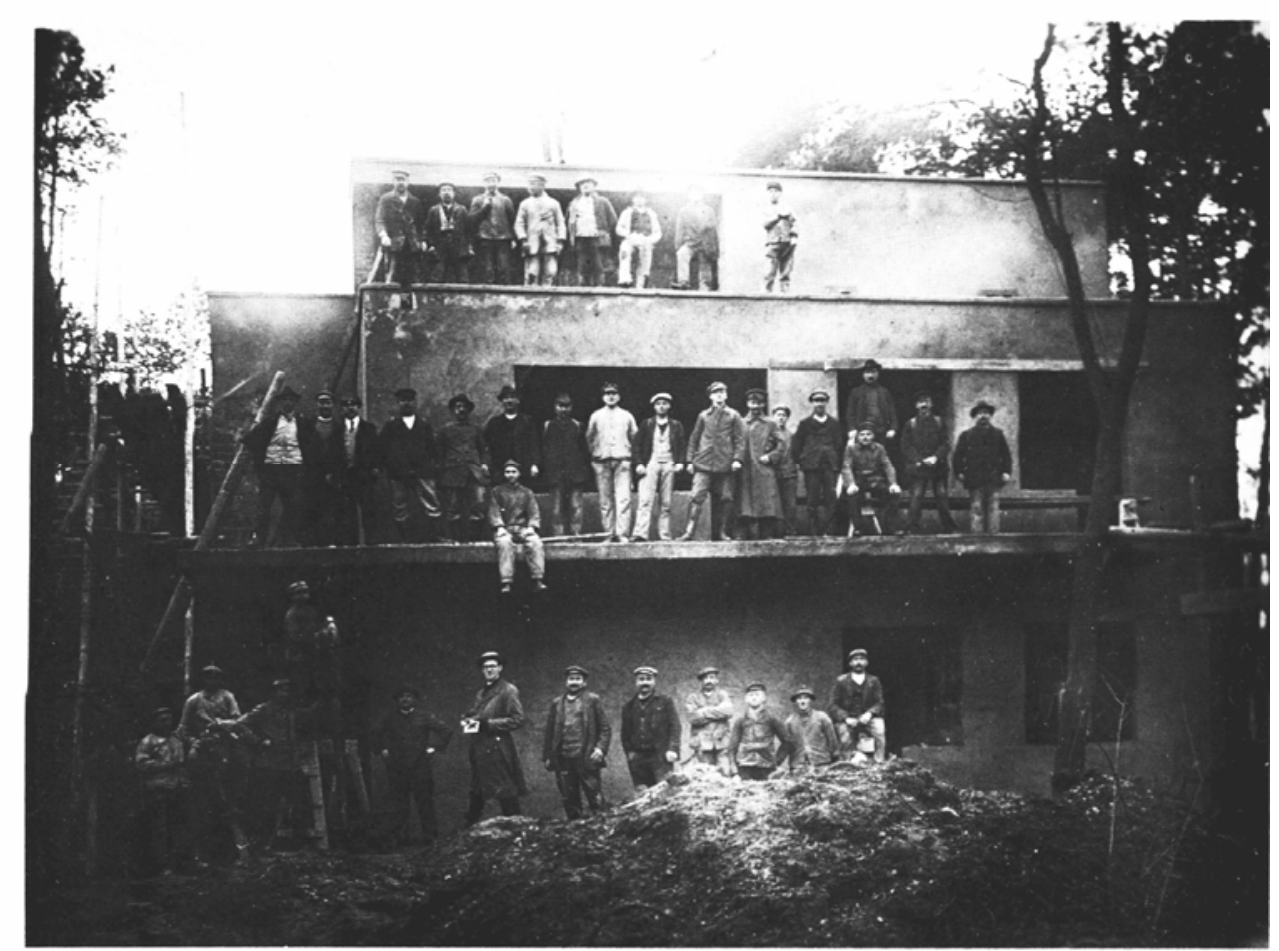

[77] Casa dos professores na Bahaus em Dessau, 1925/26. Arquiteto Walter Gropius. Fotografia da festa de cohertura das casas em nutubro de 1.925

Uma das razões da rápida decisão da cidade de Dessau em adotar a Bauhaus foi a sua falta de alojamento. A cidade, governada pelos sociais-democratas, era um grande centro industrial nas áreas de engenharia mecânica e química. Em 1925, a cidade contava com cerca de 50.00o habitantes; em 1928 este número tinha já aumentado para 8o.ooo. À grave crise de falta de habitações aliava-se a falta de desenvolvimento do planejamento urbano. Assim, é encomendado a Gropius a construção de uma urbanização-modelo em DessauTörten $[\mathbf{7 8}]^{52}$. No Bairro Törten, Gropius pôde, pela primeira vez, demonstrar técnicas de construção industrial e a sua Repartição de Trabalho para a cidade de Dessau (1927/29) constituíram o seu mais lógico e atraente exemplo da arquitetura funcional.

\footnotetext{
${ }^{52}$ Bairro Dessau-Törten, 1926/28. Arquiteto Walter Gropius.
} 


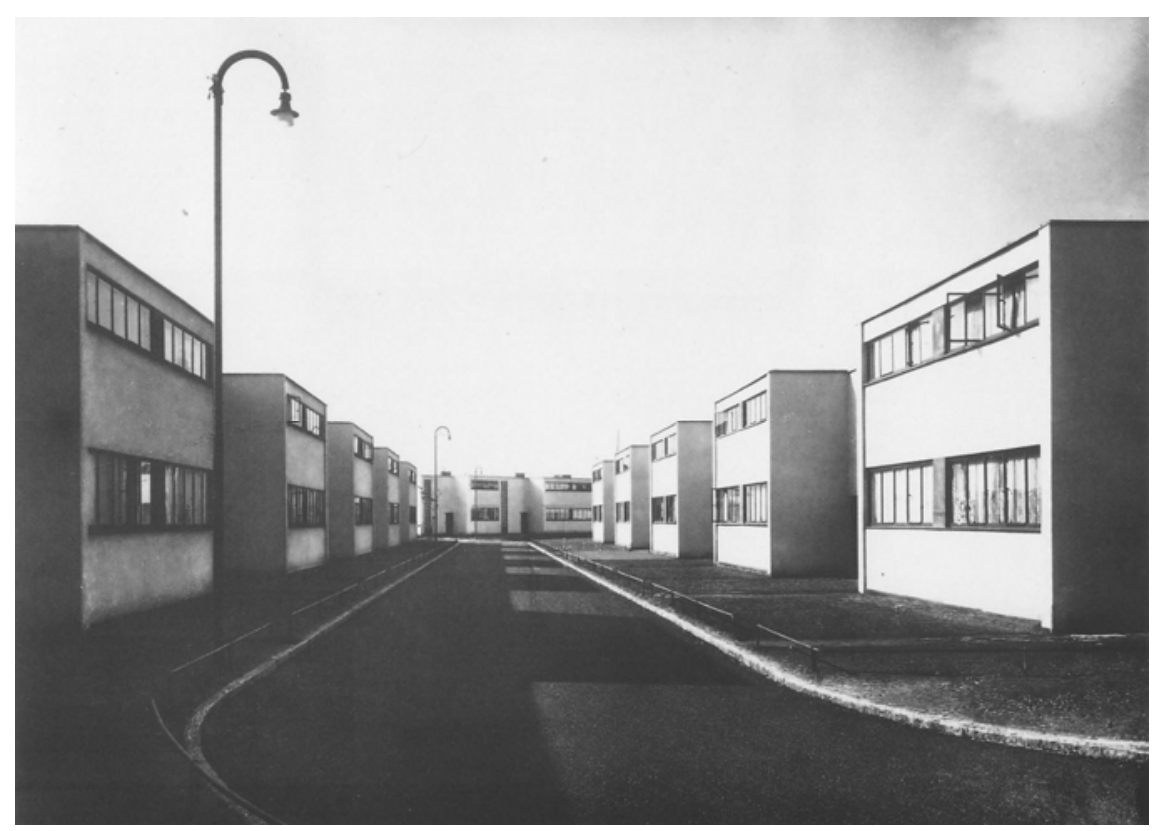

[78] Vista do Bairro Dessau-Törten, 1926/28. Arquiteto Walter Gropius. Fachada frontal casas tipo 1928.

Não só em Dessau aconteciam experiências de habitação coletiva. Na Alemanha da década de vinte, outras cidades industriais governadas pela social-democracia faziam os esforços possíveis para se chegar a uma política eficaz de construção. Como consultor do planejamento da cidade de Frankfurt, Ernst May ${ }^{53}$ - juntamente com o diretor artístico Martin Elsässer e uma grande equipe recém formada - teve grandes oportunidades de implementar o conceito de construção normativa. Os objetivos declarados dos amplos complexos habitacionais planejados para a "Nova Frankfurt" eram a unificação da

\footnotetext{
${ }^{53}$ Ernst May (1886-1970) iniciou a sua vida acadêmica na Faculdade da Universidade de Londres, em 1908, prosseguiu-a na Technische Hochschule, em Darmestádio, e, por fim, estudou com Friedrich von Thiersch e Theodor Fischer na Technische Hochschule, em Munique, tendo obtido a licenciatura em 1912. Enquanto ainda era aluno, a primeira experiência adquirida em planejamento foi no atelier londrino de Raymond Unwin (1910/12). A partir de 1913 trabalhou como arquiteto freelance em Frankfurt. Nos anos a seguir à guerra, foi diretor da Silesian Landesgesellschaft, em Breslau, de 1919 a 1925, e, em 1921, foi diretor técnico do Schlesisches Heim da Gemeinnützige Siedlungsgesellschaft. Em 1925 é nomeado diretor de planejamento urbano em Frankfurt, e aí permaneceu até 1930. Nesses cinco anos, com Martin Elsässer e uma grande equipe de assistentes, May projetou e construiu uma série de blocos residenciais para a "Nova Frankfurt". Apesar das técnicas de construção simples, May conseguiu uma variedade inédita pelo arranjo flexível de cada edifício no design geral: assim, serviu-se de uma disposição em ângulo reto para a urbanização do Bairro Praunheim (1927/29), uma forma curva para a urbanização Römerstadt (1927/28), ou aquilo que se tornou conhecido pelas “casas em zigue-zague” para a Bruchfeldstrasse (1926/27). As inovações eram visíveis nos elementos préfabricados e até na Frankfurt Küche (cozinha racionalmente desenhada por Grete Schütte Lihotzky). De 1930 até 1934, May trabalhou na União Soviética e depois emigrou para a África, em 1934, onde morou na Tanzânia como fazendeiro e arquiteto, até 1953. De regresso à Alemanha, trabalhou até 1961 para a organização do planejamento citadino social Neue Heimat, em Hamburgo, e, mais tarde, como planejador urbanístico em Wiesbaden. A partir de 1957, foi também professor na Technische Hochschule, em Darmstadt.
} 
realização máxima da função com um mínimo de forma bem como o repúdio de pormenores artísticos sobrepostos. Só através do consciencioso alinhamento das partes uniformes a habitação iria com uma existência mínima - alcançar uma qualidade estética, por meio da qual, também, se contribuiria para alcançar uma "mentalidade coletiva".

O melhoramento das condições higiênicas era um dos argumentos mais importantes na nova construção com luz e ar para todos. A consequência lógica foi a rejeição das construções costas-com-costas, ao redor de um pátio, e a sua substituição por blocos lineares de casas em zonas verdes, que deixavam cada apartamento receber a mesma intensidade de luz solar. É o que vemos no Bairro Höhenblick $[79]^{54}$, de Ernest May e equipe, em Frankfurt, 1926/27. Os edifícios de esquina, bem acentuados, com as suas pequenas lojas, marcam a entrada do quarteirão. Os corta-ventos nas portas principais eram sombreados de azul-claro, fazendo parte do esquema de cores das molduras das janelas, numa variedade de tons vibrantes e que compensavam o aspecto mais escuro das esquinas em relação à leveza luminosa das fachadas.

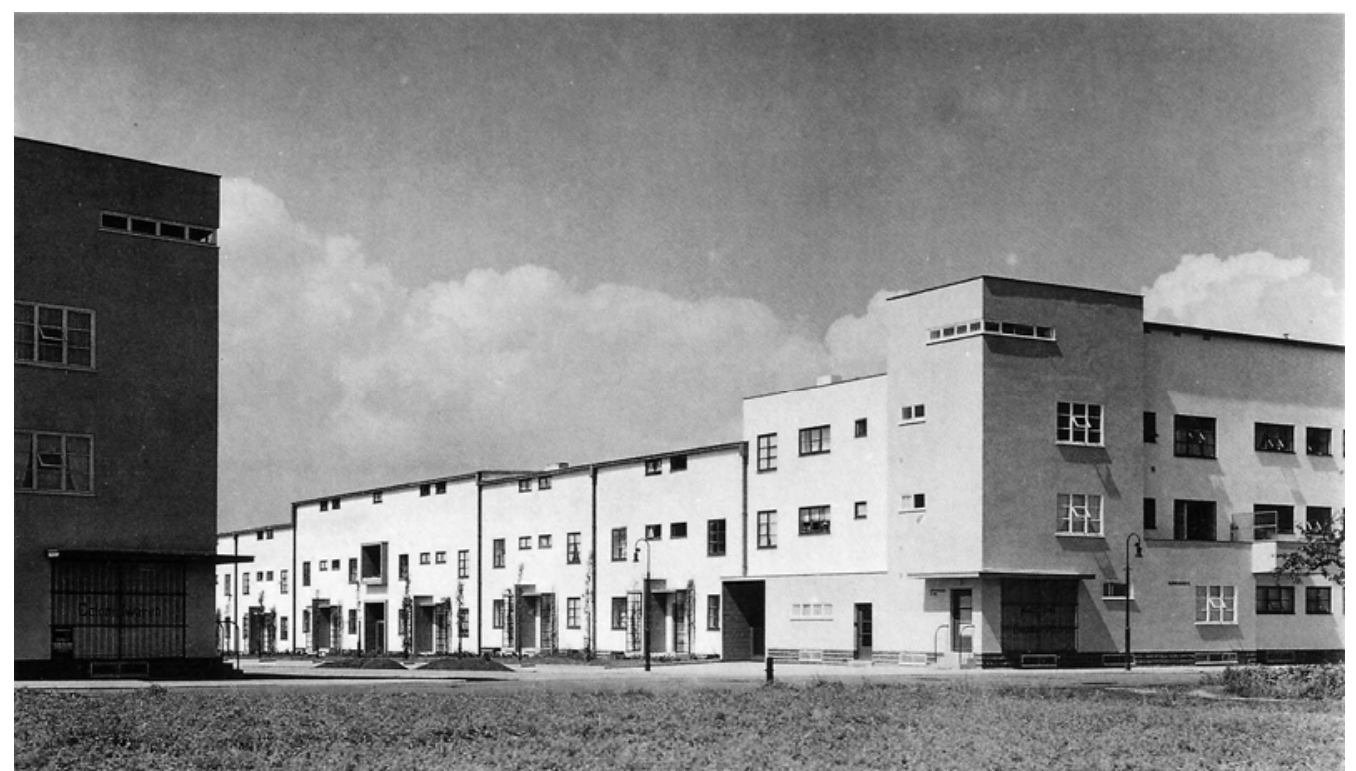

[79] Bairro Höhenblick, Frankfurt, 1926/27. Arquitetos Ernest May, H. Boehm, C. H. Rudloff. Vista panorâmica com as casas de esquina na Kurhessenstrasse.

\footnotetext{
${ }^{54}$ Bairro Höhenblick, Frankfurt, 1926/27. Arquitetos Ernest May, H. Boehm, C. H. Rudloff.
} 
Um obstáculo importante para a habitação saudável e barata eram os custos da construção. Para facilitá-la, May tentou industrializar os métodos de construção com elementos estandardizados como, por exemplo, paredes em painel, feitas em fábricas centrais. Embora isso obrigasse à utilização de guindastes, o uso de partes pré-fabricadas diminuía o longo tempo de secagem exigido pelas paredes de alvenaria. Esse tipo de solução foi usada no Bairro Römerstadt $[\mathbf{8 o}]^{55}$, de 1927/28. Aqui, ao invés do prisma retangular, o bloco se desenvolve em suave curva, pontuada por pequenas empenas que ao mesmo tempo funcionam como corta-vento e garantem privacidade das unidades.

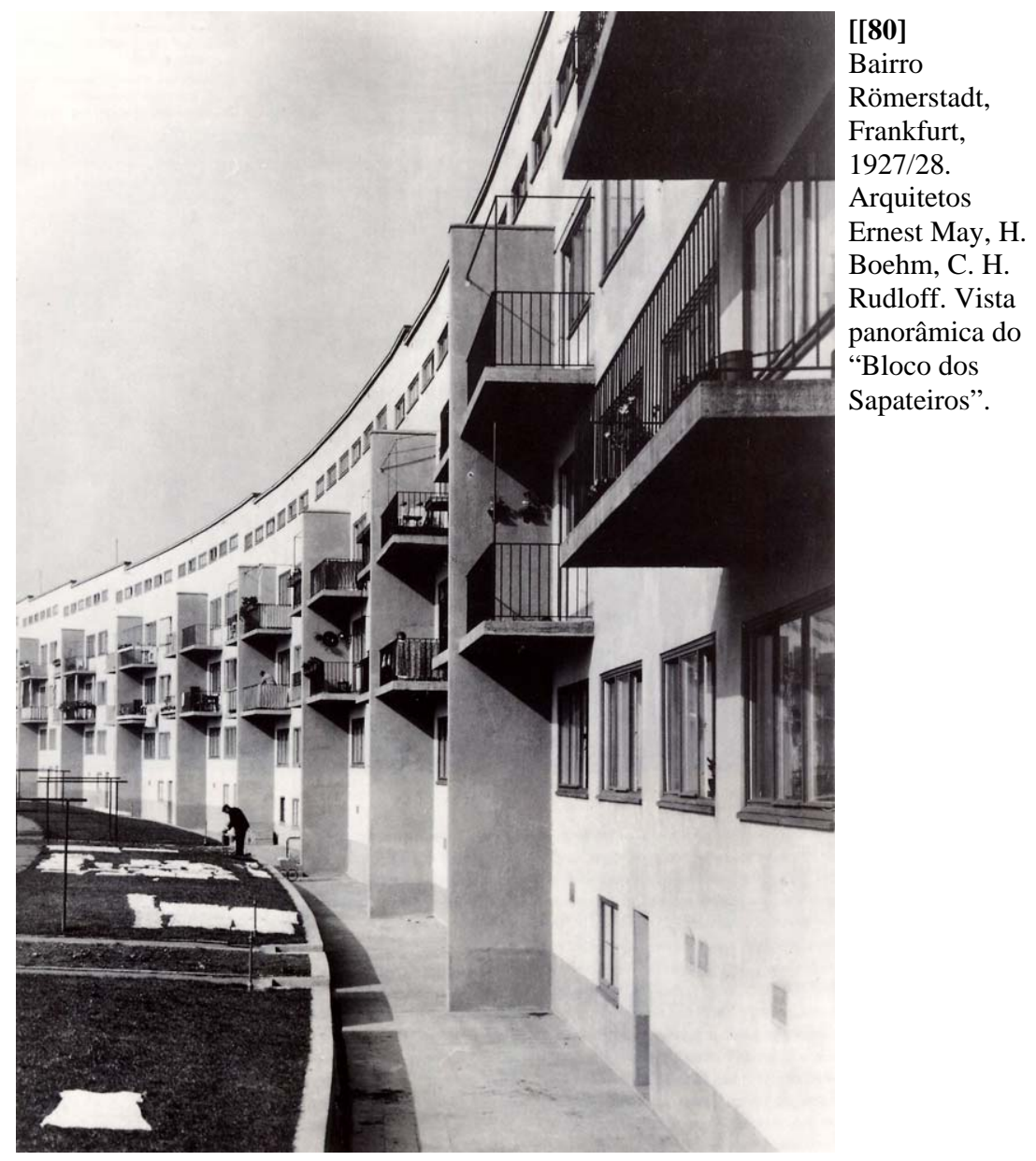

Além disso, Frankfurt se destacou pelo cuidado com que aplicava as idéias do design aos detalhes dos interiores como caixilhos, puxadores

\footnotetext{
${ }^{55}$ Bairro Römerstadt, Frankfurt, 1927/28. Arquitetos Ernest May, H. Boehm, C. H. Rudloff.
} 
de portas e janelas. Sob o lema Primeiro a cozinha - depois a fachada, a Cozinha de Frankfurt, desenhada por Grete Schütte-Lihotzky, tornou-se o modelo da organização habitacional melhorada. Um espaço de somente 3,5 x 1,9 metros continha todos os artefatos caseiros necessários. É o que podemos observar na planta do Bairro Römerstadt[81]: atrás de uma fachada enganosamente simples revelase um interior generoso, que inclui a citada cozinha.

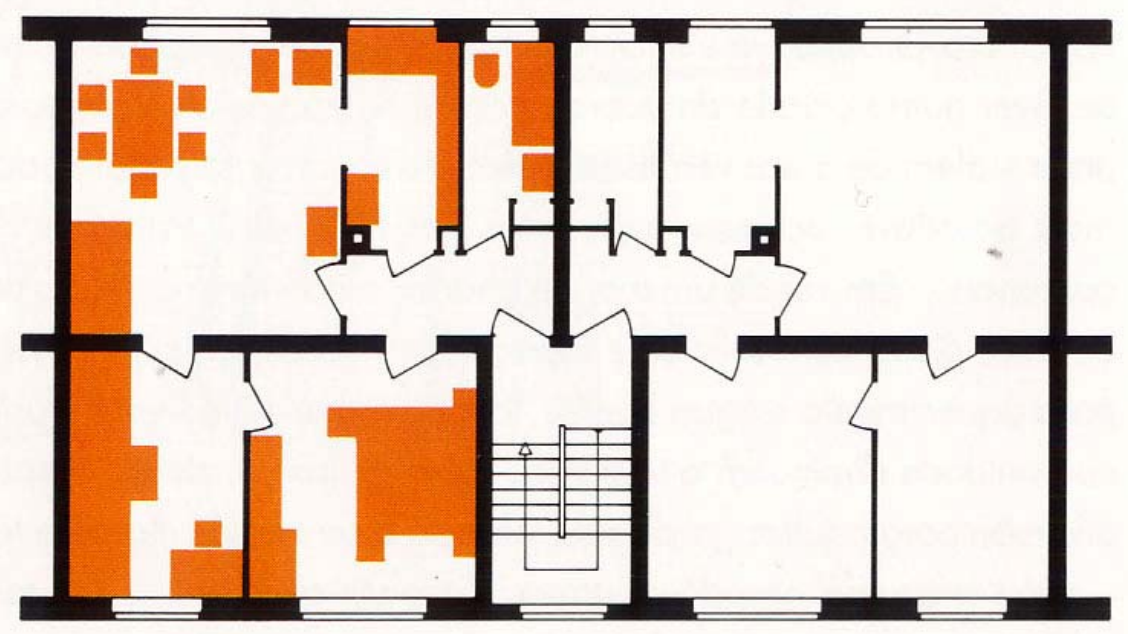

[81] Bairro Römerstadt, Frankfurt, 1927/28. Arquitetos Ernest May, H. Boehm, C. H. Rudloff. Planta de dois apartamentos do "Bloco dos Sapateiros”, incluindo a "Cozinha de Frankfurt”.

A cidade de Colônia também realizou experiências na área. $\mathrm{O}$ seu Bairro Kalkefeld, de 1927, apresenta, inclusive, edifícios mais altos. Para Gropius o edifício alto não era um mal necessário, mas uma forma conveniente de viver numa cidade de acordo com a nossa época. Apenas o edifício alto, com muitos pisos - além de áreas verdes para recreio e descontração - pode tornar a vida mais fácil e mais agradável aos seus ocupantes por meio de instalações domésticas centrais e salas comunais. A proposta de Wilhelm Riphaln $\left[\mathbf{8 2}^{5}\right]^{56}$ contempla essas exigências. Para ele, o habitante urbano deve viver em casas de, no mínimo, cinco andares, com suficiente espaço para ter luz, ar, sol e sossego.

\footnotetext{
${ }^{56}$ Bairro Kalkerfeld, Colônia, 1927. Arquiteto Wilhelm Riphahn.
} 


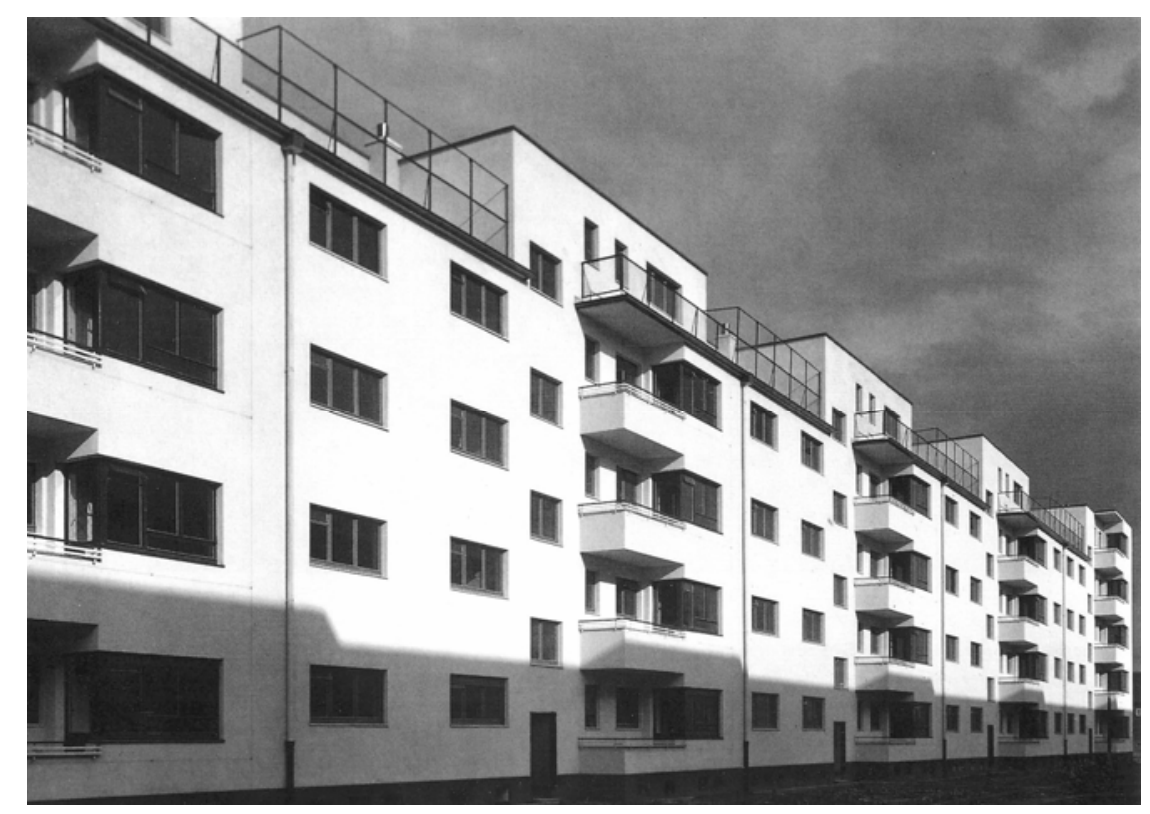

[82] Bairro Kalkerfeld, Colônia, 1927. Arquiteto Wilhelm Riphahn. Vista panorâmica dos blocos de cinco andares.

Das experiências alemãs, provavelmente a mais conhecida é a da cidade de Stuttgart. Nela, o Deutscher Werkbund (Liga de Obra Alemã) patrocina a Exposição Die Wohnung (O Apartamento), em 1927, e o seu Complexo Habitacional Weissenhof $[83]^{57}$ pretendia ser uma colônia experimental para determinar os princípios da moderna construção em série. Esse núcleo da exposição foi planejado por Ludwig Mies van der Rohe, na qualidade de seu diretor artístico. Mies também fez seu projeto, um edifício de 24 apartamentos, que ocupava o centro do Bairro Weissenhof. Além dele, dezessete arquitetos alemães e estrangeiros projetaram um total de 21 edifícios individuais. Na sua implantação[84], seguindo da direita para a esquerda a curvilínea Rathenaustrasse, estão os projetos de Hans Scharoun, Jesef Frank, Max Taut, Richard Döcker, Hans Poelzig, Ludwig Hilberseimer e Le Corbusier.

\footnotetext{
57 Die Wohnung da Exposição Werkbund, Bairro Weissenhof, Stuttgart, 1927. Arquiteto-diretor Mies van der Rohe, com mais dezessete arquitetos alemães e estrangeiros.
} 


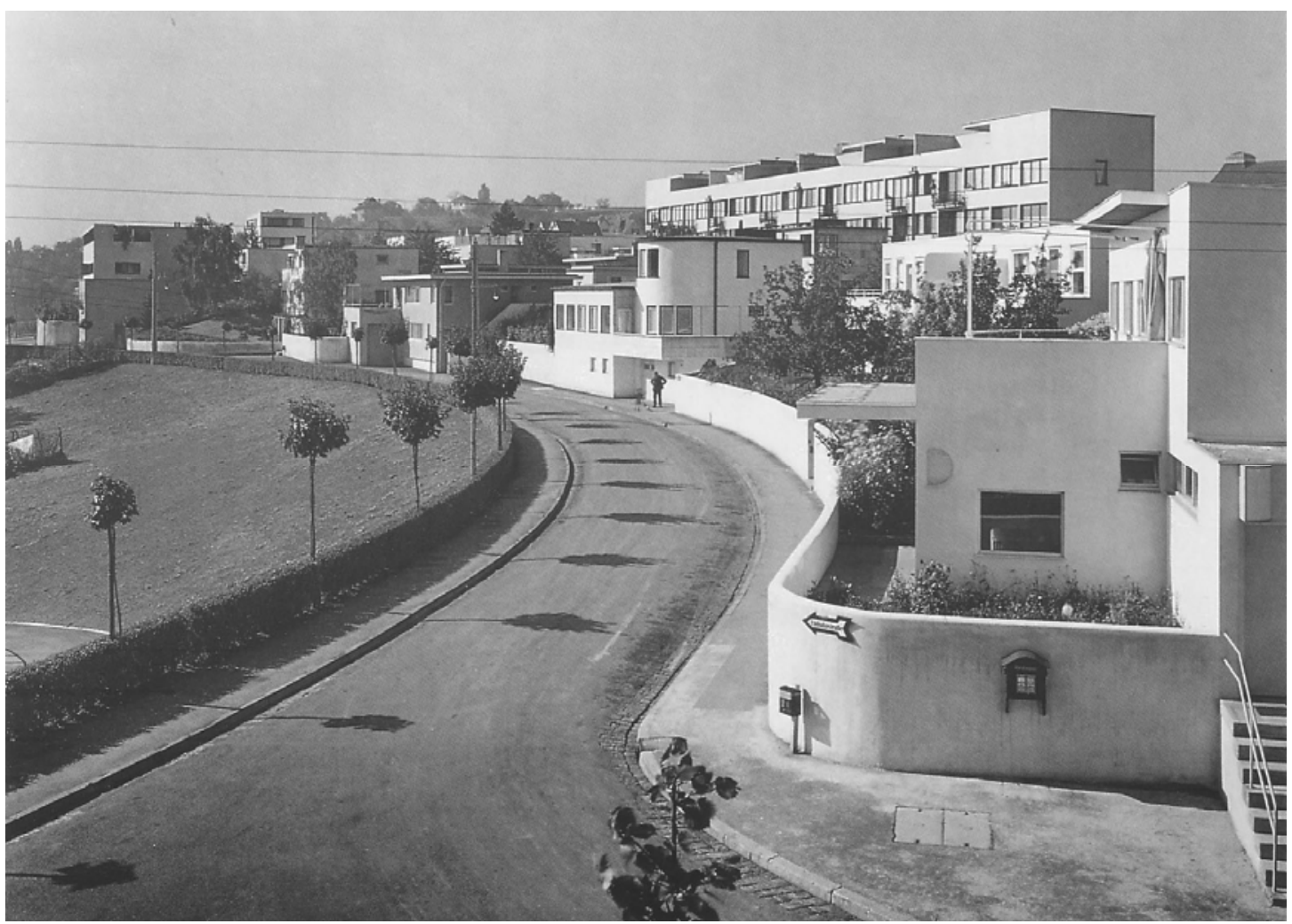

[83] Die Wohnung da Exposição Werkbund, Bairro Weissenhof, Stuttgart, 1927. Arquiteto-diretor Mies van der Rohe, com mais dezessete arquitetos alemães e estrangeiros. Vista panorâmica.

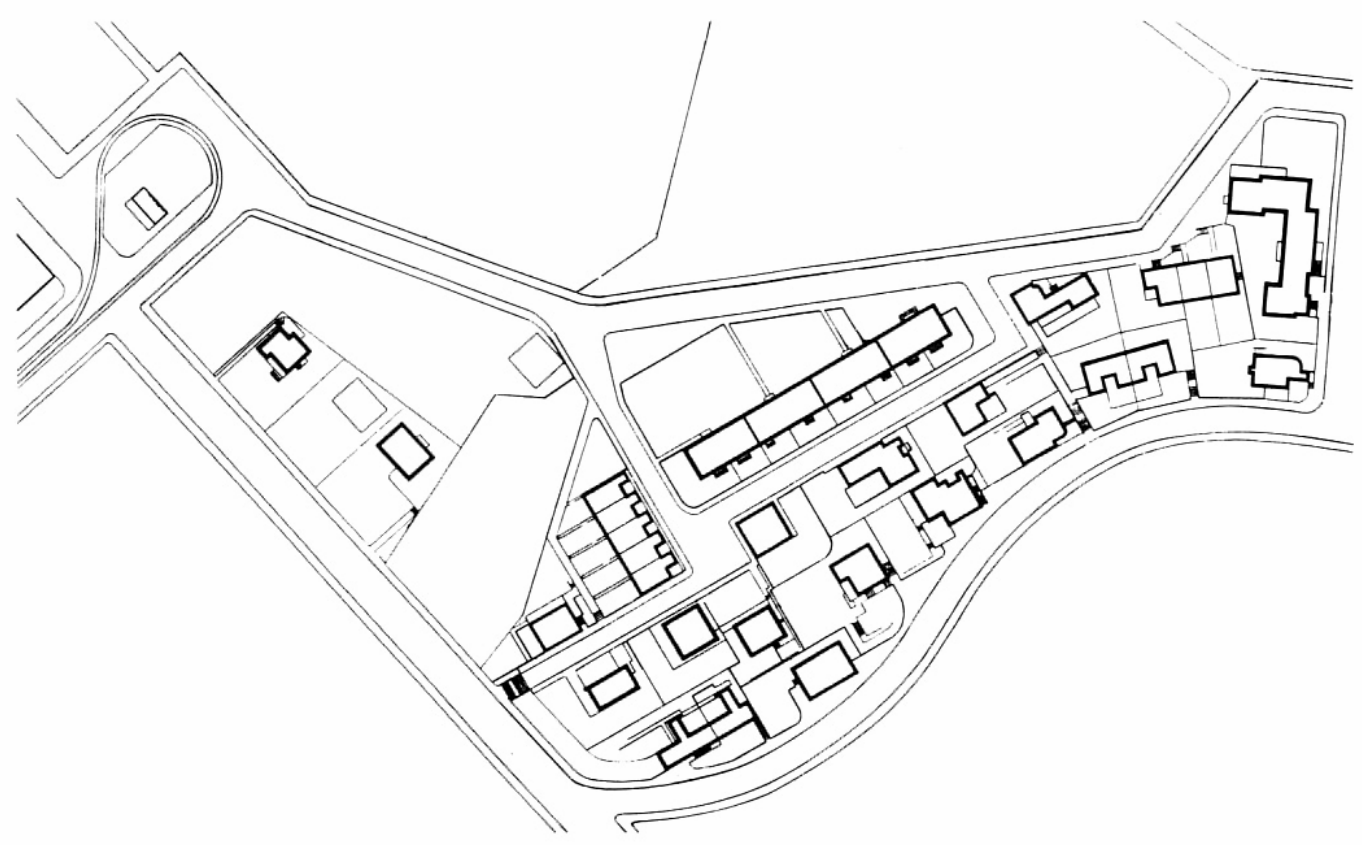

[84] Die Wohnung da Exposição Werkbund, Bairro Weissenhof, Stuttgart, 1927. Arquiteto-diretor Mies van der Rohe, com mais dezesseta arquitetos alemães e estrangeiros. Implantação. 
O Deuscher Werkbund também patrocina a Exposição Wohnung und Werkraum (Espaço para viver e trabalhar), em Vratislávia, no ano de 1929. Dela, o edifício alto de Adolf Rading $\left[8_{5}\right]^{58}$ foi o mais controverso. Originalmente destinado a ter mais pisos, a versão final permitida revelou desequilíbrios nas proporções. Duas alas simétricas, cada uma com quatro apartamentos por piso, reúnem-se numa escada iluminada por tijolos de vidro. Os corredores amplos deviam estimular a vida comunitária.

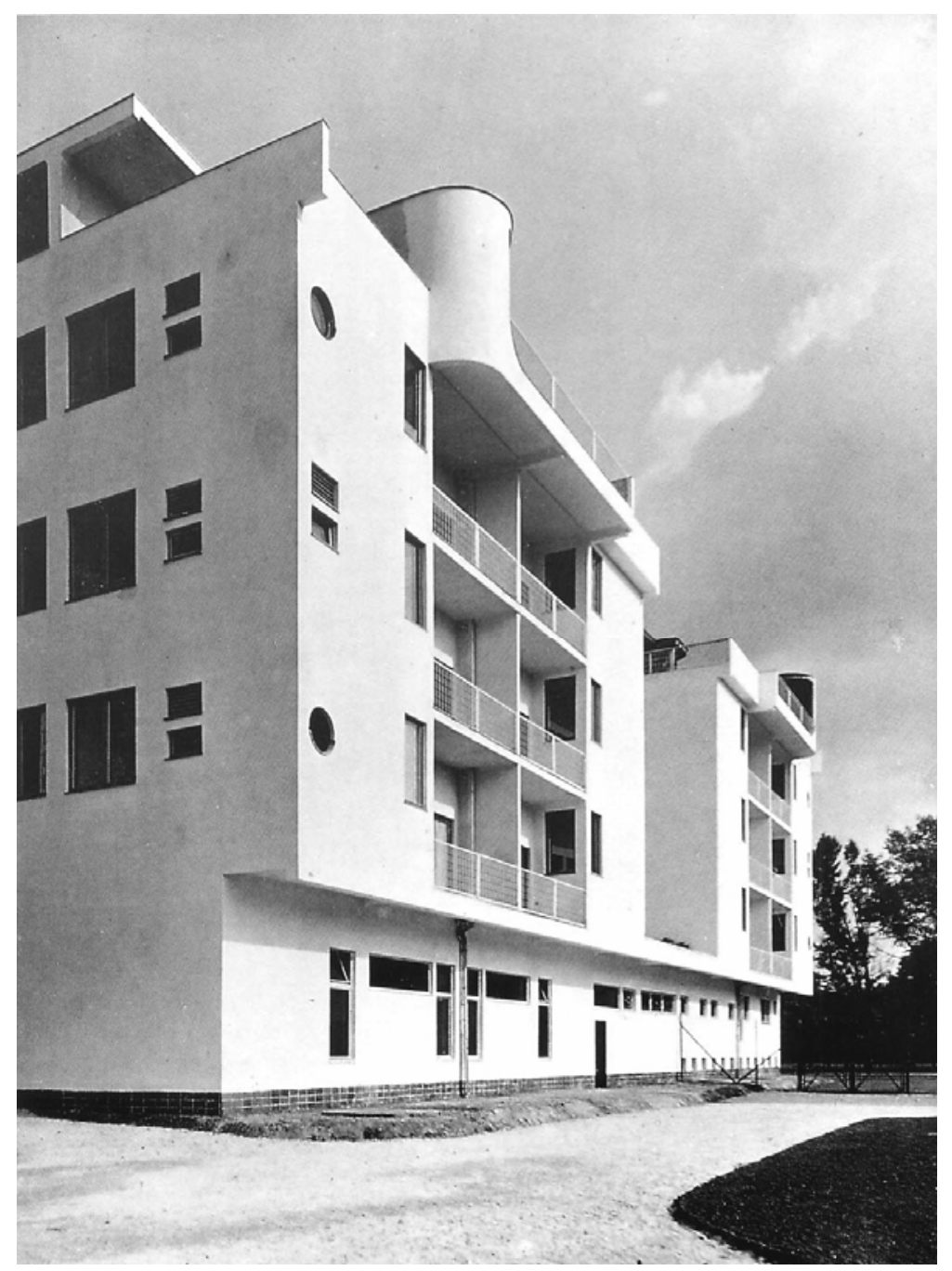

[85] Bloco de apartamentos na” Wohnung und Werkraum” da Exposição Werkbund, Vratislávia, 1929. Arquiteto Adolf Rading. Vista panorâmica.

\footnotetext{
${ }^{58}$ Bloco de apartamentos na” Wohnung und Werkraum” da Exposição Werkbund, Vratislávia, 1929. Arquiteto Adolf Rading.
} 
A participação menos dogmática é, com certeza, a de Hans Scharoun $^{59}$. Os seus Apartamentos para Solteiros e Recém Casados $[86]^{60}$, rompem os prismas regulares e as grelhas cartesianas. Scharoun é recorrentemente apontado como alternativa à estagnação formal: teria demonstrado as oportunidades para aperfeiçoar um vocabulário da forma, extraindo a organicidade das relações funcionais. No projeto de Vratislávia, a planta[87] recusa uma orientação clara: eixos que rodam, mudam as direções do movimento. Essa movimentação domina os volumes, que evitam qualquer ortogonalidade[88].

\footnotetext{
${ }^{59}$ Hans Scharoun (1893-1972) estudou de 1912 a 1914 na Technische Hochscule, em Berlim. Aí conheceu Paul Kruchen que, além de ser professor assistente, também tinha ateler próprio, onde Scharoun pôde trabalhar. Por incentivo de Kruchen, Scharoun trabalhou como arquiteto de 1915 a 1918, para o Militärbaukommando, no Programa de Reconstrução da Prússia Oriental, e, depois, tornou-se diretor interino do planejamento urbano, em Insterburg. Por fim, passou a ser arquiteto independente no atelier de Kruchen, de 1919 a 1925, e dirigiu vários projetos de alojamento e reconstrução, bem como o desenvolvimento do Bairro Kamswyken(1920), conhecido por Die Bunte Reihe (A Feleira Multicor), além de numerosos projetos para concursos, como arranha-céus para a Friedrichstrasse, em Berlim. Scharoun foi membro do grupo fundado por Bruno Taut, a Gläserne Kette (A Cadeia de Vidro), e, como Taut, executou desenhos fantasiosos para Utopias arquitetônicas. De 1925 a 1932 ensinou na Academia do Estado, em Vratislávia, e, em 1926, tornou-se membro da associação de arquitetos Der Ring. Tomou parte na urbanização do Bairro Weissennhof, em Stuttgart, em 1927, com uma casa independente, e, em 1929, desenhou um edifício de apartamentos para a Exposição da Werkbund, em Vratislávia. Em Berlim, trabalhou numa série de blocos de apartamentos e também foi diretor da urbanização residencial da Siemensstadt (1929-1930). A sua contribuição pessoal para esse projeto de grande envergadura foi o edifício de apartamentos na Jungfernheideweg e na Mäckeritzstrasse. A partir de 1932 teve atelier próprio, em Berlim. Entre os edifícios com mais êxito, contam-se as elegantes vilas que construiu nos anos 30: a Casa Schminke, em Löbau (1933), a Casa Mattern, em Bornim (1934), a Casa do Dr. Baensch, em Spandau, Berlim (1935), e a Casa Moll, em Berlim (1937). Depois da Guerra, Scharoun tornou-se diretor da Bau-um Wohunungswesen (Departamento de Construção e Alojamento), em Berlim, e, com um grupo de arquitetos imaginou um programa de reconstrução conhecido por Plano Coletivo (1946). No mesmo ano, tornou-se professor sénior de planejamento urbanístico na Technische Universität, de Berlim, um lugar que ocupou até 1958. Além disso, de 1947 a 1950, foi diretor do Institut für Bauweser der Deutschen Akademie der Wissenschaften, em Berlim Oriental. A sua idéia de conceber um edifício escolar de acordo com a categoria, ou o método, foi posta em prática no Geschwister-Scholl-Gymnasium, em Lünen (1956-1962). No mesmo período construiu a famosa Sala da Filarmônica de Berlim (19561963). Para obter a melhor acústica possível em todos os lugares, agrupou-os dinamicamente, como terraços, em níveis ascendentes rodeando o palco da orquestra. Os corredores das salas de ligação surpreendem o visitante com a sua panorâmica do resto do edifício e pormenores invulgares. Afiançou-se que a vista do prédio, do lado de fora, apresentaria uma grande variedade devido à curvatura da cobertura. Nos anos 70, surgiram mais projetos notáveis como a Embaixada da Alemanha, em Brasília (1970), o Teatro da Cidade, em Wolsburg (1965-1973) e a Staatsbibliothek Preussischer Kulturbesitz (Biblioteca do Estado), em Berlim (1964-1978), que foi acabada pelo seu sócio Edgar Wisniewski.

${ }^{60}$ Apartamentos para Solteiros e Recém Casados na "Wohnung und Wekraum” da Exposição Werkbund, Vratislávia, 1929. Arquiteto Hans Scharoum.
} 


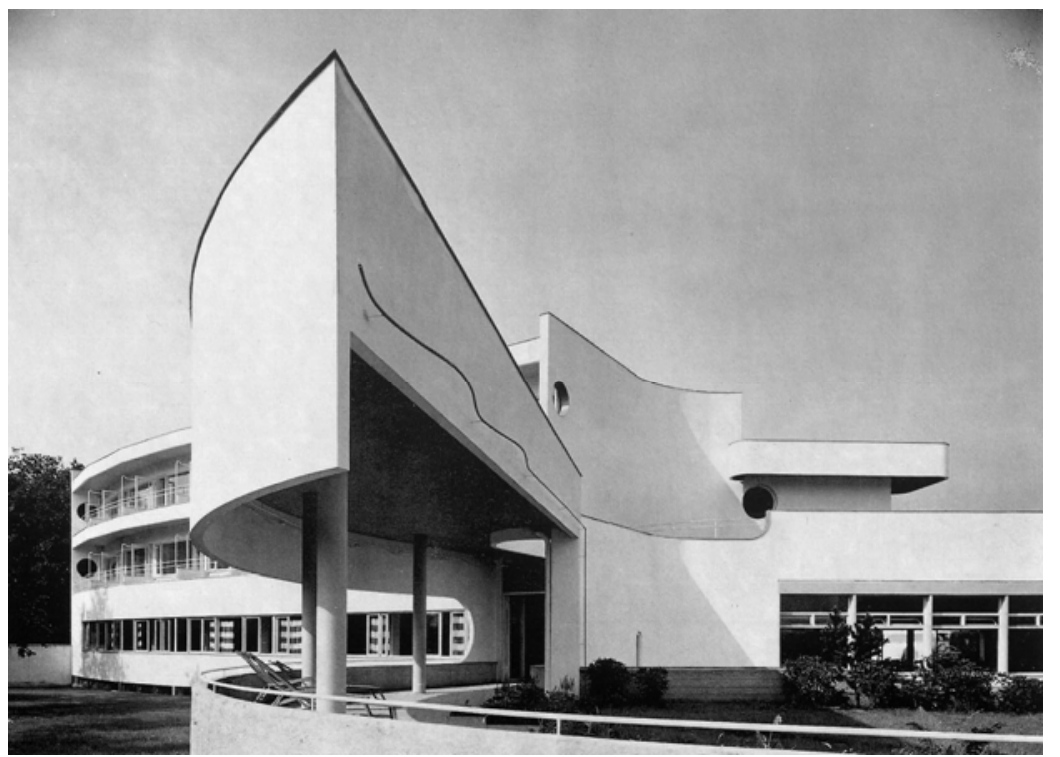

[86] Apartamentos para Solteiros e Recém Casados na "Wohnung und Wekraum" da Exposição Werkbund, Vratislávia, 1929. Arquiteto Hans Scharoum. Fachada principal.

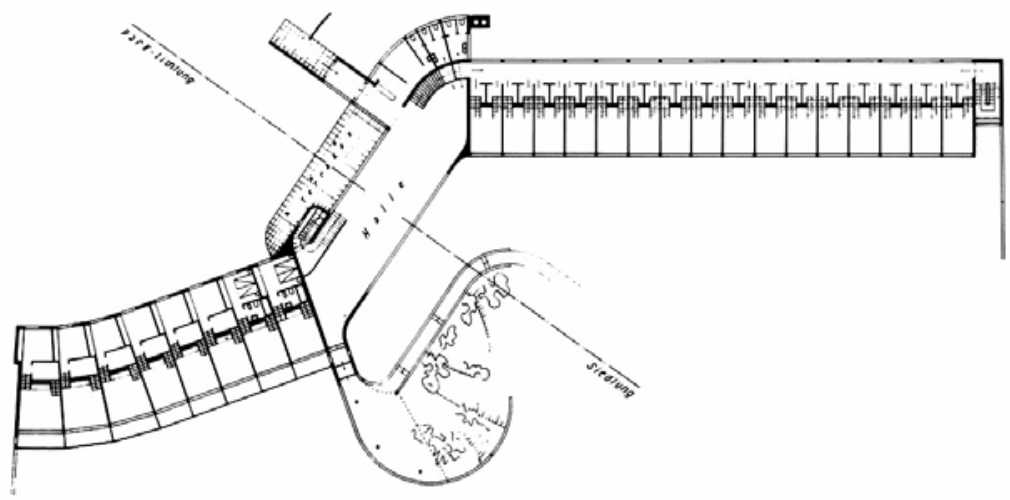

[87]

Apartamentos para

Solteiros e Recém Casados

na "Wohnung und

Wekraum" da Exposição

Werkbund, Vratislávia,

1929. Arquiteto Hans

Scharoum. Planta.

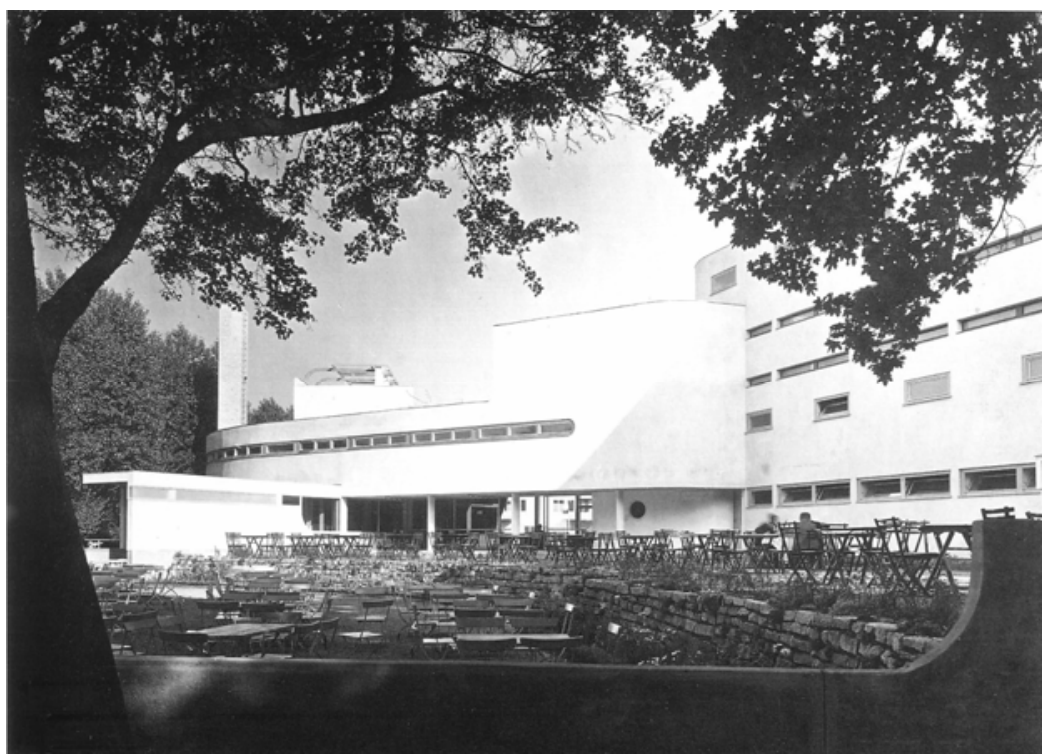

[88] Apartamentos para Solteiros e Recém Casados na "Wohnung und Wekraum” da Exposição Werkbund, Vratislávia, 1929. Arquiteto Hans Scharoum. Vista do pátio. 
Ainda pela biblioteca de Rino Levi, sabemos que ele conheceu as experiências holandesas. Em Amsterdan, em 1914, F. M. Wibaut - um membro do Partido dos Trabalhadores Sociais-Democratas - tornouse conselheiro da habitação e conseguiu ampliar bastante o alcance da construção urbana. Nos anos 20, o Schoonheidscommissie - um comitê que apreciava o valor artístico dos edifícios na propriedade urbana - era composto, em grande parte, por jovens arquitetos da Escola de Amsterdan, cujos ateliês receberam grandes encomendas e, dessa maneira, puderam trazer novas idéias ao ramo da construção de habitações.

Nesse contexto, temos a primeira experiência executada com elementos pré-fabricados em concreto, a Cidade-Jardim de Watergraafsmeer $^{61}$, da qual participam vários desses jovens arquitetos. Apesar do nome, a referência ao modelo de cidade-jardim inglesa se restringe à organização comunitária do conjunto, e não à sua espacialidade. O bairro, mais tarde, ficou conhecido como Betondorp (Aldeia de Concreto), apesar de fotos antigas - mostrando as casas em construção, ainda sem estuque - revelarem que isso não significava uma construção de lajes, mas sim uma alvenaria de blocos de concreto. De qualquer maneira, o nome Betondorp foi inspirado pelo contraste entre esse material e os outros usados nas construções de Amsterdam, na época.

O partido geral adotado no bairro é semelhante ao adotado nas experiências alemãs: lâminas acentuadamente horizontais, de casas geminadas, com raciocínio diferente nas extremidades para marcar a entrada no quarteirão, destinada a pequenas lojas que suprissem as necessidades cotidianas. É o que faz W. Greve[89] ${ }^{62}$ na sua proposta para a cidade-jardim. Aqui, Greve usa diferença no gabarito, volumes

61 Cidade-Jardim de Watergraafsmeer, Amsterdam, 1922-1926. Arquitetos vários da Escola de Amsterdam.

${ }^{62}$ Casas na Cidade-Jardim de Watergraafsmeer, Amsdertan, 1923-1925. Arquiteto W. Greve. 
salientes, mudança de cor e o elemento mais marcante, rusticagem na platibanda, para marcar a entrada.

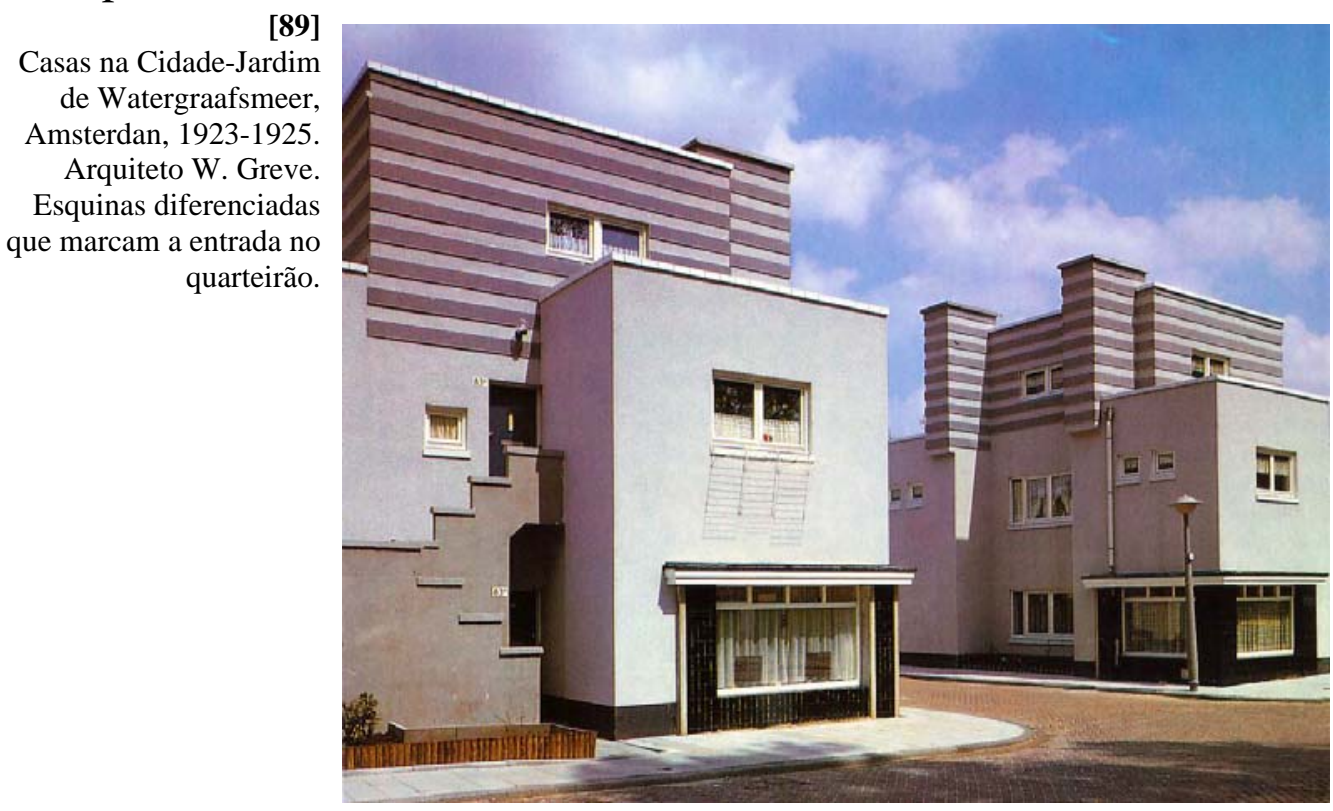

O Centro da Comunidade $[\mathbf{9 0}]^{63}$ na cidade-jardim também é objeto de projeto específico do arquiteto Dick Greiner. Na sua proposta, Greiner movimenta de tal maneira os volumes, e em tantas direções, que quase anula sua massa, transformando-os em planos. Isso o aproxima dos arquitetos, seus conterrâneos, do grupo De Stijl, mas sem a sua radicalidade. Formado na Holanda, em 1917, o grupo tinha como meta criar o estilo válido para a nova consciência da época, que substituísse o individual pelo universal.

\footnotetext{
${ }^{63}$ Centro da Comunidade na Cidade-Jardim de Watergraafsmeer, Amsterdan, 1922-1926. Arquiteto Dick Greiner.
} 


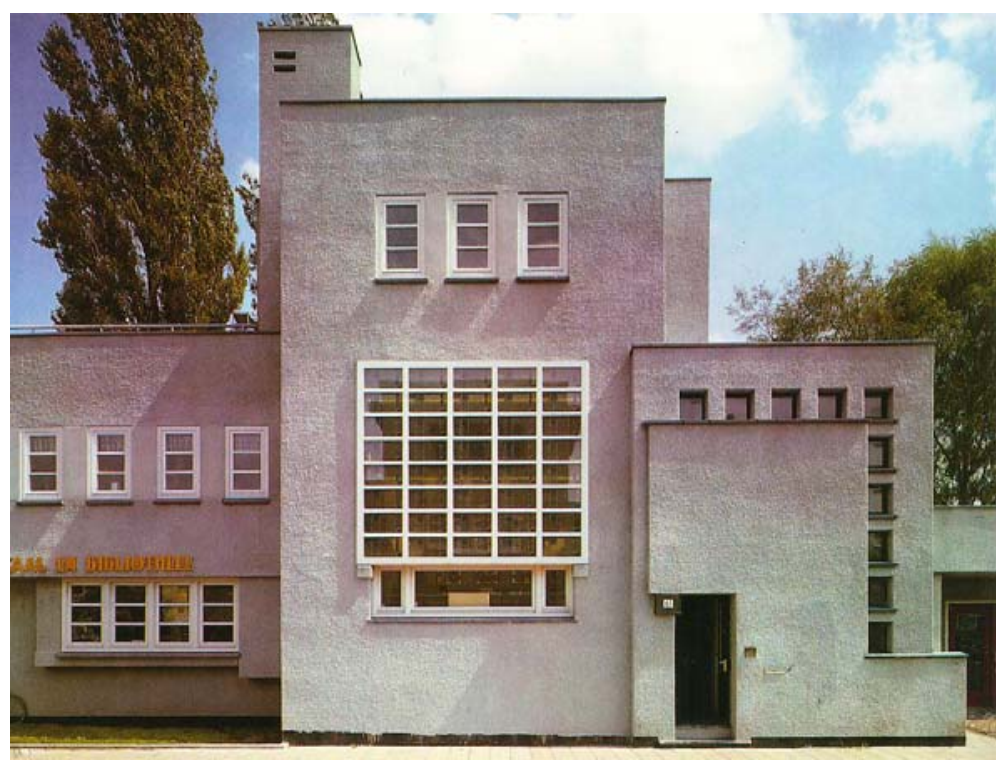

[90]

Centro da Comunidade na

Cidade-Jardim de

Watergraafsmeer,

Amsdertã, 1922-1926.

Arquiteto Dick Greiner.

Fachada principal.

$\mathrm{Na}$ pintura, isso significou o repúdio rigoroso a toda e qualquer referência representativa, incluindo assim o Cubismo e o Purismo. A natureza era demasiado material, demasiado individual. Só a arte universal permitia a composição abstrata, como um equilíbrio da posição e peso da cor. Os quadros do pintor mais importante do grupo, Piet Mondrian, reduziram-se a linhas retas pretas em combinação retangulares, juntamente a planos das cores primárias, vermelho, azul e amarelo, suportados por muito branco e um pouco de cinzento.

\section{$\mathrm{Na}$ arquitetura, isso significou a distribuição calculada de massas desiguais num sistema que aniquilasse os contornos cerrados dos corpos volumétricos. Em 1918, Jacobus Johannes Piet Oud ${ }^{64}$, um dos}

\footnotetext{
${ }^{64}$ Jacobus Johannes Pieter Oud (1890-1963) frequentou a Escola de Artes Aplicadas Quellinus, em Amsterdam, tendo entrado a seguir para o atelier de Petrus J. H. Cuypers, na mesma cidade. Depois, completou a sua instrução na Escola Estatal de desenho, em Amsterdan, e na Universidade Técnica, em Delft. Encorajado por Hendrik Petrus Berlage, trabalhou com Theodor Fischer, em Munique, antes de se estabelecer, em 1912, como arquiteto autônomo, em Purmerend, e, mais tarde, em Leida. Com o seu amigo, o artista e arquiteto Theo van Doesburg, projetou a Casa Geus, em 1916, e fundou a associação De Sphinx. Em 1917, os dois tornaram-se co-fundadores, com Piet Mondrian, Vilmos Huszar e Antony Kok, do famoso grupo de artistas e revista De Stijl, que, no entanto, Oud abandonou em 1920, depois de diferenças de opinião com Van Doesburg. Tentativas para pôr em prática a teoria de De Stijl foram, por exemplo, a urbanização em terraço para Scheninegen (1917) e o café De Unie, em Roterdâ (1924/25), onde a superfície da fachada era tratada como um desenho gráfico pintado nas cores primárias e vivas de vermelho, amarelo e azul, além de preto e branco. Em 1918, Oud tornou-se urbanista de Roterdan e construiu grandes bairros, como o projeto Oud-Mathenesse, com 343 apartamentos, a urbanização De Kiefhoek, e o complexo de apartamentos em Hoek van Holland (1924-1927). As suas casas em terraço, no bairro de Weissenhof, em Stuttgart (1927), foram frequentemente elogiadas por especialistas, devido à sua construção sólida. Daí em diante, Oud fez muito pouco. Declinou uma cátedra em Harvard que, mais
} 
fundadores do De Stijl, descrevia o papel desempenhado por Frank Lloyd Wright e as idéias na destruição da caixa: Wright lançou as bases para uma plasticidade arquitetônica nova. As massas arremessavam-se em todas as direções, para a frente, para trás, para a direita, para a esquerda... Deste modo, a arquitetura moderna vai se aperfeiçoar cada vez mais, num processo de redução a proporções positivas, comparáveis à da pintura moderna.

O Café De Unie[91 ${ }^{65}$ que J.J.P.Oud realiza em 1924/25, em Roterdam, é a materialização desses princípios. A fachada, apertada entre dois blocos sólidos da arquitetura historicista, demonstrava a provocação que devia constituir, sem nenhuma conformidade com os edifícios adjacentes. Segundo Oud, parece melhor ver o café como um corpo autônomo e tentar estabelecer a validade, tanto daquele como daquilo que o rodeia, através de contrastes lógicos. Ainda segundo Oud, foi-lhe ensinado - e não só pelos ultramodernos - que apenas o que brota organicamente da essência da época pode coexistir com o que brotou da essência de outra época.

tarde, foi aceita por Walter Gropius. Após um período longo sem encomendas, Oud construiu o Edifício da Companhia Shell, em Haia (1938-1942), mas a limpidez dos desenhos anteriores desaparecera. Os seus últimos trabalhos abrangem o Lar para Crianças Convalescentes, em Arnheim (1952-1960). Em 1954, Oud recebeu um grau honorário de doutoramento atribuído pela Universidade Técnica de Delf.

${ }^{65}$ Café De Unie, Roterdam, 1924/25. Arquiteto Jacobus Johannes Pieter Oud. 


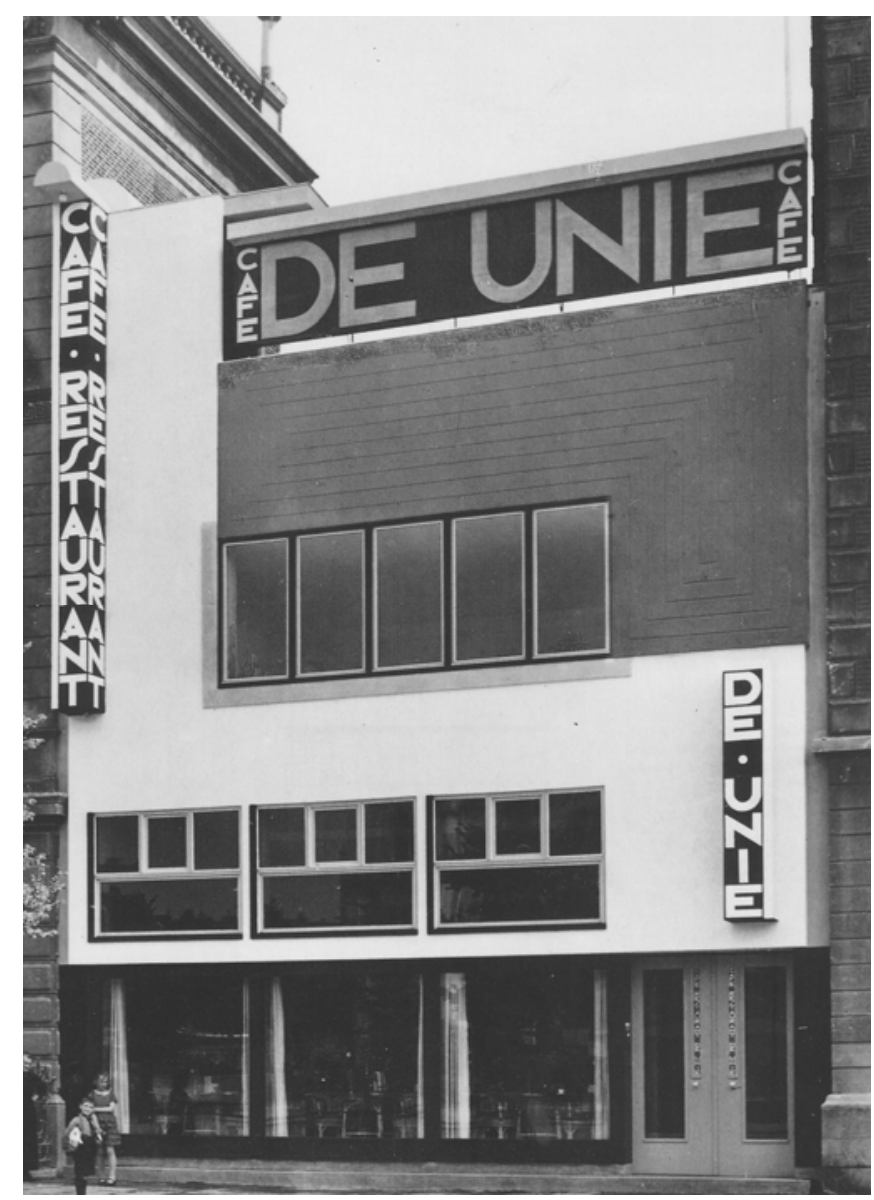

[91] Café De Unie, Roterdam, 1924/25. Arquiteto Jacobus Johannes Pieter Oud. Vista da fachada para a rua.

Também em 1918, J.J.P.Oud torna-se arquiteto do município de Roterdam e constrói grandes bairros. Surpreendentemente, neles não veremos o que se esperaria de um membro do grupo em questão. $\mathrm{O}$ Complexo Habitacional de Spangen [92 ${ }^{66}$, com cinco blocos, num total de 350 apartamentos, está muito mais próximo dos bairros vistos até agora do que do seu próprio café. Spangen ocasionou, inclusive, o rompimento entre ele e Theo van Doesburg, quando este apresentou um esquema de cores para o complexo habitacional que foi rejeitado por Oud.

\footnotetext{
${ }^{66}$ Complexo Habitacional de Spangen, Roterdan, 1919. Arquiteto Jacobus Johannes Pieter Oud.
} 


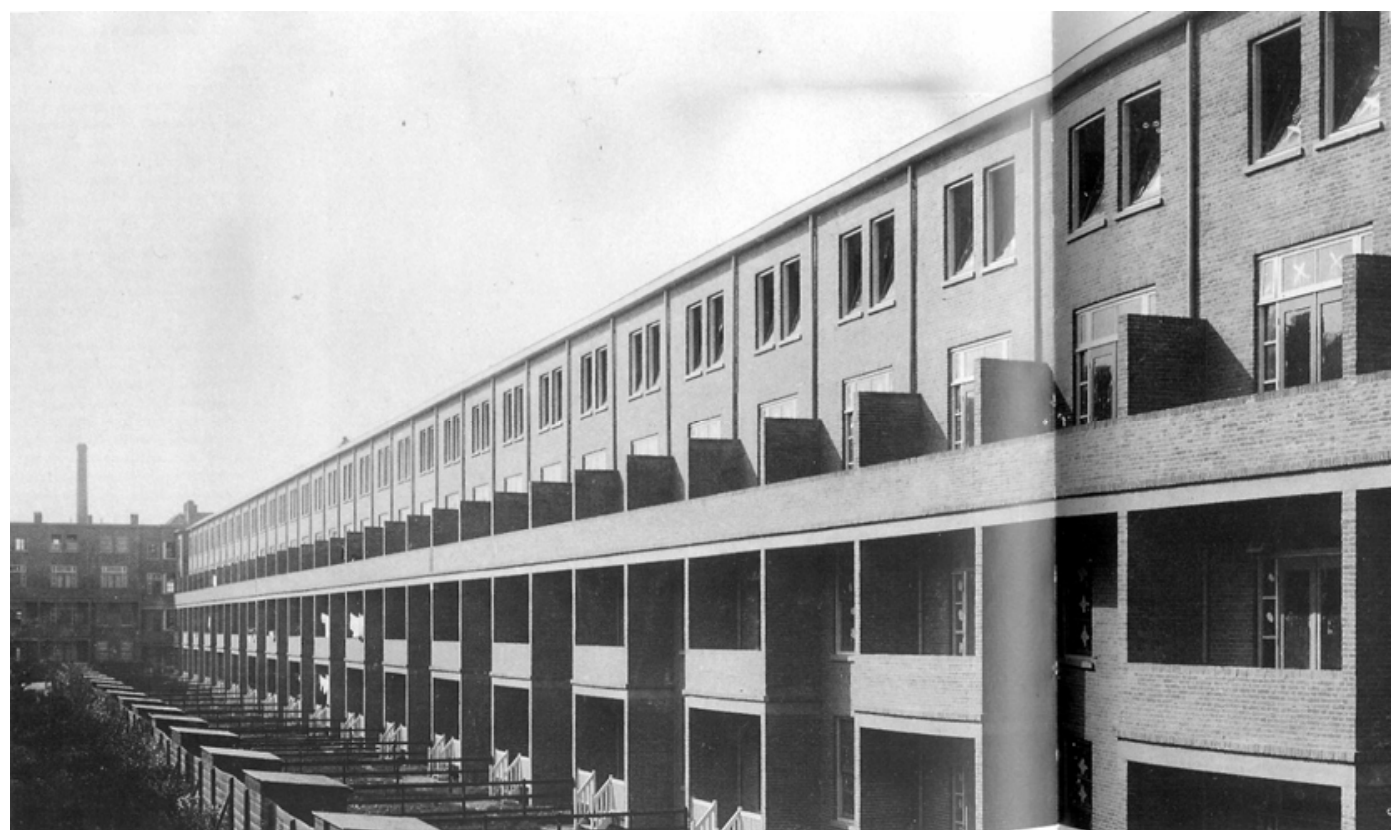

[92] Complexo Habitacional de Spangen, Roterdam, 1919. Arquiteto Jacobus Johannes Pieter Oud. Vista da fachada posterior do bloco 8.

A opção de J.J.P.Oud por lâminas mais uniformes para os grandes conjuntos se confirmaria no Complexo Habitacional em Hoek van Holland $[93]^{67}$. Aqui também, o que se vê é uma lâmina de casas planas, acentuadamente horizontal, com uma conclusão dinâmica nas extremidades arredondadas, mais uma vez destinadas ao comércio cotidiano.

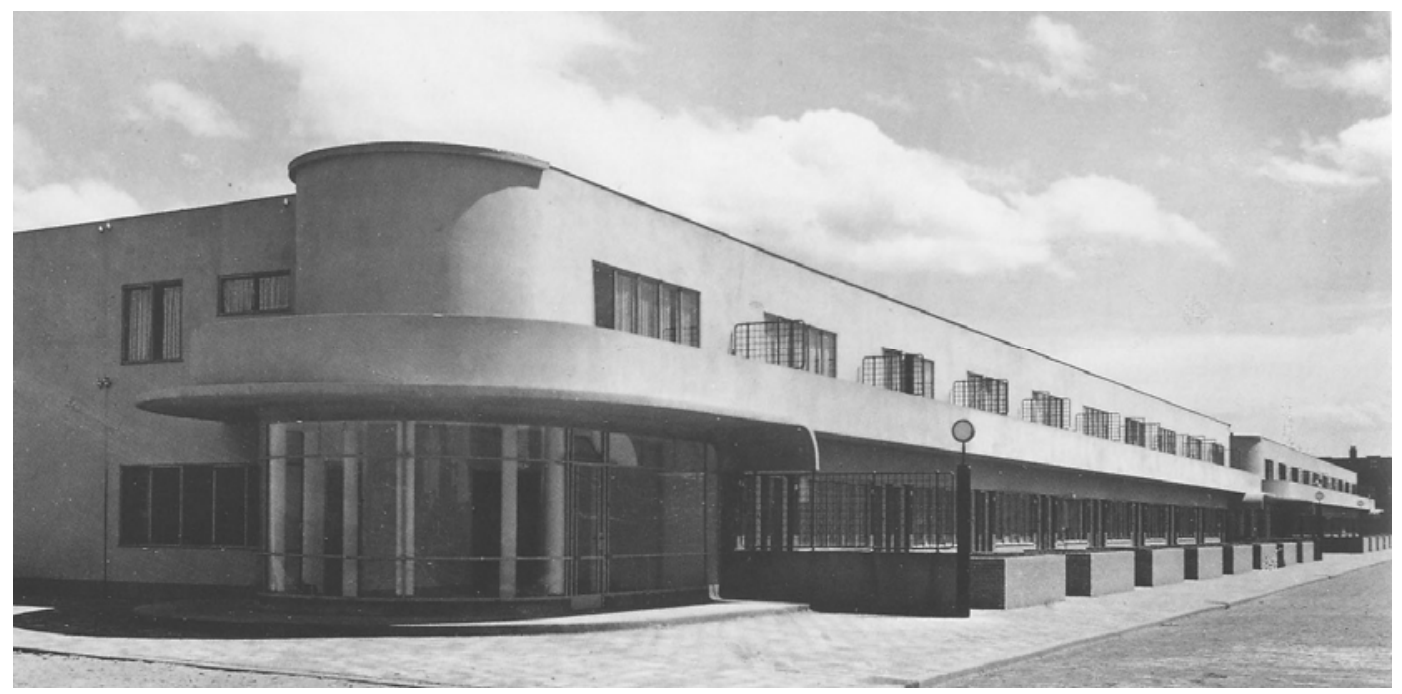

[93] Complexo Habitacional em Hoek van Holland, 1924-1927. Arquiteto Jacobus Johannes Pieter Oud. Esquinas diferenciadas que marcam a entrada do quarteirão.

${ }^{67}$ Complexo Habitacional em Hoek van Holland, 1924-1927. Arquiteto Jacobus Johannes Pieter Oud. 
A seleção apresentada até agora das vanguardas européias tem dois critérios. O primeiro, obviamente, é pertencer à biblioteca de Rino Levi. O segundo, menos óbvio, é que o conjunto mostrado, foi - muito possivelmente - referência para Levi, dada às semelhanças percebidas nos procedimentos adotados.

Já a obra de Le Corbusier não apresenta, tão claramente, rebatimento no trabalho de Levi deste período, como veremos a seguir. A proposta de Corbusier para o Bairro Weissenhof $[94]^{68}$ mostra como diferentemente do que vínhamos observando - a questão deixa de ser a movimentação de volumes e passa a ser a suspensão da forma geométrica pura. Embora ainda não plenamente realizados, vemos a orientação do projeto segundo o programa dos cinco pontos da arquitetura moderna: estrutura independente da elevação - o ponto primordial, que garante a viabilidade dos outros quatro - pilotis, terraço-jardim, planta livre e fachada livre ou janela horizontal.

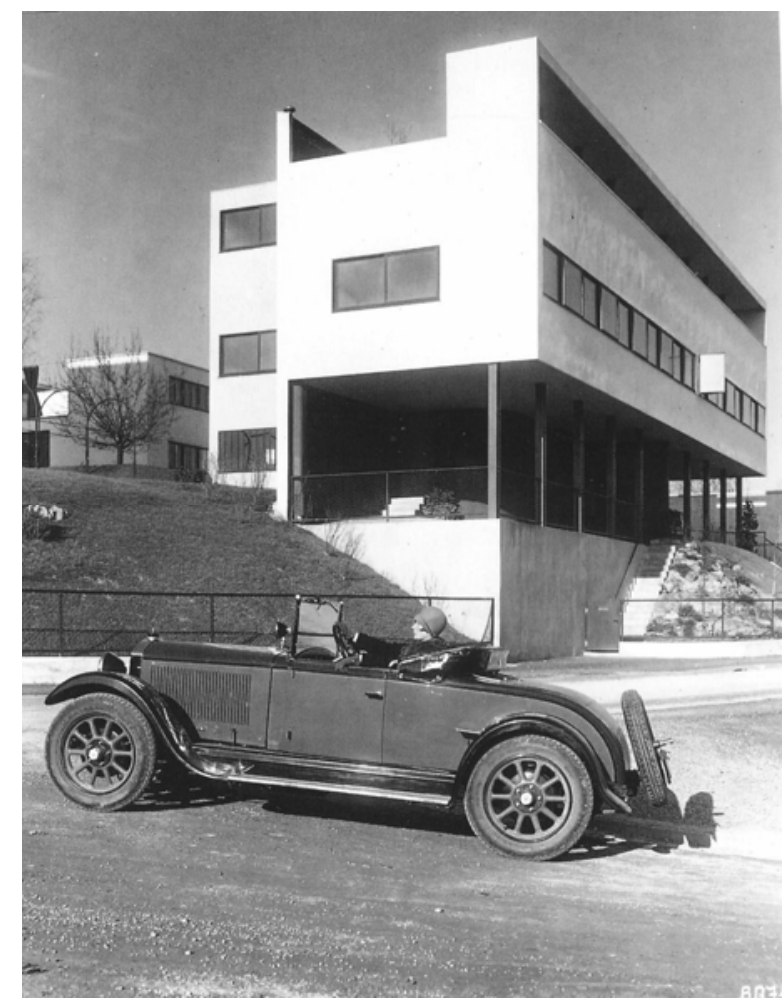

[[94] Casas 14/15

no Bairro

Weissenhof,

Stuttgard, 1927

Arquitetos Le

Corbusier e Pierre

Jeanneret. Vista

para a rua.

${ }^{68}$ Casas 14/15 no Bairro Weissenhof, Stuttgard, 1927. Arquitetos Le Corbusier e Pierre Jeanneret. 
O programa dos cinco pontos de Le Corbusier é exercitado numa série de vilas e pequenos conjuntos, ao longo da década de 20 . $\mathrm{O}$ primeiro que se destaca é o Quartiers Modernes Frugès ${ }^{69}$, Bairro em Bordeaux-Pessac, 1925. Nele, o industrial M. Frugès autoriza que sejam "realizadas na prática suas teorias, até suas consequências mais extremas. Pessac deve ser um laboratório. Em uma palavra: peço que se coloque o problema da planificação da habitação, que se encontre a standartização adequada, usando paredes, solos, teto, servindo a uma verdadeira taylorização mediante o emprego de máquinas que os autoriza a adquirir." ${ }^{\circ}$

O bairro de Pessac foi construído em menos de um ano, e foi concebido a partir do concreto armado. O objetivo era a economia, para a qual se equacionou toda a estrutura do conjunto a partir de uma única viga de $5 \mathrm{~m}$, com diferentes tipos de casas. Num deles, mais alto[95], vemos a experimentação dos cinco pontos, ainda que não tenhamos o emprego pleno dos pilotis. De qualquer maneira, examinando as plantas do tipo[96] podemos constatar que o térreo consiste apenas numa garagem, o acesso e um tipo de abrigo que percorre toda a largura da casa. A cozinha e sala de estar ficam no primeiro andar, os quartos no segundo e na cobertura temos o terraço-jardim. O mesmo raciocínio está presente em tipo mais baixo[97].

\footnotetext{
69 “Quartiers Modernes Frugès-Pessac”, bairro em Bordeaux-Pessac, 1925. Arquitetos Le Corbusier e Pierre Jeanneret.

${ }^{70}$ M. Frugès, apud BOESIGER, Willy.Le corbusier.Barcelona, Editorial Gustavo Gilli, 1992.
} 


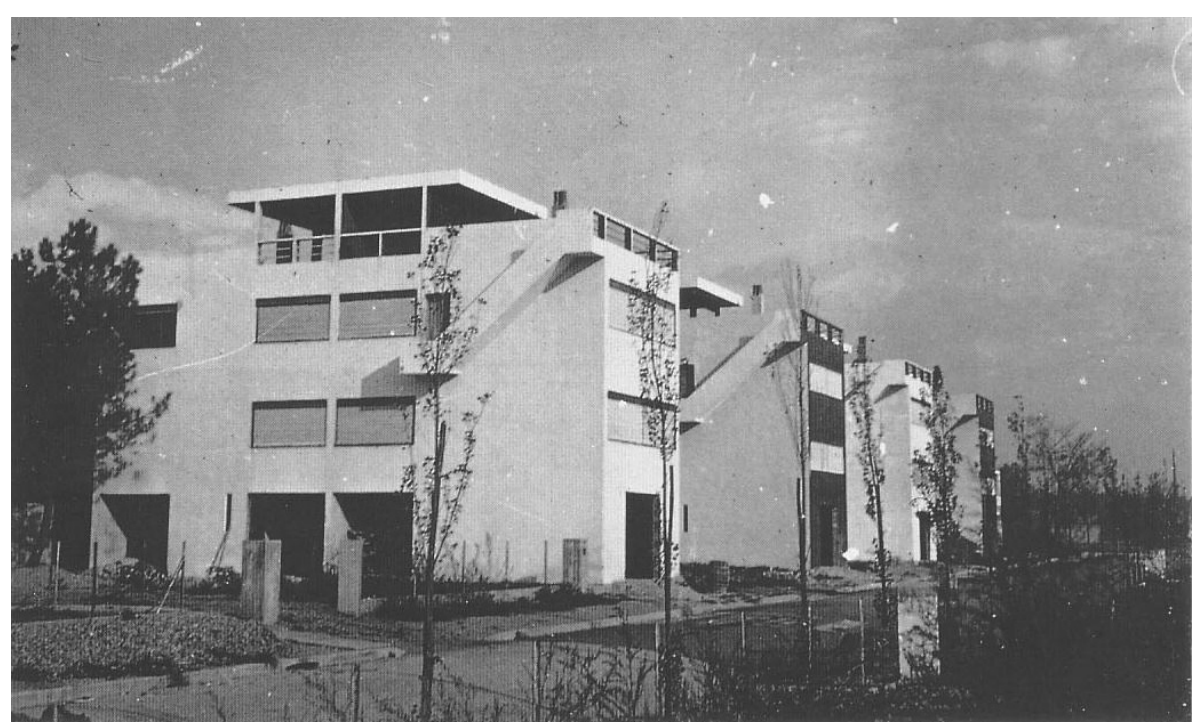

[95] "Quartiers

Modernes Frugès”,

Bairro em

Bordeaux-Pessac,

1925. Arquitetos

Le Corbusier e

Pierre Jeanneret.

Vista das casas

geminadas gratteciel..
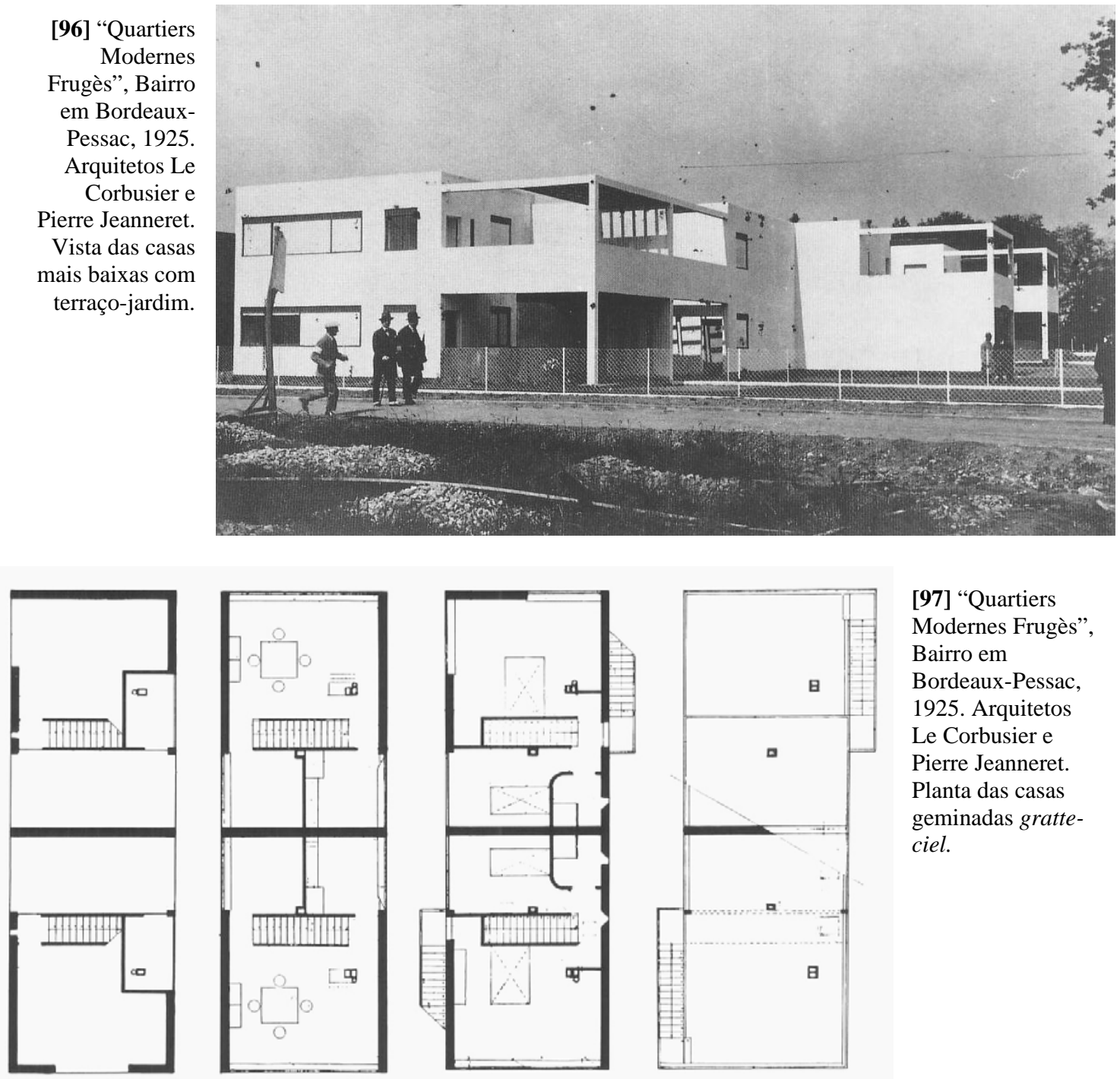

[97] "Quartiers

Modernes Frugès”,

Bairro em

Bordeaux-Pessac, 1925. Arquitetos Le Corbusier e Pierre Jeanneret.

Planta das casas geminadas gratteciel. 
Contemporânea à experiência de Weissenhof é a Vila Stein $[\mathbf{9 8}]^{71}$, em Garches, 1927. O princípio dos pilotis ainda não chegou a sua forma acabada, diferentemente da fachada - com suas janelas horizontais e da planta que tornaram-se livres. Le Corbusier abandona o uso de pisos intermediários, organizando as plantas em torno de espaços verticalmente contínuos de dois e até três níveis.

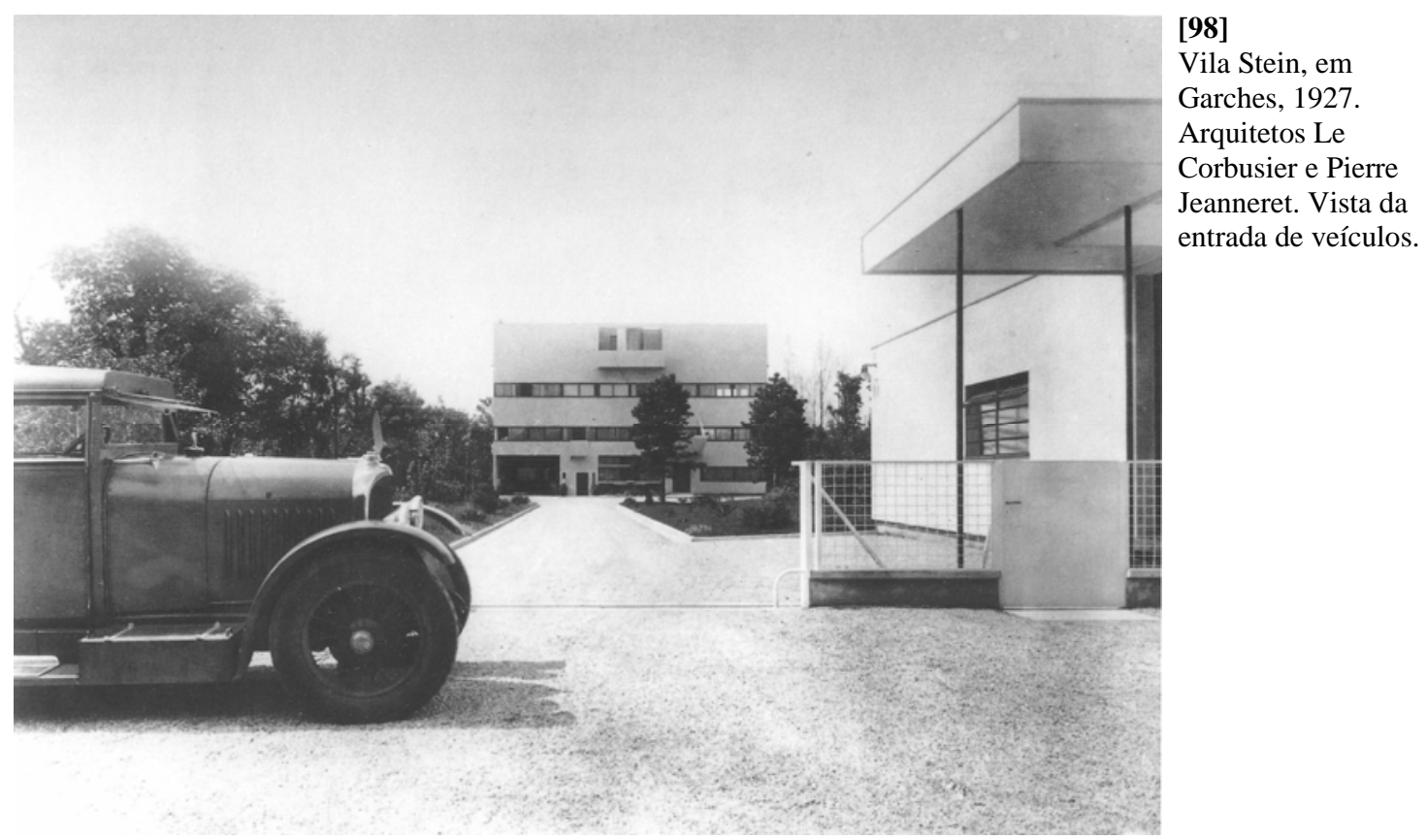

O exemplo do programa de cinco pontos levado às últimas consequências é a Vila Savoye[99] ${ }^{72}$, em Poissy, 1929/31. Nela percebemos todo o alcance desse raciocínio: os pilotis[10o] elevando totalmente o volume do chão e liberando a circulação demonstram seu caráter urbanístico, apesar do projeto ser realizado no campo,. As plantas[101], agora completamente livres, têm as escadas associadas às rampas, criando as promenades arquitetônicas. O terraço-jardim, ampliado, tem aberturas que enquadram a paisagem, ao mesmo tempo em que mantém o volume[102].

\footnotetext{
${ }^{71}$ Vila Stein, em Garches, 1927. Aequitetos Le Corbusier e Pierre Jeanneret.

${ }^{72}$ Vila Savoye, em Poissy, 1929/31. Arquitetos Le Corbusier e Pierre Jeanneret.
} 


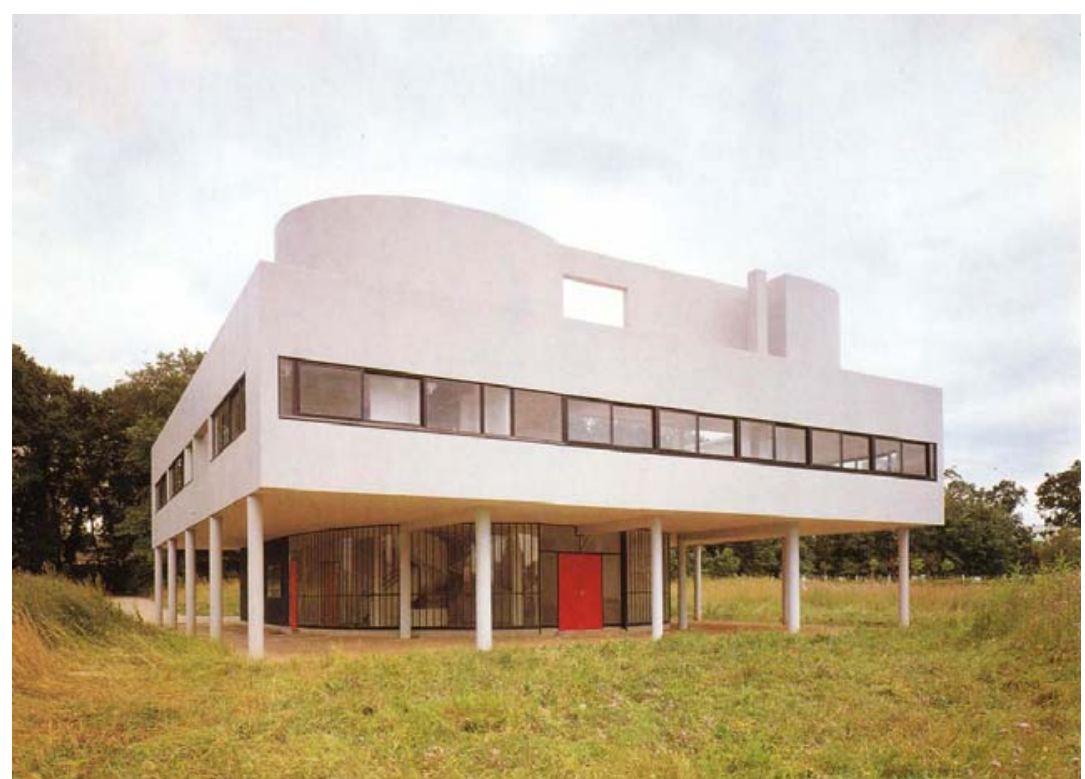

[99] Vila Savoye, em Poissy, 1929/31. Arquitetos Le Corbusier e Pierre Jeanneret. Vista fachada norte.

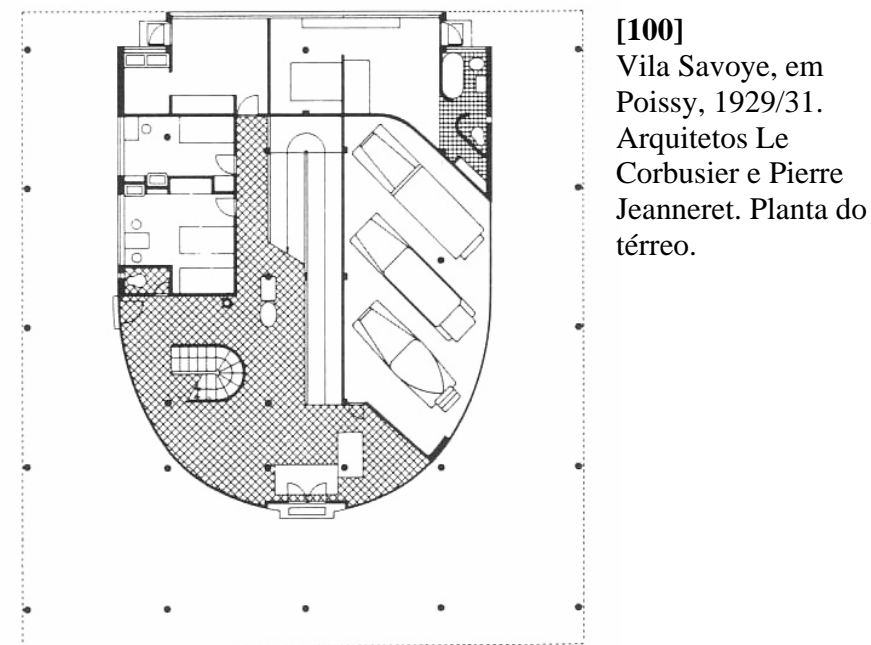




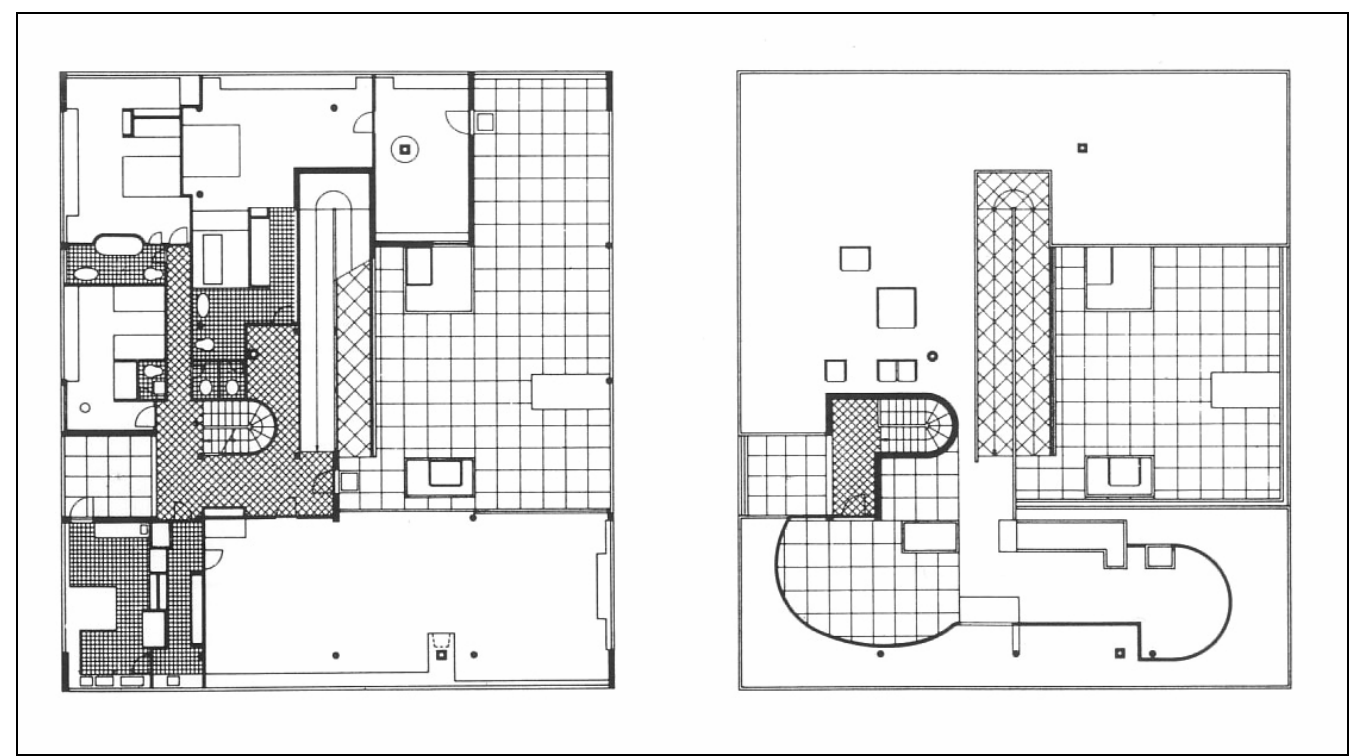

[101] Vila Savoye, em Poissy, 1929/31. Arquitetos Le Corbusier e Pierre Jeanneret. Plantas $1^{\text {o }}$ andar e terraço-jardim.

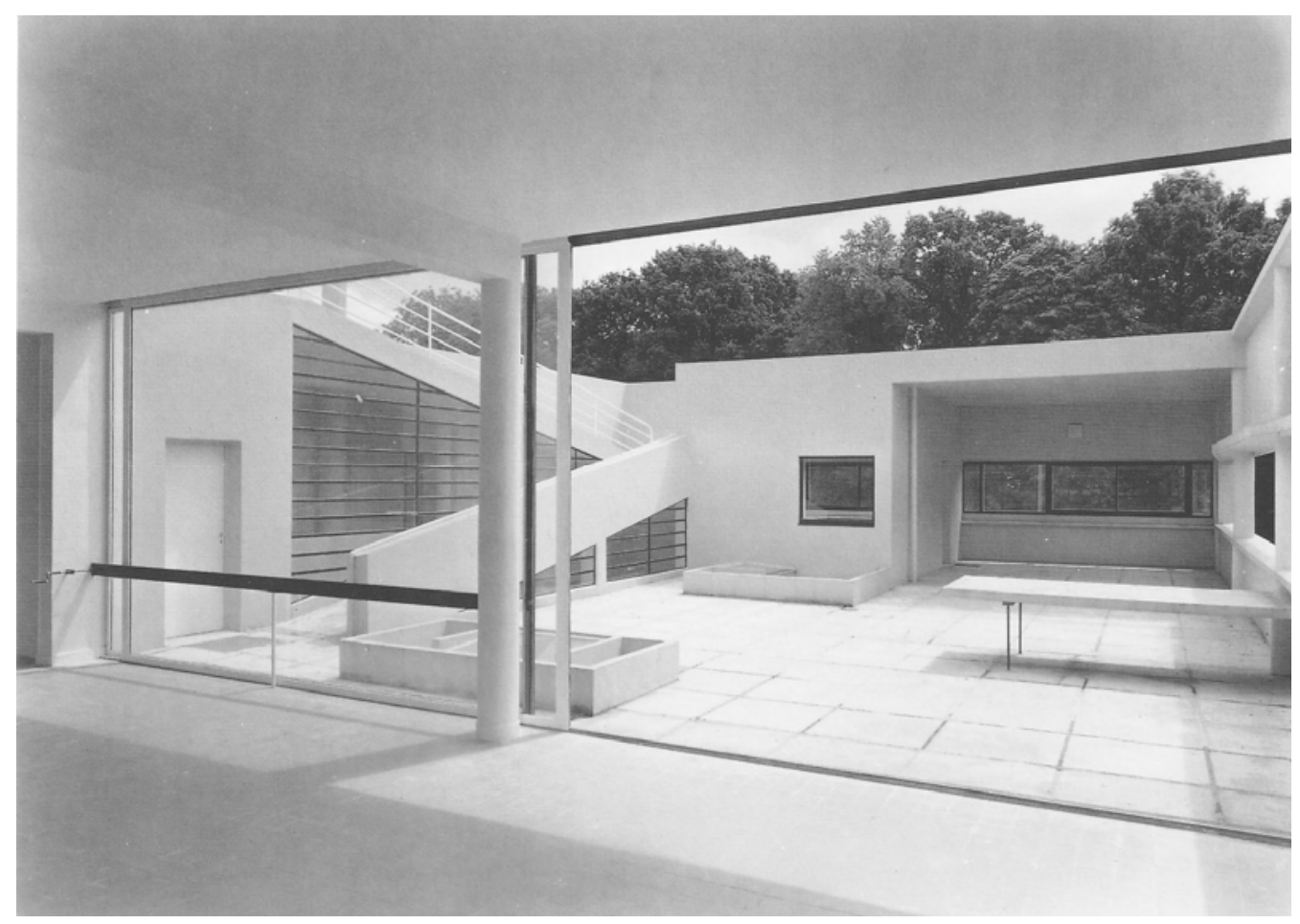

[102] Vila Savoye, em Poissy, 1929/31. Arquitetos Le Corbusier e Pierre Jeanneret. Vista $1^{\circ}$ andar com rampa que leva ao terraço-jardim.

Dessa maneira, para Le Corbusier, a única base concebível para uma arquitetura que correspondesse ao mundo exato das máquinas era a geometria: prismas, cubos, cilindros, pirâmides e esferas como "volumes puros". Esses, jamais serão rompidos, nem mesmo movimentados. Daí a afirmação de que, exceto no "conjunto para 
Regina Previdelli”, o repertório corbusiano não é importante para a produção de Rino Levi no período examinado.

O mesmo acontece com as vanguardas italianas. Delas, o nome mais importante é Giuseppe Terragni ${ }^{73}$. Colega mais novo de Rino Levi na Politécnica de Milão, é um dos fundadores do chamado Gruppo 7, em 1926 e, mais tarde, em 1928, adere ao MIAR - Movimento Italiano per l'Architettura Razionale. O Gruppo 7 tentou fundamentar a sua arquitetura moderna no espírito da tradição; o MIAR quis, em primeiro momento, que o fascismo e a arquitetura moderna se ajustassem.

Nas teses do Gruppo 7, promulgadas nos anos 1926/27, temos afirmações do tipo "o apanágio das vanguardas era um arrebatamento artificioso, uma fúria vã de destruição (...). Em nós existe um tal substrato clássico, o espírito da tradição é tão profundo (...) que evidentemente e quase mecanicamente a nova arquitetura não poderá deixar de conservar uma marca tipicamente nossa". ${ }^{74}$ Terragni, dos sete signatários destas teses, é o único a avisar do perigo do retorno aos preceitos acadêmicos. Não se satisfaz, portanto, com as indicações

\footnotetext{
${ }^{73}$ Giuseppe Terragni (1904-1943) depois de terminar o curso da Escola Técnica, em Como, Terragni frequentou a Politécnica de Milão e, em 1927, abriu um escritório com o irmão Attilio, em Como. Juntamente com Luigi Figini, Gino Pollini, Sebastiano Larco, Ubaldo Castagnoli, Guido Frette e Carlo Enrico Rava, fundou o Grupo dos 7, que exigia uma abordagem contemporânea e racional à arquitetura italiana. No mesmo ano, na Bienal em Monza, Terragni expunha o seu projeto, muitíssimo elogiado, de uma fábrica de gás. Apesar do academicismo e da forte resistência de opositores como Marcello Piacnetini, Rerragni conseguiu que se construíssem em Como (1927/28) seus Apartamentos Novocomum, um edifício rigorosamente retilíneo, em que os andares intermediários possuem esquinas arredondadas com segmentos de vidro. Em 1928 aderiu ao MIAR ( Movimento Italiano per l'Architettura Razionale). Geralmente considera-se que a sua melhor obra foi o Edifício do Partido Facista ( a Casa del Fascio), em Como (1932-1936): um prisma de mármore branco em cuja fachada geométrica conseguiu efeitos espetaculares de luz e sombra. Para a primeira Trienal de Milão, Terragni, com outros arquitetos, construiu o Estúdio dos Artistas à Beira do Lago, em 1933. em 1936 construiu o jardim infantil Antonio SantÉlia, em Como, e, em 1936 e 2937, a Vila Bianca, em Seveso, enquanto trabalhava simultaneamente com Pietro Lingeri no projeto para a Danteum, em Roma. Para a cidade de Lissone, iria mais tarde construir, em 1938, uma outra Casa do Partido Facista, em colaboração com Antonio Carminati. A Vila Frigerio, em Como (1939-1940), é considerada a última obra mais importante de Terragni.

${ }^{74}$ Guppo 7, teses publicadas em A revista italiana, citado por ZEVI, Bruno. Giuseppe Terragni. Barcelona, Editorial Gustavo Gilli, 1982, p. 15.
} 
dos mestres racionalistas; quer acrescentar elementos inquietos, de ruptura.

Segundo Zevi, comentando o edifício Apartamentos Novo comum ${ }^{75}$, em Como, 1927/28, "aos vinte e três anos, o gesto revolucionário, explosivo, levado a cabo ilegalmente, apresenta um projeto de cunho classicista e constrói, surpreendentemente, um edifício que se coloca dentro da vanguarda européia. Provoca um escândalo. A comissão de obras, sentindo-se ridicularizada, abre um inquérito para estabelecer se o Novocomum constitui um elemento de deturpação. Mas, a partir de então Terragni venceu a sua batalha pela nova arquitetura." ${ }^{76} \mathrm{~A}$ apresentação do projeto de cunho classicista[103] e a substituição pelo projeto moderno[103 $\mathrm{A}]$ repete a estratégia de Warchavchik com relação à casa da Rua Santa Cruz.

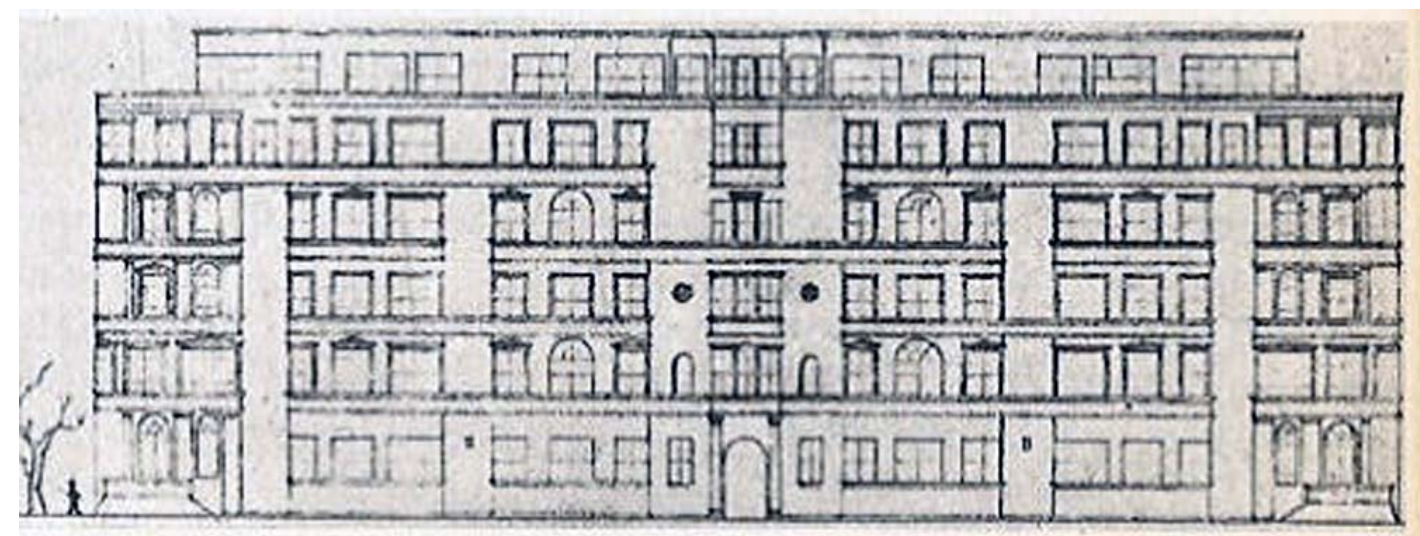

[103] Apartamentos Novocomum, Como, 1927/28. Arquiteto Giuseppe Terragni. O projeto apresentado à Comissão Técnica para aprovação.

\footnotetext{
${ }^{75}$ Apartamentos Novo comum, Como, 1927/28. Arquiteto Giuseppe Terragni.

${ }^{76}$ ZEVI, Bruno, op. cit., p. 26.
} 


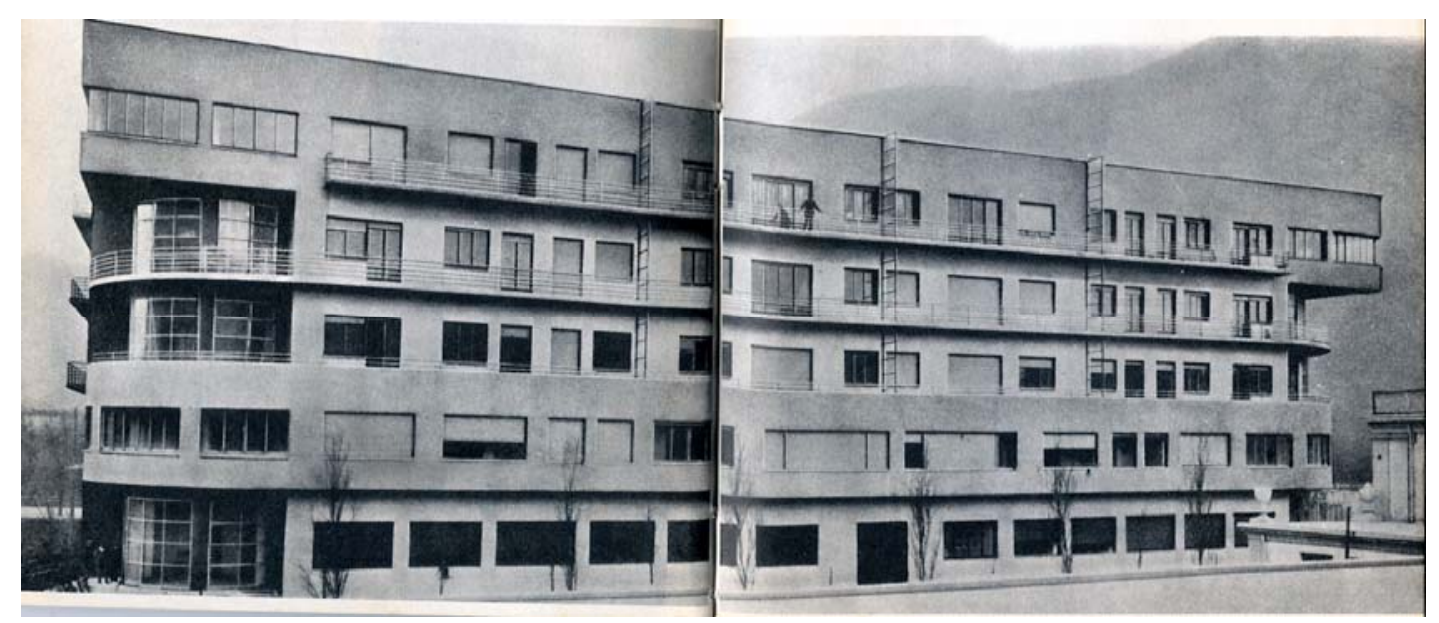

[103 A] Apartamentos Novocomum, Como, 1927/28. Arquiteto Giuseppe Terragni. Vista frontal.

Quanto ao Novocomum, numa primeira solução - da qual se conhece uma axonométrica[104] - um corpo semi-cilíndrico interrompia a horizontalidade do paralelepípedo, para depois sublinhar o seu vigor tridimensional expandindo-se no terraço superior. Numa segunda versão[105, 106, 107], esse corpo aparece eliminado para evitar uma planta simétrica da frente de 63,50 $\mathrm{m}$ de comprimento e, sobretudo, para privilegiar os ângulos escavados, onde se aninham cilindros de vidro que - em forma de dente no segundo andar - deixam o quinto suspenso no vazio. Segundo Zevi "neste período de criatividade impetuosa, Terragni não se contenta com os métodos racionalistas de Le Corbusier, Gropius, Mies e Oud. Fere a estereometria ainda que mordendo-lhe os cantos, isto é, os nós em que a fachada se move para conquistar, através de um não-finito a profundidade volumétrica." 77 É o que temos na vista lateral[108] com o cilindro de vidro dissolvendo a aresta, reposta no último andar.

${ }^{77}$ ZEVI, Bruno, op. cit., p.28. 


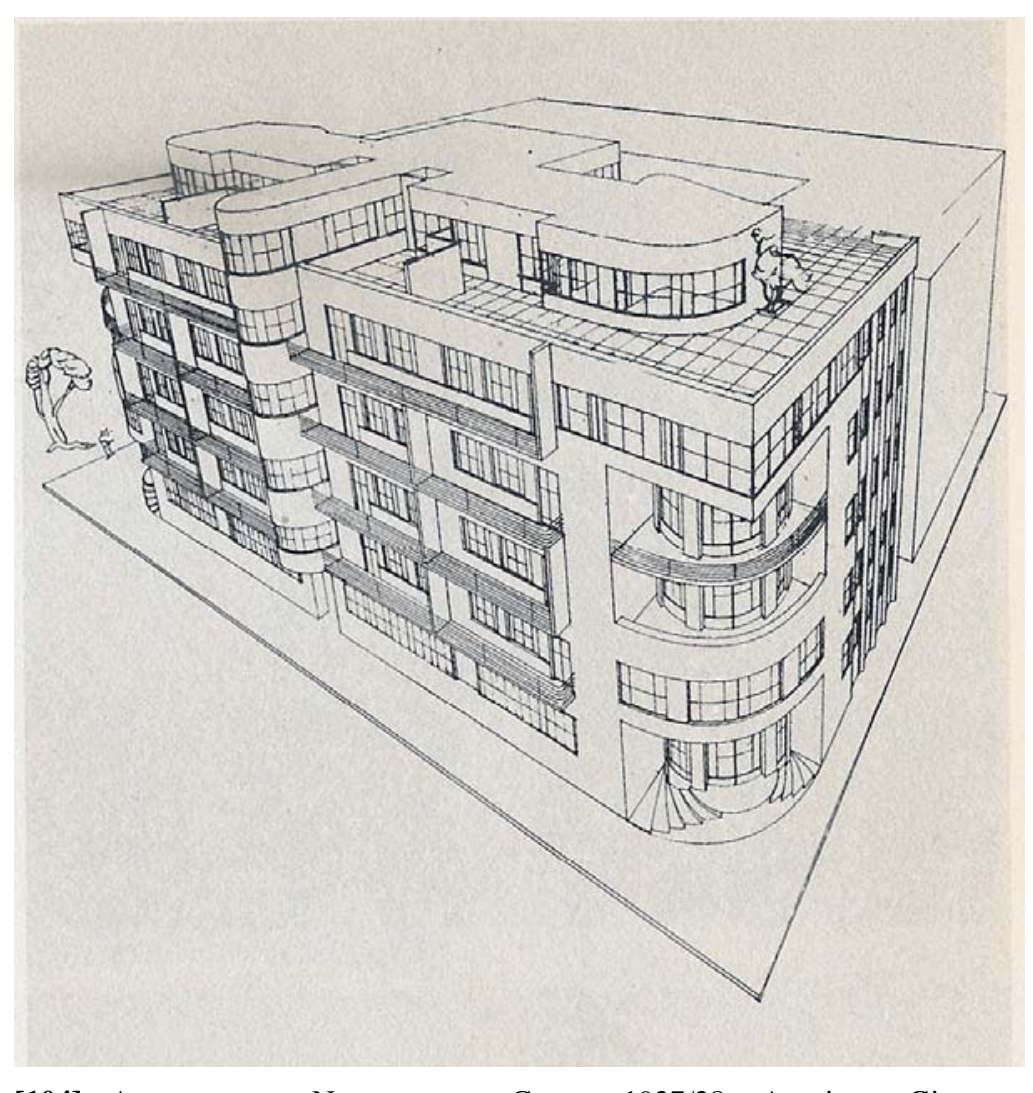

[104] Apartamentos Novocomum, Como, 1927/28. Arquiteto Giuseppe Terragni. Axonométrica: primeira solução com semi-cilindro central.

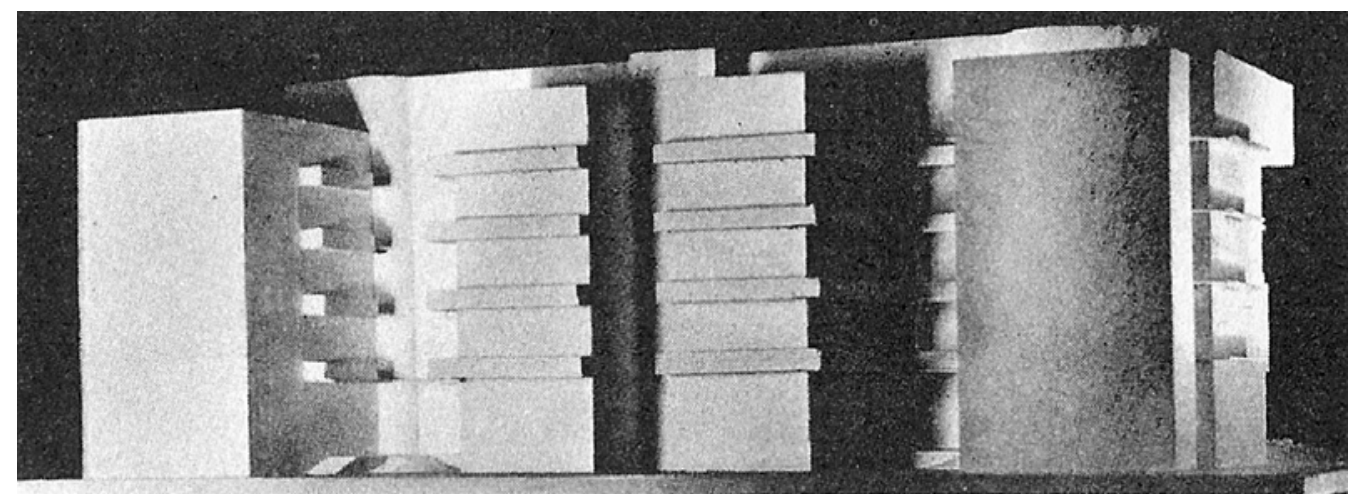

[105] Apartamentos Novocomum, Como, 1927/28. Arquiteto Giuseppe Terragni. Maquete solução intermediária, vista fachada posterior. 


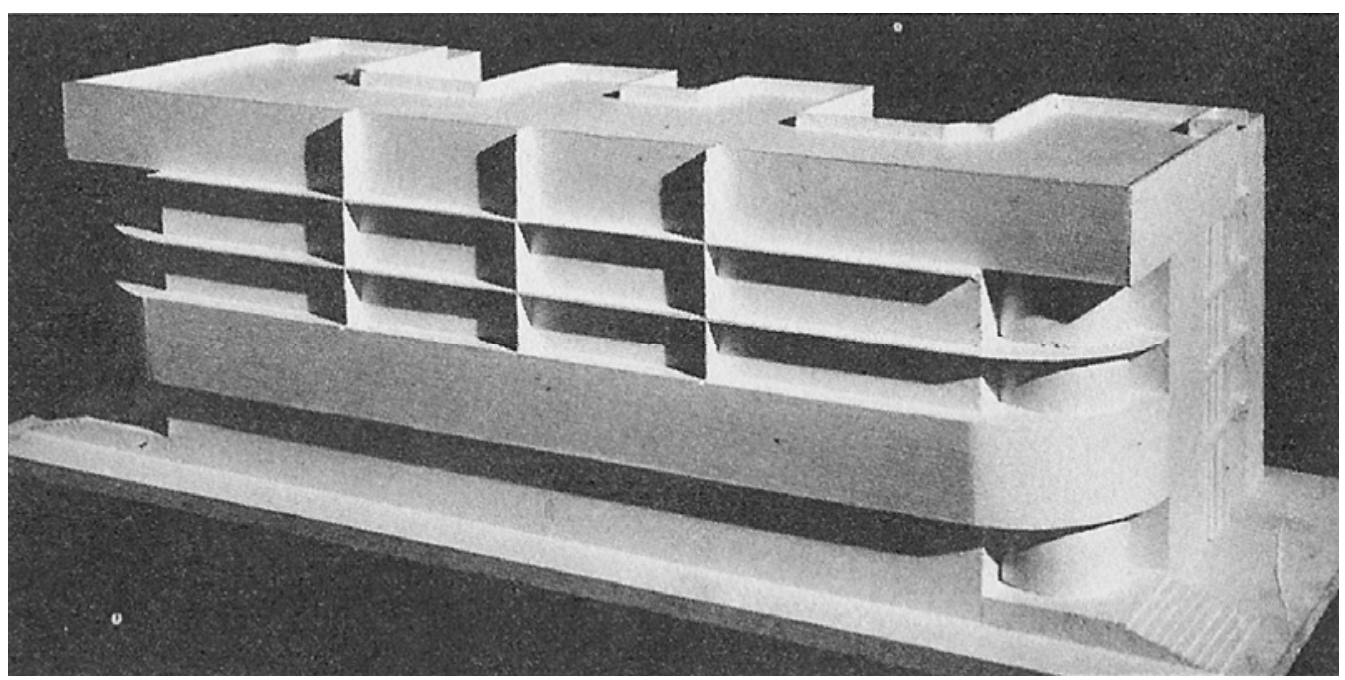

[106] Apartamentos Novocomum, Como, 1927/28. Arquiteto Giuseppe Terragni. Maquete solução intermediária, vista frontal.

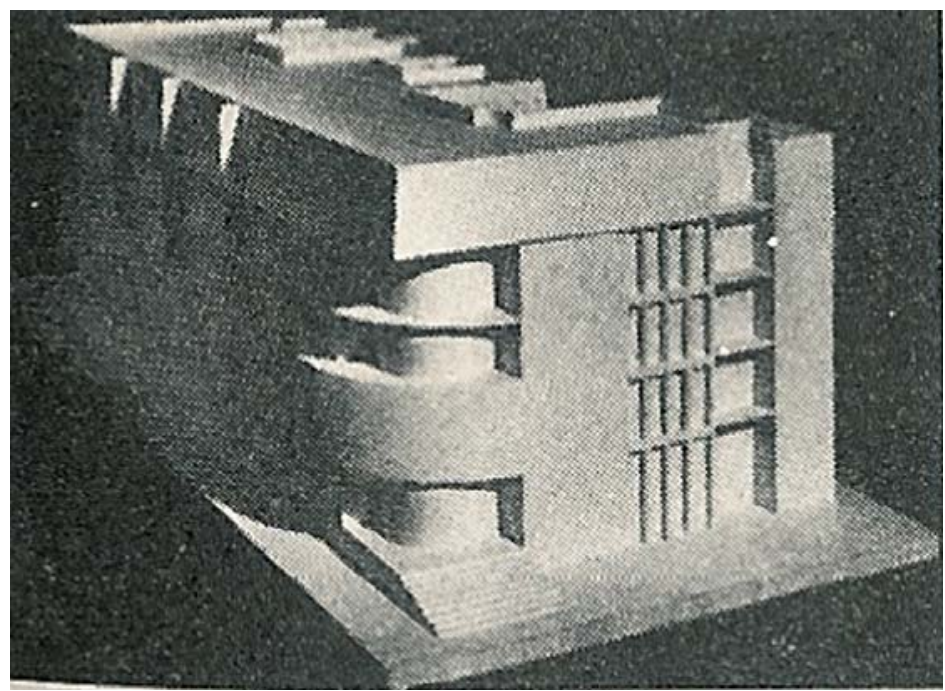

[107] Apartamentos Novocomum, Como, 1927/28. Arquiteto Giuseppe Terragni. Maquete solução intermediária, vista da esquina. 


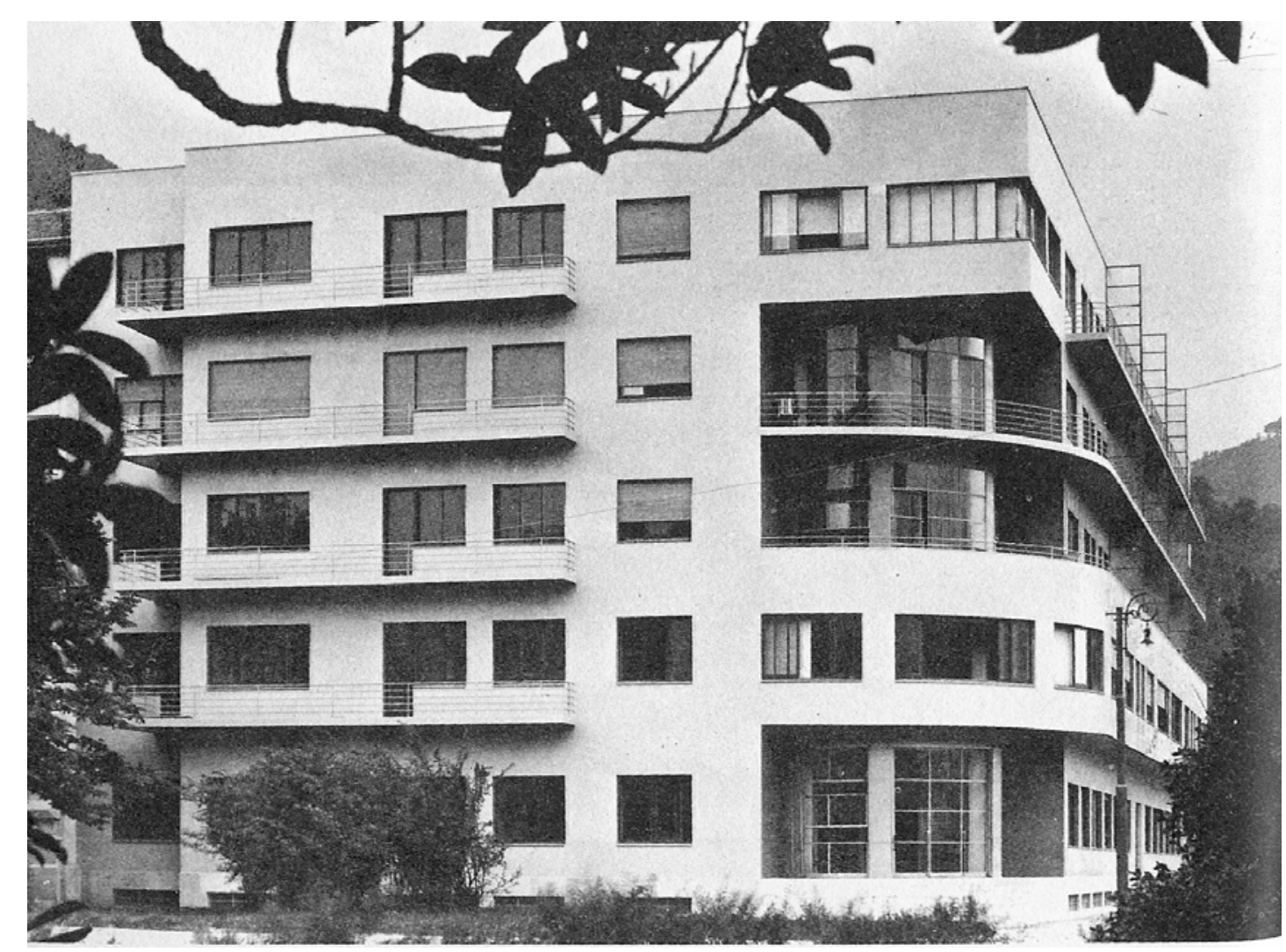

108] Apartamentos Novocomum, Como, 1927/28. Arquiteto Giuseppe Terragni. Vista lateral com o cilindro de vidro.

A Casa del Fascio[109] ${ }^{78}$, Como 1932/36, é o exemplo mais claro da paradoxal relação entre Terragni e o fascismo. Em um ensaio ilustrativo sobre o projeto, escrito pelo próprio arquiteto, o edifício aparece repetidamente como casa do povo, onde se anula toda solução de continuidade entre interior e exterior e predomina o conceito de visibilidade, do instintivo controle estabelecido entre público e responsáveis, visto que a burocracia não tem aí razão de ser. Abolidas estas artificiosas soluções planimétricas as quais visavam realizar no edifício público um conjunto de compartimentos estanques para impedir que o público transpusesse certas zonas do edifício reservadas ao dirigente, ao chefe administrativo ou ao funcionário.

\footnotetext{
${ }^{78}$ Casa del Fascio, Como, 1932/36. Arquiteto Giuseppe Terragni.
} 


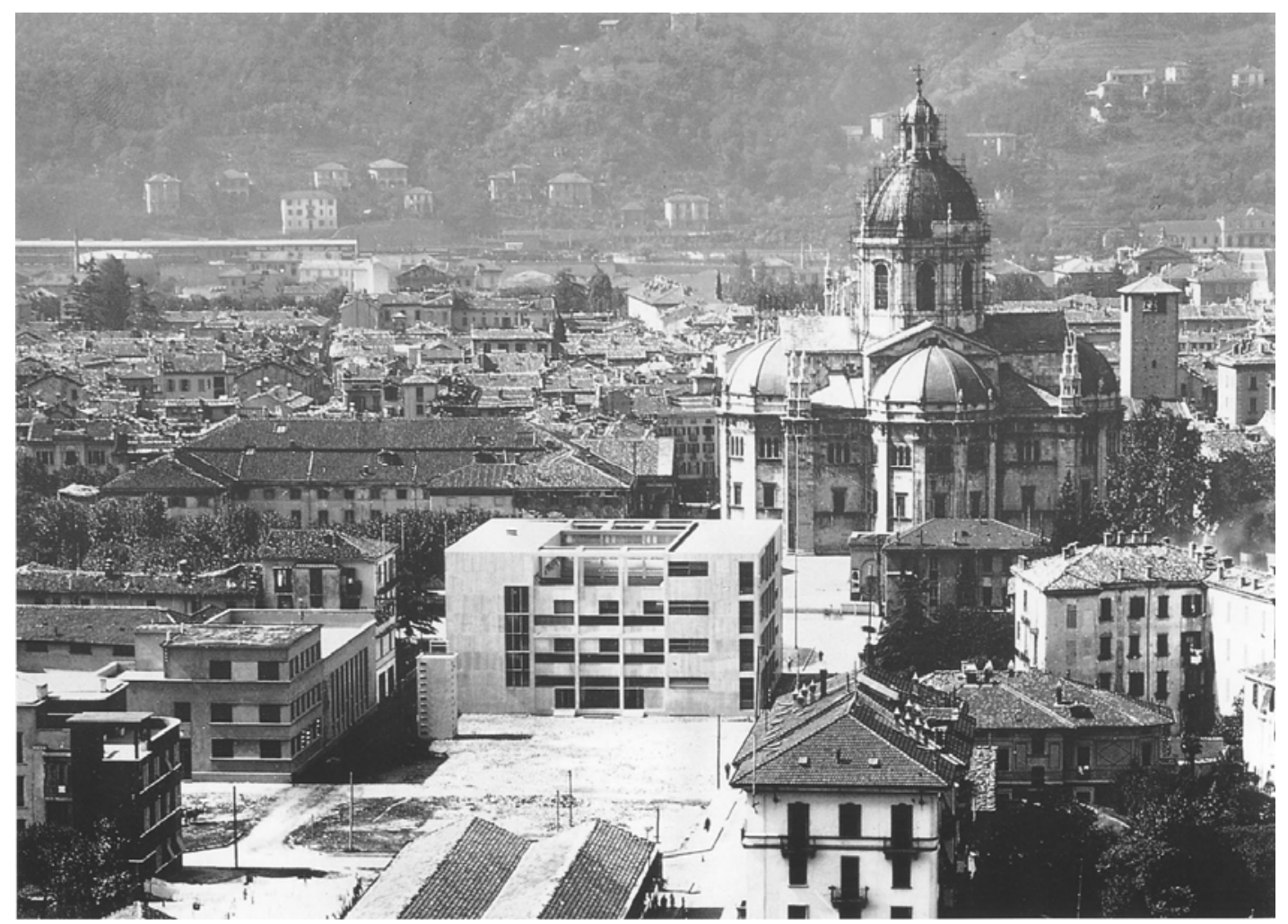

[109] Casa del Fascio, Como, 1932/36. Arquiteto Giuseppe Terragni. Vista panorâmica.

Sob o aspecto urbanístico, tratava-se de cortar os nós górdios da tímida e insidiosa oposição polêmica, levada a cabo por obstinados tradicionalistas com a ilusão de transformar as nossas belas históricas cidades italianas num sistema de praças e lugares etiquetados com as datas dos vários períodos da arquitetura. Zevi comenta que "à concepção duma casa de vidro, livre de vínculos hierárquicos, popular e democrática, Terragni dava o nome de "fascista"; mas está claro que tal, estava nos antípodas do regime."79

O projeto que Zevi nomeou de caixa de vidro é um prisma perfeito, planta quadrada de 33,20 $\mathrm{m}$ de lado, e 16,60 $\mathrm{m}$ de altura, que corresponde exatamente à metade do comprimento. Ainda segundo Zevi, "delineação rígida desde o princípio com o fim de exigir um trabalho encarniçado para queimar as suas virtudes classicistas."

\footnotetext{
${ }^{79}$ ZEVI, Bruno, op. cit., p. 17.

${ }^{80}$ ZEVI, Bruno, p. cit., p. 74.
} 
Quadrado e prisma são de fato cânones do purismo de Corbusier, mas aqui aparecem contestados, visto que o volume não está suspenso por pilotis, e as fachadas não são livres com respeito à armação estrutural, ao contrário, unem-se a ela, criando uma profundidade estratificada. Para Terragni é "monumentalidade austera, primitiva, mítica (...) nenhuma alegoria, nenhuma concessão agradável (...) nenhuma epígrafe que distraia da beleza da frase procurada, da eloquência medida dum nome ou dum cimélio."

Quatro elevações distintas[11o], todas dissimétricas, com quatro mensagens radicalmente diferenciadas. Todas de um branco radioso, vindo do mármore que cobre o concreto, plasticamente interrompido por um jogo de superfícies abertas e fechadas. Terragni tinha primeiro idealizado esta Casa do Povo como uma ferradura abrindo-se para a Piazza dell'Imperio. No fim, criou um pátio interno com uma entrada magnífica[111], cujas dezesseis portas podem ser abertas simultaneamente, como folhas de vidro.

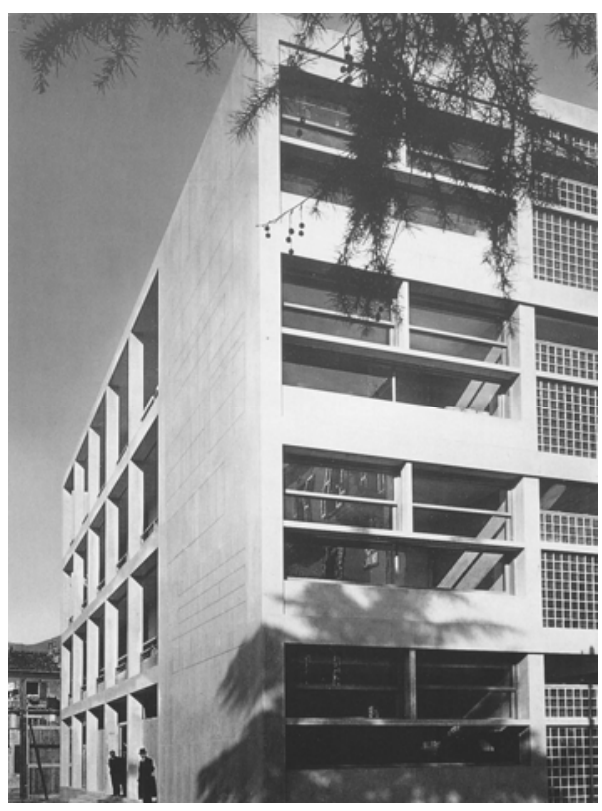

[110] Casa del Fascio, Como, 1932/36. Arquiteto Giuseppe Terragni. Vista esquina sul.

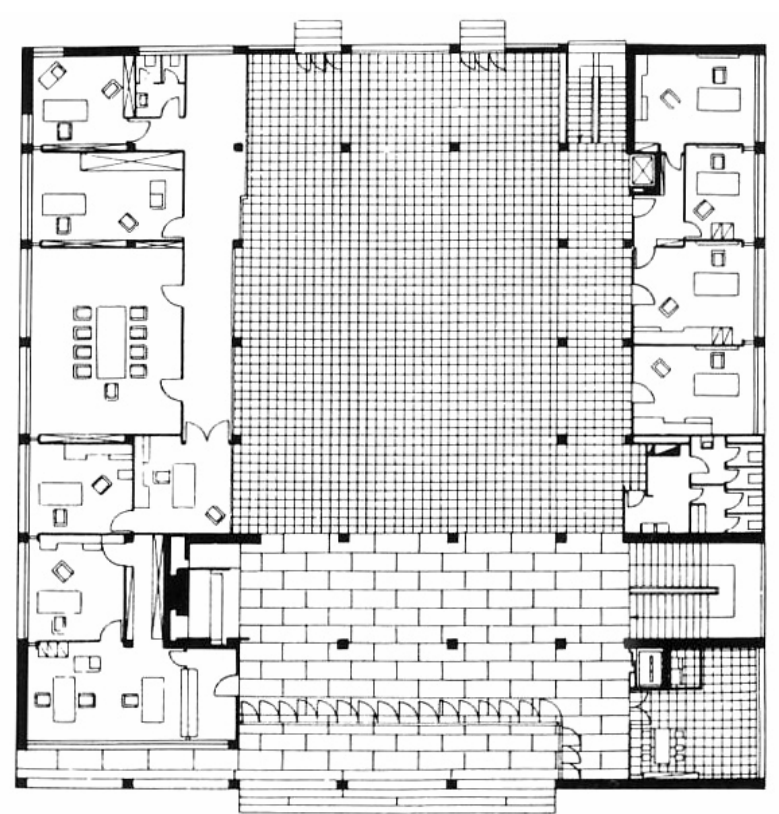

[111] Casa del Fascio, Como, 1932/36. Arquiteto Giuseppe Terragni. Planta.

${ }^{81}$ TERRAGNI, Giuseppe, apud ZEVI, Bruno, op. cit. p. 78. 
Segundo Zevi, "esse ideal intransigente de perfeição tem uma faceta política: é a antítese clara da vulgaridade fascista, quer significar o resgate mítico ou, melhor, a instintiva, desesperada negação promulgada no interior do sistema corrompido." ${ }^{82}$

Embora já tenhamos alertado para as diferenças entre Le Corbusier e Terragni, também aqui, embora não suspensos por pilotis, temos a integridade do volume. A grelha cartesiana, a rigorosa ortogonalidade, a vitalidade dos espaços internos e sua continuidade com o exterior, mais uma vez estão distantes da obra de Levi, pelo menos neste período.

Assim, parece que o interesse de Levi pelos movimentos que reagiam contra o ecletismo e que lutavam por uma renovação da arte se concentrou nas experiências das habitações em série, principalmente nas alemãs e holandesas. Da mesma maneira Le Corbusier e inclusive Terragni - de quem poderíamos esperar uma familiaridade maior pela semelhança de formação - são, nesse momento, referências secundárias para Levi.

\subsection{3 - O CONTEXTO NACIONAL}

O quadro da arquitetura brasileira do período, já estudado na análise do papel de Levi na historiografia, é de convivência de inúmeros raciocínios, entre eles, os que tentam introduzir as vanguardas modernas. Mesmo que panoramicamente - o que pressupõe uma inevitável superficialidade - me parece interessante fazer um levantamento dessas iniciativas, contemporâneas às obras examinadas de Levi.

Cronologicamente, a primeira é a de Gregori Warchavchik, já referida neste trabalho algumas vezes, mas sempre se restringindo à

${ }^{82}$ ZEVI, Bruno, op. cit., p.79. 
residência do arquiteto $^{83}$, a conhecida Casa da Rua Santa Cruz, São Paulo, 1927/28.[112]. Lendo o manifesto Acerca da Arquitetura Moderna (1925) - também já citado - onde as referências aos textos de Le Corbusier são literais, cria-se a expectativa de que os projetos repitam essa referência. Mas não é o que acontece. Desde a sua própria residência e no conjunto de obras do final da década de 20 e começo de 30, em São Paulo, a familiaridade muito mais forte é com as vanguardas alemãs e, particularmente, com Walter Gropius.

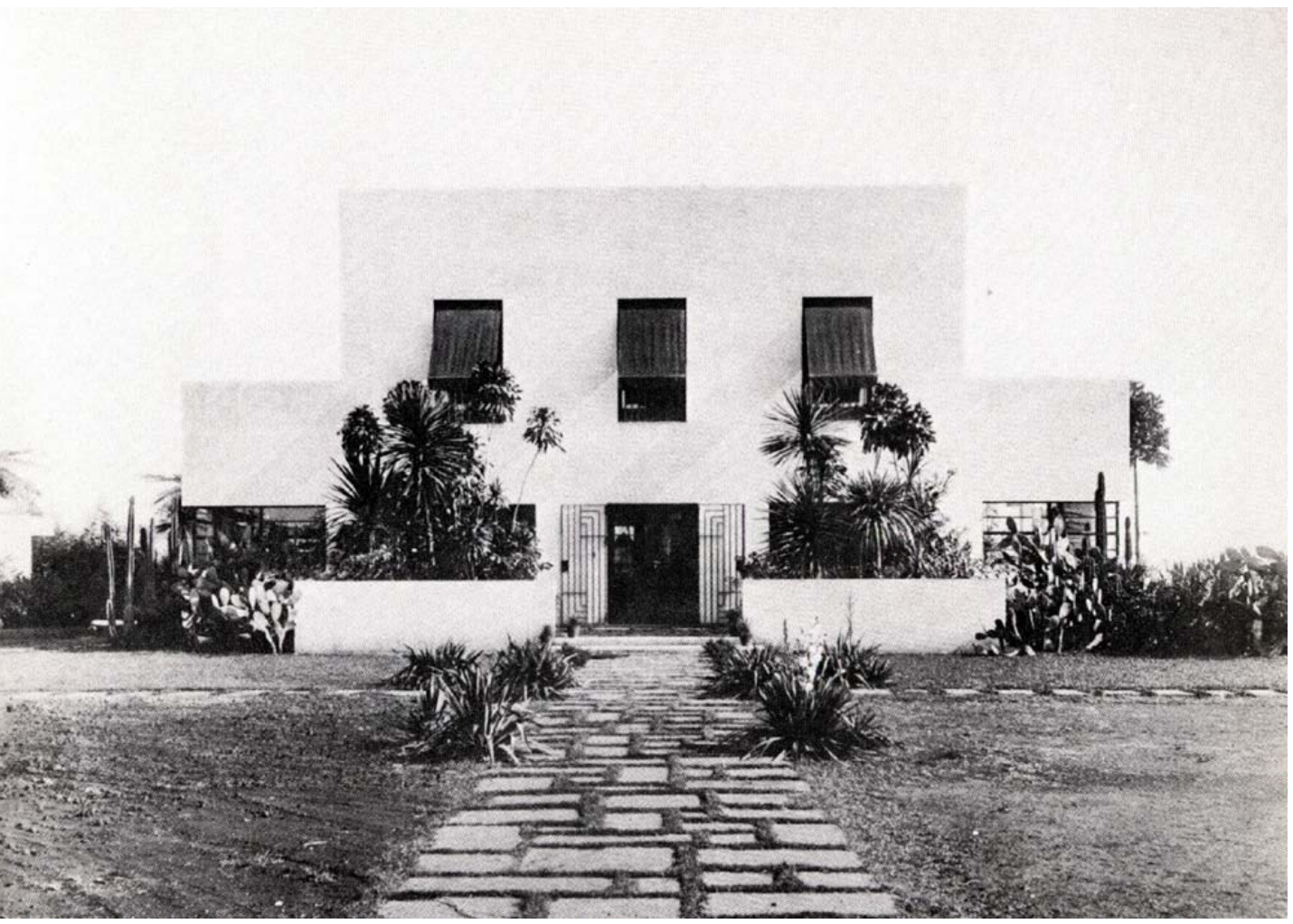

[112] Casa do arquiteto, rua Santa Cruz, São Paulo, 1927. Arquiteto Gregori Warchavchik. Vista frontal.

Na casa Max Graff ${ }^{84}$, também conhecida como casa da Rua Mello Alves, de 1929[113], é marcante a semelhança com o repertório de Gropius. A movimentação dos volumes, solidamente apoiados no chão, o uso das aberturas e a maneira de manipular as marquises, tudo remete às casas dos professores da Bauhaus.

${ }^{83}$ Casa do arquiteto, Rua Santa Cruz, São Paulo, 1927. Arquiteto Gregori Warchavchik.

${ }^{84}$ Casa Max Graff, Rua Mello Alves, São Paulo, 1929. Arquiteto Gregori Warchavchik. 


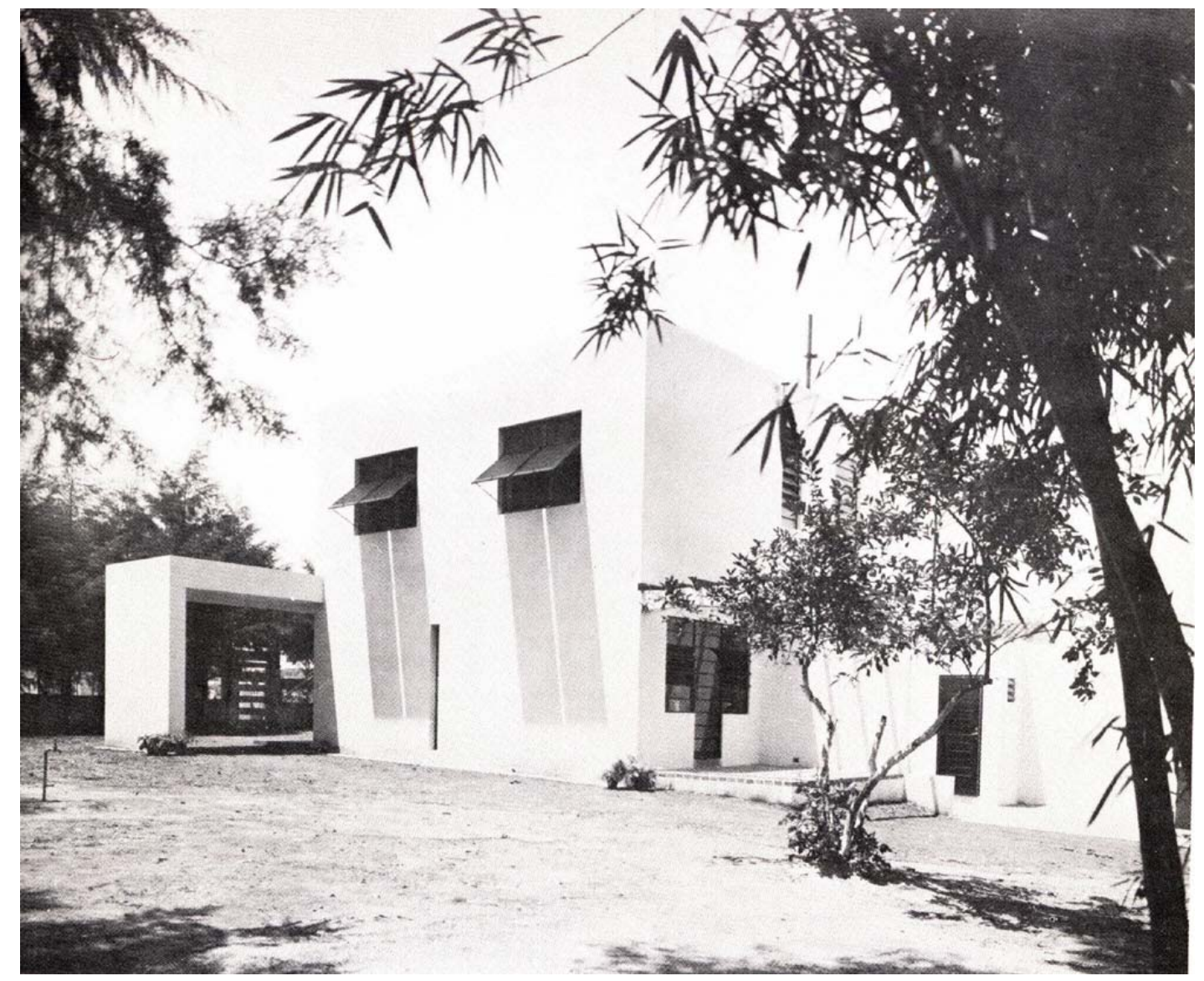

[113] Casa Max Graff, Rua Mello Alves, São Paulo, 1929. Arquiteto Fregori Warchavchik. Vista lateral.

Warchavchik está, também, preocupado com a fabricação em série dos componentes da habitação. Nesse sentido, numa oficina no fundo da sua casa, desenvolve protótipos de caixilhos, luminárias, móveis, tentando - paradoxalmente - de maneira artesanal demonstrar as possibilidades da produção industrial em série.

A produção em série de casas também foi objeto das suas preocupações. Prova disso são as casas econômicas em série ${ }^{85}$, na Rua Barão de Jaraguá, de 1929 [114] e as casas econômicas em série ${ }^{86}$, na Rua Dna. Berta, de 1930 [115]. Nas duas, o partido dos sobrados geminados formando prismas retangulares, com diferenciação nas casas de esquina, remetem às experiências alemãs.

\footnotetext{
${ }^{85}$ Casas em série, Rua Barão de Jaraguá, São Paulo, 1929. Arquiteto Gregori Warchavchik.

${ }^{86}$ Casas econômicas em série, Rua Dna. Berta, São Paulo, 1930. Arquiteto Gregori Warchavchik.
} 


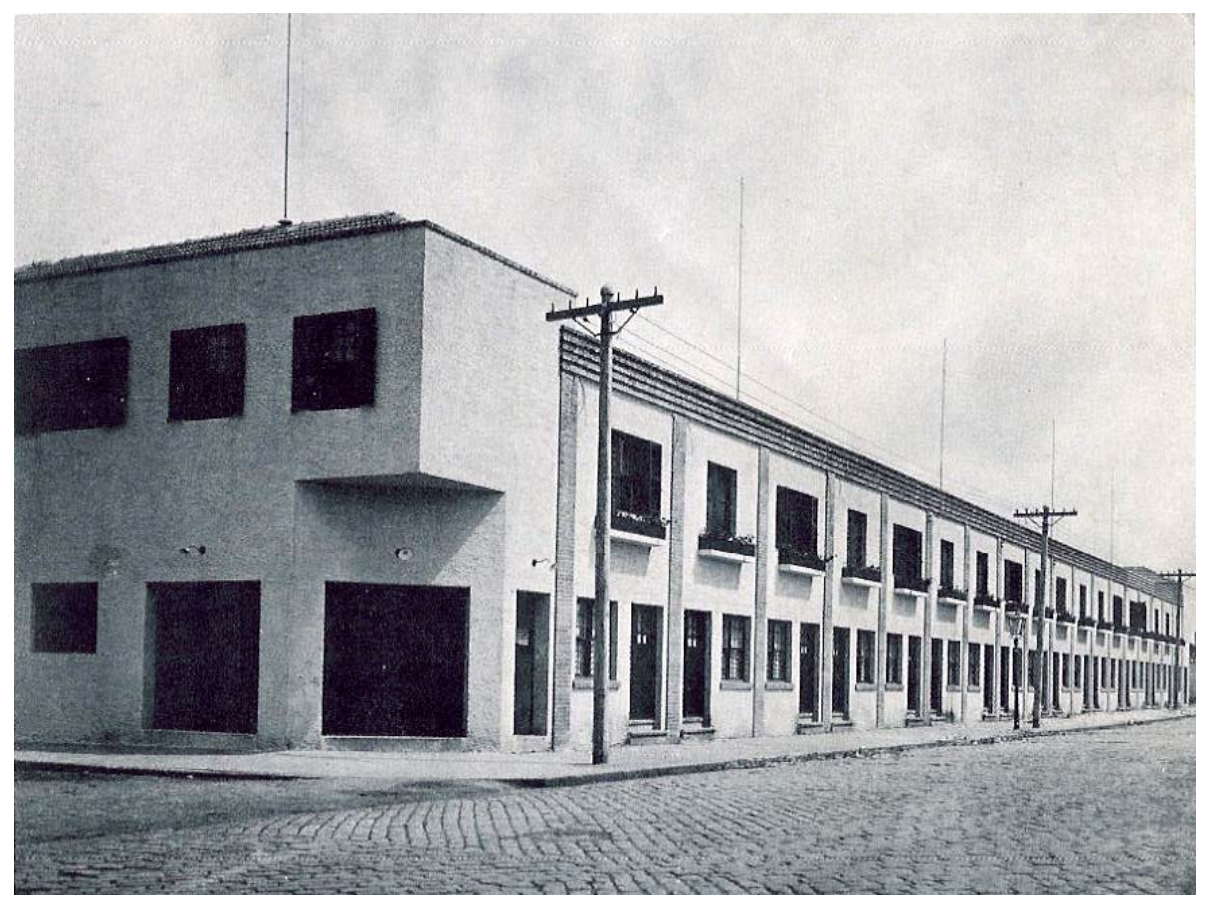

[114] Casa econômicas em série, Rua Barão de Jaguara, São Paulo, 1929. Arquiteto Gregori Warchavchik. Vista da esquina.

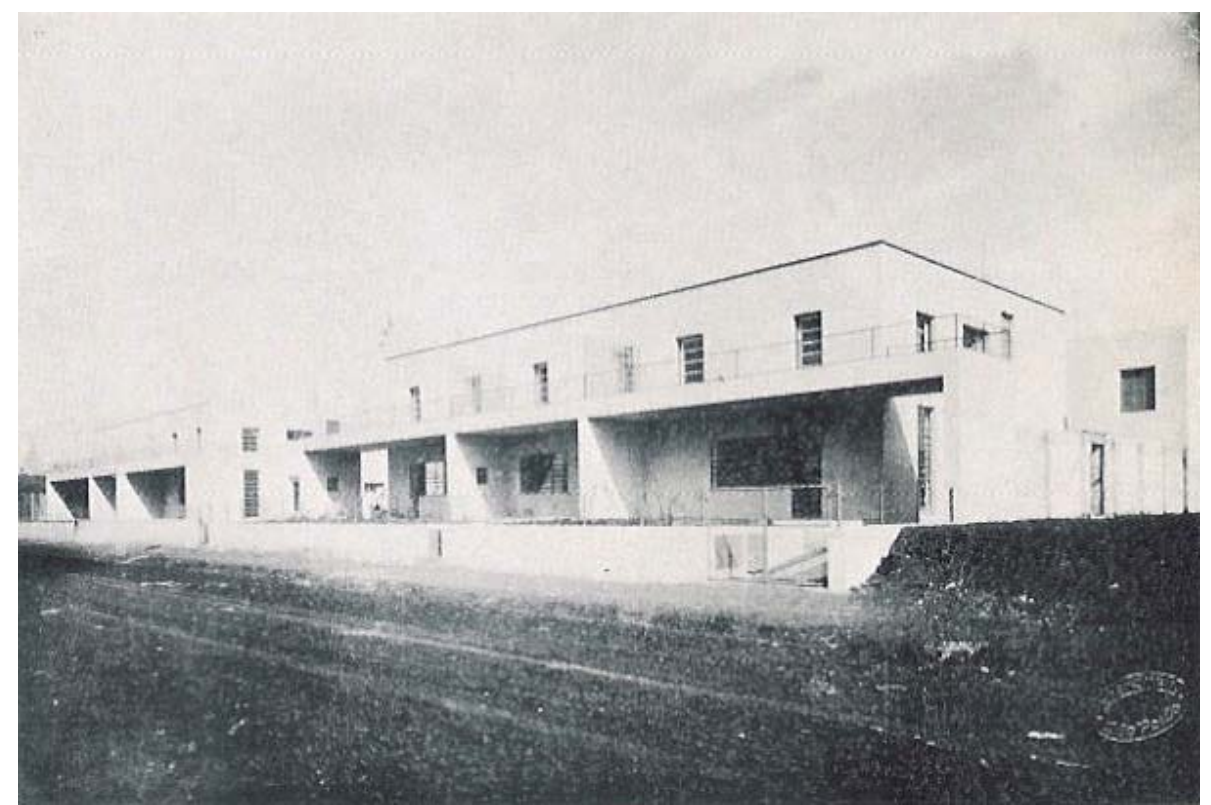

[115] Casas econômicas em séri, Rua Dna. Berta, São Paulo, 1930. Arquiteto Gregori Warchavchik. Vista panorâmica.

A Casa Modernista ${ }^{87}$ da Rua Itápolis, em 1930 [116], ganhou esse nome por conta de exposição ao público, que foi montada com o intuito de mostrar a população paulistana como morava o "homem moderno". A

\footnotetext{
${ }^{87}$ Casa Modernista, Rua Itápolis, São Paulo, 1930. Arquiteto Gregori Warchavchik.
} 
casa estava decorada com obras de Tarsila do Amaral, Regina Gomide Graz, Oswaldo Goeldi, Menotti Del Picchia, Lasar Segall, John Graz, Jenny Klabin Segall, Antonio Gomide, Esther Bessel, Emiliano di Cavalcanti, Cícero Dias, Celso Antonio, Victor Brecheret e Anita Malfati, ou seja, todo o grupo de artistas comprometido com a introdução das questões modernas na provinciana São Paulo da década de 20.

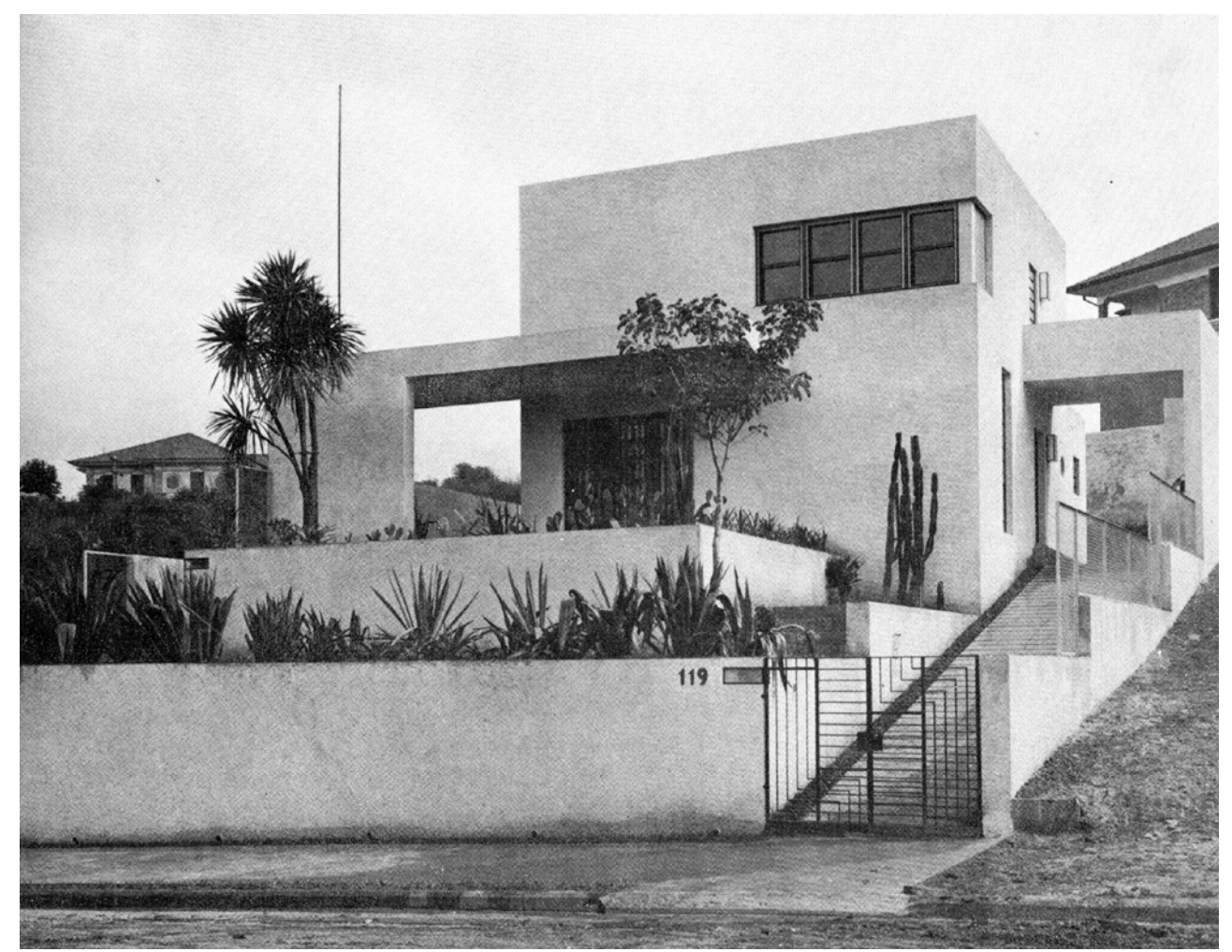

[116] Casa Modernista, Rua Itápolis, São Paulo, 1930. Arquiteto Gregori Warchavchik. Vista frontal.

Figuravam também obras de Jacques Lipschitz, Sonia Delaunay e objetos procedentes de Paris e Dessau. O caráter didático ia mais longe: na biblioteca figuravam obras de Alcântara Machado, Álvaro Moreyra, Affonso Schmidt, Arthur Carneiro, Ascenso Ferreira, Augusto Meyer, Brasil Gerson, Cassiano Ricardo, Felippe d'Oliveira, Graça Aranha, Guilherme de Almeida, Manuel Bandeira, Mario de Andrade, Menotti Del Picchia, Motta Filho, Osório César, Oswald de Andrade, Plínio Cavalcanti e Plínio Salgado. 
O projeto aprofunda e solidifica as questões que Warchavchik vinha trabalhando. Aqui, o prisma cúbico só perde a integridade com as duas marquises em fachadas diferentes, que formam verdadeira alavanca, imprimindo grande dinamismo. A primeira corre paralela à fachada frontal, ultrapassando-a para apoiar-se em pilar linear. A segunda nasce perpendicular à fachada lateral e também se apóia em pilar linear, além de marcar e proteger o acesso. Esses diferentes níveis são complementados por um jardim em patamares que vai vencendo terreno até a rua. O paisagismo deste e de todos os jardins desta série é de Mina Klabin Warchavchik, que introduz as cores e as formas da flora tropical como rico contraponto ao branco predominante nos projetos do marido. Consta que acompanhando Warchavchik na sua estadia no Rio de Janeiro, no começo da década de 1930, Nina teria introduzido o jovem Burle Marx nesse raciocínio.

As fotos da época deixam claro o quanto a casa é inaugural no novo loteamento do Pacaembu, onde ela é construída, tanto no sentido da ocupação quanto nas características do projeto, estranhas às sedes de chácaras que deram origem aos novos lotes.

O mesmo acontece com a casa da Rua Bahia ${ }^{88}$ [117], distante alguns quarteirões da casa da Rua Itápolis. Os membros do Congresso da Habitação, posando à frente da casa, em maio de 1931, dão uma mostra da novidade em que ela se constitui. Talvez aqui, mais do que em qualquer outra casa de Warchavchik, tenhamos a convivência de vários repertórios: Gropius - mais visível na fachada para a rua, marcado pela abertura vertical que ilumina a escada - e Le Corbusier mais visível na fachada posterior com suas janelas horizontais e seus terraços sobre pilotis [118]. As duas referências são, no entanto, harmonizadas com sucesso. O mesmo se observa nas plantas [119], que tira partido com inteligência da inclinação do terreno. No interior, o espaço da sala de jantar tem teto luminoso [12o], de vidros

${ }^{88}$ Casa da Rua Bahia, São Paulo, 1930. Arquiteto Gregori Warchavchik. 
granitè, opalino, opaco, amarelo e vermelho, com clara referência ao De Stijl. Os móveis embutidos, também desenhados pelo arquiteto, dialogam com a produção da Bauhaus. O jardim apresenta-se agora na parte posterior do lote e outra vez vence o desnível em patamares.

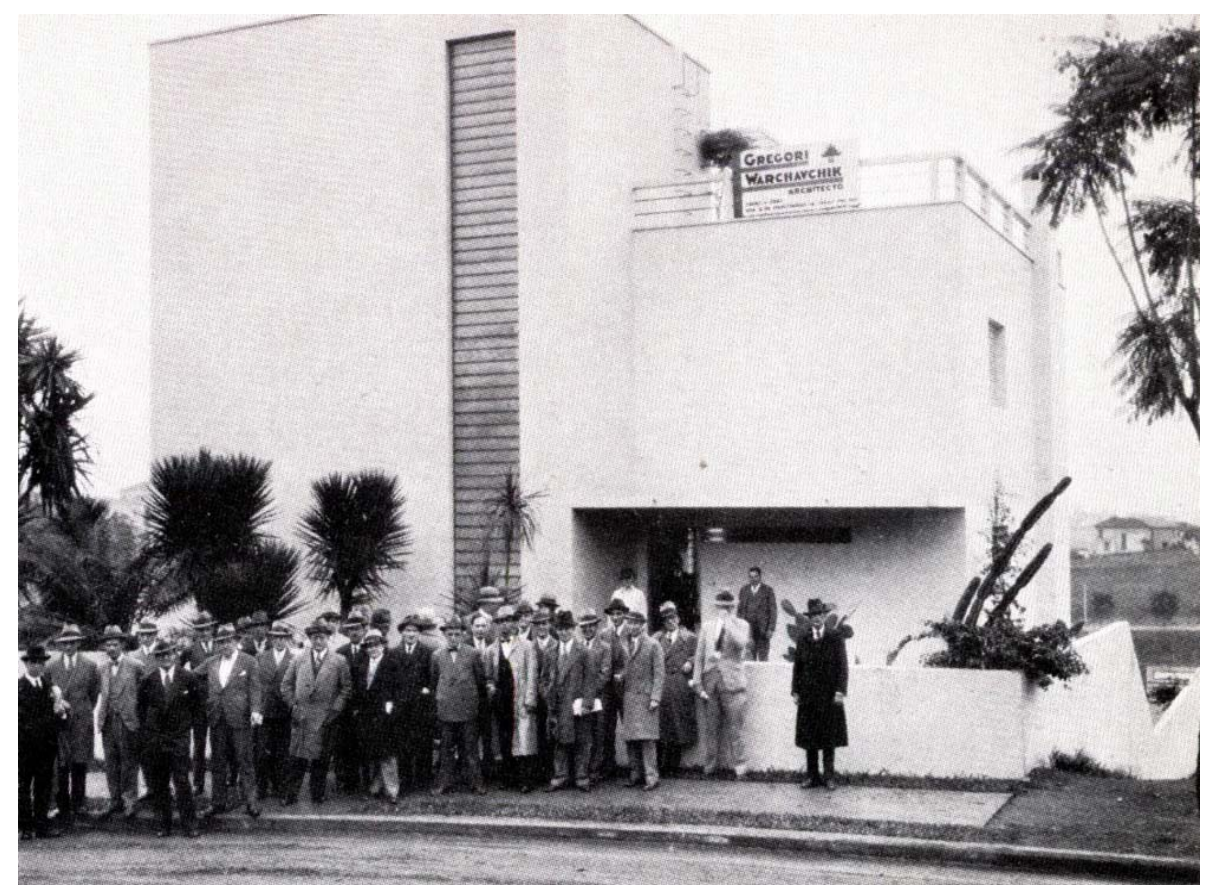

[[117] Casa da Rua Bahia, São Paulo, 1930. Vista frontal com membros do "Congresso de Habitação" de 1931.

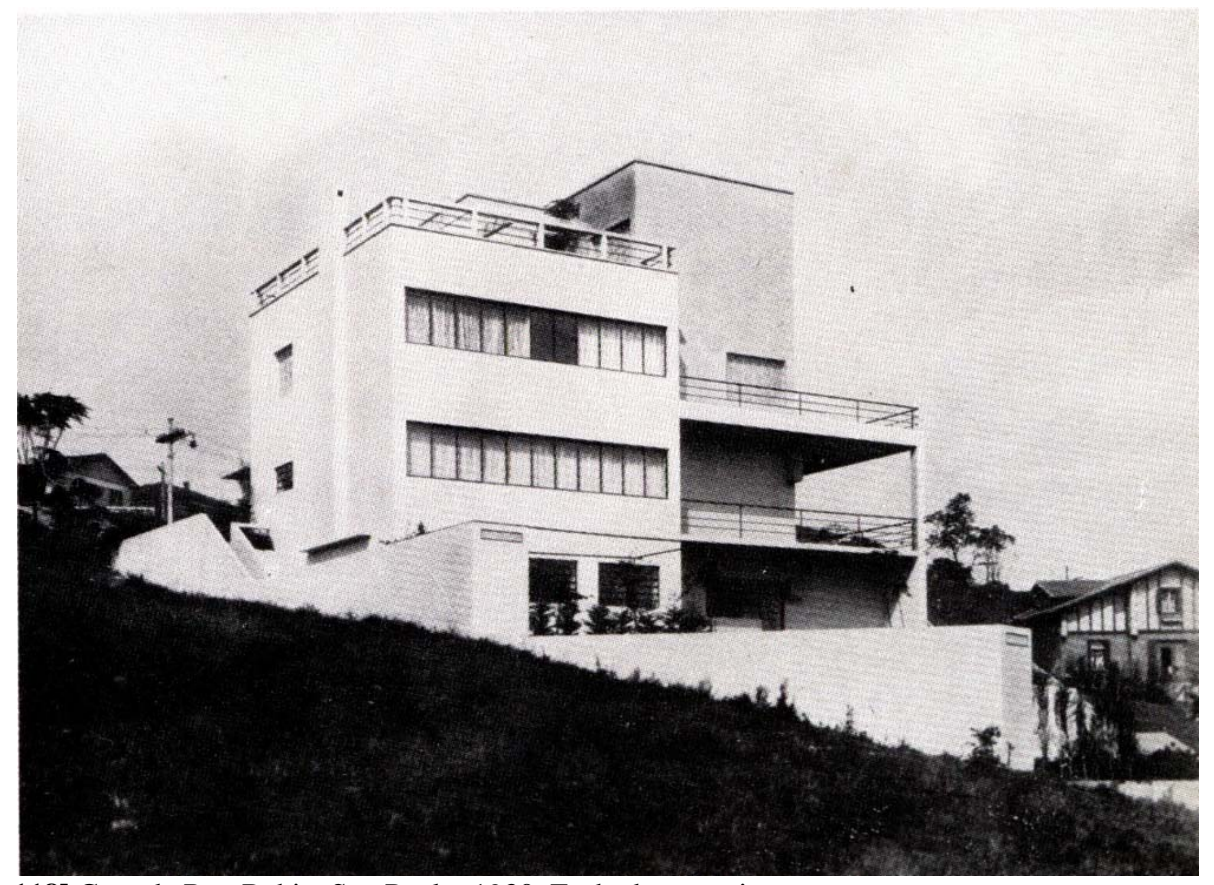

118] Casa da Rua Bahia, São Paulo, 1930. Fachada posterior. 

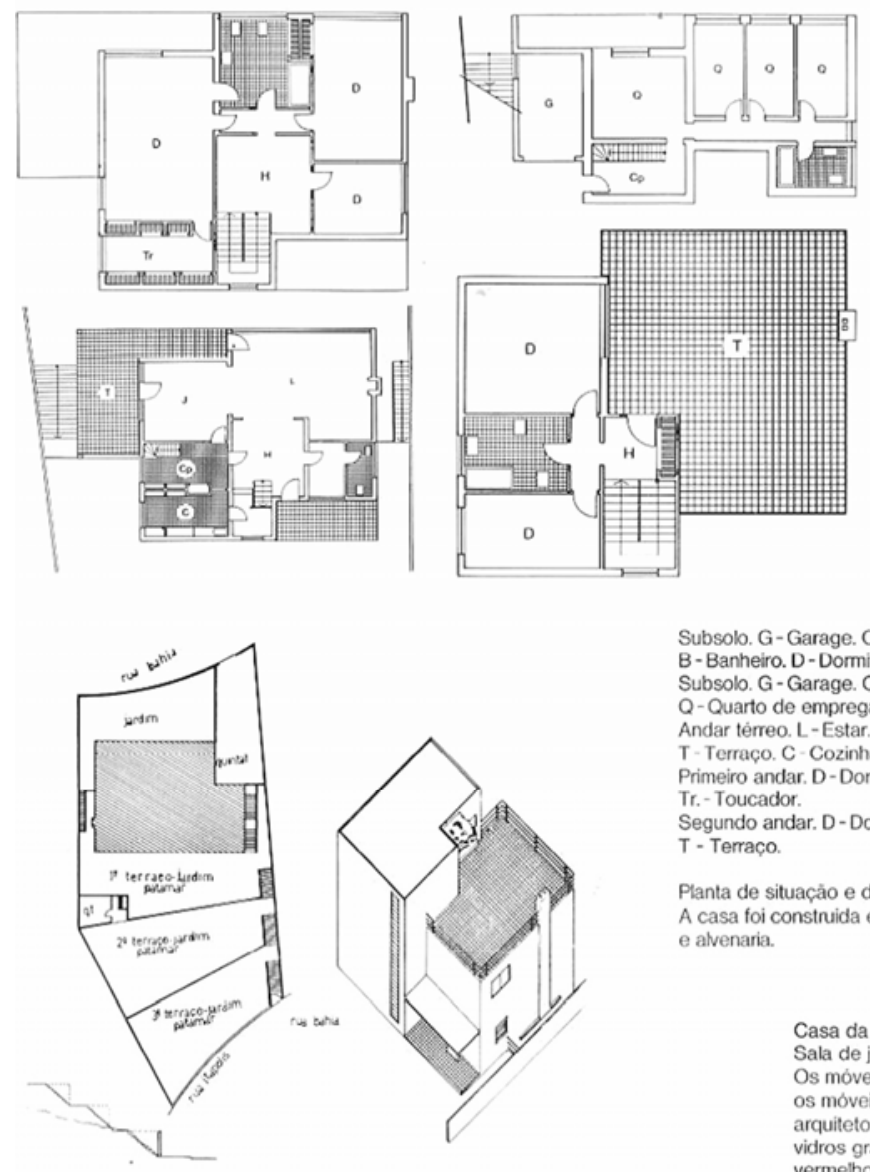

Subsolo. G-Garage. Cp-Copa

Subsolo. G-Garage. Cp-Copa. B - Banheiro.

Q-Quarto de empregada.

Andar térreo. L-Estar. J-Jantar. H-Hall

$\mathrm{T}$ - Terraço. C-Cozinha. Cp-Copa.

Primeiro andar. D-Dormitónio. $\mathrm{H}$ - Hall.

Tr. - Toucador.

Segundo andar. D-Dormitório. $\mathrm{H}$ - Hal

T - Terraço.

Planta de situação e desenho isométrico.

A casa foi construida em concreto armado e alvenaria.

Casa da Rua Bahia. São Paulo, 1930.

Sala de jantar com vista para a sala de estar. Os móveis avu'sos vieram de Paris. Todos os móveis embutidos, desenhados pelo arquiteto, assim como o teto luminoso de vidros granité, opalino, opaco, amarelo e

[119] Casa da Rua Bahia, São Paulo, 1930. Plantas.

[120]

Casa da Rua Bahia, São Paulo, 1930.

Teto Luminoso da sala de jantar.

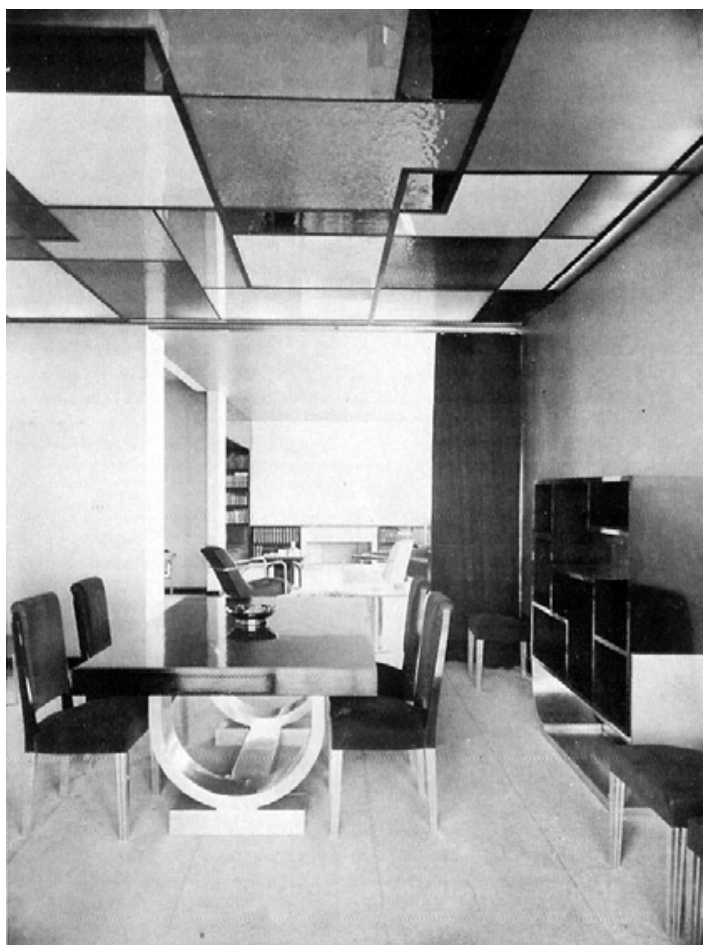


Em 1931, chamado por Lúcio Costa para lecionar Composição de Arquitetura na Escola Nacional de Belas Artes, no Rio de Janeiro, convoca para seu assistente o jovem arquiteto Affonso Reidy, então com 20 anos de idade. No mesmo ano constrói a casa da Rua Toneleiros $^{89}$ [121], conhecida como a primeira casa modernista do Rio. Nela podemos observar todos os procedimentos já apontados, aos quais se acrescenta - neste caso - o uso de patamares para vencer a declividade do terreno, na implantação da casa e não nos jardins. Também esta casa é objeto de exposição pública na época de sua inauguração. Sobre ela, Abelardo de Souza comenta que as mais altas personalidades do mundo oficial e artístico compareceram, estando entre elas o famoso arquiteto Frank Lloyd Wright. Tal foi o interesse desse arquiteto pela obra de Warchavchik, que ele compareceu por mais de uma semana, acompanhado por grande número de alunos de arquitetura, para discutir os vários detalhes e novidades construtivas que a casa apresentava.

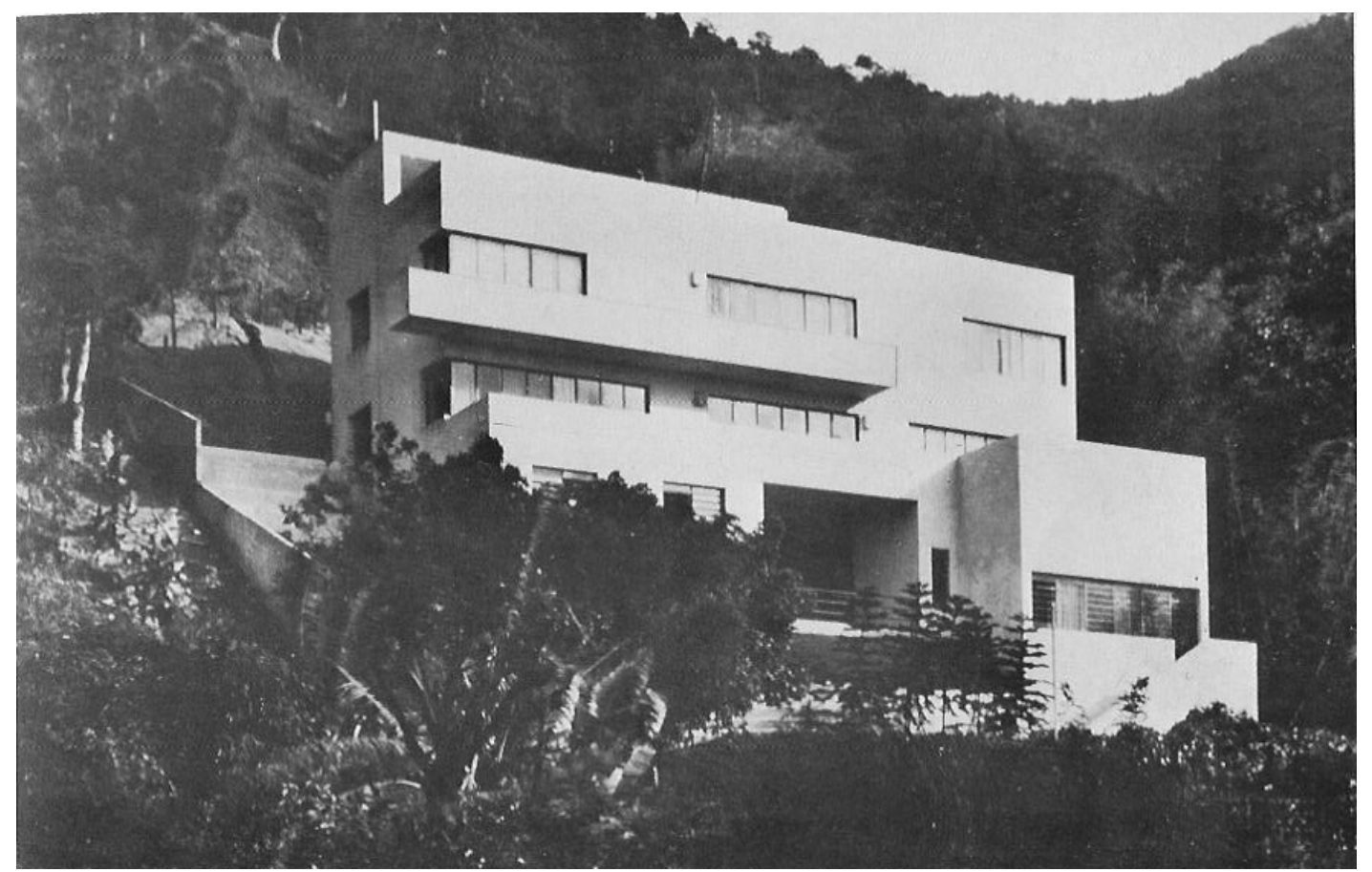

[121] Casa da Rua Toneleiros, Rio de Janeiro, 1931. Arquitetos Gregori Warchavchik. Fachada frontal.

\footnotetext{
${ }^{89}$ Casa de Rua Toneleiros, Rio de Janeiro, 1931. Arquiteto Gregori Warchavchik.
} 
Malograda a experiência de reforma da ENBA, Warchavchik se demite junto com outros colegas cariocas e associa-se a Lúcio Costa em uma firma de arquitetura e construções. Juntos constroem a Vila Operária de Gambôa ${ }^{90}$ [122], exercício de habitação em série em que dão conta de implantar, em exíguo terreno triangular, 12 unidades mínimas. Ao invés da solução em lâmina, o que se tem é a justaposição de 5 prismas ortogonais, com 2 residências cada um - deslocados entre si possibilitando a adaptação à forma do lote e garantindo privacidade aos moradores. $\mathrm{O}$ acesso às unidades do primeiro andar é feito por meio de uma passarela que funciona também como marquise, com aberturas que garantem luz e ventilação para as unidades do térreo.

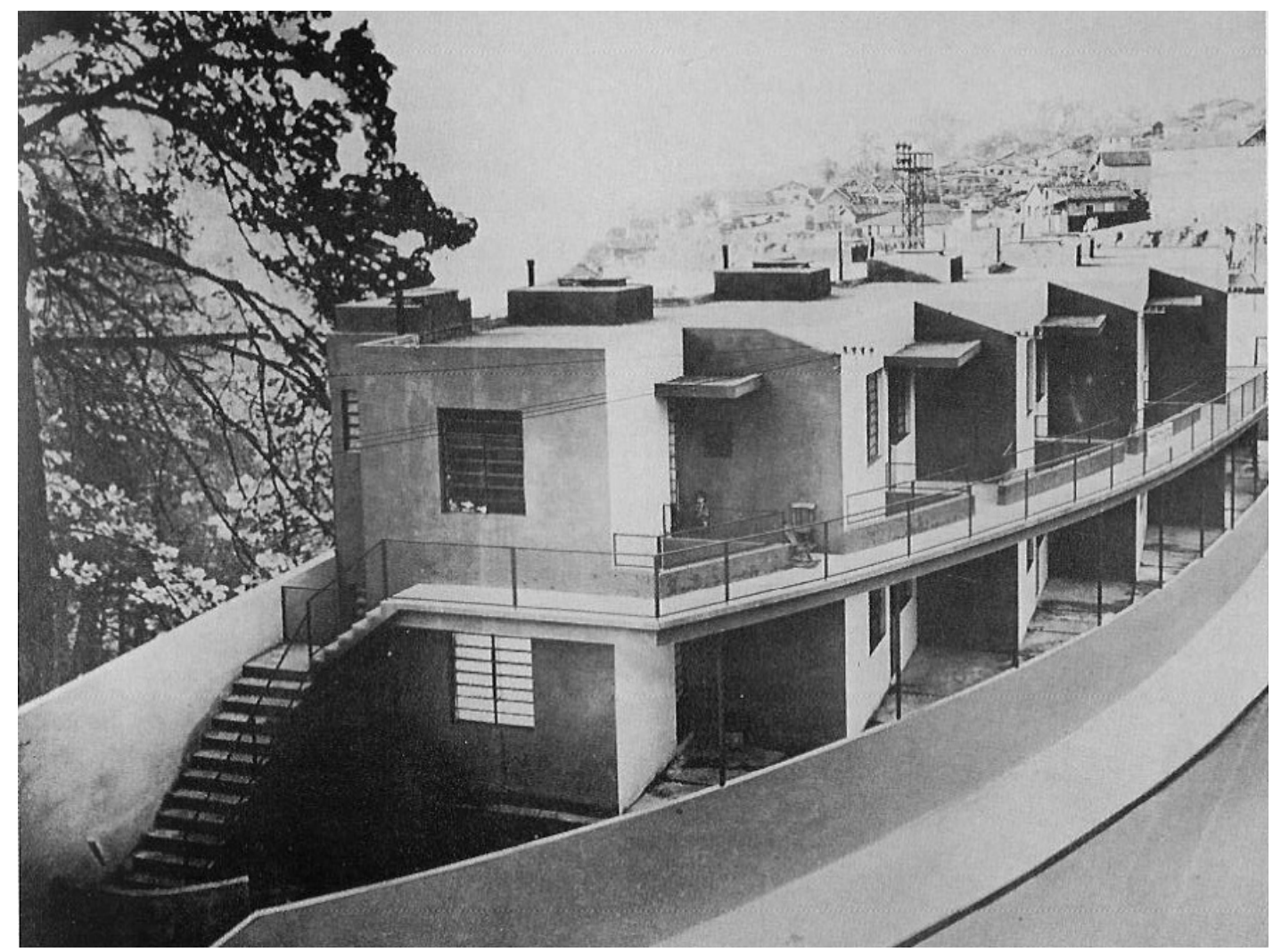

[122] Vila operária de Gambôa, Rio de Janeiro, 1933. Arquitetos Gregori Warchavchik e Lúcio Costa. Vista panorâmica.

Um panorama das outras primeiras experiências modernas no Rio de Janeiro pode ser verificado no $\mathbf{1}^{\circ}$ Salão de Arquitetura Tropical de abril

\footnotetext{
${ }^{90}$ Vila Operária de Gambôa, Rio de Janeiro, 1933. Arquitetos Gregori Warchavchik e Lúcio Costa.
} 
de 1933. O seu catálogo ${ }^{91}[\mathbf{1 2 3}]$ - organizado e composto por Alexandre Altberg - nos informa que seu presidente de honra foi Frank Lloyd Wright, aponta como precursores Lúcio Costa, Gregori Warchavchik e Emílio Baumgart e relata que a comissão organizadora era composta por João Lourenço da Silva, Alcides da Rocha Miranda e Ademar Portugal. Expuseram seus trabalhos no Salão 34 concorrentes, entre eles: Abelardo de Souza, Affonso Reidy, Alcides da Rocha Miranda, Emilio Baumgart, Gregori Warchavchik, Jorge Moreira, Lúcio Costa, Luis Nunes e Marcelo Roberto.

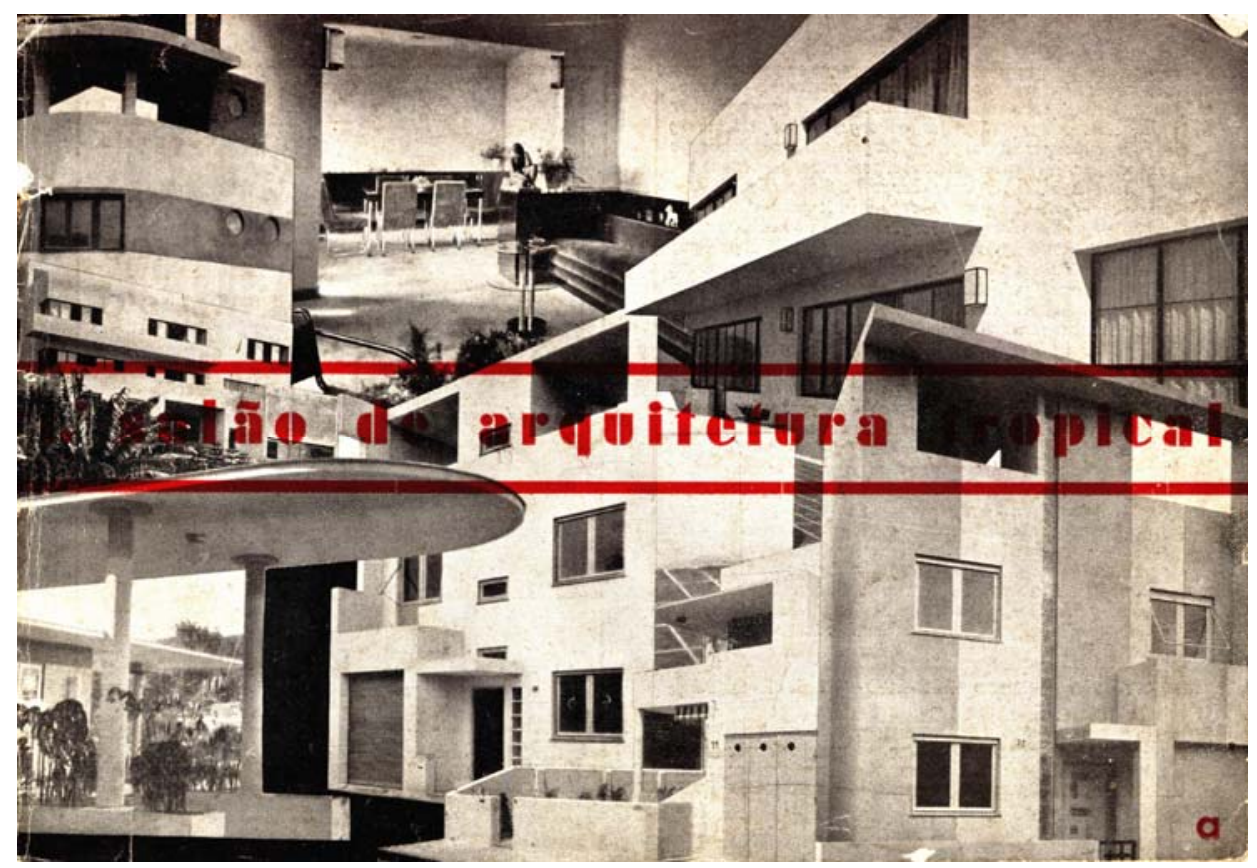

[123] $1^{\circ}$ Salão de Arquitetura Tropical, Rio de Janeiro, 1933. Foto da Capa.

Alcides da Rocha Miranda informa na introdução que "este Salão de Arquitetura Tropical, marca o início do movimento que a sessão de arquitetura da $A A B$ (Associação dos Artistas Brasileiros) vai desenvolver pela racionalização da arte de construir em nosso país. A ausência de uma arquitetura viva exprime um impasse social incompatível com a nossa civilização. Quando éramos apenas uma colônia - sem indústria e sem técnicos - onde os senhores abastados

\footnotetext{
91 ALTBERG, Alexandre, org. $1^{\circ}$ Salão de Arquitetura Tropical, catálogo. Rio de Janeiro, s/ editora,
} 1933. 
dirigiam os escravos na construção de suas próprias residências, justificava-se que sacrificassem as disposições internas para satisfazer às exigências de um estilo então em moda na metrópole.

Com as indústrias já bem desenvolvidas e o número suficiente de técnicos, continua-se a reproduzir formas mortas, porque o brasileiro do século XX não sabe que a engenharia está apta a satisfazer todas as suas necessidades e a dar solução a todas as suas exigências. A arquitetura, que aqui apresentamos, tem como caráter próprio a criação de ambientes sombrios, arejados por grandes vãos que são orientados, para o norte e para o sul - terraços cobertos de vegetação, restituem à natureza o espaço que os alicerces lhe roubaram - a pureza de suas linhas reflete bem o grau de cultura de uma raça em contraste com a arte do selvagem, que só procura a complexidade dos ornatos.

$O$ artista que cria se exprime com simplicidade, aquele que copia, complica, para deixar um vestígio de sua colaboração. (...) Os costumes regionais, pouco a pouco, se vão apagando - os meios de transporte, cada vez mais aperfeiçoados, fazem desaparecer os limites das nações e aproximam continentes - os rádios provocam a uniformização das línguas, enquanto o cinema universaliza os costumes - a arquitetura moderna que fixou suas diretrizes neste ambiente é uma arquitetura internacional pelos seus princípios, porque ela é inspirada na razão e na ciência, e estas são comuns a todo mundo. As condições do ambiente físico e social, e as criações dos artistas, fazem variar os aspectos dessa arquitetura viva que se encontram naqueles princípios gerais as bases de suas concepções. "92

O texto acima, um verdadeiro manifesto pela arquitetura viva e pela racionalização da arte de construir que conduziria a uma arquitetura internacional pelos seus princípios, esclarece as razões que levaram à publicação no catálogo do Manifesto do CIAM - Congresso

\footnotetext{
${ }^{92}$ Alcides da Rocha Miranda, Da Introdução, Apud ALTBERG, Alexandre, op.cit., s/p.
} 
Internacional de Arquitetura Moderna. Esse manifesto divulgou as regras fixadas "no dia 25 de junho de 1928, quando reuniram-se 24 dos melhores arquitetos da Bélgica, Alemanha, França, Holanda, Itália, Áustria, Suíça e Espanha no Castelo La Sarraz, na Suíça, para achar uma base de colaboração internacional" ${ }^{93}$. O manifesto e mais um texto de Walter Gropius, Considerações sobre a Arquitetura, atestam a preocupação em se manter a par das realizações das vanguardas modernas.

A seleção das obras que comporiam o catálogo inclui uma ponte de Emílio Baumgart [124] "que com o seu vão de 68 metros, representa o recorde mundial em obras similares de concreto armado; constitui também inovação audaciosa o método de construção, pois a concretagem foi feita das margens para o centro, progredindo sistematicamente à medida que se estendiam moldes, sem o auxílio de andaime que seria arrastado pelas repentinas cheias torrenciais". Na mesma página está o Interior de um apartamento,de Gregori Warchavchik e Lúcio Costa, com uma boa coleção de luminárias, tapetes, móveis e outros objetos produzidos industrialmente. A paginação parece indicar, didaticamente, a variedade de escalas ou a grande abrangência dos problemas abarcados pelo raciocínio moderno.

${ }^{93}$ Apresentação para o manifesto do $1^{\circ}$ CIAM, Apud ALTBERG, Alexandre, op. cit., s/p. 


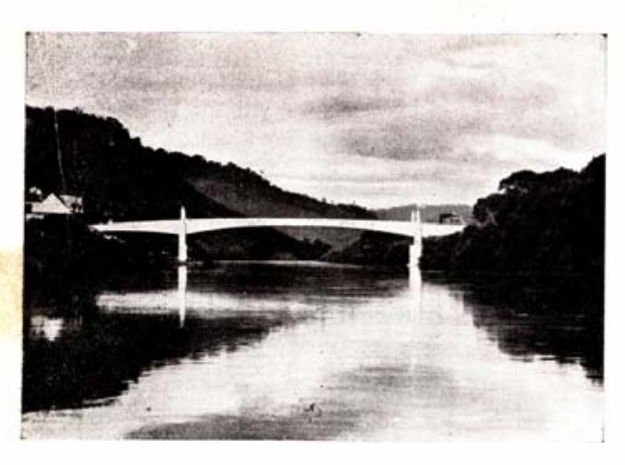

\section{emilio baumgart}

Ponte entre Herval e Cruzeiro sobre o Rio do Peixe no antigo - record mundial em obros similares do constitue tambem inovação audaciosa o metodo de construção pois a concretagem foi feita das margens para o centro, os moldes, sem o auxilio de andaime que seria arrastado pelas repentinas cheias torrenciaes.
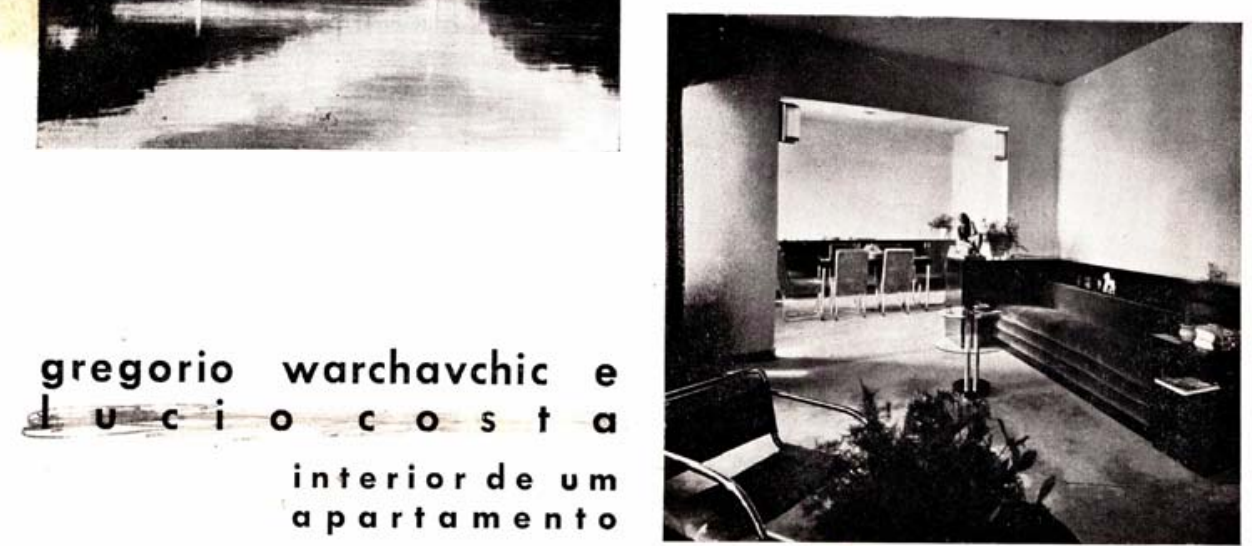

[124] $1^{\circ}$ Salão de Arquitetura Tropical, Rio de Janeiro, 1933. Ponte de Emilio Baumgart e Interior de um Apartamento de Gregori Warchavchik e Lucio Costa.

O edifício do Rio Críquet Clube, de Anton Floderer e A. S. Buddeus, e o Albergue da Boa Vontade de Affonso Reidy e Gerson Pinheiro [125], atestam a variedade de programas contemplados pela arquitetura moderna. Mas a maioria dos projetos é de residências unifamiliares, algumas já construídas. É o caso da Residência das Laranjeiras, de Marcelo Roberto e da Residência em Ipanema, de Alexandre Altberg [126]. A proposta de Roberto parece mais coesa demonstrando controle das referências utilizadas. Na proposta de Altberg o uso do raciocínio corbusiano de aberturas no terraço-jardim que enquadram a paisagem, como não reconstituem o volume, resumem-se à molduras. 

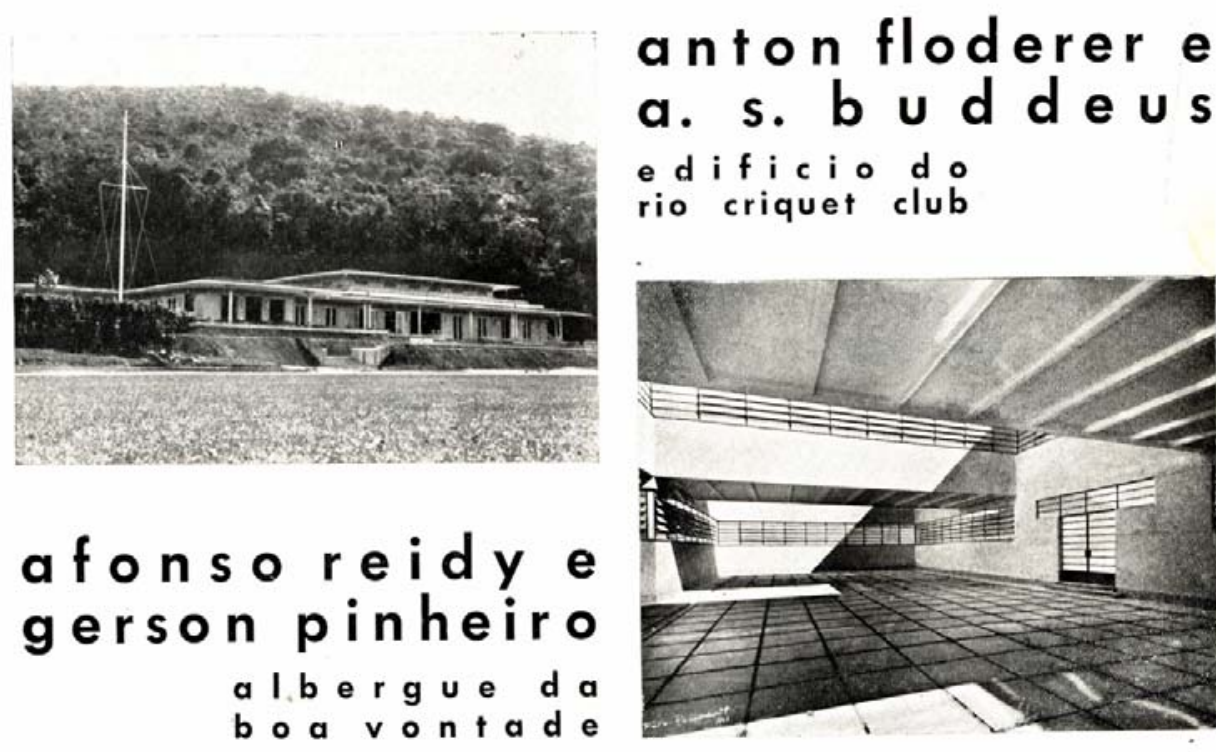

rio criquet club

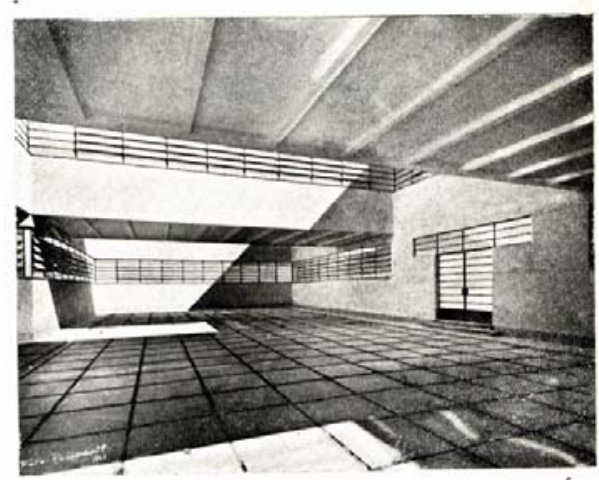

[125] $1^{\circ}$ Salão de Arquitetura Tropical, Rio de Janeiro, 1933. Vista panorâmica do Edifício do Rio Críquet Clube, de Anton Floderer e A.S. Buddeus e vista do Albergue da Boa Vontade de Affonso Heidy e Gerson Pinheiro.

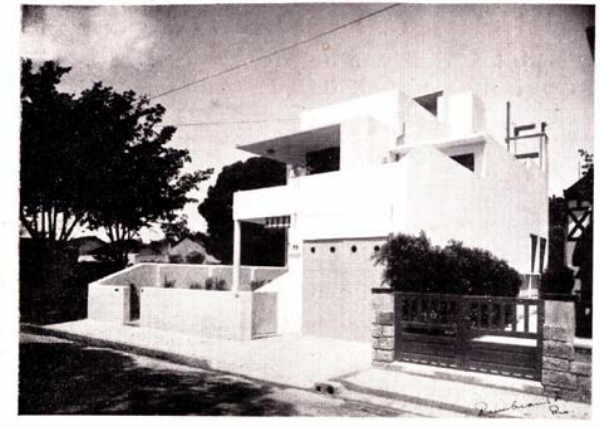

marcello roberto $r$ e s i d e n c i a e m I a r n e iras

\section{alexandre}

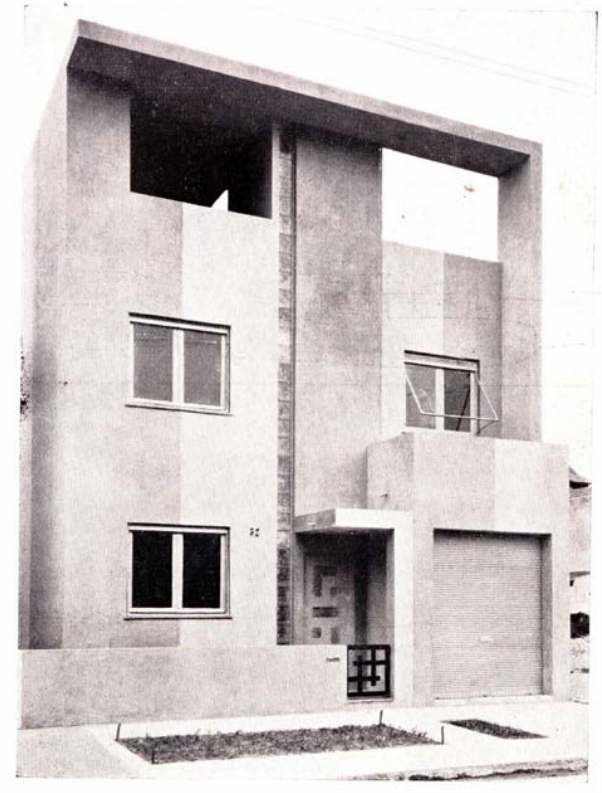

[126] $1^{\circ}$ Salão de Arquitetura Tropical, Rio de Janeiro, 1933. Vista panorâmica de Residência de Marcello Roberto e vista fachada frontal de Residência em Ipanema de Alexandre Alteberg.

A amostra do catálogo se completa com 4 residências não construídas. O projeto de Vicente Baptista, se apresenta com a Residência de Ipanema de Luis Nunes [127]. A proposta de Baptista está mais próxima da movimentação volumétrica apoiada no chão, tal 
como vimos em Gropius. Já a de Nunes se aproxima dos princípios corbusianos, com o uso parcial de pilotis suspendendo a forma geométrica. Uma pequena marquise em balanço que circunda a abertura do $1^{\circ}$ andar, no entanto, rompe a integridade da forma pura, tão apreciada por Corbusier.
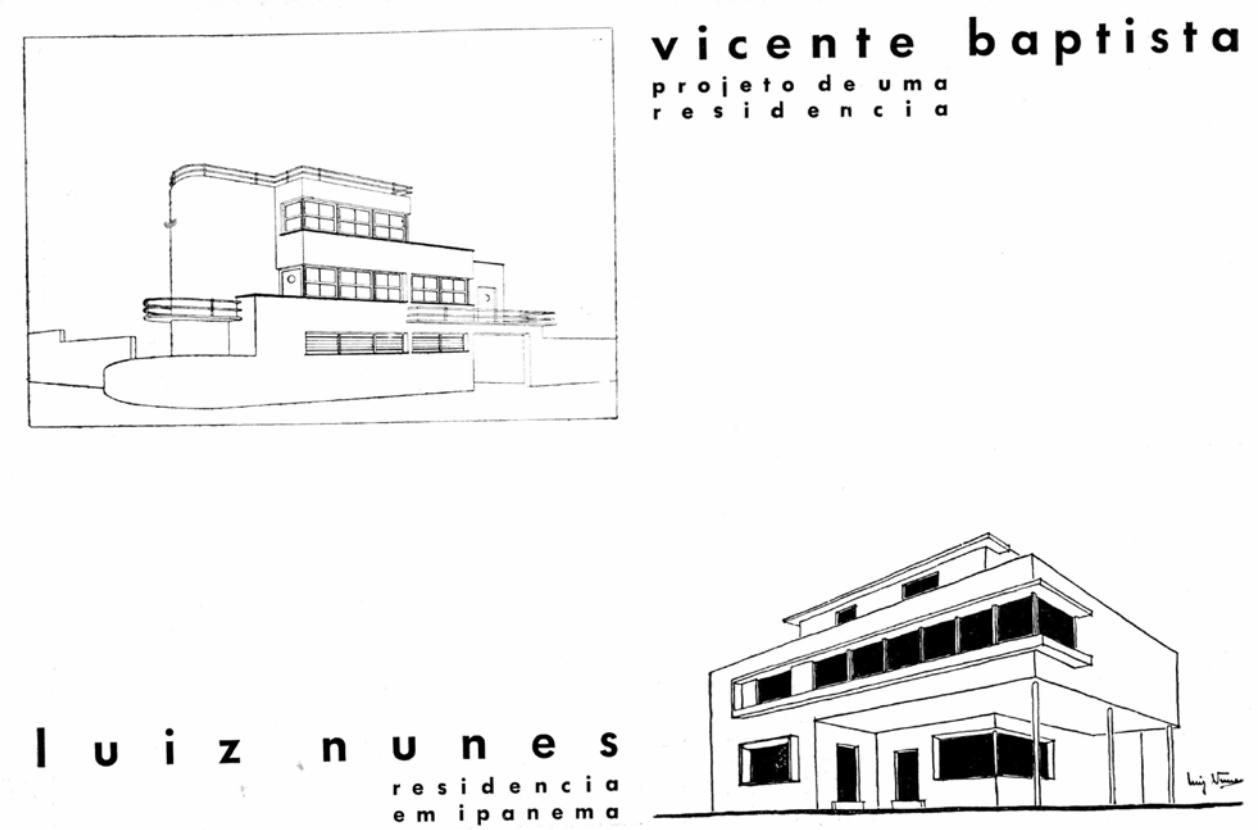

[127] $1^{\circ}$ Salão de Arquitetura Tropical, Rio de Janeiro, 1933. Perspectiva de projeto de uma Residência de Vicente Baptista e perspectiva de residência em Ipanema.

O projeto de João Lourenço da Silva e Alcides da Rocha Miranda e o projeto de Ademar Portugal [128] também têm diálogo com o raciocínio corbusiano. Na proposta de Portugal a referência parece ser das primeiras vilas, como as casas 14/15 no Bairro de Weissenhof e a Vila Stein. Na proposta de Silva e Miranda vê-se o mesmo raciocínio de Nunes, de suspensão parcial do volume. Neste caso, o afastamento dos princípios corbusianos se dá na marquise solta do terraço-jardim e na abertura total de uma das elevações, praticamente dissolvendo o volume e criando uma transparência que vai ser recorrente na escola carioca, alguns anos depois. 


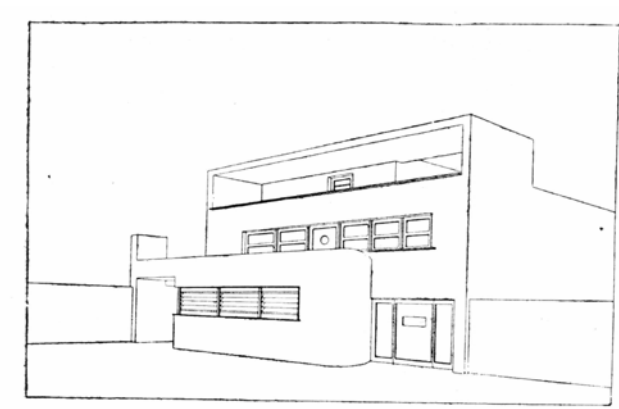

\section{a d e mar portugal}

proieto d e u mo

$r$ e s $i$ e n c i a

joão lourenço da silva e alcides da rocha miranda

projeto de uma
res i d e n i a

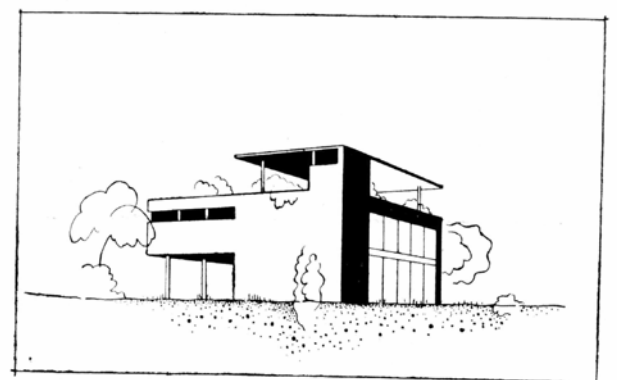

[128] $1^{\circ}$ Salão de Arquitetura Tropical, Rio de Janeiro, 1933. Perspectiva de projeto de uma Residência de Ademar Portugal e perspectiva de projeto de uma Residência de João Lourenço da Silva e Alcides da Rocha Miranda.

Desta maneira, evidenciamos um quadro da produção brasileira na passagem para a arquitetura moderna, na mesma época e com a mesma intenção dos primeiros projetos brasileiros de Levi. Com a produção paulista o contato de Levi é intenso, enquanto com a carioca é eventual, situação que se modifica nos anos posteriores.

Parece pertinente lembrar que o ambiente paulista onde Levi, Warchavchik, Carvalho e outros poucos tentam introduzir o ideário moderno é arredio, mesmo em se tratando de arquitetos. Um deles, o atuante Cristiano das Neves, criticando a Cia. City por haver permitido a construção das casas de Warchavchik no bairro do Pacaembu, escreveu no jornal Diário de São Paulo: "Imagine-se o que será da Cidade Jardim se continuarem a aparecer as casas tumulares de concreto armado. Será inevitável a desvalorização desses terrenos que mais parecerão o prolongamento do Araçá" 94 (referindo-se ao cemitério nas proximidades).

\footnotetext{
${ }^{94}$ Cristiano das Neves, o Jornal Diário de São Paulo, Apud SOUZA, Abelardo, op.cit., p.50.
} 
$\mathrm{Na}$ verdade, todas essas experiências modernas elencadas em São Paulo estão em novos loteamentos, sendo as de Levi nos Jardins e na Aclimação. Mesmo pontuais e encontrando fortes resistências, essas realizações pioneiras se constituem como referência para a ocupação desses novos bairros e marcam a paisagem construída da provinciana São Paulo do final da década de 1920 e começo de 1930.

\section{3 - OS PROJETOS DA DÉCADA DE 1950}

Após trabalhar o período de formação e as primeiras obras de Rino Levi a intenção agora é manter a categoria ou, melhor, a instância de análise e trabalhar um novo recorte. Isso significa dizer que será mantida a preocupação com as referências de projeto, mas, agora em obras da década de 50. A escolha temporal não é aleatória. Embora considerando que o uso de referências seja uma constante, nesta década um grupo particular de projetos oferece oportunidade privilegiada para o exame de como elas operam. A hipótese é que programas muito diferenciados serão resolvidos com partidos muito diversos.

No período referido, o escritório terá a possibilidade de se envolver com situações que vão desde o Concurso para o Plano Piloto de Brasília $^{95}$ até uma série de residências unifamiliares. Dessas, as mais apropriadas para a análise que se pretende são a Residência Rino Levi $^{96}$, de 1944, a Residência Milton Guper ${ }^{97}$, 1951/53, a Residência Paulo Hess ${ }^{98}$, 1952/55 e a Residência Castor Delgado Perez ${ }^{99}, 1958 / 59$.

\footnotetext{
${ }^{95}$ Plano Piloto de Brasília, concurso - $3^{\circ}$ lugar, Brasília, DF, 1957. Arquitetos Rino Levi, Roberto Cerqueira César e Luis Roberto de Carvalho Franco.

${ }^{96}$ Residência Rino Levi, São Paulo, SP, 1944. Arquitetos Rino Levi e Roberto Cerqueira César. Esta obra, embora da década anterior, oferece contribuições fundamentais para o raciocínio que se esboça.

${ }^{97}$ Residência Milton Guper, São Paulo, SP, 1951/52. Arquitetos Rino Levi e Roberto Cerqueira César.

${ }^{98}$ Residência Paulo Hess, São Paulo, SP, 1952/55. Arquitetos Rino Levi e Roberto Cerqueira César.

${ }^{99}$ Residência Castor Delgado Perez, São Paulo, SP, 1958/59. Arquitetos Rino Levi, Roberto Cerqueira César e Luis Roberto Carvalho Franco.
} 


\subsection{1 - O CONCURSO PARA O PLANO PILOTO DE BRASÍLIA}

Vários autores apontam como o Concurso para o Plano Piloto de Brasília sintetiza as diferentes propostas urbanas do período. Yves Bruand, falando dos projetos não vencedores do concurso, comenta que todos os que foram divulgados pelas revistas especializadas tinham um ponto em comum: sua inspiração racionalista. "Neles encontra-se sistematicamente a divisão entre as quatro funções principais enunciadas pela Carta de Atenas de 1933 (habitar, trabalhar, cultivar o corpo e o espírito, circular), a atribuição de setores bem definidos a cada uma delas, a preocupação de substituir a antiga rua por uma nova concepção que desse prioridade aos espaços livres e aos blocos isolados pontuando com sua massa ordenada as vastas superfícies não construídas, a definição de um tipo de célula de base cuja multiplicação constituiria um dos elementos fundamentais do plano de conjunto, enfim a regularidade e a geometria estrita tanto do conjunto quanto das partes que o formam."

O projeto de Levi e equipe [129], terceiro colocado no concurso, não fugiu às características apontadas. Sua concepção visa ordenar a cidade à sua finalidade político-administrativa na qualidade de capital do país e o tratamento de suas diversas funções pode ser assim resumido, conforme apresentação da própria equipe ${ }^{101}$.

\footnotetext{
${ }^{100}$ BRUAND, Yves, op. cit. P.356

${ }^{101}$ Rino Levi. Milano: Edizioni di Comunità, 1974. pp.96-101.
} 


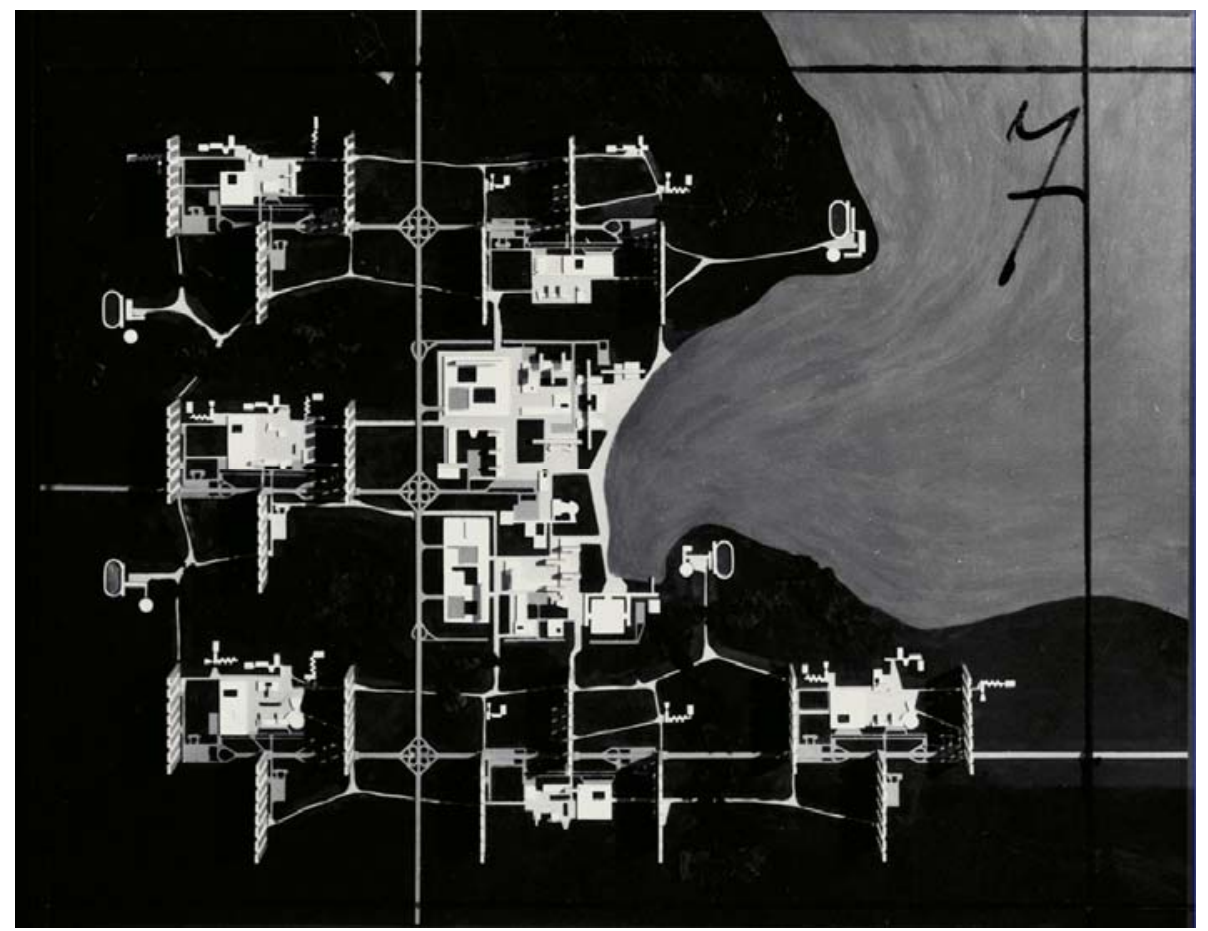

[129] Plano piloto de Brasília - $3^{\circ}$ lugar, Brasília, DF. Arquitetos Rino Levi e Roberto Cerqueira Cesar. 1957.

O Governo Federal - Palácio do Governo, Senado, Câmara dos Deputados e Supremo Tribunal - está localizado em posição de destaque em meio a um parque junto ao lago [130].

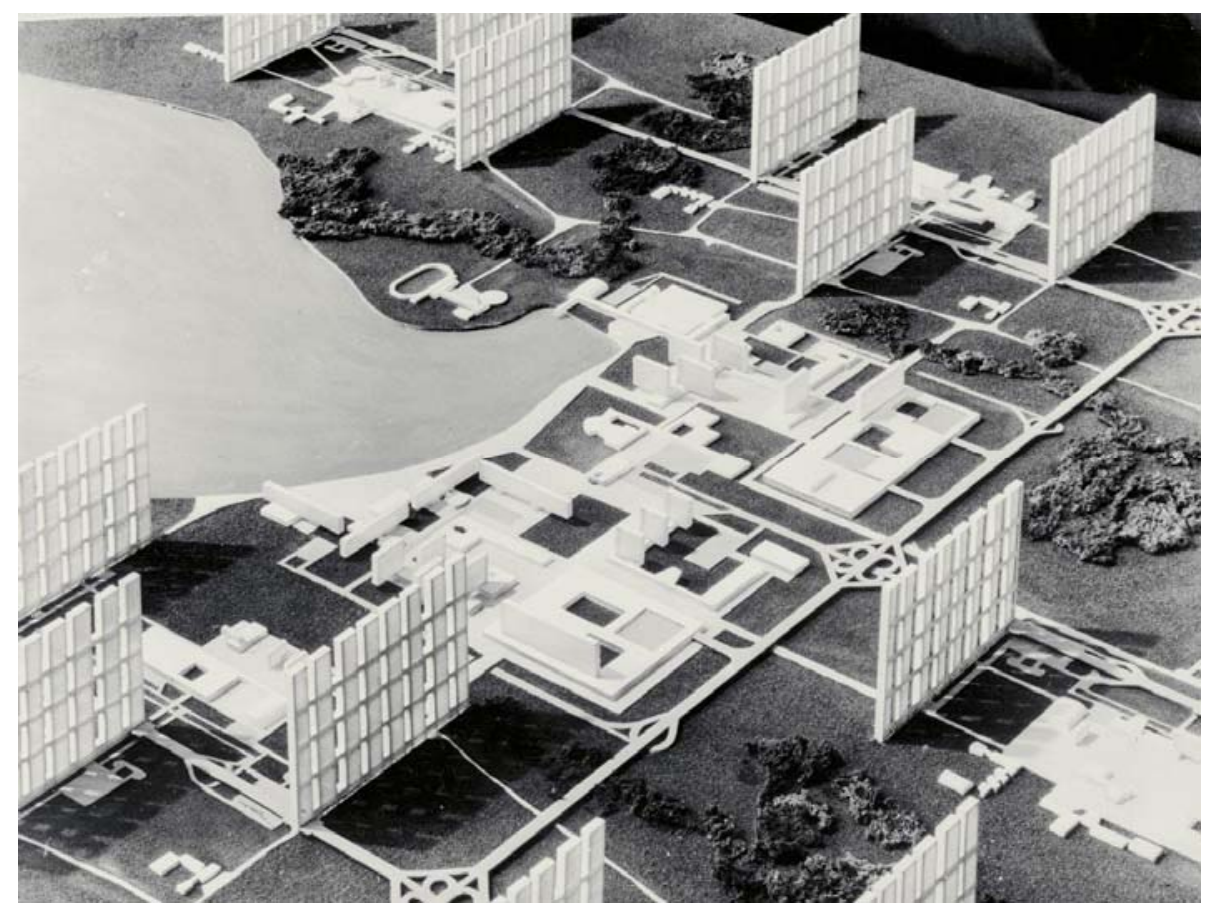

[130] Plano piloto de Brasília - $3^{\circ}$ lugar, Brasília, DF. Arquitetos Rino Levi e Roberto Cerqueira Cesar, 1957. 
A população será basicamente disposta em dois setores: habitação intensiva e habitação extensiva. A habitação intensiva se distribui em torno do centro urbano e constitui a maioria da população [131]. Os setores de habitação extensiva possuem residências individuais e alguns edifícios de apartamentos. Esses conjuntos são localizados sempre nos extremos das vias de acesso.

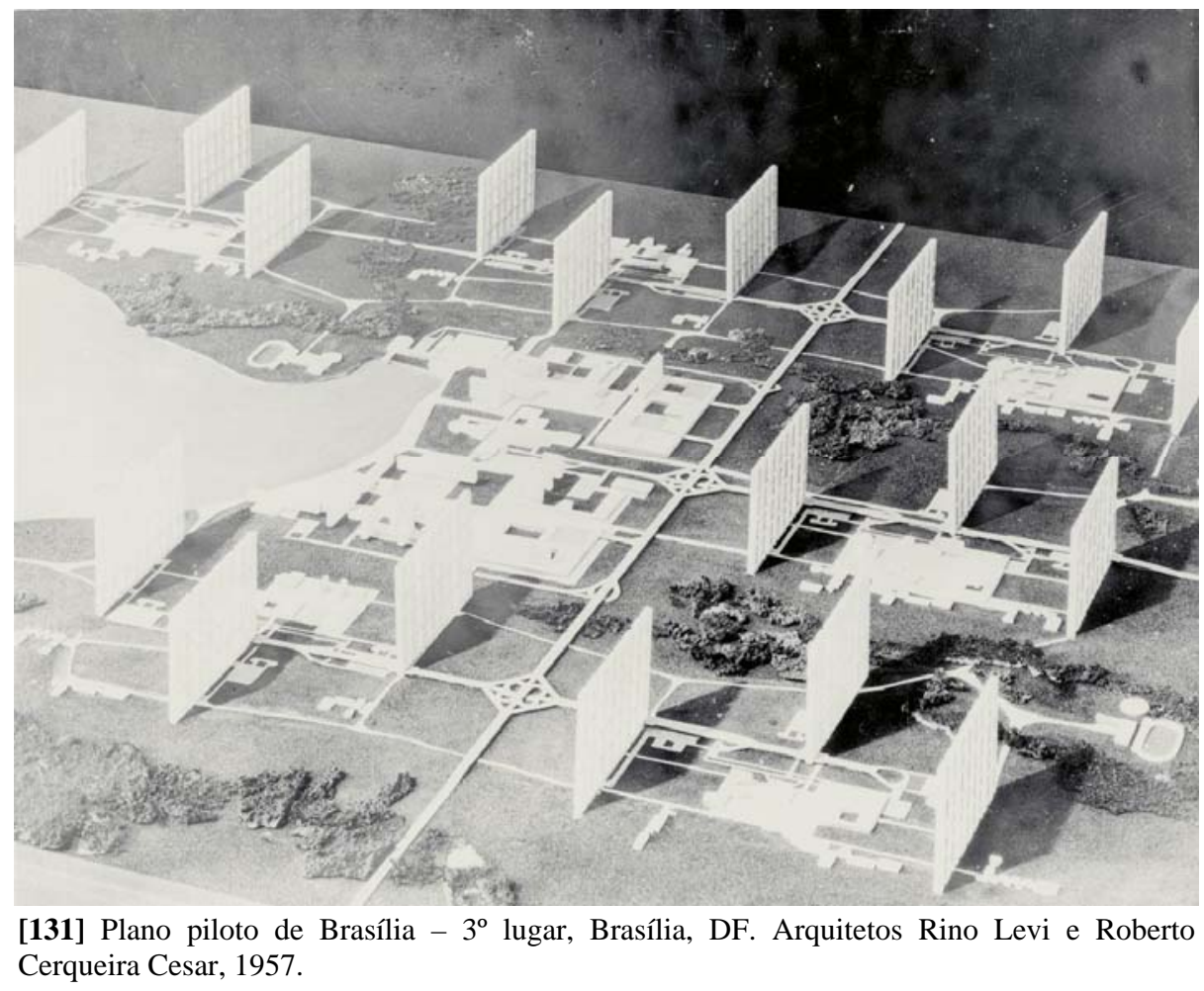

O Setor Industrial, dado o caráter político-administrativo da cidade, conta com indústrias que visam apenas a atender às necessidades da própria cidade. Está localizado junto à auto-estrada e à via férrea ligando-se à cidade por via expressa, prolongamento do tronco NorteSul.

O Centro Urbano compreende alguns órgãos federais (Ministérios e Autarquias) e as atividades centrais da cidade: administrativas, comerciais, culturais e de recreio. O centro é tangenciado pelo tronco viário Norte-Sul e liga-se por via direta à estação ferroviária e à autoestrada. 
A Cidade Universitária está localizada no extremo sul do tronco viário e contém, além dos institutos de ensino, residências para professores e estudantes, clube esportivo e centro hospitalar.

O Centro Esportivo Municipal e o Hipódromo estão vinculados às vias mestras de circulação, dada à necessidade de facilitar o transporte de grandes massas.

As Áreas Verdes constituem um problema, uma vez que o solo de Brasília é pobre. Assim, a rara vegetação existente será conservada e o restante do solo será recuperado, possibilitando a criação de áreas verdes nos espaços livres.

O Sistema de Interligações e Transportes constitui-se de 4 tipos de via: a) Vias expressas elevadas constando de um tronco Norte-Sul e 8 transversais Este-Oeste; b) Vias expressas sobre o solo, fora dos setores de habitação, ligando as vias elevadas com os diversos setores; c) Vias internas dos setores, em cul-de-sac, ladeadas, onde oportuno, por estacionamentos; d) Vias para pedestres, sem cruzamento com as vias expressas.

A justificativa na concentração da maioria da população em torno do centro urbano dá-se na medida em que se reduzem as distâncias nas caminhadas a pé. Essa concentração permite, também, a redução de toda a infra-estrutura com grande economia nos sistemas viários, hidráulicos e elétricos. Possibilita a diminuição de pessoal e meios necessários à manutenção. Permite ainda a obtenção de grandes áreas livres. O elevado índice demográfico é obtido sem prejuízo das melhores condições de insolação, ventilação e conforto.

A distribuição das facilidades proporcionadas aos habitantes do setor intensivo processa-se na seguinte seqüência: nas ruas internas, são 
oferecidas as facilidades imediatas: pequeno comércio, creche, jardim da infância, posto de saúde, etc. Ao pé de cada conjunto de 3 superblocos [132], conta-se com os serviços já mais complexos como escola primária e secundária, cinema, comércio em maior escala. Finalmente, no centro urbano encontram-se o alto comércio, os escritórios oficiais e particulares, mercado, etc.

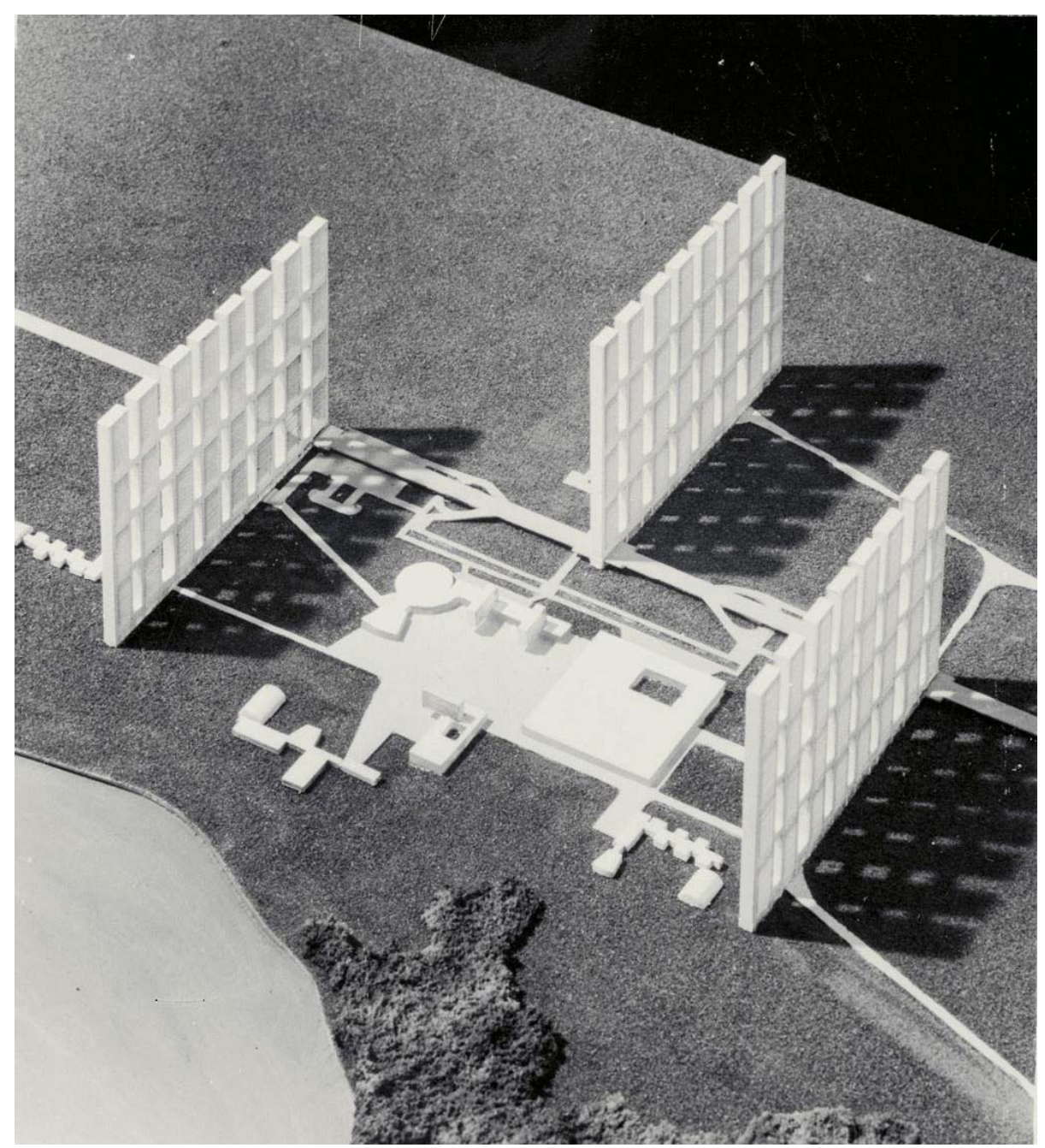

[132] Plano piloto de Brasília - $3^{\circ}$ lugar, Brasília, DF. Arquitetos Rino Levi e Roberto Cerqueira Cesar, 1957.

O superbloco [133] é um conjunto de 32 edifícios de 20 andares cada um, imaginando-se que os projetos de cada edifício poderiam, eventualmente, ser entregues a arquitetos diferentes. Todo esse conjunto é sustentado por uma grande estrutura de aço. Dado os enormes esforços gerados pela pressão do vento, foi aconselhável 
criar as aberturas que aparecem entre os edifícios de 20 andares. Cada superbloco mede 18 metros de largura, 435 de comprimento e 300 de altura.

A circulação vertical, calculada de acordo com as exigências da Associação Brasileira de Normas Técnicas, compreende dois grandes sistemas de elevadores com paradas apenas na garagem e no sub-solo, no andar térreo e nas 4 ruas internas do super bloco. Atingida a rua interna, o usuário dirige-se ao edifício que procura onde tomará o elevador de tipo convencional que o conduzirá ao andar desejado. Pode-se dizer que a função dos elevadores principais corresponde à do sistema de transporte coletivo da cidade convencional [134].
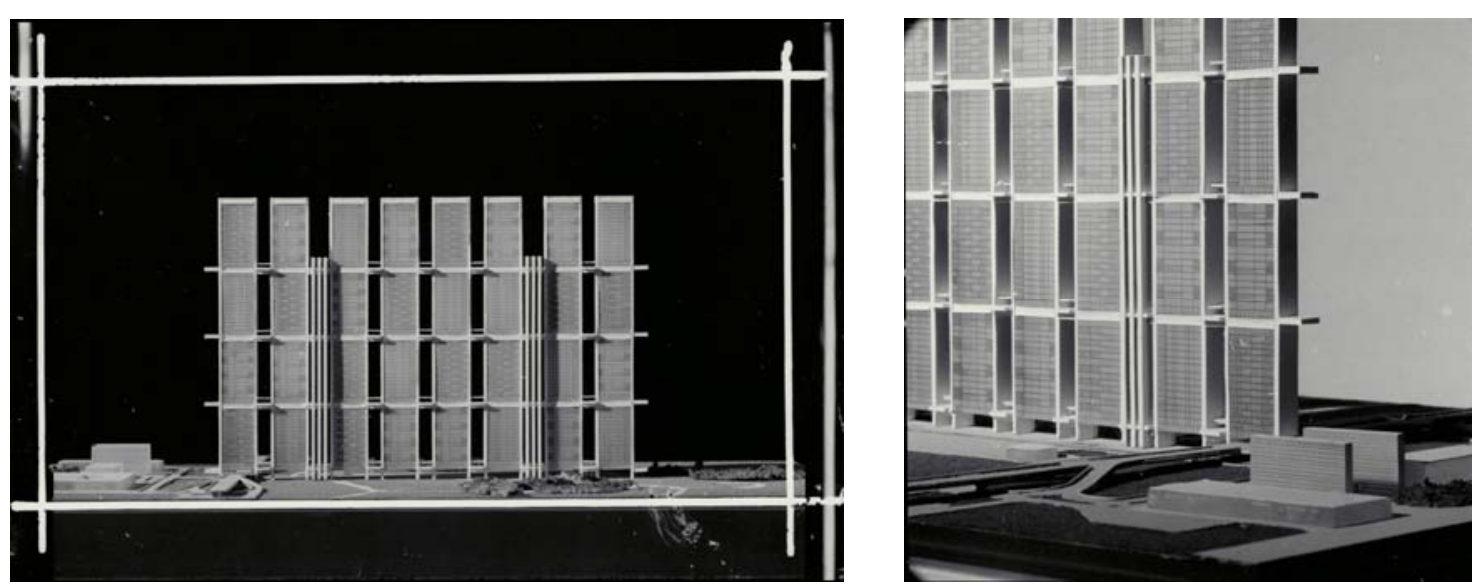

[133] e [134] Plano piloto de Brasília - $3^{\circ}$ lugar, Brasília, DF. Arquitetos Rino Levi e Roberto Cerqueira Cesar, 1957.

A proposta, como se pode imaginar, gerou polêmica e espanto. Como já foi dito, Yves Bruand comenta a amplidão dada aos estudos técnicos e a falta proposital de valorização dos edifícios administrativos: "Essa falta chegou a ser levada ao extremo, pois o efeito plástico da composição iria provir dos prédios de apartamentos de trezentos metros de altura perto dos quais as outras construções teriam parecido subalternas. Não há dúvida de que a experiência era vigorosamente original e revolucionária na maneira de colocar os problemas. Nesse sentido, ela era uma aposta, como a própria Brasília, mas pode-se perguntar se seus autores concorreram realmente com a idéia de ganhar, dando provas de muita 
ingenuidade, ou se entregaram a um brilhante exercício de estilo e a uma demonstração teórica das possibilidades oferecidas por uma cidade vertical ideal... enfim, não era lógico fazer com que a aglomeração crescesse em altura e levasse a uma forte concentração relativa quando o que menos faltava era justamente espaço". ${ }^{102}$

$\mathrm{Na}$ verdade, o próprio memorial do anteprojeto e as posições defendidas pelo escritório na polêmica instalada após o concurso, mostram que eles concorreram para ganhar. No memorial fica demonstrado como cada superbloco é sustentado por uma grande estrutura de aço em cujo cálculo foram adotados apenas perfis fabricados no Brasil e são especificados tanto o seu detalhamento quanto o seu cálculo. Impossível não lembrar das experiências com a Cidade Vertical de Ludwig Hilberseimer [135], que Levi conhecia bem.

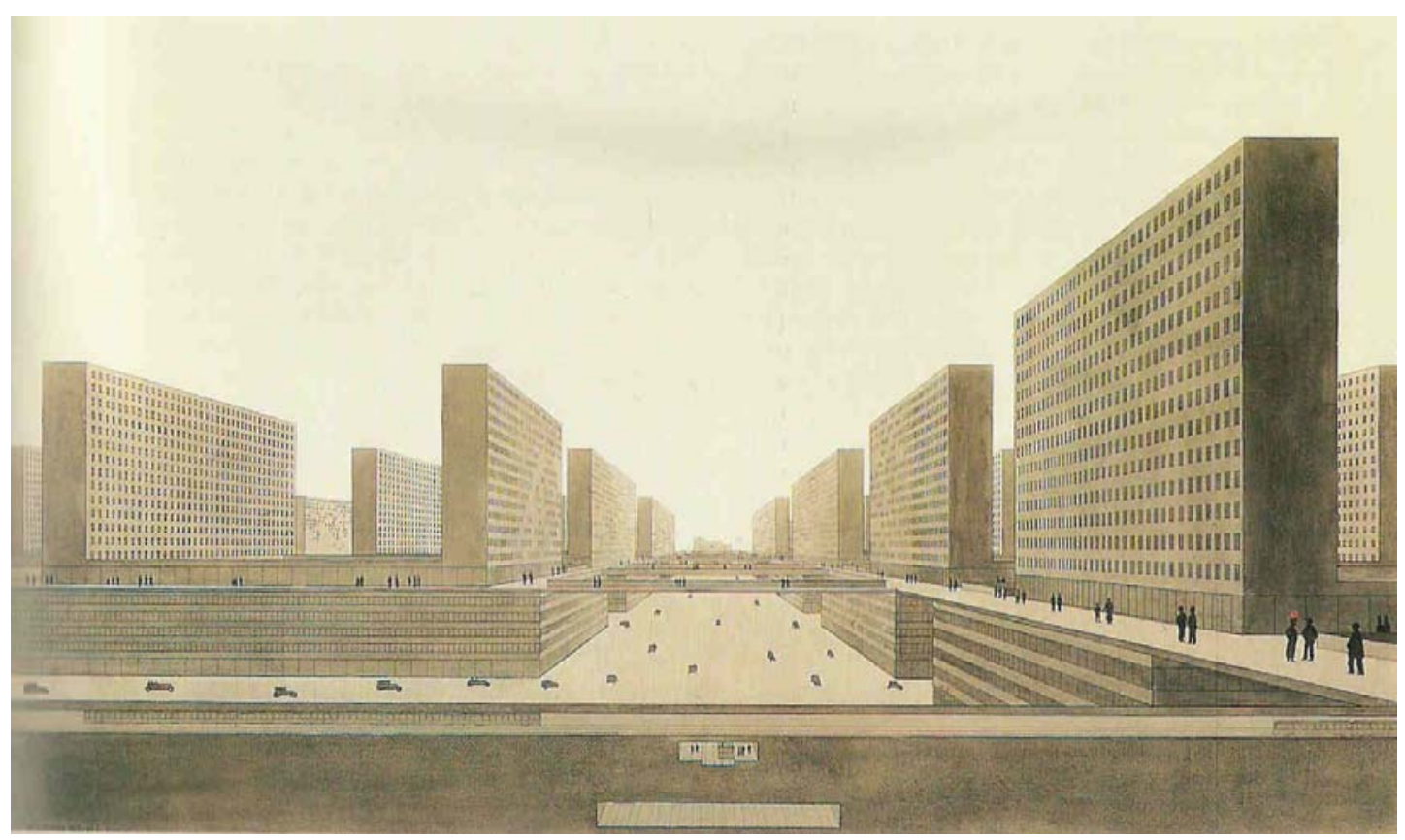

[135] Cidade Vertical, Ludwig Hilberseimer, 1924.

Quanto à questão do "espaço de sobra", o argumento para a verticalização e a alta densidade estava na inexistência de "infra-

${ }^{102}$ BRUAND, Yves, op. cit., p.357 
estrutura de sobra". O plano piloto seria implantado em pleno planalto central, deserto, e qualquer solução horizontal implicaria em custos elevados nos sistemas viários, hidráulicos e elétricos, o que se mostrou verdadeiro. Também aqui convém lembrar que a preocupação com o valor do solo está nas raízes das propostas para a cidade. O anteprojeto de Levi, diferentemente do vencedor Lúcio Costa, previa a possibilidade de crescimento com o acréscimo de novos conjuntos, o que justificaria o investimento. Além de favorecer o controle do preço do solo, permitir expansão e diminuir os custos de infra-estrutura, a previsão de distintos núcleos facilitaria a distribuição orgânica das cidades satélites.

Segundo Levi, essa disposição associava as "vantagens da cidade pequena - (no) sentido de grupo social - com as vantagens de uma cidade grande". Os vários núcleos de crescimento limitado reproduziriam as condições de vida da cidade pequena, enquanto um centro comum permitiria o surgimento das "vantagens das grandes cidades" , como serviços, comércio, cultura, concentrações administrativas públicas e privadas. A radical verticalidade das habitações - $300 \mathrm{~m}$ de altura, $435 \mathrm{~m}$ de comprimento e $18 \mathrm{~m}$ de largura - e a elevação das vias para carros liberavam o solo para um grande parque, que poderia ser percorrido a pé. Apenas os centros de vizinhança ofereciam alguma urbanidade.

A contemporaneidade dessa concepção é, no mínimo, impressionante. Levi, de certa maneira, antecipa o que arquitetos como Richard Rogers está consolidando atualmente: "Quase todas as grandes cidades já foram pequenas e quase todas as pequenas cidades já foram vilas. Quanto maior a comunidade, maior a perda de sua coesão social. Cidades como Londres, que sob muitos aspectos ainda é uma combinação de vilas e um grande centro, são melhores para se viver do que aglomerações divididas por zonas e sem dimensão 
humana". 103

Dois outros projetos de Levi na década de 50 atestam a pertinência da estrutura metálica na proposta do plano piloto. Um dos exemplos é "o primeiro edifício com estrutura de aço construído no Brasil (1954) projetado por Rino Levi e equipe; trata-se da Garagem América [136], na Rua Riachuelo, em São Paulo"104. Também a primeira garagem de grandes proporções a ser construída em São Paulo foi resultado de um cuidadoso estudo do sistema viário central e de suas tendências prováveis. O terreno, de pouco mais de 1000 metros quadrados, e de conformação um tanto ingrata permitiu, todavia, acomodar 500 carros. A estrutura do prédio é toda feita com perfis de aço, sobre a qual apóiam-se as lajes de concreto[137].
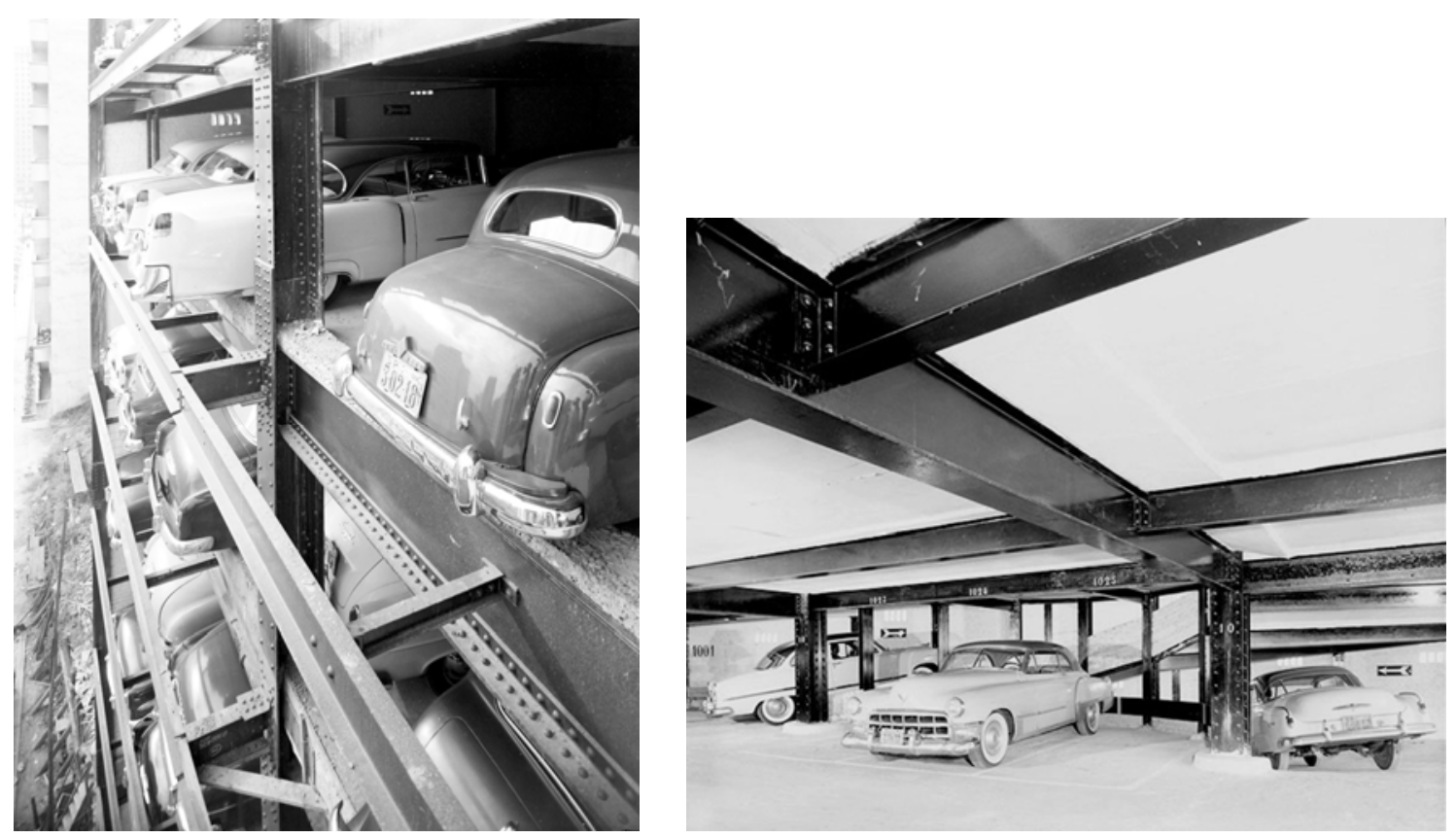

[136] e [137] Garagem América, São Paulo, SP. Arquiteto Rino Levi, 1952/54.

O segundo exemplo é solução estrutural do Galpão [138] para a fazenda da Tecelagem Parahyba, em São José dos Campos,

\footnotetext{
${ }^{103}$ ROGERS, Richard. Cidades para um pequeno planeta.Barcelona: Editorial Gustavo Gili, 2001, edição portuguesa.

${ }^{104}$ BRUAND, Yves, op. cit. P.17.
} 
1951/1955 ${ }^{105}$, resolvida com a combinação de três materiais: ferro, madeira e concreto, utilizados de maneira a renderem ao máximo dentro das suas diferentes características [139]. O programa é muito simples [14o]: abrigo de caminhões e de máquinas agrícolas da fazenda e posto de gasolina - ou seja - grandes espaços livres.

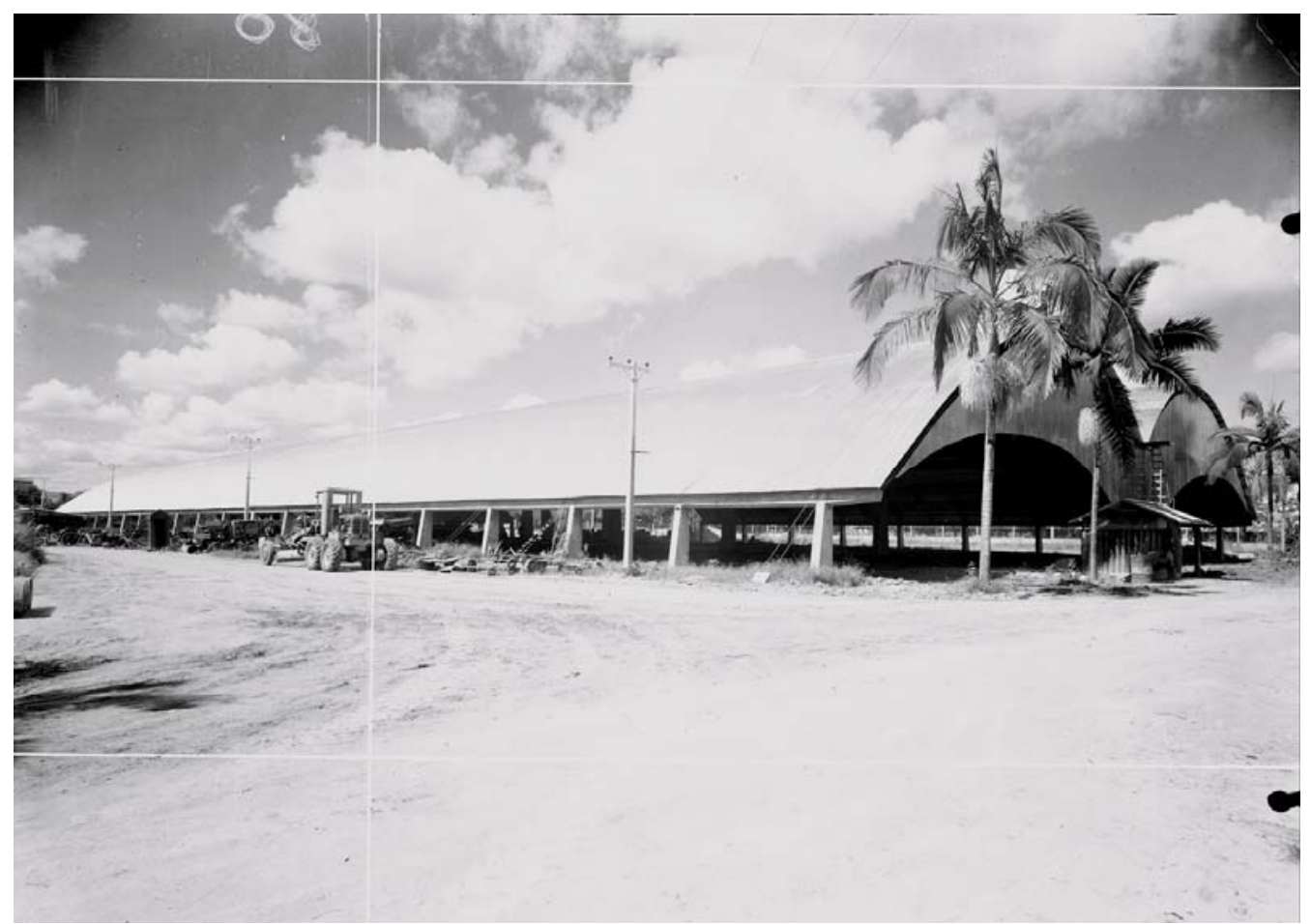

[138] Galpão, São José dos Campos, SP. Arquitetos Rino Levi, Roberto Cerqueira Cesar e Luis Roberto Carvalho Franco, 1951/55.

105 Galpão, São José dos Campos,SP, 1951/55. Arquitetos Rino Levi, Roberto Cerqueira Cesar e Luis Roberto Carvalho Franco. 


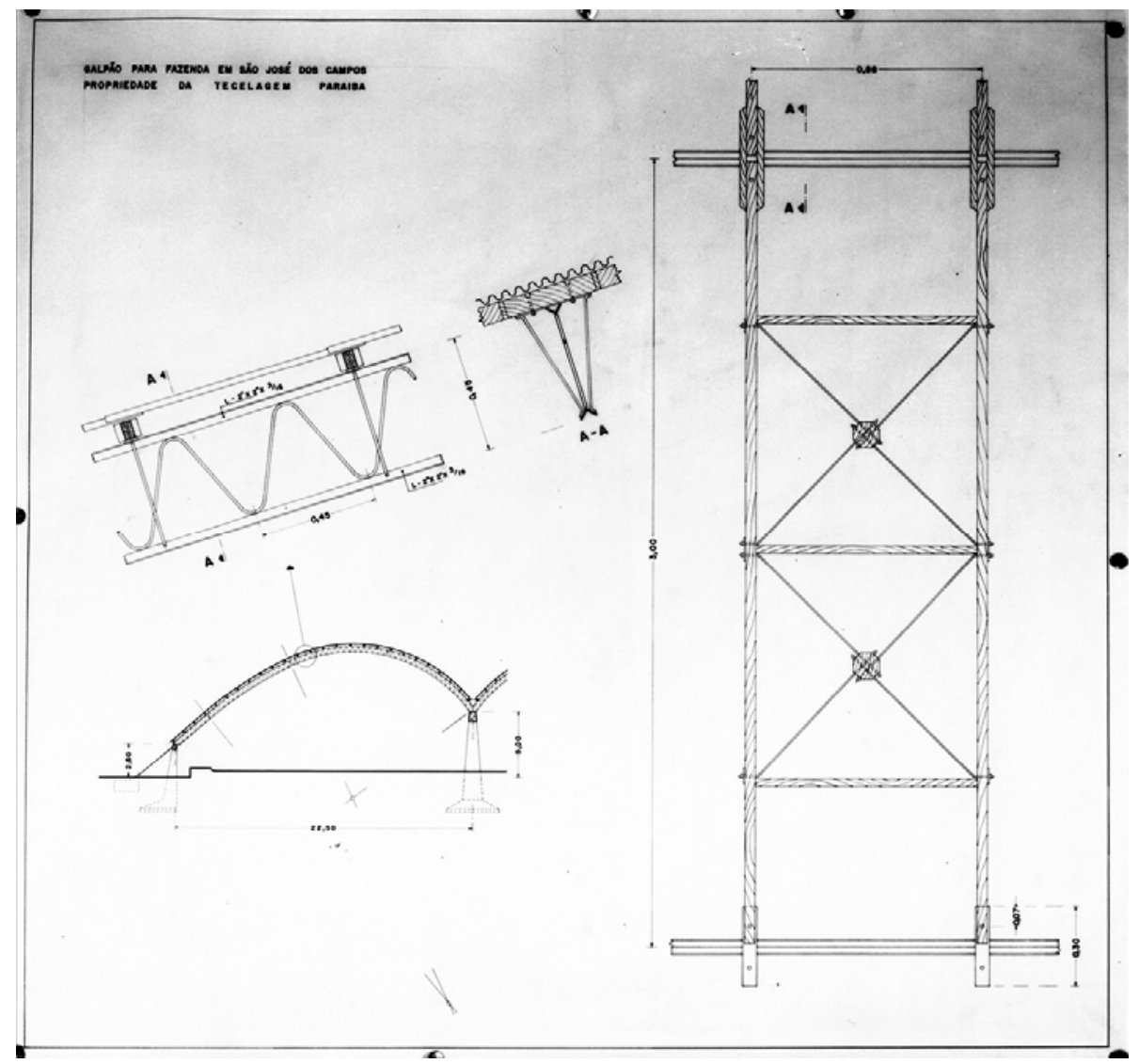

[139] Galpão, São José dos Campos, SP. Arquitetos Rino Levi, Roberto Cerqueira Cesar e Luis Roberto Carvalho Franco, 1951/55.

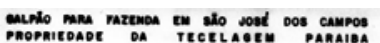

:
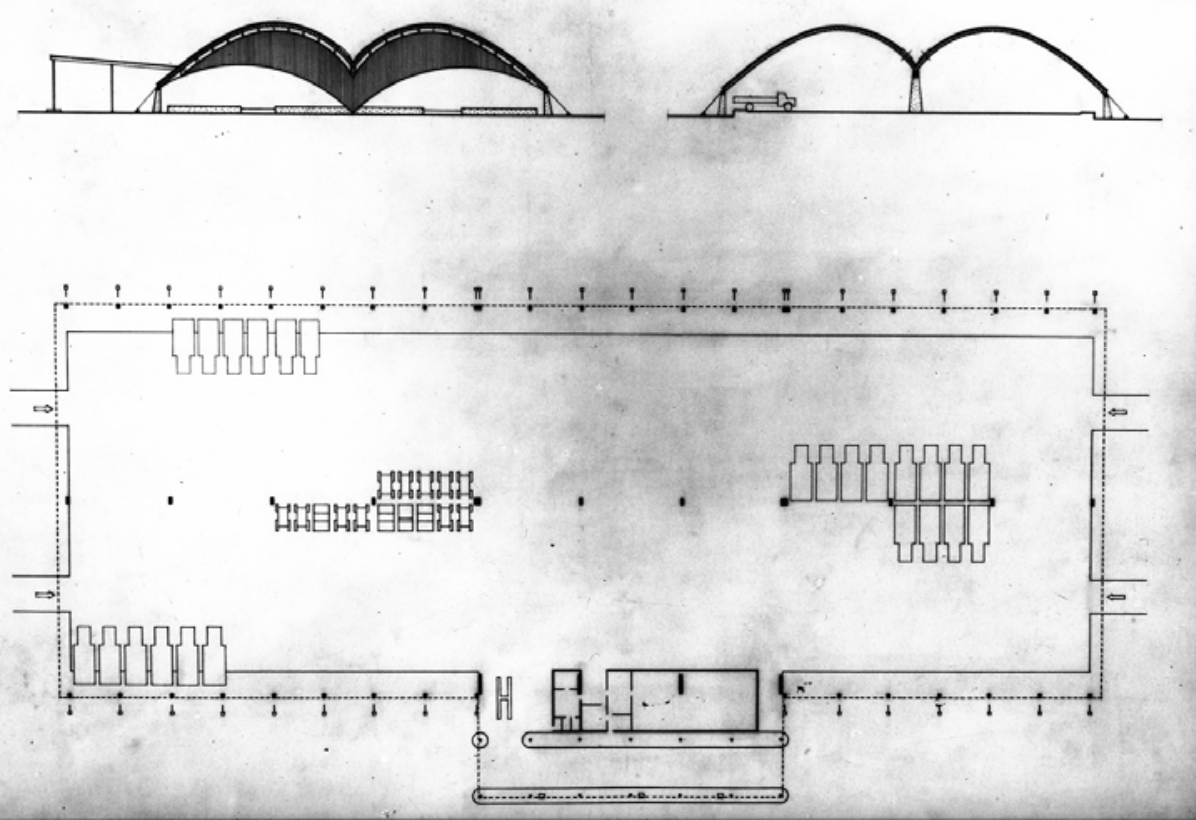

[140] Galpão, São José dos Campos, SP. Arquitetos Rino Levi, Roberto Cerqueira Cesar e Luis Roberto Carvalho Franco, $1951 / 55$. 
Em um momento em que os grandes vãos na arquitetura brasileira são sistematicamente resolvidos em concreto armado, os arquitetos optam por uma cobertura leve, de estrutura mista: duas abóbadas de 22,50 metros de vão feitas com arcos de ferro perfilado e ferro redondo [141], apoiados sobre estrutura de concreto, que absorve os empuxos [142]. O contraventamento no sentido longitudinal é feito por terças de madeira, ligadas duas a duas por cruzetas de ferro redondo. A cobertura é realizada com telhas onduladas de alumínio, que não chegam até o chão [143]. Os pilares centrais são mais altos que os laterais, o que quebra a simetria do arco e marca a elegância do seu perfil. Apenas uma das quatro faces do galpão é vedada: a suave curva do lado inferior do anteparo e o rasgo entre o lado superior e a cobertura, que não é tocada, acentuam a assimetria e a elegância [144]. Uma cobertura plana, no mesmo sistema construtivo, anexa às abóbadas, abriga o posto de gasolina [145]. Neste, um painel de ladrilhos esmaltados de autoria de Roberto Burle Marx [146] atesta a preocupação com os detalhes.

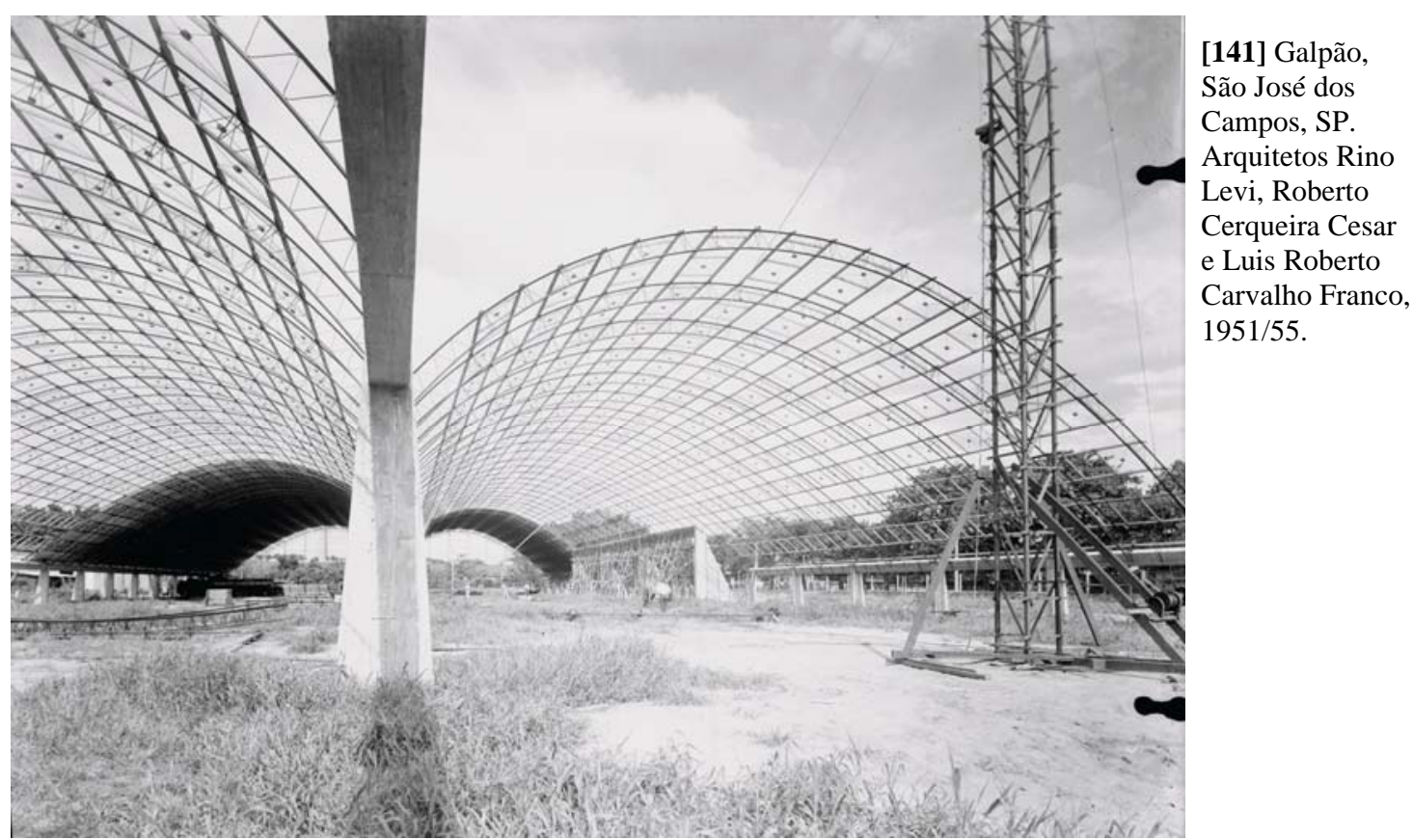




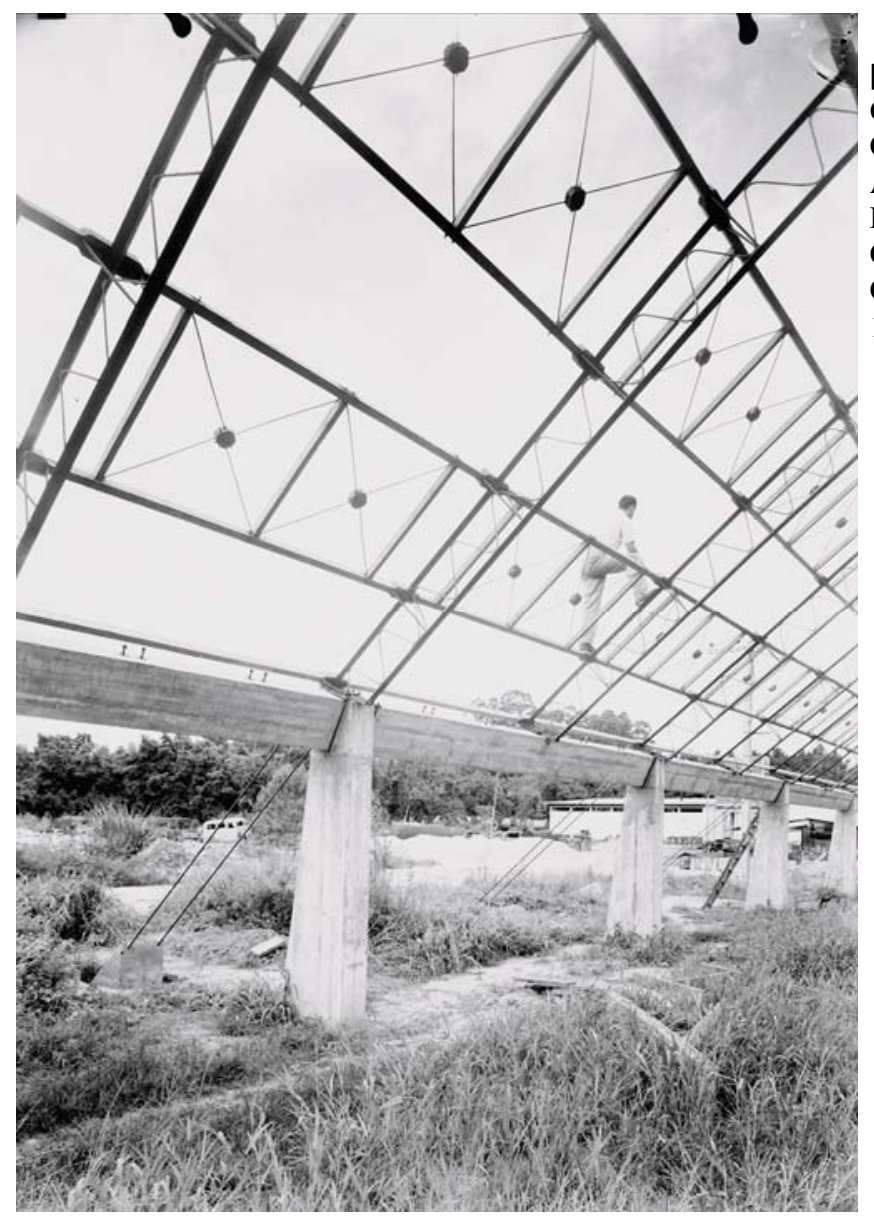

\section{[142]}

Galpão, São José dos Campos, SP.

Arquitetos Rino Levi, Roberto Cerqueira

Cesar e Luis Roberto Carvalho Franco, 1951/55.

[143] Galpão, São José dos Campos, SP. Arquitetos Rino Levi, Roberto Cerqueira Cesar e Luis Roberto Carvalho Franco, 1951/55.

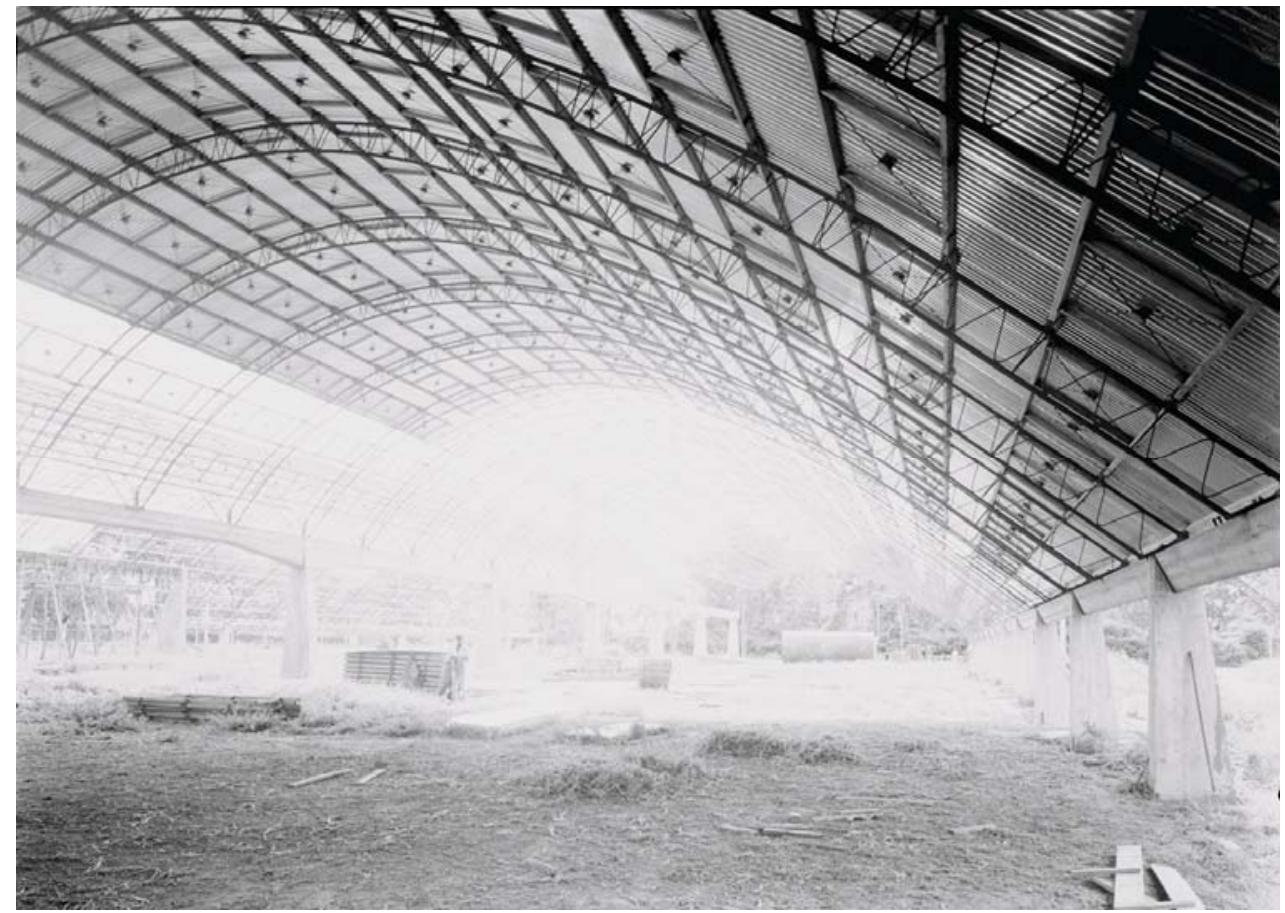




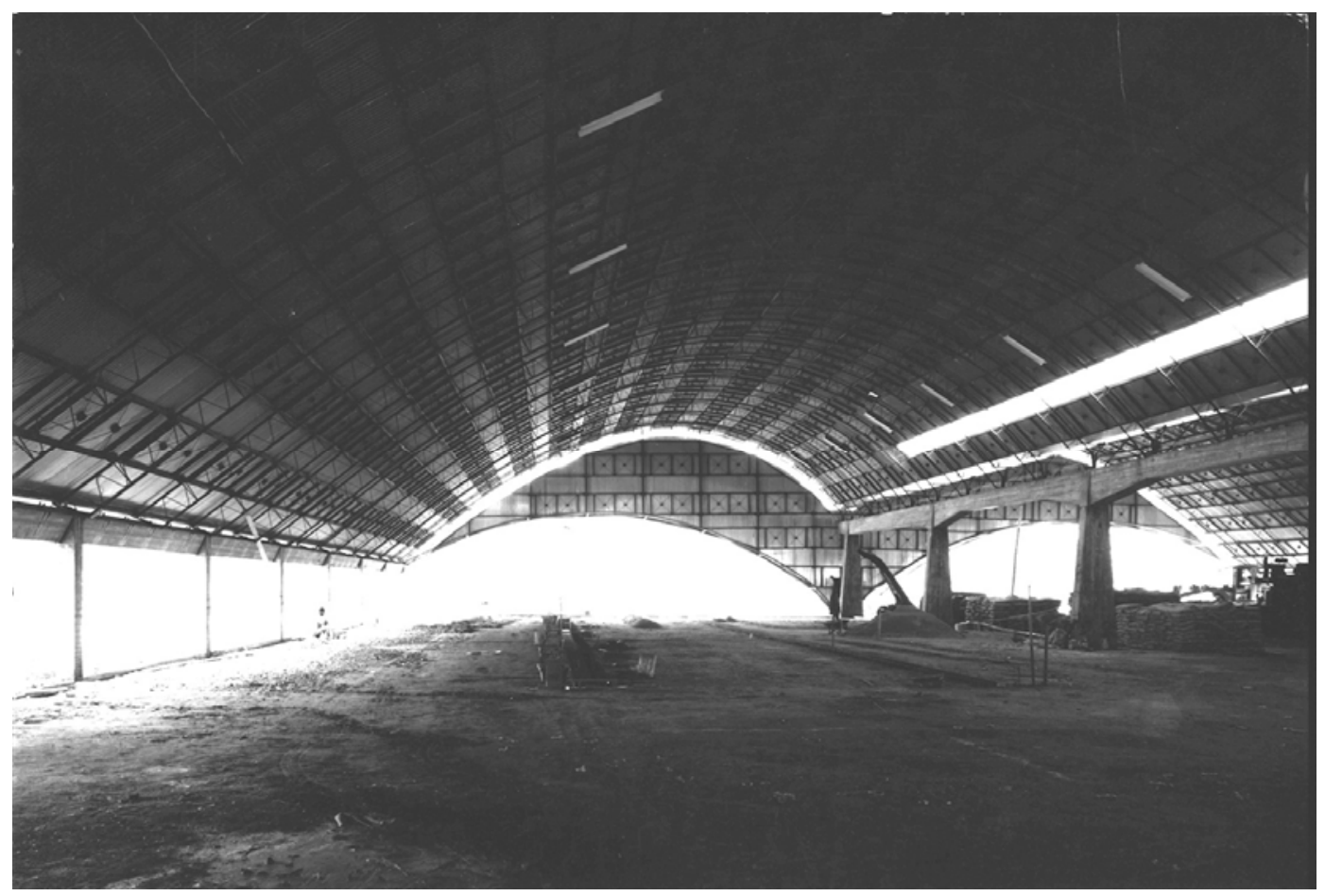

[144] Galpão, São José dos Campos, SP. Arquitetos Rino Levi, Roberto Cerqueira Cesar e Luis Roberto Carvalho Franco, 1951/55.

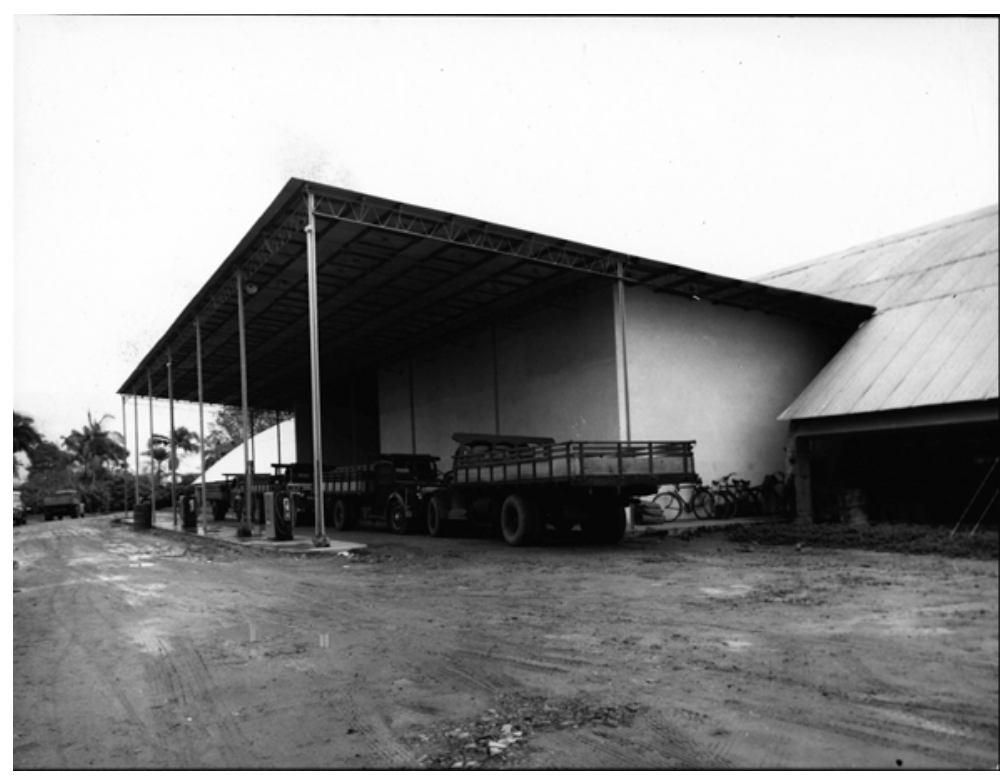

[145]

Galpão, São José dos

Campos, SP. Arquitetos Rino

Levi, Roberto Cerqueira

Cesar e Luis Roberto

Carvalho Franco, 1951/55. 


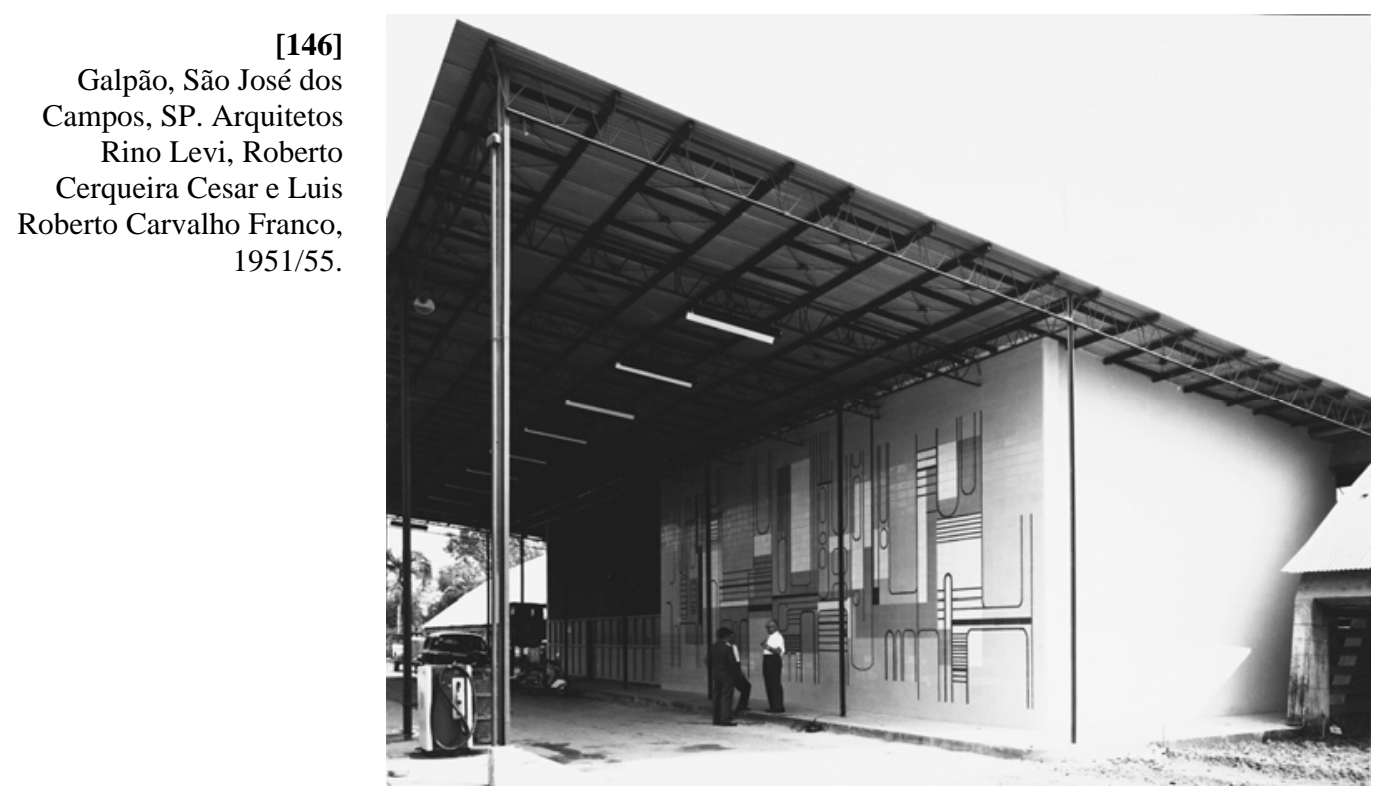

Outra vez, não deve ser mera coincidência a realização do mesmo tipo de experiência no escritório dos Irmãos Roberto, em projetos como, por exemplo, a Indústria Caterpillar [147], de 1953, Rio de Janeiro $^{106}$. Também lá a hegemonia do concreto armado é quebrada e o salão de exposição das máquinas à venda é estruturado por grandes arcos de madeira com 44 metros de vão, apoiados em pilares de concreto armado e cobertos por telhas de fibrocimento que não chegam até o chão. Novamente há a correta exploração de diferentes materiais, adaptados às características do programa. Poderia-se argumentar que essas características nos dois projetos apontados conduziriam naturalmente ao tipo de solução estrutural adotada. $\mathrm{O}$ próprio Niemeyer desmonta a argumentação: o seu projeto para a Fábrica Duchen ${ }^{107}$ [148], de 1950, São Paulo, é resolvido com pórticos rígidos de concreto armado, num raciocínio recorrente no partido que ele adota, independentemente do programa.

\footnotetext{
${ }^{106}$ Industria Caterpillar, Rio de Janeiro, 1953. Arquitetos M.M.M. Roberto.

${ }^{107}$ Fábrica Duchen, São Paulo, SP, 1950. Arquitetos Oscar Niemeyer e Hélio Uchôa
} 


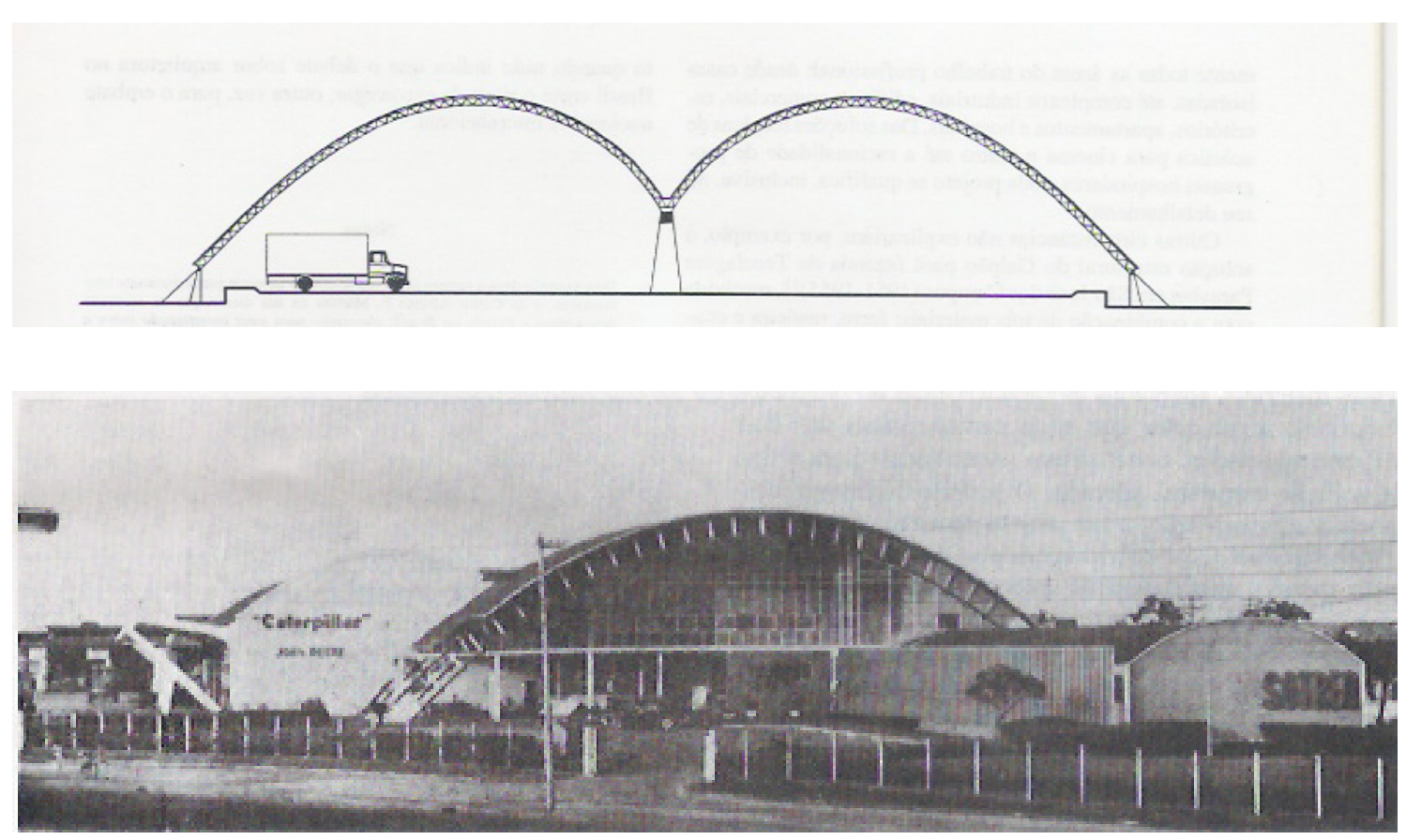

[147] Indústria Caterpillar, Rio de Janeiro. Arquitetos MMM Roberto, 1953.

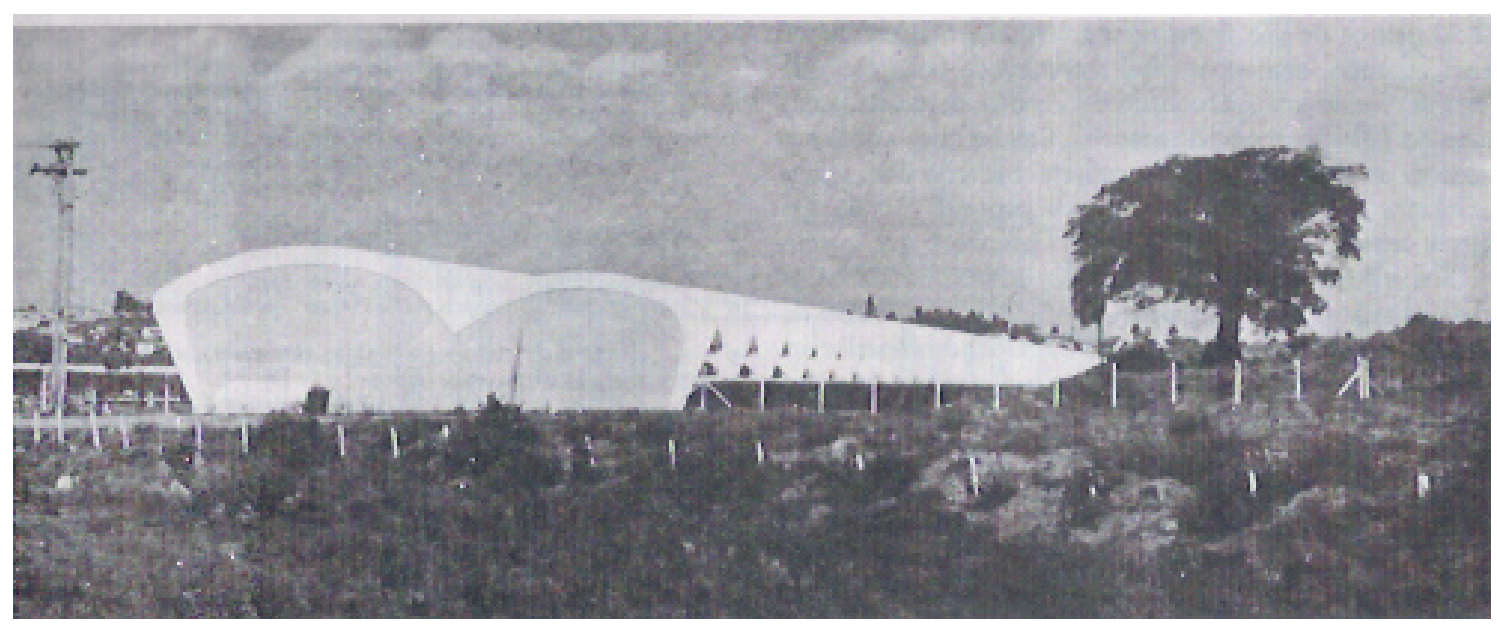

[148] Fábrica Duchen, São Paulo,SP. Arquitetos Oscar Niemeyer e Hélio Uchôa, 1950.

\subsection{2 - AS RESIDÊNCIAS UNIFAMILIARES}

Na obra de Levi, se a mudança de programa é drástica a mudança de partido também o é. Passando de um programa amplo e complexo como um plano urbanístico para um programa relativamente simples como uma residência unifamiliar, a mudança de partido é vigorosa. A afirmação fica clara na análise de uma série de casas projetadas pelo 
arquiteto e colaboradores na área dos Jardins, em São Paulo.

A primeira delas é a própria Residência do Arquiteto $^{108}$, implantada em lote de esquina no Jardim Europa [149]. A primeira característica a chamar a atenção é o tratamento dado às divisas do lote. Ao invés do tradicional muro no limite, os recuos obrigatórios ficam abertos para o passeio, numa proposta generosa que, se seguida pelos vizinhos, tornariam a região em verdadeiro Bairro-Jardim [150], [151]. Sobre os recuos, paredes ou superfícies de elemento vazado separam o interior da residência que se abre para três espaços abertos ao redor do seu corpo [152]. Os quartos dispostos em fileira abrem-se para um desses espaços. A sala abre-se para o segundo [153] e a área de serviço para o terceiro [154]. A cozinha apresenta solução totalmente moderna e funcional: organizada ao longo de uma bancada [155], é iluminada por uma janela longitudinal no nível do plano de trabalho e por outra acima do armário que o acompanha em toda a sua extensão [156]. O mobiliário concebido como equipamento da habitação não se limita ao espaço da cozinha. A lareira incorporada ao armário serve de divisória para a sala de estar [157] e vários bancos estão consolidados junto às aberturas. $\mathrm{O}$ sistema construtivo é simples: estrutura de concreto, paredes de alvenaria, telhados ondulados de fibrocimento. Apesar disso, a escolha recai sobre materiais artificiais modernos e a pré-fabricação desses materiais [158]. A maioria desses procedimentos está presente em toda a série de residências e vai evoluindo a cada uma delas.

${ }^{108}$ Residência Rino Levi, São Paulo, SP, 1944. Arquitetos Rino Levi e Roberto Cerqueira Cesar. 


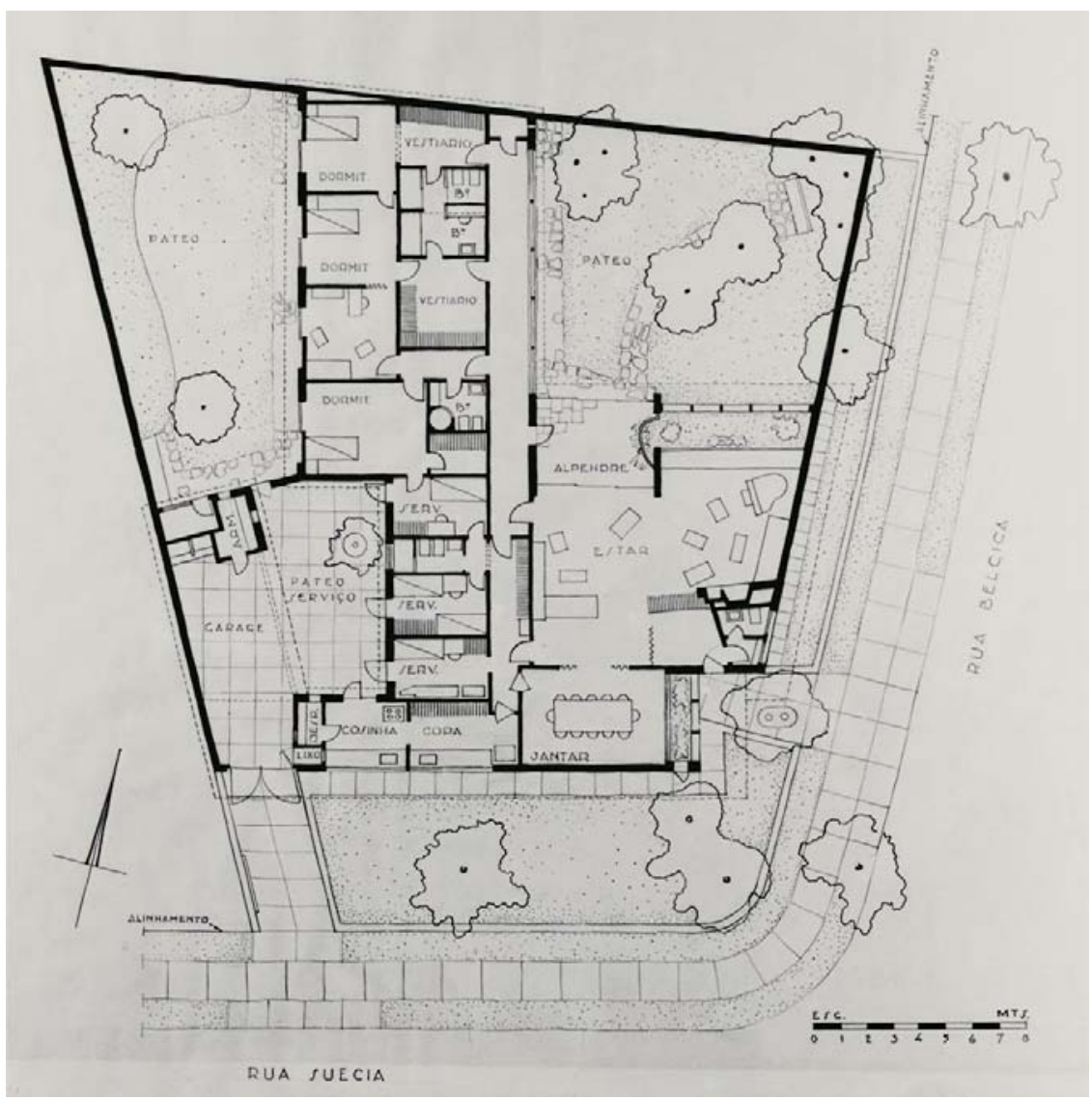

[149] Residência Rino Levi, São Paulo, SP. Arquitetos Rino Levi e Roberto Cerqueira Cesar, 1944.

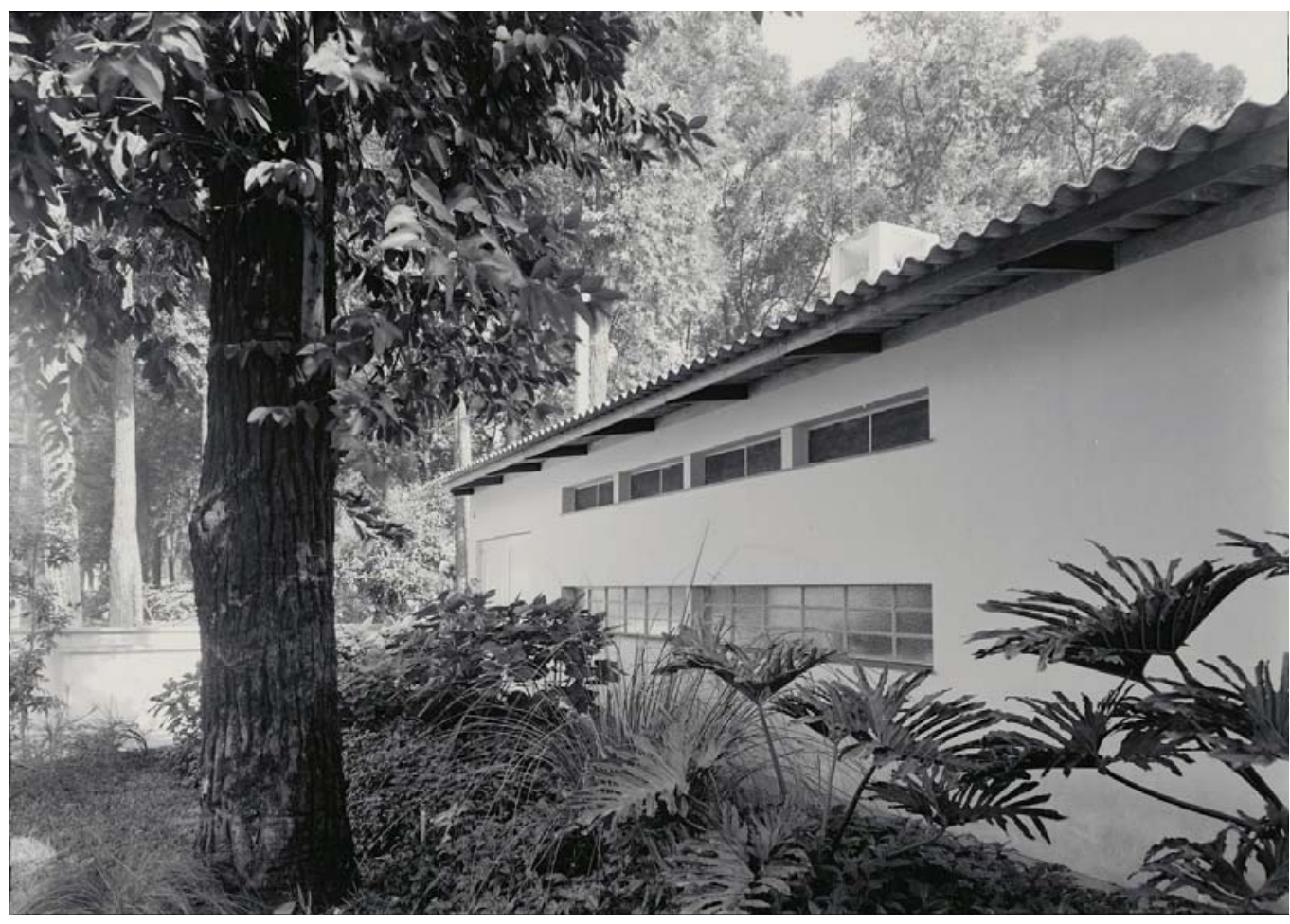

[150] Residência Rino Levi, São Paulo, SP. Arquitetos Rino Levi e Roberto Cerqueira Cesar, 1944. 


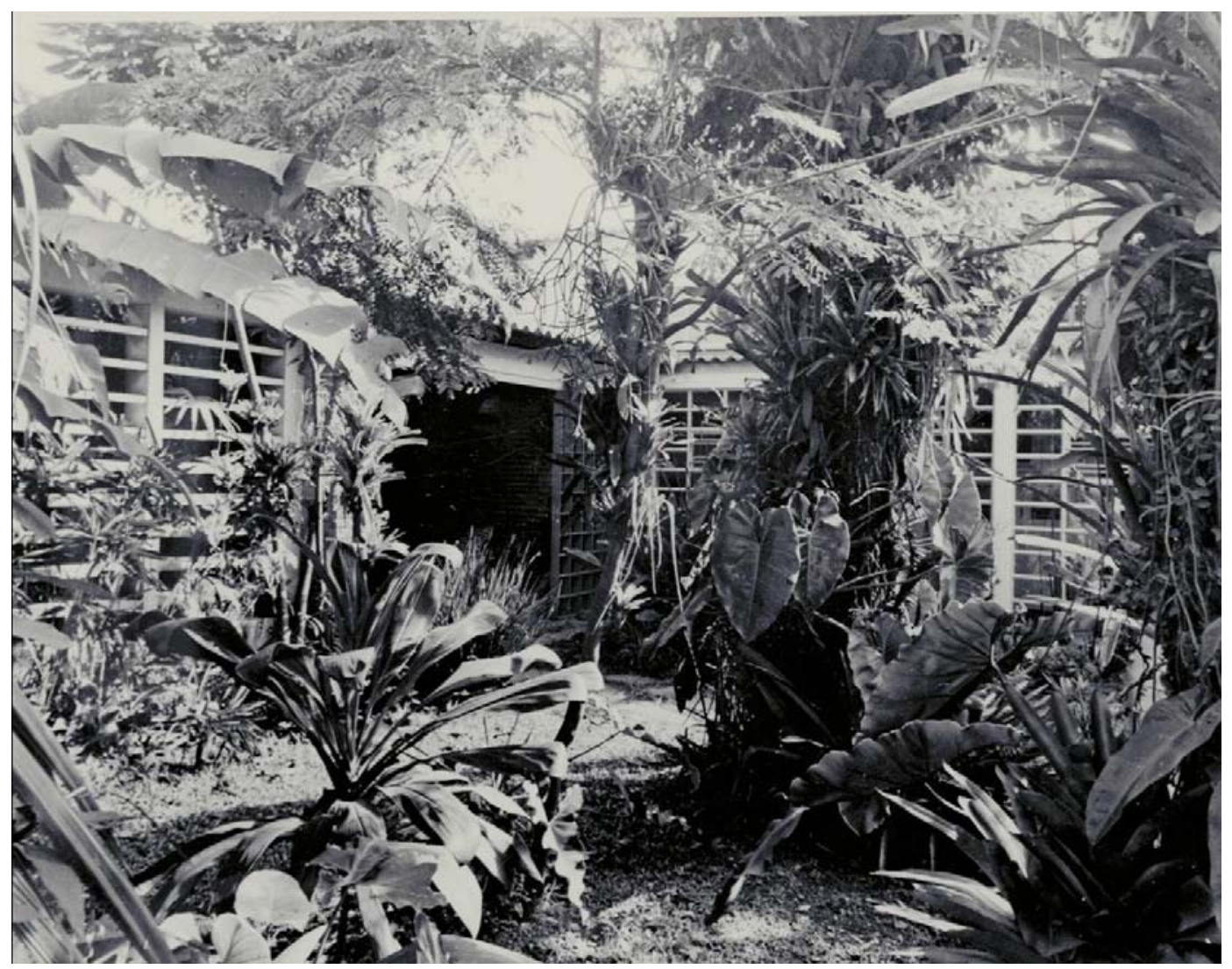

[151] Residência Rino Levi, São Paulo, SP. Arquitetos Rino Levi e Roberto Cerqueira Cesar, 1944.

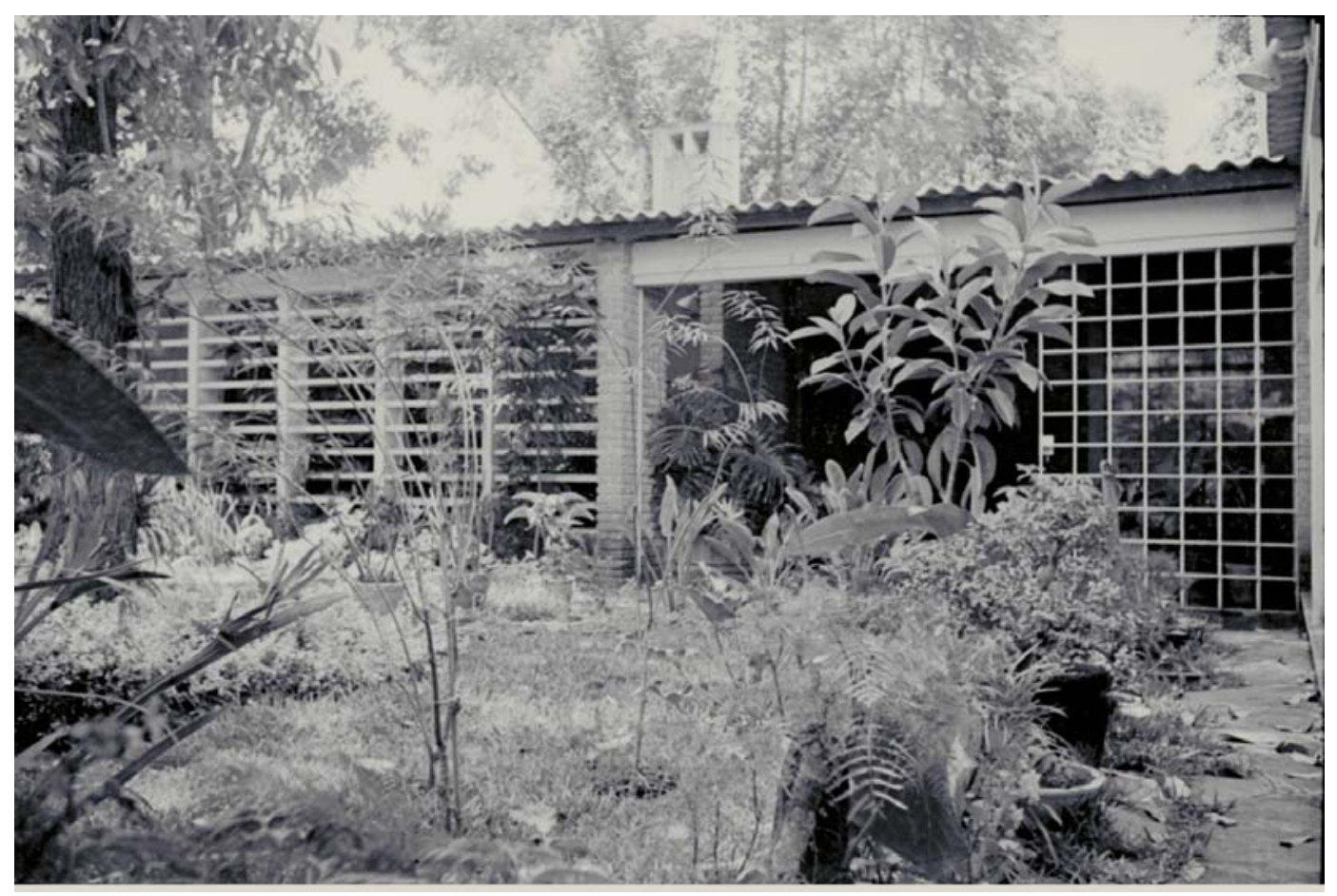

[152] Residência Rino I.evi São Paulo SP Arnuitetos Rinn I.evi e Roherto Cernueira Cesar 1.944 


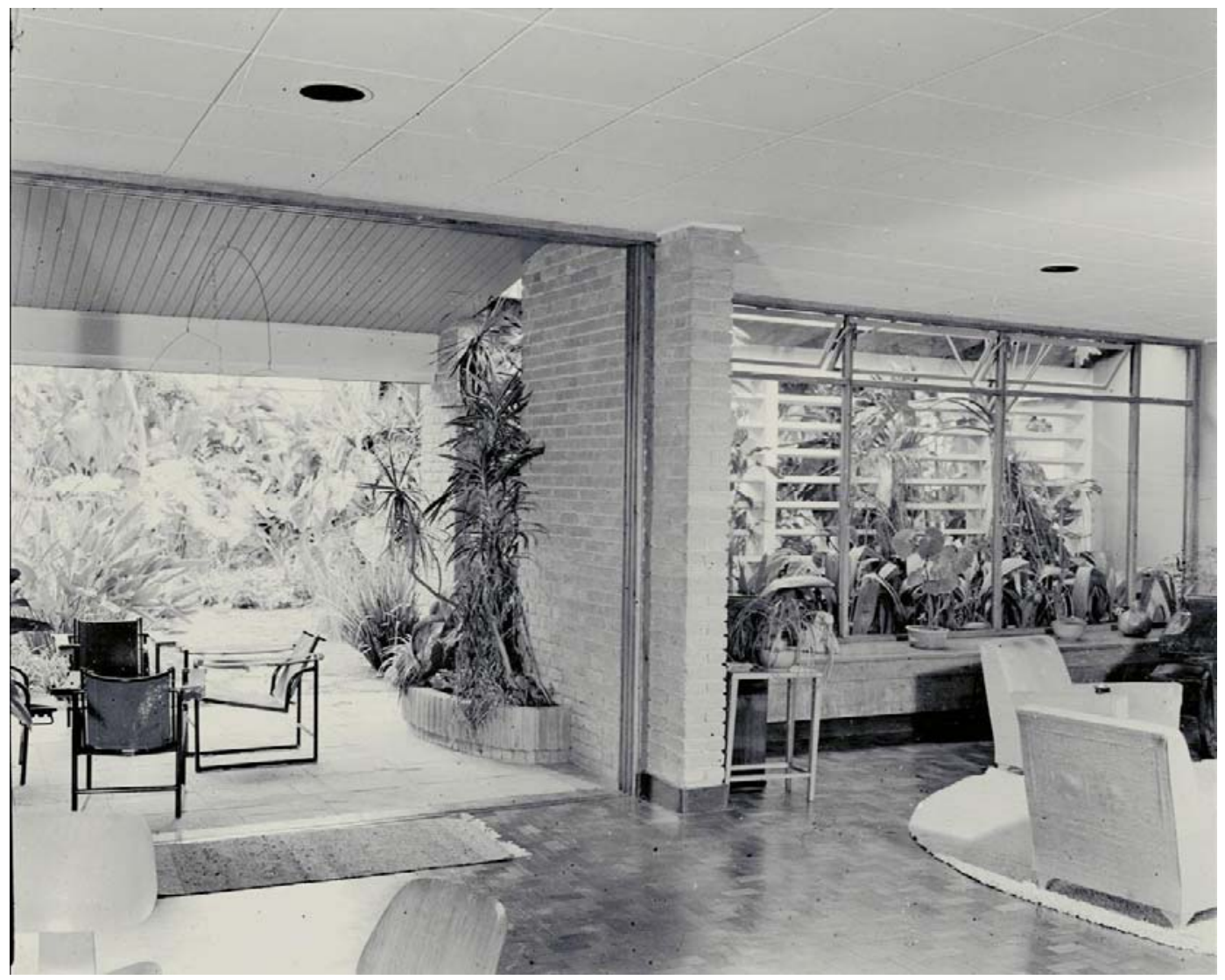

[153] Residência Rino Levi, São Paulo, SP. Arquitetos Rino Levi e Roberto Cerqueira Cesar, 1944.

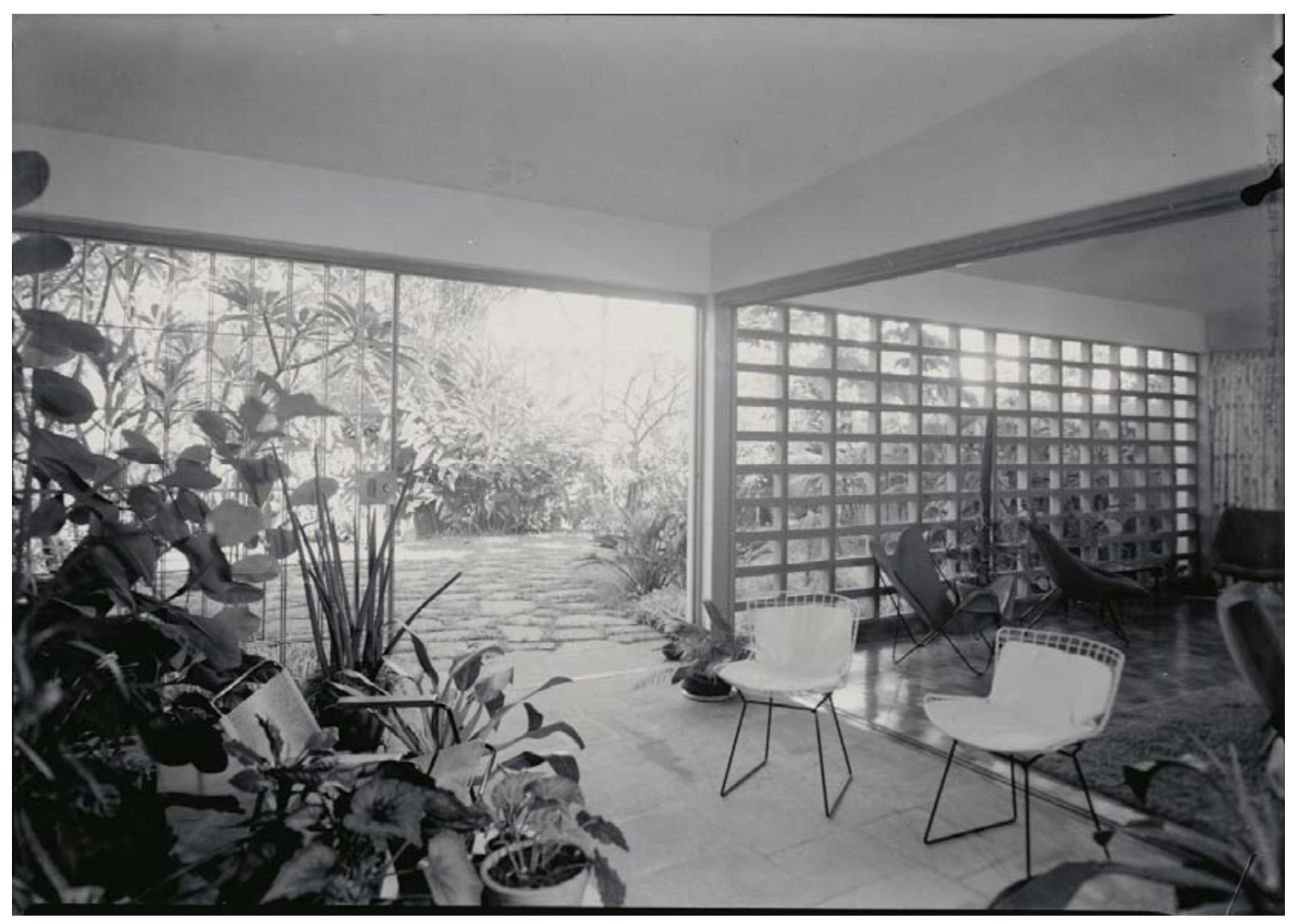

[154] Residência Rino Levi, São Paulo, SP. Arquitetos Rino Levi e Roberto Cerqueira Cesar, 1944. 


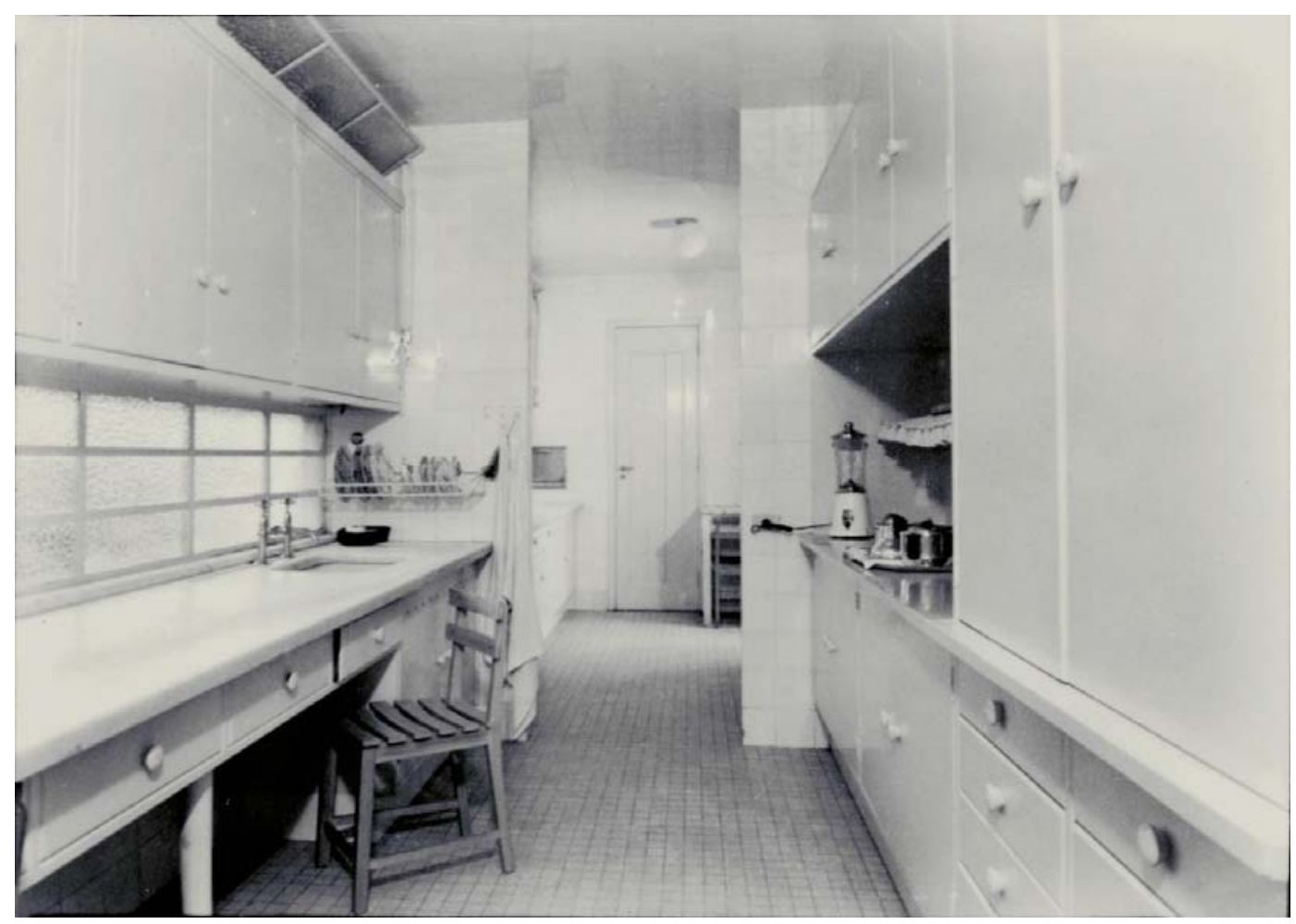

[155] Residência Rino Levi, São Paulo, SP. Arquitetos Rino Levi e Roberto Cerqueira Cesar, 1944.

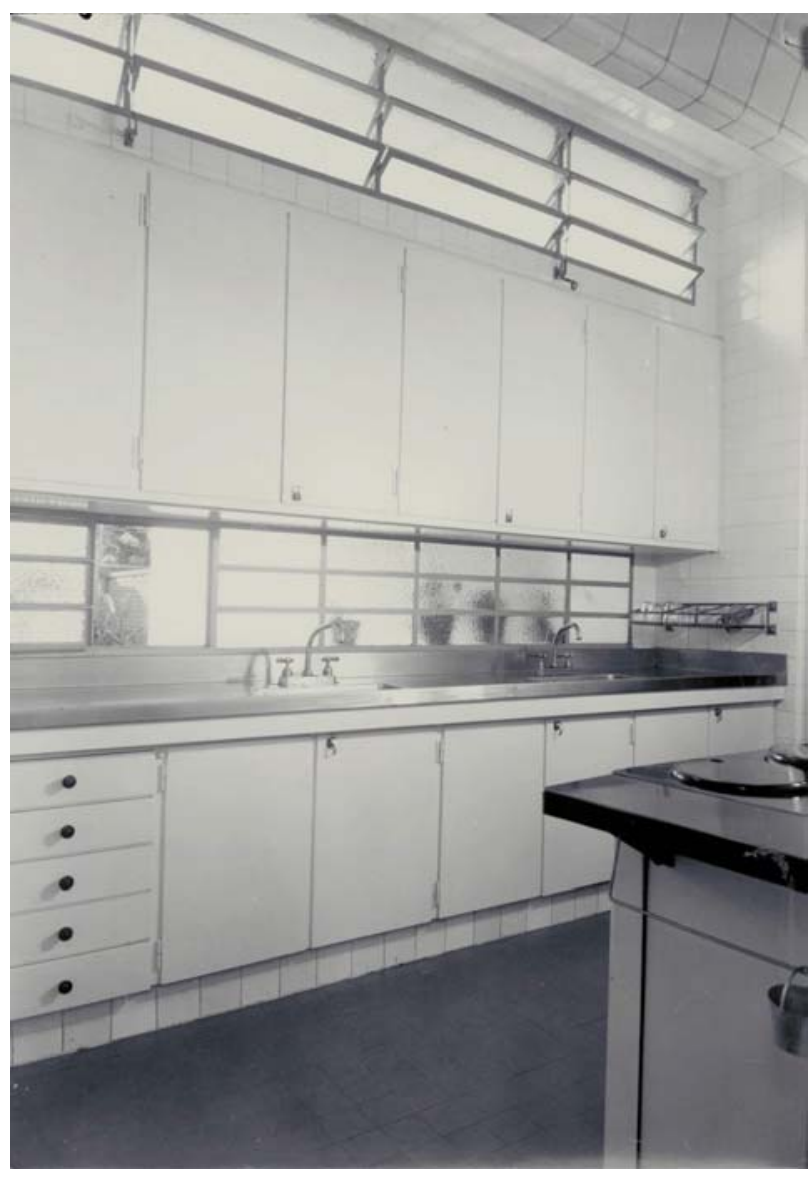

[156]

Residência Rino

Levi, São Paulo,

SP. Arquitetos Rino

Levi e Roberto

Cerqueira Cesar,

1944. 


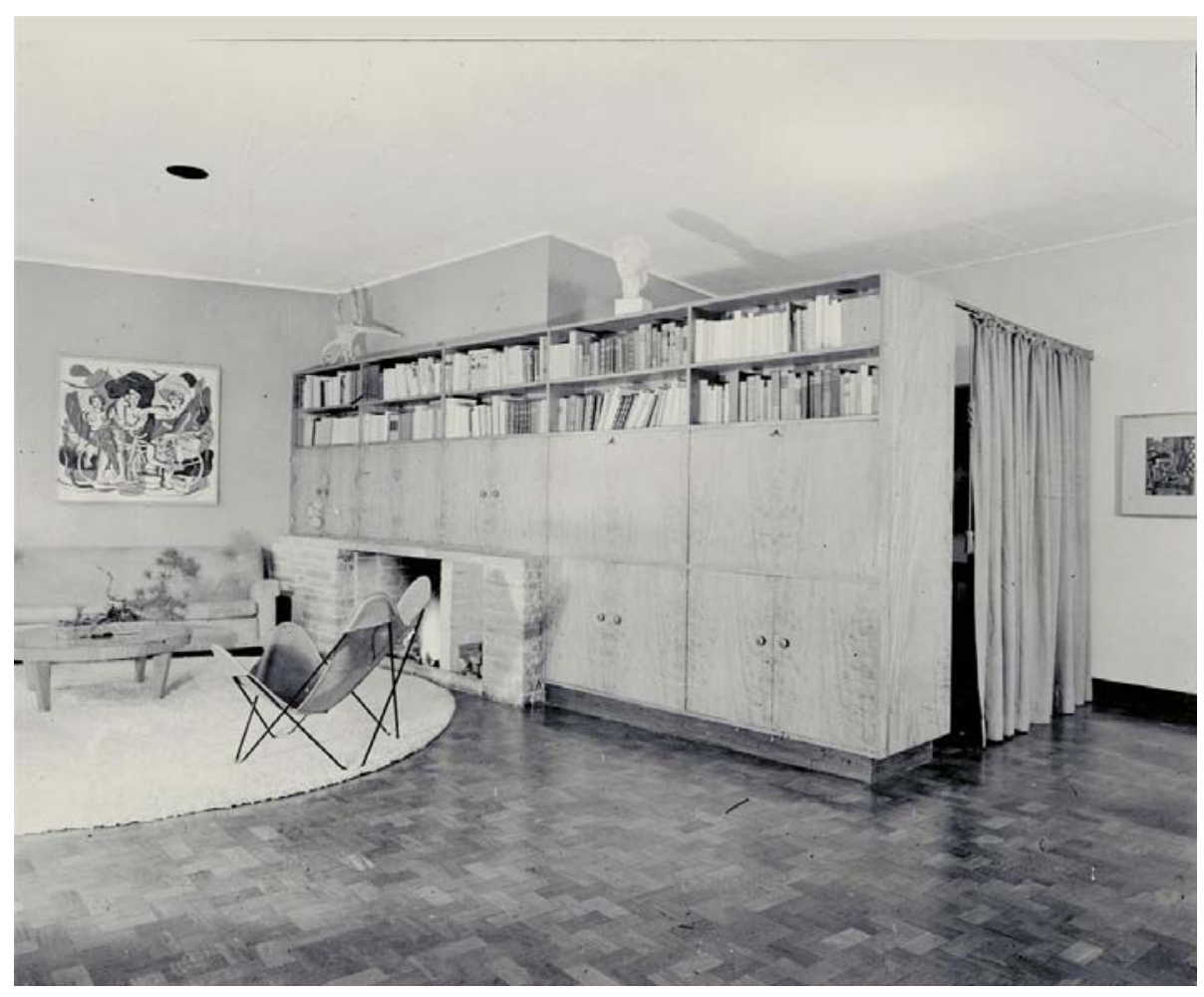

[157]

Residência Rino Levi, São Paulo, SP. Arquitetos

Rino Levi e

Roberto Cerqueira

Cesar, 1944.

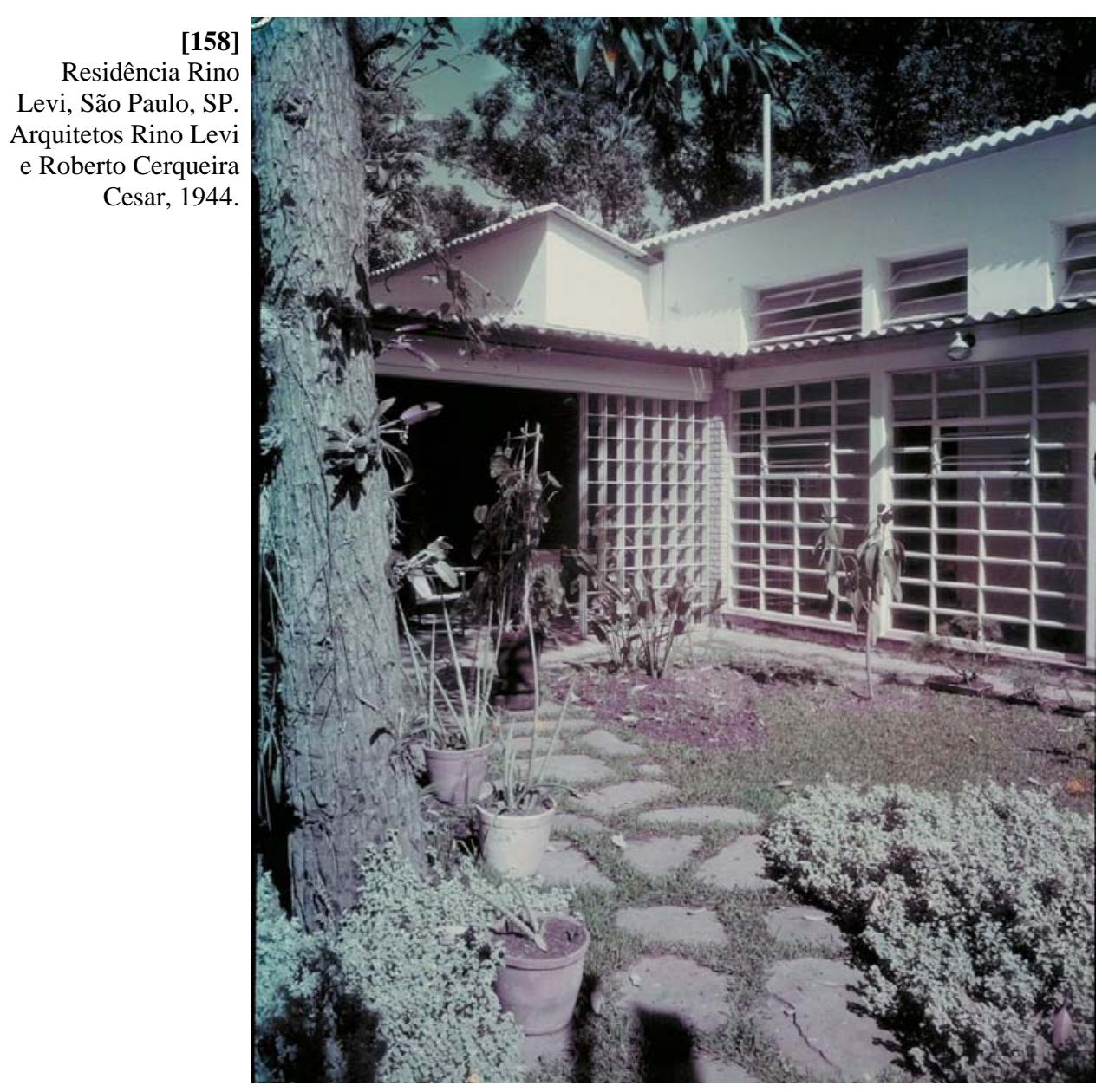


A segunda da série é a Residência Milton Guper ${ }^{109}$, também implantada em lote de esquina, desta vez no Jardim América, o primeiro bairro-jardim de São Paulo [159]. Aqui, várias das questões levantadas na Residência do Arquiteto são aprimoradas. O recuo obrigatório aberto para o espaço público se amplia [16o]. Por outro lado, o corpo da casa se afasta dos lotes vizinhos, enquanto o fechamento superior vai até o limite com pérgulas e o fechamento lateral se faz com elementos vazados [161]. Isso permite que a sala de estar e o jardim formem um espaço integrado, sem perda da continuidade [162]. De novo veremos os móveis atuarem como equipamentos da habitação. Na grande sala contínua, a lareira estrategicamente colocada funciona como sutil demarcação de espaços [163], [164]. Como já se observava na residência anterior, a garagem e a área de serviço estão voltadas para a rua, no que tradicionalmente seria a fachada principal. Dessa maneira ela é voluntariamente simples, quase desaparecendo na vegetação [165].

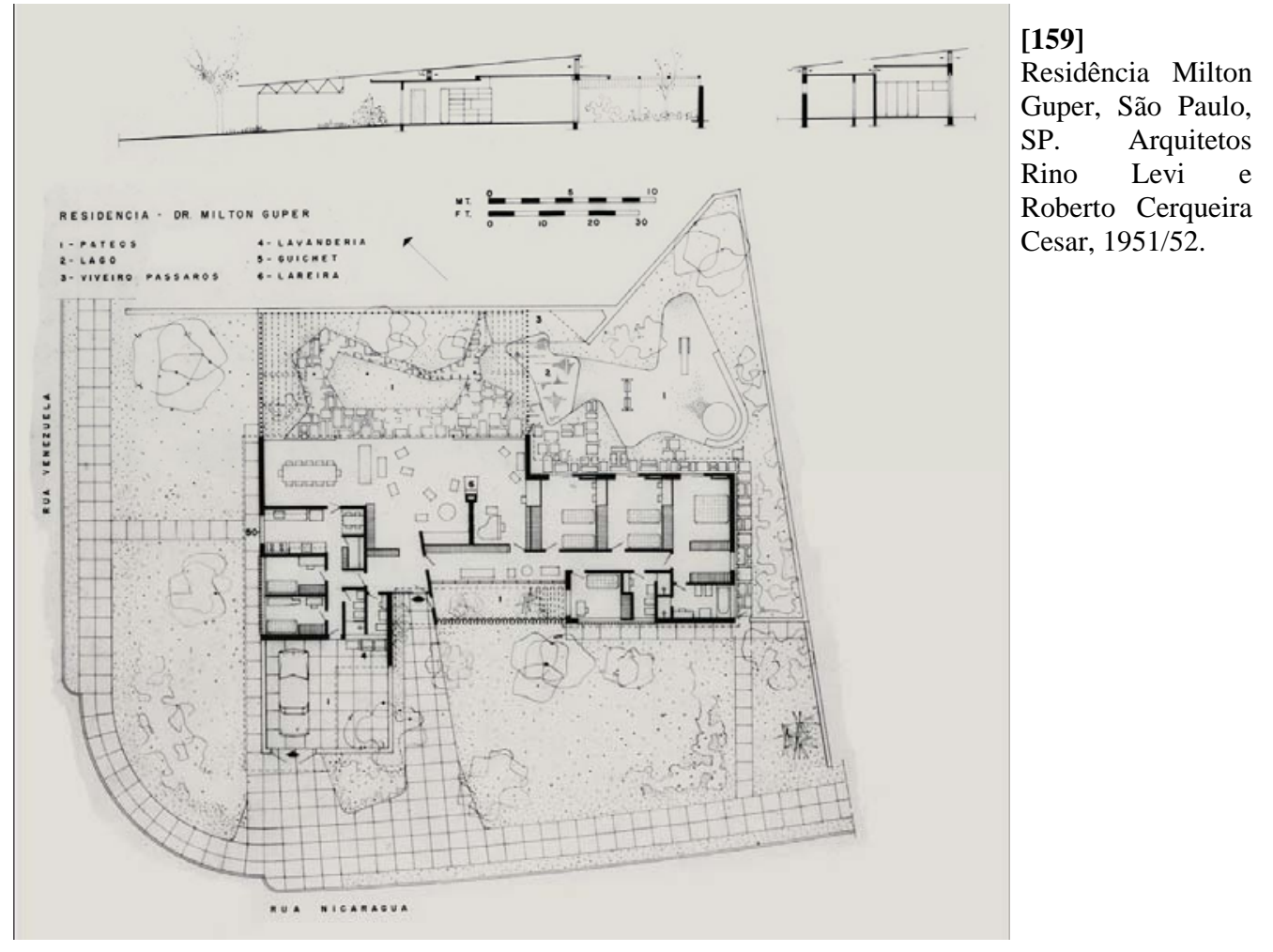

${ }^{109}$ Residência Milton Guper, São Paulo, SP, 1951/52. Arquitetos Rino Levi e Roberto Cerqueira Cesar. 


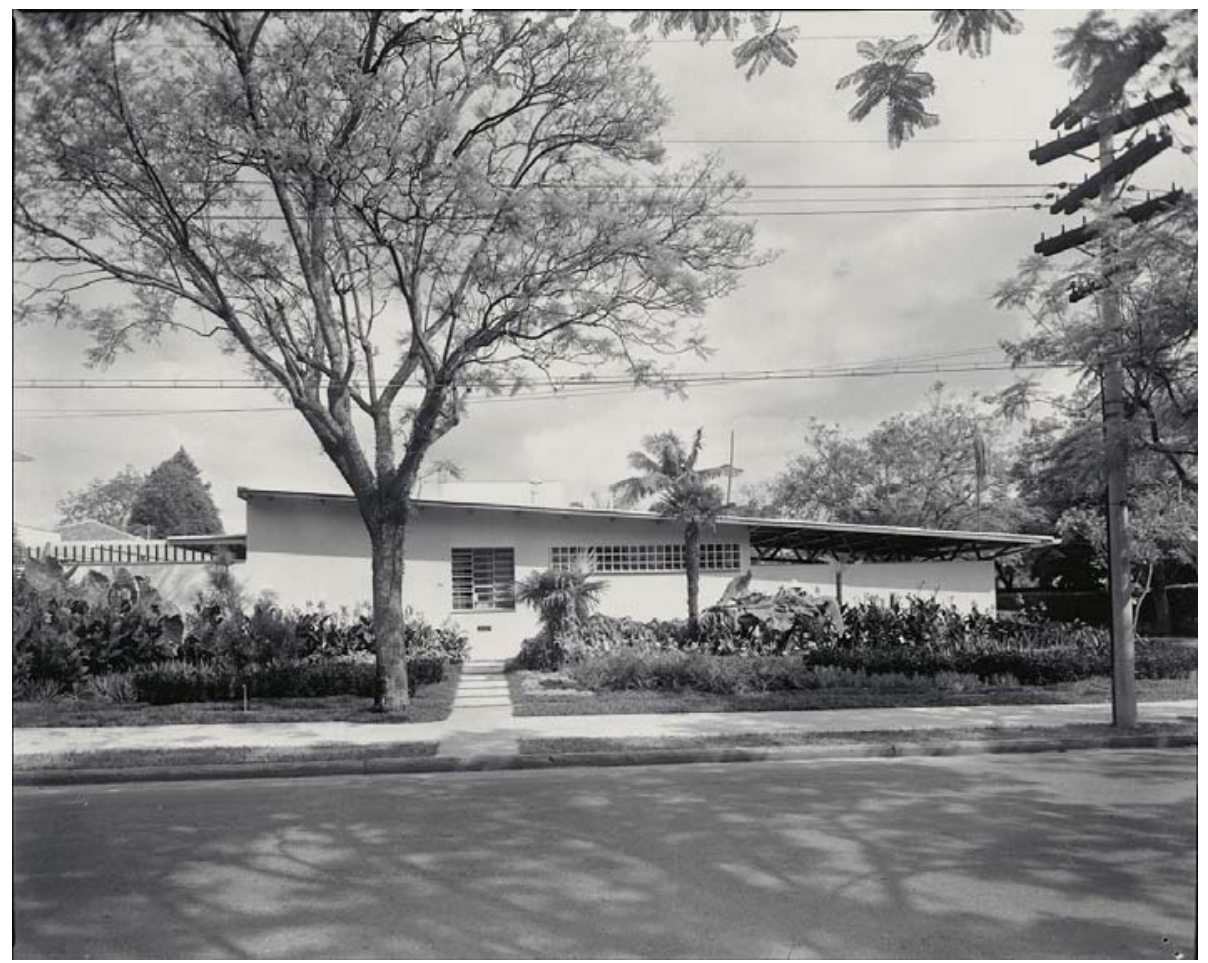

[160] Residência Milton Guper, São Paulo, SP. Arquitetos Rino Levi e Roberto Cerqueira Cesar. 1951/52.

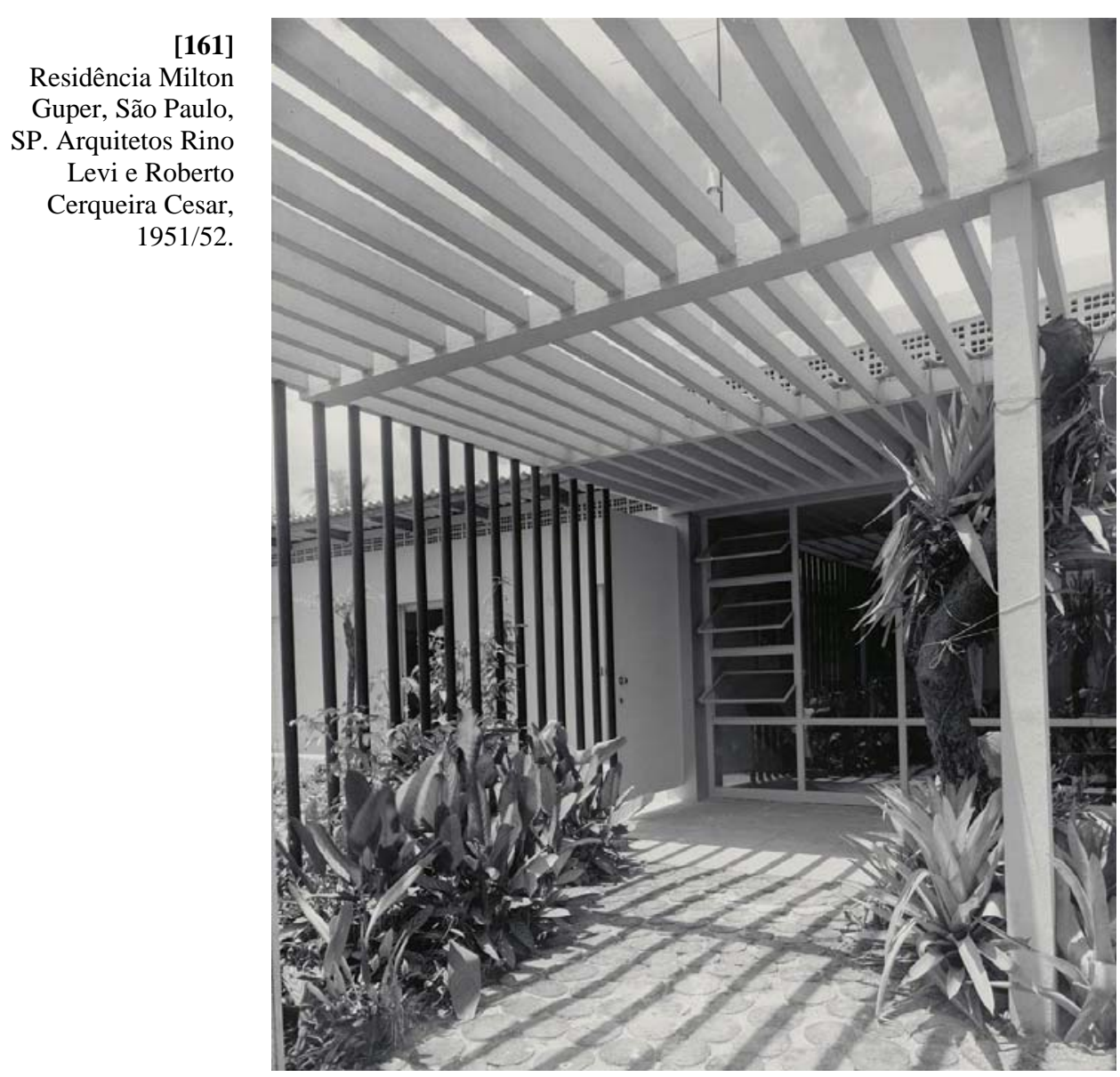




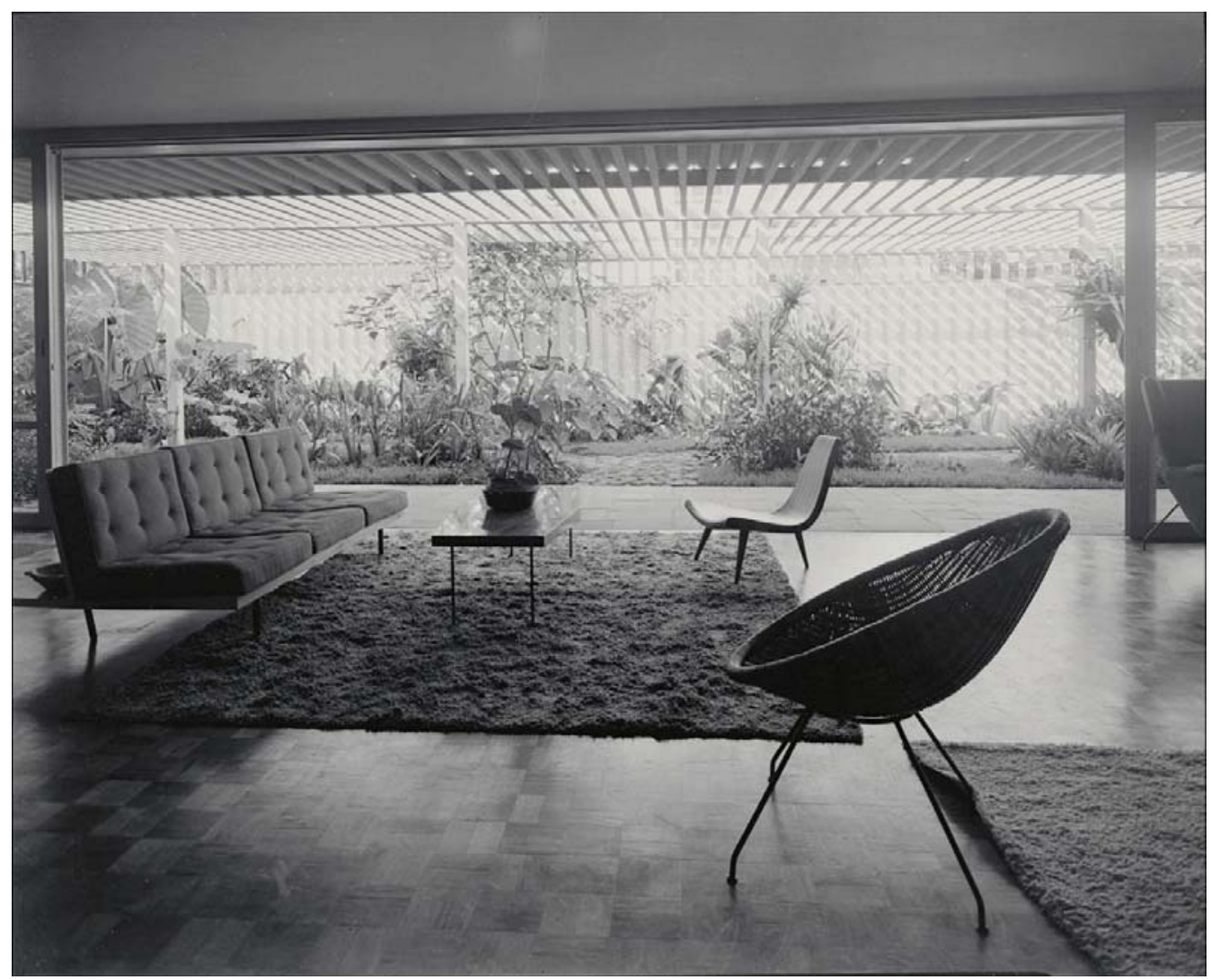

[162] Residência Milton Guper, São Paulo, SP. Arquitetos Rino Levi e Roberto Cerqueira Cesar, $1951 / 52$.

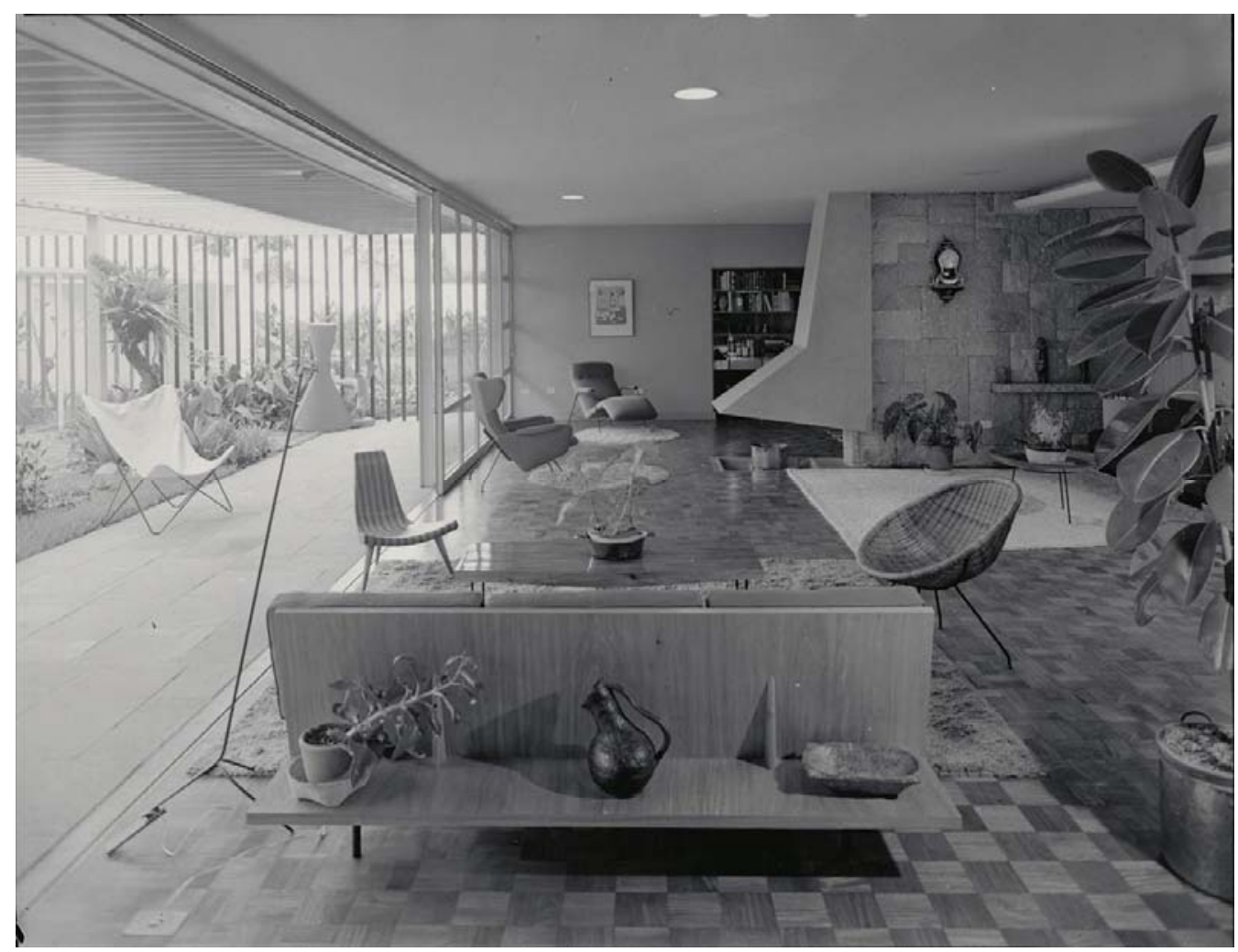

[163] Residência Milton Guper, São Paulo, SP. Arquitetos Rino Levi e Roberto Cerqueira Cesar, 1951/52. 


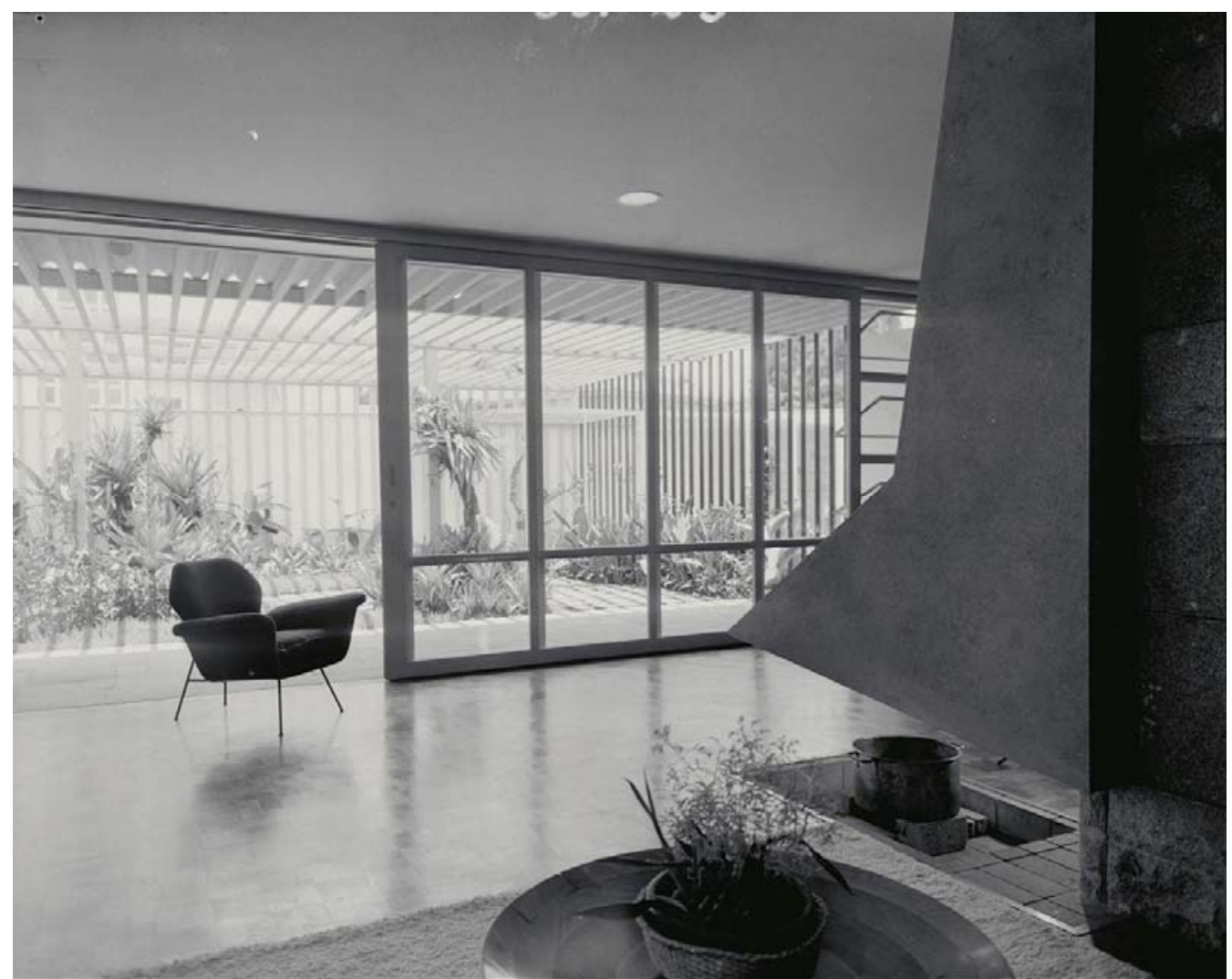

[164] Residência Milton Guper, São Paulo, SP. Arquitetos Rino Levi e Roberto Cerqueira Cesar, 1951/52.

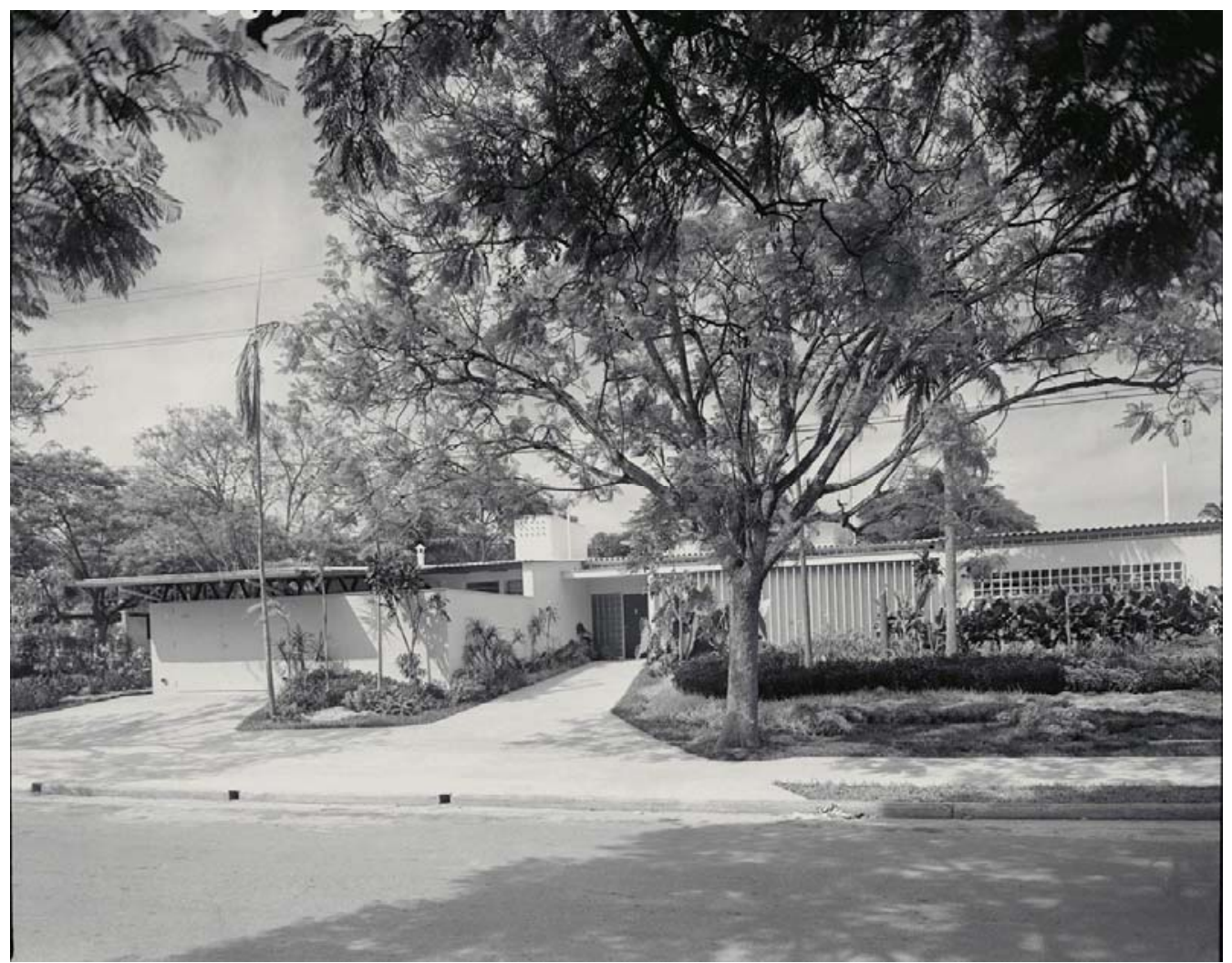

[165] Residência Milton Guper, São Paulo, SP. Arquitetos Rino Levi e Roberto Cerqueira Cesar, 1951/52. 
A terceira é a Residência Paulo Hess ${ }^{110}$ implantada, agora, em lote de meio de quadra [166]. Nela o projeto paisagístico é do próprio Levi, conforme o projeto apresentado. A nova característica do lote vai provocar algumas mudanças de procedimento e a generosidade dos recuos voltados para o espaço público vai ser prejudicada [167]. Mais compacta no centro do terreno - que é exíguo - garante a continuidade espacial abrindo-se para os espaços externos através de elementos vazados de concreto [168]. A adoção de um único material para todas as aberturas, o elemento vazado retangular, propicia agradável unidade [169]. Mais uma vez veremos os móveis como equipamentos da habitação [170].

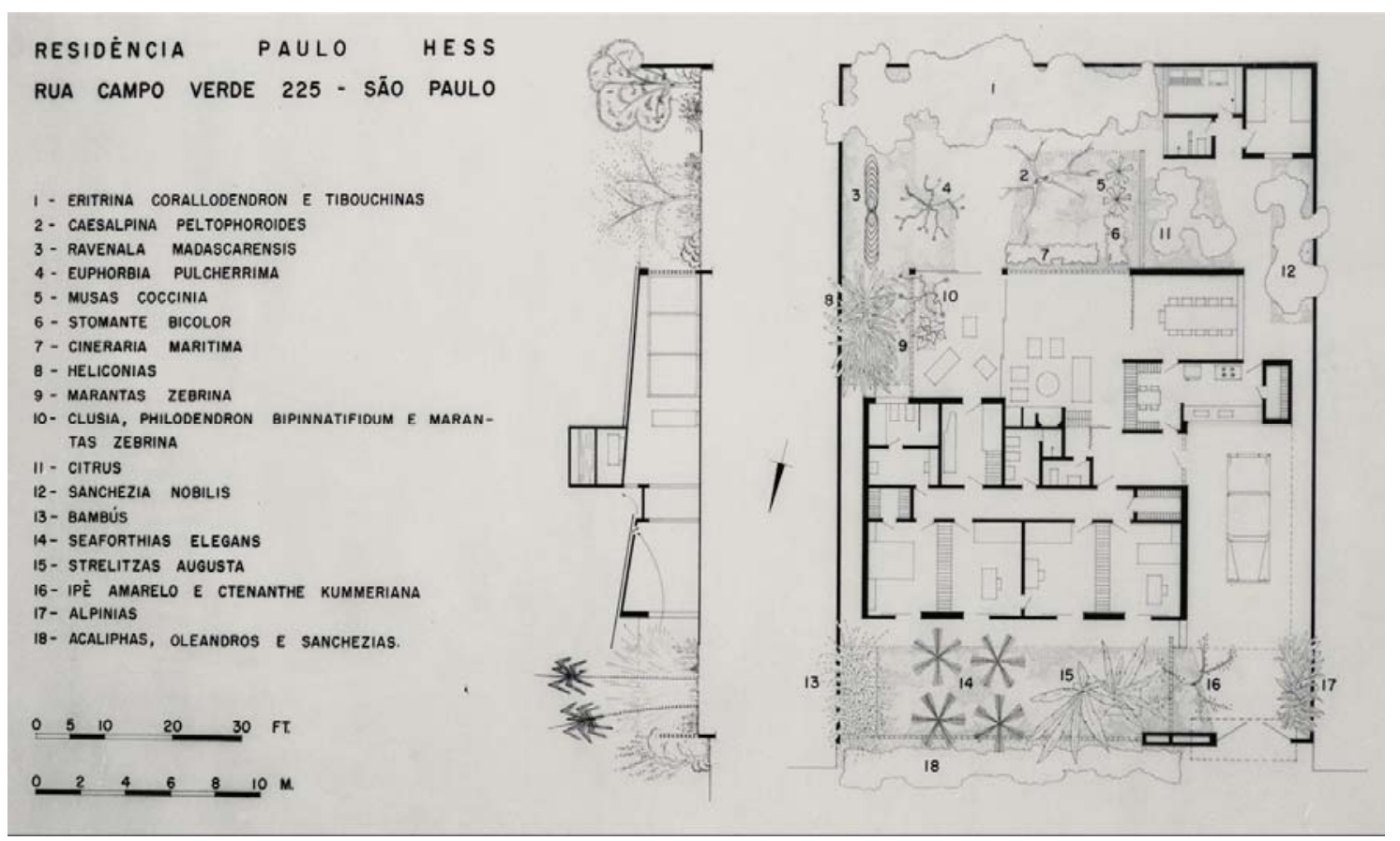

[166] Residência Paulo Hess, São Paulo, SP. Arquitetos Rino Levi e Roberto Cerqueira Cesar, 1952/53.

${ }^{110}$ Residência Paulo Hess, São Paulo, SP, 1952/53. Arquitetos Rino Levi e Roberto Cerqueira Cesar. 


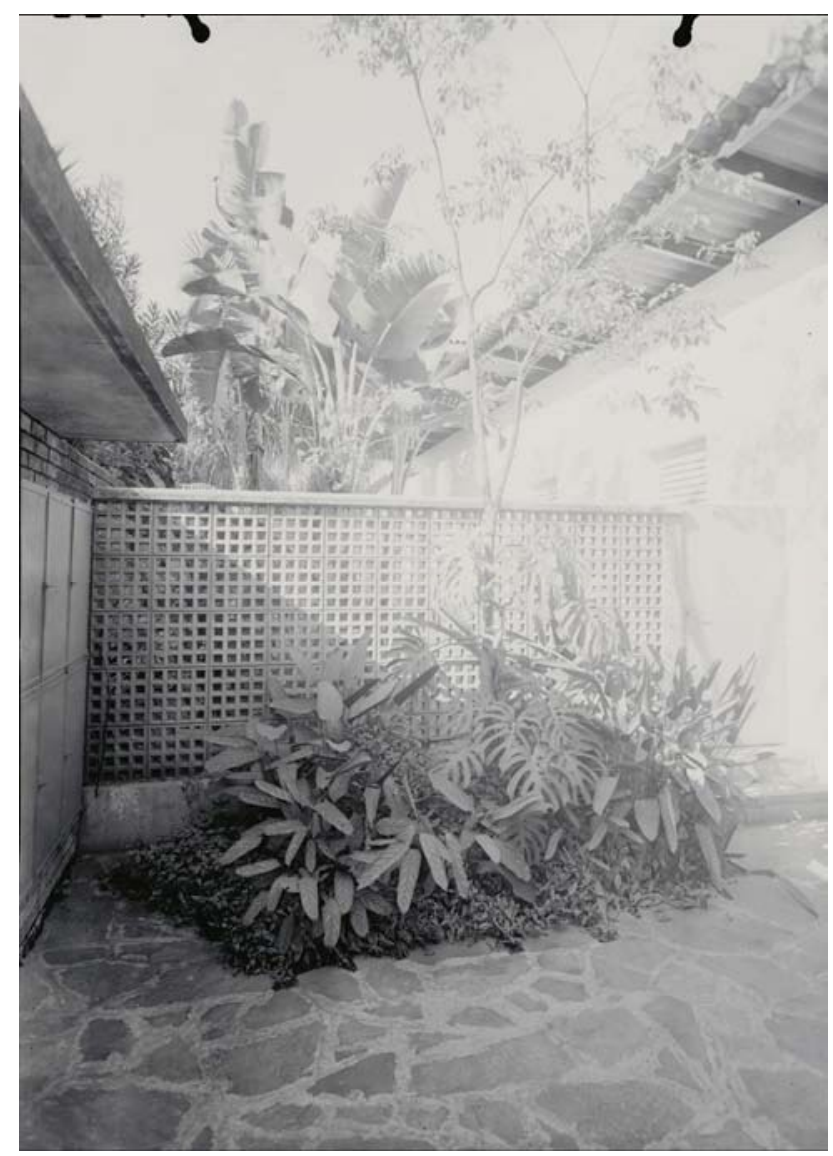

\section{[167]}

Residência Paulo

Hess, São Paulo,

SP. Arquitetos

Rino Levi e

Roberto

Cerqueira Cesar,

1952/53.

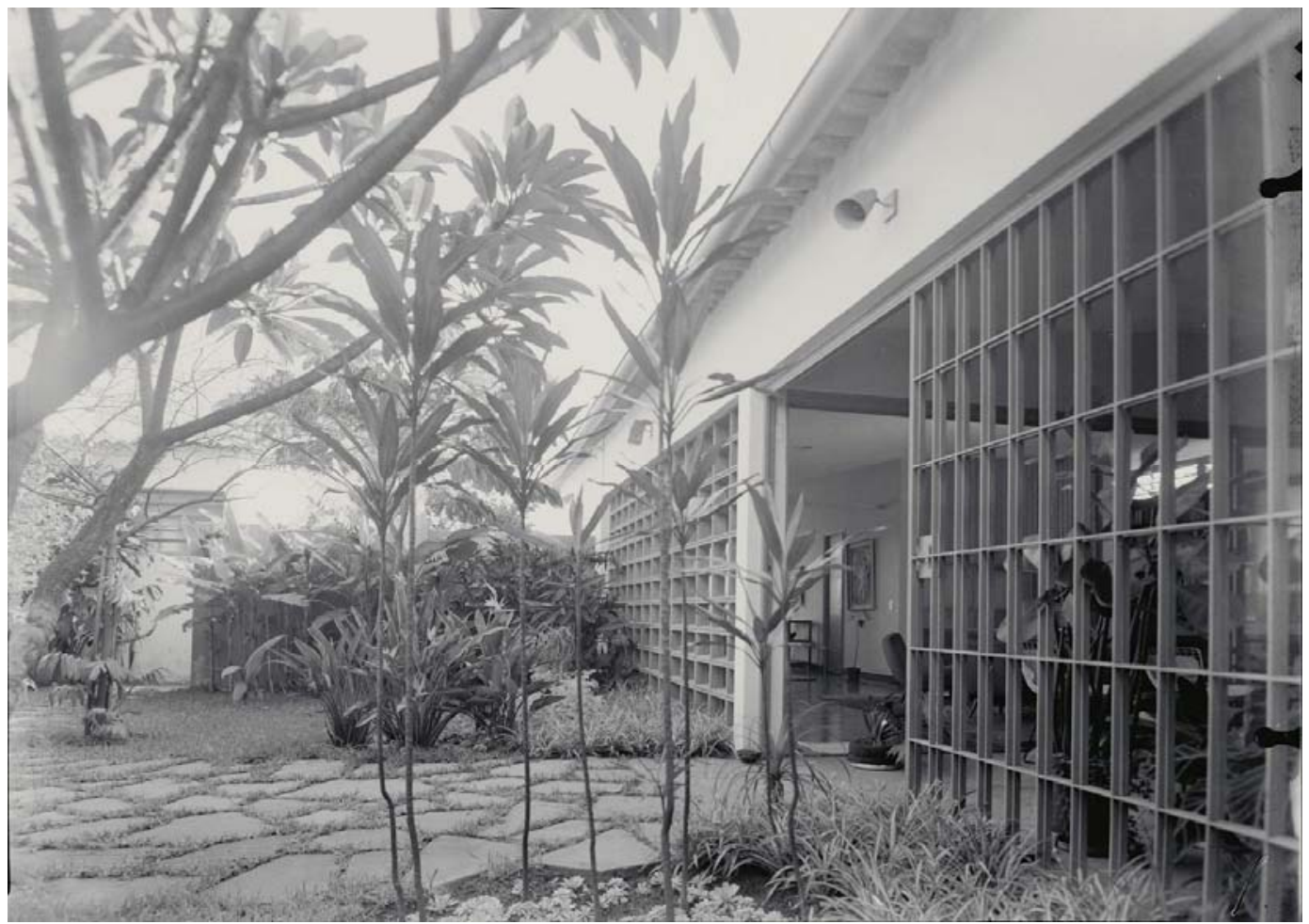

[168] Residência Paulo Hess, São Paulo, SP. Arquitetos Rino Levi e Roberto Cerqueira Cesar, 1952/53. 


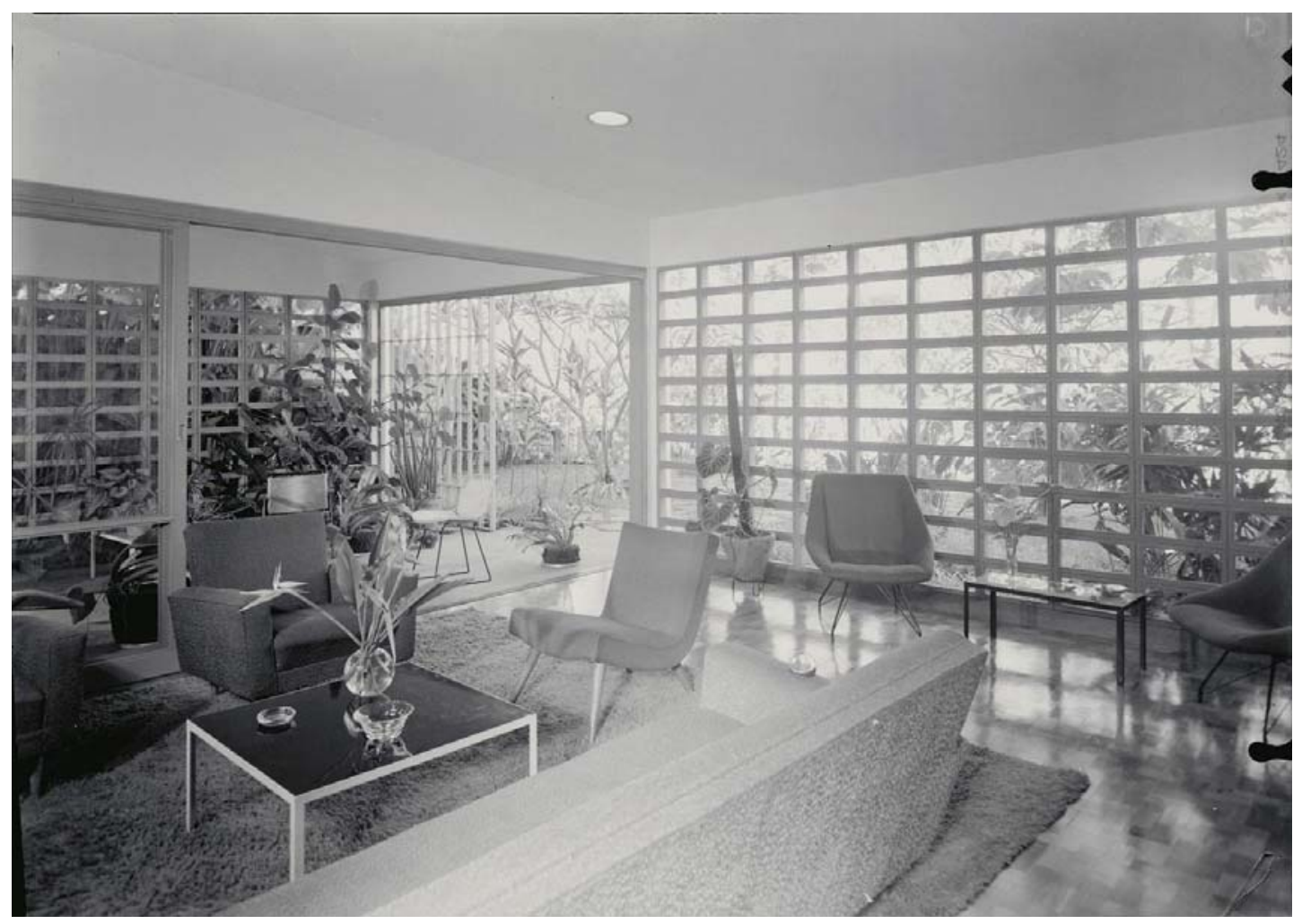

[169] Residência Paulo Hess, São Paulo, SP. Arquitetos Rino Levi e Roberto Cerqueira Cesar, 1952/53.

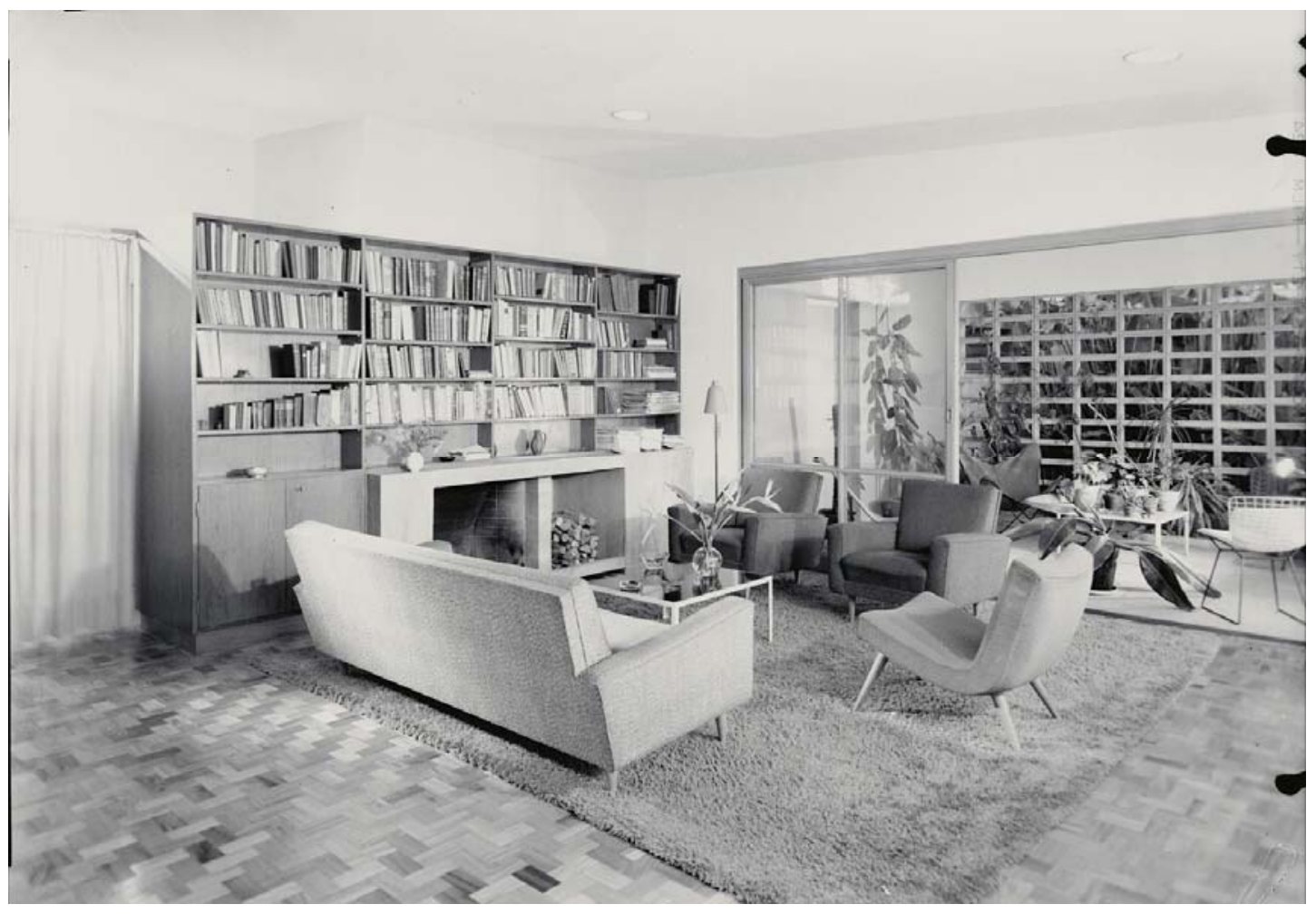

[170] Residência Paulo Hess, São Paulo, SP. Arquitetos Rino Levi e Roberto Cerqueira Cesar, 1952/53. 
A quarta e última residência da série é a de Castor Delgado Perez ${ }^{111}$, novamente em lote de esquina no Jardim Europa [171]. Nela podemos observar a síntese perfeita de todas as questões apontadas anteriormente, além de algumas circunstâncias novas. A novidade mais marcante está logo na fachada externa, que mais uma vez abriga a garagem e a área de serviço. A grande diferença está no abandono da aparência neutra substituída por vigoroso volume branco, elevado e sem aberturas [172], que abriga os dormitórios das empregadas. A síntese perfeita está no espaço central da sala integrada aos espaços externos laterais cobertos com pérgulas [173], [174]. O mesmo aprimoramento pode ser observado na cozinha longitudinal [175], onde bancadas, armários, iluminação e demais equipamentos estão funcional e racionalmente arrumados e o mesmo pode-se dizer do banheiro [176]. Os equipamentos da habitação também atingiram o mais alto requinte, como mostra a lareira acoplada às estantes que referencia o amplo espaço contínuo central [177].

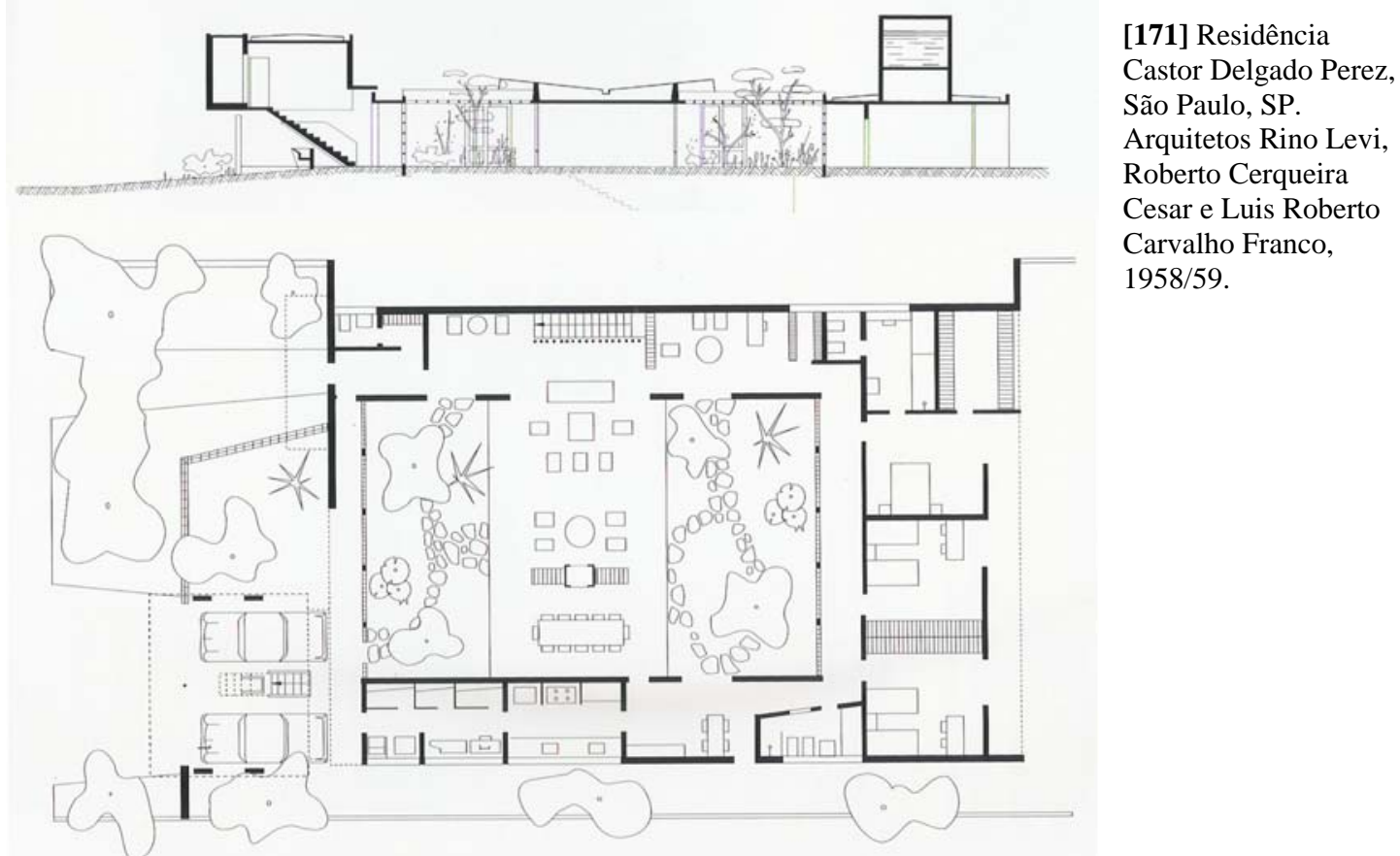

\footnotetext{
${ }^{111}$ Residência Castor Delgado Perez, São Paulo, SP, 1958/59. Arquitetos Rino Levi, Roberto Cerqueira Cesar e Luis Roberto Carvalho Franco.
} 


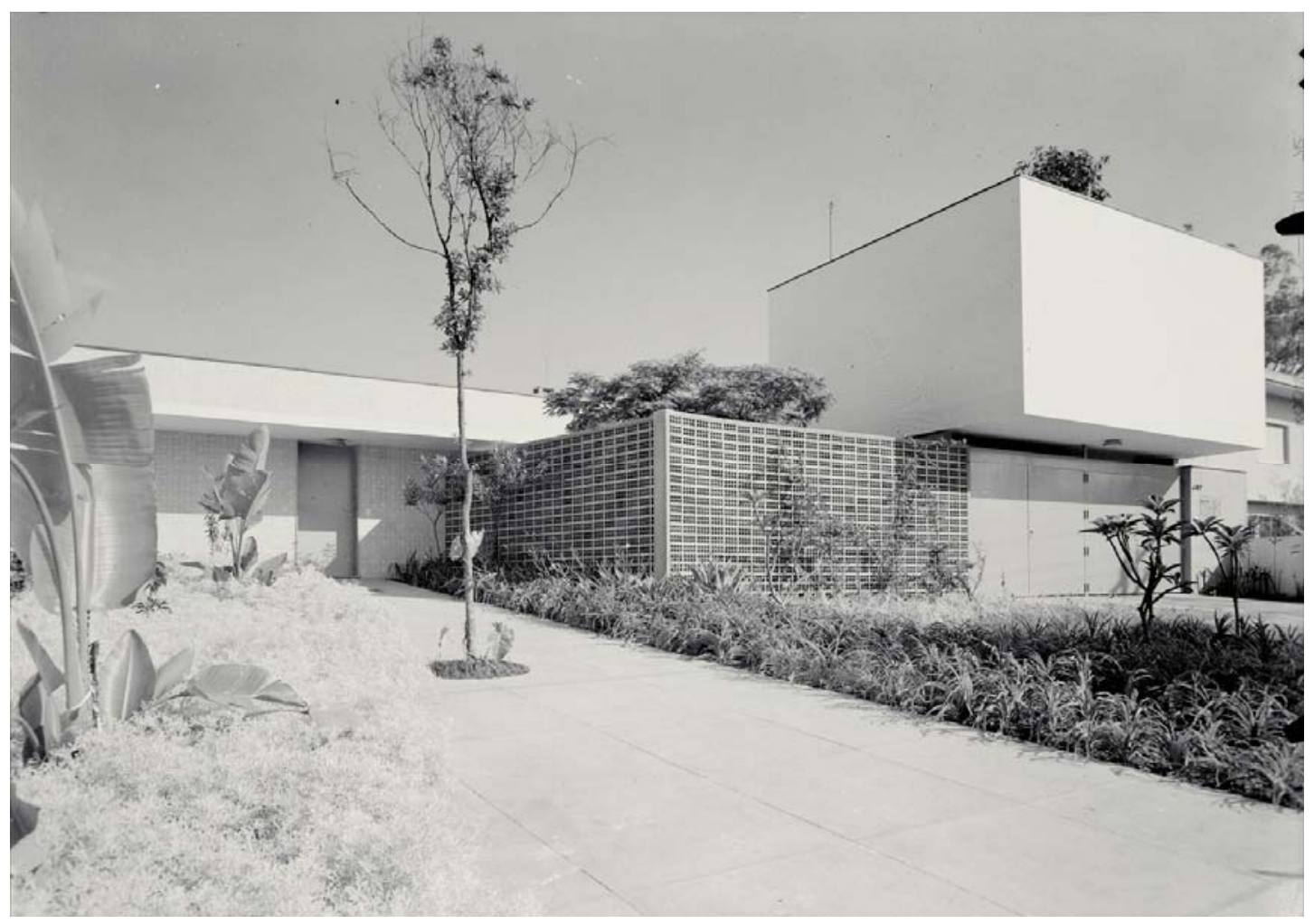

[172] Residência Castor Delgado Perez, São Paulo, SP. Arquitetos Rino Levi, Roberto Cerqueira Cesar e Luis Roberto Carvalho Franco, 1958/59.

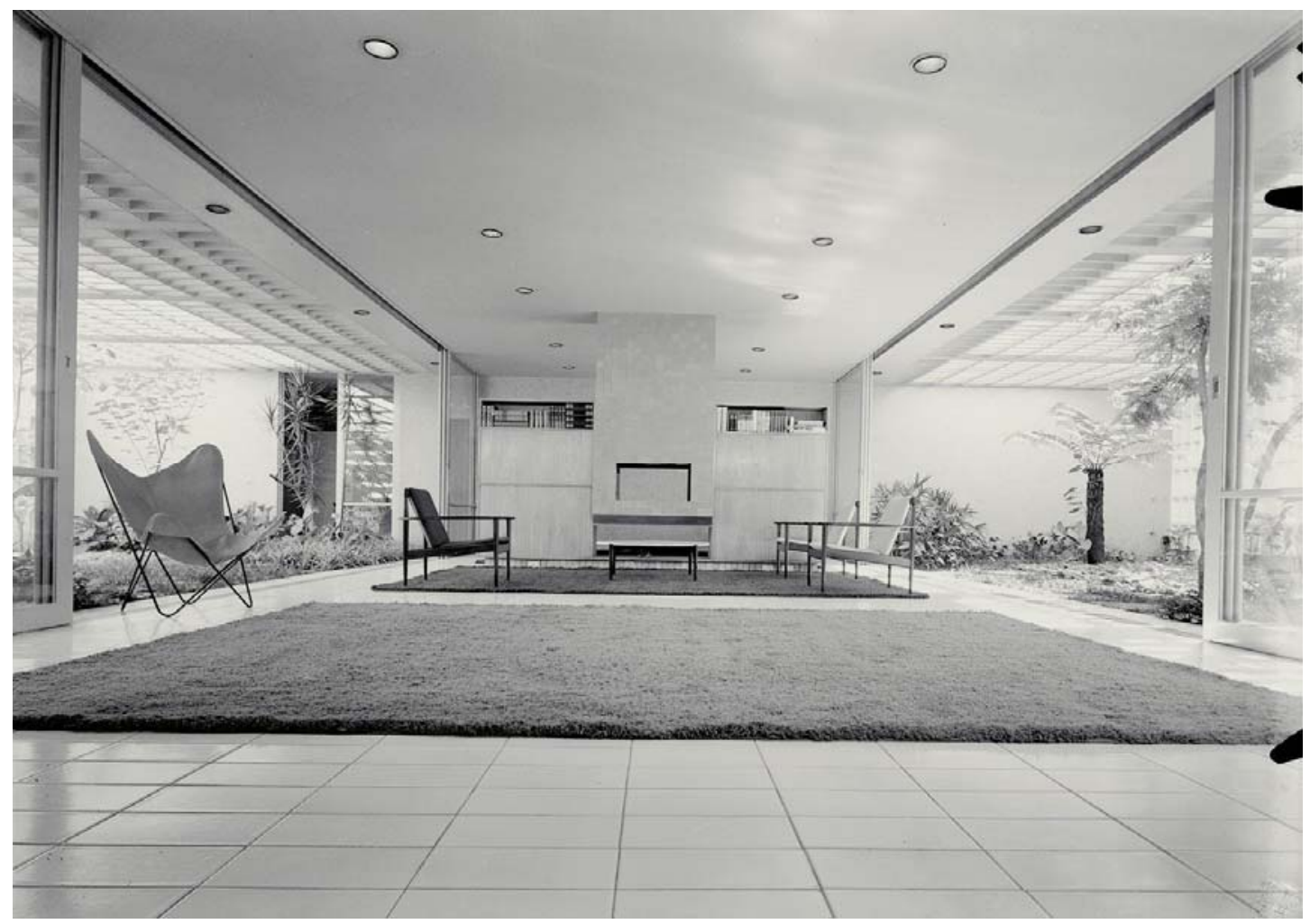

[173] Residência Castor Delgado Perez, São Paulo, SP. Arquitetos Rino Levi, Roberto Cerqueira Cesar e Luis Roberto Carvalho Franco, 1958/59. 


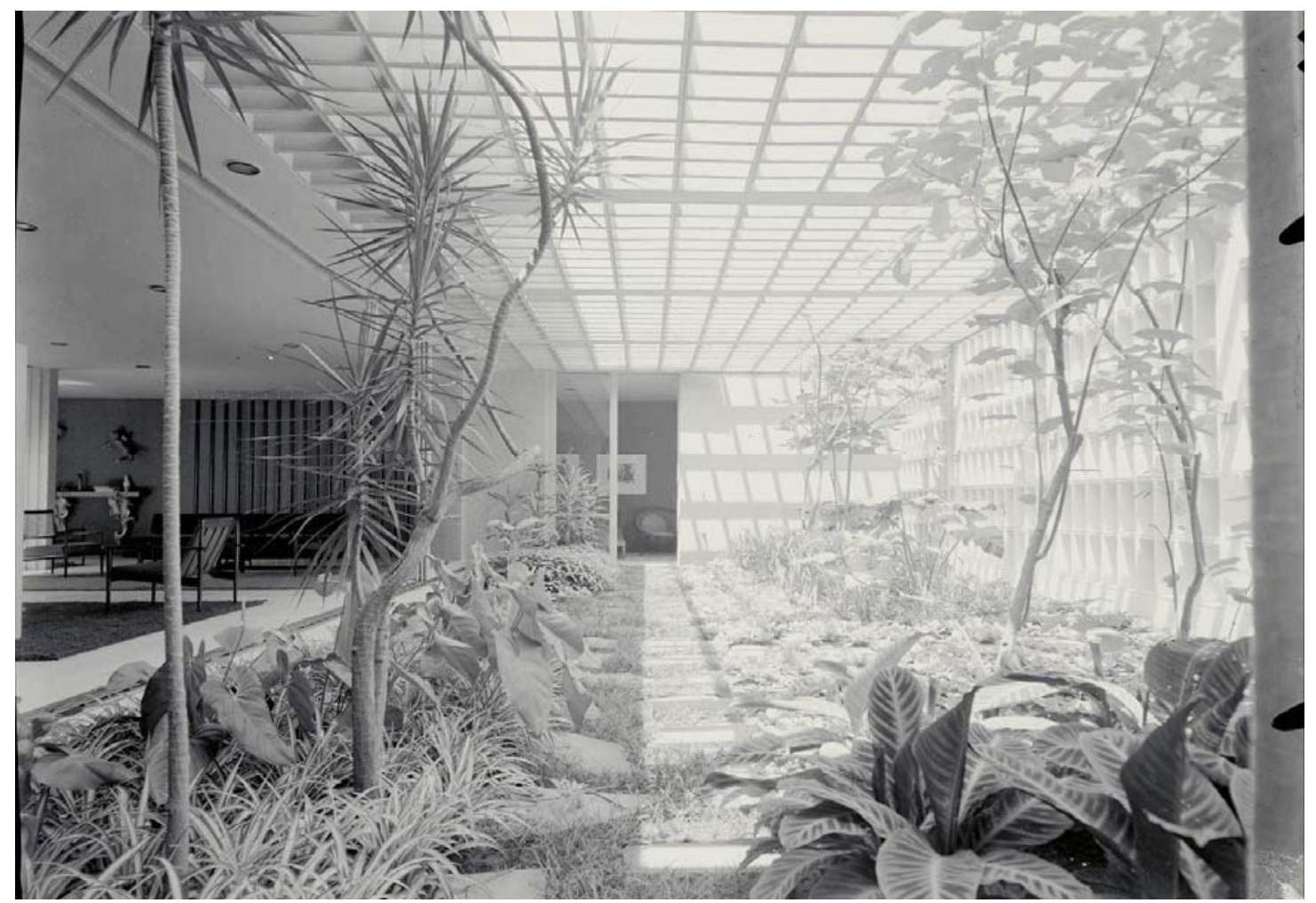

[174] Residência Castor Delgado Perez, São Paulo, SP. Arquitetos Rino Levi, Roberto Cerqueira Cesar e Luis Roberto Carvalho Franco, 1958/59.

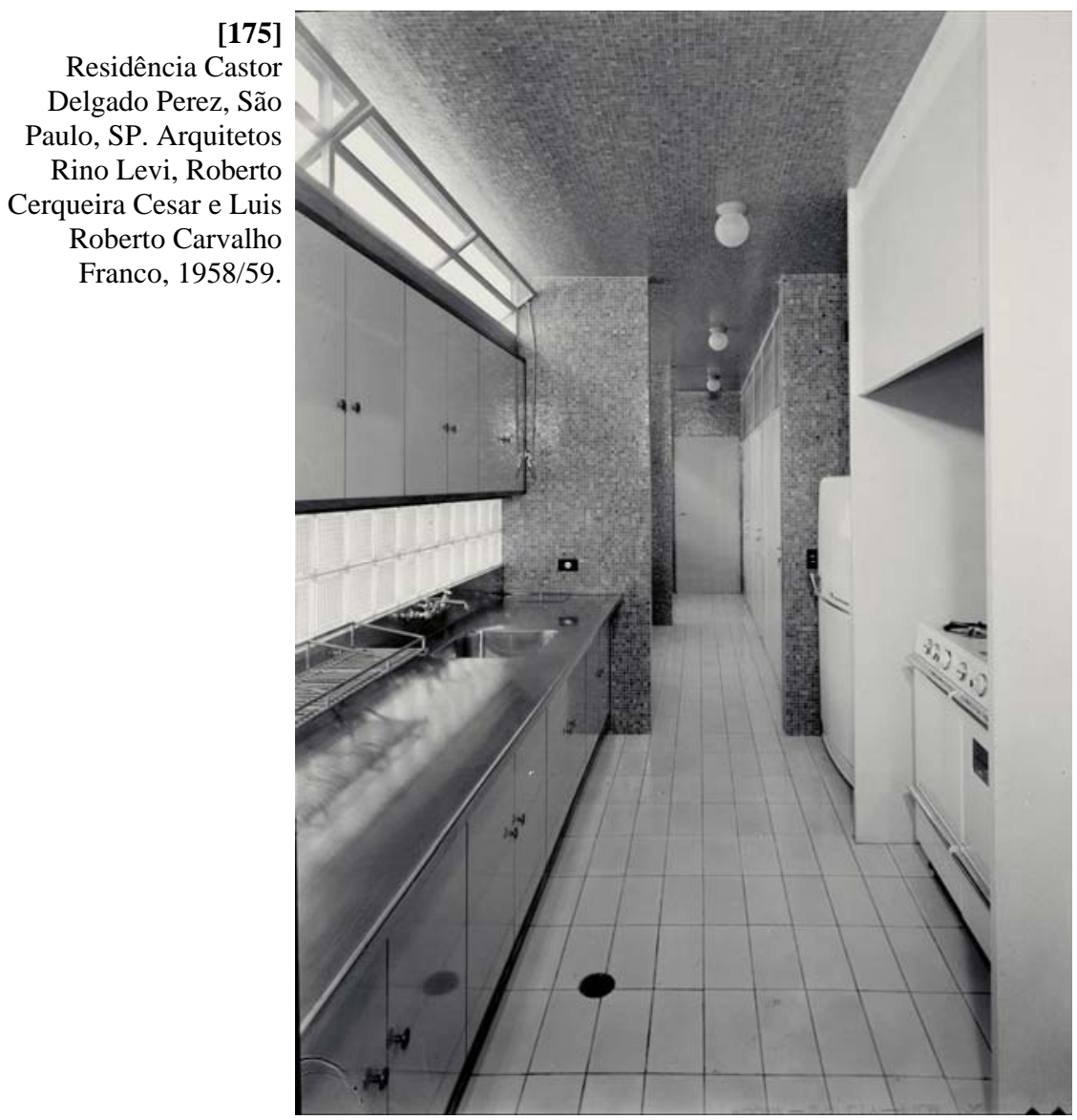




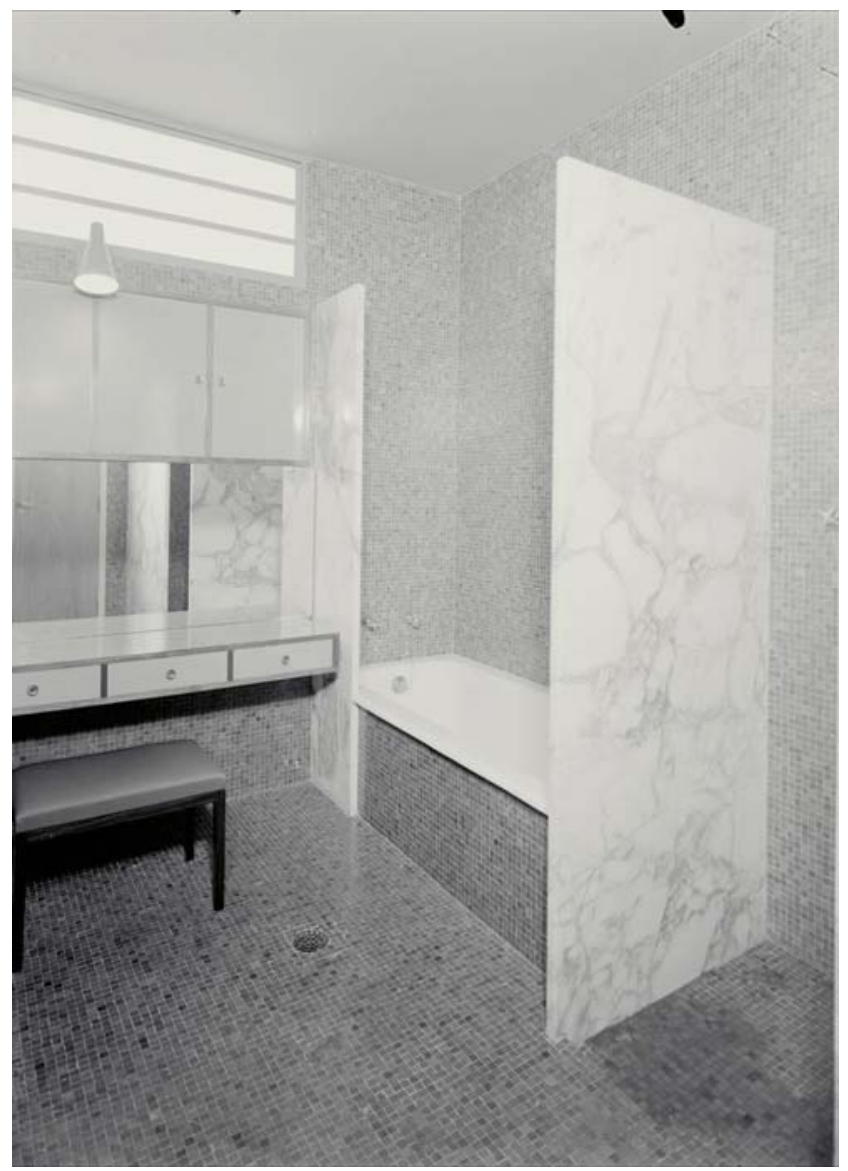

[176]

Residência Castor

Delgado Perez, São

Paulo, SP. Arquitetos

Rino Levi, Roberto

Cerqueira Cesar e

Luis Roberto

Carvalho Franco,

1958/59.

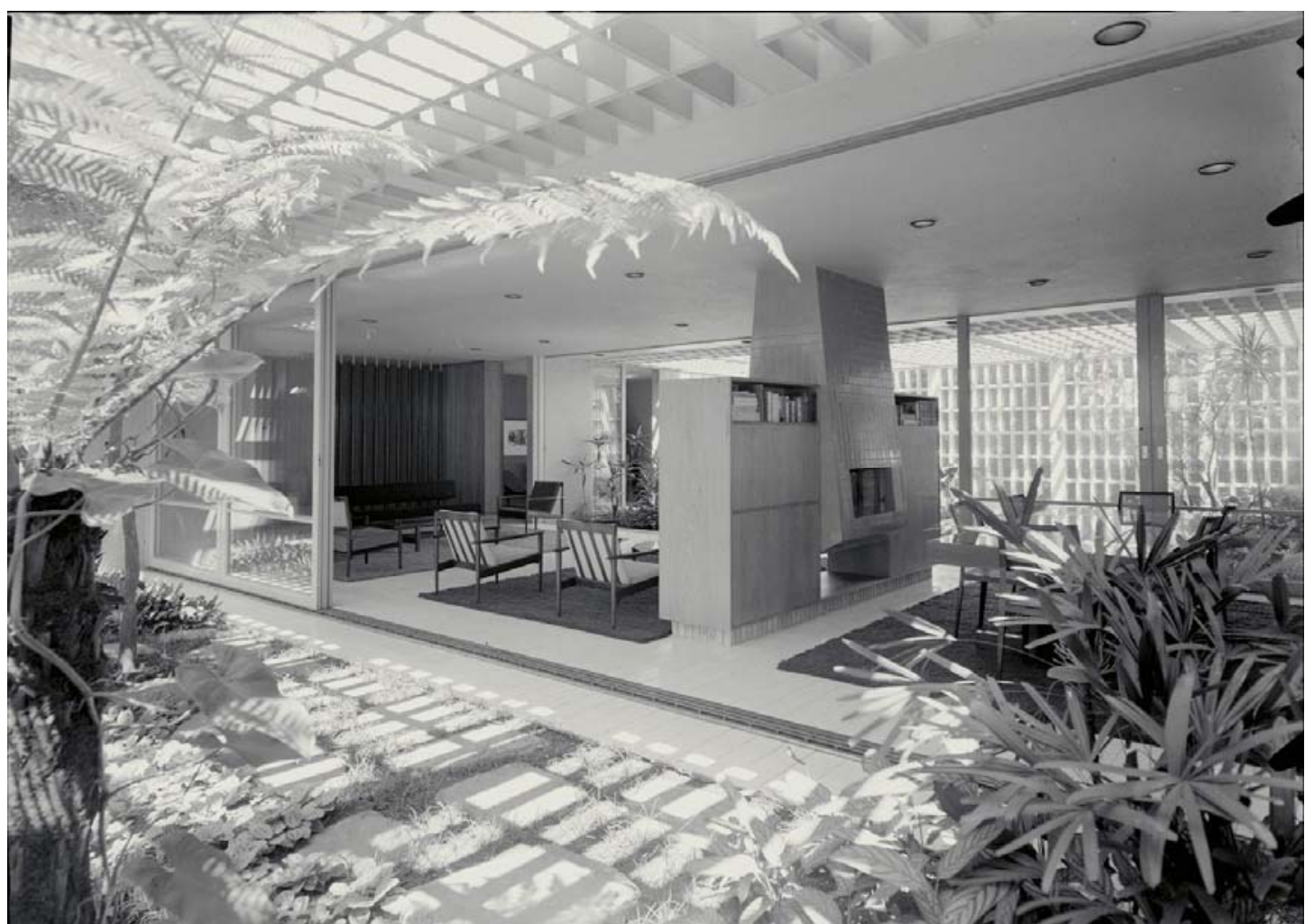

[177] Residência Castor Delgado Perez, São Paulo, SP. Arquitetos Rino Levi, Roberto Cerqueira Cesar e Luis Roberto Carvalho Franco, 1958/59. 
Esta série de residências se presta a inúmeras leituras de natureza muito diversa, às vezes quase opostas. Vimos no primeiro capítulo, quando trabalhamos com a historiografia, como Yves Bruand - se referindo a elas - vai observar que "não se pode pensar numa concepção mais intimista, mas é evidente que se trata de uma nova versão do pátio mediterrâneo, o que é facilmente explicado pelas origens e pela formação italiana de Rino Levi, mais do que por uma inspiração da corrente orgânica"112. Falando especificamente da Residência Rino Levi, Bruand comenta que "outra prova disso é a disposição das galerias abertas, protegidas apenas por um brise-soleil de cimento, nos dois lados da casa ladeados pelo jardim principal: corredor ao mesmo tempo arejado e abrigado ou elemento de transição entre o ambiente reservado interno e a orgia de luz e verde para a qual abre esse ambiente, o papel e o modo de emprego são os da tradição romana, sempreviva, adaptada a um contexto moderno e tropical”13.

Quanto a Carlos Lemos, em relação a estas residências o único comentário aparece quando - trabalhando com a questão do clima e a arquitetura brasileira - comenta que os locais quentes e úmidos provocaram providências tendentes a evitar o sol direto. Comenta as varandas protegidas por treliças e venezianas, e os pátios guarnecidos por venezianas corridas. Exemplifica com um antigo sobrado de São Luis, duas residências em Alcântara, e termina "com um exemplo de arquitetura moderna empregando um grande pergolado em pátio interno de residência paulista projetada por Rino Levi”114. O exemplo se refere à Residência Milton Guper.

\footnotetext{
112 BRUAND, Yves, op.cit., p.274.

${ }^{113}$ BRUAND, Yves, op. cit., p. 274.

${ }^{114}$ LEMOS, Carlos, op. cit., p.1222.
} 
Renato Anelli se refere à série como "as casas introvertidas de Rino Levi" $^{\prime \prime 15}$. Observa que são caracterizadas pela presença do jardim como estruturador de toda a sua espacialidade. Segundo Anelli "paredes opacas ou de elementos vazados, construídas sobre o recuo obrigatório, constituíam uma única volumetria englobando os jardins no interior da habitação. Separando o interior da casa do exterior urbano, Levi criava a possibilidade de continuidade entre salas e jardins, o que permitia a convivência cotidiana do morador com a vegetação ao ar livre, instrumento para recompô-lo dos desgastes da vida metropolitana"16. Comenta ainda que a operação que Levi faz é a transformação do pátio tradicional para o jardim tropical.

As leituras apresentadas acima formam um panorama de referências já estabelecidas pela historiografia. Uma outra leitura que pode ser oferecida é a de entender esse partido adotado por Levi como uma residência moderna, em lote urbano, onde áreas internas e externas são concebidas como espaço contínuo. Raciocínio semelhante a esse é encontrado na tipologia da casa moderna norte-americana do período pós-guerra, principalmente a que teve origem na Costa Oeste.

A arquiteta Adriana Marta I. de Touceda, na sua tese "Da Califórnia a São Paulo: referências norte-americanas na casa moderna paulista 1945-1960"117 desenvolve com profundidade a hipótese dessa referência. No entanto, ao listar os protagonistas paulistas do

\footnotetext{
${ }^{115}$ ANELLI, Renato, op. cit.,p. 94.

${ }^{116}$ ANELLI, Renato, op. cit., p.95

117 TOUCEDA, Adriana Marta Irigoyen. Da Califórnia a São Paulo: referências norte-americanas na casa moderna paulista 1945-1960. São Paulo, tese de doutorado, FAUUSP, 2005.
} 
processo, ela omite Rino Levi, que aparece apenas como um arquiteto que, junto a Warchavchik , introduziu no Brasil - no período entre as duas grandes guerras - o espírito moderno. No nosso entender, ao invés do papel de Levi estar circunscrito apenas na introdução da questão moderna, ele será um dos importantes personagens a defender a residência unifamiliar com suas conotações de modernidade, progresso e futuro, em conformidade com o American way of life. E - dentro desta nova proposta de moradia do homem moderno americano - Levi se referencia na Califórnia e, especialmente, nas Case Study Houses.

Elas fizeram parte de um programa patrocinado por John Entenza, editor da revista Arts\& Architecture, seriamente preocupado com o rumo que a arquitetura tomaria após os anos de guerra: "Nós esperamos que seja compreendido e aceito como uma tentativa sincera, não meramente de prever, mas de tomar parte dando algumas diretrizes para o pensamento criativo sobre habitação feita por bons arquitetos e bons fabricantes cujo objetivo conjunto é a boa habitação (...) Depois que todas as bruxas mexerem no caldo, a casa que surgirá dos vapores será concebida dentro do espírito de nosso tempo, usando tanto quanto possível, muitas técnicas nascidas na guerra e os materiais mais adequados para expressar a vida do homem no mundo moderno"118. Levi compactua com esses objetivos e se referencia, inclusive, nas 22 soluções que são apresentadas de 1945 a 1960. Podemos exemplificar essa aproximação observando a Case Study

\footnotetext{
${ }^{118}$ HYMANN, Isabelle, Marcel Breuer, architect: the career and the buildings.New York, 2001, p.94. citado por TOUCEDA,Adriana, op. cit., p69
} 
House no 3 [178], de 1945/49, dos arquitetos William Wilson Wurster e Theodore Bernardi, a Case Study House no 4 [179a b], de 1945, do arquiteto Ralph Rapson, a Case Study House no 19 [180], de 1957, do arquiteto Don Knorr, a Case Study House no 20 [180], de 1958, dos arquitetos Conrad Buff III, Calvin Straub e Donald Hensman ou ainda a Case Study House no 24 [181], [182], [183], de 1961dos arquitetos A. Quincy Jones e Frederich E. Emmons.
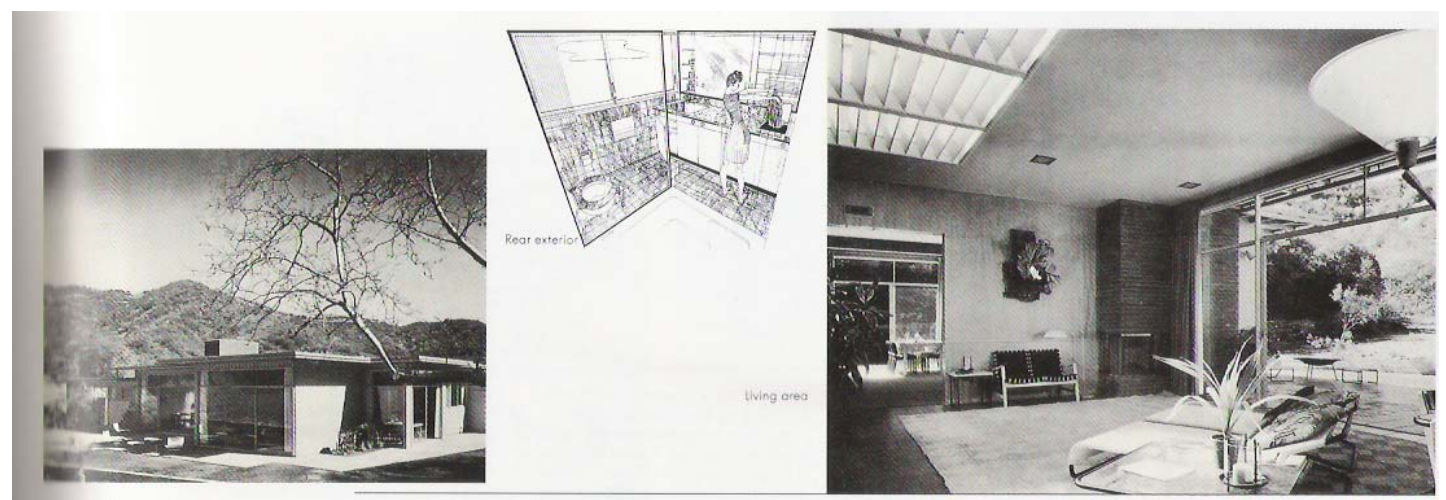

[178] (CSH-45) Case Study House nº 3, 1945/49. Arquitetos William Wilson Wurster e Theodore Bernardi. 

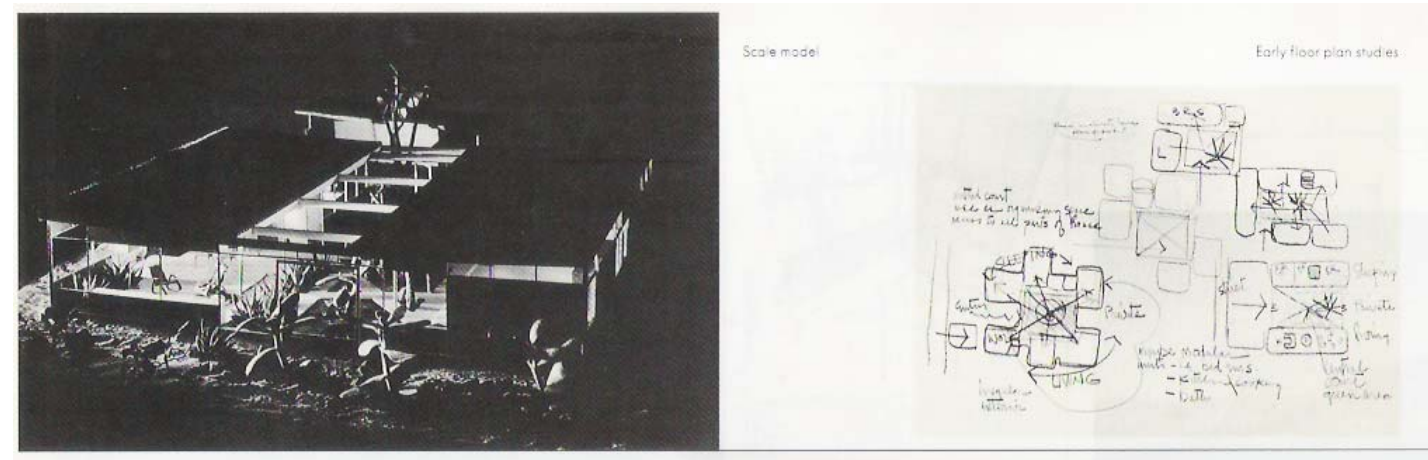

[179a] Case Study House no 4, 1945. Arquiteto Ralph Rapson.

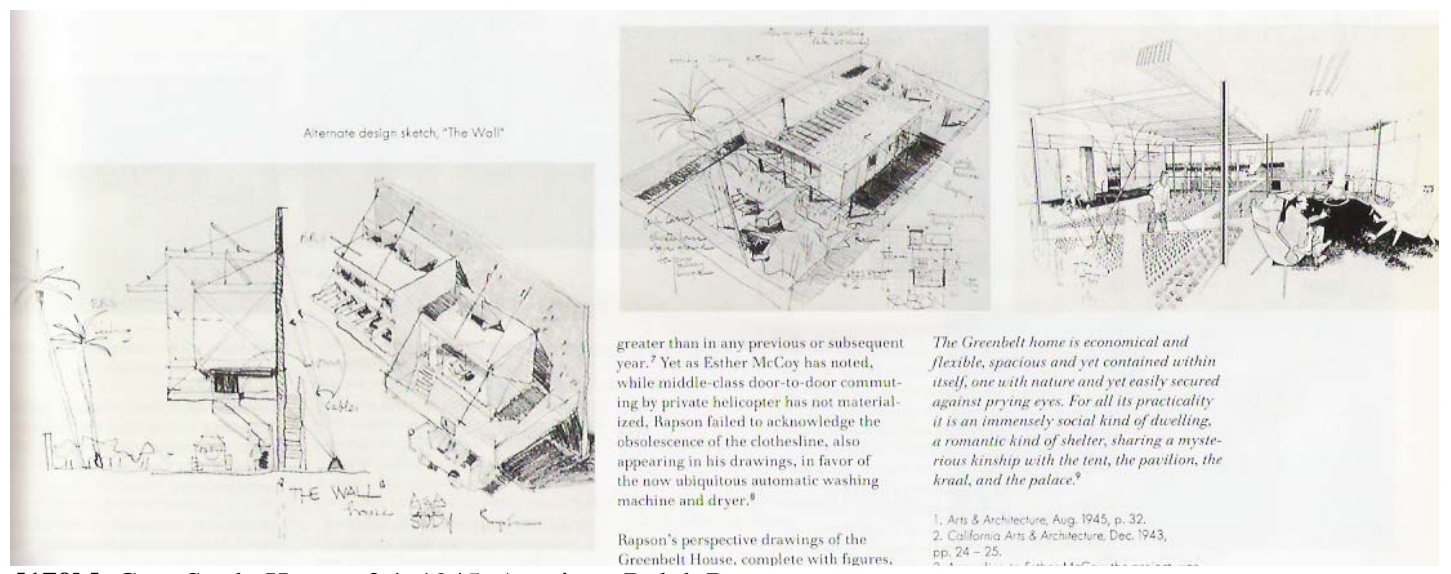

[179b] Case Study House $n^{\circ}$ 4, 1945. Arquiteto Ralph Rapson.

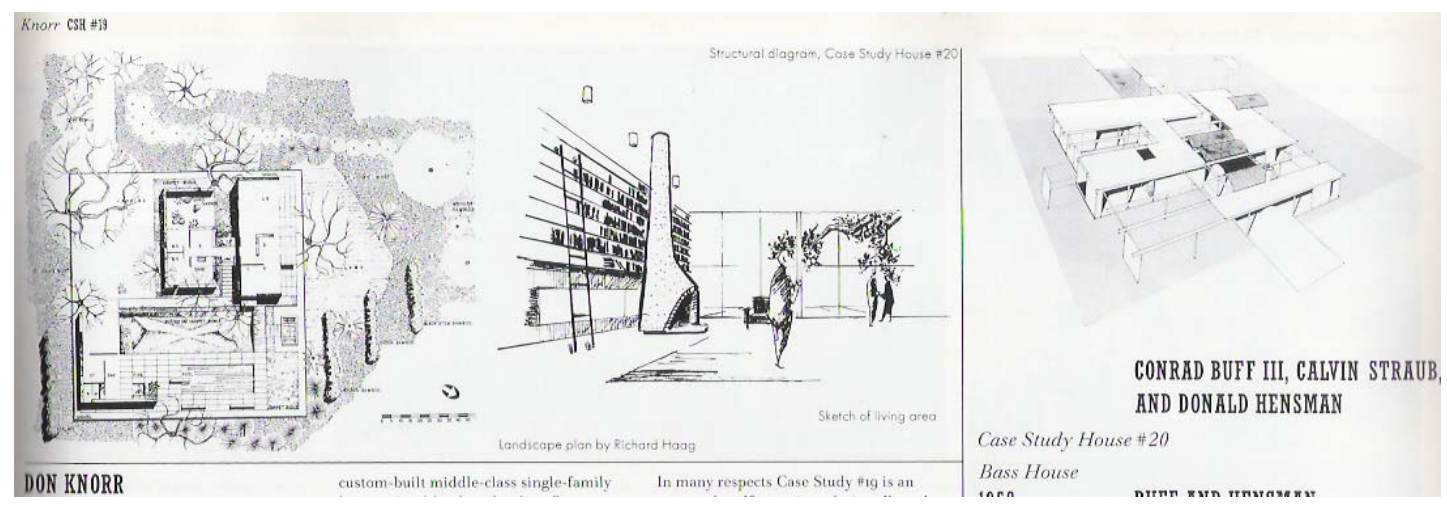

[180] Case Study House $n^{\circ}$ 19, 1957. Arquiteto Don Knorr / Case Study House $n^{\circ}$ 20, 1958. Arquitetos Conrad Buff III, Calvin Straub e Donald Hensman. 


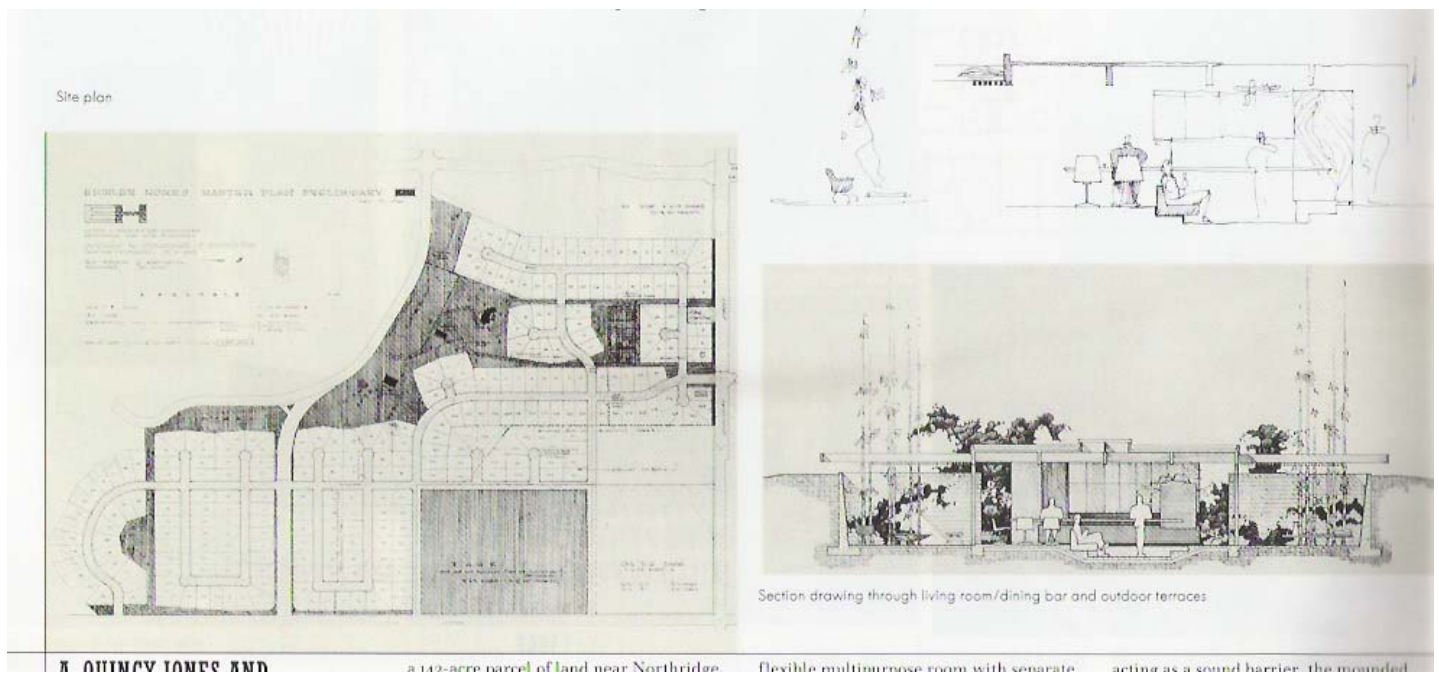

[181] Case Study House $n^{\circ}$ 24, 1961. Arquiteto A. Quincy Jones e Frederich E. Emmons.

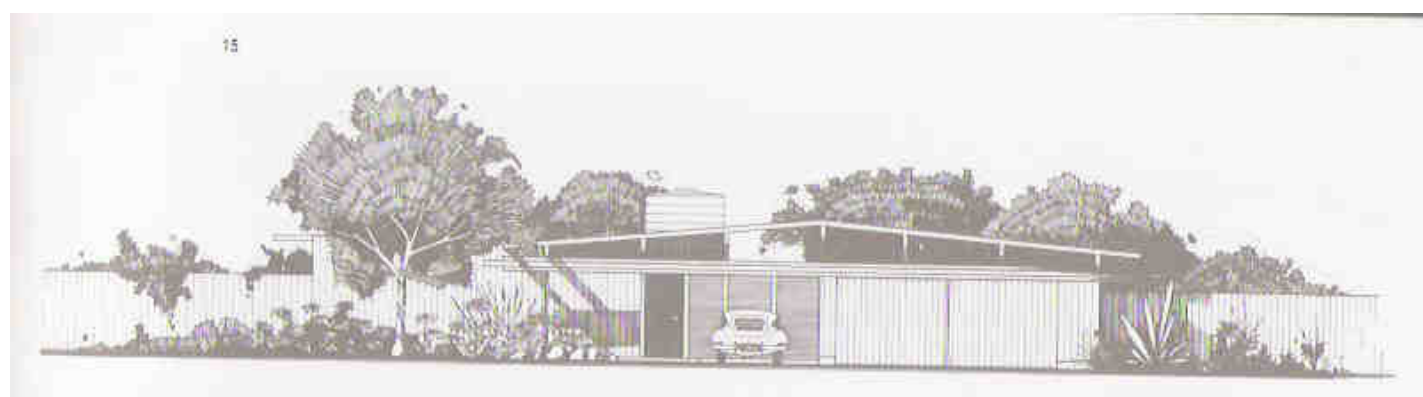

[182] Case Study House n² 24, 1961. Arquiteto A. Quincy Jones e Frederich E. Emmons.

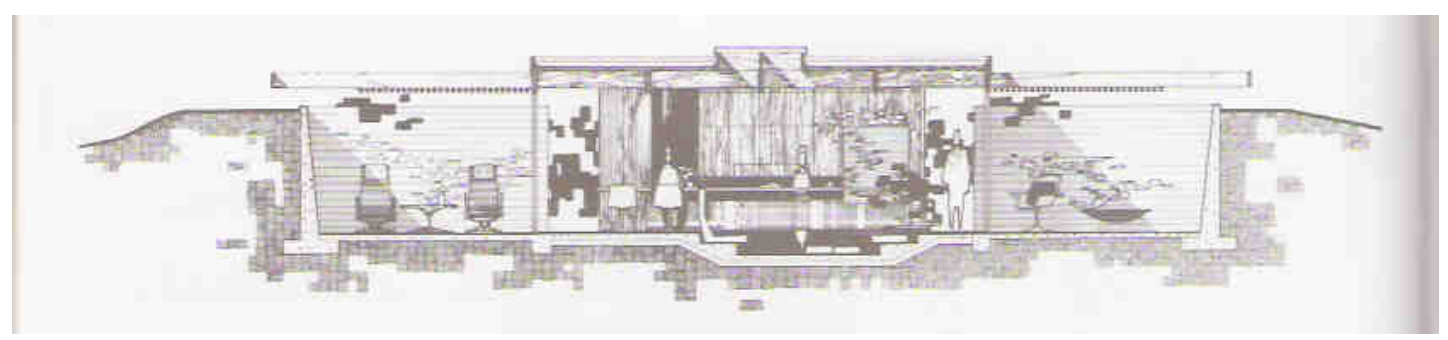

[183] Case Study House nº 24, 1961. Arquiteto A. Quincy Jones e Frederich E. Emmons. 


\section{4- SÍNTESE}

Neste segundo capítulo, através da análise de projetos, justificou-se o espaço ocupado pela arquitetura de ofício na historiografia. A questão central para a presente hipótese é que da análise dos projetos é que se pode caracterizar a postura do arquiteto perante a sua produção, e é dela que resultam ideários e realizações. Assim, foi mostrado como se materializou a arquitetura de ofício, como o programa e o detalhe é que qualificam o seu desenvolvimento, como procedimentos generalizados jamais se sobrepõe às necessidades particulares e como se opera com referências.

Trabalhou-se com a idéia de que há uma profunda diferença entre a noção de influência e a noção de referência. Por influência, entendese uma subjetiva presença de um ideário ou de repertório alheio, sem nenhum controle do autor. Ao contrário, por referência entende-se uma escolha objetiva, consciente, por um ideário ou repertório que o autor conhece profundamente, domina e elege. Os arquitetos brasileiros, de uma maneira geral, são completamente avessos a declarar que tem referências em outras produções: parecem condenados a reinventar a roda a cada novo projeto. Por outro lado, é quase comum recebermos arquitetos estrangeiros que declaram, sem nenhum constrangimento, que a arquitetura moderna no Brasil foi uma importante referência na sua produção. 
Neste capítulo mostrou-se como Rino Levi, ao contrário de seus colegas brasileiros, teve inúmeras referências e as declara. Levi conhecia profundamente a história da arquitetura e a arquitetura contemporânea à ele. Seu escritório sempre esteve na vanguarda em termos de pesquisas em pré-fabricação, uso de estruturas e materiais novos e racionalização de processos construtivos. Essas características permitiram que Bruno Zevi se referisse à arquitetura de Rino Levi como um discurso sobre o discurso de Mendelsohn, Gropius e Le Corbusier. A produção do escritório abarcou muitos outros discursos e constituiu, ele próprio, referência para a produção da arquitetura moderna no Brasil.

A abrangência da produção de Rino Levi e seu escritório - tanto em tempo quanto em quantidade - mostrou-se incompatível com a natureza deste trabalho. Mesmo se nos restringíssemos ao período em que o titular estava vivo, ainda estaríamos falando de quatro décadas. Nesse sentido, optou-se por dois recortes. O primeiro percorreu o período de formação de Levi na Itália, o cotejamento com a de seus colegas italianos e um paralelo com a formação dos arquitetos da "futura escola carioca". Trabalhou-se ainda com o inicio de sua produção no Brasil, a análise das primeiras obras e o cotejamento com as experiências européias, que ele acompanhava e que lhe serviram de referência. Outra vez, o paralelo com a experiência dos arquitetos brasileiros foi estabelecido. 
No segundo recorte a intenção foi manter a instância de análise e trabalhar um novo período. Isso significa dizer que foi mantida a preocupação com as referências de projeto mas, agora, em obras da década de 50. A escolha temporal não foi aleatória. Considerou-se que, embora o uso de referências seja uma constante, nesta década um grupo particular de projetos oferece oportunidade privilegiada para o exame de como elas operam. A idéia é que programas muito diferenciados, obedecendo à hipótese levantada, serão resolvidos com partidos muito diversos.

No período referido, o escritório vai ter a possibilidade de se envolver com situações que vão desde o Concurso para o Plano Piloto de Brasília até uma série de residências unifamiliares. Dessas, são mais apropriadas para a observação que se pretende, a Residência Rino Levi, de 1944 (embora da década anterior, oferece contribuições fundamentais para o raciocínio que se esboça), a Residência Milton Guper, de 1951, a Residência Paulo Hess, de 1953 e a Residência Castor Delgado Perez, de 1958.

Na historiografia analisada, quase não há hipóteses sobre as referências dos arquitetos para o plano piloto de Brasília, ao contrário da situação das residências, para as quais não faltam especulações. As mega-estruturas apresentadas para o concurso, e que obtiveram o terceiro lugar, só encontram explicação com relação ao programa, evidentemente calcado na cidade funcional corbusiana. Quanto ao partido, à solução estrutural e à forma só são conhecidas expressões 
de surpresa. As residências, por outro lado, se prestam a inúmeras leituras de natureza muito diversa, às vezes quase opostas. Vimos como os mesmos projetos são vistos como mediterrâneos, corbusianos, wrightianos, miesianos, cariocas, paulistas ou ainda californianos. Neste último caso com ainda diferentes vertentes: as referências variam desde Ralph Rapson até Quincy Jones passando por quase toda vasta lista das Cases Study Houses patrocinadas por John Entenza, editor da revista Arts\& Architecture. 


\section{CONCLUSÃO}

Esta tese se propôs inscrever a obra de Rino Levi na trajetória da Arquitetura Moderna no Brasil em termos diferentes dos já consagrados pela historiografia. Assim, a primeira tarefa foi uma análise historiográfica que explicitasse esses termos. Dela se ocupou o primeiro capítulo deste trabalho e, a partir dele, algumas questões foram esclarecidas.

A primeira delas é a noção de escola, presente na historiografia da arquitetura. Poucas vezes explicitada, mas, quase sempre implícita, entende-se por escola o conjunto de procedimentos e ideário comuns a um grupo de arquitetos. A historiografia da arquitetura moderna no Brasil já consolidou duas delas: a carioca e a paulista. Conseqüência imediata dessa consolidação é que a grande maioria dos arquitetos acaba sendo considerada fora, à margem, antes ou depois das ditas escolas.

Por escola carioca entende-se o grupo de arquitetos que a partir da década de 30, no Rio de Janeiro, vai desenvolver uma atitude de projeto comum. Nas questões teóricas, a figura mais importante será Lúcio Costa, papel que caberá a Oscar Niemeyer nos procedimentos diretamente ligados ao projeto.

Por escola paulista entende-se o grupo que se forma a partir da década de 5o, em São Paulo, em torno da figura de Vilanova Artigas, central tanto nas questões teóricas quanto nas de projeto. 
A produção de Rino Levi não está ligada a nenhuma das duas escolas. Isso se explica exatamente pela sua diferente atitude perante a produção da arquitetura.

A segunda questão explicita a contraposição arquitetura de gênio $x$ arquitetura de oficio. Referindo-se a Levi, Carlos Lemos vai fazer uma surpreendente análise: "Rino foi o anti-Oscar por excelência; em vez de livrar-se dos condicionantes do partido, procurava-os para tentar vencê-los. Disso decorreu uma arquitetura sobriamente bem composta, com cada coisa no seu lugar, justificando toda uma teoria bem estudada, como no caso de seus hospitais, assunto de constantes palestras, conferências e escritos. Não podemos dizer que tenha sido um artista livre, onde a liberdade aliada à imaginação levasse-o a soluções personalistas por excelência. Não. Rino Levi foi o fiel servidor das regras e seu mérito está em tê-las servido com bom gosto”.

Lemos dirigiu o escritório paulista de Niemeyer e abertamente valorizou a genialidade e a pesquisa plástica sobre as outras instâncias da criação arquitetônica. Como observa Lúcio Gomes Machado, nivela-se em posição inferior "um grande número de obras e arquitetos com propostas discordantes do partido predominante. No entanto, ao realçar, como demérito, a atenção aos detalhes e o fato de ser servidor de regras, tocou nos pontos em que, verdadeiramente, a arquitetura de

${ }^{1}$ LEMOS, Carlos, op. cit. P. 158 
Rino Levi se sobressai, não pelo bom gosto, mas pelo domínio da profissão" .

Se o primeiro capítulo define o pequeno espaço ocupado pela arquitetura de oficio, é no segundo capítulo que se justifica a sua dimensão reduzida. Através da análise dos projetos pode-se caracterizar a postura do arquiteto perante a sua produção, de onde resultam ideários e realizações. Assim, foi mostrado como se materializou a arquitetura de ofício, como o programa e o detalhe qualificam o seu desenvolvimento, como procedimentos generalizados jamais se sobrepõe às necessidades particulares e como se opera com referências.

Trabalhou-se com a idéia de que há uma profunda diferença entre a noção de influência e a de referência. Por influência, entende-se uma subjetiva presença de um ideário alheio, sem nenhum controle do autor. Ao contrário, por referência entende-se uma escolha objetiva, consciente, por um ideário ou repertório que o autor conhece profundamente, domina e elege. Os arquitetos brasileiros, de uma maneira geral, são completamente avessos a declarar que tem referências em outras produções: parecem condenados a reinventar a roda a cada novo projeto. Por outro lado, é quase comum recebermos arquitetos estrangeiros que declaram, sem nenhum constrangimento, que a arquitetura moderna no Brasil foi uma importante referência na sua produção.

\footnotetext{
${ }^{2}$ MACHADO, Lúcio Gomes, op. cit.,
} 
Mostrou-se como Rino Levi, ao contrário de seus colegas brasileiros, teve inúmeras referências e as declara. Isso ficou claro nos dois períodos trabalhados nesta tese. O primeiro percorreu o período de formação de Levi na Itália, o cotejamento com a de seus colegas italianos e um paralelo com a formação dos arquitetos da futura escola carioca. Trabalhou-se ainda com o início de sua produção no Brasil, a análise das primeiras obras e o cotejamento com as experiências européias, que ele acompanhava e que lhe serviram de referência. Outra vez, o paralelo com a experiência dos arquitetos brasileiros foi estabelecido.

No segundo recorte foi mantida a preocupação com as referências de projeto mas, agora, em obras da década de 50. A escolha temporal não foi aleatória. Considerou-se que, embora o uso de referências seja uma constante, nesta década um grupo de projetos oferece oportunidade privilegiada para o exame de como elas operam. A idéia é que programas muito diferenciados, obedecendo à hipótese levantada, serão resolvidos com partidos muito diversos. No período referido, o escritório vai ter a possibilidade de se envolver com situações que vão desde o Concurso para o Plano Piloto de Brasília até uma série de residências unifamiliares.

$\mathrm{Na}$ historiografia analisada, quase não há hipóteses sobre as referências dos arquitetos para o plano piloto de Brasília, ao contrário da situação das residências, para as quais não faltam especulações. As mega-estruturas apresentadas para o concurso, e que obtiveram o terceiro lugar, só encontram explicação com relação ao programa, 
evidentemente calcado na cidade funcional corbusiana. Quanto ao partido, à solução estrutural e à forma só são conhecidas expressões de surpresa. As residências, por outro lado, se prestam a inúmeras leituras de natureza muito diversa, às vezes quase opostas. Vimos como os mesmos projetos são vistos como mediterrâneos, corbusianos, wrightianos, miesianos, cariocas, paulistas ou ainda californianos. Neste último caso com diferentes vertentes: as referências variam desde Ralph Rapson até Quincy Jones passando por quase toda vasta lista das Cases Study Houses patrocinadas por John Entenza, editor da revista Arts \& Architecture.

Dessa maneira, pode-se concluir que Rino Levi cometeu graves pecados segundo os critérios já consagrados pela historiografia: não se preocupou excessivamente com uma arquitetura brasileira. Não valorizou apenas Le Corbusier como referência dos princípios modernos. Não inventou a roda a cada projeto. E, pecado mortal: admirou e seguiu princípios da arquitetura moderna norte-americana do pós-guerra. 


\section{DADOS BIOGRÁFICOS}

Rino Levi nasceu em 1901 em São Paulo onde cursou os ciclos elementar e médio no Colégio Dante Alighieri.

Filho de pais italianos, originários de Piemonte, faz curso superior na Itália, onde estuda primeiramente na escola Politécnica de Milão e Escola de Belas Artes de Brera.

Em 1926 forma-se em Arquitetura pela Faculdade de Arquitetura de Roma e volta à São Paulo, ingressando na Companhia Construtora de Santos, no lugar que havia sido deixado por Warchavchik. Trabalha nessa firma por dezoito meses, saindo da mesma para montar escritório próprio.

Em 1941 admite como sócio o então jovem arquiteto Roberto Cerqueira César, que será daí por diante seu constante colaborador. Em 1951 junta-se a eles o arquiteto Luis Roberto Carvalho Franco.

Foi presidente do Instituto dos Arquitetos do Brasil, departamento de São Paulo, nos períodos de 1952-53 e 1953-4.

Como membro da Comissão de Saúde Pública da União Internacional de Arquitetos representa o Brasil num Congresso na Holanda, em 1955.

Ainda em 1955 inicia outra atividade a que se entrega ardorosamente: a de catedrático da Faculdade de Arquitetura e Urbanismo da Universidade de São Paulo, cadeira de Composição de Arquitetura, ministrada no $5^{\circ}$ ano do curso. Lecionou também na Faculdade Central de Venezuela.

Exerceu as seguintes funções: membro do Centro Interamericano da Habitação de Bogotá, membro do CIAM e da Comissão de Saúde Pública da UIA, membro honorário das Sociedades de Arquitetos da Colômbia, Venezuela, México e Argentina e do Instituto Americano de Arquitetos. 
Representou o Brasil em numerosos congressos de arquitetura em países da América, da Europa, na Rússia e em Israel.

Realizou conferências na Argentina, Uruguai, México, Venezuela, Colômbia, Peru e em várias capitais do Brasil.

Participou de exposições de arquitetura no Brasil, no Museum of Modern Art de Nova York, na VIII Trienal de Milão, Galeria Maeght de Paris, em Madrid, México, Turim, Londres, Stuttgart, Lisboa, Viena, Roma, Barcelona, Oviedo e Zurich.

Faleceu em 1965.

Obs: O escritório continuou suas atividades sob a denominação de Rino Levi Arquitetos Associados S. C. Ltda. Em 1972 o arquiteto Paulo J. V. Bruna se associa e em 1986 é a vez do arquiteto Antonio Carlos Sant'Anna - que começara a trabalhar no escritório como estagiário em 1974 - tornar-se também sócio. Em 1991 a sociedade sofre as dissidências de Cerqueira César e Paulo Bruna, que passam a atuar numa nova sociedade. Após o falecimento de Carvalho Franco em 2001, o escritório passa a ser conduzido apenas por Sant’Anna. 


\section{BIBLIOGRAFIA CONSULTADA}

\section{LIVROS}

- Affonso Eduardo Reidy. Rio de Janeiro: Pontifícia Universidade Católica do Rio de Janeiro, Solar GrandJean de Montigny, 1985.

- ACAYABA, Marlene Milan. Residências em São Paulo 1947-1975. São Paulo: Projeto, 1986.

- ACAYABA, Marlene Milan. Branco e Preto: uma história do design brasileiro nos anos 50. São Paulo: Pontos sobre o Brasil \& Instituto Lina Bo e P.M. Bardi, 1994.

- ----------\& FISCHER, Silvia. Arquitetura Moderna Brasileira. São Paulo: Projeto, 1982.

- ANELli, Renato. Rino Levi. Arquitetura e cidade. São Paulo: Romano Guerra Editora, 2001.

- ARANTES, Otília. O Urbanismo em fim de Linha. São Paulo: EDUSP, 1998.

- ARTIGAS, Vilanova. Os Caminhos da Arquitetura. São Paulo: LECH, 1981.

- ---------- . Vilanova Artigas. São Paulo: Projeto, s. d. ( edição especial ).

- ---------- . O desenho. Aula inaugural proferida pelo prof. Artigas na FAUUSP/1967. São Paulo: FAUUSP, 1970, 1975.

- --------- . Vilanova Artigas. Coleção Arquitetos Brasileiros. São Paulo: Instituto Lina Bo Bardi e P. M. Bardi / Fundação Vilanova Artigas,1997. 
- BARDI, Pietro Maria. Lembranças de Le Corbusier - Atenas, Itália, Brasil. Prefácio de Alexandre Eulálio- Trad. das conferências por Anna Carboncini e Leda Maria Figueiredo Ferraz. São Paulo: Nobel, 1984.

- BATISTA, Marta Rosseti; LOPEZ, Telê P. A.; LIMA, Yone Soares. Brasil: 1o Tempo Modernista 1917-1929. São Paulo: IEB, EDUSP, 1972.

- BONDUKI, Nabil Georges. Origens da habitação social no Brasil. Arquitetura moderna, Lei do Inquilinato e difusão da casa própria. São Paulo : Estação Liberdade ; FAPESP, 1998.

- ------------ . Affonso Eduardo Reidy. Lisboa, Portugal: Blau/Inst. Lina Bo Bardi, 2000.

- BRAZIL, Álvaro Vital. 50 anos de arquitetura / Álvaro Vital Brasil. São Paulo: Nobel, 1986.

- BRUAND, Yves. Arquitetura Contemporânea no Brasil. Trad. Ana Maria Goldberg. São Paulo: Perspectiva, 1981. Tradução de L'architecture contemporaine au Brésil.

- BUCKNER, Cory. A. Quincy Jones. London/New York: Phaidon, 2002.

- CAMARGO, Mônica Junqueira. Joaquim Guedes. São Paulo: Cosac e Naify, 2001.

- CARVALHO, Flávio de Rezende. Experiência no 2 ( realizada sobre uma procissão de Corpus Christi - uma possível teoria e uma experiência). 2ª ed. São Paulo: Irmãos Ferraz, 1931.

- ------------ . Vestuário e Trópico. Pernambuco: UFP, 1967.

- ----------- . Vestuário e Trópico. Em Seminário de Tropicologia. Pernambuco: UFP, 1974. 
- CAVAlCANTE, Lauro. Guia da Arquitetura Contemporânea no Brasil. Rio de Janeiro: Aeroplano,20oo.

- COSTA, Lúcio. Lúcio Costa: registro de uma vivência. São Paulo: Empresa das Artes, 1995.

- CONDE, Luis Paulo et alii. Arquitetura Brasileira após Brasília / Depoimentos. Rio de Janeiro: IAB, 1978.

- CONDURU, Roberto. Vital Brasil. São Paulo: Cosac e Naify, 2000.

- CORONA, Eduardo \& LEMOS, Carlos A. C. . Dicionário de Arquitetura Brasileira. São Paulo: EDART, 1972.

- ------------- . Oscar Niemeyer: uma lição de Arquitetura. São Paulo: FUPAM, 2001.

- DAHER, Luis Carlos. Flávio de Carvalho: Arquitetura e Expressionismo. São Paulo: Projeto, 1982.

- ESPAllargas, Luis. Eduardo de Almeida. São Paulo: Romano Guerra Editora, 2006.

- ------------- . Flávio de Carvalho e a Volúpia da Forma. São Paulo: MWM Motores, 1984.

- FERRAZ, Geraldo. Warchavchik e a Introdução da Nova Arquitetura no Brasil: 1925-1940. São Paulo: Museu de Arte de São Paulo Assis Chateaubriand, 1965.

- FERRO, Sergio. O Canteiro e o Desenho. São Paulo: Projeto, 1982.

- --------- . A Casa Popular / Arquitetura Nova. São Paulo: CEB, GFAU, 1975 .

- --------- . O Desenho. SãoPaulo: Brasiliense, 1977. (Almanaque 3 ). 
- GOODWIN, Philip L. . Brazil Builds: Architecture New and Old, 1652-1942. New York: The Museum of Modern Art, 1943.

- GOROVITZ, Matheus. Brasília: uma Questão de Escala. São Paulo: Projeto, 1985.

- HARRIS, Elizabeth D.. Le Corbusier : Riscos Brasileiros. Tradução de Gilson César Cardoso de Souza e Antonio de Pádua Danesi. São Paulo: Nobel, 1987.

- KATINSKY, Júlio R. Lúcio Costa. São Paulo: Revista do Instituto de Estudos Brasileiros, № 12, 1972.

- LEFEVRE, Rodrigo. Notas de um Estudo sobre Objetivos do Ensino da Arquitetura e Meios para Atingí-los em Trabalhos de Projeto. São Paulo: EDUSP, 1976.

- LEITE, Rui Moreira. Exposição Flávio de Carvalho-17 $7^{\underline{a}}$ Bienal Internacional de São Paulo. São Paulo: Fundação Bienal, 1987.

- LEMOS, Carlos A. C.. Arquitetura Brasileira. São Paulo: Melhoramentos : EDUSP, 1979.

- LEVI, Rino. Evolução da Arquitetura. Porto Alegre: Centro dos Estudantes Universitários de Arquitetura, 1960. ( Cadernos de Estudos, no 8 ).

- Lina Bo Bardi / org. Marcelo Carvalho Ferraz. São Paulo: Empresa das Artes, 1993.

- Lúcio Costa: registro de uma vivência. São Paulo: Empresa das Artes, 1995.

- MILlan, Carlos. O Atelie na Formação do Arquiteto. São Paulo: EDUSP, 1962. 
- Mindlin, Henrique E.. Arquitetura Moderna no Brasil. Rio de Janeiro: Aeroplano/ IPHAN, 1999.

- MASAO, João Camita. Vilanova Artigas. São Paulo: Cosac e Naify, 2001.

- NIEMEYER, Oscar. A forma na Arquitetura. $3^{\underline{a}}$ ed. Rio de Janeiro: Avenir, 1980. (Coleção Depoimentos)

- --------- . Quase Memórias: Viagens. Tempos de entusiasmo e revolta - 1961-1968. Rio de Janeiro: Civilização Brasileira, 1968.

- --------- . Minha Experiência em Brasília. Rio de Janeiro: Civilização Brasileira, 1960.

- ---------- . Rio. Rio de Janeiro: Artes Gráficas, 1980.

- --------- et alii. Parque do Tietê: Plano de Reurbanização da Margem do Rio Tietê. São Paulo: Almed, 1986.

- -------- \& COSTA, Lúcio. Pavilhão do Brasil na Feira Mundial de Nova York de 1939. New York: H. K. Publishing, 1939.

- OSÓRIO, Luiz Camillo. Flávio de Carvalho. São Paulo: Cosac e Naify, 2001.

- PAPADAKI, Stamo. The Work of Oscar Niemeyer. $2^{\underline{a}}$ ed. New York: Rheinold, 1951.

- --------- . Oscar Niemeyer. New York: George Braziler, 1960. ( The Masters of World Architecture series).

- PEDROSA, Mário. Dos Murais de Portinari aos Espaços de Brasília. Org. por Aracy A. Amaral. São Paulo: Perspectiva, 1981. 
- PENEDO, Alexandre. Arquitetura moderna São José dos Campos. São José dos Campos,SP: A. Penedo, 1997.

- REIS FILHO, Nestor Goulart. Quadro da Arquitetura no Brasil. São Paulo: Perspectiva, 1970.

- Rino Levi. Milano: Comunità, 1974.

- ROCHA, Paulo Mendes. Paulo Mendes da Rocha. São Paulo: Cosac e Naify, 2001.

- SANTOS, Cecília Rodrigues et alii. Le Corbusier e o Brasil. São Paulo: Telessa, Projeto, 1987.

- SANTOS, Paula F.. Quatro Séculos de Arquitetura. Rio de Janeiro: $\mathrm{IAB}, 1981$.

- SEGAWA, Hugo. Arquiteturas no Brasil 1900-199o. São Paulo: Editora da Universidade de São Paulo, 1997.

- ---------------, DOURADO, Guilherme Mazza. Oswaldo Arthur Bratke. São Paulo: ProEditores, 1997.

- SEGNINI Jr.. Arquitetura e Desenvolvimento Nacional: Depoimentos de Arquitetos Paulistas. São Paulo: IAB, Pini, s.d..

- SMITH, Elizabeth (org.). Blueprints for modern living :history and legacy of the Case Study Houses. Los Angeles/Cambridge: The Museum of Contemporary Art/MIT Press, 1998.

- SOARES, Cristina Ferrão M. \& SOARES, José Paulo M.. Affonso Eduardo Reidy. Rio de Janeiro: Fundação Grandjean de Montigny, PUC/RJ, 1984.

- SOUZA, Ricardo Forjaz C.. Trajetórias da Arquitetura Modernista. São Paulo: IDART, 1982. ( Cadernos nํ10 ). 
- SOUZA, Abelardo de. Arquitetura no Brasil - Depoimentos. São Paulo: Diadorim, EDUSP, 1978.

- SPADE, Rupert. Oscar Niemeyer. London: Thames and Hudson, 1971. ( fotografias de Y. Futagawa).

- Vilanova Artigas: Série arquitetos brasileiros. São Paulo: Instituto Lina Bo e P.M. Bardi: Fundação Vilanova Artigas, 1997.

- XAVIER, Alberto; LEMOS, Carlos A. C.; CORONA, Eduardo. Arquitetura Moderna Paulista. São Paulo: Pini, 1983.

(org.). Arquitetura Moderna Brasileira - Depoimentos de uma Geração. São Paulo: ABEA, FVA, Pini, Projeto Hunter Douglas, 1987.

- ---------- . Lúcio Costa: Sôbre Arquitetura. Porto Alegre: UNP, 1962.

- ---------; BRITTO, Alfredo; NOBRE, Ana Luiza Nobre. Arquitetura Moderna no Rio de Janeiro. São Paulo: Pini : Fundação Vilanova Artigas; Rio de Janeiro ; RIOARTE, 1991.

- ---------; MIZOGUCH, Ivan. Arquitetura moderna em Porto Alegre. São Paulo: Pini, 1987.

- -----------. Arquitetura moderna em Curitiba. São Paulo : Pini; Curitiba : Fundação Cultural de Curitiba, 1985.

- WISNIK, Guilherme, Lúcio Costa. São Paulo: Cosac \& Naify Edições, 2001.

TESES 
- ANELLI, Renato Luiz Sobral - Arquitetura de Cinemas em São Paulo, Dissertação de mestrado, IFCH-UNICAMP, 1990.

-------------------------- Arquitetura e Cidade na Obra de Rino Levi, Tese de doutorado, FAU-USP, 1990.

- ARANHA, Maria Beatriz de Camargo. Rino Levi: arquitetura como ofício. Dissertação de mestrado, FAU-USP, 2003.

- BAYEUX, Glória Maria - O Debate da Arquitetura Moderna Brasileira nos anos 50, Dissertação de mestrado, FAU-USP,1991.

- BRAGA, Milton Liebentritt de Almeida, O Concurso de Brasília - os sete projetos premiados, Dissertação de mestrado, FAU-USP, 1999.

- ESPALLARGAS GIMENEZ, Luis - Arquitetura paulistana na década de 1960: técnica e forma. Tese de Doutorado, FAU-USP, 2004.

- FARIAS, Agnaldo A. C. - Arquitetura Eclipsada: notas sobre história e arquitetura a propósito da obra de Gregori Warchavchik, introdutor da arquitetura moderna no Brasil, Dissertação de mestrado, IFCH-UNICAMP, 1990.

- FICHER, Silvia, Ensino e Profissão - O curso de engenheiroarquiteto da Escola Politécnica de São Paulo, Tese de doutorado, FFLCH-USP, 1989.

- FUJIOKA, Paulo Yassuhide- Princípios da arquitetura organicista de Frank Lloyd Wright e suas influencias na arquitetura moderna paulistana. Tese de Doutorado, FAU-USP, 2004.

- GUERRA NETO, Abílio da Silva, O Homem Primitivo, origem e conformação no universo cultural brasileiro (séculos XIX e XX), Dissertação de mestrado, IFCH-UNICAMP, 1990. 
- GUERRA NETO, Abílio da Silva, Lúcio Costa: modernidade e tradição - Montagem discursiva da arquitetura moderna brasileira. Tese de Doutorado, UNICAMP, 2002.

- IMBRONITO, Maria Isabel. Tres edifícios de habitação para a Formaespaço: modulares, Gemini e Protótipo. Dissertação de mestrado, FAU-USP, 2003.

- IRIGOYEN de Touceda, Adriana Marta. Da Califórnia a São Paulo: referências norte-americanas na casa moderna paulista 1945-196o. Tese de Doutorado, FAU-USP, 2005.

- MACHADO, Lúcio Gomes - Rino Levi e a renovação da Arquitetura Brasileira, Tese de doutorado, FAU-USP, 1992.

- MARTINS, Carlos Alberto Ferreira - Arquitetura e Estado no Brasil: elementos para uma investigação sobre a Constituição do Discurso Modernista no Brasil; a obra de Lúcio Costa, Dissertação de mestrado, FFLCH-USP, 1988.

Corbusier, Tese de doutorado, Escola Politécnica de Madri, 1992.

- MIGUEL, Jorge Marão C. - As Casas de Rino Levi : um estudo de concepção espacial, Dissertação de mestrado, EESC-USP, 1985.

- MIRANDA, Clara Luiza - A crítica nas revistas de arquitetura nos anos 50 : a expressão plástica e a síntese das artes, Dissertação de mestrado, EESC-USP, 1998.

- ROCHA, Angela Maria - Uma produção de espaço em São Paulo: Giancarlo Palanti, Dissertação de mestrado, FAU-USP, 1991.

- TELLES, Sophia Silva, Arquitetura Moderna no Brasil: o desenho da superfície, Dissertação de mestrado, FFLCH-USP, s.d. 
- TONHÃO, Marcos - Marcello Piacentini: Arquitetura no Brasil, Dissertação de mestrado, IFCH-UNICAMP, 1993.

- VAZ, Rita - Arquitetura Moderna em Pernambuco: 1934-1937, Dissertação de mestrado, FAU-USP, 1988. 


\section{FONTE DAS IMAGENS}

\section{INTRODUÇÃO}

[o1] Casa da Rua Santa Cruz, São Paulo, SP. Arquiteto Gregori Warchavchik, 1927. Fonte: FERRAZ, Geraldo. Warchavchik e a Introdução da Nova Arquitetura no Brasil: 1925-1940. São Paulo, Museu de Arte de São Paulo Assis Chateaubriand, 1965, s/p.

[o2] Edifício-sede do MES-Ministério da Educação e Saúde (depois MEC, hoje Palácio Gustavo Capanema), Rio de Janeiro, RJ. Arquitetos Lúcio Costa, Jorge Machado Moreira, Ernani Vasconcelos, Affonso Eduardo Reidy, Carlos Leão e Oscar Niemeyer, consultoria de Le Corbusier, 1936. Fonte: CZAJKOWSKI, Jorge org., Jorge Machado Moreira. Rio de Janeiro, Centro de Arquitetura e Urbanismo do Rio de Janeiro, 1999, p. 95.

\section{CAPÍTULO 1}

[o3] Pavilhão do Brasil na Exposição Internacional de Nova Iorque, Nova Iorque, EUA. Arquitetos Lúcio Costa, Oscar Niemeyer e Paul Lester Wiener, 1939. Fonte: WISNIK, Guilherme. Lúcio Costa. São Paulo, Cosac \& Naify Edições, 2001.

[o4] Edifício-sede do MES-Ministério da Educação e Saude (depois MEC, hoje Palácio Gustavo Capanema), Rio de Janeiro, RJ. Arquitetos Lúcio Costa, Jorge Machado Moreira, Ernani Vasconcelos, Affonso Eduardo Reidy, Carlos Leão e Oscar Niemeyer, consultoria de Le Corbusier, 1936. Fonte: CZAJKOWSKI, Jorge org., Jorge Machado Moreira. Rio de Janeiro, Centro de Arquitetura e Urbanismo do Rio de Janeiro, 1999, p. 98.

[o5] Marquise da Casa de Baile do Conjunto da Pampulha, Belo Horizonte, MG. Arquiteto Oscar Niemeyer, 1942/43. Fonte: UNDERWOOD, David. Oscar Niemeyer and the Arquitecture of Brazil. Nova York, Rizzoli, 1994, p. 58. [o6] Instituto Superior Sedes Sapientiae, São Paulo, SP. Arquiteto Rino Levi, 1941/42. Fonte: CIDD-Centro Integrado de Documentação Digital - Projeto Piloto Rino Levi - FAUPUCAMP, 1997- o1, CD31, imagem 83.

[o7] Cine Ufa Palace, São Paulo, SP. Arquiteto Rino Levi, 1936. Fonte: CIDD - Centro Integrado de Documentação Digital - Projeto Piloto Rino Levi - FAUPUCAMP, 1997-01, $\mathrm{CD}_{3}$, imagem 35 .

[o8] Cine Ipiranga e Hotel Excelsior, São Paulo, SP. Arquiteto Rino Levi, 1941. Fonte: CIDD - Centro Integrado de Documentação Digital - Projeto Piloto Rino Levi FAUPUCAMP, 1997-01, CD4, imagem 45. 
[o9] Cia. Jardim de Cafés Finos, São Paulo, SP. Arquiteto Rino Levi, 1942. Fonte: CIDD Centro Integrado de Documentação Digital - Projeto Piloto Rino Levi - FAUPUCAMP, 1997-01, CDo5, imagem 52.

[10] Residência Rino Levi, São Paulo, SP. Arquiteto Rino Levi, 1944. Fonte: CIDD - Centro Integrado de Documentação Digital - Projeto Piloto Rino Levi - FAUPUCAMP, 1997-01, CDo5, imagem 96.

[11] Maternidade Universitária de São Paulo, São Paulo, SP. Arquitetos Rino Levi, Roberto Cerqueira Cesar e F. A. Pestalozzi, 1944. Fonte: CIDD - Centro Integrado de Documentação Digital - Projeto Piloto Rino Levi - FAUPUCAMP, 1997-01, CDo5, imagem 89.

[12] Edifício Sede do Instituto dos Arquitetos do Brasil (1o classificado ex aequo), São Paulo, SP. Arquitetos Rino Levi, Abelardo de Souza, Galiano Ciampaglia, Hélio Duarte, Jacob Ruchti, Miguel Forte e Zenon Lotufo, 1947. Fonte: CIDD - Centro Integrado de Documentação Digital -Projeto Piloto Rino Levi - FAUPUCAMP, 1997-01, CDo6, imagem 55 .

[13] Teatro de Cultura Artística, São Paulo, SP. Arquitetos Rino Levi e Roberto Cerqueira Cesar, 1942. Fonte: CIDD - Centro Integrado de Documentação Digital - Projeto Piloto Rino Levi - FAUPUCAMP, 1997-01, CDo5, imagem 23.

[14] Edifício do Banco Paulista do Comércio, São Paulo, SP. Arquitetos Rino Levi e Roberto Cerqueira Cesar, 1947. Fonte: CIDD - Centro Integrado de Documentação Digital - Projeto Piloto Rino Levi - FAUPUCAMP, 1997-01, CDo6, imagem 72.

[15] Edifício de Apartamentos Prudência, São Paulo, SP. Arquitetos Rino Levi e Roberto Cerqueira Cesar, 1944. Fonte: CIDD - Centro Integrado de Documentação Digital - Projeto Piloto Rino Levi - FAUPUCAMP, 1997-01, CDo5, imagem 75.

[16] Edifício de Escritórios da Cia. Nacional de Seguros de Vida de São Paulo, São Paulo, SP. Arquitetos Rino Levi e Roberto Cerqueira Cesar, 1952. Fonte: CIDD - Centro Integrado de Documentação Digital - Projeto Piloto Rino Levi - FAUPUCAMP, 1997-01, CDo6, imagem 84 .

[17] Conjunto Residencial Estudantil da Universidade de São Paulo, São Paulo, SP. Arquitetos Rino Levi e Roberto de Cerqueira Cesar, 1953. Fonte: CIDD - Centro Integrado de Documentação Digital - Projeto Piloto Rino Levi - FAUPUCAMP, 1997-01, CDo8, imagem 61.

[18] Residência Milton Guper, São Paulo, SP. Arquitetos Rino Levi e Roberto Cerqueira Cesar, 1951. Fonte: CIDD - Centro Integrado de Documentação Digital - Projeto Piloto Rino Levi - FAUPUCAMP, 1997-01, CDo7, imagem 65. 
[19] Residência Olívio Gomes, São José dos Campos, SP. Arquitetos Rino Levi e Roberto Cerqueira Cesar, 1953. Fonte: CIDD - Centro Integrado de Documentação Digital - Projeto Piloto Rino Levi - FAUPUCAMP, 1997-01, CDo7, imagem 05.

[2o] Conjunto Residêncial Tecelagem Parahyba S.A., São José dos Campos, SP. Arquitetos Rino Levi e Roberto Cerqueira Cesar, 1954. Fonte: CIDD - Centro Integrado de Documentação Digital - Projeto Piloto Rino Levi - FAUPUCAMP, 1997-01, CDo8, imagem 82.

[21] Hospital Antônio Cândido de Camargo, do Instituto Central do Câncer, São Paulo, SP. Arquitetos Rino Levi e Roberto Cerqueira Cesar, 1947/54. Fonte: CIDD - Centro Integrado de Documentação Digital - Projeto Piloto Rino Levi - FAUPUCAMP, 1997-01, CDo6, imagem 45.

[22] Garagem América, São Paulo, SP. Arquiteto Rino Levi, 1952/54. Fonte: CIDD Centro Integrado de Documentação Digital - Projeto Piloto Rino Levi - FAUPUCAMP, 1997-01, CDo9, imagem 13.

[23] Palácio do Governo - concurso público, São Paulo, SP. Arquiteto Flávio de Carvalho, 1927. Fonte: OSÓRIO, Luiz Camillo. Flávio de Carvalho. São Paulo, Cosac e Naify, 2001, p.14.

[24] Vila das Alamedas Lorena e Ministro Rocha Azevedo, São Paulo, SP. Arquiteto Flávio de Carvalho, 1936/38. Fonte: OSÓRIO, Luiz Camillo. Flávio de Carvalho. São Paulo, Cosac e Naify, 2001, p.34.

[25] Instituto Superior Sedes Sapientiae, São Paulo, SP. Arquiteto Rino Levi, 1941/42. Fonte: CIDD - Centro Integrado de Documentação Digital - Projeto Piloto Rino Levi FAUPUCAMP, 1997- 01, CDo4, imagem 81.

[26] Edifício de Apartamentos Prudência, São Paulo, SP. Arquitetos Rino Levi e Roberto Cerqueira Cesar, 1944. Fonte: CIDD - Centro Integrado de Documentação Digital - Projeto Piloto Rino Levi - FAUPUCAMP, 1997-01, CDo5, imagem 74.

[27] Edifício de Escritórios da Cia. Nacional de Seguros de Vida de São Paulo, São Paulo, SP. Arquitetos Rino Levi e Roberto Cerqueira Cesar, 1952. Fonte: CIDD - Centro Integrado de Documentação Digital - Projeto Piloto Rino Levi - FAUPUCAMP, 1997-01, CDo6, imagem 82.

[28] Banco Sul-Americano S/A, Av. Paulista 1948, São Paulo, SP. Arquitetos Rino Levi, Roberto Cerqueira Cesar e Luís Roberto Carvalho Franco, 1960/65. Fonte: CIDD - Centro Integrado de Documentação Digital - Projeto Piloto Rino Levi - FAUPUCAMP, 1997-01, CD11, imagem 38.

[29] Hospital Antônio Cândido de Camargo, do Instituto Central do Câncer, São Paulo, SP. Arquitetos Rino Levi e Roberto Cerqueira Cesar, 1947/54. Fonte: CIDD - Centro 
Integrado de Documentação Digital - Projeto Piloto Rino Levi - FAUPUCAMP, 1997-01, CDo6, imagem 32.

[3o] Hospital Geral Albert Einstein, São Paulo, SP. Arquitetos Rino Levi, Roberto Cerqueira Cesar e Luís Roberto Carvalho Franco, 1958. Fonte: CIDD - Centro Integrado de Documentação Digital - Projeto Piloto Rino Levi - FAUPUCAMP, 1997-01, CD10, imagem o6.

[31] Galpão e posto de gasolina da Tecelagem Parahyba, São José dos Campos, SP. Arquitetos Rino Levi, Roberto Cerqueira Cesar e Luís Roberto de Carvalho Franco, 1953. Fonte: CIDD - Centro Integrado de Documentação Digital - Projeto Piloto Rino Levi FAUPUCAMP, 1997- o1, CDo8, imagem 17.

[32] Usina de Leite Parahyba, São José dos Campos, SP. Arquitetos Rino Levi, Roberto Cerqueira Cesar e Luís Roberto de Carvalho Franco, 1963/65. Fonte: CIDD - Centro Integrado de Documentação Digital - Projeto Piloto Rino Levi - FAUPUCAMP, 1997-01, CD12, imagem 10.

[33] Centro Cívico de Santo André (concurso - 1o lugar), Santo André, SP. Arquitetos Rino Levi, Roberto Cerqueira Cesar e Luís Roberto de Carvalho Franco, 1965. Fonte: CIDD - Centro Integrado de Documentação Digital - Projeto Piloto Rino Levi FAUPUCAMP, 1997-01, CD12, imagem 98 .

[34] Praça dos Três Poderes, Brasília, DF. Arquitetos Lúcio Costa (Plano Piloto) e Oscar Niemeyer (projetos de arquitetura), 1957. Fonte: COSTA, Lúcio. Lúcio Costa: registro de uma vivência. São Paulo, Empresa das Artes, 1995, p. 306.

[35] Casa Modernista, São Paulo, SP. Arquiteto Gregori Warchavchik, 1907. Fonte: FERRAZ, Geraldo. Warchavchik e a Introdução da Nova Arquitetura no Brasil: 1925-1940. São Paulo, Museu de Arte de São Paulo Assis Chateaubriand, 1965, s/p.

[36] Edifício Esther, São Paulo, SP. Arquiteto Álvaro Vital Brasil, 1936. Fonte: CONDURU, Roberto. Vital Brasil. São Paulo: Cosac e Naify, 2000, p.55.

[37] Edifício de apartamentos na Av. Angélica. São Paulo, SP. Arquiteto Julio de Abreu Junior, 1927. Fonte: SEGAWA, Hugo. Arquiteturas no Brasil 190o-199o. São Paulo, Edusp, 1997, p.57.

[38] Edifício-sede do MES-Ministério da Educação e Saúde (depois MEC, hoje Palácio Gustavo Capanema), Rio de Janeiro, RJ. Arquitetos Lúcio Costa, Jorge Machado Moreira, Ernani Vasconcelos, Affonso Eduardo Reidy, Carlos Leão e Oscar Niemeyer, consultoria de Le Corbusier, 1936. Fonte: CZAJKOWSKI, Jorge org., Jorge Machado Moreira. Rio de Janeiro, Centro de Arquitetura e Urbanismo do Rio de Janeiro, 1999.

[39]. Residências rurais do Ceará e de Minas. Fonte: LEMOS, Carlos A. C.. Arquitetura Brasileira. São Paulo, Melhoramentos / EDUSP, 1979, p. 124 
[4o Pátio Interno de residência de Rino Levi, São Paulo, SP. Fonte: LEMOS, Carlos A. C.. Arquitetura Brasileira. São Paulo, Melhoramentos / EDUSP, 1979, p. 128.

[41] Edifício Columbus, São Paulo, SP. Arquiteto Rino Levi, 1932. Fonte: CIDD - Centro Integrado de Documentação Digital - Projeto Piloto Rino Levi - FAUPUCAMP, 1997-01, CD32, imagem 88.

[42] Instituto Superior Sedes Sapientiae, São Paulo, SP. Arquiteto Rino Levi, 1940. Fonte: CIDD - Centro Integrado de Documentação Digital - Projeto Piloto Rino Levi FAUPUCAMP, 1997-01, CDo4, imagem 91.

[43] Plano Piloto de Brasília, concurso - $3^{\circ}$ andar, Brasília, DF. Arquitetos Rino Levi e Cerqueira César,1957. Fonte: CIDD - Centro Integrado de Documentação Digital - Projeto Piloto Rino Levi - FAUPUCAMP, 1997-01, CDo9, imagem 79.

[44] ] Hotel Excelsior, São Paulo, SP. Arquitetos Rino Levi e Roberto Cerqueira César,1941. Fonte: CIDD - Centro Integrado de Documentação Digital - Projeto Piloto Rino Levi - FAUPUCAMP, 1997-01, CDo4, imagem 59.

[45] Edifício Concórdia, São Paulo, SP. Arquitetos Rino Levi, Roberto Cerqueira César e Luis Roberto Carvalho Franco, 1955. Fonte: CIDD - Centro Integrado de Documentação Digital - Projeto Piloto Rino Levi - FAUPUCAMP, 1997-o1, CDo8, imagem 94.

[46] Usina de Leite Parayba S/A, São José dos Campos, SP. Arquitetos Rino Levi, Roberto Cerqueira César e Luis Roberto Carvalho Franco,1962. Fonte: CIDD - Centro Integrado de Documentação Digital - Projeto Piloto Rino Levi - FAUPUCAMP, 1997-01, CD12, imagem 09 .

[47] Edifício Prudência, São Paulo, SP. Arquitetos Rino Levi e Roberto Cerqueira César, 1944. Fonte: CIDD - Centro Integrado de Documentação Digital - Projeto Piloto Rino Levi - FAUPUCAMP, 1997-01, CDo5, imagem 87.

[48] Edifício Sarti, São Paulo, SP. Arquiteto Rino Levi,1935. Fonte: CIDD - Centro Integrado

\section{CAPITULO 2}

[o1] Rilievo della Facciata del Pallazo Barromeo, trabalho do aluno Rino Levi na Scuola Preparatoria e di Applicazione per gli Architetti Civili, Milão, 1923. Fonte: CIDD - Centro Integrado de Documentação Digital - Projeto Piloto Rino Levi - FAUPUCAMP, 1997-01, CD31, imagem o6. 
[o2] Hotel ou sede do Touring Club Italiano, trabalho do aluno Rino Levi na Scuola Superiore di Architettura, Roma, 1923/24. Fonte: CIDD - Centro Integrado de Documentação Digital - Projeto Piloto Rino Levi - FAUPUCAMP, 1997-01, CD31, imagem 08 .

[o3] Palazzo per esposizione d'armi, trabalho do aluno Rino Levi na Scuola Superiore di Architettura, Roma, 1924/25. Fonte: CIDD - Centro Integrado de Documentação Digital Projeto Piloto Rino Levi - FAUPUCAMP, 1997-01, CD31, imagem o1.

[o4] Progetto di uma Banca - elevação, trabalho do aluno Rino Levi na Scuola Superiore di Architettura, Roma, 1925/26. Fonte: CIDD - Centro Integrado de Documentação Digital - Projeto Piloto Rino Levi - FAUPUCAMP, 1997-01, CD31, imagem o4.

[05] Progetto di uma Banca - planta, trabalho do aluno Rino Levi na Scuola Superiore di Architettura, Roma, 1925/26. Fonte: CIDD - Centro Integrado de Documentação Digital Projeto Piloto Rino Levi - FAUPUCAMP, 1997-01, CD31, imagem o3.

[o6] Projeto de um interior - decoração, trabalho do aluno Rino Levi na Scuola Superiore di Architettura, Roma, 1924/25. Fonte: CIDD - Centro Integrado de Documentação Digital - Projeto Piloto Rino Levi - FAUPUCAMP, 1997-01, CD31, imagem 10.

[o7] Porto fluviale - Scenografia, trabalho do aluno Rino Levi na Scuola Superiore di Architettura, Roma, 1925/26. Fonte: CIDD - Centro Integrado de Documentação Digital Projeto Piloto Rino Levi - FAUPUCAMP, 1997-01, CD31, imagem 05.

[o8] Veduta prospettica di uno dei due cortili simmetrici - Palazzo dello Sport, , trabalho do aluno Rino Levi na Scuola Superiore di Architettura, Roma, 1925/26. Fonte: CIDD Centro Integrado de Documentação Digital - Projeto Piloto Rino Levi - FAUPUCAMP, 1997-01, CD31, imagem 11.

[o9] Escola Normal do Rio de Janeiro, RJ, década de 20 - "falso estilo colonial" segundo Abelardo de Souza. Fonte: SOUZA, Abelardo de. Arquitetura no Brasil - Depoimentos. São Paulo, Diadorim, EDUSP, 1978, p.32-3B.

[10] Casas com fachadas reproduzindo as iniciais do proprietário, aluno da Escola Nacional de Belas Artes do Rio de Janeiro, RJ, década de 20 - "Cartilha Arquitetônica", segundo Abelardo de Souza. Fonte: SOUZA, Abelardo de. Arquitetura no Brasil Depoimentos. São Paulo, Diadorim, EDUSP, 1978, p.32-2A.

[11] Foto panorâmica "Cinelândia", Rio de Janeiro, RJ - "falso estilo clássico" segundo Abelardo de Souza. Fonte: SOUZA, Abelardo de. Arquitetura no Brasil - Depoimentos. São Paulo, Diadorim, EDUSP, 1978, p.32-4A.

[12] Projeto de residência, aluno da Escola Nacional de Belas Artes do Rio de Janeiro, RJ, década de 20 - "alta confusão arquitetônica" segundo Abelardo de Souza. Fonte: SOUZA, 
Abelardo de. Arquitetura no Brasil - Depoimentos. São Paulo, Diadorim, EDUSP, 1978, p.32-2B.

[13] "Uma entrada para uma quinta presidencial", trabalho do aluno Jorge Machado Moreira no Curso de Arquitetura da Escola Nacional de Belas Artes do Rio de Janeiro, RJ, 1927/28. Fonte: CZAJKOWSKI, Jorge org., Jorge Machado Moreira. Rio de Janeiro, Centro de Arquitetura e Urbanismo do Rio de Janeiro, 1999, p.36.

[14] "Torre elevatória de d'água", trabalho do aluno Jorge Moreira Machado no Curso de Arquitetura da Escola Nacional de Belas Artes do Rio de Janeiro, RJ, 1928/29. Fonte: CZAJKOWSKI, Jorge org., Jorge Machado Moreira. Rio de Janeiro, Centro de Arquitetura e Urbanismo do Rio de Janeiro, 1999, p.36.

[15] "A Moda - confecções, sedas e novidades", trabalho do aluno Jorge Moreira Machado no Curso de Arquitetura da Escola Nacional de Belas Artes do Rio de Janeiro, RJ, 1930/31. Fonte: CZAJKOWSKI, Jorge org., Jorge Machado Moreira. Rio de Janeiro, Centro de Arquitetura e Urbanismo do Rio de Janeiro, 1999, p.38.

[16] "Um edifício para renda", trabalho do aluno Jorge Moreira Machado no Curso de Arquitetura da Escola Nacional de Belas Artes do Rio de Janeiro, RJ, 1930/31. Fonte: CZAJKOWSKI, Jorge org., Jorge Machado Moreira. Rio de Janeiro, Centro de Arquitetura e Urbanismo do Rio de Janeiro, 1999, p. 39.

[17] Residência Rodolfo Chambelland, Rio de Janeiro, RJ, 1921/22. Arquiteto Lúcio Costa. Foto da fachada. Fonte: COSTA, Lúcio. Lúcio Costa: registro de uma vivência. São Paulo, Empresa das Artes, 1995, p. 14A.

[18] Residência Rodolfo Chambelland, Rio de Janeiro, RJ, 1921/22. Arquiteto Lúcio Costa. Projeto; fachada, plantas andar térreo, $1^{-}$andar. Fonte: COSTA, Lúcio. Lúcio Costa: registro de uma vivência. São Paulo, Empresa das Artes, 1995, p. $14 \mathrm{~B}$.

[19] Casa Arnaldo Guinle, Teresópolis, RJ, década de 20. Arquiteto Lúco Costa. Legenda do arquiteto: "Estilo inglês". Fonte: COSTA, Lúcio. Lúcio Costa: registro de uma vivência. São Paulo, Empresa das Artes, 1995, p. 30A.

[2o] Embaixada do Perú, concurso público, Rio de Janeiro, RJ, 1927/28. Arquiteto Lúcio Costa. Legenda do arquiteto: Equívoco "neo-colonial". Fonte: COSTA, Lúcio. Lúcio Costa: registro de uma vivência. São Paulo, Empresa das Artes, 1995, p. $30 \mathrm{~B}$.

[21] Embaixada da Argentina, concurso público, Rio de Janeiro, RJ, 1927/28. Arquiteto Lúcio Costa. Legenda do arquiteto: Ilusão "florentina". Fonte: COSTA, Lúcio. Lúcio Costa: registro de uma vivência. São Paulo, Empresa das Artes, 1995, p. 31.

[22] Residência Ferrabino, São Paulo, SP, 1931. Arquiteto Rino Levi. Projeto completo, $1^{\mathbf{a}}$ versão para o Sr. Alberto Ferrabino. Fonte: CIDD - Centro Integrado de Documentação Digital - Projeto Piloto Rino Levi - FAUPUCAMP, 1997-01, CD31, imagem -76. 
[23] Residência Ferrabino, São Paulo, SP, 1931. Arquiteto Rino Levi. Fachada posterior do bloco principal. Fonte: CIDD - Centro Integrado de Documentação Digital - Projeto Piloto Rino Levi - FAUPUCAMP, 1997-01, CD31, imagem 84.

[24] Residência Ferrabino, São Paulo, SP, 1931. Arquiteto Rino Levi. Fachada bloco posterior. Fonte: CIDD - Centro Integrado de Documentação Digital - Projeto Piloto Rino Levi - FAUPUCAMP, 1997-01, CD31, imagem 73.

[25] Residência Ferrabino, São Paulo, SP, 1931. Arquiteto Rino Levi. Vista desde o fundo do lote. Fonte: CIDD- Centro Integrado de Documentação Digital - Projeto Piloto Rino Levi - FAUPUCAMP, 1997-01, CD31, imagem 86.

[26] Residência Ferrabino, São Paulo, SP, 1931. Arquiteto Rino Levi. Projeto completo, $2^{\underline{a}}$ versão para a Sra. Delfina Ferrabino. Fonte: CIDD - Centro Integrado de Documentação Digital - Projeto Piloto Rino Levi - FAUPUCAMP, 1997-01, CD31, imagem 78.

[27] Residência Ferrabino, São Paulo, SP, 1931. Arquiteto Rino Levi. Fachada para a rua. Fonte: CIDD - Centro Integrado de Documentação Digital - Projeto Piloto Rino Levi FAUPUCAMP, 1997-01, CD31, imagem 77.

[28] Residência Ferrabino, São Paulo, SP, 1931. Arquiteto Rino Levi. Detalhe dos arcos e balaustres incorporados na segunda versão do projeto. Fonte: CIDD - Centro Integrado de Documentação Digital - Projeto Piloto Rino Levi - FAUPUCAMP, 1997-01, CD31, imagem 85 .

[29] Residência Ferrabino, São Paulo, SP, 1931. Arquiteto Rino Levi. O detalhe do corrimão retornará no projeto para o concurso do Viaduto do Chá. Fonte: CIDD - Centro Integrado de Documentação Digital - Projeto Piloto Rino Levi - FAUPUCAMP, 1997-01, CD31, imagem 89 .

[3o] Residência Ferrabino, São Paulo, SP, 1931. Arquiteto Rino Levi. Detalhe iluminação natural. Fonte: CIDD - Centro Integrado de Documentação Digital - Projeto Piloto Rino Levi - FAUPUCAMP, 1997-01, CD31, imagem 8o.

[31] Residência Ferrabino, São Paulo, SP, 1931. Arquiteto Rino Levi. Hall da escada. Fonte: CIDD - Centro Integrado de Documentação Digital - Projeto Piloto Rino Levi FAUPUCAMP, 1997- o1, CD31, imagem 79.

[32] Residência Ferrabino, São Paulo, SP, 1931. Arquiteto Rino Levi. Detalhe portas de correr. Fonte: CIDD - Centro Integrado de Documentação Digital - Projeto Piloto Rino Levi - FAUPUCAMP, 1997-01, CD31, imagem 81.

[33] Residência Ferrabino, São Paulo, SP, 1931. Arquiteto Rino Levi. Vista da sala de jantar. Fonte: CIDD - Centro Integrado de Documentação Digital - Projeto Piloto Rino Levi - FAUPUCAMP, 1997-01, CD31, imagem 83. 
[34] Progetto per um monumento a De Penedo sulle rive del Lago di Santo Amaro, concurso, Saõ Paulo, SP, 1927. Arquiteto Rino Levi. Fonte: CIDD - Centro Integrado de Documentação Digital - Projeto Piloto Rino Levi - FAUPUCAMP, 1997-01, CD31, imagem 09 .

[35] Fábrica de Pianos Brasil, São Paulo, SP, 1927. Arquiteto Rino Levi. Fonte: CIDD Centro Integrado de Documentação Digital - Projeto Piloto Rino Levi - FAUPUCAMP, 1997-01, CD31, imagem 32.

[36] Ante-projeto para a Sede Social do Automóvel Clube de São Paulo, concurso, São Paulo, SP, 1927. Arquiteto Rino Levi. Elevações: para o Largo do Ouvidor e lateral. Fonte: CIDD - Centro Integrado de Documentação Digital - Projeto Piloto Rino Levi FAUPUCAMP, 1997-01, CD31, imagem 21.

[37] Ante-projeto para a Sede Social do Automóvel Clube de São Paulo, concurso, São Paulo, SP, 1927. Arquiteto Rino Levi. Plantas. Fonte: CIDD - Centro Integrado de Documentação Digital - Projeto Piloto Rino Levi - FAUPUCAMP, 1997-01, CD31, imagem 37 .

[38] Ante-projeto para a Sede Social do Automóvel Clube de São Paulo, concurso, São Paulo, SP, 1927. Arquiteto Rino Levi. Plantas. Fonte: CIDD - Centro Integrado de Documentação Digital - Projeto Piloto Rino Levi - FAUPUCAMP, 1997-01, CD31, imagem 23.

[39] Ante-projeto para a Sede Social do Automóvel Clube de São Paulo, concurso, São Paulo, SP, 1927. Arquiteto Rino Levi. Perspectiva para o Vale do Anhangabaú. Fonte: CIDD - Centro Integrado de Documentação Digital - Projeto Piloto Rino Levi FAUPUCAMP, 1997-01, CD31, imagem 25.

[4o] Residência Godofredo Silva Telles, São Paulo, SP,1927. Arquiteto Rino Levi. Fachada para a rua. Fonte: CIDD - Centro Integrado de Documentação Digital - Projeto Piloto Rino Levi - FAUPUCAMP, 1997-01, CD31, imagem 27.

[41] Residência Godofredo Silva Telles, São Paulo, SP,1927. Arquiteto Rino Levi. Hall de entrada visto da escada. Fonte: CIDD - Centro Integrado de Documentação Digital Projeto Piloto Rino Levi - FAUPUCAMP, 1997-01, CD31, imagem 30.

[42] Residência Godofredo Silva Telles, São Paulo, SP, 1927. Arquiteto Rino Levi. Hall e escada visto da entrada. Fonte: CIDD - Centro Integrado de Documentação Digital Projeto Piloto Rino Levi - FAUPUCAMP, 1997-01, CD31, imagem 31.

[43] Residência H. Telles Ribeiro, Estrada Ferraz de Vasconcelos, Romanópolis, SP. Arquiteto Rino Levi. Perspectiva. Fonte : CIDD- Centro Integrado de Documentação Digital - Projeto Piloto Rino Levi - FAUPUCAMP, 1997-01, CD13, imagem 15. 
[44] Residência H. Telles Ribeiro, Estrada Ferraz de Vasconcelos, Romanópolis, SP. Arquiteto Rino Levi. Planta. Fonte: CIDD - Centro Integrado de Documentação Digital Projeto Piloto Rino Levi - FAUPUCAMP, 1997-01, CD31, imagem 16.

[45] Série de casas geminadas Melhem Zacarias, São Paulo, SP, 1928. Arquiteto Rino Levi. Elevação frontal. Fonte: CIDD - Centro Integrado de Documentação Digital - Projeto Piloto Rino Levi - FAUPUCAMP, 1997-01, CD31, imagem 48.

[46] Série de casas geminadas Luiz Manfro, São Paulo, SP. Arquiteto Rino Levi. Elevação frontal. Fonte: CIDD - Centro Integrado de Documentação Digital - Projeto Piloto Rino Levi - FAUPUCAMP, 1997-01, CD31, imagem 35.

[47] Série de casas geminadas Melhem Zacarias, São Paulo, SP. Arquiteto Rino Levi. Elevação posterior. Fonte: CIDD - Centro Integrado de Documentação Digital - Projeto Piloto Rino Levi - FAUPUCAMP, 1997-01, CD31, imagem 36.

[48] Casas econômicas em série para Regina Previdelli, São Paulo, SP, 1930. Arquiteto Rino Levi. Projeto completo. Fonte: CIDD - Centro Integrado de Documentação Digital Projeto Piloto Rino Levi - FAUPUCAMP, 1997-01, CD31, imagem 49.

[49] Residência Paulo Lajolo, Rio de Janeiro, RJ, 1931. Arquiteto Rino Levi. Projeto completo. Fonte: CIDD - Centro Integrado de Documentação Digital - Projeto Piloto Rino Levi - FAUPUCAMP, 1997-01, CD31, imagem 50.

[50] Residência Comendador Andrea Matarazzo, São Paulo, SP, 1932. Arquiteto Rino Levi. Perspectiva. Fonte: CIDD - Centro Integrado de Documentação Digital - Projeto Piloto Rino Levi - FAUPUCAMP, 1997-01, CD31, imagem 74.

[51] Residência Ferrabino, São Paulo, SP, 1931. Arquiteto Rino Levi. Perspectiva. Fonte: CIDD - Centro Integrado de Documentação Digital - Projeto Piloto Rino Levi FAUPUCAMP, 1997-01, CD31, imagem 70.

[52] Residência Luiz Manfro, São Paulo, SP, 1932. Arquiteto Rino Levi. Projeto completo. Fonte: CIDD - Centro Integrado de Documentação Digital - Projeto Piloto Rino Levi FAUPUCAMP, 1997-01, CD31, imagem 47.

[53] Residência Cesar Trípoli, São Paulo, SP, 1933. Arquiteto Rino Levi. Projeto completo. Fonte: CIDD - Centro Integrado de Documentação Digital - Projeto Piloto Rino Levi FAUPUCAMP, 1997-01, CD31, imagem 75.

[54] Casas econômicas em série para Dante Ramenzoni, 1o conjunto, São Paulo, SP, 1931. Arquiteto Rino Levi. Foto panorâmica elevação Rua Vitor Emanuel. Fonte: CIDD - Centro Integrado de Documentação Digital - Projeto Piloto Rino Levi - FAUPUCAMP, 1997-01, CD31, imagem 6o. 
[55] Residência Dante Ramenzoni, São Paulo, SP, 1931. Arquiteto Rino Levi. Foto esquina Rua Vitor Emanuel com Rua Mazzini. Fonte: CIDD - Centro Integrado de Documentação Digital - Projeto Piloto Rino Levi - FAUPUCAMP, 1997-o1, CD31, imagem 59.

[56] Residência Dante Ramenzoni, São Paulo, SP, 1931. Arquiteto Rino Levi. Foto elevação R. Mazzini. Fonte: CIDD - Centro Integrado de Documentação Digital - Projeto Piloto Rino Levi - FAUPUCAMP, 1997-01, CD31, imagem 55.

[57] Casas econômicas em série para Dante Ramenzoni, 2º conjunto, São Paulo, SP, 1932. Arquiteto Rino Levi. Panorâmica. Fonte: CIDD - Centro Integrado de Documentação Digital - Projeto Piloto Rino Levi - FAUPUCAMP, 1997-01, CD31, imagem 91.

[58] Casas econômicas em série para Dante Ramenzoni, 2º conjunto, São Paulo, SP, 1932. Arquiteto Rino Levi. Elevação para a rua. Fonte: CIDD - Centro Integrado de Documentação Digital - Projeto Piloto Rino Levi - FAUPUCAMP, 1997-01, CD31, imagem 96.

[59] Casas econômicas em série para Dante Ramenzoni, 2º conjunto, São Paulo, SP, 1932. Arquiteto Rino Levi. Elevação para o fundo do lote. Fonte: CIDD - Centro Integrado de Documentação Digital - Projeto Piloto Rino Levi - FAUPUCAMP, 1997-01, CD31, imagem 92.

[6o] Casas econômicas em série para Dante Ramenzoni, 2º conjunto, São Paulo, SP, 1932. Arquiteto Rino Levi. Elevação esquina. Fonte: CIDD - Centro Integrado de Documentação Digital - Projeto Piloto Rino Levi - FAUPUCAMP, 1997-01, CD31, imagem 93.

[61] Casas econômicas em série para Dante Ramenzoni, 2º conjunto, São Paulo, SP, 1932. Arquiteto Rino Levi. Elevação esquina. Fonte: CIDD - Centro Integrado de Documentação Digital - Projeto Piloto Rino Levi - FAUPUCAMP, 1997-01, CD31, imagem 94.

[62] Residência Francisco Gomes (Vila Júlia), São Paulo, SP, 1932. Arquiteto Rino Levi. Panorâmica. Fonte: CIDD - Centro Integrado de Documentação Digital - Projeto Piloto Rino Levi - FAUPUCAMP, 1997-01, CD31, imagem 54.

[63] Residência Francisco Gomes (Vila Júlia), São Paulo, SP, 1932. Arquiteto Rino Levi. Detalhe declive do terreno. Fonte: CIDD - Centro Integrado de Documentação Digital Projeto Piloto Rino Levi - FAUPUCAMP, 1997-01, CD31, imagem 58.

[64] Residência Francisco Gomes (Vila Júlia), São Paulo, SP, 1932. Arquiteto Rino Levi. Detalhe acesso. Fonte: CIDD - Centro Integrado de Documentação Digital - Projeto Piloto Rino Levi - FAUPUCAMP, 1997-01, CD31, imagem 53.

[65] Residência Francisco Gomes (Vila Júlia), São Paulo, SP, 1932. Arquiteto Rino Levi. Fachada posterior. Fonte: CIDD - Centro Integrado de Documentação Digital - Projeto Piloto Rino Levi - FAUPUCAMP, 1997-01, CD31, imagem 51. 
[66] Residência Francisco Gomes (Vila Júlia), São Paulo, SP, 1932. Arquiteto Rino Levi. Interior. Fonte: CIDD - Centro Integrado de Documentação Digital - Projeto Piloto Rino Levi - FAUPUCAMP, 1997-01, CD31, imagem 52.

[67] Residência Francisco Gomes (Vila Júlia), São Paulo, SP, 1932. Arquiteto Rino Levi. Interior. Fonte: CIDD - Centro Integrado de Documentação Digital - Projeto Piloto Rino Levi - FAUPUCAMP, 1997-01, CD31, imagem 57.

[68] Residência Jeanne Maronat, São Paulo, SP, 1932. Arquiteto Rino Levi. Fachada frontal. Fonte: CIDD - Centro Integrado de Documentação Digital - Projeto Piloto Rino Levi - FAUPUCAMP, 1997-01, CD31, imagem 68.

[69] Residência Jeanne Maronat, São Paulo, SP, 1932. Arquiteto Rino Levi. Fachada posterior. Fonte: CIDD - Centro Integrado de Documentação Digital - Projeto Piloto Rino Levi - FAUPUCAMP, 1997-01, CD31, imagem 69.

[7o] Vila para Lilly e Hugo Steiner, Viena, Áustria, 1910. Arquiteto Adolf Loos. Fachada frontal. Fonte: GÖSSEL, Peter e LEUTHÄUSER, Gabriele. Arquitectura no Século XX. Taschen, s/d, p.87B.

[71] Vila para Lilly e Hugo Steiner, Viena, Áustria, 1910. Arquiteto Adolf Loos. Fachada posterior. Fonte: GÖSSEL, Peter e LEUTHÄUSER, Gabriele. Arquitectura no Século XX. Taschen, s/d, p.87A.

[72] Vila para Hans e Anny Moller, Viena, Áustria, 1927/28. Arquiteto Adolf Loos. Fachada principal. Fonte: GÖSSEL, Peter e LEUTHÄUSER, Gabriele. Arquitectura no Século XX. Taschen, s/d, p.151A.

[73] Vila para Hans e Anny Moller, Viena, Áustria, 1927/28. Arquiteto Adolf Loos. Área de convívio elevada na janela da sacada que dá para a rua. Fonte: GÖSSEL, Peter e LEUTHÄUSER, Gabriele. Arquitectura no Século XX. Taschen, s/d, p.151B.

[74] Casa do diretor na Bauhaus em Dessau, 1925/26. Arquiteto Walter Gropius. Vista do norte a partir da rua e a entrada principal. Fonte: DROSTE, Magdalena. Bauhaus 19191933. Berlim, Taschen, s/d, p.127.

[75] Casa do diretor na Bauhaus em Dessau, 1925/26. Arquiteto Walter Gropius. Vista do lado sudoeste com a entrada lateral e as varandas de cima e de baixo. Fonte: DROSTE, Magdalena. Bauhaus 1919-1933. Berlim, Taschen, s/d, p.126.

[76] Casa dos professores na Bahaus em Dessau, 1925/26. Arquiteto Walter Gropius. Vista da entrada. Fonte: DROSTE, Magdalena. Bauhaus 1919-1933. Berlim, Taschen, s/d, p.128.

[77] Casa dos professores na Bahaus em Dessau, 1925/26. Arquiteto Walter Gropius. Fotografia da festa de cobertura das casas em outubro de 1925. Fonte: DROSTE, Magdalena. Bauhaus 1919-1933. Berlim, Taschen, s/d, p.128JPG. 
[78] Vista do Bairro Dessau-Törten, 1926/28. Arquiteto Walter Gropius. Fachada frontal casas tipo 1928. Fonte: GÖSSEL, Peter e LEUTHÄUSER, Gabriele. Arquitectura no Século $X X$. Taschen, s/d, p.159.

[79] Bairro Höhenblick, Frankfurt, 1926/27. Arquitetos Ernest May, H. Boehm, C. H. Rudloff. Vista panorâmica com as casas de esquina na Kurhessenstrasse. Fonte: GÖSSEL, Peter e LEUTHÄUSER, Gabriele. Arquitectura no Século XX. Taschen, s/d, p.156.

[8o] Bairro Römerstadt, Frankfurt, 1927/28. Arquitetos Ernest May, H. Boehm, C. H. Rudloff. Vista panorâmica do "Bloco dos Sapateiros". Fonte: GÖSSEL, Peter e LEUTHÄUSER, Gabriele. Arquitectura no Século XX. Taschen, s/d, p.161.

[81] Bairro Römerstadt, Frankfurt, 1927/28. Arquitetos Ernest May, H. Boehm, C. H. Rudloff. Planta de dois apartamentos do "Bloco dos Sapateiros", incluindo a "Cozinha de Frankfurt”. Fonte: GÖSSEL, Peter e LEUTHÄUSER, Gabriele. Arquitectura no Século XX. Taschen, s/d, p.16oB.

[82] Bairro Kalkerfeld, Colônia, 1927. Arquiteto Wilhelm Riphahn. Vista panorâmica dos blocos de cinco andares. Fonte: GÖSSEL, Peter e LEUTHÄUSER, Gabriele. Arquitectura no Século XX. Taschen, s/d, p.16oA.

[83] Die Wohnung da Exposição Werkbund, Bairro Weissenhof, Stuttgart, 1927. Arquitetodiretor Mies van der Rohe, com mais dezessete arquitetos alemães e estrangeiros. Vista panorâmica. Fonte: GÖSSEL, Peter e LEUTHÄUSER, Gabriele. Arquitectura no Século XX. Taschen, s/d, p.163A.

[84] Die Wohnung da Exposição Werkbund, Bairro Weissenhof, Stuttgart, 1927. Arquitetodiretor Mies van der Rohe, com mais dezessete arquitetos alemães e estrangeiros. Implantação. Fonte: GÖSSEL, Peter e LEUTHÄUSER, Gabriele. Arquitectura no Século XX. Taschen, s/d, p.163B.

[85] Bloco de apartamentos na" Wohnung und Werkraum" da Exposição Werkbund, Vratislávia, 1929. Arquiteto Adolf Rading. Vista panorâmica. Fonte: GÖSSEL, Peter e LEUTHÄUSER, Gabriele. Arquitectura no Século XX. Taschen, s/d, p.162.

[86] Apartamentos para Solteiros e Recém Casados na "Wohnung und Wekraum" da Exposição Werkbund, Vratislávia, 1929. Arquiteto Hans Scharoum. Fachada principal. Fonte: GÖSSEL, Peter e LEUTHÄUSER, Gabriele. Arquitectura no Século XX. Taschen, s/d, p.182A.

[87] Apartamentos para Solteiros e Recém Casados na "Wohnung und Wekraum" da Exposição Werkbund, Vratislávia, 1929. Arquiteto Hans Scharoum. Planta. Fonte: GÖSSEL, Peter e LEUTHÄUSER, Gabriele. Arquitectura no Século XX. Taschen, s/d, p.182B. 
[88] Apartamentos para Solteiros e Recém Casados na "Wohnung und Wekraum" da Exposição Werkbund, Vratislávia, 1929. Arquiteto Hans Scharoum. Vista do pátio. Fonte: GÖSSEL, Peter e LEUTHÄUSER, Gabriele. Arquitectura no Século XX. Taschen, s/d, p.183.

[89] Casas na Cidade-Jardim de Watergraafsmeer, Amsterdã, 1923-1925. Arquiteto W. Greve. Esquinas diferenciadas que marcam a entrada no quarteirão. Fonte: GÖSSEL, Peter e LEUTHÄUSER, Gabriele. Arquitectura no Século XX. Taschen, s/d, p.155B.

[9o] Centro da Comunidade na Cidade-Jardim de Watergraafsmeer, Amsterdã, 1922-1926. Arquiteto Dick Greiner. Fachada principal. Fonte: GÖSSEL, Peter e LEUTHÄUSER, Gabriele. Arquitectura no Século XX. Taschen, s/d, p.155A.

[91] Café De Unie, Roterdã, 1924/25. Arquiteto Jacobus Johannes Pieter Oud. Vista da rua. Fonte: GÖSSEL, Peter e LEUTHÄUSER, Gabriele. Arquitectura no Século XX. Taschen, s/d, p.141.

[92] Complexo Habitacional de Spagen, Roterdã, 1919. Arquiteto Jacobus Johannes Pieter Oud. Vista da fachada posterior do bloco 8. . Fonte: GÖSSEL, Peter e LEUTHÄUSER, Gabriele. Arquitectura no Século XX. Taschen, s/d, p.152.

[93] Complexo Habitacional em Hoek van Holland, 1924-1927. Arquiteto Jacobus Johannes Pieter Oud. Esquinas diferenciadas que marcam a entrada do quarteirão. Fonte: GÖSSEL, Peter e LEUTHÄUSER, Gabriele. Arquitectura no Século XX. Taschen, s/d, p.154.

[94] Casas 14/15 no Bairro Weissenhof, Stuttgard, 1927. Arquitetos Le Corbusier e Pierre Jeanneret. Vista para a rua. Fonte: GÖSSEL, Peter e LEUTHÄUSER, Gabriele. Arquitectura no Século XX. Taschen, s/d, p.169

[95] "Quartiers Modernes Frugès", Bairro em Bordeaux-Pessac, 1925. Arquitetos Lê Corbusier e Pierre Jeanneret. Vista das casas geminadas gratte-ciel. Fonte: GÖSSEL, Peter e LEUTHÄUSER, Gabriele. Arquitectura no Século XX. Taschen, s/d, p.168B.

[96] "Quartiers Modernes Frugès", Bairro em Bordeaux-Pessac, 1925. Arquitetos Lê Corbusier e Pierre Jeanneret. Vista das casas mais baixas com terraço-jardim. Fonte: GÖSSEL, Peter e LEUTHÄUSER, Gabriele. Arquitectura no Século XX. Taschen, s/d, p.168C.

[97] "Quartiers Modernes Frugès", Bairro em Bordeaux-Pessac, 1925. Arquitetos Lê Corbusier e Pierre Jeanneret. Planta das casas geminadas gratte-ciel. Fonte: GÖSSEL, Peter e LEUTHÄUSER, Gabriele. Arquitectura no Século XX. Taschen, s/d, p.168A.

[98] Vila Stein, em Garches, 1927. Arquitetos Le Corbusier e Pierre Jeanneret. Vista da entrada de veículos. Fonte: GÖSSEL, Peter e LEUTHÄUSER, Gabriele. Arquitectura no Século $X X$. Taschen, s/d, p.171. 
[99] Vila Savoye, em Poissy, 1929/31. Arquitetos Le Corbusier e Pierre Jeanneret. Vista fachada norte. Fonte: GÖSSEL, Peter e LEUTHÄUSER, Gabriele. Arquitectura no Século $X X$. Taschen, s/ d, p.172A.

[10o] Vila Savoye, em Poissy, 1929/31. Arquitetos Le Corbusier e Pierre Jeanneret. Planta do térreo. Fonte: GÖSSEL, Peter e LEUTHÄUSER, Gabriele. Arquitectura no Século XX. Taschen, s/d, p.172B.

[101] Vila Savoye, em Poissy, 1929/31. Arquitetos Le Corbusier e Pierre Jeanneret. Plantas $1^{\circ}$ andar e terraço-jardim. Fonte: GÖSSEL, Peter e LEUTHÄUSER, Gabriele. Arquitectura no Século XX. Taschen, s/d, p.173B.

[102] Vila Savoye, em Poissy, 1929/31. Arquitetos Le Corbusier e Pierre Jeanneret. Vista $\mathbf{1}^{\mathbf{o}}$ andar com rampa que leva ao terraço-jardim. Fonte: GÖSSEL, Peter e LEUTHÄUSER, Gabriele. Arquitectura no Século XX. Taschen, s/d, p.173A.

[103] Apartamentos Novocomum, Como, 1927/28. Arquiteto Giuseppe Terragni. O projeto apresentado à Comissão Técnica para aprovação. Fonte: CEVI, Bruno. Giuseppe Terragni. Barcelona, Editorial Gustavo Gilli, 1982, p. 27.

[103 A] Apartamentos Novocomum, Como, 1927/28. Arquiteto Giuseppe Terragni. Vista frontal. Fonte: CEVI, Bruno. Giuseppe Terragni. Barcelona, Editorial Gustavo Gilli, 1982, p. $26 / 27$.

[104] Apartamentos Novocomum, Como, 1927/28. Arquiteto Giuseppe Terragni. Axonométrica: primeira solução com semi-cilindro central. Fonte: CEVI, Bruno. Giuseppe Terragni. Barcelona, Editorial Gustavo Gilli, 1982, p. 29.

[105] Apartamentos Novocomum, Como, 1927/28. Arquiteto Giuseppe Terragni. Maquete solução intermediária, vista fachada posterior. Fonte: CEVI, Bruno. Giuseppe Terragni. Barcelona, Editorial Gustavo Gilli, 1982, p. 29.

[106] Apartamentos Novocomum, Como, 1927/28. Arquiteto Giuseppe Terragni. Maquete solução intermediária, vista frontal. Fonte: CEVI, Bruno. Giuseppe Terragni. Barcelona, Editorial Gustavo Gilli, 1982, p.29.

[107] Apartamentos Novocomum, Como, 1927/28. Arquiteto Giuseppe Terragni. Maquete solução intermediária, vista da esquina. Fonte: CEVI, Bruno. Giuseppe Terragni. Barcelona, Editorial Gustavo Gilli, 1982, p.29.

[108] Apartamentos Novocomum, Como, 1927/28. Arquiteto Giuseppe Terragni. Vista lateral com o cilindro de vidro. Fonte: CEVI, Bruno. Giuseppe Terragni. Barcelona, Editorial Gustavo Gilli, 1982, p. 28. 
[109] Casa del Fascio, Como, 1932/36. Arquiteto Giuseppe Terragni. Vista panorâmica. Fonte: GÖSSEL, Peter e LEUTHÄUSER, Gabriele. Arquitectura no Século XX. Taschen, s/d, p.198.

[110] Casa del Fascio, Como, 1932/36. Arquiteto Giuseppe Terragni. Vista esquina sul. Fonte: GÖSSEL, Peter e LEUTHÄUSER, Gabriele. Arquitectura no Século XX. Taschen, s/d, p.199A.

[111] Casa del Fascio, Como, 1932/36. Arquiteto Giuseppe Terragni. Planta. Fonte: GÖSSEL, Peter e LEUTHÄUSER, Gabriele. Arquitectura no Século XX. Taschen, s/d, p.199B.

[112] Casa do arquiteto, rua Santa Cruz, São Paulo, 1927. Arquiteto Gregori Warchavchik. Vista frontal. Fonte: FERRAZ, Geraldo. Warchavchik e a Introdução da Nova Arquitetura no Brasil: 1925-1940. São Paulo, Museu de Arte de São Paulo Assis Chateaubriand, $1965, \mathrm{~s} / \mathrm{p}$.

[113] Casa Max Graff, Rua Mello Alves, São Paulo, 1929. Arquiteto Fregori Warchavchik. Vista lateral. Fonte: FERRAZ, Geraldo. Warchavchik e a Introdução da Nova Arquitetura no Brasil: 1925-1940. São Paulo, Museu de Arte de São Paulo Assis Chateaubriand, 1965, s/p.

[114] Casa econômicas em série, Rua Barão de Jaguara, São Paulo, 1929. Arquiteto Gregori Warchavchik. Vista da esquina. Fonte: FERRAZ, Geraldo. Warchavchik e a Introdução da Nova Arquitetura no Brasil: 1925-1940. São Paulo, Museu de Arte de São Paulo Assis Chateaubriand, 1965 , s/p.

[115] Casas econômicas em série, Rua Dna. Berta, São Paulo, 1930. Arquiteto Gregori Warchavchik. Vista panorâmica. Fonte: FERRAZ, Geraldo. Warchavchik e a Introdução da Nova Arquitetura no Brasil: 1925-1940. São Paulo, Museu de Arte de São Paulo Assis Chateaubriand, 1965, s/p.

[116] Casa Modernista, Rua Itápolis, São Paulo, 1930. Arquiteto Gregori Warchavchik. Vista frontal. Fonte: FERRAZ, Geraldo. Warchavchik e a Introdução da Nova Arquitetura no Brasil: 1925- 1940. São Paulo, Museu de Arte de São Paulo Assis Chateaubriand, 1965, $\mathrm{s} / \mathrm{p}$.

[117] Casa da Rua Bahia, São Paulo, 1930. Vista frontal com membros do "Congresso de Habitação" de 1931. Fonte: FERRAZ, Geraldo. Warchavchik e a Introdução da Nova Arquitetura no Brasil: 1925-1940. São Paulo, Museu de Arte de São Paulo Assis Chateaubriand, 1965, s/p.

[118] Casa da Rua Bahia, São Paulo, 1930. Fachada posterior. Fonte: FERRAZ, Geraldo. Warchavchik e a Introdução da Nova Arquitetura no Brasil: 1925-1940. São Paulo, Museu de Arte de São Paulo Assis Chateaubriand, 1965, s/p. 
[119] Casa da Rua Bahia, São Paulo, 1930. Plantas. Fonte: FERRAZ, Geraldo. Warchavchik e a Introdução da Nova Arquitetura no Brasil: 1925-1940. São Paulo, Museu de Arte de São Paulo Assis Chateaubriand, 1965, s/p.

[12o] Casa da Rua Bahia, São Paulo, 1930.Teto Luminoso da sala de jantar. Fonte: FERRAZ, Geraldo. Warchavchik e a Introdução da Nova Arquitetura no Brasil: 1925-1940. São Paulo, Museu de Arte de São Paulo Assis Chateaubriand, 1965, s/p.

[121] Casa da Rua Toneleiros, Rio de Janeiro, 1931. Arquitetos Gregori Warchavchik. Fachada frontal. Fonte: FERRAZ, Geraldo. Warchavchik e a Introdução da Nova Arquitetura no Brasil: 1925-1940. São Paulo, Museu de Arte de São Paulo Assis Chateaubriand, 1965 , s/p.

[122] Vila operária de Gambôa, Rio de Janeiro, 1933. Arquitetos Gregori Warchavchik e Lúcio Costa. Vista panorâmica. Fonte: FERRAZ, Geraldo. Warchavchik e a Introdução da Nova Arquitetura no Brasil: 1925-1940. São Paulo, Museu de Arte de São Paulo Assis Chateaubriand, 1965, s/p.

[123] $1^{\circ}$ Salão de Arquitetura Tropical, Rio de Janeiro, 1933. Foto da Capa. Fonte: ALTEBERG, Alexandre, org. $1^{\circ}$ Salão de Arquitetura Tropical, catálogo, s/ editora, s/p.

[124] $1^{\circ}$ Salão de Arquitetura Tropical, Rio de Janeiro, 1933. Ponte de Emilio Baumgart e Interior de um Apartamneto de Gregori Warchavchik e Lucio Costa. Fonte: ALTEBERG, Alexandre, org. $1^{\circ}$ Salão de Arquitetura Tropical, catálogo, s/ editora, s/p.

[125] $1^{\circ}$ Salão de Arquitetura Tropical, Rio de Janeiro, 1933. Vista panorâmica do Edifício do Rio Críquet Clube, de Anton Floderer e A.S. Buddeus e vista do Albergue da Boa Vontade de Affonso Heidy e Gerson Pinheiro. Fonte: ALTEBERG, Alexandre, org. $1^{\circ}$ Salão de Arquitetura Tropical, catálogo, s/ editora, s/p.

[126] $1^{\circ}$ Salão de Arquitetura Tropical, Rio de Janeiro, 1933. Vista panorâmica de Residência de Marcello Roberto e vista fachada frontal de Residência em Ipanema de Alexandre Alteberg. Fonte: ALTEBERG, Alexandre, org. $1^{\circ}$ Salão de Arquitetura Tropical, catálogo, s/ editora, s/p.

[127] $1^{\circ}$ Salão de Arquitetura Tropical, Rio de Janeiro, 1933. Perspectiva de projeto de uma Residência de Vicente Baptista e perspectiva de residência em Ipanema. Fonte: ALTEBERG, Alexandre,org. I $^{\circ}$ Salão de Arquitetura Tropical, catálogo, s/ editora, s/p.

[128] $1^{\circ}$ Salão de Arquitetura Tropical, Rio de Janeiro, 1933. Perspectiva de projeto de uma Residência de Ademar Portugal e perspectiva de projeto de uma Residência de João Lourenço da Silva e Alcides da Rocha Miranda. Fonte: ALTEBERG, Alexandre, org. $1^{\circ}$ Salão de Arquitetura Tropical, catálogo, s/ editora, s/p. 
[129] Plano piloto de Brasília - $3^{\text {o }}$ lugar, Brasília, DF. Arquitetos Rino Levi e Roberto Cerqueira Cesar, 1957. FONTE : CIDD - Centro Integrado de Documentação DigitalProjeto Piloto Rino Levi - FAUPUCCAMP, 1997-01.

[130] Plano piloto de Brasília - $3^{\text {o }}$ lugar, Brasília, DF. Arquitetos Rino Levi e Roberto Cerqueira Cesar, 1957. FONTE : CIDD - Centro Integrado de Documentação DigitalProjeto Piloto Rino Levi - FAUPUCCAMP, 1997-01.

[131] Plano piloto de Brasília - $3^{\text {o }}$ lugar, Brasília, DF. Arquitetos Rino Levi e Roberto Cerqueira Cesar, 1957. FONTE : CIDD - Centro Integrado de Documentação DigitalProjeto Piloto Rino Levi - FAUPUCCAMP, 1997-01.

[132] Plano piloto de Brasília - 3o lugar, Brasília, DF. Arquitetos Rino Levi e Roberto Cerqueira Cesar, 1957. FONTE : CIDD - Centro Integrado de Documentação DigitalProjeto Piloto Rino Levi - FAUPUCCAMP, 1997-01.

[133] Plano piloto de Brasília - 3o lugar, Brasília, DF. Arquitetos Rino Levi e Roberto Cerqueira Cesar, 1957. FONTE : CIDD - Centro Integrado de Documentação DigitalProjeto Piloto Rino Levi - FAUPUCCAMP, 1997-01.

[134] Plano piloto de Brasília - $3^{\text {o }}$ lugar, Brasília, DF. Arquitetos Rino Levi e Roberto Cerqueira Cesar, 1957. FONTE : CIDD - Centro Integrado de Documentação DigitalProjeto Piloto Rino Levi - FAUPUCCAMP, 1997-01.

[135] Cidade Vertical, Ludwig Hilberseimer, 1924. FONTE: DETHIER, Jean e GUIHEUX, Alain. La Ville, art et architecture em Europe, 1870-1993. Paris, Éditions du Centre Pompidou, 1994, p. 283.

[136] Garagem América, São Paulo, SP. Arquiteto Rino Levi, 1952/54. Fonte: CIDD Centro Integrado de Documentação Digital- Projeto Piloto Rino Levi - FAUPUCCAMP, 1997-01.

[137] Garagem América, São Paulo, SP. Arquiteto Rino Levi, 1952/54. Fonte: CIDD Centro Integrado de Documentação Digital- Projeto Piloto Rino Levi - FAUPUCCAMP, 1997-01.

[138] Galpão, São José dos Campos, SP. Arquitetos Rino Levi, Roberto Cerqueira Cesar e Luis Roberto Carvalho Franco, 1951/55. Fonte: Centro Integrado de Documentação Digital- Projeto Piloto Rino Levi - FAUPUCCAMP, 1997-01.

[139] Galpão, São José dos Campos, SP. Arquitetos Rino Levi, Roberto Cerqueira Cesar e Luis Roberto Carvalho Franco, 1951/55. Fonte: Centro Integrado de Documentação Digital- Projeto Piloto Rino Levi - FAUPUCCAMP, 1997-01. 
[14o] Galpão, São José dos Campos, SP. Arquitetos Rino Levi, Roberto Cerqueira Cesar e Luis Roberto Carvalho Franco, 1951/55. Fonte: Centro Integrado de Documentação Digital- Projeto Piloto Rino Levi - FAUPUCCAMP, 1997-o1.

[141] Galpão, São José dos Campos, SP. Arquitetos Rino Levi, Roberto Cerqueira Cesar e Luis Roberto Carvalho Franco, 1951/55. Fonte: Centro Integrado de Documentação Digital- Projeto Piloto Rino Levi - FAUPUCCAMP, 1997-01.

[142] Galpão, São José dos Campos, SP. Arquitetos Rino Levi, Roberto Cerqueira Cesar e Luis Roberto Carvalho Franco, 1951/55. Fonte: Centro Integrado de Documentação Digital- Projeto Piloto Rino Levi - FAUPUCCAMP, 1997-01.

[143] Galpão, São José dos Campos, SP. Arquitetos Rino Levi, Roberto Cerqueira Cesar e Luis Roberto Carvalho Franco, 1951/55. Fonte: Centro Integrado de Documentação Digital- Projeto Piloto Rino Levi - FAUPUCCAMP, 1997-o1.

[144] Galpão, São José dos Campos, SP. Arquitetos Rino Levi, Roberto Cerqueira Cesar e Luis Roberto Carvalho Franco, 1951/55. Fonte: Centro Integrado de Documentação Digital- Projeto Piloto Rino Levi - FAUPUCCAMP, 1997-01.

[145] Galpão, São José dos Campos, SP. Arquitetos Rino Levi, Roberto Cerqueira Cesar e Luis Roberto Carvalho Franco, 1951/55. Fonte: Centro Integrado de Documentação Digital- Projeto Piloto Rino Levi - FAUPUCCAMP, 1997-01.

[146] Galpão, São José dos Campos, SP. Arquitetos Rino Levi, Roberto Cerqueira Cesar e Luis Roberto Carvalho Franco, 1951/55. Fonte: Centro Integrado de Documentação Digital- Projeto Piloto Rino Levi - FAUPUCCAMP, 1997-01.

[147] Indústria Caterpillar, Rio de Janeiro. Arquitetos MMM Roberto, 1953. Fonte: Revista Óculum, Campinas, FAUPUCCAMP, no 3, março de 1993, p.51.

[148] Fábrica Duchen, São Paulo,SP. Arquitetos Oscar Niemeyer e Hélio Uchôa, 1950. Fonte: Revista Óculum, Campinas, FAUPUCCAMP, no 3, março de 1993, p.51.

[149] Residência Rino Levi, São Paulo, SP. Arquitetos Rino Levi e Roberto Cerqueira Cesar, 1944. Fonte: Centro Integrado de Documentação Digital- Projeto Piloto Rino Levi FAUPUCCAMP, 1997-01.

[150] Residência Rino Levi, São Paulo, SP. Arquitetos Rino Levi e Roberto Cerqueira Cesar, 1944. Fonte: Centro Integrado de Documentação Digital- Projeto Piloto Rino Levi FAUPUCCAMP, 1997-01.

[151] Residência Rino Levi, São Paulo, SP. Arquitetos Rino Levi e Roberto Cerqueira Cesar, 1944. Fonte: Centro Integrado de Documentação Digital- Projeto Piloto Rino Levi FAUPUCCAMP, 1997-01. 
[152] Residência Rino Levi, São Paulo, SP. Arquitetos Rino Levi e Roberto Cerqueira Cesar, 1944. Fonte: Centro Integrado de Documentação Digital- Projeto Piloto Rino Levi FAUPUCCAMP, 1997-01.

[153] Residência Rino Levi, São Paulo, SP. Arquitetos Rino Levi e Roberto Cerqueira Cesar, 1944. Fonte: Centro Integrado de Documentação Digital- Projeto Piloto Rino Levi FAUPUCCAMP, 1997-01.

[154] Residência Rino Levi, São Paulo, SP. Arquitetos Rino Levi e Roberto Cerqueira Cesar, 1944. Fonte: Centro Integrado de Documentação Digital- Projeto Piloto Rino Levi FAUPUCCAMP, 1997-01.

[155] Residência Rino Levi, São Paulo, SP. Arquitetos Rino Levi e Roberto Cerqueira Cesar, 1944. Fonte: Centro Integrado de Documentação Digital- Projeto Piloto Rino Levi FAUPUCCAMP, 1997-01.

[156] Residência Rino Levi, São Paulo, SP. Arquitetos Rino Levi e Roberto Cerqueira Cesar, 1944. Fonte: Centro Integrado de Documentação Digital- Projeto Piloto Rino Levi FAUPUCCAMP, 1997-01.

[157] Residência Rino Levi, São Paulo, SP. Arquitetos Rino Levi e Roberto Cerqueira Cesar, 1944. Fonte: Centro Integrado de Documentação Digital- Projeto Piloto Rino Levi FAUPUCCAMP, 1997-01.

[158] Residência Rino Levi, São Paulo, SP. Arquitetos Rino Levi e Roberto Cerqueira Cesar, 1944. Fonte: Centro Integrado de Documentação Digital- Projeto Piloto Rino Levi FAUPUCCAMP, 1997-01.

[159] Residência Milton Guper, São Paulo, SP. Arquitetos Rino Levi e Roberto Cerqueira Cesar, 1951/52. Fonte: Centro Integrado de Documentação Digital- Projeto Piloto Rino Levi - FAUPUCCAMP, 1997-01.

[16o] Residência Milton Guper, São Paulo, SP. Arquitetos Rino Levi e Roberto Cerqueira Cesar, 1951/52. Fonte: Centro Integrado de Documentação Digital- Projeto Piloto Rino Levi - FAUPUCCAMP, 1997-01.

[161] Residência Milton Guper, São Paulo, SP. Arquitetos Rino Levi e Roberto Cerqueira Cesar, 1951/52. Fonte: Centro Integrado de Documentação Digital- Projeto Piloto Rino Levi - FAUPUCCAMP, 1997-01.

[162] Residência Milton Guper, São Paulo, SP. Arquitetos Rino Levi e Roberto Cerqueira Cesar, 1951/52. Fonte: Centro Integrado de Documentação Digital- Projeto Piloto Rino Levi - FAUPUCCAMP, 1997-01. 
[163] Residência Milton Guper, São Paulo, SP. Arquitetos Rino Levi e Roberto Cerqueira Cesar, 1951/52. Fonte: Centro Integrado de Documentação Digital- Projeto Piloto Rino Levi - FAUPUCCAMP, 1997-01.

[164] Residência Milton Guper, São Paulo, SP. Arquitetos Rino Levi e Roberto Cerqueira Cesar, 1951/52. Fonte: Centro Integrado de Documentação Digital- Projeto Piloto Rino Levi - FAUPUCCAMP, 1997-01.

[165] Residência Milton Guper, São Paulo, SP. Arquitetos Rino Levi e Roberto Cerqueira Cesar, 1951/52. Fonte: Centro Integrado de Documentação Digital- Projeto Piloto Rino Levi - FAUPUCCAMP, 1997-01.

[166] Residência Paulo Hess, São Paulo, SP. Arquitetos Rino Levi e Roberto Cerqueira Cesar, 1952/53. Fonte: Centro Integrado de Documentação Digital- Projeto Piloto Rino Levi - FAUPUCCAMP, 1997-01.

[167] Residência Paulo Hess, São Paulo, SP. Arquitetos Rino Levi e Roberto Cerqueira Cesar, 1952/53. Fonte: Centro Integrado de Documentação Digital- Projeto Piloto Rino Levi - FAUPUCCAMP, 1997-01.

[168] Residência Paulo Hess, São Paulo, SP. Arquitetos Rino Levi e Roberto Cerqueira Cesar, 1952/53. Fonte: Centro Integrado de Documentação Digital- Projeto Piloto Rino Levi - FAUPUCCAMP, 1997-01.

[169] Residência Paulo Hess, São Paulo, SP. Arquitetos Rino Levi e Roberto Cerqueira Cesar, 1952/53. Fonte: Centro Integrado de Documentação Digital- Projeto Piloto Rino Levi - FAUPUCCAMP, 1997-01.

[17o] Residência Paulo Hess, São Paulo, SP. Arquitetos Rino Levi e Roberto Cerqueira Cesar, 1952/53. Fonte: Centro Integrado de Documentação Digital- Projeto Piloto Rino Levi - FAUPUCCAMP, 1997-01.

[171] Residência Castor Delgado Perez, São Paulo, SP. Arquitetos Rino Levi, Roberto Cerqueira Cesar e Luis Roberto Carvalho Franco, 1958/59. Fonte: Centro Integrado de Documentação Digital- Projeto Piloto Rino Levi - FAUPUCCAMP, 1997-01.

[172] Residência Castor Delgado Perez, São Paulo, SP. Arquitetos Rino Levi, Roberto Cerqueira Cesar e Luis Roberto Carvalho Franco, 1958/59. Fonte: Centro Integrado de Documentação Digital- Projeto Piloto Rino Levi - FAUPUCCAMP, 1997-01.

[173] Residência Castor Delgado Perez, São Paulo, SP. Arquitetos Rino Levi, Roberto Cerqueira Cesar e Luis Roberto Carvalho Franco, 1958/59. Fonte: Centro Integrado de Documentação Digital- Projeto Piloto Rino Levi - FAUPUCCAMP, 1997-01. 
[174] Residência Castor Delgado Perez, São Paulo, SP. Arquitetos Rino Levi, Roberto Cerqueira Cesar e Luis Roberto Carvalho Franco, 1958/59. Fonte: Centro Integrado de Documentação Digital- Projeto Piloto Rino Levi - FAUPUCCAMP, 1997-01.

[175] Residência Castor Delgado Perez, São Paulo, SP. Arquitetos Rino Levi, Roberto Cerqueira Cesar e Luis Roberto Carvalho Franco, 1958/59. Fonte: Centro Integrado de Documentação Digital- Projeto Piloto Rino Levi - FAUPUCCAMP, 1997-01.

[176] Residência Castor Delgado Perez, São Paulo, SP. Arquitetos Rino Levi, Roberto Cerqueira Cesar e Luis Roberto Carvalho Franco, 1958/59. Fonte: Centro Integrado de Documentação Digital- Projeto Piloto Rino Levi - FAUPUCCAMP, 1997-01.

[177] Residência Castor Delgado Perez, São Paulo, SP. Arquitetos Rino Levi, Roberto Cerqueira Cesar e Luis Roberto Carvalho Franco, 1958/59. Fonte: Centro Integrado de Documentação Digital- Projeto Piloto Rino Levi - FAUPUCCAMP, 1997-01.

[178] Case Study House no 3, 1945/49. Arquitetos William Wilson Wurster e Theodore Bernardi. Fonte: SMITH, Elizabeth (org). Blueprints for modern living history and legacy of the Case Study Houses. Los Angeles/Cambridge: The Museum of Contemporary Art/MIT Prees, 1988, p 45.

[179a] Case Study House no 4, 1945. Arquiteto Ralph Rapson. Fonte: SMITH, Elizabeth (org). Blueprints for modern living history and legacy of the Case Study Houses. Los Angeles/Cambridge: The Museum of Contemporary Art/MIT Prees, 1988, p.46/47

[180] Case Study House $n^{0} 19,1957$. Arquiteto Don Knorr / Case Study House $n^{0} 20$, 1958. Arquitetos Conrad Buff III, Calvin Straub e Donald Hensman. Fonte: SMITH, Elizabeth (org). Blueprints for modern living history and legacy of the Case Study Houses. Los Angeles/Cambridge: The Museum of Contemporary Art/MIT Prees, 1988, p.67

[181] Case Study House $n^{\circ}$ 24, 1961. Arquiteto A. Quincy Jones e Frederich E. Emmons.Fonte: SMITH, Elizabeth (org). Blueprints for modern living history and legacy of the Case Study Houses. Los Angeles/Cambridge: The Museum of Contemporary Art/MIT Prees, 1988, p.75

[182] Case Study House no 24, 1961. Arquiteto A. Quincy Jones e Frederich E. Emmons. Fonte: SMITH, Elizabeth (org). Blueprints for modern living history and legacy of the Case Study Houses. Los Angeles/Cambridge: The Museum of Contemporary Art/MIT Prees, 1988, p.

[183] Case Study House $n^{0}$ 24, 1961. Arquiteto A. Quincy Jones e Frederich E. Emmons. Fonte: SMITH, Elizabeth (org). Blueprints for modern living history and legacy of the Case Study Houses. Los Angeles/Cambridge: The Museum of Contemporary Art/MIT Prees, 1988, p. 


\section{ANEXOS}




\section{ANEXO 1: LISTAGEM DOS PROJETOS DO ESCRITÓRIO RINO LEVI}

Em negrito: obras construídas

Sem negrito: obras não construídas

1926

- Edifício Cia. Construtora de Santos (para Gustavo Olhinto de Aquino), R. Marquês de Itu esq. R. Bento Freitas, São Paulo, SP.

1927

- Residência Godofredo da Silva Telles, R. Conselheiro Nébias 635, São Paulo, SP.

- Fábrica de Pianos Nardelli, Av. Rodrigues Alves e R Humberto Primo, São

Paulo, SP.

- Túmulo Familiar, São Paulo, SP.

- Automóvel Clube de São Paulo, São Paulo, SP.

- Monumento a "De Penedo" (concurso), Lago Santo Amaro, São Paulo, SP.

- Monumento Comemorativo do II Centenário do Café no Brasil (concurso), São Paulo, SP.

- Residência H. Telles Ribeiro, Estrada Ferraz de Vasconcelos, Romanópolis, SP.

1928

- Casas Geminadas Melhen Zacharias, R. Caramuru, Chácara Inglesa, São Paulo, SP.

- Casas Geminadas Luiz Manfro, R. Morgado de Mateus esq. R. Áurea, São

Paulo, SP.

1929

- Edifício Gazeau, R. da Glória esq. R. Conselheiro Furtado 172, São Paulo, SP.

- Residência Vicente Giaccaglini, Av. Conselheiro Rodrigues Alves 8, São Paulo, SP. RINO LEVI: ARQUITETURA COMO OFÍ́CIO 204

- Residência Olívia Guedes Penteado (reforma da entrada), São Paulo, SP.

1930

- Residência Arthur Horta O'Leary, R. Oscar Freire 51, São Paulo, SP.

- Residência Regina Previdelli, R. Oscar Freire 49, São Paulo, SP.

- Conjunto Residencial para Regina Previdelli, R. Padre João Manuel, São Paulo, SP.

1931

- Residência Paulo Lajolo, Rio de Janeiro, RJ.

- Residência Delfina Ferrabino, R. Estados Unidos, São Paulo, SP.

- Residências para Dante Ramenzoni, R. Vítor Emanuel 102 a 111 esq. R. Mazzini 82, São Paulo, SP.

- Pavilhões Elekeiroz, Feira de Amostras da Água Branca, São Paulo, SP.

1932

- Residências para Dante Ramenzon ( $2^{\circ}$ conjunto), R. Vítor Emanuel 102 a 111

esq. R. Mazzini 82, São Paulo, SP.

- Depósito de Enxofre Elekeiroz, São Paulo, SP.

- Residência Carlos Rusca, R. Mazzini, São Paulo, SP.

- Residência Comendador Andrea Matarazzo, R. São Carlos do Pinhal, São Paulo, SP. 
- Residência Francisco Gomes (Vila Júlia), Al. Franca 146, São Paulo, SP.

- Residência Jeanne Maronat, travessa Loefgren 5, São Paulo, SP.

- Residência Luiz Manfro, R. dos Apeninos, São Paulo, SP.

\section{3}

- Residência Cesar Trípoli, Av. Brasil 2021, São Paulo, SP.

- Casas Geminadas Dante Ramenzoni, R. Mazzini, São Paulo, SP.

- Edifício de apartamentos Nicolau Shiesser, R. Augusta 201 (atual 153), São Paulo, SP.

1934

- Edifício Columbus, Av. Brigadeiro Luís Antônio 23/29, São Paulo, SP.

- Prédio de Escritórios e Cinema (para Luís e Raul Medici), São Paulo, SP.

1935

- Edifício de Apartamentos Henrique Jovino, R. Paraíso 1, São Paulo, SP.

- Edifício Wancole, R. do Arouche 153, São Paulo, SP.

- Edifício Sarti, R. Vieira de Carvalho 465 esq. Pç. Da República, São Paulo, SP.

- Residência Luis Medici, Guarapiranga, Lago de Santo Amaro, São Paulo, SP.

- Edifício Higienópolis, R. Conselheiro Brotero 1092, São Paulo, SP.

- Edifício de Escritórios (para Angelo Pocci), Pç. do Correio, São Paulo, SP.

Anexos 205

- Concurso doViaduto do Chá, $2^{\circ}$ lugar, co-autores:Humberto Nobre Mendes e Joseph

Grabenweger, Vale do Anhangabaú, São Paulo, SP.

1936

- Residência Pedro Porta, R. Leais Paulistanos, São Paulo, SP.

- Edifício Guarany, Av. Rangel Pestana 1092 esq. Av. Exterior, São Paulo, SP.

- Cine UFA-Palácio, Av. São João 419, São Paulo, SP.

- Edifício para Conde Crespi, R. Ipiranga, São Paulo, SP.

- Cine Universo, Av. Celso Garcia 378, São Paulo, SP.

- Pavilhão de Exposições de Artes Plásticas, Pç. da república, São Paulo, SP.

- Fábrica de Chapéus Dante Ramenzoni Cia. Ltda., São Paulo, SP.

1937

- Edifício para Maria L. da Silva Prado, R. Marquês de Itu, São Paulo, SP.

- Aeroporto Santos Dumont (concurso), Pç. Santos Dumont, Rio de Janeiro, RJ.

- Garagem Pública, R. Anhangabaú, São Paulo, SP.

- Edifício de Apartamentos (para Antônia das Neves), R. Marconi, São Paulo, SP.

- Cine Art Palácio e Edifício de Escritórios, Pç. Duarte Coelho, R. do Cajú, R.

Santo

Amaro e Av. Guararapes, Recife, PE.

1938

- Edifício para Guilherme Seabra, R. Senador Feijó esq. R. Quintino Bocaiuva, São Paulo, SP.

- Edifício de Apartamentos e Consultório (para Cyro Resende), R. Santo Amaro, São Paulo, SP.

- Edifício de Apartamentos (para Cleópatra Marsiglia), R. Epitáfio Pessoa, São Paulo, SP.

- Residência José Cardoso de Almeida Sobrinho, R. Gal. FonsecaTtelles, São Paulo, SP. 
- Instituto Agronômico do Estado (ampliação), Av. Barão de Itapura, Campinas, SP.

- Banco Holandês Unido S/A, R. XV de Novembro, São Paulo, SP.

- Banco Noroeste do Estado de São Paulo S/A, R. Àlvares Penteado, São Paulo, SP.

- Edifício de Apartamentos (para Antônio Devisatti), R. Conselheiro Furtado, São

Paulo, SP.

- Edificio de Apartamentos (para Luiz Medici), R. Líbero Badaró, São Paulo, SP.

- Edifício de Apartamentos (para Paulo Pacheco Bacelar), R. Maria Teresa, São Paulo, SP.

- Casas Geminadas (para Renato Dantas), R. Humberto I, São Paulo, SP.

- Conjunto Comercial para o I.A P.I., Largo de São Bento, Viaduto Santa Efigênia e Av. Anhangabaú, São Paulo, SP.

1940

- Conjunto-Sede da Caixa Beneficiente do Asilo Colônia Sto Antonio, Mogi das Cruzes, SP.

- Edifício de Apartamentos para Otavio Marcondes Ferraz, R. Major Quedinho, São Paulo, SP.

Santa Efigênia e Av. Anhangabaú, São Paulo, SP.

- Ginásio Estadual, Itú, SP.

- Residência Oswald de Andrade, R. Capote Valente, São Paulo, SP.

- Instituto Superior Sedes Sapientiae, R. Marquês de Paranaguá 111, São Paulo, SP.

- Edifício de Apartamentos Porchat, Av. São João esq. R. Apa, São Paulo, SP.

1941

- Edifício para Pedro Baldassari e irmãos, R. Maria Paula, São Paulo, SP.

- Cine Ipiranga e Hotel Excelsior, Av. Ipiranga 786, São Paulo, SP.

- Cine Piratininga e Edifício Copag, Av. Rangel Pestana 1554, São Paulo, SP.

- Edifício de Apartamentos (para Noé Ribeiro), Av. da Liberdade, São Paulo, SP.

- Laminação e Trefilação de Metais Langone, R. Joaquim Távora 550, São Paulo, SP.

- Tipografia Henrique Scheliger e Cia., R. Anhangabaú, São Paulo, SP.

- Edifício de Apartamentos Trussardi, Av. São João 1050 esq. Com Pç. Júlio de Mesquita, São Paulo, SP.

1942

- Edifício de Escritórios (para Bellandi e Cia.), R. Muniz de Souza 532, São Paulo, SP.

- Edifício de Apartamentos (para Carolino da Motta e Silva), Pç. Deodoro, São Paulo, SP.

- Edifício de Apartamentos (para Irmãos Gonçalves), Av. São João, São Paulo, SP.

- Edifício de Apartamentos (para Irmãos Gonçalves), R. José Bonifácio 139 e Benjamin Constant 162, São Paulo, SP.

- Edifício de Escritórios (para Paulo Trussardi), Pç. Da República, São Paulo, SP.

- Cia. Jardim de Cafés Finos, Av. do Estado 5748, São Paulo, SP.

- Edifício de Escritórios Stig, R. Martins Fontes 266, São Paulo, SP.

- Teatro de Cultura Artística, R. Nestor Pestana 230, São Paulo, SP.

- Edifício Comercial (para Nicolau de Moraes Barros), R. Líbero Badaró 374, São

Paulo, SP.

1943

- Edifício Comercial e de Escritórios Cofermat, R. Florêncio de Abreu 305, São

Paulo, SP. 
- Edifício da Cia. Importadora de São Paulo, R. Mauá esq. R. Plínio Ramos e R.

Antônio

Paes, São Paulo, SP.

- Edifício Comercial e de Escritórios (para Irmãos Petrella), R. Dom José de Barros 25,

São Paulo, SP.

- Edifício de Apartamentos (para J. M. Pinheiro Júnior), R. 2 de Dezembro esq. Beco do

Pinheiro, Rio de Janeiro, RJ.

- Edifício de Apartamentos (para Luiz Médici), R. Gal. Olímpio da Silveira, São Paulo, SP.

- Fábrica Trussardi S/A, São Paulo, SP.

\section{4}

- Banco da América S/A, R. São Bento 413, São Paulo, SP.

- Edifício de Apartamentos Monduba, Av. Beira-Mar, Guarujá, SP.

Anexos 207

- Edifício de Apartamentos (para Antônio Prudente), R. Helvétia, São Paulo, SP

- Edifício de Apartamentos (para Fernando Costa e Antônio Prudente), R. Pêro Correa da

Silva, São Vicente, SP.

- Edifício da Sociedade Imobiliária Itaipava Ltda., Av. São João 1613-1617, São Paulo, SP.

- Edifício de Apartamentos (para Reynaldo Porchat Neto), R. Joaquim Antunes, São

Paulo, SP.

- Edifíco de Apartamentos Texnovo, Av. da Conceição, São Paulo, SP.

- Indústria Pol-o-Nor, R. Sara Souza, São Paulo, SP.

- Residência Rino Levi, R. Bélgica 116 esq. R. Suécia, São Paulo, SP.

- Edifício de Apartamentos Prudência, Av. Higienópolis 265, São Paulo, SP.

- Maternidade Universitária de São Paulo, Av. Rebouças, São Paulo, SP.

1945

- Clínica Dr. Godoy Moreira, Av. Brigadeiro Luís Antônio 2050, São Paulo, SP.

- Edifício de Apartamentos (para João Gonçalves), Av. Beira-Mar esq. R. Santos, Guarujá, SP.

- Edifício de Apartamentos (para Roberto Simonsen), R. Marquês de Itú, São Paulo, SP.

\section{6}

- Banco Central de Crédito, R. São Bento esq. R. Líbero Badaró, São Paulo, SP.

- Banco Sul-Americano do Brasil S/A, Presidente Prudente, SP.

- Banco Sul-Americano do Brasil S/A, R. Silva Bueno 1431, São Paulo, SP.

- Edifício de Apartamentos (para Betty e José Kauffmann), R. 13 de Maio, São Paulo, SP.

- Edifício de Escritórios da Prudência Capitalização, Av. 9 de Julho esq. R.

Avanhandava,

São Paulo, SP.

- Edifício de Escritórios (para Alfredo Egydio de Souza Aranha), Av. 23 de Maio esq.

Av.

Brig. Luís Antônio, São Paulo, SP.

- Edifício Sede do Instituto dos Arquitetos do Brasil ( $1^{\circ}$ classificado ex aequo com

Abelardo de Souza, Galiano Ciampaglia, Hélio Duarte, Jacob Ruchti, Miguel Forte e Zenon

Lotufo), R. Bento Freitas 306, São Paulo, SP. 
1947

- Residência Pré-Fabricada (para Serva Ribeiro)

- Edifício de Apartamentos (para a Santa Casa de Misericórdia), Al. Barão de Limeira, São Paulo, SP.

- Garagem Coletiva, Guarujá, SP.

- Banco Paulista do Comércio, R. Boa Vista esq. Ladeira Porto Geral, São Paulo, SP.

- Hospital Antônio Cândido de Camargo, do Instituto Central de Câncer, R. Prof. Antônio Prudente 211, São Paulo, SP.

- Edifíco Sede da Cia. Seguradora Brasileira, Largo da Pólvora esq. R. da Liberdade,

São Paulo, SP.

1948

- Edifício de Apartamentos (para Antônio Prudente), R. Avanhandava, São Paulo, SP. - Hospital da Cruzada Pró-Infância, Av. Brigadeiro Luís Antônio 683, São Paulo, SP.

1949

- Banco Sul-Americano do Brasil S/A, R. Álvares Penteado, São Paulo, SP.

- Clínica Dr. Ernesto Mendes, Av. Washington Luís esq. R. Imarés, São Paulo, SP. - Manufatura de Brinquedos Estrela S/A, R. Joaquim Carlos 530/540, São Paulo, SP.

- Residência Olivo Gomes, Av. Olivo Gomes, São José dos Campos, SP.

1950

- Indústria Arno S/A, Ind. E Com., R. Pres. Costa Pinto, São Paulo, SP.

1951

- Edifício de Apartamentos Andorinhas, R. dos Gusmões 556, São Paulo,SP.

- Residência Sanson Flexor, R. Joaquim Távora, São Páulo, SP.

- Residência para o gerente da Fábrica de Cobertores Parahyba (Luiz Roberto C.

Franco,

Carlos Milan e Sidney Fonseca), São José dos Campos, SP.

- Residência Luiz Fernando Rodrigues Alves, R. Sergipe 651, São Paulo, SP.

- Residência Milton Guper, R. Venezuela 309 esq. R. Nicarágua, São Paulo, SP.

1952

- Residência Benedito Oscar Carvalho Franco, Av. São Gualter, São Paulo, SP.

- Residência Paulo Hess, R. Campo Verde 225, São Paulo, SP.

- Centro Cívico (não construido) e Torre (construida) da Cidade Universitária de São Paulo, São Paulo, SP.

- Casa do Estudante da Escola Superior de Agricultura Luiz de Queiroz-ESALQ,

Piracicaba, SP.

- Edifício Administrativo da Cia. Distribuidora Geral Brasmotor, Santo André, SP.

- Edifício de Escritórios da Cia. Nacional de Seguros de Vida, R. do Carmo e R.

Silveira

Martins, São Paulo, SP.

- Igreja da Escola de Técnicos da Aeronáutica, Guaratinguetá, SP.

- Igreja São Domingos, R. Atibaia, São Paulo, SP.

- Hospital do Instituto de Moléstias do Aparelho Digestivo, R. Borges Lagoa, São

Paulo, SP.

- Lar das Crianças da Congregação Israelita, Av. Brig. Luís Antônio, São Paulo, SP. 
- Garagem América, Av. 23 de Maio e R. Riachuelo 209, São Paulo, SP.

1953

- Conjunto Residencial Estudantil da Universidade de São Paulo, São Paulo, SP.

- Conjunto Residencial para Operários da Tecelagem Parahyba S/A, Av. Olivo Gomes,

São José dos Campos, SP.

Anexos 209

- Edifício de Apartamentos (para Florentina de Falco), Av. 9 de Julho, São Paulo, SP.

- Galpão e Posto de Gazolina da Tecelagem Parahyba, São José dos Campos, SP.

- Edifício de Escritórios e Sede da Ordem dos Advogados do Brasil, Pç. da Sé 375,

São Paulo, SP.

1954

- Banco Sul-Americano do Brasil S/A, R. Augusta 1595, São Paulo, SP.

- Conjunto Habitacional Fazenda Monte Alegre, Complexo Tecelagem Parahyba,

Estrada Vargem Grande, São José dos Campos, SP.

- Residência Yara Bernette, R. Uranium 133, São Paulo, SP.

- Residência Jacob Szporn, R. L, São Paulo, SP.

- Sinagoga Congregação Israelita (concurso), R. Antônio Carlos, São Paulo, SP.

- Edifício de Apartamentos XX de Setembro, R. Álvaro de Carvalho 108, São

Paulo, SP.

1955

- Banco Sul-Americano do Brasil S/A, R. Santos Dumont esq. Av. Ipiranga, Maringá, SP.

- Banco Sul-Americano do Brasil S/A, R. XV de Novembro esq. R. Bento Dias, Capivari, SP.

- Edifício de Apartamentos (para Jovira Rolim Sodré), R. Asdrúbal do Nascimento, São Paulo, SP.

- Residência Jovira Rolim Sodré, Fazenda São Luiz, Lins, SP.

- Residência Robert Kanner, R. da Paz 285, São Paulo, SP.

- Edifício Concórdia, R. Paula Souza 355 esq. R. Plínio Ramos, São Paulo, SP.

1956

- Banco Sul -Americano do Brasil S/A, São João do Caiuá, PR.

- Centro Comercial do Brooklin, Av. Cordeiro esq. Av. Marginal, São Paulo, SP.

- Centro Profissional La Parabola (Rino Levi em co-autoria com os arquitetos Guido

Bernardes, Pedro Lluberes, Carlos Brando e eng. J.O. Cardenas), Caracas,

Venazuela.

- Edifício para Bomba de Cobalto do Hospital Central do Câncer, R. Prof. Antônio

Prudente 211, São Paulo, SP.

- Garagem Copana, Av. Copacabana, Rio de Janeiro, RJ.

- Garagem Ofasa, Av. Anhangabaú, São Paulo, SP.

- Garagem Polielicoidal, protótipo.

- Residência Anselmo Fontana, R. Floriano Peixoto, Concórdia, SC.

- Residência Omar Fontana, R. Alm. Pereira Guimarães 257, São Paulo, SP.

- Residência para Engenheiros das Usinas Elclor, Rio Grande da Serra, SP.

- Laboratório Paulista de Biologia, R. Maria Cândida 1639, São Paulo, SP. 
- Cine Clube para Operários das Usinas Elclor, Rio Grande da Serra, SP.

- Garagem Erasmo Braga, Av. Erasmo Braga, Rio de Janeiro, RJ.

- Grupo Escolar para Usina Elclor, Rio Grande da Serra, SP.

- Plano Piloto de Brasília (concurso - $3^{\circ}$ lugar), Brasília, DF.

- Sede do Clube de Operários da Tecelagem Parahyba S/A, São José dos Campos, SP.

1958

- Banco Sul-Americano do Brasil S/A, Av. Dr. Armando de Arruda Penteado, Itapevi, Cotia, SP.

- Clube de Campo de São Paulo, Represa de Guarapiranga, São Paulo, SP.

- Laboratório Rex Filmes S/A, R. Frei Caneca, São Paulo, SP.

- Residência Castor Delgado Perez, Av. 9 de Julho 5170, Saõ Paulo, SP.

- Hospital Geral Albert Einstein, Av. Albert Einstein 665, São Paulo, SP.

1959

- Banco Sul-Americano do Brasil S/A, R. João P. Lima 50/99 esq. R. José Matarésio, Auriflama, SP.

- Banco Sul-Americano do Brasil S/A, R. Pacheco Chaves 1104 esq. R.

Taiaçupeba,

São Paulo, SP.

- Banco of London \& South América Ltda., R. XV de Novembro esq. R. da Quitanda, São

Paulo, SP.

- Escritórios e Galeria R. Monteiro, R. 24 de Maio 77, São Paulo, SP.

- Hospital Geral (em co-autoria com Roberto Lampo), Av. Soublette, Maiquetia,

Venezuela.

- Hospital Geral, Coche, Caracas, Venezuela.

- Hospital Geral, Av. Gusmán Blanco, Caracas, Venezuela.

- Hospital Geral, Calle Cementeiro, Chacão, Venezuela.

- Hospital Geral, Calle Yunque, Catia, Venezuela.

- Hospital Geral, La Guaira, Venezuela.

- Instituto de Gastroenterologia de São Paulo, R. Sílvia 276, São Paulo, SP.

- Jockey Club de São Paulo (concurso), Largo do Ouvidor, São Paulo, SP.

1960

- Banco Sul-Americano do Brasil S/A, R. 7 de Setembro 98, Santos, SP.

- Banco Sul-Americano do Brasil S/A, R. 9 de Julho 142/154, Vinhedo, SP.

- Residência Musical de Maracaibo, Maracaibo, Venezuela.

- Hospital do Sandu-Hospitec, Rio de Janeiro, RJ.

- Hospital Geral (co-autoria com Helena Ruiz e Margot Lampo), Puerto Cabello, Venezuela.

- Hospital Geral, Maracay, Venezuela.

- Residência Vítor Brecheret, R. João Moura 100, São Paulo, SP.

- Banco Sul-Americano do Brasil S/A, Av. Paulista 1948, São Paulo, SP.

1961

- Banco Sul-Americano do Brasil S/A, Pç. da Matriz esq. R. Coronel Aureliano Chaves, Tatuí, SP.

- Edifício Condomínio Parque Balneário, Vicente de Carvalho, Santos, SP.

Anexos 211

- Edifício de Escritórios Elclor, Av. Paulista, São Paulo, SP.

- Edifício de Escritórios Plavinil Elclor, Al. Santos 2101, São Paulo, SP. 
1962

- Conjunto Nacional, Av. Tocantins, Belo Horizonte, MG.

- Hospital Psiquiátrico, Araraquara, SP.

- Centro Social da Universidade de São Paulo, Cidade Universitária, São Paulo, SP.

- Hospital Psiquiátrico, Rio Claro, SP.

- Residência Irmãos Gomes, Praia Grande, Ubatuba, SP.

- Residência Luiz Roberto de Carvalho Franco, R. General Figueiredo 163, São

Paulo, SP.

- Residência Roberto Cerqueira César, R. D. Balduína 203, São Paulo, SP.

1963

- Residência Clemente Gomes, R. Cons. José Guimarães 273, São Paulo, SP.

- Residência José Monteiro, R. Espanha 104, São Paulo, SP.

- Usina de Leite Parahyba, São José dos Campos, SP.

1964

- Edifício O Estado de São Paulo (ampliação), R. Major Quedinho 90, São Paulo, SP.

- Colônia de Férias do O Estado de São Paulo, Praia Grande, SP.

- Cooperativa e Clube do O Estado de São Paulo, R. P. Mendes 186, São Paulo, SP

- Residência Rino Levi, Clube de Campo de São Paulo, São Paulo, SP.

- Fábrica Permetal S/A, Guarulhos, SP.

- Residência Aziz Simão, R. Souza Ramos, São Paulo, SP.

- Residência Gaston Foucrier, R. 36 n 391, São Paulo, SP.

- Residência Paulo Amarante, Av. da Praia, Ubatuba. SP.

- Edifício Gravatá, Av. 9 de julho 4861, São Paulo, SP.

- Fábrica da Tecelagem Parahyba S/A, Salvador, BA.

1965

- Edifício Araucária, Av. 9 de julho 4776, São Paulo, SP.

- Estádio do S. C. Corinthians Paulista, São Paulo, SP.

- Gran Kusaal de San Sebastian (concurso), San Sebastian, Espanha.

- Hangar da Tecelagem Parahyba S/A, São José dos Campos, SP.

- Posto de Gazolina da NASA - Nova Aliança S/A, Av. Nelson D'Avila 29, São José dos Campos,SP.

- Centro Cívico de Santro André (concurso - $1^{\circ}$ lugar), Pç. IV Centenário, Santo André, SP.

Rino Levi morreu em 1965. O Escritório Rino Levi Arquitetos Associados seguiu produzindo

até 1992. Suas principais obras são:

1966

- Edifício Jardim Paulista, Av. 9 de Julho 5017, São Paulo, SP.

1967

- Conjunto Residencial "Cidade Nova Araraquara”, Araraquara, SP

- Faculdade de Medicina da Cidade Universitária do ABC, Santo André, SP.

- Centro da Criança Retardada de São Paulo (atual APAE - concurso - $1^{\circ}$ lugar),

R. Loefgreen, São Paulo, SP.

- Residência José Monteiro, Fazenda Nossa Senhora Aparecida, Pinhal, SP.

1968

- Plano de Desenvolvimento Integrado de Sumaré (em consórcio com Brasconsult), Sumaré, SP. 
- Universidade do Vale do Paraiba, São José dos Campos, SP.

1969

- Estação de Tratamento d'Água, Votuporanga, SP.

- Clube Araraquarense, (concurso - $1^{\circ}$ lugar), Araraquara, SP.

- Ed. Sede da FIESP - CIESP - SESI, Av. Paulista 1313, São Paulo, SP.

1970

- Depósito de Prod. Acabados da Tecelagem Parahyba, São José dos Campos, SP.

- Graciano R. Affonso S/A Veículos, Araraquara, SP.

- Santa Paula Country Club-Plano Diretor, São Paulo, SP.

1971

- Edifício de Escritórios da Santa Casa de Misericórdia, Largo de São Bento, São

Paulo, SP.

- Hospital Municipal de Santo André, Santo André, SP.

- Projeto Ponte Pequena, São Paulo, SP.

1972

- Ed. Cia. Br. De Fibras Sintéticas Nailonsix, Av. das Nações Unidas 2449, São

Paulo, SP

- Ed. Jornal “O.E.S.P”, Av. Otaviano Alves de Lima, São Paulo, SP.

- Ed. Sede SENAI, Av. Paulista 750, São Paulo, SP.

- Permetal S/A Metais Perfurados, Estrada Velha de São Miguel 991, Guarulhos, SP.

- Ed. Sede Siemens S/A., Av. Mutinga 3716, São Paulo, SP.

- Colégio Miguel de Cervantes, R. Jorge Saad 905, São Paulo, SP.

1974

- Centro Administrativo Municipal de São Paulo (em consorcio com Promom Engenharia S/A), Vila Guilherme, São Paulo, SP.

- Concurso para a Gessy Lever

1975

- Minisa S/A Com. E Ind., São José dos Campos, SP.

1976

- Indústrias Gessy Lever - Divisão Elida Gibbs, Vinhedo, SP.

1977

- Indústrias Gessy Lever Fábrica de Detergentes em Pó, Indaiatuba, SP.

1978

- Centro de Desenvolvimento de Pessoal - Usiminas, Ipatinga, MG.

- Edifício Victor Brecheret, Av. 9 de Julho esq. R. João Cachoeira, São Paulo, SP.

- P.P.L. do Brasil Ind. Com. Ltda, Fábrica de Essências, Aromas e Sabores (concurso - $1^{\circ}$ lugar), Vinhedo, SP.

- Gessy Lever - Vila Anastácio, São Paulo, SP.

- Conjunto Residencial "Morro Verde" - Inocoop, Santo André, SP.

- Centro Administrativo Comind, Barueri, S.P.

- Centro Cultural de Rio Claro, SP. 
1979

- Porto Turístico Esportivo, Enseada do Flamengo, Ubatuba, SP.

- Creche para 300 crianças, Mogi das Cruzes, SP.

- "Guest-House" - Cia. Brasileira de Metalurgia e Mineração, Araxá, MG.

- Conjunto Res. para Funcionários da Cia Brasileira de Metalurgia e Mineração, Araxá, MG.

- Escola do Sesi/Senai, Araxá, MG.

- Ideal Standard Wabco Ind Com Ltda., Sumaré, SP.

1980

- Union Carbide do Brasil Ltda. Fábrica de Pesticidas, Cubatão, SP. RINO LEVI: ARQUITETURA COMO OFÍCIO 214

- Fábrica de Cosméticos da Ceil Comércio e Exportações Ltda. //Bozzano /

Revlac

Comercial Ltda, Via Anhanguera, Km. 13, São Paulo, SP.

- Residência Paulo Amarante - Fazenda Santa Ernestina, Batatais, SP.

1982

- Pátio de Descarga - Gessy Lever, Valinhos, SP.

- Sede de Pinheiros da Sociedade Brasileira da Cultura Inglesa. R. Deputado Lacerda

Franco 333, São Paulo, SP.

1983

- SESI - Centro Educacional e Assistencial, Av. Getúlio Vargas, Osasco, SP.

1984

- Escola de Inglês da Sociedade Brasileira da Cultura Inglesa, Av. Santo Amaro, São Paulo, SP

1985

- Escolas Estaduais de $1^{\circ}$ Grau da Conesp, Mogi das Cruzes e São Paulo, SP.

- Banco do Estado de São Paulo, Av. da Saudade, Ribeirão Preto, SP.

- Edificio de Escritórios da Hochtief do Brasil S/A, R. Laplace esq. R. Barão do

Triunfo, São Paulo, SP.

- Centro de Desenvolvimento Profissional do Senac, Franca, SP.

1986

- Escola Integrada do Colégio Pueri Domus, Alphaville, Barueri, SP.

- Recuperação e conversão de área degradada no Parque Pedreira São João,

Emplasa,

Itapevi, SP.

- Reciclagem de Edifícios Industriais para escritórios, depósitos e clube de funcionários

da Congás, R. da Figueira, São Paulo, SP.

- Plano Urbanístico da Freguesia do Ó para a Secretaria Municipal de

Planejamento

(coordenação de onze equipes de especialistas), São Paulo, SP.

- Edifício Industrial e Edifício Administrativo e Social da Pirelli, Cerquilho, SP.

- Edifício para Refeitório, Treinamento e Administração da Indústria Gessy Lever Ltda., São Paulo, SP.

- Escritórios, Lojas e Sede Administrativa da Mitra Arquidiocesana de São Paulo, Pç. da

Sé, São Paulo, SP. 
1987

- Paço Municipal de Votorantim (concurso), Votorantim, SP

Anexos 215

- Condomínio Residencial Edifício Embaúba, São Paulo, SP.

- Divisão Elida Gibbs da Indústria Gessy Lever Ltda. (ampliação), Vinhedo, SP.

- Complexo Indústrial do Círculo do Livro (concurso), Rod. Raposo Tavares, Osasco, SP.

- Escola de Aministração de Empresas Getúlio Vargas, ampliação (concurso), São

Paulo, SP.

- Edifício Administrativo e Sede Social da Paramount Lansul, R. Alexandre

Dumas,

São Paulo, SP.

- Cozinha e refeitórios na Usina Intendente Câmara da Usiminas, Ipatinga, MG.

1988

- Centro Empresarial Transatlântico (concurso), R. Alexandre Dumas, São Paulo, SP.

1989

- Indústria CICA SIA, Patos de Minas, MG.

- Indústria Wacker Química (ampliação) Itapevi, SP.

1991

- Edifício de Escritórios para a FAPESP (concurso), São Paulo, SP.

- Pavilhão do Brasil - Expo Internacional de Sevilha (concurso), Espanha

- Escritório e agência bancária Morumbi Square, São Paulo, SP,

1992

- Plano Diretor de São Bernardo do Campo (consórcio com Sadak Nucci)

- Escola de Inglês da Sociedade Brasileira de Cultura Inglesa, Vila Mariana, São

Paulo, SP.

- Sede da Indústria Perstorp do Brasil (concurso), São Bernardo do Campo, SP. RINO LEVI: ARQUITETURA COMO OFÍCIO 


\section{ANEXO 2}

\section{A OBRA DO ESCRITÓRIO RINO LEVI NOS PERIÓDICOS}

\section{Os Projetos Indexados}

$\mathrm{Na}$ extensa lista dos artigos sobre a obra do escritório Rino Levi que foram publicados em periódicos, a primeira divisão feita para a indexação foi entre os de documentação e os de crítica ou ensaio. Dentre os artigos de documentação de projeto e documentação de obra, optou-se por uma nova divisão enquanto programas de uso. Com esse critério, ficaram definidos os seguintes itens:

1 - Residência Unifamiliar

2 - Edifício Residêncial

3 - Edifício Comercial / Bancos

4 - Edifício de Escritórios / Administrativos

5 - Teatro / Cinema / Cinema-Hotel

6 - Hospitais

7 - Escolas

8 - Indústrias

9 - Projetos Urbanísticos

10 - Garagens

11 - Centro Esportivo

Definidos esse itens os projetos foram indexados como na listagem a seguir:

\section{1 - Residência Unifamiliar}

1.1 Residência Medici - 1935

1.2 Residência Rino Levi - 1944

1.3 Residência Olivo Gomes - 1950

1.4 Residência Milton Guper - 1951

1.5 Residência Paulo Hess - 1953

1.6 Residência Castor Delgado Perez - 1958

\section{2 - Edifício Residêncial}

2.1 Edifício Columbus - 1932

2.2 Edifício Schiesser - 1934

2.3 Edifício Trussardi - 1941

2.4 Edifício Porchat - 1943

2.5 Edifício Prudência - 1944 
2.6 Edifício Cia. Seguradora Brasileira - 1948

2.7 Residências p/ Engenheiros - Usinas Elclor - 1956

3 - Edifício Comercial / Bancos

3.1 Banco Paulista do Comercio - 1947

3.2 Edifício Concordia - 1956

3.3 Banco Sul Americano / Capivari - 1955

3.4 Centro Comercial de Brooklin - 1956

3.5 Edifício R. Monteiro - 1959

3.6 Banco Sul Americano / Av. Paulista - 1962

4 - Edifício de Escritórios / Administrativos

4.1 Edifício IAPI - 1939

4.2 Edifício Cia. Nacional de Seguros - 1952

4.3 Edifício Sede do IAB - 1952

4.4 Ordem dos Advogados do Brasil - OAB -1953

4.5 Edifício Plavinil-Elclor - 1961

4.6 SESI /FIESP / CIESP - 1969

4.7 Sede Administrativa Paramount Lansul - 1987

4.8 Centro Administrativo ZF do Brasil - 1988

4.9 Edifício Sede do Instituto de Engenharia - 1989

5 - Teatro / Cinema / Cinema-Hotel

5.1 Cine Universo - 1939

5.2 Cine UFA-Palace - 1936

5.3 Cine Art-Palácio - 1938

5.4 Cine Ipiranga / Hotel Excelcior - 1941

5.5 Teatro Cultura Artística - 1943

6 - Hospitais

6.1 Maternidade Universitária da USP - 1945

6.2 Hospital Central do Câncer - 1947

6.3 Hospital Cruzada Pró-Infância - 1950

6.4 Laboratório Paulista de Biologia - 1956

6.5 Hospital Albert Einstein -1958

6.6 Instituto de Gastroenterologia - 1959

6.7 Hospital Central, Maiquetia, Venezuela - 1959

6.8 Hospital Central, Caracas - 1959

6.9 Hospital Central, Puerto Cabello, Venezuela -1959

6.10 Hospital Psiquiátrico Araraquara - 1962

6.11 Hospital Psiquiátrico Rio Claro - 1962

7 - Escolas

7.1 Sedes Sapientiae - 1941

7.2 Centro Profissional "La Parabola", Venezuela - 1956 

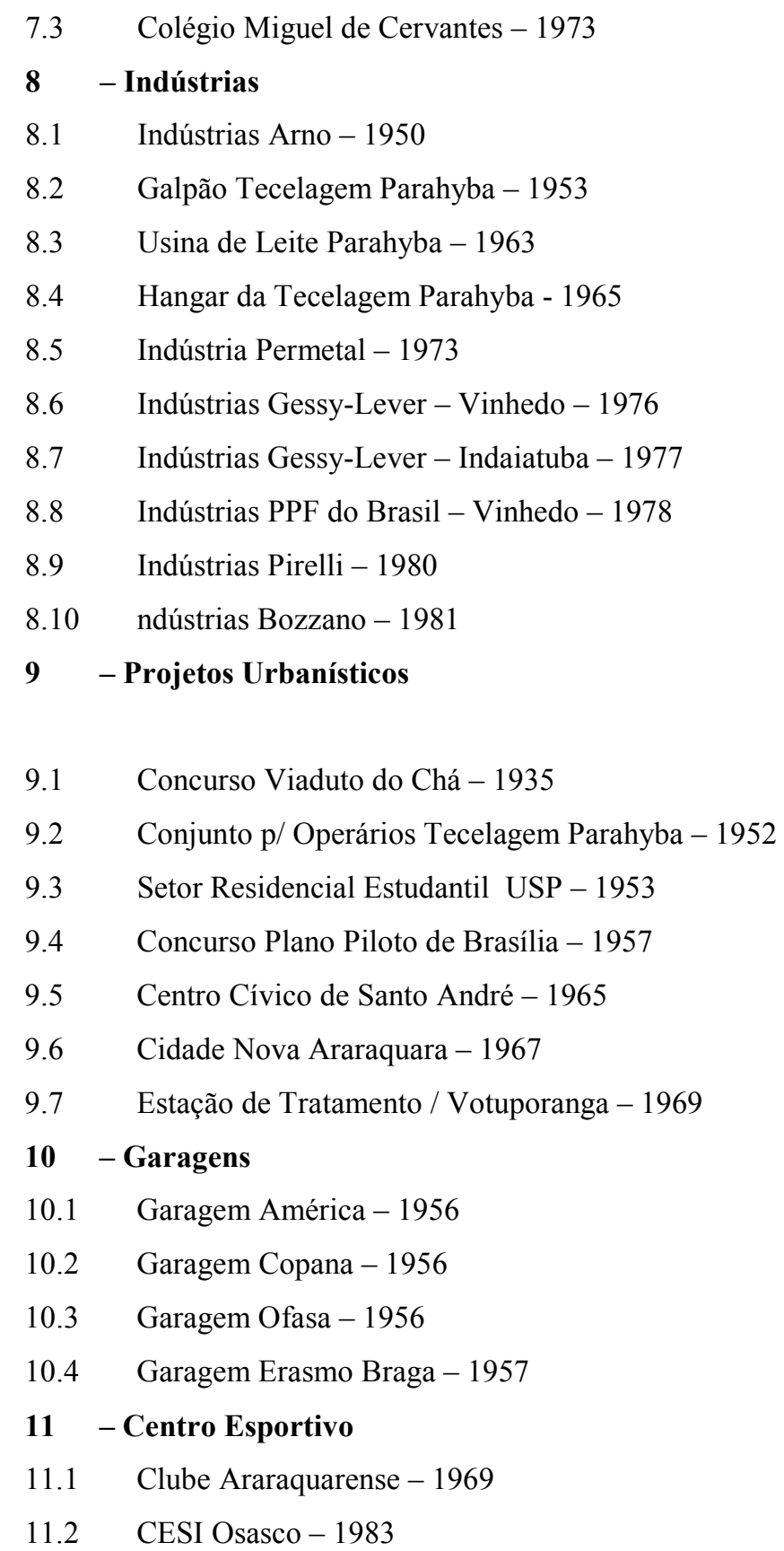


\section{Os Artigos Indexados}

A partir da listagem dos projetos já descrita, os artigos dos periódicos foram indexados como se segue:

\section{1 - ITEM DO PROGRAMA}

\subsection{NOME DO PROJETO ( em ordem cronológica)}

FONTE : NOME DO PERIÓDICO ( na lingua original), local, ano, $\mathrm{n}^{\circ}$, data, páginas do artigo

ARTIGO : nome do artigo ( na lingua original)

PROJETO : nome do projeto

$\mathbf{N}^{\circ}$ ARQUIVO : $\mathrm{n}^{\circ}$ do periódico no acervo do escritório

Com esses critérios, foram indexados todos os artigos dos periódicos que tratavam de projetos e obras enquanto documentação.

\section{I - RESIDÊNCIA UNIFAMILIAR}

\subsection{RESIDÊNCIA MEDICI- 1935 fig 001 e fig 002}

FONTE: L'ARCHITECTURE D'AUJOURD'HUI, Paris; $10^{\circ}$ année; ${ }^{\circ} 2$; fevereiro 1939; p.26

ARTIGO: Habitations particulières - Maison de Week-end près de São Paulo

PROJETO: Residência Medici

No ARQUIVO: 8

\section{I.2 RESIDÊNCIA RINO LEVI - 1944 fig 003}

FONTE: A CONSTRUÇÃO SÃO PAULO; ano XXXII; nº 1623; 19 março 1979; p.18

ARTIGO: Residência do Arquiteto / 1944

PROJETO: Residência do Arquiteto

\section{$N^{\circ}$ ARQUIVO:}

FONTE: DOMUS, revista mensale di architettura, arredamento, arte, Milão; $n^{\circ}$ 258; maio 1951; p. 6-7

ARTIGO: Casa a Sao Paulo

PROJETO: Residência do Arquiteto

N ARQUIVO: 49

FONTE: THE ARCHITECTURAL REVIEW, Londres; vol. 108; $n^{\circ}$ 647; novembro 1950; p.303

ARTIGO: Threeb Houses in Brazil - House at Sao Paolo, Rino Levi architect

PROJETO: Residência do Arquiteto

N ARQUIVO: 45

FONTE: AC, Zurique; $n^{\circ} 3$; julho 1956; p.31-34

ARTIGO: Das Haus des Architekten in Sao Paulo

PROJETO: Residência do Arquiteto

N ARQUIVO: 127 
FONTE: CASA E JARDIM, São Paulo; n 23, março 1956; p.6-15

ARTIGO: A residência do arquiteto Rino Levi

PROJETO: Residência do Arquiteto

N ARQUIVO: 122

FONTE: WERK, Zurich; Junho 1949; 36 Jahrgang/heft6; p. 178-180

ARTIGO: Eigenhein von architekt Rino Levi, São Paulo, Brasilien

PROJETO: Residência do Arquiteto

N ARQUIVO: 31

\subsection{RESIDÊNCIA OLIVO GOMES - 1950 fig 004 e fig 005}

FONTE: DOMUS, revista mensile di architettura, arredamento , arte, Milão; n 264/65; dezembro 1951; p. $42-43$

ARTIGO: Un Edificio e una Villa

PROJETO: Residência Olivo Gomes

No ARQUIVO: 54

FONTE: DIE KUNST, Munchen; nº 09; junho 1953; p. 340-343

ARTIGO: Neves Bauen in Brasilien

PROJETO: Residência Olivo Gomes

N' ARQUIVO: 69

FONTE: DOMUS, Milão; $n^{\circ}$ 302; janeiro 1955; p.30

ARTIGO: Casa e paesaggio brasiliano

PROJETO: Residência Olivo Gomes

N ARQUIVO: 95

FONTE: AUJOURD’HUI Art et Architecture, Paris; n¹; janeiro-fevereiro 1955; p.35

ARTIGO: Habitation individuelle à São José dos Campos, Bresil

PROJETO: Residência Olivo Gomes

N ARQUIVO: 96

FONTE: INFORMES DE LA CONSTRUCCION, Madrid; ano IX; nº8; fevereiro 1957; p.162-2

ARTIGO: Vivienda en una granja

PROJETO: Residência Olivo Gomes

N ARQUIVO: 136

FONTE: HABITAT, revista das artes no Brasil, São Paulo; n² ; janeiro-março 1951; p.19-26

ARTIGO: Residência em São José dos Campos de Rino Levi

PROJETO: Residência Olivo Gomes

N ARQUIVO: 47

FONTE: CASA CLAUDIA, São Paulo; ano XIV; n 165-A; p.42-44

ARTIGO: Uma fazenda com arquitetura moderna

PROJETO: Residência Olivo Gomes

N ARQUIVO:234

FONTE: ARCHITECTURAL DESIGN, London; vol. XXV; n 7; julho 1955; p.229

ARTIGO: Review of Periodical - Small Spiral Staircases

PROJETO: Residência Olivo Gomes

N ARQUIVO: 101

FONTE: PERSPECTIVE OF BRAZIL, New York; 1956; p.35-42

ARTIGO: Reproductions of Art and Architecture

PROJETO: Residência Olivo Gomes

N ARQUIVO: 135

FONTE: ARQUITETURA E ENGENHARIA, Belo Horizonte; ano VI, n 34; janeiro-março 1955; p.

26-31

ARTIGO: Residência de Fazenda em São José dos Campos

PROJETO: Residência Olivo Gomes

N ARQUIVO: 97 
FONTE: ARCHITECTURAL RECORD, New York; julho 1955; vol 118; n¹; p. 156

ARTIGO: Architectural Interiors - Stairs

PROJETO: Residência Olivo Gomes

N ARQUIVO: 102

FONTE: L’ARCHITECTURE D’AUJOURD’HUI, Paris; 25année; setembro-outubro 1954; n56; p.82

ARTIGO: Equipement de l'habitation - escaliers en spirales, scaliers combes

PROJETO: Residência Olivo Gomes

N ARQUIVO: 91

FONTE: NUESTRA ARQUITECTURA, Buenos Aires; n³03; outubro 1954; p.329-332

ARTIGO: Casa de Campo en una "Fazenda" de São Jose dos Campos, Est. De S. Paulo, Brasil

PROJETO: Residência Olivo Gomes

N ARQUIVO: 90

FONTE: ARQUITECTURA - organo oficial de la sociedad de arquitectos del Uruguay; ${ }^{\circ} 229$; outubro 1954; p. 28-30

ARTIGO: Casa de Campo en una "Fazenda" Brasil

PROJETO: Residência Olivo Gomes

N ARQUIVO: 89

FONTE: ACROPOLE, São Paulo; ano 19; n²17; novembro 1956; p.39

ARTIGO: Escada de acesso para terraço superior

PROJETO: Residência Olivo Gomes

N' ARQUIVO: 132

FONTE: CASA E JARDIM, São Paulo; n¹7; setembro 1955; p.10-14

ARTIGO: Casa de Fazenda

PROJETO: Residência Olivo Gomes

N' ARQUIVO: 105

\subsection{RESIDÊNCIA MILTON GUPER - 1951 fig 006}

FONTE: BRASIL - ARQUITETURA CONTEMPORÂNEA, Rio de Janeiro; nº 7; 1956; p.48-49

ARTIGO: Exposição de arquitetura latino americana no Museu de Arte Moderna de New York, desde 1945

PROJETO: Residência Milton Guper

N ARQUIVO:

FONTE: ESPACIO, publicacion bimestral de los alumnos de la Escuela de Arquitetura de la Universidad de la Habana, Cuba; Vol III; n 13-14; janeiro-abril 1954; p. 96-100

ARTIGO: Arquitetura Brasileira - Rino Levi - Residência Guper, São Paulo

PROJETO: Residência Milton Guper

N ARQUIVO: 78

FONTE: ARQUITETURA E ENGENHARIA,; ano VI; n³1; julho-setembro 1954; p.3-7

ARTIGO: Residência em São Paulo

PROJETO: Residência Milton Guper

N ARQUIVO: 85

FONTE: A CONSTRUÇÃO SÃO PAULO; ano XXXII; nº 1644; 13 agosto 1979; p. 30

ARTIGO: Arquitetura Moderna em São Paulo

PROJETO: Residência Milton Guper

N ARQUIVO: 243

FONTE: INTEGRAL- Arquitetura, urbanismo, ingenieria, artes plásticas, folklore, Caracas (Venezuela); Sociedad Venezolana de Arquitetos y Centro Profesional del Este; $n^{\circ} 14 ;$ fevereiro 1959; s/p

ARTIGO: Dos Obras del Arquitecto Rino Levi: Residencia del Dr. Milton Guper, San Paulo

PROJETO: Residência Milton Guper

N' ARQUIVO: 168

FONTE: CASA E JARDIM, São Paulo; nº; 1954; p.10-15

ARTIGO: $\mathrm{O}$ arquiteto Rino Levi projetou

PROJETO: Residência Milton Guper 
N ARQUIVO: 94

FONTE: AD, arquitetura e decoração, São Paulo; dezembro-janeiro 1954; n³; s/p

ARTIGO: Residência Dr. Milton Guper - S. Paulo

PROJETO: Residência Milton Guper

N ARQUIVO: 77

1.5 RESIDÊNCIA PAULO HESS - 1953 fig 007

FONTE: CASA E JARDIM; n 107; dezembro 1963; p.47-51

ARTIGO: A Casa do Mês

PROJETO: Residência Paulo Hess

N ARQUIVO: 207

FONTE: HABITAT, revista brasileira de arquitetura, decoração, artes plásticas e artesanato,; $10^{\circ}$ ano; maio-junho 1959; ${ }^{\circ} 54$; p.20-22

ARTIGO: Residência em São paulo

PROJETO: Residência Paulo Hess

N ARQUIVO: 171

1.6 RESIDÊNCIA CASTOR DELGADO PEREZ - 1958 fig 008

FONTE: CLAUDIA, São Paulo; ano 31; n³58; julho 1991; p.120-123

ARTIGO: Especial 30 anos - Uma casa atemporal

PROJETO: Residência Castor Delgado

N ARQUIVO: $s / n$

FONTE: THE ARCHITECTURAL REVIEW, Londres; Vol. 128; nº765; novembro 1960; p. 338-340

ARTIGO: Four Foreign Houses

PROJETO: Residência Castor Delgado

N ARQUIVO: 184

FONTE: ACROPOLE, São Paulo; ano XXIV; n 286; setembro 1962; p.332

ARTIGO: Conjunto Divisório para ambientes

PROJETO: Residência Castor Delgado

N ARQUIVO: 200

FONTE:ZODIAC, Milano; $n^{\circ}$ 6; 1960; p. 84-87

ARTIGO:Rino Levi: uma nuova dignità all'habitat Bruno Alfieri

PROJETO: Residência Castor Delgado

N ARQUIVO: 207A

FONTE: MLISSET’S BOUWWERELD, Holanda; n²0; 29 setembro 1961; p. 854 - 857

ARTIGO: Villa in het stadsdeel Jardin Europa te Sao Paulo (Brazilie)

PROJETO: Residência Castor Delgado

N ARQUIVO: 193

FONTE: INFORMES DE LA CONSTRUCCION, revista de informacion técnica, Madrid; ano XV;

$\mathrm{n}^{\circ} 140$; maio 1962; p.161-97

ARTIGO: Vivienda Unifamiliar Brasil

PROJETO: Residência Castor Delgado

N ARQUIVO: 198

FONTE:CASA E JARDIM, São Paulo; n 73; Fevereiro 1961; p. 32 - 39

ARTIGO: Rino Levi - Residência Castor Delgado Perez

PROJETO: Residência Castor Delgado

N ARQUIVO: 186

FONTE: EL ARQUITECTO PERUANO, Lima, Peru; julho - agosto - setembro 1961; n 288, 289, 290; p. $52-54$

ARTIGO: Residência en Sao Paulo

PROJETO: Residência Castor Delgado

N ARQUIVO: 192 
FONTE: ACROPOLE; 258; São Paulo; abril 1960; ano XXII; n²58; p.121-126

ARTIGO: Residência no Jardim Europa

PROJETO: Residência Castor Delgado

N ARQUIVO: 180

FONTE: L'ARCHITECTURA D’AUJOURD’HUI, Paris; $31^{\circ}$ année; junho-julho 1960; n90; p. $62-63$

ARTIGO: Habitacion a Sao Paulo

PROJETO: Residência Castor Delgado

N ARQUIVO: 181

FONTE: HABITAT, revista brasileira de arquitetura, artes plasticas, artesanato e decoração contemporâneas, São Paulo; 11 ano; n 58; janeiro-fevereiro 1960; p.13-16

ARTIGO: Residência aberta para pátios

PROJETO: Residência Castor Delgado

N ARQUIVO: 178

2 - EDIFÍCIO RESIDENCIAL

2.1 EDIFÍCIO COLUMBUS - 1932 fig 009 e fig 010

FONTE: REVISTA POLYTECHNICA, órgão do grêmio Polytechnico; ano XXXII, n 120; julho outubro 1935; série $15 ; \mathrm{s} / \mathrm{p}$

ARTIGO: Um Prédio de Apartamentos

PROJETO: Edifício Columbus

No ARQUIVO: 03

FONTE: L'ARCHITECTURE D'AUJOURD'HUI, Paris, 10 année; $n^{\circ}$ 2; fevereiro 1939; p.52

ARTIGO: Immeubles d'appartements_Immeubles à São Paulo, Brésil

PROJETO: Edifício Columbus

No ARQUIVO: 08

2.2 EDIFÍCIO SCHIESSER - 1934 fig 011

FONTE: REVISTA POLYTECHNICA, órgão do Grêmio Polytechnico; nº 119; março - junho 1935, série $15^{\circ} ; \mathrm{s} / \mathrm{p}$

ARTIGO: Prédio de habitação do tipo semi-intensivo

PROJETO: Edifício Schiesser

No ARQUIVO: 2

2.3 EDIFÍCIO TRUSSARDI - 1941 fig 012

FONTE: L'ARCHITECTURE D'AUJOURD'HUI - Paris; revue internationale d'architecture contemporaine; $19^{\text {ème }}$ année; $n^{\circ} 16$; janeiro 1948; p.29

ARTIGO: L'Habitation Collective - Immeuble d'Appartments a São Paulo

PROJETO: Edifício Trussardi

No ARQUIVO: 27

2.4 EDIFÍCIO PORCHAT - 1943 fig 013 
FONTE: REVISTA POLITECNICA, São Paulo, ano 39; n¹42; maio 1943; capa

ARTIGO: Edifício Reynaldo Porchat

PROJETO: Edifício Porchat

No ARQUIVO: 14

FONTE: REVISTA DE ENGENHARIA “MACKENZIE”, São Paulo, ano XXVIII; Vol. XIV; n84; outubro 1943; p.28-30

ARTIGO: Conjunto de 4 prédios de apartamento

PROJETO: Edifício Porchat

No ARQUIVO: 16

2.5 EDIFÍCIO PRUDÊNCIA - 1944 fig 014 e fig 015

FONTE: THE ARCHITECTURAL REVIEW, Londres, vol 110, nº 660, dezembro de 1951, pp. 368/375

ARTIGO: Three Buildigs by Rino Levi in São Paulo, Brazil

PROJETO: Edifício Prudência

N ARQUIVO: 55

FONTE: ARQUITETURA E ENGENHARIA - Instituto de Arquitetos do Brasil - Departamento de Minas Gerais; ano III; n 17; maio - junho 1951; p.42-47

ARTIGO: Prédio de Apartamentos Prudência

PROJETO: Edifico Prudência

No ARQUIVO: 50

FONTE: L'ARCHITECTURE D'AUJOURD'HUI, Paris; Revue internacionale d'architecture contemporaine; $19^{\circ}$ année; $n^{\circ} 16$; Janeiro 1948; p. 25-27

ARTIGO: L'Habitation Collective - Immeuble Prudência à São Paulo

PROJETO: Edifico Prudência

No ARQUIVO: 27

FONTE: A CONSTRUÇÃO, São Paulo; ano XXXII; n 1623; 19 março 1979; p. 17

ARTIGO: Edifício Prudência

PROJETO: idem

No ARQUIVO: 241

FONTE: DOMUS, revista mensile di architettura, arredamento , arte, Milão; n 264/65; dezembro 1951; p. $40-41$

ARTIGO: Un Edificio e una Villa

PROJETO: Edifício Prudência

No ARQUIVO: 54

FONTE: PROGRESSIVE ARCHITECTURE, New York; nº; agosto 1952; p.63-67

ARTIGO: Apartment House: São Paulo, Brazil

PROJETO: Edifício Prudência

No ARQUIVO: 62

FONTE: AC, revue internationale d'amiante-ciment, Zurique; $\mathrm{n}^{\circ} 1$, janeiro $1956 ; \mathrm{p} .5-8$ 
ARTIGO: Ein Appartementhaus in São Paulo

PROJETO: Edifício Prudência

No ARQUIVO: 117

FONTE: WERK, Berna (Suiça); n 8; agosto 1953; p.247-249

ARTIGO: Moderne Architektur und Kurnst in Brasilien - Wohnblock Prudencia in São Paulo PROJETO: Edifício Prudência

No ARQUIVO: 70

FONTE: DIE KUNST, Munchen; $n^{\circ}$ 09; junho 1953; p. 340-343

ARTIGO: Neves Bauen in Brasilien

PROJETO: Edifício Prudência

No ARQUIVO: 69

2.6 EDIFÍCIO CIA. SEGURADORA BRASILEIRA - 1948 fig 016

FONTE:DOMUS, arte e stile nella casa, acte e stile nell'industria (industrial design); Milão; ${ }^{\circ}$ 287; outubro $1953 ;$ p.8

ARTIGO: Antologia di Rino Levi

PROJETO: Ed. Cia. Seguradora Brasileira

No ARQUIVO: 72

FONTE: REVISTA DA POLITECNICA, órgão oficia do grêmio Politécnico, São Paulo; ano 47; n 162 ; julho - agosto 1951; p. 41-48

ARTIGO: Edifício de Apartamentos

PROJETO: Cia. Seguradora Brasileira

No ARQUIVO: 52

FONTE: L'ARCHITECTURE D’AUJOURD'HUI , Paris; n 74; outubro - novembro 1957; p.94-95

ARTIGO: Habitations Collectives - Immeuble à São Paulo

PROJETO: Cia. Seguradora Brasileira

No ARQUIVO: 155

FONTE: BOUW,Amsterdam; n46; novembro 1962; p. 1690-1691

ARTIGO: Flatgebouw Te Sao Paulo

PROJETO: Cia. Seguradora Brasileira

No ARQUIVO: $\mathrm{s} / \mathrm{n}$

FONTE: INFORMES DE LA CONSTRUCION, del Instituto Tecnico de la Construccion y del Cement, Madrid; n 103; ano XI; agosto - setembro 1958; p.123-48

ARTIGO: Edifício de Apartamentos

PROJETO: Cia. Seguradora Brasileira No ARQUIVO: 161

FONTE: L’ARCHITECTURE D’AUJOURD’HUI, Paris; 20 année; n³1; setembro 1980; p.16-17

ARTIGO: Habitations 50 - Deuxième Série / Brésil - Immeuble d’appartements à São Paulo

PROJETO: Cia. Seguradora Paulista

No ARQUIVO: 43 
FONTE: HABITAT - Arquitetura e Artes no Brasil, São Paulo; $7^{\circ}$ ano; novembro-dezembro 1957; $\mathrm{n}^{\circ} 45$; p. $40-43$

ARTIGO: Edifícios de apartamentos, na Liberdade

PROJETO: Cia. Seguradora Brasileira

No ARQUIVO: 152

FONTE: ACROPOLE, São Paulo; ano XV; nº 176; março 1953; p. 276-280

ARTIGO: Edifício de apartamentos - propriedade da Cia. Seguradora Brasileira

PROJETO: Cia. Seguradora Brasileira

No ARQUIVO: 65

2.7 RESIDÊNCIAS P/ ENGENHEIROS - USINAS ELCLOR - 1956 fig 017

FONTE:ZODIAC, Milano; $n^{\circ}$ 6; 1960; p. 84-87

ARTIGO:Rino Levi: uma nuova dignità all'habitat Bruno Alfieri

PROJETO: Residência de Engenheiros da Elclor

N ARQUIVO: 207A

FONTE: ACROPOLE - Revista Mensal, São Paulo; ano XXII; n²55; janeiro 1960; p.83-87

ARTIGO: Sede Social e Residëncia

PROJETO: Residência para Engenheiro - Usinas Elclor

No ARQUIVO: 176

FONTE: ARQUITECTURA MÉXICO, Cidade do México; ano XXIII; Tomo XVIII; dezembro 1961; $\mathrm{n}^{\circ} 76$

ARTIGO: Instalacion Industrial en Sao Paulo, Brasil

PROJETO: Residência para Engenheiro - Usinas Elclor

N ARQUIVO: 194

FONTE: REVISTAS INFORMES DE LA CONSTRUCCION, Madrid; revista de informacion técnica; Ano XIV; abril 1962

ARTIGO: Elclor Brasil

PROJETO: Residência para Engenheiro - Usinas Elclor

$\mathrm{N}^{\circ}$ ARQUIVO: 19

3 - EDIFÍCIO COMERCIAL/BANCOS

\subsection{BANCO PAULISTA DO COMERCIO - 1947 fig 018}

FONTE: THE ARCHITECTURAL REVIEW, Londres, vol 110, nº 660, dezembro de 1951, pp. 368/375

ARTIGO: Three Buildigs by Rino Levi in São Paulo, Brazil

PROJETO: Banco Paulista do Comercio

N ARQUIVO: 55

FONTE: REVISTA DE ENGENHARIA MACKENZIE - Propriedade do Centro Acadêmico Horácio Lane da Escola de Engenharia Mackenzie, São Paulo, ano XXXVI, nº 104, janeiro/fevereiro de 1951, pp. $41 / 43$

ARTIGO: Edifício Paulista

PROJETO: Banco Paulista do Comercio

N ARQUIVO: 46

FONTE: ARCHITECTURAL RECORD, Nova Iorque, vol. 111, nº 1, janeiro de 1952, pp. 154/158

ARTIGO: "Office Building for São Paulo, Brazil"

PROJETO: Banco Paulista do Comercio

N ARQUIVO: 56 
FONTE: ARQUITETURA E ENGENHARIA, Belo Horizonte, anoIII, nº 13, abril/junho de 1951, pp. $49 / 56$

ARTIGO: Edifício Paulista - Banco do Comércio de São Paulo

PROJETO: Banco Paulista do Comércio

N ARQUIVO: 40

\subsection{EDIFICIO CONCORDIA - 1955 fig 019}

FONTE: AC - Revue Internationale d'Amiante-Ciment, Zurich (Suisse); $9^{\text {ème }}$ année; Cahier 1; janeiro $1964 ; n^{\circ} 33 ;$ p. 41-42

ARTIGO: Immeuble commercial à São Paulo, Brésil

PROJETO: Edifício Concórdia

No ARQUIVO: 209

FONTE: ACROPOLE - Boletim do Instituto de Arquitetos do Brasil - Departamento de São Paulo; ano 22; n²29; novembro 1957 ; p.36

Quebra-Sol fixo de Fibro-Cimento

ARTIGO: Edifício Concórdia

PROJETO: idem

N'ARQUIVO: 151

3.3 BANCO SUL AMERICANO / CAPIVARI - 1955 fig 020

FONTE: ACROPOLE, São Paulo, ano XIX, n 223, maio de 1957, pp. 258/259

ARTIGO: Ladrilhos de Cimento aplicados em parede

PROJETO: Banco Sul - Americano / Capivari

$\mathbf{N}^{\circ}$ ARQUIVO: 141

FONTE: AD - ARQUITETURA E DECORAÇÃO, São Paulo, ano IV, nº 22, março/abril de 1957, pp. $3 / 4$

ARTIGO: Banco Sul - Americano / Capivari

PROJETO: idem

N ARQUIVO: 140

FONTE: INFORMES DE LA CONSTRUCION, Madrid, ano XVI, nº 153, agosto/setembro de 1963, pp. $145 / 56$

ARTIGO: Agencia de la Banca Sud - Americana del Brasil, em Capivari

PROJETO: idem

N ARQUIVO: 205

FONTE: NUESTRA ARQUITECTURA, Bueno Aires, n 356, julho de 1959, pp. 33/35

ARTIGO: "Obras : Agencia de un banco"

PROJETO: Banco Sul - Americano / Capivari

N ARQUIVO: 174

\subsection{CENTRO COMERCIAL DO BROOKLIN - 1956 fig 21}

FONTE: INTEGRAL, arquitetura, urbanismo, ingeniería, artes plásticas, cine, folklore; Venezuela, Sociedade Venezuelana de Aarquitetura y Centro Profesional del Este, no 6, fevereiro de 1957, s/p.

ARTIGO: Revista de Revistas: Centro Comercial em São Paulo

PROJETO: Centro Comercial do Brooklin

N ARQUIVO: 137

FONTE: ACRÓPÓLE - Boletim do Instituto de Arquitetos do Brasil - Departamento de São Paulo; anoXIX; n²27; setembro 1957; pp. 398-401

ARTIGO: Centro Comercial no Brooklin Paulista

PROJETO: Centro Comercial do Brooklin

N ARQUIVO: 148 
FONTE: L'ARCHITECTURE D'AUJOURD'HUI - Paris; revue internationale d'architecture contemporaine; $27^{\text {ème }}$ année; ${ }^{\circ} 67 / 68$; outubro de 1956, pp.166/16

ARTIGO: "Construction em pays chauds: Centre Commercial a SaoPaulo"

PROJETO: Centro Comercial do Brooklin

N ARQUIVO: 131

FONTE: ARQUITECTURA MÉXICO, México DF, Tomo XII, nº 54, junho de 1956, pp. 107/110

ARTIGO: "Centro Comercial em el Brooklin ( São Paulo)"

PROJETO: Centro Comercial do Brooklin

N ARQUIVO: 126

3.5 EDIFÍCIO R. MONTEIRO - 1959 fig 022

FONTE: INFORMES DE LA CONSTRUCCION, Madrid; ano XIX; n¹80; maio 1966; p.15-29

ARTIGO: Edificio R. Monteiro en São Paulo, Brasil.

PROJETO: Edifício R. Monteiro

No ARQUIVO: 220

FONTE: HABITAT, São Paulo; ano XIV; n 77; maio - junho 1964; p.17-22

ARTIGO: Edifício R. Monteiro, São Paulo

PROJETO: idem

No ARQUIVO: 21

\subsection{BANCO SUL AMERICANO / AV. PAULISTA - 1962 fig 023}

FONTE: L'INSDUSTRIA ITALIANA DEL CEMENTO, revista mensile dell'Associazione Italiana Tecnico-Economica del Cemento ( AITEC) e dell'Associazione dell'Industria Italiana del Cemento, Amianto-Cemento, Calce e Gesso ( Assocemento), Roma, ano XXXVII, nº 12, dezembro de 1967, pp. 894/895

ARTIGO: "Note e commenti: L'edificio della Banca Sudamericana del Brasile a São Paulo"

PROJETO: Banco Sul - Amerricano Av. Paulista

N ARQUIVO: 225

FONTE: ACROPOLE, São Paulo, ano 28, no 334, novembro de 1966, pp, 32/37

ARTIGO: Sede de Banco e Escritórios

PROJETO: Banco Sul - Americano Av. Paulista

N'ARQUIVO: 223

FONTE: INGENIERIA Y ARQUITECTURA - Organo de la Sociedad Panamericana de Ingenieros y Arquitectos, Panamá, no 124, maio/abril de 1966, pp. 16/23

ARTIGO: "Uma Charla com Rino Levi"

PROJETO: Banco Sul - Americano Av. Paulista

N ARQUIVO: 221

FONTE: HABITAT - Revista Brasileira de arquitetura, artes plásticas e artesanato: São Paulo, anoXIII, $\mathrm{n}^{\mathrm{o}}$ 74, dezembro de 1963, pp. 15/20

ARTIGO: Banco Sul - Americano Av. Paulista

PROJETO: idem

N ARQUIVO: 206

FONTE: A CONSTRUÇÃO SÃO PAULO, São Paulo, ano XXXIV, nº 1759. 26 de outubro de 1981, pp. 19

ARTIGO: Banco Sul - Americano Av. Paulista

PROJETO: idem

N' ARQUIVO: 249

FONTE: ACROPOLE, São Paulo, ano XIX, nº 223, maio de 1957, pp. 258/259

ARTIGO: Ladrilhos de Cimento aplicados em parede 
PROJETO: Banco Sul - Americano Av. Paulista

N ARQUIVO: 141

4 - EDIFÍCIO DE ESCRITÓRIOSIADMINISTRATIVOS

4.1 EDIFÍCIO IAPI - 1939 fig 024

FONTE: REVISTA MUNICIPAL DE ENGENHARIA, Rio de Janeiro; Vol. X; n 1; janeiro 1943; p.3243

ARTIGO: Projeto de um Conjunto de Edifícios para o Centro Comercial de São Paulo PROJETO: Edifício I.A.P.I.

No ARQUIVO: 13

4.2 EDIFÍCIO CIA. NACIONAL DE SEGUROS - 1952 fig 025

FONTE: DIE KUNST, Munchen; n 09; junho 1953; p. 340-343

ARTIGO: Neves Bauen in Brasilien

PROJETO: Edifício São Paulo - Cia. Nacional de Seguros No ARQUIVO: 69

FONTE: ACROPOLE, arquitetura, urbanismo, decoração, São Paulo; ano XIV; n¹66; fevereiro 1952; p.349-354

ARTIGO: Projeto de Prédio de Escritórios para as ruas do Carmo e Silveira Martins, São Paulo PROJETO: Edifício São Paulo - Cia. Nacional de Seguros No ARQUIVO: 58

4.3 EDIFÍCIO SEDE DO IAB - 1952 fig 026

FONTE: CONSTRUÇÃO SÃO PAULO; São Paulo; Ano XXXII; n 1627; 16 abril 1979; p.19

ARTIGO: Edifício Sede do IAB / 1947

PROJETO: idem

No ARQUIVO: 242

\subsection{ORDEM DOS ADVOGADOS DO BRASIL-OAB - 1953}

FONTE: AC - Revue internathionale d'amiante-ciment, Zurique, ano 9, vol 1, nº33, janeiro de 1964, pp. $39 / 40$

ARTIGO: Siège de L'Ordre des Avocats du Brésil

PROJETO: Ordem dos Advogados do Brasil

N ARQUIVO: 209

FONTE: NUESTRA ARQUITECTURA, Bueno Aires, n 356, julho de 1959, pp. 30/32

ARTIGO: "Obras : Ordem dos Advogados, San Pablo"

PROJETO: Ordem dos Advogados do Brasil

N ARQUIVO: 174

FONTE: L'ARCHITECTURE D'AUJOURD'HUI, Paris, $27^{\circ}$ année; n 67/68, dezembro de 1956, pp. 156/157

ARTIGO: Construction em pays chauds - Siege de L'ordre des avocats a São Paulo

PROJETO: Ordem dos Advogados do Brasil

No ARQUIVO: 131 
4.5 EDIFÍCIO PLAVINIL - ELCLOR - 1961 fig 028 e fig 029

FONTE: ARQUITETURA E CONSTRUÇÃO, São Paulo; Vol I; nº4; abril-maio-junho 1967; p.17-20

ARTIGO: Realismo como método na arquitetura de um edifício. José Luis $P$. Backheuser

PROJETO: Edifico Plavinil - Elclor

No ARQUIVO: 224

4.6 SESI / FIESP / CIESP - 1969 fig 030

FONTE: PROJETO - Arquitetura, planejamento, desenho industrial, construção, São Paulo; $\mathrm{n}^{\circ} 21$; julho 1980; p.21-27

ARTIGO: SESI / FIESP / CIESP

PROJETO: idem

No ARQUIVO: 244

FONTE: FIESP / CIESP, São Paulo; Boletim 1979; capa; p. 8-13

ARTIGO: FIESP / CIESP - Enfrentando os Desafios do Futuro

PROJETO: SESI / FIESPI CIESP

No ARQUIVO: s/n

FONTE: ACROPOLE, São Paulo, ano XXXII, n 373; março 1970; p.16-19

ARTIGO: Edifício Sede SESI - CIESP

PROJETO: SESI / FIESP/ CIESP

No ARQUIVO: 230

FONTE: ELLE, ano I; $n^{\circ} 7$; novembro 88; p. 46-47

ARTIGO: Arquitetura - Criando forma, projetando Estilos

PROJETO: SESI / FIESP/ CIESP

No ARQUIVO: 272

FONTE: INDUSTRIA E DESENVOLVIMENTO, São Paulo; Vol. II; nº 6; junho 169; p.42

ARTIGO: Futuro prédio da FIESP / CIESP e do SESI

PROJETO: SESI / FIESP/ CIESP

No ARQUIVO: 228

FONTE: PROJETO, arquitetura, planejamento, desenho industrial, construção, São Paulo; n 21; julho $1980 ;$ p $21-27$

ARTIGO: Edifícios Administrativos / Projetos - SESI / FIESP/ CIESP

PROJETO: SESI / FIESP/ CIESP

No ARQUIVO: 122

4.7 SEDE ADMINISTRATIVA PARAMOUNT LANSUL - 1987

FONTE: ORGÃO INFORMATIVO DO GRUPO PARAMOUNT LANSUL, São Paulo; n4; agosto setembro 1987 ; p.6-7 
ARTIGO: Sede Administrativa Paramount Lansul, São Paulo

PROJETO: Edifício Paramount Lansul

No ARQUIVO: $\mathrm{s} / \mathrm{n}$

FONTE: PROJETO - Revista Brasileira de Arquitetura, Planejamento, Desenho Industrial, Construção, São Paulo; n¹23; junho 1989; p.100-102

ARTIGO: Diálogo com o Contexto através de dois Blocos

PROJETO: Edifício Paramount Lansul

No ARQUIVO: 277; 277A

FONTE: PROJETO - Revista Brasileira de Arquitetura, Planejamento, Desenho Industrial, Construção, São Paulo; n ${ }^{117}$; dezembro 1988; p. D18

ARTIGO: Arquitetura no Brasil / anos 80 - Região Sudeste - Rio de Janeiro/São Paulo

PROJETO: Edifico Paramount Lansul

No ARQUIVO: 282

4.8 CENTRO ADMINISTRATIVO ZF DO BRASIL - 1988 fig 031

FONTE: PROJETO - Revista Brasileira de Arquitetura, Planejamento, Desenho Industrial, Construção, São Paulo, $\mathrm{n}^{\circ} 113$, agosto de 1988, pp. 70/74

ARTIGO: Duas propostas para Centro Administrativo

PROJETO: Centro Administrativo ZF do Brasil

N ARQUIVO: 271

\subsection{EDIFÍCIO SEDE DO INSTITUTO DE ENGENHARIA - 1989}

FONTE: ENGENHARIA - Revista do Instituto de Engenharia, São Paulo; julho - agosto 1989; n 474, capa, p. 6-8.

ARTIGO: Presidente expõe suas metas. Eng. Maçahico Tisaka

PROJETO: Sede do Instituto de Engenharia

No ARQUIVO: 278 , 278A

\section{5- TEATRO / CINEMA / CINEMA-HOTEL}

\subsection{CINE UNIVERSO - 1936 fig 032 e fig 033}

FONTE: REVISTA POLITÉCNICA - Orgão do Grêmio Politecnico, São Paulo, ano 35, n 130, pp. $105 / 107$

ARTIGO: Cine Universo

PROJETO: idem

N ARQUIVO: 09

\subsection{CINE UFA - PALACE -1936 fig 034 e fig 035}

FONTE: L'ARCHITECTURE D'AUJOURD'HUI, Paris, nº 9 , setembro de1938, pp. 62/64

ARTIGO: "Le spectacle - documents réunis par Pierre Vago- Cinéma UFA - Palace a São Paulo"

PROJETO: Cine UFA - Palace

N ARQUIVO: 07

\subsection{CINE ART - PALÁCIO - 1938 fig 036}

FONTE: ACRÓPOLE, Arquitetura, Urbanismo e Decoração, São Paulo, ano III, nº 25, maio de 1940, pp. $41 / 48$

ARTIGO: Cine Art-Palacio e Prédio para Escritórios, Recife, Pernambuco 
PROJETO: Cine Art-Palácio

N ARQUIVO: 10

\subsection{CINE IPIRANGA/ HOTEL EXCELCIOR - 1941 fig 037}

FONTE: L'ARCHITECTURE D'AUJOURD'HUI, Paris, ano 20, nº 23, maio de 1949, pp. 49/51

ARTIGO: Spectacles - Cinema-Hotel a São Paulo

PROJETO: Cine Ipiranga/Hotel Excelcior

N ARQUIVO: 30

FONTE: THE ARCHITECTURAL REVIEW, Londres, vol 106, nº 636, dezembro de 1949, pp. 350/352

ARTIGO: "Cinema and Hotel in São Paolo"

PROJETO: Cine Ipiranga/Hotel Excelcior

N ARQUIVO: 34

FONTE: LIGHT AND LIGHTING, Londres, vol 50, nº 03, março de1957, pp. 90

ARTIGO: Cinema lighting - examples from abroad - Cinemas in Portugal and Brasil

PROJETO: Cine Ipiranga/Hotel Excelcior

N ARQUIVO: 139

FONTE: TECHNIQUES ET ARCHITECTURE, Paris, ano 6, $n^{\circ}$ 7/8, 1946, pp. 356/357

ARTIGO: Architecture a l'étranger - Brésil: Cinéma et Hotel Ipiranga a São Paulo

PROJETO: Cine Ipiranga/Hotel Excelcior

N ARQUIVO: 21

FONTE: LA MAISON - revue mensuelle d'architecture, decoration, d'art-ménager, Bruxelas, ano 3, $\mathrm{n}^{\mathrm{O}} 11$, novembro de 1947 , capa

ARTIGO: foto da capa

PROJETO: Cine Ipiranga/Hotel Excelcior

N ARQUIVO: 26

5.5 TEATRO CULTURA ARTÍSTICA - 1943 fig 038

FONTE: L'ARCHITECTURE D'AUJOURD'HUI; Paris, $20^{\circ}$ année; n 29, MAIO de 1950, pp. 62/64

ARTIGO: Architecture Contemporaine - Nouveau Theatre a São Paulo

PROJETO: Teatro Cultura Artística

No ARQUIVO: 39

FONTE: DOMUS, rivista mensile di architettura, arredamento, arte, Milão, nº 259, junho de 1951, pp.

$6 / 9$

ARTIGO: Teatro a S. Paolo del Brasile

PROJETO: Teatro Cultura Artística

N ARQUIVO: 51

FONTE: THE ARCHITECTURAL REVIEW, Londres, vol 110, nº 660, dezembro de 1951, pp. 368/375

ARTIGO: Three Buildigs by Rino Levi in São Paulo, Brazil

PROJETO: Teatro Cultura Artística

N ARQUIVO: 55

FONTE: INFORMES DE LA CONSTRUCCION - Revista de informcion tecnica del Instituto Tecnico se la construcion y del cemento, Madri, ano VIII, $\mathrm{n}^{\circ} 75$, novembro de 1955, pp. 145/44

ARTIGO: "Cultura Artística en São Paulo"

PROJETO: idem

N ARQUIVO: 109

FONTE: ACROPOLE - Arquitetura, Urbanismo, Decoração, São Paulo, ano XII, nº 145, maio de 1950, pp. 1-8

ARTIGO: Teatro Cultura Artística

PROJETO: idem

N ARQUIVO: 41

FONTE: ARCHITECTURAL RECORD, Nova Iorque, vol 108, $\mathrm{n}^{\circ}$ 7, julho de 1950, pp. 85/90

ARTIGO: Teatro Cultura Artística 
PROJETO: idem

N ARQUIVO: 42

6 - HOSPITAIS

6.1 MATERNIDADE UNIVERSITÁRIA - USP - 1945 fig 039

FONTE: DIE KUNST, Munchen; n 09; junho 1953; p. 340-343

ARTIGO: Neves Bauen in Brasilien

PROJETO: Maternidade Universitária - USP

N ARQUIVO: 69

FONTE: PROGRESSIVE ARCHITECTURE, New York; dezembro 1949; p.48 a 54

ARTIGO: Specialized Hospitals - Maternity Hopital, São Paulo, Brasil

PROJETO: Maternidade Universitária - USP

N ARQUIVO: 35

FONTE: ACROPOLE, arquitetura, urbanismo e decoração, São Paulo; ano XIV; nº 162; outubro 1951; p.198

ARTIGO: Prêmios da Exposição Internacional de Arquitetura - $1^{\circ}$ Bienal do Museu de Arte Moderna PROJETO: Maternidade Universitária - USP

N ARQUIVO: 53

FONTE: ARQUITETURA, órgão oficial do Instituto de Arquitetos do Brasil - I.A.B. G.B.; n 35; maio 1965 ; p. 21-23

ARTIGO: Maternidade Universitária de São Paulo

PROJETO: Maternidade Universitária - USP

N ARQUIVO: 214

FONTE: L'ARCHITECTURE D'AUJOURD'HUI, Revue Internationale d'Architecture contemporaine, Paris; ano 19, $\mathrm{n}^{\circ} 17$, abril 1948; p.90-95

ARTIGO: La Santé Publique (deuxiéme partie) - Maternité Universitaire à São Paulo

PROJETO: Maternidade Universitária - USP

N ARQUIVO: 28

FONTE: ARQUITETURA E ENGENHARIA, I.A.B. - Minas Gerais, BH; ano IV; ${ }^{\circ}$ 20; janeiro fevereiro 1952; p. 24-38

ARTIGO: Maternidade Universitária de São Paulo

PROJETO: Maternidade Universitária - USP

N ARQUIVO: 57

FONTE: ARQUITECTURA, México; n 37; março 1952; p.70-82

ARTIGO: Universidade de São Paulo - Maternidade Universitária

PROJETO: Maternidade Universitária - USP

N ARQUIVO: 59

FONTE: HABITAT, arquitetura e artes no Brasil; ano 6; dezembro 1955; n 25; p. 11

ARTIGO: Um grande projeto que não se concretiza

PROJETO: Maternidade Universitária - USP

N ARQUIVO: 112

FONTE: ARQUITETURA, órgão oficial do Instituto de Arquitetos do Brasil; IAB - GB; $\mathrm{n}^{\circ}$ 35; maio 1965; p. 21-23 e capa

ARTIGO: Maternidade Universitária de São Paulo

PROJETO: Maternidade Universitária - USP

N'ARQUIVO: s/n

FONTE: SELEZIONE MONDIALE DE EDILIZIA OSPEDALIERA, Torino; 1954; p.21-22

ARTIGO: Maternita Universitaria di San Paolo

PROJETO: Maternidade Universitária - USP 
No ARQUIVO: s/n

6.2 HOSPITAL CENTRAL DO CANCER - 1947 fig 040

FONTE: CONSTRUÇÃO SÃO PAULO; São Paulo; Ano XXXII; nº 1627; 16 abril 1979; p.19

ARTIGO: Hospital Central do Câncer, São Paulo

PROJETO: idem

No ARQUIVO: 242

FONTE: STRUCTURAL CONCRETE, published by the joint committee on structural concrete and the cement and concrete Association; London; September 1957; P.1,2,e 16.

ARTIGO: Hospitals

PROJETO: Hospital do Câncer

No ARQUIVO: 150

FONTE: INFORMES DE LA CONSTRUCCION, Madrid; Ano III; nº 28; fevereiro 1951; p.143 - 1 a 9. ARTIGO: Hospital Antonio Candido de Camargo en São Paulo

PROJETO: Hospital do Câncer

No ARQUIVO: 48

FONTE: ARCHITECTURAL RECORD, New York; Vol 115; nº 2; fevereiro 1954;p.202-205.

ARTIGO: Hospital with a New Look

PROJETO: Hospital do Câncer

No ARQUIVO: 80

FONTE: L'ARCHITECTURE D’AUJOURD’HUI; $20^{\circ}$ année; n² 21, dezembro 1949.

ARTIGO: L'architecture Contemporaine dans le monde. Hopital Antonio Candido de Camargo - São Paulo

PROJETO: Hospital do Câncer

No ARQUIVO: 33

FONTE:DOMUS, arte e stile nella casa, acte e stile nell'industria (industrial design); Milão; $\mathrm{n}^{\circ} 287$; outubro 1953 ; p.5-8.

ARTIGO: Antologia di RinoLevi

PROJETO: Hospital do Câncer

No ARQUIVO: 72

FONTE:DIE BAUZEITUNG DEUTCHE BAUZEITUNG; Alemanha; n5; maio 1958; p. 212 - 215.

ARTIGO: Antonio Candido de Camargo, Zentral-Krebskrankenhaus in Sao Paulo, Brasilien, 1948

begonnen

PROJETO: Hospital do Câncer

N'ARQUIVO: 158

FONTE: ARCHITECTURAL RECORD, New York; Vol 107; n²; fevereiro 1950; p.108 - 111.

ARTIGO: Building Types Study n ${ }^{\circ} 158$ - Hospitals - Instituto Central do Cancer, Sao Paulo

PROJETO: Hospital do Câncer

No ARQUIVO: 37

FONTE: HABITAT, revista brasileira de arquitetura, artes plásticas, artesanato e decoração contemporânea; São Paulo; n¹3; dezembro 1953; p.11 a 18.

ARTIGO: Instituto Central do Câncer, São Paulo. Hospital Antônio Cândido de Camargo

PROJETO: idem

No ARQUIVO: 75

FONTE: DESIGN AND INTERIORES, revista brasileira dedes. Industrial, comunicação visual e arquitetura de interiores; Ano II, n 09; julho - agosto 1988; p.70 - 75. 
ARTIGO: As novas possibilidades de um material milenar (revestimento cerâmico)

PROJETO: Hospital do Câncer

No ARQUIVO: $\mathrm{s} / \mathrm{n}^{\circ}$

FONTE: INFORMES DE LA CONSTRUCCION; Madrid; Ano VIII; n 71; maio 1955.

ARTIGO: Hospital del Cancer, São Paulo

PROJETO: Hospital do Câncer

No ARQUIVO: 98

FONTE: REVISTA PAULISTA DE HOSPITAI; Órgão Oficial da Associação Paulista de Hospitais; Ano II; setembro 1954; Vol. II; n 9; p. 15 - 18.

ARTIGO: Seguimento em Câncer: Dr. Odair Pacheco Pedroso; Dra. Lourdes de Freitas Carvalho PROJETO: Hospital do Câncer

No ARQUIVO: 87

FONTE: ARCHITECTURAL DESIGN, London; Vol. XXVI, janeiro 1956

ARTIGO: Two hospitals in Brazil: Cancer Hospitals - Children's Hospital, p.9-11

PROJETO: Hospital do Câncer

No ARQUIVO: 116

FONTE: HOSPITAL DE HOJE - Órgão Oficial do IPH - Instituto Brasileiro de Desenvolvimento de Pesquisas Hospitalares; 1958 (?); Ano III; Vol.9; p. 303.

ARTIGO: Bomba de Cobalto do Instituto Central do Câncer

PROJETO: Hospital do Câncer

No ARQUIVO: 115

FONTE: DIE KUNST, Munchen; n 09; junho 1953; p. 340-343

ARTIGO: Neves Bauen in Brasilien

PROJETO: Hospital do Câncer

No ARQUIVO: 69

FONTE: SELEZIONE MONDIALE DE EDILIZIA OSPEDALIERA, Torino; 1954; p.22

ARTIGO: Istituto Centrale - Ospedale Antonio Candido de Camargo

PROJETO: Hospital Central do Câncer

N ARQUIVO: s/n

FONTE: ACROPOLE, São Paulo, ano XIX, nº 223, maio de 1957, pp. 258/259

ARTIGO: Ladrilhos de Cimento aplicados em parede

PROJETO: Hospital Central do Câncer

N ARQUIVO: 141

6.3 HOSPITAL CRUZADA PRO-INFÂNCIA - 1950 fig 041

FONTE: ACROPOLE, São Paulo; Ano XIV; n¹62; outubro 1951; capa e p.01.

ARTIGO: Hospital Cruzada Pró-Infância

PROJETO: idem

No ARQUIVO: 53

FONTE: ARCHITECTURAL DESIGN, London; Vol. XXVI, janeiro 1956; p.12

ARTIGO: Two hospitals in Brazil: Cancer Hospitals - Children's Hospital.

PROJETO: Hospital Cruzada Pró-Infância

N'ARQUIVO: 116

FONTE: REVISTA PAULISTA DE HOSPITAIS; órgão oficial da Associação Paulista de Hospitais; Ano V; Vol V; n5; maio 1957; p. 73 a 82. 
ARTIGO: A “Mãe do Ano" de 1957 e o Hospital da Cruzada Pró-Infância

PROJETO: Hospital Cruzada Pró-Infância

No ARQUIVO: 142

FONTE: HOSPITAL DE HOJE - órgão oficial do IPH - Instituto Brasileiro de Desenvolvimento e de Pesquisas Hospitalares; Vol 1; $4^{\circ}$ trimestre; 1955

ARTIGO: Hospital da Cruzada Pro-Infância

PROJETO: Hospital da Cruzada Pro-Infância

N ARQUIVO: 113

FONTE: ACROPOLE; São Paulo; Ano XXIV; nº 286; setembro 1962; p. 319.

ARTIGO: Tubulações na Fachada

PROJETO: Hospital Cruzada Pró-Infância

No ARQUIVO: 200

6.4 LABORATÓRIO PAULISTA DE BIOLOGIA - 1956 fig 042

FONTE: MAYGAR EPITOMUVESZET, Budapest; 1964-5; p. 9-13

ARTIGO: Paulista Biological Laboratory, São Paulo

PROJETO: Laboratório Paulista de Biologia

N ARQUIVO: 214

6.5 HOSPITAL ALBERT EINSTEIN - 1958 fig 043

FONTE: L'ARCHITECTURE D’AUJOURD’HUI, Paris; 30 Année; n 84; junho - julho 1959; p. 60.

ARTIGO: Santé Publique - Brésil

PROJETO: Hospital Albert Einstein

No ARQUIVO: 173

FONTE: HABITAT, Arquitetura e Artes no Brasil; São Paulo; $8^{\circ}$ Ano; setembro - outubro 1958; n50; p. 2-3.

ARTIGO: Maqueta do Hospital Albert Einstein, São Paulo

PROJETO: Hospital Albert Einstein

No ARQUIVO: 164

FONTE: HABITAT, Arquitetura e Artes no Brasil; São Paulo; Ano XX; n 48; maio-junho 1958; p.2 7.

ARTIGO: Hospital Albert Einstein

PROJETO: idem

No ARQUIVO: 159

FONTE: HOSPITAL DE HOJE - órgão oficial do IPH - Instituto Brasileiro de Desenvolvimento e de Pesquisa Hospitalar, São Paulo; Vol. 10; Ano IV; capa

ARTIGO: Hospital Albert Einstein

PROJETO: idem

No ARQUIVO: 114

FONTE: VISÃO, São Paulo; Vol. 13; n 13; 26 setembro 1958; p. 81

ARTIGO: Hospital Colorido

PROJETO: Hospital Albert Einstein

No ARQUIVO: 163

FONTE: BOLETIN, Sociedad de Arquitectos del Uruguay; Ano XXIV; agosto 1959; n¹66; p. 8 - 9 e capa. 
ARTIGO: Hospital Albert Einstein

PROJETO: idem

No ARQUIVO: 175

FONTE: ACROPOLE, São Paulo; Ano XX; n 239; setembro 1958; p.510 - 515.

ARTIGO: Ante-projeto para o Hospital Albert Einstein

PROJETO: Idem

No ARQUIVO: 162

FONTE: CONCRETE QUARTERLY, cement and concret association, London; $\mathrm{n}^{\circ}$ 46; julho - setembro 1960; p. $18-24$.

ARTIGO: New Hospitals from Abroad

PROJETO: Hospital Albert Einstein

No ARQUIVO: 182

FONTE: Informativo ABEA; s/d; s/p.

ARTIGO: Hospital Albert Einstein

PROJETO: idem

No ARQUIVO: $\mathrm{s} / \mathrm{n}$

FONTE: RPH - REVISTA PAULISTA DE HOSPITAIS, órgão oficial da Associação Paulista de Hospitais; Ano VI; Vol. VI; n6; junho 1958; p.30-41.

ARTIGO: Hospital Albert Einstein

PROJETO: idem

No ARQUIVO: 160

6.6 INSTITUTO DE GASTROENTEROLOGIA - 1959 fig 044

FONTE: L'ARCHITECTURE D’AUJOURD’HUI, Paris; 30 Année; n 84; junho - julho 1959; p. 63.

ARTIGO: Santé Publique - Brésil

PROJETO: Instituto de Gastroenterologia

No ARQUIVO: 173

6.7 HOSPITAL CENTRAL, MAIQUETIA, VENEZUELA - 1959 fig 045

FONTE: ACROPOLE, São Paulo; ano XXIII; n 269; março - abril 1961; p. 176 e179

ARTIGO: Esquemas de três Hospitais

PROJETO: Hospital para Maiquetia

No ARQUIVO: 18

6.8 HOSPITAL CENTRAL, CARACAS - 1959 fig 046

FONTE: ACROPOLE, São Paulo; ano XXIII; nº 269; março - abril 1961; p. 176 - 177

ARTIGO: Esquemas de três Hospitais

PROJETO: Hospital Caracas

N'ARQUIVO: 187

6.9 HOSPITAL CENTRAL, PUERTO CABELLO, VENEZUELA - 1960 fig 047

FONTE: Revista COLEGIO DE INGENIEROS DE VENEZUELA, Venezuela, $\mathrm{n}^{\circ} 291$; Abril-MaioJunho 1961; p. 17 e plantas.

ARTIGO: Hospital General para Puerto Cabello 
PROJETO: Hospital Geral Porto Cabello, Venezuela

No ARQUIVO: $\mathrm{s} / \mathrm{n}$

FONTE: Revista S.V.A.; organo de la sociedad venezuelana de arquitectos; $\mathrm{n}^{\circ}$ 17, maio-junho 1964; p.14-18.

ARTIGO: Hospital General de Puerto Cabello

PROJETO: Hospital Geral Porto Cabello, Venezuela

No ARQUIVO:211

FONTE: ACROPOLE, São Paulo; ano XXIII; n 269; março - abril 1961; p. 176 e 178

ARTIGO: Esquemas de três Hospitais

PROJETO: Hospital Geral Porto Cabello, Venezuela

No ARQUIVO: 187

\subsection{HOSPITAL PSIQUIATRICO ARARAQUARA - 1962 fig 048}

FONTE: HABITAT, revista brasileira de arquitetura, artes plásticas, artesanato e decoração contemporânea; São Paulo; $12^{\circ}$ Ano; ${ }^{\circ} 70$; dezembro 1962; p.15-19.

ARTIGO: Hospital Psiquiátrico de Araraquara, São Paulo

PROJETO: idem

No ARQUIVO: 204

\subsection{HOSPITAL PSIQUIATRICO RIO CLARO - 1962 fig 049}

FONTE: HABITAT, revista brasileira de arquitetura, artes plásticas, artesanato e decoração contemporânea; São Paulo; n62; março 1962; p.1-3.

ARTIGO: Hospital Psiquiátrico de Rio Claro

PROJETO: idem

No ARQUIVO: 196

\section{7 - ESCOLAS}

\subsection{SEDES SAPIENTIAE - 1941 fig 050 e fig 051}

FONTE: DESIGN AND CONSTRUCTION, London, vol XV, nº 09, setembro de 1945, pp. 231

ARTIGO: Brazilian Schools

PROJETO: Sedes Sapientiae

N ARQUIVO: 17

FONTE: REVISTA MUNICIPAL DE ENGENHARIA, Rio de Janeiro, vol IX, nº 5 setembro de 1942, pp. $14 / 23$

ARTIGO: Instituto Superior de Filosofia, Ciências, e Letras "Sedes Sapientiae"

PROJETO: Sedes Sapientiae

No ARQUIVO: 12

FONTE: A CONSTRUÇÃO SÃO PAULO, São Paulo, ano XXXII, nº 1619, 19 de fevereiro de 1979, pp. 10

ARTIGO: Instituto Sedes Sapientiae

PROJETO: idem

N ARQUIVO: 240

FONTE: TECHNIQUES ET ARCHITECTURE, Paris, ano 6, n7/8, 1946, pp. 350/351

ARTIGO: Architecture a l'étranger - Brésil - Institut "Sedes Sapientiae"

PROJETO: Sedes Sapientiae

N ARQUIVO: 21

FONTE: ACRÓPOLE, Arqitetura, Urbanismo e Decoração, São Paulo, ano VI, nº 64, agosto de 1943, pp. $65 / 72$ 
ARTIGO: Faculdade de Filosofia do Instituto Sedes Sapientiae PROJETO: idem N ARQUIVO: 15

\subsection{CENTRO PROFISSIONAL “LA PARABOLA”, Venezuela - 1956 fig 052}

FONTE: HABITAT, revista de arquitetura e artes no Brasil, São Paulo; n³4; setembro 1956; p.54-56

ARTIGO: Centro Profissional La Parábola

PROJETO: idem

N'ARQUIVO: 129

FONTE: INTEGRAL, Venezuela; n $^{\circ} ;$ 1956; s/p

ARTIGO: Centro Profesional La Parábola

PROJETO: Centro Profissional La Parábola No ARQUIVO: 123

FONTE: VISÃO, São Paulo; Vol11; n²1; 22 novembro 1957; p.32

ARTIGO: Arquitetura nossa na Venezuela

PROJETO: Centro Profissional La Parabola No ARQUIVO: 156

\subsection{COLÉGIO MIGUEL DE CERVANTES - 1973 fig 053}

FONTE: MANCHETE, Rio de Janeiro, nº 1230, 15 de novembro de 1975, pp. 110/111

ARTIGO: Colégio Miguel de Cervantes

PROJETO: idem

N ARQUIVO: 237

\section{8 - INDÚSTRIAS}

\subsection{INDÚSTRIAS ARNO - 1950}

FONTE: HABITAT, revista das artes no Brasil, São Paulo, nº 10, janeiro/fevereiro/março de 1953, pp. $24 / 25$

ARTIGO: Arquitetura Industrial

PROJETO: Indústrias Arno

N ARQUIVO: 74

\subsection{GALPÃO TECELAGEM PARAHYBA - 1953 fig 54}

FONTE: HABITAT, Arquitetura e Artes no Brasil, São Paulo, $8^{\circ}$ ano, setembro/outubro 1958, $n^{\circ}$ 50, pp. 4-6.

ARTIGO: Galpão para fazenda em São José dos Campos PROJETO: Galpão Tecelagem Parahyb N ARQUIVO: 164

FONTE: Acrópole, São Paulo, ano XXI, nº 241, novembro de 1958, pp. 5-7 ARTIGO: Galpão para abrigo de máquinas agrícolas PROJETO: Galpão da Tecelagem Parahyba No ARQUIVO: 165

FONTE: Informes de la Construcion, Madrid, ano XII, n 112, junho/julho 1959, pp. 841-11 ARTIGO: Nave agricola - Brasil PROJETO: Galpão da Tecelagem Parahyba N ARQUIVO: 172 
FONTE: L'Architecture D'Aujourd'hui, Paris, $31^{\circ}$ année, junho/julho 1960, nº 90, pp. 68/69 ARTIGO: Hangar pour une ferme PROJETO: Galpão da Tecelagem Parahyba NN ARQUIVO: 181

\subsection{USINA DE LEITE PARAHYBA - 1963 fig 055}

FONTE: A CONSTRUÇÃO SÃO PAULO, São Paulo, ano XXVIII, nº 1451, dezembro de 1975, pp. $23 / 24$

ARTIGO: "Novas tendências e rumos da Arquitetura industrial"

PROJETO: Usina de Leite Parahyba

N ARQUIVO: 236

FONTE: ARQUITETURA E CONSTRUÇÃO, São Paulo, vol I, nº 0, juilho de 1966, pp. 14/20

ARTIGO: Um conjunto de construções em meio rural

PROJETO: Usina de Leite Parahyba

N ARQUIVO: 222

FONTE: A CONSTRUÇÃO SÃO PAULO, São Paulo, ano XXVIII, n 1451, dezembro de 1975, pp. $23 / 24$

ARTIGO: "Novas tendências e rumos da Arquitetura industrial"

PROJETO: Usina de Leite Parahyba

\subsection{HANGAR DA TECELAGEM PARAHYBA - 1965 fig 056}

FONTE: Acrópole, São Paulo, ano XXX, n 349, abril 1968, pp. 15-17

ARTIGO: Hangar para pequenos aviões

PROJETO: Hangar Tecelagem Parayba

$\mathrm{N}^{\circ}$ ARQUIVO: 226

8.5 INDUSTRIA PERMETAL-1973 fig 057

FONTE: Informativo ABEA; s/d ; s/p.

ARTIGO: PERMETAL - Industria de Metais Perfurados, Guarulhos

PROJETO: idem

$\mathrm{N}^{\circ}$ ARQUIVO: $\mathrm{s} / \mathrm{n}$

\subsection{INDÚSTRIAS GESSY-LEVER - VINHEDO - 1976 fig 058}

FONTE: PROJETO-arquitetura, planejamento, desenho industrial, construção, São Paulo, nº 32, agôsto de 1981, pp. 24/32

ARTIGO: Projetos Industriais: Indústrias Gessy-Lever Ltda., Divisão Elida Gibbs, Vinhedo

PROJETO: idem

N' ARQUIVO: 248

8.7 INDÚSTRIAS GESSY-LEVER - INDAIATUBA -1977 fig 059

FONTE: A CONSTRUÇÃO SÃO PAULO, São Paulo, ano XXXIV, n 1747, 3 de agôsto de 1981, capa pp.4/7

ARTIGO: Peças pré-moldadas no canteiro permitem soluções inovadoras

PROJETO: Indústrias Gessy-Lever, Divisão detergente em pó, Indaiatuba

N ARQUIVO: 247

FONTE: PROJETO, revista brasileira de arquitetura, planejamento e desenho industrial, São Paulo, $n^{\circ} 121$, maio de 1989 , pp. 66/67

ARTIGO: "Edifícios Industriais - Conjunto Industrial Gessy-Lever, Indaiatuba

PROJETO: idem

N ARQUIVO: 276 
FONTE: FOLHETO GESSY-LEVER, janeiro de 1983, pp. 2/23

ARTIGO: Indústrias Gessy-Lever, Indaiatuba

PROJETO: idem

N' ARQUIVO: $s / n$

\subsection{INDÚSTRIAS PPF DO BRASIL - VINHEDO - 1978 fig 060}

FONTE: PROJETO, revista brasileira de arquitetura, planejamento, desenho industrial, construção, São Paulo, no 10, agôsto de 1986, pp. 68/70

ARTIGO: PPF do Brasi - Vinhedol

PROJETO: idem

N ARQUIVO: 260

\subsection{INDÚSTRIAS PIRELLI - 1980}

FONTE: A CONSTRUÇÃO SÃO PAULO, ano XXXIV, nº 1771, 18 de janeiro de 1982. pp. 4/10

ARTIGO: Um laboratório planejado para crescer e se adaptar a novos programas

PROJETO: Indústrias Pirelli

N ARQUIVO: 252

\subsection{INDÚSTRIAS BOZZANO - 1981}

FONTE: PROJETO, revista brasileira de arquitetura, planejamento, desenho industrial, construção, São Paulo, no 101,julho de 1987, pp. 82/87

ARTIGO: Implantação como composição arquitetônica e lógica produtiva

PROJETO: Indústrias Bozzano

N ARQUIVO: 265

\section{9 - PROJETOS URBANÍSTICOS}

\subsection{CONCURSO VIADUTO DO CHÁ fig 061}

FONTE: VIDA DAS ARTES, Rio de Janeiro/São Paulo, ano 1, n 3, agôsto 1957, pp. 20-23

ARTIGO: Concursos públicos: porque terminaram?

PROJETO: Concurso Viaduto do Chá

No ARQUIVO: 235

\subsection{CONJUNTO P/ OPERÁRIOS TECELAGEM PARAHYBA - 1953 fig 62}

FONTE: EL ARQUITECTO PERUANO, Lima, ano XXIII, n 204/205, julho/agôsto 1954, pp. $96 / 100$ ARTIGO: "La casa barata: comunidad obrera, por el arq. Rino Levi" PROJETO: Conjunto p/ operários Tecelagem Parahyba No ARQUIVO: 84

FONTE: NUESTRA ARQUITECTURA, Buenos Aires, no 302, setembro 1954, pp. 293/299

ARTIGO: Conjunto residencial para obreros em São José dos Campos

PROJETO: Conjunto p/ operários Tecelagem Parahyba

No ARQUIVO: 86

FONTE: ACRÓPOLE, São Paulo, ano 17, nº 193, outubro 1954, pp. 1-5

ARTIGO: Conjunto residêncial para operários

PROJETO: Conjunto p/ operários Tecelagem Parahyba

$\mathrm{N}^{\circ}$ ARQUIVO: 88

FONTE: L'ARCHITECTURE D'AUJOURD'HUI, Paris, nº 57, dezembro 1954, pp.2

ARTIGO: Groupe d'habitations ouvrières

PROJETO: Conjunto p/ operários Tecelagem Parahyba

No ARQUIVO: 93

FONTE: BRASIL - ARQUITETURA CONTEMPORÂNEA, Rio de Janeiro, nº 7, 1956 pp. 14-19 
ARTIGO: Conjunto residêncial para operários

PROJETO: Conjunto p/ operários Tecelagem Parahyba

$\mathrm{N}^{\mathrm{o}}$ ARQUIVO: 134

FONTE: HABITAT, Revista de Arquitetura e Artes no Brasil, vol. VII, no 37, dezembro 1956, pp. 60-63 ARTIGO: Tecelagem Parahyba, Fazenda Monte Alagre, Projeto Urbanístico

PROJETO: Conjunto $\mathrm{p} /$ operários Tecelagem Parahyba

$\mathrm{N}^{\mathrm{o}}$ ARQUIVO: 133

\subsection{SETOR RESIDENCIAL ESTUDANTIL USP - 1953 fig 063}

FONTE: DOMUS, arte e stile nella casa, acte e stile nell'industria (industrial design); Milão; $n^{\circ} 287$; outubro 1953 ; p.6-7

ARTIGO: Antologia di RinoLevi

PROJETO: Setor Residencial estudantil USP

No ARQUIVO: 72

FONTE: INTEGRAL- Arquitetura, urbanismo, ingenieria, artes plásticas, folklore, Caracas (Venezuela); Sociedad Venezolana de Arquitetos y Centro Profesional del Este; $n^{\circ} 14$; fevereiro 1959 ; $s / p$ ARTIGO: Dos Obras del Arquitecto Rino Levi: Ciudad Universitaria de San Paulo: Centro de Residencia del Estudante

PROJETO: Setor Residencial Estudantil USP

N ARQUIVO: 168

\subsection{CONCURSO PLANO-PILÔTO BRASÍLIA - 1957 fig 064}

FONTE:ZODIAC, Milano; n 6; 1960; p. 84-87

ARTIGO:Rino Levi: uma nuova dignità all'habitat Bruno Alfieri

PROJETO: Brasília

N ARQUIVO: 207

FONTE: DIE BAUZEITUNG, Berlim, ano 63, nº 05, maio de 1958, pp. 210/211

ARTIGO: "Brasília : Die fertige Hochhaus-Park-Stadt met Slast Kem"

PROJETO: Brasília

N ARQUIVO: 158

FONTE: L'ARCHITECTURE D'AUJOURD'HUI, Paris, nº 13, junho de 1957, pp. 52/63

ARTIGO: "Concours pour la nouvelle capitale du Brésil"

PROJETO: Brasília

N ARQUIVO: 144

FONTE: BAUWELT, Berlim, nº44, novembro de 1957, pp. 1173/1172

ARTIGO: "Brasilien baut Brasília-ein nationales experment oder mehn?

PROJETO: Brasília

N' ARQUIVO: 153

FONTE: HABITAT, São Paulo, n40/41, março/abril de 1957, pp.4/11

ARTIGO: Plano -Pilôto para Brasília

PROJETO: idem

N ARQUIVO: 114

\subsection{CENTRO CÍVICO DE SANTO ANDRÉ - 1965 fig 065}

FONTE: ARQUITETURA, revista do Instituto de Arquitetos do Brasil, IAB-GB, nº 38, agôsto de 1965, pp. $4 / 7$ 


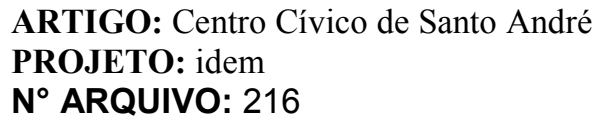

FONTE: A CONSTRUÇÃO SÃO PAULO, São Paulo, ano XXXIV, nº 1763, 23 de novembro de 1981, pp. 23

ARTIGO: Centro Cívico de Santo André

PROJETO: idem

N ARQUIVO: 250

FONTE: ACRÓPOLE, São Paulo, anoXXIII, nº 320, agôsto de 1965, pp. 24/28

ARTIGO: Centro Cívico de Santo André

PROJETO: idem

N ARQUIVO: 215

FONTE: Informativo ABEA; s/d; s/p.

ARTIGO: Centro Cicio de Santo André

PROJETO: idem

No ARQUIVO: $\mathrm{s} / \mathrm{n}$

FONTE: INGENIERIA Y ARQUITECTURA - Organo de la Sociedad Panamericana de Ingenieros y Arquitectos, Panamá, no 124, maio/abril de 1966, pp. 16/23

ARTIGO: "Uma Charla com Rino Levi"

PROJETO: Centro Cívico de Santo André

N ARQUIVO: 221

9.6 CIDADE NOVA ARARAQUARA - 1967 fig 066

FONTE: ACRÓPOLE, São Paulo, ano XXX, nº 350, maio 1968, pp. 20-21

ARTIGO: Cidade Nova Araraquara

PROJETO: Cidade Nova Araraquara

N ARQUIVO; 227

9.7 ESTAÇÃO DE TRATAMENTO D’ÁGUA / VOTUPORANGA - 1969 fig 067

FONTE: Informativo ABEA; s/d; s/p.

ARTIGO: Estação de Tratamento de Água , Votuporanga

PROJETO: idem

No ARQUIVO: $\mathrm{s} / \mathrm{n}$

10 - GARAGENS

10.1 Garagem América - 1956 fig 068

FONTE: L'ARCHITECTURE D'AUJOURD’HUI, Paris, $28^{\circ}$ année, nº 70, fevereiro/maço 1957, pp. $80 / 83$

ARTIGO: Quate garages a São Paulo

PROJETO: Garagem América

No ARQUIVO: 138

10.2 Garagem Copana - 1956 fig 069

FONTE: L'ARCHITECTURE D'AUJOURD'HUI, Paris, $28^{\circ}$ année, nº 70, fevereiro/maço 1957, pp. $80 / 83$

ARTIGO: Quate garages a São Paulo

PROJETO: Garagem Copana

No ARQUIVO: 138

10.3 Garagem Ofasa - 1956 fig 070 
FONTE: L'ARCHITECTURE D'AUJOURD'HUI, Paris, $28^{\circ}$ année, $\mathrm{n}^{\circ}$ 70, fevereiro/maço 1957, pp. $80 / 83$

ARTIGO: Quate garages a São Paulo

PROJETO: Garagem Ofasa

$\mathrm{N}^{\circ}$ ARQUIVO: 138

10.4 Garagem Erasmo Braga - 1957 fig 071

FONTE: L'ARCHITECTURE D'AUJOURD'HUI, Paris, $28^{\circ}$ année, nº 70, fevereiro/maço 1957, pp. $80 / 83$

ARTIGO: Quate garages a São Paulo

PROJETO: Garagem Erasmo Braga

No ARQUIVO: 138

\section{1- CENTRO ESPORTIVO}

\subsection{Clube Araraquarense - 1969 fig 072}

FONTE: AC- Internacional asbestos - cement review, Zurique, $\mathrm{n}^{\circ}$ 58, abril 1979, pp. 49-50

ARTIGO: Social and sports club

PROJETO: Clube Araraquarense

$\mathrm{N}^{\mathrm{o}}$ ARQIVO: $\mathrm{s} / \mathrm{n}$

\subsection{CESI Osaco - 1983}

FONTE: PROJETO, São Paulo, no 96, fevereiro 1987, pp. 33-36 ARTIGO; Horizontalidade: uma boa opção para o SESI de Osasco PROJETO: CESI Osasco

No ARQUIVO: 263 


\section{ANEXO 3: MEMORIAL DO PLANO PILOTO DE BRASÍLIA DO ESCRITÓRIO RINO LEVI}

PLANO PILOTO № $17^{1}$

\section{Autores:}

Rino Levi, Roberto Cerqueira, L. R. Carvalho Franco, arquitetos

\section{Projeto Estrutural}

Paulo Fragoso, engenheiro civil

\section{Apresentação}

Rino Levi e equipe apresentaram seis pranchas de desenhos, a maioria delas colorida, com os assuntos:

- plano piloto (1: 25.000),

- setor de habitação intensiva e centro urbano (1:5.00o),

- as funções humanas,

- organização dos conjuntos de habitação,

- superbloco - 16.00o habitantes (1:1.00o, 1:500),

- dados técnicos do superbloco (1:1.00o, 1:200 e 1:25),

Apresentaram duas maquetes: uma do setor de habitação intensiva e centro urbano e outra do superbloco. E também um curto relatório, equivalente em extensão à metade do texto de Lúcio Costa.

\section{Princípios do plano piloto}

Na definição do plano piloto, a equipe obedeceu à intensão de ordenar e equipar a cidade para a sua finalidade primordial, político-administrativa, na qualidade de capital do país, e tendo em vista o bem-estar físico e espiritual da sua população.

\footnotetext{
${ }^{1}$ Módulo, no 8, edição especial: Brasília, Rio de Janeiro, julho de 1957, pp. 56-91; Arquitetura e Engenharia, no 46, Belo Horizonte, agosto-outubro de 1957, pp. 4-9; Babitat, nº 40-41, São Paulo, marçoabril de 1957, pp. 4-11.
} 
O local escolhido para a sua implantação foi a região envolvida em três lados pelo lago, praticamente plana.

\section{Governo Federal}

O governo federal, composto pelos órgãos supremos dos três poderes, o Palácio do Governo, o Congresso Nacional e o Supremo Tribunal Federal, foram dispostos em posição destacada da área mais densamente urbanizada, em meio a um parque à margem do lago, próximo à residência presidencial, cujo projeto e implantação foram predefinidos pela Novacap. A grande avenida de acesso ao seu conjunto seria destinada aos desfiles e outras manifestações cívicas e militares. Os ministérios, autarquias e demais órgãos governamentais ou ligados ao governo foram situados no centro urbano, tendo desse modo o seu necessário contato com a sociedade facilitado e agilizado.

\section{Centro urbano}

O centro urbano foi implantado na posição central da cidade, às margens do lago, contando com uma grande esplanada. Sua área foi dimensionada prevendo-se de 2,5 a $3 \mathrm{~m}^{2}$ por habitante e abrigaria, além das repartições públicas já mencionadas, o centro administrativo, comercial, cultural, de diversões e de abastecimento da cidade, abrangendo entre outros o paço municipal, lojas de vários tipos, mercados, escritórios, bancos, hotéis, restaurantes, teatros, museus, bibliotecas, cinemas, catedral e estação rodoviária, esta última localizada junto ao trevo viário da entrada.

\section{Zonas residenciais}

Próxima ao centro urbano foi localizada a maior parte da população. Setores de habitação intensiva foram implantados num raio de pouco mais de $1 \mathrm{~km}$ em torno do centro da cidade, permitindo aos seus moradores o acesso a pé, sem 
cruzamentos com o tráfego mecanizado, aos serviços e comodidades lá localizados. As habitações seriam agrupadas em unidades e estas em conjuntos residenciais, ambos convenientemente equipados, formando núcleos orgânicos. As características das unidades e conjuntos foram fixadas atendendo às necessidades a população e visando o desenvolvimento da consciência de grupo, do sentido de autodeterminação e do espírito cívico. Do mesmo modo, a concentração da população, reduzindo as distâncias à escala do pedestre, contribuiria para possibilitar os contatos entre indivíduos e destes com a coletividade. As zonas residenciais mais afastadas e localizadas junto às margens do lago foram projetadas segundo princípios semelhantes, porém definidas por setores de habitação extensiva.

\section{Demais usos, circulação e articulação dos setores da cidade}

O governo federal, o centro urbano, os setores residenciais e os demais usos especiais situados em zonas e núcleos autônomos foram articulados por tramas independentes de circulação de veículos e pedestres.

Vias expressas estabeleceriam a rápida ligação entre as diversas partes da cidade e desta com a rodovia e dariam o acesso adequado a todos os centros de atração de grande público.

As vias que cortariam a região central seriam elevadas junto aos setores de habitação intensiva e ao centro urbano e voltariam ao nível do solo nos seus prolongamentos. Os trechos elevados centrais foram organizados num sistema ortogonal: um tronco principal norte-sul, tangente ao centro urbano, e três transversais leste-oeste, servindo aos conjuntos de habitação intensiva. O tronco principal, ao prolongar-se, atingiria nos seus dois extremos as margens do lago, terminando ao norte no centro esportivo e ao sul na cidade universitária, e deste lado passaria pelo meio do conjunto formado pelo jardim zoológico e pelo jardim botânico e depois pelo centro médico, contíguo à universidade. O prolongamento oeste da via transversal central faria ligação a principal ligação da cidade com a 
rodovia e com a estação ferroviária, localizada nesta interseção, enquanto o prolongamento leste da via transversal mais ao sul constituiria o acesso interno à cidade ao governo federal.

Outras vias expressas, desenvolvidas no nível do solo fora das regiões ocupadas, completariam o sistema de grande velocidade, dando acesso a hospitais, ao longo delas distribuídos, ao jardim zoológico, ao jardim botânico, ao hipódromo, já do outro lado da rodovia,aos setores de habitação extensiva e à zona industrial, localizada no extremo norte da cidade, nas adjacências da ferrovia e separada do respectivo setor de habitação extensiva pela rodovia e por uma zona verde. $\mathrm{O}$ aeroporto, cuja pista já estava em construção, teria acesso pela rodovia.

Nos diversos setores urbanos, o tráfego local se daria em vias internas em "cul-desac”, ladeadas, onde oportuno, por áreas de estacionamento. Estendendo-se destes, a trama independente da circulação dos pedestres propiciaria a articulação capilar dos diversos equipamentos dos conjuntos residenciais, do centro urbano e mesmo daqueles implantados no meio das áreas verdes, como os clubes esportivos.

A cidade universitária, situada às margens do lago, seria composta pelas várias faculdades de ensino, setores residenciais para alunos e professores, clube dos estudantes, clube esportivo, centro hospitalar especializado e demais anexos e institutos complementares.

O setor industrial foi projetado para atender apenas à própria cidade, dado o caráter político-administrativo de Brasília. Além das indústrias de alimentação, das indústrias da construção e de outras de natureza semelhante, foi prevista nessa zona a instalação dos depósitos de combustíveis e de materiais de construção, das garagens para ônibus e para veículos de limpeza pública e dos depósitos para a engenharia municipal.

\section{Parques e jardins}


Com tratamento adequado, o pobre solo de Brasília poderia ser recuperado para a constituição das áreas verdes. As melhores áreas, cobertas por matas ciliares, seriam conservadas e ampliadas para a preservação dos cursos d'água que alimentavam o lago. Um sistema de parques e lagos foi previsto na totalidade da área urbana, destacando-se o complexo formado pelo jardim zoológico e pelo jardim botânico, enquanto na periferia imediata da cidade seriam criadas chácaras e granjas.

\section{Habitação extensiva}

Próximo à zona industrial, junto à orla do lago, foi previsto o desenvolvimento de uma das zonas de habitação extensiva, com três conjuntos residenciais. Mais duas zonas estariam do outro lado da cidade, também nas margens do lago, uma com três e outra com quatro conjuntos de habitação. Cada conjunto abrigaria 15.000 habitantes, divididos em três unidades de habitação de 5.000 moradores, distribuídos em dois tipos de residências: residências individuais, na região periférica do conjunto, e apartamentos semi-intensivos, projetados em torno do centro, na confluência das três unidades. As respectivas densidades seriam da ordem de 100 e 200 habitantes por hectare. Para cada unidade de 5.000 pessoas, foram situados no meio das residências o jardim de infância, a escola primária, a creche, o centro saúde e o playground. No centro do conjunto, atendendo aos 15.00o habitantes, foram previstos os centro comercial, o centro social e cultural, centro de saúde, igreja e cinema. As escolas secundárias, os clubes esportivos e os hospitais foram distribuídos de forma a atender dois ou mais conjuntos. Escolas e clubes foram situados, de um modo geral, em áreas verdes nas margens do lago, e os hospitais próximos às vias expressas.

\section{Habitação intensiva}


Enquanto as zonas residenciais extensivas propostas poderiam abrigar até 150.000 pessoas em dez conjuntos de habitação, os setores de habitação intensiva, desenvolvidos em torno do centro urbano, comportariam o grosso da população: 288.ooo habitantes. Cada um dos seis conjuntos de habitação intensiva poderia abrigar até 48.00o pessoas em três superblocos para 16.0oo pessoas cada.

Os três superblocos seriam implantados ao longo das vias expressas elevadas a cada $400 \mathrm{~m}$, de lados alternados. Assim, a menor distância entre os dois superblocos colocados frente a frente resultaria em $800 \mathrm{~m}$, a qual garantiria boas visuais panorâmicas. Os superblocos, medindo $435 \mathrm{~m}$ de frente, no seu conjunto ocupariam uma área de cerca de 800 x $800 \mathrm{~m}$, levando a uma densidade líquida de 750 habitantes por hectare. Se considerarmos os intervalos entre os conjuntos de habitação, de $600 \mathrm{~m}$ no eixo da vias expressas elevadas e de $400 \mathrm{~m}$ na transversal deste, a densidade bruta seria de 364 habitantes por hectare. Nesse arranjo seria atingido um índice demográfico elevado, sem prejuízo das melhores condições de insolação e ventilação, reservando-se, praticamente, a totalidade do solo para espaços livres.

A concentração de parte considerável da população traria outras vantagens, além de proporcionar curtas distâncias até o centro urbano, adequadas à escala do pedestre. Todos os serviços públicos, como transporte, luz, energia, telefonia, água, esgoto, limpeza e policiamento, seriam mais econômicos. As obras para a construção dos seus sistemas seriam reduzidas, assim como o pessoal e o equipamento necessários para a sua operação e manutenção. Do mesmo modo, as obras de construção da cidade seriam facilitadas, com maiores possibilidades de serem executadas dentro do mais alto padrão técnico e de forma que a capital pudesse ser transferida num prazo relativamente curto, conforme desejava o governo.

No espaço central aos três superblocos de cada conjunto de habitação intensiva foram previstos centro comercial, centro social e cultural, duas escolas primárias em dois turnos de 650 alunos cada uma (quatorze alunos por ano escolar para cada mil habitantes), escola secundária, centro de saúde, igreja, cinema, 
playgrounds etc. Clubes esportivos e hospitais foram distribuídos nos jardins da área urbana de forma a servir dois ou mais conjuntos.

Cada superbloco possuiria estacionamento próprio com posto de serviço, além de garagem em subsolo, ligada aos elevadores gerais. Os ônibus teriam parada no próprio andar térreo, projetado como um pilotis de 10 metros de altura livre, no qual passariam também as pistas elevadas da via expressa, no eixo do módulo da respectiva extremidade.

Cada superbloco seria dividido em quatro unidades de habitação para 4.00o pessoas, compostas cada uma por oito corpos ou edifícios de vinte andares, para 500 moradores. As unidades seriam organizadas como quatro grandes "fiadas" superpostas com ruas internas ao superbloco na sua base e andares neutros no seu topo.

Assim, um superbloco seria constituído por 32 edifícios e teria, além do andar térreo e de dois andares em subsolo, oitenta andares de apartamentos, quatro ruas internas e quatro andares neutros, totalizando uma altura de $300 \mathrm{~m}$ acima do solo.

Nas ruas internas, onde se daria a ligação dos elevadores gerais com os elevadores locais de cada um dos oito edifícios, seriam localizados os serviços complementares às habitações de cada unidade: cerca de trinta lojas comerciais (para comestíveis, restaurantes, lavanderias etc., calculadas na razão de uma loja para cada 130 habitantes), jardim da infância com duas classes (uma classe para cada 2.00o habitantes), creche, centro de saúde e cinco praças para recreio, intermediárias ao longo do percurso da rua interna. A creche e o centro de saúde estariam situados num dos extremos desta e o jardim da infância no outro. A creche e o jardim da infância disporiam de áreas em balanço, destinadas ao recreio ao ar livre.

Os superblocos foram orientados no sentido norte-sul, garantindo às suas duas faces úteis ótimas condições de insolação. As prumadas de edifícios seriam 
destacadas umas das outras pela praça de elevadores ou por intervalos de 15 metros, coincidentes com a posição das praças de recreio na rua interna. Esta separação quebraria (...) a continuidade da superfície, conferindo ao superbloco leveza, transparência e permeabilidade aos ventos, aliviando os esforços originados por esses na estrutura e melhorando as condições de ventilação transversal dos apartamentos, ao reduzir, consideravelmente, a zona de depressão a sotavento.

A circulação nos superblocos foi resolvida em dois sistemas de elevadores: 24 elevadores "standard", com entrada e saída nos lados opostos e com capacidade para 28 passageiros, estabeleceriam a circulação vertical geral, interligando os andares da garagem subterrânea, o térreo e as ruas internas, e os elevadores gerais foram estudados para dar vazão de $10 \%$ da população do superbloco em 5 minutos, equivalendo ao sistema de transporte coletivo da cidade convencional. A rua interna resolveria a passagem obrigatória entre os elevadores gerais e os elevadores locais, cujo papel e funcionamento seria semelhante ao daqueles de qualquer edifício de apartamentos.

Para a estrutura dos superblocos, estudada em detalhes pela equipe, foi definida a utilização do aço, tendo em vista a conveniência da redução do seu peso próprio, a grandeza dos esforços, a desejada rapidez executiva e o sistema estrutural adotado. $\mathrm{O}$ arcabouço principal deste seria constituído por quadros rígidos múltiplos nas duas direções, formados por pilares de perfis compostos em seção celular, treliçados na transversal e por grandes vigamentos treliçados na longitudinal, correspondentes aos andares neutros. Nas grandes treliças seriam pendurados os diversos andares de apartamentos, por uma malha de tirantes de 6 $\mathrm{m}$ de lado. Tal sistema estrutural evitaria pilares nas ruas internas e daria completa autonomia arquitetônica a cada edifício, admitindo soluções variadas de planta, de circulação vertical e de instalações. Permitiria, desse modo, que cada superbloco assumisse fisionomia própria e que fosse criada uma identidade para cada conjunto de habitação intensiva. 
Os andares neutros, resultantes das grandes treliças, seriam aproveitados para a localização das máquinas dos elevadores, dos reservatórios de água, dos transformadores, de tubulações, de eventuais equipamentos de ar-condicionado e para o desvio de chaminés de ventilação de banheiros e cozinhas.

Os superblocos tiveram as áreas calculadas adotando-se a razão de $25 \mathrm{~m}^{2}$ por pessoa. Assim, as plantas dos andares de apartamentos foram projetadas com $18 \mathrm{x}$ $35 \mathrm{~m}$. Somadas as áreas das garagens, das ruas internas e dos edifícios de apartamentos, os superblocos teriam $455.000 \mathrm{~m}^{2}$ de área construída.

\section{Crescimento da cidade}

Os arquitetos projetaram Brasília para uma população máxima de cerca de 500.0oo habitantes, conforme estabelecia o Edital do Concurso, e recomendaram a limitação do crescimento da cidade e dos vários setores por uma legislação adequada. No entanto, admitiam um crescimento acima deste limite para atender circunstâncias supervenientes, imperiosas e imprevisíveis. Três conjuntos adicionais de habitação intensiva e alguns conjuntos de habitação extensiva foram previstos para acomodar o eventual crescimento da população, de modo a que sua construção não desvirtuasse os princípios orientadores do plano, mantendo as condições de equilíbrio das várias funções da cidade, sem prejuízo da conservação dos espaços verdes.

\section{COMENTÁRIOS DO JURI ${ }^{2}$}

\section{Suposições:}

- $\quad 288.000$ pessoas em blocos de 300 metros de altura $+\%$, isto é, $16.000 \mathrm{em}$ cada bloco $\mathrm{x}_{3}$ = setor.

- 150.000 pessoas nos blocos de densidade alongada ou média (100 - 200 p./hect.)

\footnotetext{
${ }^{2}$ Módulo, no 8, edição especial: Brasília, op. cit., p. 14.
} 
- 70.0oo pessoas em extensões fora do plano.

\section{Críticas}

1. Não há centro de transporte.

2. Altura desnecessária; resistência aos ventos; troca de elevadores; concentração desaconselhável.

3. Pistas de alta velocidade através dos edifícios.

4. Mercado central inacessível, embora previstos mercados locais.

5. Do ponto de vista plástico, são os apartamentos que dão feição à capital não os edifícios governamentais.

\section{Vantagens}

Boa aparência e orientação. 